\title{
THE INDIAN CIVIL SERVICE AND INDIAN FOREIGN POLICY, 1923-1961
}

\section{Amit Das Gupta}
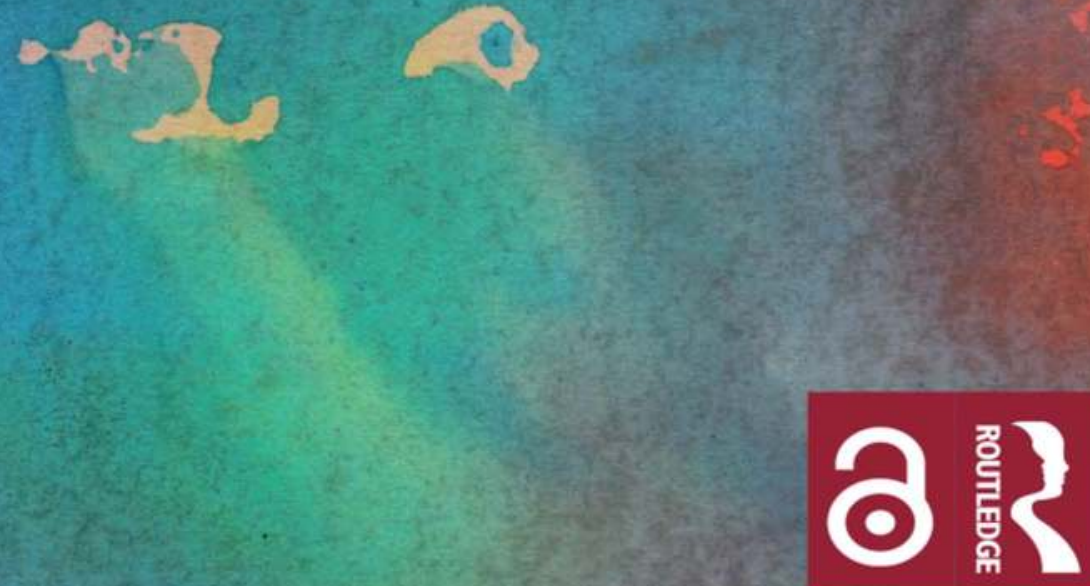


\section{THE INDIAN CIVIL SERVICE AND INDIAN FOREIGN POLICY, 1923-1961}

This book provides an authoritative account of the first significant overseas diplomatic missions and forays made by Indian civil servants. It recounts the key events in the formative decades of Indian foreign policy and looks at the prominent figures who were at the centre of this decisive period of change.

The book explores the history and evolution of the civil and foreign services in India during the last leg of British rule and the following era of post-independence Nehruvian politics. Rich in archival material, it looks at official files, correspondences and diaries documenting the terms served by the pioneers of Indian diplomacy, Girja Shankar Bajpai, K.P.S. Menon and Subimal Dutt, in Africa, China, the USSR and other countries and their relationship with the Indian political leadership. The book also analyses and pieces together the activities, strategies, worldviews and contributions of the first administrators and diplomats who shaped India's approach to foreign policy and its relationship with other political powers.

An essential read for researchers and academics, this book will be a useful resource for students of international relations, foreign policy, political science and modern Indian history, especially those interested in the history of Indian foreign affairs. It will also be of great use to general readers who are interested in the history of politics and diplomacy in India and South Asia.

Amit Das Gupta is Senior Researcher at the Universität der Bundeswehr, München, Germany. His previous work includes Serving India: A Political Biography of Subimal Dutt (1903-1992), India's Longest Serving Foreign Secretary; The Sino-Indian War of 1962: New Perspectives (coedited with Lorenz M. Lüthi, McGill); and Handel, Hilfe, Hallstein-Doktrin. Die bundesdeutsche Südasienpolitik unter Adenauer und Erhard 1949 bis 1966. 
$\Longrightarrow$ Taylor \& Francis

Taylor \& Francis Group

http://taylorandfrancis.com 


\section{THE INDIAN CIVIL SERVICE AND INDIAN FOREIGN POLICY, 1923-1961}

Amit Das Gupta 
First published 2021

by Routledge

2 Park Square, Milton Park, Abingdon, Oxon OX14 4RN

and by Routledge

52 Vanderbilt Avenue, New York, NY 10017

Routledge is an imprint of the Taylor \& Francis Group, an informa business

(C) 2021 Amit Das Gupta

The right of Amit Das Gupta to be identified as author of this work has been asserted by him in accordance with sections 77 and 78 of the Copyright, Designs and Patents Act 1988.

With the exception of Chapter 1, no part of this book may be reprinted or reproduced or utilised in any form or by any electronic, mechanical, or other means, now known or hereafter invented, including photocopying and recording, or in any information storage or retrieval system, without permission in writing from the publishers.

Chapter 1 of this book is available for free in PDF format as Open Access from the individual product page at www.routledge.com. It has been made available under a Creative Commons AttributionNon Commercial-No Derivatives 4.0 license.

Trademark notice: Product or corporate names may be trademarks or registered trademarks, and are used only for identification and explanation without intent to infringe.

British Library Cataloguing-in-Publication Data A catalogue record for this book is available from the British Library

Library of Congress Cataloging-in-Publication Data

A catalog record for this book has been requested

ISBN: 978-1-138-06424-9 (hbk)

ISBN: 978-1-003-11884-8 (ebk)

Typeset in Sabon

by Apex CoVantage, LLC 
To the memory of

my late father Prasanta Kusum Das Gupta (28 August 1928-15 May 2014)

my beloved 'uncle’ Maneck Mana (17 January 1935-8 June 2018)

and

mentor and friend Hari Shankar Vasudevan (15 February 1952-10 May 2020) 
$\Longrightarrow$ Taylor \& Francis

Taylor \& Francis Group

http://taylorandfrancis.com 


\section{CONTENTS}

List of photographs $\quad$ ix

Preface $\quad x$

Acknowledgements xii

List of abbreviations $\quad \mathrm{xv}$

1 Introduction 1

PART I

$\begin{array}{ll}\text { Set-up } & 19\end{array}$

2 How it all began - Indians overseas 21

3 Key protagonists - Girja Shankar Bajpai, K.P.S. Menon and Subimal Dutt 28

PART II

Interwar years - The Department of Education, Health and Lands

4 South Africa 47

5 East Africa $\quad 72$

6 Ceylon 94

7 Malaya 120

8 Fiji, British Guiana, Australia and North America 140

9 Second World War $\quad 150$ 
PART III

Nehruvian foreign policy

10 Return to power

11 The Bajpai Years in the MEA

12 Bajpai's heirs

13 Conclusion

Bibliography

300

Index

309 


\section{PHOTOGRAPHS}

1 Girja Shankar Bajpai as Secretary-General of the Ministry of External Affairs

2 Girja Shankar Bajpai in his study

3 K.P.S. Menon at a family ceremony

4 K.P.S. Menon with Jawaharlal Nehru and Y.D. Gundevia

188

5 Subimal Dutt with Jawaharlal Nehru

6 Subimal Dutt with Jawaharlal Nehru and Indira Gandhi

190 


\section{PREFACE}

This foreword was meant to be written by Professor Emeritus Hari Shankar Vasudevan from Calcutta University. Tragically, only a few days after he had written to me that he was working on it, he was taken away from us on 10 May 2020 by the COVID-19 virus. For me and for many others, this means the loss of a wonderful friend as well as an eminent scholar. Hari had accompanied my research work since late 2011, when thanks to Ambassador Krishnan Srinivasan I came in touch with him in his capacity as the director of the Maulana Abul Kalam Azad Institute of Asian Studies. From then on, we would see each other whenever I came to visit Kolkata. My research has profited greatly from the numerous opportunities when he invited me to give talks about work in progress at the Institute of Foreign Policy Studies at the University of Calcutta. The regular discussions with his Ph.D. students and senior colleagues provided the most useful feedback I received over the last decade.

As a renowned historian in the field of international relations, Hari took to my preferred style of researching topics (i.e., extensive archival work). Over the years, we established a regular exchange about archives, in particular those in South Asia, London and Moscow. The latter are known as rather difficult to investigate but also providing highly relevant, hitherto unknown documentation. In 2017, when India and Russia celebrated the 70th anniversary of the establishment of diplomatic relations, Hari was the expert behind the Indian embassy's exhibition. He never hesitated to share his tremendous knowledge on Russian history and Indo-Russian relations.

Hari combined an unusual amount of qualities in one person. Whether it be with a junior scholar like me or with any of his students, he demonstrated an admirable listening power and patience. There are not too many in academia who are both eminent scholars and dedicated teachers, but he set standards in both fields. Furthermore, he had a knack for languages. Whenever we had the opportunity for an extended exchange in the cafeteria of the Alipore Campus of Calcutta University, he easily switched from his polished Cambridge English to his similarly elaborate Russian. Last, but certainly not least, he never made me feel anything but an equal, though I certainly was 
no equal to him in any field. He was among those rare mentors who make friends of their protégés.

After I had authored the first version of the manuscript of this book, Hari did me a great favour by writing a full-fledged review. The final version owes much to his valuable advice. As a tribute to his support, in the following I am taking the liberty to summarise some of his central comments: Apart from criticising certain shortcomings, he saw 'a major contribution to knowledge of the history of Indian foreign policy and decolonization' in telling and analysing the near untouched story of the interaction of a group of (embryo) diplomats with political leaders in the late years of the Raj and the Nehruvian era. Though this is not at the centre of the book, he also welcomed dealing with the profile of Indian migration in the contexts of caste, region and gender in various overseas territories. As was to be expected, Hari liked the grounding in a close reading of archives, meticulously footnoted and gathered from a large number of collections', the narrative not driven by a specific archive. As 'overall effect', he stated 'awe at the level of intricacy that the author has achieved'.

With great likelihood, this is among the first books being published after Hari's premature demise and highlighting his enormous contribution to the academia. Those who like it will hopefully honour the memory of a great scholar and a wonderful friend.

Berlin, 7 June 2020 


\section{ACKNOWLEDGEMENTS}

This book is based on extensive archival research in four countries, but it would not have been possible to give a balanced account without the advice and support of various institutions, eyewitnesses, colleagues and friends. The very first to be mentioned here is Ambassador Kayatyani Shankar Bajpai, who over the years has supported my research on his father Girja Shankar Bajpai, even by forwarding me some of his father's private papers. Thanks to numerous exchanges in person or via email, he helped to put archival findings into proper perspective. From the academic side, I have profited at large from the support of Professor Hari Vasudevan from Calcutta University. An expert on the history of Indian foreign policy, he has shown keen interest in my research for a decade and has provided me with helpful comments and contacts plus numerous opportunities to discuss provisional results with colleagues and students. Furthermore, he has done me a great favour with his detailed review of the draft manuscript. The German Research Foundation, for the second time, has been so generous to finance a research project of mine. I am most grateful for the ongoing trust in my research work, which in the meantime has resulted in the funding of a third project around the development consortia for India, Pakistan and Turkey. Last but not least, I am deeply indebted to my editor, Shoma Choudhury, who has accompanied my work on this book with expertise and patience.

This monograph on the influence of the Indian Civil Service on Indian foreign policy owes much to my earlier work on India's longest-serving foreign secretary, Subimal Dutt. The archival research I undertook for Serving India has to no small extent flown into this new book. Therefore, once again, I would like to express my deep gratitude to Supriya Guha, who entrusted her grandfather Subimal Dutt's private papers to me, which provide unique insights in the inner mechanisms of Indian foreign policy, in particular in the second half of the 1950s. No one else had supported my research on Dutt as much as Ambassador Krishnan Srinivasan, wherefore he has contributed to this new monograph at large too. Finally, my work again owes much to the Ministry of External Affairs. Although many of the files I had been given special permission to see in the ministry's internal archives have since been 
transferred the National Archives of India, my research until today profits from this privileged access. In this context, I am deeply obliged to Joint Secretary Dr Anupam Ray, who not only took the crucial initiative on my behalf but also became a fellow researcher and a most appreciated friend.

There are two more IFS officers who have helped my research work on various occasions. Whenever we met, the discussions with Ambassador Chandrashekhar Dasgupta, himself publishing on foreign policy in the Nehru years, provided me with new insights. Ambassador Pankaj Saran, who had earlier supported my research work in Bangladesh, did so again in Moscow, permitting me to present and discuss my work on India's early ambassadors in the Russian capital.

Over many years, I have used my regular visits to Delhi to keep in contact with the Centre for Historical Studies at the Jawaharlal Nehru University. Mridula and Aditya Mukherjee and Sucheta Mahajan have not only shared their unique expertise but have also become friends who continue to make my stays in India's capital most enjoyable. The same is true of the Institute of Foreign Policy Studies of Calcutta University, where for many years I have had the honour and pleasure to discuss my research with the leading foreign affairs experts Professors Hari Vasudevan, Shantanu Chakrabarti, Jayanta Kumar Ray and Kingshuk Chatterjee. I have also profited much from an exchange with Rakesh Ankit, another foreign policy expert, especially his research on Indo-Soviet relations and the Kashmir dispute. Regarding the former topic, for many years I have counted on the expertise of Dr Andreas Hilger, an eminent expert on Soviet history, now vice director of the German Historical Institute in Moscow.

It was a lucky coincidence when during one of my research trips to Delhi I came in touch with Dr Marina Martin from Frankfurt University and Heena Mistri, Research Associate at Queen's University. My work on IndoSouth African relations in the interwar period owes much to their friendly support. They also took care that a long research trip turned out to be not only particularly successful but also pleasant. The latter is true also of Dr Joshua Ehrlicher, now at the University of Macau, thanks to whom my weeks in Chennai were particularly enjoyable.

I am deeply indebted to the many archivists who supported my work in four countries. They are too many to be named individually, but I would like to express my particular gratitude to two of them. Dr Kevin Greenbank's support at the Centre of South Asian Studies of Cambridge University was invaluable during and after the weeks I spent there. Archivoberrat Knud Piening from the Political Archives of the German Foreign Office has supported my work for a quarter century and counts among my close friends.

Owing to family in India and Russia, even long research trips always had an enjoyable side for me. I would like to use this opportunity to thank my brothers Subir, Prabir and Kabir Dasgupta, their spouses and their children for all the wonderful encounters in Kolkata. Mr Subhas Roy must be 
mentioned here as well; although not by blood, he is a true uncle of mine. In addition to his and his wife's hospitality, I enjoy the extended academic discussions with a genuine intellectual. Whenever I visited Moscow, my wonderful in-laws were waiting to spend the weekends with me. Therefore, my thanks go to Irina Semyonovna Arjamkina, Vladilen Arjamkin and Sergo Vasgenyevich Egikjan and their families.

The last on this list is by far the most important. Over the past 19 years, nobody has been more inspiration to me than my beloved daughter Nina Aruna Das Gupta. May she forgive me all those months I spent far away from home. 


\section{ABBREVIATIONS}

$\begin{array}{ll}\text { ADS } & \text { additional deputy secretary } \\ \text { AIEB } & \text { Archives Indian Embassy Berlin } \\ \text { AVP RF } & \text { Arhiv vneshnej politiki Rossijskoi Federacii } \\ \text { BAK } & \text { Bundesarchiv Koblenz } \\ \text { BL } & \text { British Library } \\ \text { CGA } & \text { Clover Growers' Association } \\ \text { CRO } & \text { Commonwealth Relations Office } \\ \text { CS } & \text { chief secretary } \\ \text { CSAS } & \text { Centre of South Asian Studies, Cambridge } \\ \text { DEHL } & \text { Department of Education, Health and Lands } \\ \text { DEHLO } & \text { Department of Education Health and Lands, Overseas Branch } \\ \text { DO } & \text { Dominions Office } \\ \text { DoS } & \text { Department of State } \\ \text { DS } & \text { deputy secretary } \\ \text { EAD } & \text { External Affairs Department } \\ \text { FO } & \text { Foreign Office } \\ \text { FPD } & \text { Foreign and Political Department } \\ \text { GoI } & \text { Government of India } \\ \text { ICAR } & \text { Indian Council of Agricultural Research } \\ \text { ICS } & \text { Indian Civil Service } \\ \text { IOR } & \text { India Office Records } \\ \text { JS } & \text { joint secretary } \\ \text { JWP } & \text { John Walton Papers } \\ \text { KM } & \text { Krishna Menon } \\ \text { KPSMP } & \text { K.P.S. Menon Papers } \\ \text { MEA } & \text { Ministry of External Affairs } \\ \text { MEAA } & \text { Ministry of External Affairs Archives } \\ \text { MEMCON } & \text { Memorandum of Conversation } \\ \text { MID } & \text { Ministerstvo Innostrannych Del } \\ \text { NAI } & \text { National Archives of India } \\ \text { NAUK } & \text { National Archives of the United Kingdom } \\ \text { NMML } & \text { Nehru Memorial Museum and Library } \\ & \end{array}$




$\begin{array}{ll}\text { Offg } & \text { officiating } \\ \text { OSD } & \text { officer on special duty } \\ \text { PA AA } & \text { Politisches Archiv des Auswärtigen Amts } \\ \text { PCS } & \text { Provincial Civil Service } \\ \text { PM } & \text { prime minister } \\ \text { RAD } & \text { Revenue and Agriculture Department } \\ \text { SDP } & \text { Subimal Dutt Papers } \\ \text { SEC } & \text { Standing Emigration Committee } \\ \text { SSC } & \text { Secretary of State for the Colonies } \\ \text { SSI } & \text { Secretary of State for India } \\ \text { SWJN2 } & \text { Selected Works of Jawaharlal Nebru, Second Series } \\ \text { TNSA } & \text { Tamil Nadu State Archives } \\ \text { ToP } & \text { transfer of power } \\ \text { UNGA } & \text { United Nations General Assembly } \\ \text { UNSC } & \text { United Nations Security Council } \\ \text { UP } & \text { United Provinces } \\ \text { UPSA } & \text { Uttar Pradesh State Archives } \\ \text { USSC } & \text { Under Secretary of State for the Colonies } \\ \text { USSI } & \text { Under Secretary of State for India } \\ \text { VLPP } & \text { Vijaya Lakshmi Pandit Papers }\end{array}$




\section{1 \\ INTRODUCTION}

Jawaharlal Nehru left a strong imprint on global affairs. Charismatic, handsome and a brilliant orator and writer, he led the largest decolonised country, setting examples with state-driven industrialisation and efforts to establish a new style in foreign affairs. He gave those a face and a voice who, until the end of the Second World War, had been denied looking after their own affairs and having a say in international politics. As Nehru was a towering figure at home and abroad, the years between 1947 and 1964 are rightfully termed the Nehruvian era. Accordingly, books on Indian foreign policy mostly start with the assumption that Nehru was its main or even sole architect. It appears to be self-evident that a country's first prime minister would set everything on the right track, all the more so as Nehru was considered a foreign affairs expert even before India attained independence.

Nevertheless, foreign policy never is a one-man show. Apart from Nehru's main advisor, V.K. Krishna Menon, ministers like Sardar Vallabhbhai Patel or G. B. Pant exercised a certain influence. At least equally important was the support and the counsel of officers of India's Foreign Service (IFS), who enabled Nehru to pursue his goals in the international arena. The vast majority of them were neither mere tools to implement decisions nor men or women of Nehru's making. Instead, many of them looked back on distinguished careers in British-trained services of the colonial period. Those formative years, when politics and foreign policy had taken place in a different setting and under partly different predominating political views, had left a lasting impression. What is rightfully termed Nehruvian foreign policy as part of an era, therefore, is not necessarily Nehru's foreign policy but the outcome of the interaction of several actors with diverse ideas and attitudes.

Suranjan Das has criticised Nehru for talking leftist while permitting free rein to rightist forces in the Congress Party. ${ }^{1}$ If so, the exception from the rule was foreign affairs, where neither parliament nor party was involved. On this field of policy, the well-known, somewhat leftist and idealist views of the prime minister and Krishna Menon interacted and partly clashed with what might be termed an Indian Civil Service (ICS) school. Indian officers of that service formed the core of the IFS, established and ran the Ministry 
of External Affairs (MEA), represented India abroad and counselled the prime minister. This was more than continuance in terms of personnel: Over the quarter century before independence, they had developed a distinct worldview of their own which was rather 'conservative', staunchly anticommunist, sceptical vis-à-vis the US and deeply realist. Around the turn of 1945/1946, the mastermind of the ICS school, Sir Girja Shankar Bajpai, had authored a conclusive concept for the foreign policy of independent India, the outcome of through and through realist thinking. The conclusion was striking: 'Sentiment must serve, not master the national interest'. ${ }^{2}$

This distinguished the ICS school from Nehru who, when he came to power, confessed that he had not much of an idea about what foreign policy to pursue. ${ }^{3}$ Contemporaries drew an even darker picture of the prime minister's capacities in general. According to one of his closest aides, M.O. Mathai, the prime minister lacked an 'original mind. . . . He was all heart and less mind' ${ }^{4}$ Durga Das, a journalist in close touch with politics during the Nehruvian years, characterised Nehru as 'tormented . . . by the spirit of self-questioning. Nehru's genius lay in romanticising politics' ${ }^{5}$ Historian Harish Kapur follows the same line, adding that Nehru's 'irresolute (Hamletian) character always made him question what he really believed in. ... Nehru was an impulsive intellectual, who liked living with ideas, while playing with them'. 6 This study strengthens these assessments of his pursuit of foreign affairs.

The second established truth to be questioned is that colonies for lack of sovereignty cannot pursue a foreign policy of their own. The British Indian Foreign and Political Department (FPD) appears to confirm this point for being mostly a branch of the Foreign Office in London, its personnel near exclusively European. British India, however, was an unusual colony in many ways. Among others, it was the only member of the League of Nations which lacked sovereignty. It also participated in various international organisations like the International Labour Organisation (ILO), wherefore it has rightly been termed as an 'anomalous international person'. ${ }^{7}$ In 1942, Under Secretary for India and Burma David Taylor Monteath lamented that British India's 'international status and functions not justified by its constitutional position' had resulted in ' 25 years of skating over very thin ice and occasionally putting one's foot through it'. ${ }^{8}$

British India's activities on the international floor during the interwar period had various facets. Historiography has, first, highlighted the impact of the Congress Party, which, however, was negligible with a most notable exception. Typically, utterances of politicians are overrated as guidelines for post-independence foreign policy. Indeed, statements from those prior to attaining power are often not much in touch with reality, and this is true for India, too. Nehru was living proof of this. His long-lasting interest in international affairs proved to be of little value when he took office in September 1946. As a matter of fact, he had to 
learn on the job and relied heavily on ICS officers, who had been trained in classical diplomacy.

The notable exception was Mohandas Karamchand Gandhi, although he was no systematic thinker and has not left any rules for the conduct of foreign affairs. Nevertheless, means and aims of his South African campaigns became guidelines for the interwar policy around Indians overseas and, to a lesser extent, post-independence foreign policy. Therefore, the Government of India (GoI) attached greatest importance to the Mahatma's approval of its activities abroad. Obviously, this paid tribute to Gandhi's enormous influence on Indian public opinion. Furthermore, the viceroys and their subordinates understood that British India had no more efficient means at hand.

Allegedly, imperial tradition, second, had a tangible effect on the foreign affairs of independent India. Robert J. Blyth has investigated British India's extended neighbourhood policy from Tanganyika over the Gulf and the northern Himalayas to Southeast Asia. ${ }^{9}$ Whether this policy as pursued by the FPD has laid down any tradition for independent India is questionable. British Indian foreign and security policy had started from the axiom that the colony was safe behind the walls of the Himalayas. With partition, the Indian Union - with Pakistan - faced an archenemy within the enclosure, and with the Chinese occupation of Tibet four years later, it lost its buffer in the north as well. The coordinates of the colonial period together with its representatives from the FPD had disappeared, with the notable exception of K.P.S. Menon.

What so far has been mostly ignored is the third aspect: a foreign policy pursued by Indians for Indians for two decades by means of classical diplomacy. It began with moderate Indian politicians like Satyendra Prasanno Sinha, V.S. Srinivasa Sastri or Tej Bahadur Sapru representing the colony at international conferences and bodies. ${ }^{10}$ From 1923, unconnected with the FPD, British India established a few missions abroad, called agencies, and employed indigenous proto-diplomats. The agents were all recruited from the civil service; only with the third mission in South Africa, created in 1927 , an anomaly occurred. This is the aspect of pre-independence foreign policy the first part of this book focuses on.

After the Great War, Great Britain faced a 'crisis of Empire' with unrest in numerous colonial territories and Ireland. ${ }^{11}$ Therefore, the British had to concede to public demands; in South Asia, this meant helping the case of Indians overseas whenever they were denied equal rights or fair wages. For that purpose, under a completely misleading name, the Department of Education, Health and Lands (DEHL) was established with predominantly Indian personnel, tacitly rivalling the FPD. While the latter kept busy with the Great Game, the former ran agencies in Ceylon, Malaya and South Africa. Moreover, with the notable exception of Europe, it kept an eye on developments in territories with Indian minorities. Deputations were sent to investigate conditions on the ground and to negotiate with the authorities. 
This covered large parts of the Empire, including the dominions of Australia, Canada and New Zealand and colonies like British Guiana, East Africa and Fiji. Furthermore, the DEHL observed developments outside the Empire, for example, in the US or Brazil. Indian officials represented the interests of their countrymen abroad, partly against representatives of the same colonial power ruling South Asia. This undoubtedly qualifies as indigenous Indian foreign policy.

Such policy willy-nilly threatened the very foundations of the Empire, which was implicitly built on the assumption of the superiority of the white race. The creation of the DEHL was meant primarily as a gesture to appease the feelings of Indians in British India. They were disappointed for not being rewarded with reforms towards self-governance despite their immense contribution to the Great War. Against the success of the Gandhian campaigns, London and Delhi wanted to demonstrate resolve to support Indian claims, at least abroad. Indeed, the British were jumping from the frying pan into the fire. In particular in South Africa, the official policy in the name of Indians overseas in essence was a continuation of the Gandhian campaigns. ${ }^{12}$ Even its means were comparable. Gandhi wanted 'to convert, not coerce, the wrong doer'.$^{13}$ Even if British India had wanted to, it was in no position to coerce the Union government. Instead, it had to convince its counterparts of the fairness of its demands by appealing to common values - via distinguished Indians, finding personal access to South African politicians. Therefore, it was only logical that policy makers (hardly camouflaged) regularly consulted Gandhi: The latter knew everyone relevant in South Africa and commanded unmatched sustainable experience in that type of personal diplomacy. No major decision was taken without the Mahatma's consent. Cooperation went so far that all agents were suggested by Gandhi.

This resulted in a paradox constellation: Those in charge in British India seriously fought for fair treatment and equal rights of Indians overseas including franchise. At the same time, the authorities did not grant such treatment and rights in British India itself. Regarding the economic side, Bajpai correctly observed 'that India is not exactly a paradise' for the underprivileged. 'Even working for a less than subsistence wage' abroad 'may ... be preferable to starvation or semi-starved dependence on others in India'. ${ }^{14}$ Regarding the political status, the contrast was even stronger. South African Prime Minister Jan Smuts in 1922 warned that initially it had not been the people of Indian origin demanding equal franchise. Instead, those he considered as political agitators allegedly had 'largely created' such demands. ${ }^{15}$

This warning was obviously true for British India itself too. For a long while, Delhi was not aware of being the sorcerer's apprentice. Demands for equal rights and fair wages outside the colony sooner or later had to bounce back to the subcontinent. If Gandhi's aims, tactics and counsel were relevant for relations with other colonies and dominions, why should they be 
considered unacceptable back home? In any case, relying on the Mahatma beyond India-South Africa affairs meant giving the very opponent of British rule in South Asia even more weight. Nevertheless, the European officers working in the DEHL did so with the same dedication to their tasks as their Indian colleagues, and the viceroys approved the department's policy. Only from the late 1930s, British officials and politicians in London and Delhi grew uneasy. The outbreak of the Second World War nipped the debate in the bud. The issue was put on the backburner and its main protagonists were transferred.

Over two and a half decades before India and Pakistan won independence, Delhi pursued a line of foreign policy focusing on the interests of Indians rather than Europeans. Many relevant issues of the interwar period - among them segregation in South Africa or citizenship and franchise in Ceylon remained on the agenda of independent India, though of much less relevance. This is mirrored in the continuity of personnel. Many of those serving with the DEHL or the agencies were recruited from the ICS or the Madras Civil Service. The IFS, established in 1947, relied heavily on British trained servicemen; all higher ranks were occupied by ICS officers. Three of them represent that continuity more than anyone else. Since the early 1920s, Bajpai was considered India's leading indigenous foreign policy expert. He was the key figure in the DEHL long before he finally was appointed its member in 1940. From then on, he was part of the Viceroy's Executive Council, the de facto cabinet of British India. An officer of unique qualities, Bajpai was the brain and the motor of the department, representing British India at numerous international conferences. He also selected promising officers, training them as foreign policy experts. Among his discoveries was K.P.S. Menon, who served as agent in Ceylon, led a delegation to East Africa and, for a short while, worked in the department. Furthermore, during the Second World War, he represented British India in China and, thereafter, accompanied the Indian delegation to the United Nations. Whereas he disliked desk work in Delhi and Simla, he was an extraordinary diplomat abroad: a great orator, a capable negotiator and a sharp observer. The third person in focus is Subimal Dutt, another discovery of Bajpai. Dutt's role during the Raj is difficult to assess, with the notable exception of the eight months he served as agent in Malaya in 1941. His hour came as foreign secretary between 1955 and $1961 . .^{16}$

After independence, Bajpai and Dutt represented the ICS school, whereas Menon rather embodied the traditions of the Political Service coined by officers like Olaf Caroe or Hugh Weightman. Unlike Bajpai and Dutt, he also had close links with the Congress Party and especially Nehru, with whom he had been friends since the early 1930s. The three came to form the troika of secretaries on top of the MEA between 1948 and 1952. The one calling the shots in Delhi (with an interruption from 1942 to 1947) was Bajpai. The one to shine abroad was Menon, be it in Ceylon, China or the 
USSR. Dutt preferred to keep in the background, but his role as Nehru's near invisible but remarkably influential advisor cannot be overstated.

This book investigates the long lines of Indian foreign policy between 1921 and 1961. Its starting point is India's first diplomatic mission around the issue of Indians overseas, the dominions tour of Srinivasa Sastri, accompanied by the young Bajpai. In 1961, with the end of the terms of Menon in Moscow and Dutt as foreign secretary, an era ended during which ICS officers, who had learned foreign affairs around the issue of Indians overseas, had a strong impact on India's external relations. This monograph provides the first history of the DEHL, highlighting its set-up and internal functioning, its main activities, its foreign policy style and the selection and role of its officers. From this perspective, it is also a contribution to the hitherto unwritten history of Indians in the late years of the ICS. It analyses the mindset prevalent in the department, especially political views relating to the rest of the world. After investigating developments during the Second World War it turns toward Nehruvian foreign policy, investigating, among others, the establishment of the IFS and the MEA. It further analyses to what extent the worldview of prominent IFS officers with a British service background influenced Indian foreign policy from 1947, and to what extent this worldview was reconfirmed, modified or abolished during the Nehruvian years.

It would have been desirable to follow a large group of these officers, finding out where exactly they consented and differed. Unfortunately, the lack of sources made this near impossible. In Bajpai's case, there is a tremendous number of official files documenting his work, allowing reliable conclusions on his mindset notwithstanding the lack of private papers. This, however, is not true for the majority of those who held lower ranks in the DEHL and the MEA, with the exceptions of Menon and Dutt. The former's terms in Ceylon, East Africa, China, and the USSR are rather well documented in the files of both departments. Moreover, he has left diaries covering three decades from 1918. In the case of Dutt, there are sufficient official files on his terms in Malaya and West Germany and for the years he served as foreign secretary. Detailed diaries complement the picture.

Though the book focuses on these three officers, it is no triple biography. Random findings about the role of other officers during the Raj have been essential to complete the picture, and from 1947 onwards there is no lack of material documenting work and views of numerous other Indian diplomats. Therefore, this study also contributes to the history of the little researched roots of the IFS and the MEA as an institution.

Methodologically, this book to a large extent relies on archival sources. Earlier research on Indian foreign affairs willy-nilly was based upon public statements plus memoirs of protagonists, the latter a not too reliable source. Apart from having been written decades after the actual events, their main intention is highlighting the contribution of the author rather than drawing 
a balanced picture appreciating the merits of others. Especially in the case of the history of Indian foreign policy, again and again retold narratives and clichés dominate the discussion, established on and strongly coloured by the recollections of a few. Today, official files, correspondences and diaries allow more reliable analyses of opinion-forming and decision-making processes. This monograph is written with the intention to draw a more authentic picture, which together with the research of colleagues will sooner rather than later amend, if not replace, partly outdated narratives.

For the pre-independence years, archival research has been undertaken in the National Archives of India, housing the files of the DEHL for the years from 1923 to 1941 . For the years from 1927 to 1930 and particularly from 1938 to 1941, though, files are available at random only. To a lesser extent, documents of the FPD offer additional insights as far as they relate to the worldview of the higher ranks, the institutional rivalry with the DEHL, the selection of ICS officers for the Political Service and the work of K.P.S. Menon. Files of the Home Department help understand the process of Indianisation of the services. The same is true for the collections of the State Archives of Tamil Nadu and Uttar Pradesh. Madras Province provided most agents, but other provincial governments too were involved in discussions around the selection of personnel and the balance between European and Indian officers. Furthermore, those archives occasionally allow insights into the careers of officers who later joined the IFS. British archives offer the opportunity to understand the perception of the changes in British India through the eyes of Europeans. The Centre of South Asian Studies at Cambridge holds private papers of British ICS officers and even of some of their wives. In the manuscript collection of the British Library, similar papers of higher-ranking officers are found, including a few Indians. The India Office Records provide official exchanges between Whitehall and Delhi. They are concerned with changes in the ICS in the interwar period but also with issues related to the work of the DEHL. Only owing to the documentary available on Dutt's posting in Malaya and that of Bajpai in Washington has it been possible to assess their performance.

For the Nehruvian years, the research is based on files of the MEA, available both in the National Archives and (owing to special permission) the internal archives of the ministry and the Indian Embassy in Berlin. The manuscript section of the Nehru Memorial Museum and Library (NMML) holds various private papers and collections of ICS officers who joined the IFS, most prominently K.P.S. Menon and Subimal Dutt. The Selected Works of Jawaharlal Nehru are another relevant source for internal communication and decision-making in the early years of independent India. ${ }^{17}$ As Bajpai, Dutt and Menon spent various terms abroad, archives in host countries have been investigated, first, for a better understanding of their tasks and, second, to get an idea how they were perceived. Therefore, the archives of the foreign ministries in Berlin and Moscow have been visited as well as the 
National Archives of the United Kingdom in London. Besides, Bajpai's work in Washington is reflected in the Foreign Relation Series of the United States.

The body of literature around Indian foreign policy is steadily growing, but overall views are rare. A Diplomatic History of Modern India by Charles M. Heimsath and Surjit Mansingh remains the most comprehensive work for the early years. It correctly states that British India during the interwar years 'achieved a measure of autonomy in international affairs unprecedented for a non-self-governing dependency'. ${ }^{18}$ Furthermore, it acknowledges the issue of Indians overseas, though only as far as discussed at imperial conferences shortly after the Great War and its repercussions after independence. ${ }^{19}$ The most recent overall view has been authored by Jayanta Kumar Ray and provides the state of the art in terms of historiography written without access to archival sources. ${ }^{20}$ Partly drawing century-long lines from pre-independence history to India's contemporary relations with its immediate neighbours and the great powers, the issues discussed in this monograph do not come into the focus. Harish Kapur is the one historian who has emphasised the impact of advisors on Nehru. Though he too considers the prime minister the sole architect of Indian foreign policy and overlooks the professional experience gathered around the issue of Indians overseas, he highlights the role of Secretary-General Bajpai and his successor, Narayanan Raghavan Pillai. Without having consulted archival sources, he names main points of difference between Bajpai and Nehru, the former taking care for thoughtful positions 'in an atmosphere that was suffused with "high morality"'.21 Regarding Pillai, he properly assesses his personality without providing any details on his work or influence.

Most recently, Deepak Gupta in a non-academic monograph has shown interest in the Indians in the ICS. ${ }^{22}$ On the contrary, the only monograph on the ICS as a whole, by David Potter, says almost nothing about the issue. ${ }^{23}$ An article by the same author about manpower shortage, however, investigates causes and effects of the decision for Indianisation. ${ }^{24}$ Ann Ewing's research of the interwar period relies only on interviews with British officers. ${ }^{25}$ In Arudra Burra's investigation of the relationship between the ICS and the independence movement, once again British views dominate, combined with those of Indian politicians. ${ }^{26}$ The analysis of T.H. Beaglehole not only provides statistical data around the Indianisation of the ICS but is also a useful overview of career paths in the service. ${ }^{27}$ The most reluctant Indianisation of the Political Service has been investigated by W. Murray Hogben. ${ }^{28}$ Various Indian ICS officers have left memoirs, though usually lacking any details about the pre-independence part of their careers. N.B. Bonarjee and Jayavant Mallanah Shrinagesh form the exception, the latter discussing the dilemma between loyalty to his British superiors and to his countrymen. ${ }^{29}$ The recollections of H.M. Patel with the introduction by Sucheta Mahajan are most useful in this context as well. ${ }^{30}$ As of today, there are only two full biographies of Indian ICS officers: On the basis of private papers, Ashna Sen 
has written the story of her grandfather, S. M. Murshed, nominated to the service; ${ }^{31}$ and in 2017 , the present author published the political biography of Subimal Dutt, one of the protagonists of this book. ${ }^{32}$

There is a growing body of literature around the history of Indians overseas. Sugata Bose's overview provides a useful introduction, ${ }^{33}$ but the most profiled author on that field remains Hugh Tinker. His books cover emigration from South Asia, the history of indentured labour and the discussions of the early 1920s together with the struggle for political rights in the Empire and the Commonwealth. ${ }^{34}$ The contribution of Srikant Dutt is of relevance for his analysis of the mindset and the social history of Indians overseas. ${ }^{35}$ Recently, Sunil S. Amrith has focused on Indian emigration south-eastwards; his chapters on interwar Malaya are most valuable for this study. ${ }^{36}$ The fate of Indian labourers in Ceylon until 1940 has been investigated by Patrick Peebles in a monograph with many factual errors and doubtful assessments. ${ }^{37}$ K.L. Gillion and John Dunham Kelly have examined the history of those in Fiji, focusing on debates of the early 1920s. ${ }^{38}$ South Africa has drawn much attention for obvious reasons. For this study, Goolam Vahed's observations around 'the making of "Indianness", Dhupelia-Mesthrie's biography of Manilal Gandhi and Cheddie Anand's work around Indian political organisations have been particularly useful. ${ }^{39}$ For East Africa, Robert G. Gregory provides a comprehensive overview from 1890 onwards. ${ }^{40}$ The case of the Indian struggle in Kenya especially has been researched in much detail with excellent contributions by Sana Aiyar, Levi I. Izuakor and Christopher P. Youé. ${ }^{41}$ Stephen G. Rabe in his study of British Guiana in the Cold War has touched on the history of Indians in the colonial period. ${ }^{42}$

Research around British Indian foreign affairs in the interwar years is dearly lacking. T.A. Keenleyside analyses nationalist Indian attitudes towards Asia and elaborates how they stood in the way of Pan-Asianism and, therefore, formed a 'troublesome legacy' after independence. ${ }^{43}$ Bimla Prasad's book on the origins of Indian foreign policy focuses exclusively on the Congress Party and must be considered outdated. ${ }^{44}$ The same is true for the contribution of S.R. Mehrotra. ${ }^{45}$ A. Appadorai even falsely holds that 'the exclusion of Indians from the decision-making process in India's foreign policy before the country achieved independence' was a feature of the interwar years. ${ }^{46}$ Only recently, Vineet Thakur has published on the first politician-diplomats, all moderates, whose general role has been researched in detail by B.R. Nanda. ${ }^{47}$ V.S. Srinivasa Sastri, the main protagonist of this group in this monograph, has been dedicated a useful biography by his secretary, P. Kodanda Rao. ${ }^{48}$ The role of Indian agents during the Second World War has but been touched, and only in the case of Bajpai. Johannes Voigt mentions his role in land-lease negotiations and projects for Indo-US cooperation on war production. ${ }^{49}$ Bajpai also plays a minor role in Auriol Weigold's research around British Indian propaganda in the US. ${ }^{50}$ 
The Indian interim government was in power for less than a year, but its decisions shape South Asia until today. Given its relevance, the lack of research comes as surprise. Only recently, Rakesh Ankit has authored a monograph. Notwithstanding valuable research on various departments and personalities, both the MEA and Bajpai have been left out completely. ${ }^{51}$ Subrata Mitra has emphasised the phenomenon of the strong influence of the ICS and its officers from the transition period until today but has not gone into historical detail. ${ }^{52}$ The aspect of continuity plays a role in V. Subramaniam's volume on the social background of Indian administrators as well. ${ }^{53}$ Helpful for understanding the relevance of civil servants in years of transition has been the research of Andreas Eckert on their key role in colonial and post-colonial Tanzania, where, unlike in India, they came to form the government. ${ }^{54}$ Regarding foreign affairs, at least India's policy in the formative years of the UN has come into the focus. Manu Bhagavan has investigated the Indian role in the making of the Universal Declaration of Human Rights, while Lorna Lloyd and Vineet Thakur separately covered India's first success at the UNGA with a resolution against the discrimination of people of Indian origin in South Africa. ${ }^{55}$ An important contribution on early Indo-Soviet relations before and after independence is authored by Rakesh Ankit. ${ }^{56}$

The set-up of the IFS and the MEA is discussed in detail in Vineet Thakur's Postscripts on Independence. Notwithstanding the extensive usage of not too reliable memoirs, this is by far the best study on this subject. Pallavi Raghavan's text provides both useful observations on the continuity of foreign policy institutions and personnel with an emphasis on Bajpai, as well as basic errors: Two out of the four wartime heads of mission are wrongly named; the DEHL is completely overlooked, with its successor, the Department for Indians Overseas, seemingly popping up out of the blue in 1941. ${ }^{57}$ The overview of the foreign policy bureaucracy by Jeffrey Brenner is of a most general nature, and the same is true for the rather outdated book of Jayantanuja Bandyopadhyaya. ${ }^{58}$ Former Foreign Secretary J. N. Dixit has highlighted the role of the three protagonists of this study. ${ }^{59}$ The author's biography of Foreign Secretary Dutt provides detailed insights into the internal working of the MEA, tensions in the IFS and decision-making in the Nehru years, next to certain foreign policy aspects such as relations with China, Germany or the USSR.

There is no lack of books on Nehruvian foreign policy, but when Indian archives opened in the new millennium, the quality of research ascended to a new level. Before, only Sarvepalli Gopal, as director of the Historical Division of the MEA (himself an eyewitness to the Nehru years), had full access to all archival material. Until today, it has been impossible to cover this era without referring to his biography of Nehru. ${ }^{60}$ Srinath Raghavan has set standards, among others with his book on crisis management in the Nehru years. ${ }^{61}$ Another example is Rakesh Ankit's study of the international 
dimensions of the Kashmir conflict, covering the years up to $1966 .{ }^{62}$ Studies on India's bilateral relations with western countries, based on extensive archival research, have helped to understand motives and conflicts in Indian foreign policy. Paul McGarr has recently investigated Indo-American and Indo-British relations, whereas Srinath Raghavan has focused on the history of the US in South Asia. ${ }^{63}$ A history of Indo-Canadian relations has been authored by Ryan Touhey. ${ }^{64}$ Monographs by Johannes Voigt and the present author about India's complicated relations with East and West Germany have unearthed major contradictions in opinion-forming and decisionmaking. ${ }^{65}$ Research on India's other partners among the Soviet satellites is lacking, but Andreas Hilger has recently authored a detailed study of IndoSoviet relations based on extensive research in archives of both countries. ${ }^{66}$

The difficult relations between India and China, and especially the boundary conflict, have attracted much scholarly attention. Bérénice GuyotRéchard's recent award-winning monograph draws long lines, investigating the pre-history of the border war of 1962 over half a century ${ }^{67} \mathrm{~A}$ decisive moment, when Bajpai and Home Minister Patel challenged Nehru's China policy in vain, has been analysed by Chandrashekhar Dasgupta. ${ }^{68}$ The present author has researched the crucial years between 1955 and 1961, when Dutt formulated a strategy to settle the dispute. ${ }^{69}$

Quite a few Indian diplomats of the Nehruvian years have left memoirs, the majority providing little of relevance for researchers. Among the set of recollections of K.P.S. Menon, Many Worlds offers some valuable insights. ${ }^{70}$ More important are those of Gundevia and Tyabji, throwing light on the internal workings of the MEA. ${ }^{71}$ Dutt's With Nehru in the Foreign Office is based on thorough archival work, with useful chapters on the boundary conflict with China, ${ }^{72}$ and his unpublished autobiography, among others, provides intimate insider knowledge of the Nehru years.

The present monograph explains how the issue of Indians overseas became a national concern before the outbreak of the Great War. Since the colonial power was unwilling to fulfil promises for more Indian rights in return for British India's contribution to the war, the GoI adopted the struggle for fair wages and political emancipation of people of Indian origin abroad. A part of that policy was the establishment of the DEHL, which quickly acted with a vigour not intended by its creators and witnessed the rise of Indian officers.

Chapter 2 outlines the personal and professional backgrounds of three key protagonists embodying the continuity of foreign policy from the interwar years into the Nehru years. With his comet-like rise in the ICS and the department, Bajpai personifies how the policy around overseas Indians quickly gained relevance. K.P.S. Menon was India's most outstanding diplomat between 1929 and 1961, excelling on various postings abroad. Subimal Dutt, for most parts of his career a 'desk-man', worked mostly in the background. When he came to consider Nehru misled, he took the initiative, modifying the course of Indian foreign policy between 1956 and 1961. 
The following chapters focus on those parts of the world where the DEHL was active, South Africa and Ceylon being the most difficult cases. Personal diplomacy and two round table conferences buried all schemes for expatriation, enhanced the status of South African Indians and led to the establishment of an agency. In Ceylon, the GoI successfully negotiated minimum standard wages, but Sinhalese nationalism was after depriving even domiciled people of Indian origin of political rights and replacing them as a workforce. As British India underwent a comparable process of Indianisation, it faced difficulties turning down similar demands of another Asian ethnicity; no lasting solution was found.

In East Africa, where the Colonial Office vetoed an agency, a conflict occurred between Indian traders and white settlers trying to take control over Kenya. Delhi warded off such attempts and ensured that equal franchise for people of Indian origin was acknowledged on principle. In Zanzibar, Europeans tried, in vain, to exclude long-established Indian businesses from the profitable clove trade. Malaya, with its ongoing demand for Indian labourers, was mostly willing to cooperate and compromise. After the outbreak of the Second World War, the rubber boom, combined with a repressive government policy, caused severe conflicts that were not settled until the Japanese invasion. Unlike Malaya, Fiji witnessed violent conflicts in the early 1920s, but when the situation calmed down in the course of intense bilateral talks, the economic situation of Indian labourers improved.

Various schemes of the governors of British Guiana to attract even more Indian labourers failed due to financial stringency in Georgetown and lack of interest in Delhi. In Australia and Canada, people of Indian origin were discriminated against in certain provinces. After informal talks, the Australian government convinced Queensland to grant Indians full political franchise; this did not occur in the Canadian province of British Columbia until 1947. Negotiations with the US fell under the competence of the Foreign Office, but when Indians were declared ineligible for citizenship and immigration of Asiatics was banned, the EHL Department was consulted, though to no avail.

The ups and downs of Bajpai's and Menon's careers during the Second World War stand for the emancipation of India, or rather the lack of it. Whereas the former fell from grace, the latter considered his appointment as agent-general in Chungking a career jump. Bajpai's status over the years became the bone of contention among British politicians, some anxious not to encourage Indian nationalism while others seeing the time ripe to enhance British India's standing on the international floor and train a cadre of Indian diplomats. Though Bajpai considered his term frustrating, it made him an expert in early Cold War politics, which to a lesser extent was true for Menon as well, as he accompanied the Indian delegation to the San Francisco Conference. 
December 1946 saw a turnaround, because Nehru understood that newcomers were not capable of setting up a foreign ministry or properly representing new India abroad. Calling back Bajpai to establish the IFS and the MEA meant ensuring ICS dominance in foreign policy. For his return to China, Menon, on the contrary, exercised no influence on that process at all. Although he was appointed foreign secretary in the spring of 1948, he remained nearly invisible over the next four years.

Until the end of his term in the summer of 1952, Bajpai exercised much influence on foreign affairs. Though he never broke with Nehru, his ideas were distinctly different from those of the prime minister. He was opposed to Nehru's decision to appoint career changers as heads of the most important missions abroad. Regarding the Kashmir conflict, he favoured a pragmatic, sustainable compromise. Furthermore, Bajpai tried to keep relations with the West as friendly as possible, struggling with the prime minister's and Krishna Menon's anti-western reflexes. Finally, Bajpai, in vain, urged Nehru to prepare for the possibility of a military conflict with communist China. His attitude vis-à-vis the USSR, too, was characterised by caution, partly caused by his pronounced anti-communism.

Bajpai's departure led to a power vacuum in the MEA, and Indian foreign policy became less realist and cautious. This lasted until late 1955, when Secretary-General N. R. Pillai and Foreign Secretary Dutt formed an efficient tandem. After India's disastrous performance in the Hungarian crisis, Dutt managed to alert Nehru to the Chinese threat and formulated the first-ever Indian strategy in the boundary conflict. Trying to keep relations with the West friendly, Dutt, however, had no means to limit the influence of K.P.S. Menon, the ambassador in Moscow, on the prime minister and Indo-Soviet relations. Painting the USSR in brightest colours, Menon functioned as a door-opener for bilateral friendship.

\section{Notes}

1 Suranjan Das, The Nehru Years in Indian Politics. From a Historical Hindsight, Edinburgh Papers in South Asian Studies, 2001, 16.

2 BL, IOR, L/PS/12/4627. Quarterly Report October to December 1945, Bajpai, undated.

3 NMML, M.O. Mathai Papers, Correspondence with K.P.S. Menon. Letter, Nehru to K.P.S. Menon, 5 December 1946.

4 M.O. Mathai, Reminiscences of the Nehru Age, New Delhi: Vikas, 1978, p. 170.

5 Durga Das, India from Curzon to Nehru and After, New Delhi: Rupa, 2012, 5th edition, p. 48.

6 Harish Kapur, Foreign Policies of India's Prime Ministers, New Delhi: Lancer, 2009, p. 26.

7 T. T. Polouse, 'India as an Anomalous International Person', British Yearbook for International Law, 1970, 44: 201.

8 BL, IOR, L/E/PS/2636. Note, Monteath, 1 February 1942. 
9 Robert J. Blyth, The Empire of the Raj. India, Eastern Africa and the Middle East, 1858-1947, Basingstoke: Palgrave Macmillan, 2003.

10 Vineet Thakur, 'Liberal, Liminal and Lost: India's First Diplomats and the Narrative of Foreign Policy', Journal of Imperial and Commonwealth History, 2017, 45(2): 232-258.

11 Lawrence James, The Rise and Fall of the British Empire, London: Little, Brown, 1994, p. 371.

12 Judith Brown, Gandhi's Rise to Power. Indian Politics 1915-1922, Cambridge: Cambridge University Press, 1972, pp. 1-15.

13 Harijan, vol. VII, 25 March 1939, 'Requisite Qualifications'. See also Thomas Weber, 'Gandhian Philosophy, Conflict Resolution Theory and Practical Approaches to Negotiation', Journal of Peace Research, 2001, 38(4): 494-495.

14 NAI, DEHLO, 1932, B, 206-2. Note, Bajpai, 19 November 1932.

15 NAI, EHL, March 1924, no. 4-3 Appendix. Statement, Smuts at the Imperial Conference of 1923, 18 October 1923.

16 Amit Das Gupta, Serving India. A Political Biography of Subimal Dutt (19031992), India's Longest Serving Foreign Secretary, New Delhi: Manohar, 2017, pp. 228-404.

17 Selected Works of Jawaharlal Nehru, Second Series, New Delhi: Jawaharlal Nehru Memorial Fund, 1984-.

18 Charles H. Heimsath and Surjit Mansingh, A Diplomatic History of Modern India, Bombay: Allied, 1971, p. 4.

19 Ibid., pp. 7-10, 299-321.

20 Jayanta Kumar Ray, India's Foreign Relations, 1947-2007, New Delhi: Routledge, 2011.

21 Kapur, Foreign Policies of India's Prime Ministers, p. 33.

22 Deepak Gupta, The Steel Frame. A History of the IAS, New Delhi: Roli Books, 2019.

23 David C. Potter, India's Political Administrators 1919-1983, Oxford: Clarendon Press, 1986.

24 David C. Potter, 'Manpower Shortage and the End of Colonialism. The Case of the Indian Civil Service', Modern Asian Studies, 1973, 7(1): 47-73.

25 Ann Ewing, 'The Indian Civil Service 1919-1924: Service Discontent and the Response in London and in Delhi', Modern Asian Studies, 1984, 18(1): 33-53; Ewing, Survey of Former Officers of the Indian Civil Service, 1978, Ewing Papers, Centre of South Asian Studies, Cambridge.

26 Arudra Burra, 'The Indian Civil Service and the Nationalist Movement: Neutrality, Politics and Continuity', Commonwealth \& Comparative Politics, 2010, 48(4): 404-432.

27 T.H. Beaglehole, 'From Rulers to Servants. The I.C.S. and the British Demission of Power in India', Modern Asian Studies, 1977, 11(02): 237-255.

28 W. Murray Hogben, 'An Imperial Dilemma: The Reluctant Indianization of the Indian Political Service', Modern Asian Studies, 1981, 15(04): 751-769.

29 Neil Bruniat Bonarjee, Under Two Masters, London: Oxford University Press, 1970; Jayavant Mallanah Shrinagesh, Between Two Stools. My Life in the ICS before and after Independence, New Delhi: Rupa, 2007.

30 H.M. Patel, Rites of Passage: A Civil Servant Remembers, Sucheta Mahajan (ed.), New Delhi: Rupa, 2005.

31 Ashna Sen, The Rusted Trunk, Kolkata: Writers’ Workshop, 2011.

32 Das Gupta, Serving India.

33 Sugata Bose, A Hundred Horizons. The Indian Ocean in the Age of Global Empire, Cambridge, MA: Harvard University Press, 2009. 
34 Hugh Tinker, The Banyan Tree. Overseas Emigrants from India, Pakistan, and Bangladesh, Oxford: Oxford University Press, 1977; Tinker, A New System of Slavery. The Export of Indian Labour Overseas 1830-1920, London: Oxford University Press, 1974; Tinker, Separate and Unequal. India and the Indians in the British Commonwealth 1920-1950, London: C. Hurst, 1976.

35 Srikant Dutt, 'India and the Overseas Indians', India Quarterly. A Journal of International Affairs, 1980, 36(3-4): 307-335.

36 Sunil S. Amrith, Crossing the Bay of Bengal. The Furies of Nature and the Fortunes of Migrants, Cambridge, MA: Harvard University Press, 2013.

37 Patrick Peebles, The Plantation Tamils of Ceylon, London: Leicester University Press, 2001.

38 K.L. Gillion, Fiji's Indian Migrants. A History to the End of Indenture in 1920, Melbourne: Oxford University Press, 1962; Gillion, The Fiji Indians. Challenge to European Dominance, Canberra: Australian National University Press, 1977; John Dunham Kelly, A Politics of Virtue: Hinduism, Sexuality, and Countercolonial Discourse in Fiji, Chicago: University of Chicago Press, 1991.

39 Goolam Vahed, "The Making of "Indianess": Indian Politics in South Africa during the 1930 and 1940s', Journal of Natal and Zulu History, 1997, 17: 1-36; Uma Dhupelia-Mesthrie, Gandhi's Prisoner? The Life of Gandhi's Son Manilal, Cape Town: Kwela, 2004; Anand Cheddie, The Colonial-Born and Settlers' Indian Association in Natal Indian Political 1933-1939, M.A. thesis, Durban, 1992, https://researchspace.ukzn.ac.za/bitstream/handle/10413/7623/Cheddie_ Anand_1992.pdf?sequence=1\&isAllowed=y [accessed 12 December 2018].

40 Robert G. Gregory, India and East Africa. A History of Race Relations within the British Empire 1890-1939, Oxford: Clarendon Press, 1971.

41 Sana Aiyar, 'Anticolonial Homelands across the Indian Ocean: The Politics of the Indian Diaspora in Kenya, ca. 1930-1950', American Historical Review, 2011, 116(4): 987-1013; Levi I. Izuakor, 'Kenya: The Unparamount African Paramountcy, 1923-1939', Transafrican Journal of History, 1983, 12: 33-50; Christopher P. Youé, 'The Threat of Settler Rebellion and the Imperial Predicament: The Denial of Indian Rights in Kenya, 1923', Canadian Journal of History, 1978, 12(3): 348-360.

42 Stephen G. Rabe, U.S. Intervention in British Guiana. A Cold War Story, Chapel Hill: University of North Carolina Press, 2005.

43 T. A. Keenleyside, 'Nationalist Indian Attitudes towards Asia. A Troublesome Legacy for Post-Independence Indian Foreign Policy', Pacific Affairs, 1982, 55(2): 210-230.

44 Bimla Prasad, The Origins of Indian Foreign Policy. The Indian National Congress and World Affairs, 1885-1947, Calcutta: Bookland, 1960.

45 S.R. Mehrotra, 'The Development of the Indian Outlook on World Affairs before 1947', Development Studies, 1965, 1(3): 269-294.

46 A. Appadorai, The Domestic Roots of India's Foreign Policy 1947-1972, New Delhi: Oxford University Press, 1981, p. 49.

47 Thakur, 'Liberal, Liminal and Lost', 232-258; B. R. Nanda, Gokhale. The Indian Moderates and the British Raj, Oxford: Oxford University Press, 1977.

48 P. Kodanda Rao, The Right Honourable V.S. Srinivasa Sastri. A Political Biography, London: Asia Publishing House, 1963.

49 Johannes Voigt, Indien im Zweiten Weltkrieg, Stuttgart: Deutsche-VerlagsAnstalt, 1978.

50 Auriol Weigold, Churchill, Roosevelt and India. Propaganda during World War II, New York: Routledge, 2008. 
51 Rakesh Ankit, India in the Interregnum. Interim Government, September 1946August 1947, New Delhi: Oxford University Press, 2019.

52 Subrata Mitra, 'Symbiosis, Re-Use and Evolution: Administrators, Politicians, Citizens, and Governance in Postcolonial India', Commonwealth and Comparative Politics, 2010, 48(4): 457-478.

53 V. Subramaniam, Social Background of India's Administrators. A Socioeconomic Study of the Higher Civil Services of India, New Delhi: Publication Division Government of India, 1971.

54 Andreas Eckert, Herrschen und Verwalten. Afrikanische Bürokraten, staatliche Ordnung und Politik in Tanzania, 1920-70, Munich: Oldenbourg, 2007.

55 Manu Bhagavan, 'A New Hope: India, the United Nations and the Making of the Universal Declaration of Human Rights', Modern Asian Studies, 2010, 44(2): 311-347; Lorna Lloyd, “A Most Auspicious Beginning”: The 1946 United Nations General Assembly and the Question of Treatment of Indians in South Africa', Review of International Studies, 1990, 16(2): 131-153; Vineet Thakur, 'The "Hardy Annual": A History of India's First UN Resolution', India Review, 2017, 16(4): 401-429.

56 Rakesh Ankit, 'India-USSR, 1946-1949. A False Start?', in Madhavan Palat (ed.), India and the World in the First Half of the Twentieth Century, New Delhi: Routledge, 2018: 160-188.

57 Pallavi Raghavan, 'Establishing the Ministry of External Affairs', in David M. Malone et al. (eds.), The Oxford Handbook of Indian Foreign Policy, Oxford: Oxford University Press, 2015, pp. 80-91; Marie Lall, 'Mother India's Forgotten Children', in Eva Østergaard Nielsen (ed.), International Migration and Sending Countries: Perceptions, Policies and Transnational Relations, Houndmills: Palgrave Macmillan, 2003, p. 124.

58 Jeffrey Brenner, The Indian Foreign Policy Bureaucracy, Boulder: Westview Press, 1985; Jayantanuja Bandyopadhyaya, The Making of India's Foreign Policy. Determinants, Institutions, Processes and Personalities, Bombay: Allied, 1970, Revised edition.

59 Jyotindra Nath Dixit, Indian Foreign Service: History and Challenge, New Delhi: Konark, 2005.

60 Sarvepalli Gopal, Nehru: A Biography, 3 vols., New Delhi: Oxford University Press, 1975-1984.

61 Srinath Raghavan, War and Peace in Modern India. A Strategic History of the Nebru Years, Ranikhet: Permanent Black, 2010.

62 Rakesh Ankit, The Kashmir Conflict. From Empire to the Cold War, 1945-66, London: Routledge, 2016.

63 Paul McGarr, The Cold War in South Asia. Britain, the United States and the Indian Subcontinent, 1945-1965, Cambridge: Cambridge University Press, 2013; Srinath Raghavan, Fierce Enigmas. A History of the United States in South Asia, New York: Basic Books, 2018.

64 Ryan Touhey, Conflicting Visions. Canada and India in the Cold War World, 1946-76, Vancouver: University of British Columbia Press, 2015.

65 Johannes Voigt, Die Indienpolitik der DDR. Von den Anfängen bis zur Anerkennung (1952-1972), Cologne: Böhlau, 2008; Amit Das Gupta, Handel, Hilfe, Hallstein-Doktrin. Die bundesdeutsche Südasienpolitik unter Adenauer und Erhard, 1949-1966, Husum: Matthiesen, 2004.

66 Andreas Hilger, Sowjetisch-indische Beziehungen 1941-1966. Imperiale Agenda und nationale Identität in der Ära von Dekolonisierung und Kaltem Krieg, Vienna: Böhlau, 2018. 
67 Bérénice Guyot-Réchard, Shadow States. India, China and the Himalayas, 1910-1962, Cambridge: Cambridge University Press, 2017.

68 Chandrashekhar Dasgupta, 'Nehru, Patel and China', Strategic Analysis, 2014, 38(5): 717-724.

69 Amit R. Das Gupta, 'Foreign Secretary Subimal Dutt and the Prehistory of the Sino-Indian Border War', in Amit R. Das Gupta and Lorenz M. Lüthi (eds.), The Sino-Indian War of 1962. New Perspectives, New Delhi: Routledge, 2017, pp. 48-67.

70 K.P.S. Menon, Many Worlds, An Autobiography, Bombay: IBH, 1971.

71 Yezdezard Dinshaw Gundevia, Outside the Archives, Hyderabad: Sangam Books, 1984; Badr-ud-din Tyabji, Memoirs of an Egoist, vol. 1, 1907 to 1956, New Delhi: Roli Books, 1988.

72 Subimal Dutt, With Nehru in the Foreign Office, Calcutta: Minerva Associates, 1977. 
$\Longrightarrow$ Taylor \& Francis

Taylor \& Francis Group

http://taylorandfrancis.com 
Part I

SET-UP 
$\Longrightarrow$ Taylor \& Francis

Taylor \& Francis Group

http://taylorandfrancis.com 


\section{HOW IT ALL BEGAN - INDIANS OVERSEAS}

For centuries, Indian merchants had done business in areas around the Indian Ocean. In the late 19th century they started settling abroad too. Most of them kept themselves busy with retail and petty trade and, with the notable exception in Burma, none of them played a prominent role in the economies of their host countries. 'By the early 20th century, they were found throughout the British Empire and in some colonial areas under other European powers' ${ }^{1}$ The majority of overseas Indians, however, were labourers, mostly from South India, many of them being plantation workers. With the abolition of slavery across the Empire, which was implemented in two steps in 1833 and 1843, the demand for cheap unskilled labour had been covered by indentured labour often akin to slavery. ${ }^{2}$ In the acclaimed novel Sea of Poppies, Amitav Ghosh has paid homage to their sufferings. ${ }^{3}$

A prominent feature of these communities was their exclusiveness. Like in South Asia, they did not mix with others and opposed intermarriage. A racist undercurrent prevailed in Africa. Clinging on to their Indian identity was often interpreted as arrogance, and such beliefs were reinforced by the fact that their migration was inevitably linked to the interests of European imperialists. Though the local inhabitants considered them economic rivals, apart from a few rich businessmen, most overseas Indians had counted among the underprivileged in South Asia, wherefore none cared much about their fate until the Gandhian campaigns in South Africa changed the atmosphere. ${ }^{4}$ By 1913, British India, including Viceroy Lord Hardinge, arose to the case and expressed sympathies towards the victims of atrocities committed by the South African police. ${ }^{5}$

A few months prior to the outbreak of the Great War, the story of an attempted sexual abuse of Kunti, an Indian female plantation worker in Fiji, caused a stir. ${ }^{6}$ In the summer of 1913, an Indian newspaper had published a letter titled 'The Cry of an Indian Woman from Fiji' by Manoharanand Saraswati, an Arya Samaj missionary, telling how a plantation manager and an overseer tried to violate Kunti's chastity. In 1914, the story was retold in My Twenty-One Years in the Fiji Islands. The book depicted the British as 
'evil oppressors of the devout and pure', explicitly relating 'the Fiji narratives to Ramayan themes'?

Sexual exploitation of Indian women triggered an outcry in British India and a debate about indenture. Delhi presented the Fiji government a series of official inquiries, which continued until September 1915. The campaign was renewed in January 1917. Prominent politicians like Motilal Nehru and Sarojini Naidu fuelled public protests and, in an unprecedented event, a deputation of Indian women went to see the viceroy. On 12 March 1917, all recruitment for the colonies was stopped for the duration of the war and two years afterwards. "Largely from the pressure of this "Indian agitation" - the first successful "agitation" on a national scale of nascent Indian nationalism - the indenture system was not revived'. ${ }^{9} \mathrm{By}$ 1920, Delhi completely stopped the migration of labourers to Fiji. Emigration on the whole continued, but Act No. 7 of 1922 prohibited it in places where Indians were denied equal rights. ${ }^{10}$

The early 1920 s were particularly unruly years for the by now visibly overstretched Empire, a period when British rule was being challenged in many colonies and in Ireland. ${ }^{11}$ Also, the dominions, first of all Canada and South Africa, pushed for maximum independence. In 1926, the Balfour Definition clarified that though they retained their allegiance to the Crown, they were autonomous communities equal in status and, particularly in the context of their external affairs, in no way subordinate. This was a compromise worked out to avoid confrontation. ${ }^{12}$ India, however, was denied such status, notwithstanding its contribution to the war, and this raised a number of questions.

On the issue of common electoral franchise in the Commonwealth in general, Kenya came into the focus first. Though SSC Winston Churchill in August 1921 suggested that neither race, nor colour nor creed should form a barrier, in a confidential memo titled 'Equal Rights for Civilised Men' he clarified that he did not intend to include the mass of Indians: common electoral franchise should be granted only to those Indian men (not women) with a good knowledge of English together with a capital of a thousand pounds or an annual income of $£ 150$. What was later termed as 'civilisation tests' were never accepted by the Kenyan government and London did not push the matter, unwilling to estrange white settlers. Instead, from 1923, the British cabinet adopted a new logic: Indian franchise would threaten the interests of natives, whose protection was of paramount importance to the British government. Thereafter, if the issue was debated at all, it was to revolve around communal voting rolls. ${ }^{13}$

To counterbalance discontent in South Asia, the GoI found it convenient to support interests of Indians overseas. One of the best-known champions of that policy became V.S. Srinivasa Sastri, a disciple of Gopal Krishnan Gokhale. One of the moderates in the Congress, ${ }^{14}$ he won the respect of heads of government at the Imperial Conference in London in June 1921, 
where he highlighted the incongruity that existed between India theoretically treated as an equal member of the Empire and Indians overseas being subjected to several prohibitions. ${ }^{15} \mathrm{He}$ demanded to give the latter the right to citizenship in the respective territories. In the following debate of 'Empire Solidarity Versus White Solidarity in the Empire', Sastri won wider support, ${ }^{16}$ isolating South Africa, the only dominion to oppose the resolution.

As a result, the prime ministers of Australia, Canada and New Zealand asked Sastri to visit their countries. It had been easy to pass the resolution at the conference, but it was a different story to get it implemented at home. Sastri was meant to create a favourable public opinion. From May to October 1922, the GoI sent him to investigate the situation of Indians in these three dominions. Smuts, however, refused Sastri entry. At the Imperial Conference of 1923, he argued that the mission and Sastri's speeches attacking South Africa's Indian policy had agitated public opinion. Demands for equal franchise made the denial appear to be a stigma and went further than the opposition staged by local Indians. Indians overseas were better off than those in British India 'and no questions are more difficult and dangerous than those involving national dignity and honour' ${ }^{17}$ Such views would become commonplace with governments of territories with a noticeable Indian population.

In British India, the mission was considered a success, taking care of institutional changes. Until 1923, the Overseas Branch of the Department of Revenue and Agriculture looked after issues around migration. In April that year, the department was merged with the one for Education and Health, and the new DEHL came into being, mostly concerned with Indians overseas. As in the case of the departments of law and finance, an Indian was appointed as member, tantamount to a minister. Sir Muhammad Shafi had made himself a name in the Imperial Legislative Assembly back in 1915 when he demanded a separate Indian representation at Imperial Conferences. His appointment served two purposes: first, it was only logical that Indians should look after Indians overseas; second, in the Viceroy's Executive Council, equivalent to a cabinet, nominal parity was established between Europeans and Indians. Both aspects created the impression of British willingness to compromise. Indeed, the key portfolios (defence, home, FPD) remained under British members.

The name of the new department gave the wrong impression that it kept busy with everything not covered by the other five, wherefore in the Legislative Assembly its head was nicknamed 'the Honorary Member with the vast Portfolio'. ${ }^{18}$ Education, health or lands hardly played a role. The extravagant designation obviously aimed at avoiding white criticism against Indians interacting with foreign governments. The department was officially concerned with two aspects of foreign relations: the status of Indians in the Empire and the conditions under which emigration to certain parts was permitted. In this context, the GoI was free to negotiate directly with 
governments of other parts of the Empire and appoint agents there. If such negotiations raised important questions of policy, Delhi had to ensure that it did not prejudice or hamper the free consideration of the Secretary of State for India (SSI), i.e., the British government. The former had the power of superintendence, direction and control, vested in him under Section 2 of the Government of India Act of 1919.

There were, however, certain relaxations. Delhi enjoyed specific authority to communicate and negotiate directly with the Government of South Africa on the position of local Indians. In cases where emigration to other parts of the Empire was made lawful, the GoI was free to correspond directly with the respective authorities. Such freedom was also granted in matters of urgency, as long as the SSI received copies of all communication. ${ }^{19}$ This part-autonomy in dealing with certain aspects of foreign affairs fits into the Empire-wide picture of those years. Its major parts (the dominions and British India) were meant to settle inter-Empire disputes on their own, unburdening the overstrained metropolis.

British India's foreign affairs actually were the domain of the FPD. The latter was mostly an outlet of the Foreign Office and kept itself busy with Indian princes and the Great Game. Its officers, until the 1920s exclusively European, belonged to the prestigious Political Service, and as part of the political wing were serving either in the North West Frontier Province (NWFP) or as dewans with princely states in South Asia. The foreign wing covered areas neighbouring British India towards the north and the Gulf. In sum, the field of activity of the FPD was limited, even more so in comparison with the DEHL, sending delegations to all continents except for Europe. The imminent rivalry between the two departments was deepened by the fact that one was a European and the other mostly an Indian affair. It took until the late 1930s, however, that high-ranking officers of the FPD openly criticised the other department. The second delicate issue was the establishment of agencies abroad, as foreseen in Act No. 7 of 1922. To soften the impression of interference in domestic affairs by appointing representatives near exclusively looking after an ethnic minority, those proto-diplomats were initially called emigration agents. ${ }^{20}$ Their actual work, however, had little to do with promoting large-scale migration, which had mostly ended with the Great War.

Initially, the staff of the DEHL was surprisingly small. One secretary, one deputy and one under secretary together with a registrar made no more than a small office. Whether this indicated that the British intended the department to play but a minor role is open to debate. In any case, the permanent struggle to limit expenses was applied. The merger of two departments had reduced the number of officers by 55.5 per cent. ${ }^{21}$ B.N. Sarma, the former member of the Revenue and Agriculture Department, stayed on board for a while. Montagu Sherard Daws Butler, an experienced officer from the 1896 ICS batch from Punjab, was selected as secretary. Deputy Secretary Robert 
Benson Ewbank from the 1907 batch of the Bombay ICS cadre had made a name as an expert for agriculture, propagating co-operative societies. $\mathrm{He}$ had been in charge of the Overseas Branch in the Revenue and Agriculture Department and guaranteed some continuity. ${ }^{22}$ Assistant Secretary A.K. Sarkar completed the small group of ICS officers.

The initial dominance of British officers in the top ranks was not surprising. The Indian element in the ICS had been kept small until the Great War, and there were not enough Indian officers with sufficient experience to run a department. In 1783 Lord Hastings, on behalf of the East India Company, had outright banned all Indians from higher administrative ranks. The Charter Act of 1833 and the Queen's Proclamation of 1858 nominally had declared all applicants eligible independent of race or creed. ${ }^{23}$ Nevertheless, the British had no intention to open up the higher ranks even for highly qualified Indians, as those were mostly graduates of universities in Calcutta and Madras, the two provinces which had the most reputed academic institutions. Neither the 'effeminate' Bengali 'babus' ${ }^{24}$ nor the 'black' Tamil brahmins, however, were considered to be masculine 'men of character', with a 'natural ability to rule'. Instead, the British associated such qualities with Indians from the north-west. Unfortunately, the latter did not master the annual ICS examination in London. Due to syllabus and age limits, Indians formed but 5 per cent of the 528 ICS officers recruited between 1904 and $1913 .{ }^{25}$

The Indianisation of the service, a long-standing Indian demand, began only in 1924. Recruitment had been stopped during the war. Thereafter, due to casualties in the generation of young men who could have been possible ICS candidates, along with the declining prestige of working in the increasingly restless colonies, the British had to employ a steadily growing number of Indians. ${ }^{26}$ By 1939, numeral parity had been reached. On 1 January 1940, the ICS cadre was composed of 597 Indians and 588 Europeans. ${ }^{27}$ Most of the top ranks, nevertheless, remained in European hands as the most of the Indians were not yet senior enough in the service.

Accordingly, in 1923, the new department faced difficulties in selecting agents for Ceylon and Malaya. The press communiqué read:

The chief function of these officers will be to protect and advise all classes of Indian emigrants within their charge and to bring any requirements of such emigrants to the notice of the proper authorities in India or in the country in which they are appointed. ${ }^{28}$

Therefore, there was a need for officers fluent in Tamil, and to a lesser extent Telugu or Malayalam, which were the languages of the vast majority of labourers. The Madras government was approached for either senior officers from the Provincial Service or junior ICS officers. ${ }^{29}$ The posts were considered attractive for both prestige and high salaries. Notwithstanding some 
discreet pressure, the DEHL hardly got what it had asked for. Subramaniyam Ranganathan, ICS, commanding only six years of service, was released for Ceylon. Arulanandam Pillai from the Provincial Service, who was transferred to Malaya at the age of 53, looked forward to retirement within two years, though agents were meant to be appointed for a three-year term. The department, nevertheless, did not complain: Pillai was knowledgeable about labour conditions, and compared to Ceylon, Malaya was considered rather a routine job..$^{30}$ By appointing officers from two different services, the DEHL created a pattern, remaining in force until 1938.

The new agents received instructions to open offices easily accessible for the majority of local Indians. Also, they were to establish close relations with the colonial government, especially the controller of labour, and estate managers. They needed to keep diaries and send monthly reports on everything affecting Indians, with special emphasis on their wages. In case the Commerce Department required information, the agents had to communicate through the DEHL. ${ }^{31}$

\section{Notes}

1 Srikant Dutt, 'India and the Overseas Indians', India Quarterly. A Journal of International Affairs, 1980, 36(3-4): 315.

2 I. M. Cumpston, Indians Overseas in British Territories 1834-1854, London: Oxford University Press, 1953; Amarajit Kaur, 'Plantation Systems, Labour Regimes and the State in Malaysia, 1900-2012', Journal of Agrarian Change, 2014, 14(2): 195-196.

3 Amitav Ghosh, Sea of Poppies, London: John Murray, 2008.

4 Usha Mahajani, 'India and the People of Indian Origin Abroad', in M. S. Rajan (ed.), India's Foreign Relations during the Nehru Era, Bombay: Asia Publishing House, 1976, pp. 201-202.

5 Bipan Chandra, Mridula Mukherjee, Aditya Mukherjee, K.N. Panikkar, and Sucheta Mahajan, India's Struggle for Independence 1857-1947, New Delhi: Penguin Books, 1988, p. 175.

6 For the following, see John Dunham Kelly, A Politics of Virtue: Hinduism, Sexuality, and Countercolonial Discourse in Fiji, Chicago: University of Chicago Press, 1991, pp. 45-60; see also Lal, Brij V., Chalo Jahaji. On a Journey through Indenture in Fiji, Australian National University Press, 2012, http://press-files. anu.edu.au/downloads/press/p212781/pdf/book.pdf?referer=123 [accessed 3 February 2018], pp. 195-214.

7 Kelly, A Politics of Virtue, p. 45.

8 K.L. Gillion, Fiji's Indian Migrants. A History to the End of Indenture in 1920, Melbourne: Oxford University Press, 1962, pp. 182-183.

9 Kelly, A Politics of Virtue, p. 48.

10 Patrick Peebles, The Plantation Tamils of Ceylon, London: Leicester University Press, 2001, p. 115.

11 Ronald Hyam, Britain's Declining Empire. The Road to Decolonisation, 19181968, Cambridge: Cambridge University Press, 2006, pp. 30-34.

12 Ibid., pp. 69-70.

13 Kelly, A Politics of Virtue, pp. 96-97. 
14 P. Kodanda Rao, The Right Honourable V.S. Srinivasa Sastri. A Political Biography, London: Asia Publishing House, 1963, pp. 84-85.

15 Vineet Thakur, 'Liberal, Liminal and Lost: India's First Diplomats and the Narrative of Foreign Policy', Journal of Imperial and Commonwealth History, 2017, 45(2): 242-246.

16 Kodanda Rao, The Right Honourable V.S. Srinivasa Sastri, p. 101.

17 NAI, DEHLO, March 1924, A, 4-3, Appendix. Statement of Prime Minister Smuts at the Imperial Conference of 1923, 18 October 1923.

18 CSAS, Richard Tottenham Papers. Memoirs, book II, chapter 15, 'The Legislative Assembly'.

19 NAI, DEHLO, 1932, B, 172. Memorandum on Indians Overseas, Bajpai, 2 June 1931.

20 NAI, DEHLO, January 1924, B, 204-206. Letter, Ewbank to Emigration Agents Ranganathan (Ceylon) and A. Pillai (Malaya), 17 September 1923.

21 NAI, DEHLO, August 1925, B, 68-74. Note, Bajpai, 4 December 1924.

22 I. J. Catanach, Rural Credit in Western India 1875-1930. Rural Credit and the Co-Operative Movement in the Bombay Presidency, Bombay: Oxford University Press, 1970, pp. 95-99.

23 Speeches and Documents on Indian Policy, 1750-1921, vol. I, Arthur Berriedale Keith (ed.), London: Milford, 1922, pp. 382-383.

24 Meenakshi Mukherjee, An Indian for all Seasons. The Many Lives of R. C. Dutt, New Delhi: Penguin Books, 2009, pp. 16-17; see also Michael Silvestri, 'The Bomb, Bhadralok, Bhagavad Gita, and Dan Breen: Terrorism in Bengal and its Relation to the European Experience', Terrorism and Political Violence, 2009, 21(1): 9; Mrinalini Sinha, Colonial Masculinity: The 'Manly Englishman' and the 'Effeminate Bengali' in the Late Nineteenth Century, Manchester: Manchester University Press, 1995.

25 David C. Potter, 'Manpower Shortage and the End of Colonialism. The Case of the Indian Civil Service', Modern Asian Studies, January 1973, 7(1): 49.

26 Amit Das Gupta, Serving India. A Political Biography of Subimal Dutt (19031992), India's Longest Serving Foreign Secretary, New Delhi: Manohar, 2017, pp. 33-35.

27 T.H. Beaglehole, 'From Rulers to Servants. The I.C.S. and the British Demission of Power in India', Modern Asian Studies, April 1977, 11(2): 240-241.

28 NAI, DEHLO, January 1924, B, 36-82. Press Communiqué, DEHL, 31 August 1923.

29 NAI, DEHLO, January 1924, B, 36-82. Letter, Ewbank to Moore, Government of Madras, 20 February 1923.

30 NAI, DEHLO, January 1924, B, 36-82. Note, Sarkar.

31 NAI, DEHLO, January 1924, B, 204-206. Letter, Ewbank to Ranganathan and Pillai, 17 September 1923. 


\section{KEY PROTAGONISTS - GIRJA SHANKAR BAJPAI, K.P.S. MENON AND SUBIMAL DUTT}

\section{Girja Shankar Bajpai}

By early 1924, the DEHL and the two agencies had been put in operation. The few officials in Delhi and abroad would have been of little relevance had it not been for Girja Shankar Bajpai, the very expert on the issue of Indians overseas in the ICS. After joining the department as under secretary in 1923, he was appointed officer on special duty for Indians overseas in August 1924. ${ }^{1}$ His career in that field, however, had started earlier already. Born on 3 April 1891 in Allahabad, like most ICS officers he belonged to the educated urban upper middle class. ${ }^{2}$ His father Pandit Seetla Prasad Bajpai was a judge who rose to the rank of minister of justice in Jaipur State. Girja Shankar attended Jubilee High School, Lucknow, and Merton College, Oxford. In 1914, in his second attempt, he passed the ICS entrance examination, standing first after the final examination at the end of the usual one-year probation in the UK. ${ }^{3}$ Bajpai qualified as one of those 'brown Englishmen' who the British hoped to educate for and within the ICS. For serving the colonial power, they were despised by the independence movement. Highly anglicised, Bajpai (like so many of his colleagues who had made similar use of their leisure time while in Europe) loved France, especially Paris, which was more vibrant and permissive than London. Having a knack for languages, he was fluent in French, among others.

Returning to India in late 1915, he joined the cadre of the United Provinces (UP). His first posting was Varanasi; thereafter he served in Bareilly and Muttra. ${ }^{4}$ In later years, Bajpai indicated that he found nothing in the life of a district officer. According to N.B. Bonarjee, who served under him in the late 1930s, he 'looked on district officers as a somewhat uncouth species, addicted to riding and shooting and generally lacking in spirit and polish'. ${ }^{5}$ Preferring secretariat work, Bajpai was appointed under secretary with the UP government as early as July 1920. From April 1921 onwards, he worked with the central government, and in a rare exception was never transferred back to his home province. 
The background of his meteoric rise in the early stages of his career is unknown; at any rate, the exceptional situation created by the war sped up careers. The war effort went along with an increasing demand for ICS officers in Delhi, causing vacancies in the higher ranks of the provinces. The few Indians in the service, however, usually were not trusted with postings of greater relevance. Most of them worked as judges. The judicial service provided better chances for promotion, ${ }^{6}$ but its 'sedate and monotonous life' horrified most officers. ${ }^{7}$

Usually, it took at least eight years in the service until it was decided whether an officer would join the executive or the judicial line; provincial governments tended to transfer substandard officers to the latter. ${ }^{8}$ Bajpai escaped this fate and climbed the ranks with most unusual speed. The reasons for his transfer to Delhi are unknown. He did, however, make himself a name and friends with Sastri, who insisted on Bajpai accompanying him as private secretary when attending the Imperial Conference in 1921, the Conference for Limitation of Armaments in Washington in 1921/1922 and the League of Nations in 1922. ' In Washington, Bajpai won 'valuable experience' when attending meetings once a week as secretary to the British delegation. ${ }^{10}$

The decision to let Bajpai accompany Sastri at such important occasions indicates that the officer was capable to win the confidence of rivalling parties. Sastri counted among those moderates 'who occasionally acted as "honest brokers" between Gandhi and the government'. ${ }^{11}$ Nevertheless, he remained a nationalist, who after long hesitation, by April 1922, accepted the concept of self-determination for India. ${ }^{12}$ The official sent along with him clearly was meant to be a watchdog. On the other hand, Sastri would not have asked for Bajpai's services if he had not trusted him. In his report on the Washington conference, he praised Bajpai as indispensable, 'prompt, always cheerful and thoroughly efficient'. ${ }^{13}$ The latter responded with warmth, praising Sastri for his 'very exceptional eloquence'. ${ }^{14}$

Sastri's delicate tour needed expert knowledge regarding Indians overseas. At the latest, upon his return, Bajpai, only 31 years old, had become an authority on that field. While still on tour, he suggested that the Department of Revenue and Agriculture should put him on special duty 'to write a history of our emigration policy'. ${ }^{15}$ Deputy Secretary Ewbank did not want Bajpai to do so in official capacity and on government costs, even more as the GoI had no interest in drawing special attention to its emigration policy. Nevertheless, he approved 'a brief and lucid account of the overseas position generally published in the India of Today series', which might 'be useful in clearing away prejudices and misunderstandings and in justifying the general policy pursued by the Govt. of India'. ${ }^{16}$ Bajpai ensured Ewbank that he had 'no desire to write a controversial book' but only 'a plain narrative of carefully selected facts' based on classified documents. ${ }^{17}$ The department granted permission ${ }^{18}$ but initially did not approve parts of the manuscript; 
Bajpai privately complained to his friend John Walton that 'it was impossible to write a book without expressing some opinions'. ${ }^{19}$ It was finally published in 1924 without carrying the author's name. ${ }^{20}$

Bajpai complained even more vehemently when he was appointed under secretary but not in charge of Indians overseas. Butler, he believed, was 'probably afraid that with Ewbank and myself both working on overseas questions, there will be too much for him to read'. ${ }^{21}$ Nevertheless, after he had officiated as deputy secretary in 1924, Bajpai was appointed officer on special duty for the task of Indians overseas in 1925.22 By early 1927 , Ewbank reverted to Bombay and Bajpai became the new deputy secretary. ${ }^{23}$

The correspondence between him and Walton, covering the years between January 1921 and December 1925, shows the former expressing personal views versus the latter's rather formal replies. At the occasion of his first visit to the US, Bajpai indicated a certain dislike for the country that would remain one for life. He found New York impressive but an 'anaesthetic disarray', notwithstanding women's dresses 'almost as striking as in Paris.... English is spoken with the most cacophonous accent - and is not all pleasing from American mouths'. Temporarily, frustration got hold of him for other reasons too. Typically, he found his allowances insufficient. ${ }^{24}$ When talks in Australia got stuck, the seemingly tireless official felt that the 'association with statesmen is slowly but surely destroying the robust optimism with which nature has endowed me'. ${ }^{25}$

The young Bajpai showed no sympathies for the independence movement, ${ }^{26}$ but did not feel that 'these fellows can do much harm now. The majority of people are tired of strikes, hartals and other amenities of noncooperation'. ${ }^{27}$ He deeply regretted that his own reasoning had not made 'many converts among my Indian friends. You know perfectly well how sentiment often gets the better part of one's judgment, and politics in India at the present moment are pre-eminently sentimental'. The Swarajists he considered the 'most sentimental of all Indian politicians'. ${ }^{28}$ They did not realise that their campaigns against racialism worsened the situation of their countrymen abroad. 'Unconsciously perhaps most of them, if not all, are permeated by a spirit of non-cooperation; Gandhi's philosophy has enslaved them, though they may not admit it'. ${ }^{29}$ Bajpai despised certain members of the Standing Emigration Committee (SEC), who were 'afraid of their very shadows and spend sleepless nights in devising formulae which could not be construed even by the most ingenious casuists as committing them to anything, ${ }^{30}$ At the same time, he criticised Churchill for his uncompromising stand on the status of Indians in Kenya. ${ }^{31}$ 'Both the Liberals and the Gandhiites are badly in need of a rallying cry - and they have got one now in Kenya. I can see a trust alliance for mischief rapidly forming. ${ }^{32}$

Instead, and throughout his career, Bajpai sympathised with realists or moderates like Sastri and Tej Bahadur Sapru for having 'plenty of sound sense and a healthy respect for realities' ${ }^{33} \mathrm{He}$ welcomed the appointment 
of Lord Birkenhead as SSI for the combination of firmness, imagination and sympathy needed for stability and continuity of policy. In the case of Smuts, he expressed 'a certain amount of admiration for the gallant general's insight into the character of some of his colleagues'. ${ }^{34}$

Bajpai was the right man at the right time, commanding talents that would have made him the pride of any foreign service. Multilingualism is a great advantage for those occupied with international affairs. Moreover, Bajpai was an extraordinary writer and orator with an outstanding command of English. When he once gave a speech at the Legislative Assembly, K.P.S. Menon, himself a great orator, found him 'as usual excellent, noncommitted, logical, slightly cynical and irritatingly self-complacent'. ${ }^{35}$

Bajpai always stayed on top of things thanks to his photographic memory. Richard Tottenham, ICS, tells the story how Bajpai had been asked to give a detailed report on a meeting, but was found 'fast asleep'. A few hours later, nevertheless, he handed over

a neatly typed, almost verbatim report of the whole proceedings.... If he just sat and made his mind a blank, he could remember practically everything that was said, even if he did not understand it. But the record had to be made quickly, because the memory faded after a few hours. ${ }^{36}$

This capacity was useful. Even more relevant, however, was his impeccable knowledge of all files in his offices. ${ }^{37}$

Bajpai was soon considered indispensable in the DEHL. In 1925/1926, he was secretary to the deputation to South Africa. A year later and again in 1932, he played a crucial role at the Round Table Conferences with South Africa. In 1926 and again in 1930, he functioned as advisor to the delegations at the Imperial Conferences; in the same capacity, he served the delegation to the League of Nations in 1929 and 1930. His promotions lagged behind his relevance; it was only in 1929 that he was appointed joint secretary. The rise to the rank of secretary - the first Indian ever - followed only two years later. On 12 March 1940, Bajpai finally became head of the department.

Month-long absences, mostly due to delegations abroad and partly due to rather poor health, did not limit his influence. On the contrary, the department could come to a standstill without Bajpai, who had the last word in everything relevant. In August 1929, the publication of the final version of a half-yearly report of the agent in South Africa - a delicate task - was postponed until Bajpai's return from a delegation in November. ${ }^{38}$ There is good reason to talk of the 'Bajpai Department' at a juncture when the officer held but the rank of joint secretary.

Bajpai's social skills contributed to his quick rise. It is telling that he was hardly ever contradicted by any superior. Muhammad Shafi hardly 
interfered in day-to-day business. His successor Mian Fazl-i Husain, who Viceroy Willingdon in 1933 considered 'probably the keenest political Indian, with more wires to pull than anybody else in all parts of the country', ${ }^{39}$ was more assertive. Nevertheless, right at the beginning of his term Bajpai put him in his place, insisting that the preparations for the Round Table Conference with South Africa were to be done along the secretary's and not the member's line. ${ }^{40}$ Jagdish Prasad was the most dominant head of department, regularly commenting letters from agents and giving orders to his officials. A former ICS officer from the 1908 batch and former UP chief secretary, he and Bajpai were, nevertheless, kindred spirits. Therefore, Jagdish Prasad reduced Bajpai's workload rather than his influence.

Bajpai's superiors both appreciated his outstanding work and saw no reason to trouble him for personal reasons. Such a constellation is necessary for every career, and Bajpai's case was no different. He lived in style - beyond his means, according to rumours - and knew how to entertain guests. ${ }^{41} \mathrm{His}$ critiques considered this his Achilles heel: N.C. Mehta, deeply frustrated from serving under Bajpai though belonging to the same batch, gave a particularly venomous account. Whereas Bajpai indeed promoted promising Indian officers, Mehta held that his superior looked down on them and flattered the British instead. Besides, he

used to visit Sir M[ohammed] Habibullah's house twice every day. He used to superintend the kitchen if there was a tea party in Sir M. Habibullah's house. After the death of Lady Habibullah, he used to read the namaz at her graveyard once a week. ${ }^{42}$

K.P.S. Menon, a favourite of Bajpai's, took an ambivalent stand. On the one hand, he admired his mentor as a 'great politician', ${ }^{43}$ 'capable fellow'44 and 'real diplomat', ${ }^{45}$ but on the other hand he found him 'a little pompous' ${ }^{46}$ clever, 'but an egoist. A little too much of a tactician, too' ${ }^{47}$

Subimal Dutt, another favourite of the secretary and among those who came to know him well, after the latter's demise emphasised that all rumours that he had been 'selfish, ambitious, unscrupulous' were wrong and had been spread by those envying him..$^{48}$ Nevertheless, as late as 1953 , Dutt in his diary lamented Bajpai's vanity, driving the then governor of Bombay back to Delhi 'to be in the thick of things' ${ }^{49}$ Moreover, in 1938, as a newcomer to Delhi, Dutt felt that initially Bajpai had treated him unfairly. ${ }^{50}$ N.B. Bonarjee too indicated a certain arrogance in Bajpai when working in the DEHL, and so did Badr-ud-din Tyabji, an IFS officer serving under the then secretary general of the MEA:

He rather enjoyed turning up his nose at the gaucheries of others, and particularly of his immediate subordinates, and to make bon 
mots at their expense - so much so that he would rather let them stew in their own ignorant juice than deprive himself of the pleasure of laughing at them, so feeling immeasurably superior. ${ }^{51}$

Obviously, one occasionally needed to have a thick skin when working under Bajpai. Moreover, the secretary was blunt or even harsh with those he considered substandard. Bajpai criticised Kurma Vekata Reddi, agent in South Africa from 1929 to 1932, for making 'unnecessarily heavy weather's2 and 'unintelligible' suggestions; ${ }^{53}$ Reddi lacked presence of mind, ${ }^{54}$ 'as usual' raised points of no practical importance ${ }^{55}$ or acted 'really inconsistent with our instructions'. ${ }^{56}$ Beyond doubt, Bajpai was power-conscious and powerhungry. Some junior officers working under him disapproved that (though they all belonged to the 'ICS brotherhood') he did not consider himself primus inter pares but the unchallenged boss. ${ }^{57}$

Tyabji claims that Bajpai did not care to discuss decisions even with those next below in the hierarchy. During the daily morning rounds in the MEA, the secretary-general would give a 'masterly summing up of the most important issues of the day, livening up the proceeding by his barbed wit. This he freely exercised on all and sundry, not excluding the Foreign Secretary [K.P.S. Menon] and the other officers present'. As both Menon and Commonwealth Secretary Dutt had worked under Bajpai earlier, 'they served more as clay pigeons to be shot down at will rather than as sparring partners with whom the champion could not only exercise his own skill but also teach them how to develop their own'. ${ }^{58}$ Tyabji's recollections, however, have to be taken with a pinch of salt, as he felt fit for the highest ranks but never made it. Not to respond to his partly absurd suggestions and schemes became routine in the MEA. ${ }^{59}$ Gundevia, self-confident too but not vain, mocked the stiff ceremonial of meetings, but found them 'both instructive and interesting' due to open discussions. ${ }^{60}$

Though it is problematic to do Bajpai justice only on the base of recollections of others, those have some observations in common: Bajpai appears as a self-confident, demanding superior commanding extraordinary knowledge. Those who had no problem to accept him as the undisputed boss and worked hard themselves went on well with him. Like every head of department, Bajpai promoted capable officers, and his favourites were all Indians. Given the (in part) willy-nilly subversive nature of the DEHL, it is somewhat surprising, however, that he was popular with most of the British in the GoI. When he finally had to leave Delhi in 1941, Viceroy Linlithgow wondered if he could spare Bajpai. ${ }^{61}$

Among Bajpai's many essential contributions to Indian foreign policy, bringing the best officers into the realm of international relations was among the more important. From the spring of 1948, the MEA was led by Foreign Secretary K.P.S. Menon and Commonwealth Secretary Subimal Dutt, assisting Secretary-General Bajpai. Both were discoveries from the colonial 
period, and both exercised a lasting influence on Indian foreign policy long after their mentor's demise.

\section{K.P.S. Menon}

Kumara Padmanabha Sivasankara Menon was born on 18 October 1898 in Palakkad/Phalgat and grew up in Kottayam in the princely state of Travancore. As in Bajpai's case, his father Kumara Menon had studied law. As the second son, K.P.S. attended CMS College in Kottayam and Madras Christian College. Before he sailed off to England in August 1918 to join Christ Church College at Oxford University, his father passed away on 16 December 1917. The elder brother K.P. Gopala Menon, also a lawyer, financed K.P.S.'s studies until the latter passed the ICS entrance examination in the summer of 1921.

K.P.S. was an exceptional student in Madras, standing first in his year in history, ${ }^{62}$ politics and English. ${ }^{63}$ He took up history at Oxford, ${ }^{64}$ where he excelled once again. Menon would have done well in the academia; all his life, he published and spoke on historical subjects. His true passion, however, was politics. Already in his first year, he joined the Oxford Majlis Asian Society, a students' association promoting Asian (i.e., mostly Indian) culture. First, this meant debates on cultural and political topics, with the young men sharpening their rhetoric skills. Second, apart from those internal meetings, the Majlis invited guest speakers. Among them were prominent Indian politicians like Sarojini Naidu, ${ }^{65}$ Srinivasa Sastri and Bal Gangadhar Tilak $^{66}$ - all propagating dominion status or independence for India. On the other hand, the Majlis also invited USSI Lord Lytton, speaking on 'the future of India as a partner in the British Commonwealth'. ${ }^{67}$ Menon was among the many clearly sympathising with the former. Somewhat typical for a politicised enthusiastic young Indian, he was disappointed that Sastri was 'perfectly bright and reasonable, but desperately moderate' ${ }^{68}$ Menon's ambition manifested in his election first as treasurer ${ }^{69}$ and later as president of the Majlis. ${ }^{70} \mathrm{He}$ remained active until his final departure from Oxford in November 1922.

Menon's political activities made him suspicious in British eyes; he appeared particularly dangerous for his great ability. His ideas were considered 'those of thoroughgoing revolutionaries'. According to police reports, he made no secret of his 'hatred of the British Government'. In the years between the end of the Great War and the beginning of the Indianisation of the ICS, however, manpower shortage in the service was that dramatic that the authorities could hardly afford not appointing the candidate standing first in the 1921 entrance examination. ${ }^{71}$ During his one-year probation, Menon, however, attended a conference discussing the future constitution of India. He allegedly established 'that India cannot long remain a partner in the British Empire'. Interrogated by British officials, Menon and his 
co-probationer S. K. Kirpalini 'both expressed revolutionary sentiments and had announced their intention of working on revolutionary lines in their capacity as government servants and that, should this not prove a success, they would resign their appointment in 3 or 4 years' time'. When confronted with these reports soon thereafter, Menon, feeling his 'conscience alerted against the civil service, ${ }^{72}$

asserted that he had been altogether incorrectly reported. His own view ... was that India should in time have a place like that of the dominion in the federation of nations forming the British Empire. He agreed that to work for anything like disruption would be incompatible with clause 1 of his covenant and expressed his willingness to sign the covenant and abide by its terms.

The India Office warned that Menon and Kirpalini 'might both be a source of danger to government', ${ }^{73}$ but appointed both.

In April 1923, Menon's marriage with Saraswati Anujee, the daughter of former Congress President Sir Sankaran Nair, was prone to make things even more difficult. Nair, member for education from 1915, was a critic of colonial rule. Other ICS officers from families with strong Congress links, depending on the respective political climate, were viewed with suspicion. Most prominently, there were three from the Nehru family. Dr S.S. Nehru from the 1913 batch was kept in high esteem, among others, for his aerodynamic research. ${ }^{74}$ On the contrary, Ratan Kumar Nehru from the 1924 batch was considered a problematic candidate, as his father had signed the volunteer pledge in $1921^{75}$ and had been sent to prison for six months. Though the son was 'reported to have borne a good character and not to have developed any strong political leanings', he had to serve outside his home province. ${ }^{76}$ After joining the cadre of the Central Provinces, however, he met no further obstacles. Braj Kumar Nehru from the 1931 batch did not face any such problems. His mother had 'on more than one occasion come to notice for rather violent remarks to various [political] meetings' in London. As he himself had kept aloof from politics, the issue was discussed without any consequences. ${ }^{77}$ The British authorities took into account that S.S. and R.K. Nehru had proven reliable and his father held the post of Deputy Chief Auditor, East Indian Railways. ${ }^{78}$

In Menon's case, marrying the daughter of a prominent Congress politician even turned out to be an enormous asset. Most wives of Indian ICS officers lived in purdah and hardly participated in the social life of British Indian administrators, as it took place in the clubs or at social functions. Until the mid-1930s, this was true among others for the wives of G.S. Bajpai or Jagdish Prasad. ${ }^{79}$ The wife of a British ICS officer found it 'almost impossible to get to know any Indians. Though the English men and the Indians . . . did fraternise and made friends ... the fourth of the quartet 
was always missing' ${ }^{80}$ On the contrary, Saraswati Menon was a charming and entertaining host. Thereby, she helped her husband's career, himself easy-going and likeable. Certain features of the private life of the Menons remained South Indian. Otherwise, they adapted to the anglicised social life of British India much easier than most of their contemporaries.

Starting as assistant magistrate in Tiruchirappalli, Menon was a promising candidate among the ICS freshmen of Madras Province. That he came into the focus of the FPD, however, was mostly coincidence. By 1921, Indian officers in the Political Service, all of them posted in the NWFP, held less than 1 per cent of the higher ranks. The preference for Europeans not only reflected the feeling of white superiority in this most exclusive service. In the interwar period, it also became a refuge for conservative officers against the reforms in the ICS. ${ }^{81}$ Typically, Governor of Madras and later Viceroy Willingdon considered the attempts for an Indianisation of the Political Service as another indication that the GoI was 'plunging down the hill'. ${ }^{82}$ Indigenous rulers, within India and outside, felt humiliated when an Indian represented British India. Appointing an Indian resident of a princely state meant that the local ruler had to follow orders of someone ranking much lower in South Asian hierarchies. Furthermore, 'in postings abroad, the British Foreign Office were concerned about the trustworthiness of Indian officers with access to cipher files and codes. Many British officials also held racial assumptions that Indian candidates lacked the decisiveness needed for success'. ${ }^{83}$

Menon was among the few Indians to join the Political Service. He profited from the recommendations of the Royal Commission on the Superior Civil Service in India, suggesting Indian officers form one-fourth of the cadre. Accordingly, the FPD approached provincial governments for suitable candidates. To great disappointment, only members of the provincial services applied. ${ }^{84}$ The Madras government explained that South Indians were 'traditionally looked down upon' in North India. Furthermore, the rule that candidates had to be bachelors excluded nearly all South Indians, who married at a young age. ${ }^{85}$ Menon did not appear on the list of suggestions of the Madras government in March $1924,{ }^{86}$ but in June he was approached by Duncan George Mackenzie from the Political Department. ${ }^{87}$ Madras Chief Secretary Robert Arthur Graham was not unduly impressed. The young officer did not come up 'to the old time standard with regard to proficiency in, or keenness on, field sports and probably he is not much of a horseman'. South Indian officers sent to North India should have 'some force of character. In the respect I think Sivasankar Menon compares favourably with most of our Indians recruited by competitive examination, though he is not up to the best of those' officers who had been nominated. ${ }^{88}$ Nomination had become a means to fill up gaps in the ICS after the Great War. The Indian candidates were meant to be selected from minorities, whose members hardly qualified via the competitive examination. De facto, nomination 
turned out to be a quota for Muslims, who lagged behind Hindus, Parsis or Christians in terms of academic performance. ${ }^{89}$ Among the Muslims, however, the British believed to find 'born rulers'.

In February 1925, Menon was appointed assistant to the resident of Hyderabad State. A transfer to Aden, 'the extreme point to which a member of the Political Dept. can be posted', was announced in January 1927 but never manifested..$^{90}$ Instead, Menon was sent to the NWFP. This too was a token of confidence, as Indians from the East and the South were considered 'black' (i.e., inferior) there. ${ }^{91}$ Menon was enthusiastic about the transfer, but much less so about working as judge in Peshawar.

The next career jump followed in 1929. For the agency in Ceylon, Bajpai in early March asked for 'an ICS officer possessing tact and resource' and, for unknown reasons, suggested either Menon or Cadambi Sheshachar Venkatachar, preferring the former for wrongly taking him a Tamil. ${ }^{92}$ Menon initially favoured the post of census superintendent in the NWFP ${ }^{93}$ but finally accepted for higher pay and status. ${ }^{94} \mathrm{He}$ arrived in Ceylon only two weeks before the Wall Street Crash of 24 October, which triggered the Great Depression and heavily affected Ceylon. Menon had to master the difficult task of renegotiating the minimum wages agreed in 1925 . Moreover, against the background of unemployment and ethnic tensions, the Ceylonese wanted the GoI to support repatriation of local Indians. Finally, Menon intensely discussed the franchise issue. His performance was outstanding, Bajpai praising him as 'the best Indian Agent who ever went there'. ${ }^{95}$

Menon developed a taste for a diplomat's life for its far-reaching independence and importance, the many opportunities to shine in public appearances and the financial benefits. Furthermore, he was uncertain about his career prospects in the Political Service. Foreign Secretary Aubrey Metcalfe, finding Menon 'both in intellect and character above the average' and 'fit for any employment . . . in the Political Department', wondered whether 'constitutional changes may make it difficult to retain any Indians on this side'. ${ }^{96}$ Menon, therefore, asked Bajpai to consider him either as agent for South Africa or deputy secretary in the DEHL. ${ }^{97}$ Bajpai was agreeable, ${ }^{98}$ but in August 1934 Menon was asked to visit Zanzibar, British East Africa and Uganda, where new laws challenged the status of Indians and, in particular, their part in the clove trade. On the two-month tour he again performed well, being rewarded with his appointment as deputy secretary in the DEHL on 1 July 1935.

Naturally, the secretary's appreciation stroked Menon's ego: 'Bajpai has adopted my attitude over the Zanzibar Question - which is very satisfactory yes, very', he noted in his diary. ${ }^{99}$ Initially, he responded in a similar fashion, feeling 'great admiration for Bajpai. He is distinctly able'. ${ }^{100}$ This, combined with the uncertain career prospects in the Political Service, made him turn down Political Secretary Bertrand James Glancey, who told him 'that he had received 
the highest feasible reports about me. Bajpai, however, advises me to chuck $\mathrm{F}$ [oreign] $+\mathrm{P}$ [olitical Department]'. ${ }^{101}$

The tone changed the moment Menon joined the DEHL. Already in his second week, he characterised 'Baji', the secretary's nickname in office, an egoist and 'tactician. He may overreach himself' ${ }^{102}$ The third week, he had already grown tired of 'too much routine work', ${ }^{103}$ good enough for a clerk. ${ }^{104}$ Apparently, the time abroad together with his rather independent work in the Political Service had made him that self-confident that working immediately under a superior had become unbearable. Moreover, he missed public appearances. Grudgingly, he described a speech by Bajpai as 'brilliant, non-committal, futile'. ${ }^{105}$

Nevertheless, there was more to Menon's intense and lasting dislike than mere hierarchies. When Metcalfe offered Menon the post of deputy secretary in the FPD, ${ }^{106}$ Bajpai did not bother to make him stay. On 1 April 1936, Menon returned to his mother department, feeling in much better company and more appreciated. ${ }^{107}$ Unlike Bajpai, the foreign secretary did not even change a comma in Menon's drafts. ${ }^{108}$ The latter's idol was the 'magnificent official' Olaf Caroe, ${ }^{109}$ soon among Bajpai's most influential opponents. Nevertheless, Menon kept an eye on the Indian agencies, painfully aware that this would bring him back into Bajpai's sphere. When Bajpai offered Menon the agency in Malaya, ${ }^{110}$ he readily agreed. ${ }^{111}$ In the case of the agency in Burma, under consideration since 1936 but never sanctioned, the initiative came from Menon. ${ }^{112}$ Both plans never manifested, however.

From October 1929, Menon had learned about Indians overseas, in particular British India's relations with Ceylon and East and South Africa. In the FPD, he worked with files on British India's immediate neighbourhood Kashgar, Nepal, Tibet ${ }^{113}$ - and occasionally on disabilities of Indians in the US or relations with Japan. ${ }^{114}$ Apart from that, he formed opinions on international politics. Menon abhorred the Italian annexation of Abyssinia ${ }^{115}$ and the Japanese exploitation of Manchukuo. ${ }^{116} \mathrm{He}$ expected the world heading towards another war, 'Germany, Japan and Italy versus England, France and Russia. Fascism versus Bolshevism and Democracy'. ${ }^{117}$ The League of Nations he blamed to swallow 'camels and strain at gnats', doing nothing to help the Negus but insisting on a report on slavery in Assam. ${ }^{118}$ Great Britain was not shunned from massive criticism against its 'beautiful impartiality', selling planes to both sides in the Spanish Civil War: 'Truly, a nation of shopkeepers', he burst out ${ }^{119}$ in the fashion of German war polemics comparing despicable British traders with German heroes. ${ }^{120}$ The Anglo-Italian pact in the Mediterranean he characterised as 'dealing with the butcher!'121

Menon was on excellent terms with British colleagues and superiors throughout, even dining with the Linlithgows. ${ }^{122}$ His dearest dream was to climb to the rank of foreign secretary. ${ }^{123}$ At the same time, he harboured anti-colonial sentiments, among them praising the independent stand of the earlier Member of the DEHL, Fazl-i Husain, ready to raise the Indian point 
of view. ${ }^{124}$ Menon strongly sympathised with the Independence Movement and in particular Jawaharlal Nehru, whom he had known since 1931: ${ }^{125}$ If anyone could make India, it would be him, though he had 'all the vested interests . . . against him'. ${ }^{126}$ Compared to Nehru, Menon found officials like himself 'ease-loving hangers-on'. ${ }^{127}$ Dedicating his life to the struggle for independence, as Subhas Chandra Bose had done in 1920 instead of joining the ICS, ${ }^{128}$ never occurred to him. His own sons, however, he wanted to become perfect Indians instead of perfect Englishmen. ${ }^{129}$

In April 1937, Menon left for Baluchistan, ${ }^{130}$ considering this as a necessary step towards the foreign secretaryship. ${ }^{131}$ After his arrival in Zhob in November, he dreamed to leave a mark and, thereafter, apply for the posting in Burma. ${ }^{132}$ Two months later, however, he declined the overseas job. ${ }^{133}$ His tasks in Baluchistan were comparable to those of a district officer in British India and the term, ending in August 1939, was altogether uneventful. Menon was in regular contact with Caroe, who promised to make him joint secretary in the Foreign Department. ${ }^{134}$ In 1940, however, he was appointed dewan in Bharatpur State instead. Menon's diaries show that he kept informed about the last steps towards the world war. Apart from condemning the Munich Agreement a British and French 'gross betrayal' of Czechoslovakia ${ }^{135}$ or the prosecution of Jews in Germany, ${ }^{136}$ he hardly commented on events. Regarding Congress politics, he trusted Gandhi and Nehru but not Bose. ${ }^{137}$

\section{Subimal Dutt}

The list of the ICS officers who were trained in the DEHL and after independence exercised strong influence on Indian foreign affairs would be incomplete without Subimal Dutt, though there is comparatively little known about his role in the interwar period. ${ }^{138}$ Among the three protagonists, he seemed least likely to have a distinguished career. Born on 5 December 1903 in Kanungopara, a village located in rather remote Chittagong district in East Bengal, he grew up with 14 siblings and little wealth. Circumstances did not predestine him to become India's longest-serving foreign secretary. His sharp brain, tremendous work discipline and great ambition, nevertheless, paved his way into the ICS in 1928. After performing well as district officer in Bengal, a decade later he was sent on deputation to the central government where he came to work in the DEHL. Dutt had no genuine interest in politics, let alone foreign affairs; his dearest ambition was to become secretary with the central government in any department. Unlike Bajpai and Menon, he did not qualify as a 'brown Englishman' but considered himself 'totally of the vernacular type'. ${ }^{139}$ Menon occasionally sighed under the duties coming with social life in Delhi and Simla, ${ }^{140}$ but altogether enjoyed it and used it for intensive networking; in contrast, the reserved, religious and rather unpolished Dutt hated it. With deep disgust, he felt obliged to drink alcohol 
and play cards in order not to become a complete outsider. He did not play golf or tennis and eluded any conversation with the wives even of befriended Indian colleagues once they turned up without their husbands, fearing this might be perceived as lack of decency. Whenever possible, he avoided visiting the club, the heart of social life of the colonial society. Whereas Bajpai and Menon came in touch with everyone of relevance in the civil service and politics, Dutt, after three years in Delhi, had not made himself known outside his department.

Bajpai, however, discovered Dutt's qualities as a quiet, reliable, efficient and loyal subordinate and an outstanding administrator. Dutt had joined the DEHL as one of three under secretaries; in early 1940, he was appointed additional deputy secretary. The few files covering the work of the DEHL between 1938 and 1941 show him working on Malaya, where he was transferred as agent in early 1941. Earlier, he had turned down Bajpai's offer of the post of dewan in Cooch Behar State, which would have brought him into the Political Service. ${ }^{141}$ One of the least anglicised Indian ICS officers, he would not have fitted into this European elite club.

Dutt's political views were mostly in harmony with Menon's, whom he had not met before 1948. Both, for example, complained of the lack of willingness on part of Great Britain to stand up against the aggressive policy of the Axis Powers or Japan. In his diaries, however, Dutt was much more outspoken. In June 1938, when the crisis around German territorial claims against Czechoslovakia seemed to escalate into a war, he criticised British silence: 'It can easily be assumed how bad the condition must be of a nation that has to tolerate so much humiliation'. ${ }^{142}$ Given the concentration camps, he found the prospect of German rule over Europe a nightmare. ${ }^{143}$ 'The name "Germany" creates a burning sensation in me', he noted after the occupation of Poland. Otherwise, he feared that the subcontinent might come under the control of Japan or the USSR. Although the latter occupied the eastern part of Poland, with the KGB imprisoning thousands, Dutt was hesitant to condemn Stalin's policy. Instead, he wondered whether 'in this anarchic situation, will it be very strange if Russia also tries to safe-guard her own interest?' 144

The burden-sharing among the three ICS officers holding the top ranks of the MEA after independence seemed to be obvious. Bajpai was the centre of power: a power-hungry mastermind, well connected in British Indian circles, a top negotiator with an uncompared knowledge of international affairs. Menon by 1939 was the second-best Indian foreign policy expert. Other than Bajpai, he stood in the tradition of both the DEHL and the FPD, commanding expertise regarding Indians overseas plus the tricky details of territorial claims in British India's neighbourhood or in the last rounds of the Great Game. Furthermore, Menon disliked deskwork but was made to represent India abroad. Typically, he was friends with almost everyone: Indian and British colleagues and superiors, and at the same time Congress 
politicians. On the contrary, Bajpai concentrated on pleasing his superiors. Privately, he was on good terms with M.K. Gandhi, the guest of honour at the sacred thread ceremony of his second son, Kayatyani Shankar. ${ }^{145}$ Professionally, however, whenever he requested the Mahatma's advice, he did so via intermediaries, on principle. When posted in Washington during the Second World War, he vehemently agitated against the Congress. Nevertheless, he had proven that he was more than apt to adapt to changing environments. Dutt, not yet playing a relevant role, appeared rather the man to support his superiors but silently working in the background. $\mathrm{He}$ felt no urge to become a public face at all and seemed totally unfit for a diplomat's life.

\section{Notes}

1 NAI, DEHLO, August 1925, B, 68-74. Note, Bajpai, 24 August 1925.

2 V. Subramaniam, Social Background of India's Administrators. A Socioeconomic Study of the Higher Civil Services of India, New Delhi: Publication Division Government of India, 1971, pp. 33, 45.

3 UPSA, Application, 45/1915. India Office, Public no. 217, 17 December 1915.

4 UPSA, Application, 45/1915. Note, 25 November 1915.

5 Neil Bruniat Bonarjee, Under Two Masters, London: Oxford University Press, 1970, pp. 140-141.

6 UPSA, Appointment, 635/1933. Letter, Deputy Commissioner Garhwal W.F.G. Browne to CS U.P. Clay, 9 September 1933, quoting Joint Magistrate Atman Charan.

7 UPSA, Appointment, 635/1933. Letter, Charan to Clay, 15 September 1933.

8 UPSA, Appointment, 635/1933. Confidential Report on the Work of Assistant Commissioners and Deputy Collectors 1932/33, L. M. Stubbs, undated.

9 BL, IOR, L/E/7/1230, 1547. Telegram, Sastri to India Office, 27 September 1921.

10 BL, MSS EUR, JWP, D.545/1. Letter, Bajpai to Walton, 16 November 1921.

11 B. R. Nanda, Gokbale. The Indian Moderates and the British Raj, Oxford: Oxford University Press, 1977, p. 493.

12 P. Kodanda Rao, The Right Honourable V.S. Srinivasa Sastri. A Political Biography, London: Asia Publishing House, 1963, p. 115.

13 BL, IOR, L/E/7/1234, 1877. Report, Sastri, 1 March 1922, 11.

14 BL, MSS EUR, JWP, D.545/2. Letter, Bajpai to Walton, 13 June 1923.

15 NAI, RAD, Emigration, January 1923, B, 3-5. Letter, Bajpai to Ewbank, 10 August 1922.

16 NAI, RAD, Emigration, January 1923, B, 3-5. Note, Ewbank, 10 September 1922.

17 NAI, DEHLO, May 1923, B, 35. Letter, Bajpai to Ewbank, 10 May 1923.

18 NAI, DEHLO, May 1923, B, 35. Letter, Ewbank to Bajpai, 19 May 1923.

19 BL, MSS EUR, JWP, D.545/2. Letter, Bajpai to Walton, 13 December 1923.

20 BL, MSS EUR, JWP, D.545/2. Letter, Bajpai to Walton, 31 July 1924.

21 BL, MSS EUR, JWP, D.545/2. Letter, Bajpai to Walton, 12 September 1923.

22 NAI, DEHLO, August 1925, B, 68-74. Note, Bajpai, 24 August 1925.

23 NAI, DEHLO, November 1927, B, 9-34. Letter, Bajpai to Emigration Commissioner for British Malaya C. Wilson, 1 March 1927.

24 BL, MSS EUR, JWP, D.545/1. Letter, Bajpai to Walton, 2 November 1921.

25 BL, MSS EUR, JWP, D.545/1. Letter, Bajpai to Walton, 16 June 1922.

26 BL, MSS EUR, JWP, D.545/1. Letter, Bajpai to Walton, 4 May 1922. 
27 BL, MSS EUR, JWP, D.545/1. Letter, Bajpai to Walton, 13 April 1922.

28 BL, MSS EUR, JWP, D.545/2. Letter, Bajpai to Walton, 13 December 1923.

29 BL, MSS EUR, JWP, D.545/2. Letter, Bajpai to Walton, 21 February 1924.

30 BL, MSS EUR, JWP, D.545/2. Letter, Bajpai to Walton, 19 June 1924.

31 BL, MSS EUR, JWP, D.545/1. Letter, Bajpai to Walton, 4 May 1922.

32 BL, MSS EUR, JWP, D.545/2. Letter, Bajpai to Walton, 12 September 1923.

33 BL, MSS EUR, JWP, D.545/2. Letter, Bajpai to Walton, 13 June 1923.

34 BL, MSS EUR, JWP, D.545/2. Letter, Bajpai to Walton, 13 December 1923.

35 NMML, KPSMP, Diary 1935, 18 September.

36 CSAS, Richard Tottenham Papers. Memoirs, book II, chapter 13, 'Imperial Conferences and Retrenchment'.

37 Yezdezard Dinshaw Gundevia, Outside the Archives, Hyderabad: Sangam Books, 1984, pp. 65-66.

38 NAI, DEHLO, February 1930, B, 94-95. Note, A. B. Reid, 22 August 1929.

39 BL, MSS Eur, E240/6. Letter, Willingdon to SSI Hoare, 23 October 1933.

40 NAI, DEHLO, December 1931, B, 100. Notes, Fazl-i Husain, 30 June, and Bajpai, 6 July 1931.

41 Badr-ud-din Tyabji, Memoirs of an Egoist, vol. 1, 1907 to 1956, New Delhi: Roli Books, 1988, p. 59.

42 Dutt Diary 4a, 28 April 1938.

43 NMML, KPSMP, Diary 1935, 9 July.

44 NMML, KPSMP, Diary 1935, 8 August.

45 NMML, KPSMP, Diary 1935, 19 November.

46 NMML, KPSMP, Diary 1935, 13 August.

47 NMML, KPSMP, Diary 1935, 15 July.

48 Dutt Diary 8, 5 December 1954.

49 Dutt Diary 6, 22 February 1953.

50 Amit Das Gupta, Serving India. A Political Biography of Subimal Dutt (19031992), India's Longest Serving Foreign Secretary, New Delhi: Manohar, 2017, p. 61.

51 Tyabji, Memoirs of an Egoist, p. 198.

52 NAI, DEHLO, August 1931, B, 2-26. Note, Bajpai, 12 February 1931.

53 NAI, DEHLO, August 1931, B, 2-26. Note, Bajpai, 25 February 1931.

54 NAI, DEHLO, August 1931, B, 2-26. Note, Bajpai, 24 March 1931.

55 NAI, DEHLO, August 1931, B, 2-26. Note, Bajpai, 14 March 1931.

56 NAI, DEHLO, August 1931, B, 2-26. Note, Bajpai, 7 March 1931.

57 NMML, KPSMP, Diary 1935, 28 August 1935.

58 Tyabji, Memoirs of an Egoist, p. 257.

59 Das Gupta, Serving India, p. 362.

60 Gundevia, Outside the Archives, pp. 23-24.

61 BL, IOR, L/PS/12/2636. Letter, Linlithgow to Amery, 27 November 1940.

62 NMML, KPSMP, Diary 1918, 7 and 9 January.

63 NMML, KPSMP, Diary 1918, 10 January.

64 NMML, KPSMP, Diary 1918, 21 October.

65 NMML, KPSMP, Diary 1919, 19 October.

66 NMML, KPSMP, Diary 1919, 15 June.

67 NMML, KPSMP, Diary 1921, 27 November.

68 NMML, KPSMP, Diary 1919, 2 November.

69 NMML, KPSMP, Diary 1919, 30 November.

70 NMML, KPSMP, Diary 1920, 29 February.

71 BL, IOR, L/PJ/12/115. Letter, W. Sheppard to C. Bayley, 31 October 1922.

72 NMML, KPSMP, Diary 1922, 20 November. 
73 BL, IOR, L/PJ/12/115. Letter, J. E. Ferard to Home Secretary GoI S. P. O’Donell, 22 November 1922.

74 UPSA, Appointment, 362/1916. Letter, Deputy Commissioner Lucknow to Lovett, 10 July 1916.

75 R.D. Mathur, 'British Policy toward the Volunteer Movement in India during the Non-cooperation Campaign', Proceedings of the Indian History Congress, 1970, 32(II): 214-225.

76 UPSA, Appointment, 45/1924. Note, 20 September 1924.

77 UPSA, Appointment, 195-1/1931. Letter, India Office to Home Secretary UP Emerson, 1 July 1931.

78 UPSA, Appointment, 195-1/1931. Letter, Commissioner Allahabad to DS General Branch Civil Secretariat UP R.D.W.D. Macleod, 14 August 1931.

79 Dutt Diary 3, 11 March 1940.

80 CSAS, H. Barkeley Smith Papers, no. 79. Interview with Mrs. H. Barkeley Smith on 5 December 1979.

81 Barbara Ramusack, The Indian Princes and Their States, Cambridge: Cambridge University Press, 2004, p. 103.

82 TNSA, Public Department, G.O. no. 219, 29 August 1924. Note, Willingdon, 19 March 1924.

83 Ramusack, The Indian Princes and Their States, p. 103.

84 TNSA, Public Department, G.O. no. 219, 29 August 1924. Circular, Deputy Secretary FPD to the Chief Secretaries of the Provinces, 1 March 1924.

85 TNSA, Public Department, G.O. no. 219, 29 August 1924. Letter, Madras Public Department to Secretary FPD, undated [April 1924].

86 TNSA, Public Department, G.O. no. 219, 29 August 1924. Departmental Note, 14 March 1924.

87 NMML, KPSMP, Diary 1924, 5 June.

88 TNSA, Public Department, G.O. no. 219, 29 August 1924. Note, CS Graham, 25 July 1924.

89 TNSA, Public Department, G.O. No. 1552, 23 September 1935. Resolution no. F 14/17-B/33, Home Department (Establishment), 4 July 1934.

90 NMML, KPSMP, Diary 1924, 10 January.

91 Rudyard Kipling, Life's Handicap, being Stories of Mine Own People, London: Macmillan, 1891, chapter 19, 'The Head of the District'.

92 NAI, FPD, Establishment Branch, 60(2)-E, 1929. Letter, Bajpai to Denys Bray, 4 March 1929.

93 NAI, FPD, Establishment Branch, 60(2)-E, 1929. Telegram, Political Department Peshawar to Foreign Department, 6 March 1929.

94 NMML, KPSMP, Diary 1929, 3 May.

95 NMML, KPSMP, Diary 1934, 13 March.

96 NAI, FPD, Establishment Branch, 60(2)-E, 1929. Foreign Secretary Metcalfe to Political Secretary B. J. Glancey, 6 June 1932.

97 NMML, KPSMP, Diary 1934, 16 July.

98 NMML, KPSMP, Diary 1934, 26 July.

99 NMML, KPSMP, Diary 1934, 30 October.

100 NMML, KPSMP, Diary 1934, 3 November. Emphasis in the original.

101 NMML, KPSMP, Diary 1934, 1 November.

102 NMML, KPSMP, Diary 1935, 15 July.

103 NMML, KPSMP, Diary 1935, 19 July.

104 NMML, KPSMP, Diary 1935, 30 July.

105 NMML, KPSMP, Diary 1936, 13 February.

106 NMML, KPSMP, Diary 1936, 22 January. 
107 NMML, KPSMP, Diary 1936, 21 April.

108 NMML, KPSMP, Diary 1936, 13 November.

109 NMML, KPSMP, Diary 1936, 5 April.

110 NMML, KPSMP, Diary 1937, 1 March.

111 NMML, KPSMP, Diary 1937, 5 March.

112 NMML, KPSMP, Diary 1938, 9 January.

113 NMML, KPSMP, Diary 1937, 29 March.

114 NMML, KPSMP, Diary 1936, 12 April.

115 NMML, KPSMP, Diary 1936, 5 May.

116 NMML, KPSMP, Diary 1936, 13 October.

117 NMML, KPSMP, Diary 1936, 20 November.

118 NMML, KPSMP, Diary 1936, 1 August.

119 NMML, KPSMP, Diary 1936, 17 August.

120 Werner Sombart, Händler und Helden. Patriotische Besinnungen, Munich: Duncker \& Humblot, 1915.

121 NMML, KPSMP, Diary 1937, 4 January.

122 NMML, KPSMP, Diary 1936, 26 May.

123 NMML, KPSMP, Diary 1936, 11 December.

124 NMML, KPSMP, Diary 1936, 9 April.

125 NMML, KPSMP, Diary 1936, 11 May.

126 NMML, KPSMP, Diary 1931, 31 May.

127 NMML, KPSMP, Diary 1936, 1 June.

128 Sugata Bose, His Majesty's Opponent. Subhas Chandra Bose and India's Struggle against Empire, Cambridge, MA: Harvard University Press, 2011, pp. 38-44.

129 NMML, KPSMP, Diary 1937, 20 February.

130 NMML, KPSMP, Diary 1937, 28 April.

131 NMML, KPSMP, Diary 1936, 11 December.

132 NMML, KPSMP, Diary 1937, 26 November.

133 NMML, KPSMP, Diary 1938, 9 January.

134 NMML, KPSMP, Diary 1939, 9 July.

135 NMML, KPSMP, Diary 1938, 2 October.

136 NMML, KPSMP, Diary 1938, 17 November.

137 NMML, KPSMP, Diary 1939, 2 February.

138 For Dutt's career in the ICS, see Das Gupta, Serving India, pp. 44-106.

139 Dutt Diary 4a, 8 May 1938. Original in Bangla.

140 NMML, KPSMP, Diary 1936, 8 October.

141 Private Collection Supriya Guha. Letter, Bajpai to Dutt, 6 November 1939.

142 Dutt Diary 4a, 15 June 1938. Original in Bangla.

143 Dutt Diary 2, undated entry [Summer 1938].

144 Dutt Diary 3, 10 October 1939. Original in Bangla.

145 Interview with K. S. Bajpai, 2 March 2018. 


\section{Part II}

\section{INTERWAR YEARS - THE DEPARTMENT OF EDUCATION, HEALTH AND LANDS}


$\Longrightarrow$ Taylor \& Francis

Taylor \& Francis Group

http://taylorandfrancis.com 


\section{4 \\ SOUTH AFRICA}

Indian migration into Southern Africa began in 1860 when sugar planters in Natal required indentured labourers; their entry was followed by Indian traders. After completing their five-year term, the labourers settled in large numbers. Already in 1885 , Transvaal introduced a law restricting residence, trade and the right to acquire immobile property. A decade later, Natal too put pressure on Indians by imposing an annual tax of $£ 3$, denying them political franchise as well as restricting free immigration of traders and the issue of trade licences. The GoI acquiesced to those measures, hoping, in vain, that anti-Indian feelings would ebb down with the end of immigration and the Union government would care to improve the conditions for domiciled Indians. Hence, in 1904, Delhi turned down a South African request for 20,000 labourers for railway construction; in 1914 it stopped indentured emigration to Natal. Most of the Indians lived in this province, whereas they formed only small minorities in Transvaal and Cape Province and were hardly visible in Orange Free State. ${ }^{1}$ Of around 165,000 people of Indian origin, some 102,000 were born in South Africa. ${ }^{2}$

In the meantime, Gandhi had come into the picture. From 1906, by means of passive resistance, he campaigned for franchise, abolition of discriminatory taxes, free movement between the various provinces, freedom of settlement and opening businesses outside restricted areas, domiciliary rights and acceptance of Indian marriages. He also stood against any limitation of further immigration. ${ }^{3}$ Though the GoI did not approve the means, it stopped migration to South Africa. ${ }^{4}$ Furthermore, by deputing Sir Benjamin Robertson, ICS, a member of the Governor-General's Council, as official mediator, it helped to bring about the Indian Relief Act and the Smuts-Gandhi Agreement of 30 June 1914. South Africa, among others, lifted the per capita tax, accepted the registration of monogamous marriages and allowed the issuing of temporary permits for Indians to travel to other provinces. A part of Gandhi's success story was that he, despite belonging to a 'lower' race, impressed his counterparts with his personality. ${ }^{5}$ Typically, he combined a civil rights campaign with personal diplomacy. ${ }^{6}$ 


\section{Struggle for Indian rights}

After Gandhi left South Africa, no permanent solution to the issue of Indian rights had been attained, let alone equal status. Conditions worsened after the Great War. The Reciprocity Resolution of 1918, agreed at the Imperial War Conference, ruled that each community within the Empire had the right to regulate the composition of its population. While the GoI hoped that this would end fears of a permanent influx of ever more Indians and thereby reduce the disabilities of those domiciled, South Africa's Act XXXVII of 1919 forbade Indians to acquire new leases on proclaimed areas or own property outside certain locations. In response to protests from Delhi, Pretoria established the Asiatic Enquiry Commission and admitted representatives of the GoI. Delhi nominated Robertson and Sastri, but the Union government emphasised that an Indian would have to accept a socially inferior status, wherefore Robertson travelled alone. ${ }^{7}$ The proposed Class Areas Bill from 1923 became the very symbol of discrimination against Indians, demanding compulsory segregation in urban areas. It never passed the Union Parliament but hung over South African Indians like a sword of Damocles. Moreover, between 1921 and 1925, in certain provinces and the Union, many more bills and ordinances were discussed and partly introduced, all of which aimed at reducing Indian political rights and eliminating economic competitors. Smuts argued that a strong party in South Africa demanded even further restrictions. This could be kept at bay only if the government maintained a strictly negative attitude regarding demands for enlarged privileges and equality. ${ }^{8}$

In response, the DEHL's first member, Muhammad Shafi, considered appointing an agent to bring grievances of local Indians to the notice of the Union government. The first such proposal to establish agencies in all parts of the Empire with a considerable Indian population had been made at the Imperial War Conference in 1918, and Delhi had pursued the matter further at the follow-up conferences of 1921 and $1923 .{ }^{9}$ For South Africa, however, the British Indian Finance Department turned the proposal down 'on political grounds', warning that 'the appointment would quickly lead to new troubles and difficulties'. ${ }^{10}$

This ignored that emotions ran high in all sections of British Indian society. On 27 July 1923, the Legislative Assembly passed a non-binding, nonofficial bill to regulate entry and residence of persons domiciled in other British possessions, thereby introducing the idea of reciprocity. The GoI understood it as retaliatory and warned that it might come in the way of a negotiated settlement but let it pass. Some in the DEHL were as embarrassed as the public; B. N. Sarma, former member of the Revenue and Agriculture Department, chose a remarkably nationalist tone:

The Indian may have to fight the Empire's battles, but he is not only to be excluded but gently evicted from every inch of territory 
marked red where his presence may be inconvenient. It is a war against India, Asia and humanity.

If silent acquiescence was London's new policy, the Empire provided nothing more but protection against foreign aggression. Every government within the Empire was free to reduce certain classes to serfdom and could even claim assistance from other governments against the consequences of such policy. India should reciprocate by introducing a duty on South African coal, imposing restrictions on immigration, refusing concessions, and excluding South Africans from British Indian services. ${ }^{11}$

Bajpai did not share such sentiments but favoured a compromise. Political equality was but a remote ideal; the issue had to be considered 'as primarily economic. Similarly, leaders of opinion in South Africa must learn to realise the inherent iniquity of a policy of repatriation and reconcile themselves to a policy of economic uplift of the Indian'. ${ }^{12}$ Reciprocity only envisaged retaliation to the detriment of Indians in the dominions 'without in any way injuring the nationals of the dominions themselves' ${ }^{13}$ It would mostly penalise Europeans and embitter relations in general. Legally, furthermore, the Queen's Proclamation of 1858 ruled that nobody could be excluded from applying for the civil services. Heavy duties for South African coal and sugar were under discussion, but closing the ports to South African vessels would be tantamount to a hostile act. ${ }^{14}$

Butler agreed and even mused whether Delhi should support repatriation notwithstanding public sentiment, ${ }^{15}$ an idea soon adopted by Bajpai. Accordingly, in February 1924, Delhi protested rather mildly against the Class Areas Bill. ${ }^{16}$ It criticised the extension of segregation far beyond municipal areas, the de facto commercial segregation, the loss of value or property outside restricted areas and the lack of safeguards for a renewal of trading licences. Interestingly, it referred to and indicated consensus with Gandhi, who criticised the bill as a breach of his agreement with Smuts. ${ }^{17}$ A colonial government arguing with those challenging its legitimacy to make another colonial government change its mind appears somewhat paradoxical; it would continuously do so for the years to come.

The Mines and Works Amendment Bill of 1925, too, did not pass the Union Senate but sparked even more protests. It not only shut out nonEuropean workers from skilled occupations but also placed Indians and Africans together against the rest of the population. Bajpai considered this 'an insult', even more deliberate as 'in practice Indians are showing little or no tendency to enter the occupations which the proposed colour bar is designed to protect'. ${ }^{18}$

Pretoria was not impressed by Indian representations at all. A new government under James Barry Munnick Hertzog, with Minister of the Interior Daniel François Malan as the driving force, further pursued segregation. Already in 1921, a voluntary repatriation scheme had been introduced, 
providing those Indians who abandoned all rights to enter and reside in South Africa free passage together with a bonus of $£ 5$ per head and a maximum of $£ 25$ per family. Owing to vigorous campaigning, nearly 3,000 Indians accepted the offer in 1921. Thereafter the numbers fell, notwithstanding a doubling of the bonus; in 1926, a mere 2,100 Indians left South Africa. ${ }^{19}$ Pretoria increased the pressure: In early 1925, against the rules of voluntary repatriation, a few Indians of unsound mind were returned to India. ${ }^{20} \mathrm{Baj}$ pai found it 'an abuse of the word "voluntary"' that Pretoria wanted 'to saddle us with lunatics . . who are practically nationals of the Union'. ${ }^{21}$ Once again, Whitehall refused to get involved but gave Delhi permission for bilateral talks, ${ }^{22}$ ending the new practice.

Most provocative was the introduction of the Areas Reservation and Immigration and Registration (Further Provisions) Bill. Like the Class Areas Bill, but 'with rather double force', it foresaw segregation and further restricted immigration. In Natal, Indians could buy real estate but in the coast belt, and only from other Indians. ${ }^{23}$ In order to discuss the condition of Indians as a whole, Delhi suggested a round table conference in South Africa, but Pretoria feared agitation from both sides. Furthermore, it again refused any courtesies to Indian members of any deputation. ${ }^{24}$

The DEHL developed a sense of urgency to make the Indian position heard before the Union Parliament would discuss the bill in February 1926. Secretary Joseph William Bhore's suggestion to send a deputation of ICS officers and Indian public men ${ }^{25}$ to collect first-hand information was accepted by Pretoria. ${ }^{26}$ In December 1925, Commissioner of Labour of Madras Province, George F. Paddison, ICS, arrived in South Africa, accompanied by two non-officials - Deva Prasad Sarvadhikary, a Hindu, and Raza Ali, a Muslim. Bajpai as secretary and C.S. Ricketts as assistant completed the team. They were meant to investigate, among others, facilities for education and the oftencriticised sanitary standards. Furthermore, they were to examine the repeated allegations with regard to pressure exercised in the context of the voluntary repatriation scheme. Delhi also hoped for an assessment whether retaliatory measures might be beneficial for people of Indian origin. ${ }^{27}$

This marked the beginning of a remarkable diplomatic success story. The GoI was fully aware that it was to negotiate with empty hands. It could neither exercise pressure nor allure Pretoria with benefits of any kind. Nevertheless, the GoI managed to prevent any further anti-Asiatic legislation, calm down anti-Indian feelings and lift the prestige of India and Indians, resulting in improvements for South African Indians. The key to success was the establishment of friendly personal relations between leading actors on both sides, notably including Indians. The key figure was Bajpai, the only Indian top official involved over the whole period, being part of all exchanges and drafting nearly all communications with the Union government or the agents. At least as important was that even racist politicians like Malan came to respect, trust and like Bajpai. 
The interim report of the Paddison deputation confirmed that anti-Indian attitudes were based on prejudice rather than economic facts and that Indians were strongly disadvantaged, especially regarding education facilities. ${ }^{28}$ The deputation had been successful for the impression its members left on South African politicians. Their start had not been easy: Bajpai reported that they had avoided racist incidents only due to travel arrangements and never trying to get into a hotel in Natal or Transvaal: 'Socially we trust ourselves on none, and therefore, avoided rebuffs' ${ }^{29}$ Therefore, it was the first task of the three Indians to win respect, which they managed via numerous informal talks. Hertzog and Malan indicated their readiness to see the deputation in January. ${ }^{30}$ Towards the end of the month, Hertzog ${ }^{31}$ and Governor-General Alexander Cambridge Athlone ${ }^{32}$ had warmed up to the idea to let the deputation present its case before a select committee of the Union Parliament. This took place from 3 March 1926, i.e., before the second reading of the bill, after which changes on its principles would become impossible.

The DEHL advised the deputation to emphasise India's role in the Empire, recognised by its admission to the War Council, Imperial Conferences and the League of Nations. India's contribution to the Empire justified its citizens' claim for equal rights and Indians formed an integral part of the population of South Africa. Various Union governments had promised to protect the rights of minorities, and this should include people of Indian origin. Only thereafter, the principles of current legislation were to be discussed without going into details. ${ }^{33}$ Paddison let the others do all the talking, 'as the committee are so much more impressed by an Indian speaking than by an ordinary European like myself. Bajpai has been especially admirable, but they have all three won golden opinions from all the members of the committee'. ${ }^{34}$

Bajpai shared that impression but warned that 'the Asiatic question has, for some time, been looked upon as good political capital by all parties'. The Union government was 'anxious to exploit it' and had manoeuvred itself in a difficult position, as it could hardly admit that there was either no Asiatic menace or the bill would have no effect.

This primarily accounts for their frantic insistence on our offering some alternative, sufficiently startling to enable them to cover up their retreat. . . Unless the Government of India agree to discuss ways and means of making repatriation more effective, they will decide to go on with the measure.

Enforced repatriation was out of discussion, but public opinion demanded something more efficient than the current voluntary scheme. ${ }^{35}$ Actually, Bajpai vehemently opposed repatriation, which he considered tantamount to expatriation in the case of domiciled Indians. He would have preferred 
'some system of settling the Indian on suitable land'. ${ }^{36}$ Tactics, however, dictated another approach.

Informal talks with Hertzog and Malan finally paved the way towards the first Round Table Conference. Malan held that Delhi in October 1925 had refused to cooperate with any repatriation scheme. The DEHL replied that it was still 'unable to agree to enter a conference of which the object would be to effect a considerable reduction of the Indian population'. Nevertheless, the GoI was ready to take part in exchanges without any preconditions, both sides openly discussing their difficulties regarding Indians in South Africa. ${ }^{37}$ Informal talks took place on 1 and 2 April 1926 and brought the breakthrough. Paddison emphasised that Smuts earlier had guaranteed that proper treatment would be meted out to Indians, resident in South Africa, as soon as the fear of further immigration disappeared. But Pretoria had not kept to its word even after immigration had come to an end. Delhi was, nevertheless, willing to re-examine the voluntary repatriation scheme, especially the opposition of South African Indians and the possible defects in the arrangements made for the returnees in India. This enabled Malan to save face, pretending a misunderstanding. After the clarification, he saw no more reason why the conference should not be held.

There was still a problem to be solved: Indian public opinion would not like repatriation on the agenda, whereas South African public opinion would insist on it. A compromise formula satisfied both sides:

The Government of the Union have impressed on the Government of India that public opinion in South Africa will not view with favour any settlement which does not hold out a reasonable prospect of safeguarding the maintenance of western standards of life by just and legitimate means.

While Delhi would explore all possible methods to help, Pretoria postponed the disputed bill until the end of the conference. ${ }^{38}$ The GoI approved the formula and agreed that the conference should be held in Pretoria in December after the upcoming Imperial Conference. Though it should not be connected with the latter, the weeks in London were to be used for further informal bilateral talks. Furthermore, Delhi suggested sending a South African deputation to India to make itself familiar with conditions there; ${ }^{39}$ the Union government wholeheartedly agreed to this. ${ }^{40}$

Gandhi gave his blessings to the conference, declaring that 'the only "remedy is diplomatic pressure" , not retaliation. ${ }^{41}$ It had been mostly Paddison and Bajpai, though, who had paved the way for the conference. The former, as the leader of the delegation and senior-most European official, was the preferred partner for South African politicians to open informal talks. Bajpai had wondered whether a European secretary to the delegation would have been more efficient, given racial prejudice, ${ }^{42}$ but was praised 
by Athlone for having helped 'a mutually better understanding and appreciation'. ${ }^{43}$ For an Indian officer with merely 11 years of service, this was a remarkable success.

In his numerous reports, Bajpai appeared well informed, self-conscious and occasionally somewhat arrogant. For example, he despised local Indians for their refusal to give evidence before the Select Committee. He did not understand 'this attitude of aloofness. Because the odds are against one, there is no heroism in refusing to give battle'. ${ }^{44}$ Moreover, Bajpai had no sympathies for non-professionals. Missionary Charles Freer Andrews had made himself a name by campaigning against indentured labour all over the Empire and had become a confidant of Gandhi. ${ }^{45} \mathrm{He}$ and Bajpai had started an exchange on Indians overseas in 1924, apparently encouraged by journalist Henry S. L. Polak, ${ }^{46}$ who had become friends with Gandhi in South Africa and was dedicated to the issue of Indians overseas. Polak and Bajpai stayed in touch over the issue deep into the 1930s. Right before the first appearance of the deputation before the Select Committee, Andrews spread that a South African delegation should visit India, an idea both governments approved soon thereafter. Bajpai, nevertheless, blamed him as 'one of those dangerous optimists who do not profit by former mistakes. I do not know what justification he has for making such suggestions' ${ }^{47}$ It would take another five years until Bajpai acknowledged Andrew's qualities as

an enthusiast, and an honest and impecunious one. He has been very useful to us in S[outh] Africa and it is politic that we should not lose his goodwill, particularly as his views on overseas questions carry great weight with Indian non-officials both in S. Africa and in this country. ${ }^{48}$

Bajpai's performance with the deputation paid off; he became the man in charge for South Africa with the GoI. Over the summer, he prepared the brief for the Round Table Conference, stating that in order to acquiesce South African public opinion, the GoI would have to accept some quid pro quo. The main suggestion related, first, to voluntary repatriation. Bajpai recommended an enhancement of the bonus, an advisory committee of influential South African Indians to assist local officials and better conditions for returnees after their arrival in India. If needed, the GoI might promise further exploration of possibilities of South African Indians to migrate to other parts of the Empire. Second, regarding residential segregation, he advised to support the enforcement of sanitary standards for everyone in South Africa, if in return the authorities took care for suitable housing for poorer Indians. Third, he believed that commercial segregation would ruin Indian traders. The only acceptable restrictions were rules on sanitary conditions, safeguarding against overcrowding and defective conservancy arrangements. Standard minimum wages had to be accepted, if 
Indian shop assistants could receive a part of them in kind. The best way to ensure western standards was to encourage education, facilities lacking. Here, Delhi could offer assistance in selecting teachers or by lending personnel. An agent would promote better general relations and improve South African prospects for trade and commerce. In the conclusion, Bajpai suggested 'the fostering of relations which will bind South Africa to India by ties of self-interest', i.e., bilateral trade. ${ }^{49}$

Bajpai further established himself by accompanying the South African delegation to India and thereafter attending the Imperial Conference in London. The SSI had requested his services for informal talks with the South African delegation, ${ }^{50}$ but the India Office refused to have any hand in those talks. ${ }^{51}$ The officer felt the need to explain himself for acting as de facto chief negotiator, who occasionally 'had to trust to the instinct of the moment to decide on my line and to choose my words'. Conversations took place in a most benevolent atmosphere. Hertzog assured Bajpai 'that if only there were no electorate to think of, he would treat the Indians in South Africa on the same footing as the Europeans'. As Bajpai had foreseen, Hertzog asked for some give and take, with India showing genuine desire to help repatriation and South Africa dropping the bills. Bajpai replied that if no undue emphasis was placed publicly on this question, the GoI would do its best 'to facilitate the economic reabsorption of any Indians'. The Union government, however, 'must endeavour to carry the Indian community in South Africa with them'. Hertzog and Bajpai agreed on the appointment of an agent. ${ }^{52}$ Regarding the Round Table Conference, Hertzog welcomed Sastri's participation, which made sure that all shades of opinion would be represented. ${ }^{53}$

Bajpai introduced Hertzog to Indian students, trying to give him a better understanding of Indian views. After the end of the conference, the two sailed to Cape Town together, using the opportunity for more informal talks, in which Bajpai 'greatly impressed Hertzog' ${ }^{54}$ The Round Table Conference started on 17 December 1926. The Indian delegation was led by Member Mohammed Habibullah, who was inexperienced in foreign affairs. He was assisted by Secretary to the Commerce Department Geoffrey Latham Corbett, ICS; Sastri; Darcy Lindsay, leader of the European Mercantile Community in India; Phiroze S. Sethna, member of the Council of States; Paddison; and Bajpai as secretary ${ }^{55}$ In the proceedings of the conference, Bajpai appears a silent participant. ${ }^{56}$ According to Sastri's biographer Rao, however, Sastri and Bajpai cared for the breakthrough. ${ }^{57}$

The Cape Town Agreement from 21 February 1927 had three major components: First, restrictions on settlement and economic development of Indians were withdrawn; second, South Africa was to uplift Indians to the same level of civilisation as Europeans; and third, the GoI were to support voluntary repatriation. To the relief of the DEHL, Gandhi called the outcome 'an honourable compromise'. ${ }^{58}$ An agency was created as a consequence. Bajpai 
wanted someone with sufficient seniority who would have it easier to access ministers and the governor-general. ${ }^{59}$ Furthermore, as Europeans in South Africa believed 'that every Indian has a low standard of living . . . the agent should be able to conform to "western standards" of men of his class" ${ }^{60}$ Andrews agreed that 'it is a long job of educating the Afrikaners to get rid of the "coolie" idea of India and only one who is a born aristocrat from India with an obvious superiority of culture can do it' ${ }^{61}$

The Cape Times' suggestion to appoint Sastri won broad support in both countries, including Gandhi. Given that the new agent arriving in Pretoria on 28 June 1927 was a politician, Habibullah found it worth to 'tactfully convey to him that' he had to avoid public pronouncements or making commitments on questions of policy without previously consulting Delhi. ${ }^{62}$ Therefore, two British civil servants assisted Sastri, both sympathetic to the Indian case: Ricketts, who had been part of the Paddison deputation, became superintendent of the office, ${ }^{63}$ and the experienced John Dawson Tyson from the Bengal ICS cadre was appointed secretary to the agent. ${ }^{64}$

Sastri's instructions show the Gol's willingness to adhere to the Cape Town Agreement. They emphasised that the majority of Europeans did not favour a policy of uplifting Indians unless they could expect 'that the aim of their government to limit the size of the Indian community . . . will be achieved'. Therefore, apart from active propaganda, Sastri should do everything to support emigration. ${ }^{65}$ His performance was outstanding. The local press praised him for his sobriety, and everywhere Europeans accepted his hospitality. Sastri made it a point that he had come to help the Union government to implement the Round Table Agreement including assisted emigration. Accordingly, the number of returnees increased from 1,358 in 1925 to 2,975 in 1927. This helped Sastri in the uplift of Indians, particularly in Natal, where the agreement had been viewed with great suspicion. Now even the diehards in the province actively supported schemes for better housing and sanitation. Only Transvaal saw no progress. ${ }^{66}$ When Sastri agreed to extend his term until the end of 1928, the Union government responded with an amnesty to all Indians who had entered the Union without registration before 5 July $1924 .{ }^{67}$

When Reddi and Evelyn Baring took over in 1929, the general picture was a 'marked spirit of friendliness and good-will'. ${ }^{68}$ The positive effect of the Cape Town Agreement, however, faded away as it did not fulfil expectations. There were no serious efforts to uplift Indians by educational means, and until 1939 only 16,209 Indians were repatriated. ${ }^{69}$ By 1930, tensions increased again. Malan held that the agreement had to be re-evaluated after a period of five years and the proposed Transvaal Asiatic Tenure (Amendment) Bill, which would revitalise racial feelings, needed to be examined. The latter foresaw to prevent future ownership of fixed property by Asiatics outside special areas and to make trade licenses depend on a lawful title to 
occupy the premises, where trade was carried on. The rights of Indians who had acquired such premises since 1919 were not protected by the Union Act 37 of that year; they had to vacate them within five years. Nevertheless, the DEHL acknowledged that 'as the measure aims at rendering impossible in future evasion of what the laws of the province have all along intended, no legitimate objection can be taken to its provisions' ${ }^{70}$

Discriminatory measures of that kind affected both Indians and the indigenous population of South Africa. The GoI, however, did not care for the fate of the latter; it rather complained that it negatively affected the situation of Asiatics. The 'colour complex' was seen as 'mainly the product of the contact of black and white in South Africa', ${ }^{71}$ and racism as 'primarily anti-native', the 'anti-Indian feeling . . . a by-product'. ${ }^{72}$ As Hertzog's support was crucial for preventing the proposed bill, Bajpai warned 'that on this native question Hertzog is quite a fanatic and that any attempt to plead for the native will only irritate him and also antagonise him'. ${ }^{73}$

Instead, Bajpai once again proposed informal talks at another Imperial Conference. ${ }^{74}$ On 28 October 1930, a consensus was attained that Delhi should intensify efforts to support the emigration of Indians from South Africa. The desired extended protection of Indian occupants of immovable property in Transvaal might be made conditional on assurances of the Transvaal Indian Congress to support the modified bill. The measure of support by the GoI depended 'entirely on the support of Indian opinion both in South Africa and India', wherefore the incriminated bill 'should be suitably modified'.${ }^{75}$ Hertzog was 'sincerely anxious to help' ${ }^{76}$ and Bajpai offered discussions on the settlement of Indians in Tanganyika. ${ }^{77}$ By March 1931, another Round Table Conference was announced.

Whereas the GoI counted on Hertzog influencing Malan, major problems surfaced with the South African Indian Congress and Agent Reddi. The former demanded the cessation of diplomatic relations if the incriminated bill was not withdrawn. ${ }^{78}$ Furthermore, the Congress sections in Natal and Transvaal were at odds with each other and under poor leadership. ${ }^{79}$ Reddi tried to help, but it turned out rather a burden. Apart from severe health problems, forcing him to leave South Africa for around four months from the turn of 1929/1930, he was unable to cope with the delicate tasks that came with the post. In his absence, Tyson, representing the Indian case before the Select Committee to enquire matters affecting Indian and European interests in Transvaal, wrote to Bajpai 'that no community in South Africa would be very cast down if Reddi would not return' ${ }^{80}$ Andrews ${ }^{81}$ and Reddi's superiors in Delhi agreed full-heartedly: Fazl-i Husain criticised his confusing communication ${ }^{82}$ and the private secretary to the viceroy warned the SSI that Reddi had 'not got clear grasp of our views', forming a considerable risk if used as negotiator. ${ }^{83}$ Reddi even embarrassed the DEHL when suggesting an inexperienced white South African non-official as secretary to the agent. ${ }^{84}$ In response, Andrews demanded from Bajpai that 'on no 
account should anyone ever at any time be appointed secretary here who was not from India'. ${ }^{85}$

Nevertheless, to protect the agent's dignity, he was co-opted to the delegation to the Round Table Conference. ${ }^{86}$ Bajpai favoured a venue in South Africa again, as this permitted mediation by Hertzog, 'far more human than Dr. Malan'. If the conference took place in India, then South African delegates if accepting a compromise would be blamed to have been defeated by Indian hospitality. Furthermore, South African Indians would send a deputation dominated by extremists. Regarding the agenda, Bajpai felt that 'we should deem ourselves fortunate if we can manage to preserve the status quo'. Minor issues suggested by Andrews, like franchise in Cape Province, were not important enough for more than informal discussion. The focus once again lay on assisted emigration and the upliftment of Indians. ${ }^{87}$ Bajpai warned that 'nothing but disaster would ensue from any attempt in the present state of European opinion in South Africa to ask for complete equality of political status between Indians and Europeans'. ${ }^{88}$

Fazl-i Husain wanted to send as many of the members of the last delegation again ${ }^{89}$ - a point supported by Andrews, holding that Afrikaners were easily antagonised but had a perfect passion for old friends. Furthermore, Andrews insisted on Bajpai as secretary, whose 'work is more arduous and important than that of one member among many others' ${ }^{90}$ Finally, the delegation consisted of Fazl-i Husain as leader, Corbett, Darcy Lindsay, Sarojini Naidu, Reddi, Sastri, Sethna and Bajpai. From the team of the first Round Table Conference, Paddison had passed away. The immediate preparations show Bajpai calling the shots. He, first, insisted that the brief should be prepared along the lines of 1926, turning down suggestions by Fazl-i Husain. ${ }^{91}$ No work was done on the brief while Bajpai was absent. After his return from the Round Table Conference on India in late November 1931, the papers had to be finalised in a hurry to permit discussion in the Viceroy's Executive Council. This ensured, second, that there was hardly any time to discuss Bajpai's drafts beforehand, which covered only the most relevant issues. ${ }^{92}$ Therefore, on 30 November 1931, the Viceroy's Executive Council debated what were exclusively Bajpai's views.

Interestingly, in the brief on the assisted emigration scheme Bajpai admitted that India's support for the latter, which he himself had suggested and negotiated in 1926/1927, had turned out a boomerang. He confirmed public criticism ranging from Gandhi to the rather conservative Times of India that returnees to British India were most unhappy with the conditions they found. The Mahatma argued that the agreement was morally unacceptable as it had bartered away the rights of the poor against those of the ones better off. The newspaper held that after Indians had been lured to South Africa, it was up to the government in Pretoria to look after them. Notwithstanding the weight of public opinion, Bajpai found it unwise to insist on abandoning the scheme. He preferred to explain why assisted emigration 
and other efforts to reduce the Indian population had failed. The latter even had grown, but not due to immigration, and the number of Europeans was increasing faster. Given the anti-Indian sentiment among European voters, Bajpai, nevertheless, harboured no illusions that political leaders would not admit those facts in public. The GoI could not argue with the hardships of returnees, as Pretoria might then have replied that they were better off with segregation in South Africa. As with the first Round Table Conference, the GoI should give the scheme more time and provide better conditions for returnees. If asked, it also needed to offer advice on alternative destinations for emigrants like British Guiana or Fiji. In return, Delhi should demand the withdrawal of objectionable legislation and intensified efforts for the upliftment of Indians. More or less, these were the positions from 1926/1927.

Accordingly, the mood in the Viceroy's Executive Council was most pessimistic. Fazl-i Husain gave for consideration that South Africa held 173,000 Indians hostage, whereas India had no means to exercise any pressure. Therefore, the upcoming conference would be no meeting of equals; India would appear a beggar and have to promise further assistance to emigration. Viceroy Willingdon supported Fazl-i Husain's suggestion to leave the conference in case South Africa offered nothing but unacceptable terms. The council left the delegation without any practical advice. ${ }^{93}$

When the conference opened on 12 January 1932, Fazl-i Husain had fallen ill. Soon thereafter, Sastri sustained a heart attack. Until early February, this gave Bajpai the leading role. South Africa wanted to scrap the Cape Town Agreement but keep the agency as a symbol of friendship. Both sides considered the scheme of assisted emigration exhausted. According to Bajpai,

neither Malan nor any sane person believes that Indians are menacing or that Indian population of Union can substantially be reduced, but they feel that the illusion which they themselves have helped to create must be kept up. We ... must recognise that to retain goodwill of Union Government toward Indians here GoI must continue to humour them so long as this can be done honourably and without detriment to interests of local Indians.

Only the offer to investigate alternative destinations for the emigration of Indians both from South Africa and India, which was of little practical value, made it possible to renew the Cape Town understanding in some general form. ${ }^{94}$ The instructions for Reddi's successor, Maharaj Singh, show the calculation behind this move: If suitable destinations for emigration were found, Europeans in South Africa would be satisfied, and this would enable the government to uplift the vast majority of Indians staying behind.

[If] the investigation shows that the possibility of reducing the Indian element by colonisation in other countries is non-existent, 
the Union government would be in a strong position vis-à-vis antiAsiatic influences and would be able to say that ... the Indian community must remain a section of the permanent population of South Africa and that all necessary steps should be taken for their upliftment as is the recognised duty of every civilised government. ${ }^{95}$

At the conference, Sastri and Bajpai propagated British Guiana, where delegations had allegedly found 'excellent scope for colonisation' ${ }^{96}$ In order to win public opinion, Bajpai made Mrs Naidu confirm that she did not see why Gandhi should object to a scheme of emigration as long as it was not connected with repatriation. ${ }^{97}$ Sastri and Bajpai smartly involved the local Indian community, too, by insisting that such exploration could not be undertaken without their support. ${ }^{98}$ If the conference failed for lack of their backing, they were responsible for the consequences. In return, the South African delegation acknowledged that if they wanted to keep the agency, the new Transvaal bill could not be implemented in its current form..$^{99}$

This was the compromise reached on 4 February. ${ }^{100}$ The modified version of the disputed bill de facto gave Indians the freedom to remain at their places of residence and business, protected property lawfully registered until 1 May 1930 and foresaw the right to appeal against any refusal of trade licences. ${ }^{101}$ For the time being, the conference proved to be a turning point for South African-Indian relations. For the years to come, no antiAsiatic legislation of relevance was introduced. Personal relations among key actors remained cordial, and although South African Indians did not enjoy equal rights, their prestige had distinctly improved since the Paddison deputation in 1926. The Union government was willing to do its part; expenses on Indian education in Natal rose from $£ 28,000$ in $1926 / 1927$ to $£ 86,000$ in $1934 .{ }^{102}$

Relevant South African politicians had become more sympathetic to the Indian case, most prominently Hertzog, but more surprisingly even Malan. When in 1935, the latter as minister for the interior was succeeded by Jan Hendrik Hofmeyr, a liberal politician from the United South African National Party, the atmosphere improved further. The party faced hardly any opposition in parliament, but the Union government avoided public statements in favour of Indians. After the Feetham Commission, established to enquire into the occupation of proclaimed land in Transvaal by Indians, had recommended protection of Indian proprietary rights, Hofmeyr refused to modify the Transvaal Asiatic Land Tenure (Amendment) Bill. Instead, he promised to handle it in a manner favourable for Indians. ${ }^{103}$ Bajpai was disappointed, wondering if ever a better opportunity for changes of legislation would arise. ${ }^{104}$ Agent Raza Ali also found the ambitious Hofmeyr too sensitive to public criticism. He would have preferred to deal with Malan, extremely difficult to convert, but thereafter not unduly influenced by the public any more. ${ }^{105}$ 


\title{
Agents and DEHL
}

The change of atmosphere had been brought about via the establishment of personal relations. In this process, the various Indian agents played the most important role. More or less capable negotiators, they represented India in a dignified way, demonstrating that educated Indians were at eye level with Europeans. Therefore, they took part in all sorts of social functions, gave speeches and cultivated contacts with local Indians and Europeans up to the governor-general. Sastri as a great orator had been an immediate success, and his successor Sir Kurma Venkata Reddi was popular too. In 1929, after he had succeeded Sastri, as did Baring Tyson, ${ }^{106}$ the DEHL gave in to public expectation that the constellation of an Indian non-official as head of the agency and a British ICS secretary should be the standard. ${ }^{107}$ Reddi, a lawyer by profession, was member of the Justice Party and had served as minister of development in Madras Province from 1920 to 1923. Andrews had suggested his appointment, and Gandhi, approached by the DEHL, had approved. ${ }^{108}$

The third agent, Maharaj Singh, even outmatched his widowed predecessors for bringing along his equally educated and dignified wife, who attended social functions independently of her husband. She won such an enormous reputation that Governor-General Clarendon strongly suggested that any 'successor should be accompanied by a wife "able to hold her own in European society" '. ${ }^{109}$ Fazl-i Husain praised Mrs Singh for having

\begin{abstract}
given to the Europeans in South Africa a conception of cultured and enlightened womanhood, of which, unfortunately, our countrywomen in South Africa can furnish no example. Her presence has also, I am sure, kindled amongst Indians of her sex in the Union an enormous zeal to be likewise. ${ }^{110}$
\end{abstract}

A speech of hers, criticised by Hofmeyr, even led to a clarification of the agent's status. When asked for an explanation, the latter, in the spirit of the time, pleaded that due to the fact that he and his wife gave dozens of speeches, it was not always possible, 'especially for a woman, to avoid an occasional emotional or even extravagant statement'. Nevertheless, he insisted that they were both perfectly entitled to criticise the Union government whenever asked to elaborate the Indian standpoint on unjust legislation. He would rather leave than accept any restrictions. Hofmeyr had to give in, ${ }^{111}$ and Fazl-i Husain bolstered the agent up, confirming that 'he is really an ambassador' and was to receive instructions from the GoI only. ${ }^{112}$

Maharaj Singh had been selected rather by coincidence. The DEHL agreed with Muslim demands that after the Hindus Sastri and Reddi, the next agent should be a fellow believer. When all Muslim candidates 
turned the offer down, Maharaj Singh appeared the best choice for being married and commanding sufficient experience. He had been in government service since 1904 and, among others, had officiated as judicial secretary in the United Provinces in 1920. Moreover, with recent deputations to British Guiana and Mauritius, he provided expert knowledge on the issue of Indians overseas including colonisation schemes. ${ }^{113}$ As heir of the Kapurthala family, he represented princely India as well. ${ }^{114}$ It certainly did not hurt that his younger sister Rajkumari Amrit Kaur was a prominent member of the Congress. Like in the case of Reddi, Andrews, after consulting Gandhi, ${ }^{115}$ had recommended Maharaj Singh. ${ }^{116}$ That the latter was the first official to hold the post did not bother anyone. His successor Raza Ali was the first Muslim agent, selected for being 'a man of tact and resource who will not lose his head in a crisis' and 'a first-class lawyer', capable to handle the 'extraordinarily complicated' Transvaal land laws. ${ }^{117}$ Even better, Raza Ali had been part of the Paddison deputation in 1926. ${ }^{118}$

Both agents struggled with two major problems: the deep division between the South African Indian Congress and the Colonial-Born and Settlers' Indian Association, ${ }^{119}$ and massive difficulties to understand and explain the relevance of the colonisation scheme as finally manifested in the report of the Indian Colonisation Enquiry Committee in 1935. Both issues were related insofar as, unlike the Congress, the Association refused to cooperate with the committee right from the beginning. ${ }^{120}$ Among its leading figures was Manilal M. Gandhi, second son of the Mahatma ${ }^{121}$ and editor of the journal Indian Opinion. The rivalry weakened the standing of South African Indians vis-à-vis both the Union government and hostile parts of the European community. The DEHL considered the Congress the only political organisation representing Indian interests, which led to embittered criticism from the Association with a personal touch for the clumsy handling of the conflict by Maharaj Singh. ${ }^{122}$ Accordingly, his farewell party was overshadowed by a major assault by Manilal Gandhi in Indian Opinion and speeches by members of the Congress vehemently attacking the Association. ${ }^{123}$ Notwithstanding reiterated warnings by the DEHL - Bajpai considered Manilal Gandhi 'not amenable to reason'124 - Raza Ali made it a point to befriend the Association without alienating the Congress. ${ }^{125}$ Owing to his endeavours, Manilal Gandhi resigned from leadership in the Association. ${ }^{126}$ The latter and the Natal Indian Congress established a sort of cooperation. ${ }^{127}$

If the quarrels of South African Indians were annoying, the disputes around the colonisation scheme became a real headache. The GoI had agreed to a South African commission for mostly two reasons: first, to explore possibilities for Indians in general, not singling out those in the Union; second, and more important, such exploration was expected to prove that there were no suitable territories worldwide. This would bury the idea of driving 
Indians out of South Africa once and for all. In May 1935, Jagdish Prasad elaborated for Raza Ali:

If we thought merely of satisfying Indian leaders in South Africa and more vocal sections of opinion in this country, it would be quite easy for us to tell the Union government that we wash our hands of the whole affair and that they can do what they like.

This, however, would 'play into the hands of anti-Asiatics in the Union, who are still in a great majority, and throw the door wide open to the reentry ... of such measures as the Class Areas Bill'. The work of ten years would be undone and

we shall be powerless to protect the Indian community . . . against repressive legislation. In the circumstances, the only prudent and possible course for us is to reassure the Union Government that we stand by the undertaking of 1932 and, if they take the initiative in suggesting some country for purposes of exploration, to co-operate with them. ... Our objective must be to retain the good-will of the Union Government and to play for time. ${ }^{128}$

Whereas leading politicians and officials with both governments tacitly agreed on this, South African Indians and Indian agents had difficulties to comprehend such logic. During the Round Table Conference, it had been agreed to explore prospects for British New Guinea, British North Borneo and British Guiana. It turned out that the first was closed for Indian migrants, whereas health conditions and finances in British North Borneo and British Guiana made it impossible to absorb considerable numbers of immigrants. ${ }^{129}$ Nevertheless, the South African Indian Congress, having promised support during the Round Table Conference, vehemently campaigned against it as soon as the Indian Colonisation Enquiry Committee came into being. It managed to pull along Maharaj Singh. ${ }^{130}$ In a particularly harsh letter to Fazl-i Husain from August 1933, he burst out that the position of the agency

has been rendered weaker and more vulnerable by . . . the Colonisation Scheme. I sometimes have the wicked idea viz: that you and the other members of the last delegation should be in South Africa to face the music or at any rate to support me in facing it!! Of course I appreciate the last delegation's difficulties but mine are even greater!!131

Fazl-i Husain got 'sick' of the agent's 'platitudes' $;{ }^{132}$ he and Bajpai consented that 'no useful purpose will be served by arguing the matter further'. ${ }^{133}$ 
It took the agent a full year to comprehend that the report 'really killed colonisation for Indians from India and consequentially for Indians from this country'. ${ }^{134}$ Such insights were helped by the South African Indian Congress admitting that the forthcoming report 'recognises the fact that the South African born Indian is a product of the West and will not be able to adapt himself to Eastern conditions of life'. ${ }^{135}$ Ironically, Maharaj Singh's successor Raza Ali, shortly after his arrival in early 1935, again emphasised that 'the first thing to do is to kill colonisation' by refusing any cooperation. ${ }^{136}$ Jagdish Prasad's explanation, mentioned above, settled the matter with the agency once and for all.

The committee's report confirmed that all destinations investigated were out of discussion. Nevertheless, the GoI responded unwisely, emphasising that

India will not be justified in taking steps now ... to explore the possibility of large-scale colonisation from India in any outside country. ... Whether and when the Government of India will be able to take advantage of any scheme of colonisation ... will depend upon conditions in India, in particular the cost involved. ${ }^{137}$

Many in the South African cabinet understood this as provocative breach of the Round Table Agreement, ${ }^{138}$ endangering the position of domiciled Indians once again.

Only in October 1935 did Bajpai find a solution. He warned Hofmeyr that Italy, a newcomer on the African continent, might seek to extend its influence 'either by direct aggression aiming at territorial conquest or indirectly by arousing the African native'. South Africa needed the friendship of the Commonwealth, including India. The latter 'was no longer a mere seeker of favours and South African policy might well be given a fresh orientation in the matter of the treatment of Indians in the Union primarily in the Union's own interest'. Hofmeyr admitted the force of this argument and took care for the matter to be finally settled. ${ }^{139}$

This chapter as well as the files highlight the work of the agents and the top ranks of the DEHL, but the contribution of ICS officers working with the agency must not be overlooked. They were all ad hoc recruited British, who, according to the department, 'should possess tact, pleasant manners, social adaptability and a temperament which would lend itself to sympathetic understanding and advocacy of the Indian point of view in both official and private dealings with Europeans in South Africa'. ${ }^{140}$ As the selection of Geoffrey Stephen Bozman from the 1922 batch of the Madras ICS cadre shows, the key criterion was availability rather than qualification. Nevertheless, Bozman made himself a name in both South Africa and later in the $\mathrm{DEHL}^{141}$ and rose to the rank of secretary in the Department of Information and Broadcasting during the war. Provincial governments were throughout 
reluctant to release promising officers, be it for secretariat work in Delhi or the agencies. Nearly all of those set free, nevertheless, performed well. Their role was twofold. As Europeans, they were socially acceptable to the European community in South Africa. Therefore, they could both provide Delhi with information on the community's views and open doors for the agents. ${ }^{142}$ In a manner of speaking, they were also meant to counterbalance the agents by forwarding their own assessments, which were formulated in a more professional manner. ${ }^{143}$ Finally, the ICS secretaries provided an element of stability and continuity. Tyson returned to South Africa in early 1930 to represent the Indian case before a committee; C.S. Ricketts had been part of the Paddison Deputation ${ }^{144}$ and served as office superintendent under Sastri. ${ }^{145}$ In the 1930s, he returned as assistant secretary, occasionally officiating as secretary to the agent. ${ }^{146}$

All agents praised the performance of the secretaries, and so did Raza Ali in the case of Secretary C.F.V. Williams. Seemingly out of the blue, however, matters escalated in December 1935. Both men had their share. Already as junior officer, Williams had been criticised for his 'rather brusque manner'. ${ }^{147}$ When he learned of marriage plans of Raza Ali, he correctly emphasised with him that this was no private affair, agents representing their government. He must, therefore, ask for approval from Delhi. Williams also warned that the marriage with Miss Pounee Sammy, belonging to South Africa's Hindu community, might harm the prestige of the agent, as Europeans considered all local Indians coolies. Choosing a wife from this community, however, might also prove such prejudices wrong. ${ }^{148}$

Raza Ali followed Williams' advice and informed Bajpai, holding that the marriage was approved even by Hofmeyr. ${ }^{149}$ The letter, however, arrived at such short notice that it left Delhi hardly any time to intervene had it wanted so. Against explicit instructions of the agent, Williams sent an official letter of his own, warning of the possible effects of the marriage. Bajpai fully shared those concerns. He wrote to the private secretary to the viceroy that Raza Ali

may not be culturally superior to this lady - my only recollection of her 'culture' is a Cockney accent - but the fact that he comes direct from India hides many of his faults, and, at any rate, is a guarantee that he is of good birth.

If the viceroy and Clarendon shared such concerns, the GoI should 'plainly warn Raza Ali that we would expect him to seek an early and reasonable excuse for vacating his appointment'. ${ }^{150}$

For once, Bajpai's superiors did not share his views. After the marriage, more letters arrived from South Africa, Raza $\mathrm{Ali}^{151}$ and Williams ${ }^{152}$ blaming each other. The latter held that it was his duty to contact the department directly as the agent had not adequately portrayed the situation in his 
communication with Delhi. Bajpai approved in parts: 'An Indian agent may not fully appreciate the effects of an act or proposed decision on European opinion in the Union ... Govt. should, therefore, have means of knowing the European secretary's views of the matter'. Such communication must be, however, 'entirely unofficial and without challenge to the or disparagement of the authority of the agent'. ${ }^{153}$

Jagdish Prasad saw 'a state of affairs which we cannot allow to continue'. ${ }^{154}$ 'One may be able to understand Mr. Williams's motives, but his procedure would be subversive of all discipline'. ${ }^{155}$ Bajpai admitted 'temperamental defects' and a problematic 'conception of official duties', wherefore the secretary should be transferred. Nevertheless, he insisted that in certain circumstances secretaries should have the right for direct communication, though obliged to inform the agent about the content. ${ }^{156}$ Against Jagdish Prasad, ${ }^{157}$ Bajpai secured the viceroy's support in this matter. ${ }^{158}$

Although that far communalism had played no role in South Africa, Indian political leaders there protested against Raza Ali's interreligious marriage. When their representations did not foster any results, many stepped back in protest, harming the agent's authority. ${ }^{159}$ The concerns about European reactions and the protests of South African Hindus once again demonstrated that the status of local Indians was highly vulnerable. Their reputation had much improved, but Clarendon still ignored Raza Ali's repeated suggestions to invite local Indians to his garden parties. ${ }^{160}$ The decision from December 1935 to enhance the prestige of the agency and Indians by giving its head the title agent-general had no effect. ${ }^{161}$

One might have expected Indian cooperation with the equally discriminated natives. There was, however, nothing of a joint anti-colonial struggle. If the fate of the natives came into the focus ever, it was because it was feared that linking theirs with that of Indians might be detrimental for the latter. In conjunction with the debate of a colonisation scheme, the South African Indian Congress held that local Indians were too westernised to live in territories like North Borneo together with Chinese and locals. ${ }^{162}$ This, first, reflected the general attitude: Indians considered themselves a class of their own, struggling for equality with Europeans, distancing themselves from other disadvantaged groups. Furthermore, it was in harmony with basic Indian attitudes, dark skin being associated with low or no caste. Indian exclusiveness could also be seen in Raza Ali's refusal to side with the Jewish community. ${ }^{163}$

There were tactical reasons too. When at a reception of the Congress a discussion came up whether to link the status of Indians with that of the natives, Raza Ali warned that

the native problem is a huge and extremely complicated problem and it would be an extremely short-sighted policy for us to set up the resident Indian community in co-operation with the natives 
against the European population which . . . is extremely nervous being a fraction of the native population in South Africa. ${ }^{164}$

He felt reassured when visiting Zulu areas and talking with some of their leaders - the first agent ever to do so. He found the Zulus living in the countryside primitive, lazy and unfit to suggest political changes; for a long time, no reasonable man could grant them franchise, and comparing them with Indians was the 'height of absurdity'. ${ }^{165}$ The agent even pleaded for segregation, as allegedly crime rates among Indians were higher in areas where they lived together with natives. ${ }^{166}$

For Bajpai's sake, it must be emphasised that he contradicted such statements:

The native undoubtedly is bad company for the more advanced races. Personally, however, I hold the view that this is due not so much to any moral turpitude in him as to the lack of moral stamina in members of the more advanced races to resist the temptation to exploit his weakness.

Raza Ali should remind local Indians that they had a responsibility to the natives. ${ }^{167}$ Like in 1930, for tactical reasons he, nevertheless, welcomed 'that, unlike Andrews and a few others, you are not disposed to take the view that the Indian should make common cause with the native'. Given the European attitude, 'such a step would be suicidal'. ${ }^{168}$

\section{Notes}

1 NAI, DEHLO, May 1926, B, 1-12. Interim Report of the Indian Deputation to South Africa, 14 January 1926, G.F. Paddison, Deva Prasad Sarvadhikary, S. Raza Ali.

2 NAI, DEHLO, March 1926, B, 1-88. Telegram, J.H. Green to SSI, 2 January 1926.

3 Paul F. Power, 'Gandhi in South Africa', The Journal of Modern African Studies, 1969, 7(3): 448-454.

4 Hugh Tinker, The Banyan Tree. Overseas Emigrants from India, Pakistan, and Bangladesh, Oxford: Oxford University Press, 1977, p. 22.

5 William K. Hancock, Smuts: The Sanguine Years, 1870-1919, Cambridge: Cambridge University Press, 1962, pp. 346-347.

6 Brian M. Du Toit, 'The Mahatma Gandhi and South Africa', The Journal of Modern African Studies, 1996, 34(4): 652.

7 P. Kodanda Rao, The Right Honourable V.S. Srinivasa Sastri. A Political Biography, London: Asia Publishing House, 1963, pp. 207-210.

8 NAI, DEHLO, 1923, B (B), September, 1-8. Prime Minister's Office, Minute 984, 15 December 1922.

9 NAI, DEHLO, 1923, B, October, 21-22. Draft letter to SSI [Summer 1924].

10 NAI, DEHLO, 1924, B, April, 115. Unofficial memorandum 1321-Ex, offg. DS Macleod, Financial Dept., 6 June 1923. 
11 NAI, DEHLO, May 1924, B, 17-33. Note, Sarma, 17 January 1924.

12 BL, MSS EUR, JWP, D.545/2. Letter, Bajpai to Walton, 6 November 1924.

13 BL, MSS EUR, JWP, D.545/2. Letter, Bajpai to Walton, 13 December 1923.

14 NAI, DEHLO, May 1924, B, 17-33. Note, Bajpai, 19 January 1924.

15 NAI, DEHLO, May 1924, B, 17-33. Note, Butler, 21 January 1924.

16 NAI, DEHLO, September 1924, B, 41. Telegram 257, DEHL to Governor General South Africa, 14 March 1924.

17 NAI, DEHLO, May 1924, B, 17-33. Telegram 192, Reading to Olivier, 29 February 1924.

18 NAI, DEHLO, August 1925, B, 5-19. Memorandum, Bajpai, 16 April 1925.

19 NAI, DEHLO, May 1931, A, 1-77. Note 'South Africa, Assisted Emigration Scheme', [early 1931].

20 BL, MSS EUR, JWP, D.545/2. Letter, Bajpai to Walton, 18 September 1924.

21 NAI, DEHLO, June 1925, B, 25-31. Note, Bajpai, 9 February 1925.

22 NAI, DEHLO, June 1925, B, 25-31. Letter, G. Grindle, Colonial Office, to USSI, 17 February 1925.

23 NAI, DEHLO, March 1926, B, 1-88. Note, G. R., 29 August 1925.

24 NAI, DEHLO, April 1925, B, 1-4. Note, Bajpai, 5 February 1925.

25 NAI, DEHLO, March 1926, B, 1-88. Note, Bhore, 31 August 1925.

26 NAI, DEHLO, March 1926, B, 1-88. Telegram 1420-S, DEHL to PSV, 11 November 1925.

27 NAI, DEHLO, March 1926, B, 1-88. Telegram 1476-S, DEHL to PSV, 20 November 1925.

28 NAI, DEHLO, May 1926, B, 1-12. Interim Report of the Indian Deputation to South Africa, 14 January 1926.

29 NAI, DEHLO, August 1926, A, 1-107. Letter, Bajpai to Ewbank, 12 March 1926.

30 NAI, DEHLO, August 1926, A, 1-107. Telegram, Paddison, 6 January 1926.

31 NAI, DEHLO, August 1926, A, 1-107. Telegram, Paddison, 20 January 1926.

32 NAI, DEHLO, August 1926, A, 1-107. Telegram, Paddison, 13 January 1926.

33 NAI, DEHLO, May 1926, B, 1-12. Note, Bhore, 15 February 1926.

34 NAI, DEHLO, August 1926, A, 1-107. Letter, Paddison to Bhore, 11 March 1926.

35 NAI, DEHLO, August 1926, A, 1-107. Letter, Bajpai to Bhore, 11 March 1926. Emphasis in the original.

36 BL, MSS EUR, JWP, D.545/2. Letter, Bajpai to Walton, 18 September 1924.

37 NAI, DEHLO, August 1926, A, 1-107. Telegram 257-O.S. to Governor-General South Africa, 26 March 1926.

38 NAI, DEHLO, August 1926, A, 1-107. Telegram, Paddison, 2 April 1926.

39 NAI, DEHLO, August 1926, A, 1-107. Telegram to Governor-General South Africa, 31 May 1926.

40 NAI, DEHLO, August 1926, A, 1-107. Telegram, Governor-General, 28 June 1926.

41 NAI, DEHLO, May 1926, B, 31-43. Note, Ewbank, 14 January 1926.

42 BL, MSS EUR, JWP, D.545/2. Letter, Bajpai to Walton, 10 December 1925.

43 NAI, DEHLO, August 1926, A, 1-107. Telegram, Governor-General to Viceroy, DEHL, 13 April 1926.

44 NAI, DEHLO, August 1926, A, 1-107. Letter, Bajpai to Bhore, 27 February 1926.

45 Hugh Tinker, The Ordeal of Love. C. F. Andrews and India, New Delhi: Oxford University Press, 1979, pp. 84-90.

46 NAI, DEHLO, September 1925, B, 4-6. Letter, Bajpai to Andrews, 15 September 1924.

47 NAI, DEHLO, August 1926, A, 1-107. Letter, Bajpai to Bhore, 27 February 1926. 
48 NAI, DEHLO, June 1931, B, 40-41. Note, Bajpai, 26 March 1931.

49 NAI, DEHLO, November, B, 123-125. Summary of the Brief, forwarded by Bhore to Honourable Members, 29 September 1929.

50 NAI, DEHLO, September 1926, B, 17. Note, Bhore, 24 August 1926.

51 NAI, DEHLO, December 1926, B, 26-34. Telegram, Bajpai to DEHL, 25 October 1926.

52 NAI, DEHLO, December 1926, B, 26-34. Note, Bajpai, 3 November 1926.

53 NAI, DEHLO, December 1926, B, 26-34. Note, Bajpai, 18 November 1926.

54 Rao, The Right Honourable V.S. Srinivasa Sastri, p. 218.

55 NAI, DEHLO, December 1926, B, 128-149. Telegram 1055-O.S., DEHL to Governor-General South Africa, 14 October 1926.

56 NAI, MEA, South Africa Papers, 26-A/H/C/SA/1926.

57 Rao, The Right Honourable V.S. Srinivasa Sastri, p. 218.

58 NAI, DEHLO, May 1927, B, 43. Summary of Important Events in the DEHL during the Year 1926-1927.

59 NAI, DEHLO, July 1928, B, 263-340. Note, Bajpai, 8 March 1927.

60 NAI, DEHLO, July 1928, B, 263-340. Note, Bajpai, 11 March 1927.

61 NAI, DEHLO, December, A, 1-65: Letter, Andrews to Viceroy.

62 NAI, DEHLO, July 1928, B, 263-340. Telegram, Habibullah to Viceroy, 7 April 1927.

63 NAI, DEHLO, March 1931, B, 12-25. Note, 2 January 1931.

64 NAI, DEHLO, August 1927, B, 5-8. Letter, Bajpai to Accountant General, Central Revenues, 4 August 1927.

65 NAI, DEHLO, June 1927, B, 39. Secret Instructions, undated.

66 NAI, DEHLO, April 1928, B, 10-13. Half-yearly Report South Africa, Tyson, 31 December 1927.

67 NAI, DEHLO, November, B, 3-5. Half-yearly Report South Africa, Sastri, 12 December 1928.

68 NAI, DEHLO, June 1930, B, 74-76. Note, G. R., 1 May 1930.

69 Tinker, The Banyan Tree, p. 23.

70 NAI, DEHLO, May 1931, A, 1-77. Memorandum Regarding Certain Rights of Indians in the Transvaal, [summer 1930].

71 NAI, DEHLO, July 1926, B, 34. Summary of Instructions for the Round Table Conference, Bajpai, 9 September 1926.

72 NAI, DEHLO, January 1931, B, 13-17. Telegram 3507-S, DEHL to PSV, 20 October 1930.

73 NAI, DEHLO, January 1931, B, 13-17. Letter, Bajpai to Ram Chandra, [November 1930].

74 NAI, DEHLO, May 1931, A, 1-77. Note, Bajpai, 7 August 1930.

75 NAI, DEHLO, May 1931, A, 1-77. Letter, Bajpai to Fazl-i Husain, 31 October 1930.

76 NAI, DEHLO, May 1931, A, 1-77. Telegram 3491, SSI to Viceroy, 2 November 1930.

77 NAI, DEHLO, May 1931, A, 1-77. Letter, Bajpai to Fazl-i Husain, 31 October 1930.

78 NAI, DEHLO, January 1931, B, 13-17. Ram Chandra for Bajpai, 20 October 1930.

79 NAI, DEHLO, December 1931, A, 1-65. Letter, Baring to Bajpai, 5 August 1931.

80 NAI, DEHLO, April 1930, A, 1-28-K.W. Telegram 235, Tyson to Bajpai, 3 April 1930.

81 NAI, DEHLO, December 1931, A, 1-65. Letter, Andrews to Viceroy, 6 February 1931. 
82 NAI, DEHLO, May 1931, A, 1-77. Note, Fazl-i Husain, 28 December 1930.

83 NAI, DEHLO, May 1931, A, 1-77. Telegram 15-C, PSV to SSI, 7 January 1931.

84 NAI, DEHLO, March, 12-25. Letter, Reddi to Fazl-i Husain, 9 January 1931, and Note, Bajpai, 19 February 1931.

85 NAI, DEHLO, April 1931, B, 210-211. Letter, Andrews to Bajpai, 16 February 1931.

86 NAI, DEHLO, December 1931, A, 1-65. Note, Ram Chandra, 13 November 1931.

87 NAI, DEHLO, December 1931, A, 1-65. Note, Bajpai, 27 March 1931.

88 NAI, DEHLO, December 1931, A, 1-65. Note, Bajpai, 27 April 1931.

89 NAI, DEHLO, December 1931, A, 1-65. Note, Fazl-i Husain, 29 April 1931.

90 NAI, DEHLO, December 1931, A, 1-65. Letter, Andrews to Viceroy, 8 April 1931.

91 NAI, DEHLO, December 1931, B, 100. Notes from Fazl-i Husain, 30 June, and Bajpai, 6 July 1931.

92 NAI, DEHLO, December 1931, B, 100. Note, Bajpai, 22 November 1931.

93 NAI, DEHLO, December 1931, B, 100. Note, Bajpai, 1 December 1931.

94 NAI, DEHLO, 1932, B, 209. Telegram 16, Fazl-i Husain to Viceroy, 1 February 1932.

95 NAI, DEHLO, 1932, B, 310. Instructions for Agent Kunwar Sir Maharaj Singh, undated.

96 NAI, MEA, South Africa Section, South Africa Papers, 26-A/H/C/SA/1926. Proceedings, Meeting on 15 January 1932. Kindly provided by Heena Mistry.

97 NAI, MEA, South Africa Section, South Africa Papers, 26-A/H/C/SA/1926. Proceedings, Meeting on 19 January 1932. Kindly provided by Heena Mistry.

98 NAI, MEA, South Africa Section, South Africa Papers, 26-A/H/C/SA/1926. Proceedings, Meeting on 15 January 1932. Kindly provided by Heena Mistry.

99 NAI, DEHLO, 1932, B, 209. Letter, Bajpai to Ram Chandra, 22 January 1932.

100 NAI, DEHLO, 1932, B, 310. Statement made in the Legislative Assembly and the Council of State, 5 April 1932.

101 NAI, DEHLO, 1932, B, 209. Letter, Ram Chandra to Director of Public Information R.S. Bajpai.

102 NAI, DEHLO, B, 19-2. Letter, Fazl-i Husain to Maharaj Singh, 11 December 1934.

103 NAI, DEHLO, 1935, B, 4-3. Letter, Raza Ali to Bajpai, 24 October 1935.

104 NAI, DEHLO, 1935, B, 4-3. Letter, Bajpai to Raza Ali, 26 November 1935.

105 NAI, DEHLO, 1935, B, 4-3. Letter, Raza Ali to Bajpai, 24 October 1935.

106 NAI, DEHLO, February 1930, B, 94-95. Half-yearly Report South Africa, Tyson, 1 July 1929.

107 NAI, DEHLO, November 1931, B, 103. Note, Noyce, 30 November 1931.

108 NAI, DEHLO, November 1931, B, 103. Note, Ram Chandra, 13 November 1931.

109 NAI, DEHLO, 1934, B, 19-2. Letter, Maharaj Singh to Fazl-i Husain, 26 November 1934.

110 NAI, DEHLO, 1934, B, 19-2. Letter, Fazl-i Husain to Maharaj Singh, 11 December 1934.

111 NAI, DEHLO, 1933, B, 44-2, part 2. Letter, Maharaj Singh to Fazl-i Husain, 28 November 1933.

112 NAI, DEHLO, 1933, B, 44-2, part 2. Letter, Fazl-i Husain to Maharaj Singh, 18 December 1933.

113 NAI, DEHLO, 1933, B, 249-1. Note, DEHL, 11 May 1932. 
114 NAI, DEHLO, 1935, B, 332, part 1. Letter, Bajpai to PSV Mieville, 28 December 1935.

115 NAI, DEHLO, 1931, B, 103. Note, Ram Chandra, 13 November 1931.

116 NAI, DEHLO, 1931, B, 103. Note, F. Bryce, 30 November 1931.

117 NAI, DEHLO, 1934, B, 168. Letter, Fazl-i Husain to Willingdon, 6 October 1934.

118 NAI, DEHLO, 1934, B, 19-2. Letter, Fazl-i Husain to Maharaj Singh, 11 December 1934.

119 See Anand Cheddie, The Colonial-Born and Settlers' Indian Association in Natal Indian Political 1933-1939, M.A. thesis, Durban 1992, https://researchspace.ukzn.ac.za/bitstream/handle/10413/7623/Cheddie_Anand_1992. pdf? sequence $=1 \&$ isAllowed $=y$ [accessed 12 December 2018].

120 NAI, DEHLO, 1933, B, 288. Manifesto of the Colonial-Born and Settlers' Indian Association, attached to Letter, G. S. Bozman to Bajpai, 25 September 1933.

121 Uma Dhupelia-Mesthrie, Gandhi's Prisoner? The Life of Gandhi's Son Manilal, Cape Town: Kwela, 2004, pp. 224-230.

122 Ibid., p. 228.

123 NAI, DEHLO, 1935, B, 4. Letter, C.F.V. Williams to Fazl-i Husain, 28 January 1935.

124 NAI, DEHLO, 1933, B, 44-2, part 1. Note, Bajpai, 12 September 1933.

125 NAI, DEHLO, 1934, B, 1934, 168. Letter, Raza Ali to Hydari, 11 January 1935.

126 NAI, DEHLO, 1935, B, 4-1. Letter, Raza Ali to Jagdish Prasad, 10 April 1935. See also Dhupelia-Mesthrie, Gandhi's Prisoner, pp. 237-238.

127 NAI, DEHLO, 1935, B, 4-2. Letter, Raza Ali to Jagdish Prasad, 29 August 1935.

128 NAI, DEHLO, 1935, B, 4-1. Letter, Jagdish Prasad to Raza Ali, 17 May 1935.

129 NAI, DEHLO, 1932, B, 228(2). Note, Hydari, 16 April 1934.

130 NAI, DEHLO, 1932, B, 310. Instructions for Kunwar Sir Maharaj Singh, undated.

131 NAI, DEHLO, 1933, B, 44-2, part 1. Letter, Maharaj Singh to Fazl-i Husain, 7 August 1933.

132 NAI, DEHLO, 1933, B, 44-2, part 1. Note, Fazl-i Husain, 24 August 1933.

133 NAI, DEHLO, 1933, B, 44-2, part 1. Note, Bajpai, 21 October 1933.

134 NAI, DEHLO, 1934, B, 19-2. Letter, Maharaj Singh to Fazl-i Husain, 20 August 1934.

135 NAI, DEHLO, 1934, B, 19-2. Letter, Honorary Secretary A.I. Kajee, South African Indian Congress, to Agent Singh, 20 August 1934.

136 NAI, DEHLO, 1935, B, 4-1. Letter, Raza Ali to Jagdish Prasad, 24 April 1935.

137 NAI, DEHLO, 1932, 288(2). Letter, Willingdon to Clarendon, 25 December 1934.

138 NAI, DEHLO, 1935, A, 111. Minute 36, Ministers of the Government of the Union of South Africa, 9 March 1935.

139 NAI, DEHLO, 1935, A, 111. Letter, Bajpai to PSV Mieville, 15 October 1935.

140 NAI, DEHLO, 1932, B, 250. Letter, Ram Chandra to Secretary in the Commerce Dept. J.C.B. Drake, 12 December 1931.

141 BL, IOR, L/SG/11/7/9. Report 1940-41, Jagdish Prasad, 28 March 1940.

142 NAI, DEHLO, 1935, B, 4-3. Letter, Raza Ali to Bajpai, 2 October 1935.

143 For example, NAI, DEHLO, 1935, B, 76. Half-yearly Report, Ending 31st December, Williams, 25 March 1935.

144 NAI, DEHLO, 1926, B, 1-88. Telegram 1519-S to PSV, 25 November 1925.

145 NAI, DEHLO, 1927, B, August, 5-8. Letter, Bajpai to Accountant General, Central Revenues, 4 August 1927.

146 NAI, DEHLO, 1937, B, 23. Note, DEHL, 28 January 1937. 
147 BL, IOR, L/SG/11/7/73. Annual Report on Officers of ICS, Ganjan Collectorate, Chatrapur, 11 January 1929.

148 NAI, DEHLO, 1935, B, 332, part 2. Letter, Williams to Bajpai, 27 February 1936.

149 NAI, DEHLO, 1935, B, 332, part 1. Letter, Raza Ali to Bajpai, 10 December 1935.

150 NAI, DEHLO, 1935, B, 332, part 1. Letter, Bajpai to PSV Mieville, 28 December 1935.

151 NAI, DEHLO, 1935, B, 332, part 2. Letter, Raza Ali to Jagdish Prasad, 12 March 1936.

152 NAI, DEHLO, 1935, B, 332, part 2. Letter, Williams to Bajpai, 27 February 1936.

153 NAI, DEHLO, 1935, B, 332, part 1. Note, Bajpai, 15 January 1936.

154 NAI, DEHLO, 1935, B, 332, part 2. Note, Jagdish Prasad, 24 March 1936.

155 NAI, DEHLO, 1935, B, 332, part 2. Note, Jagdish Prasad, 1 April 1936.

156 NAI, DEHLO, 1935, B, 332, part 2. Note, Bajpai, 31 March 1936.

157 NAI, DEHLO, 1935, B, 332, part 2. Note, Jagdish Prasad, 1 April 1936.

158 NAI, DEHLO, 1935, B, 332, part 2. Note, Bajpai, 3 April 1936.

159 NAI, DEHLO, 1935, B, 332, part 1. Letter, Clarendon to Willingdon, 1 April 1936.

160 NAI, DEHLO, 1935, B, 4-2. Note, Jagdish Prasad, 31 July 1935.

161 NAI, DEHLO, 1935, B, 185. Letter, Bajpai to USSI, 19 July 1935, and Press Note, DEHL, 10 December 1935.

162 NAI, DEHLO, 1934, B, 19-2. Letter, Honorary Secretary A.I. Kajee, South African Indian Congress, to Agent Singh, 20 August 1934.

163 NAI, DEHLO, 1935, B, 4-3. Letter, Raza Ali to Bajpai, 8 November 1935.

164 NAI, DEHLO, 1935, B, 4-1. Letter, Raza Ali to Fazl-i Husain, 18 March 1935.

165 NAI, DEHLO, 1935, B, 4-3. Letter, Raza Ali to Bajpai, 10 October 1935.

166 NAI, DEHLO, 1935, B, 4-3. Letter, Raza Ali to Bajpai, 17 October 1935.

167 NAI, DEHLO, 1935, B, 4-3. Letter, Bajpai to Raza Ali, 12 November 1935.

168 NAI, DEHLO, 1935, B, 4-3. Letter, Bajpai to Raza Ali, 26 October 1935. 


\section{5 \\ EAST AFRICA}

\section{Kenya}

For centuries, Indians had done business along the coast of East Africa. For once in line with Churchill, ${ }^{1}$ Bajpai emphasised that 'the British flag followed the Indian trader'. ${ }^{2}$ With the colonisation of Kenya, Uganda and Zanzibar in the 1880s, a significant number of South Asians settled inland too. Unlike in South Africa, these were craftsmen, artisans and traders. The latter nearly held a monopoly in the area. Until the Second World War, the position of Indians was never challenged in Uganda or Tanganyika (after the Great War British trusteeship territory); the same was true for Zanzibar until 1934. In 1904, after the colonial power had invited European settlers, Kenya became a political battlefield. British administrators viewed Indians with contempt as they allegedly exploited the natives' weaknesses by offering barter and loans leading to indebtedness. ${ }^{3}$ The first open conflict developed around the Kenya Highlands, which offered unique conditions for agriculture. In 1908, SSC Earl of Elgin reserved the area for Europeans. In 1913, Indian feelings were further aggravated by W.J. Simpson's report on sanitary matters, recommending residential and commercial segregation. Moreover, in 1918, the report of a local Economic Commission of Enquiry into post-war development demanded strict control of immigration from India.

The interwar period was characterised by ruthless though unsuccessful efforts by the settlers to gain full control over Kenyan affairs. They were to no small extent supported by some of the governors, partly acting against instructions from London. ${ }^{4}$ The Colonial Office repudiated the creation of another dominion, but supported all efforts to limit and reduce political and economic influence of Indians, often by unfair means. This discriminatory policy was based but on the belief in white supremacy: The settlers, nearly all public investments in Kenya made to their benefit, were utterly inefficient economically. ${ }^{5}$ Furthermore, according to the census of 1931, there were 16,842 Europeans, forming a mere 0.5 per cent of the population, vis-à-vis almost 40,000 Indians. Given the rapid political changes which British India underwent, in all quarters of Indian opinion up to the viceroys the settlers' 
attitude was considered completely out of time. The DEHL saw the Colonial Office as the actual antagonist. Over more than a decade, it engaged in an intense struggle around the issue of equal franchise, never implemented but finally accepted on principle. By the mid-1930s, there existed sufficient safeguards against further political and economic discrimination and against settlers' rule.

\section{Struggle for equality}

Represented by a governor, supported by executive and legislative councils, the highest authority lay with the British government. Until the end of the Great War, members of both bodies were nominated. When in 1920, Kenya became a crown colony, on the one hand Europeans were given the right to elect 11 members to the Legislative Council. Furthermore, SSC Alfred Milner supported segregation in residential and commercial areas. On the other hand, there were no discriminatory restrictions on immigration and Indians were granted two seats in the Legislative Council plus representation in municipal councils. The candidates, however, were to be elected on communal franchise. ${ }^{6}$ This met neither settlers' demands for self-rule nor Indian claims for equal rights. That the latter could not be ignored any more became evident in January 1922, when Churchill under public pressure had to recall settler-friendly Governor Edward Northey. ${ }^{7}$ His successor Robert Coryndon, nevertheless, took a similar stand, like many governors sharing a South African background with the majority of the settlers. ${ }^{8}$

In the autumn of 1922, Colonial Office and India Office jointly produced the so-called Wood-Winterton Report, named after the two under secretaries of state. It suggested a common electoral roll for all British subjects; due to property and education qualifications, however, only about 10 per cent male Indians were to be granted franchise. Furthermore, in the Legislative Council there would remain an official majority, a safeguard against settlers' rule. Seven seats were reserved for Europeans, four for Indians. In some of the constituencies, both European and Indian candidates would be eligible. The nominated Indian member in the executive council was to continue. There should be no segregation and no restrictions on immigration. The SSC, however, reserved the right to intervene if the currently low influx of Indians increased dramatically. Regarding the Highlands, the two offices were unable to find a compromise, wherefore the SSI reserved the right to reopen the issue at a later opportunity. Though emphasising that the Wood-Winterton Report did not fully meet Indian claims, the GoI accepted the proposals. The Kenyan government, however, turned them down for insufficient safeguards against future Indian predominance. The settlers even prepared for an uprising if the proposals were implemented. ${ }^{9}$ 
A near complete turnover resulted from the conservatives coming to power in London in October 1922. The Colonial Office under the influence of USSC William Ormsby-Gore turned against Kenya's Indians. ${ }^{10}$ In the Devonshire Declaration of 25 July $1923,{ }^{11}$ native interests were declared to be of paramount consideration for all future policies in Kenya, without giving any indication how to implement that paramountcy. ${ }^{12}$ Formally, the British government declared to be committed to trusteeship and against self-government. The continuation of the status quo, however, favoured the settlers. ${ }^{13}$ As a token of goodwill, Indians were granted a fifth seat in the Legislative Council.

Naturally, the declaration was repudiated by those supporting the Indian case. Andrews complained of 'lack of statesmanship and . . callousness to Indian interests'. ${ }^{14}$ Sastri saw a 'grave national humiliation'; London had convinced itself 'that we are a danger to the native, that we are a moral and physical infection'. ${ }^{15}$ Accordingly, when a new Franchise Bill without the common electoral roll was passed, the Indian members of the Legislative Council resigned. ${ }^{16}$ While the GoI expressed regret ${ }^{17}$ the British top officials of the recently created DEHL found little to criticise: Ewbank emphasised that most male Indians were granted franchise ${ }^{18}$ and Butler observed that manhood suffrage in Kenya was 'far in excess of what we give in India'. ${ }^{19}$

Delhi was willing to wait for a more favourable atmosphere to raise the franchise issue again ${ }^{20}$ but considered to protest with the India Office when the Colonial Office planned to restrict immigration. ${ }^{21}$ The new Kenya Immigration Bill, however, was kept so general that Ewbank doubted the wisdom of representations. Much discretion lay with the immigration officer, expected to administer the bill to the detriment of Indians. ${ }^{22}$ The Commerce Department, nevertheless, provided a new type of argument, shifting the focus from political to economic issues: As 21 per cent of Kenya's and Uganda's total exports went to India, Indian merchants needed Indian employees. The proposed restrictions, therefore, were calculated rather to damage Indian economic interests than to protect the natives. ${ }^{23}$ Special attention should be given to Uganda, where Indians played a key role in developing the cotton trade..$^{24}$

In December 1923, Delhi learned that against earlier assurances from the Colonial Office, the second reading of the bill was arranged without prior consultation. ${ }^{25}$ The GoI protested that against the Devonshire Declaration the new legislation affected immigration into landlocked Uganda as well. The terms of the bill were so wide that there was 'good ground for fear that its provisions are likely to be utilised mainly to exclude Indians'. Indian trade would suffer massively and the bill would 'be a perpetual source of friction'. ${ }^{26}$ On New Year's Eve, the Colonial Office gave in, admitting the need for more time and consideration. ${ }^{27}$ 
In order to impress the Indian public, Delhi urged publication of the related correspondence, but the Colonial Office wanted to hush up its dubious role: The papers indicated

that on three separate occasions the secretary of state for the colonies had contemplated a settlement on terms which ... included the 'common roll' franchise, and that suddenly a settlement was decided up on a different basis involving smaller degree of concession to Indian sentiment.

Their publication would 'confirm the impression ... that the settlement was a surrender to threats of violence on the part of Europeans in Kenya, and that the standpoint of native interests was adopted as an expedient to justify the surrender'. This was indeed an accurate analysis. The Colonial Office maintained that its earlier more moderate attitude had been due to the massive British difficulties in India, ${ }^{28}$ but its anti-Indian sentiment became even more pronounced after an East African Commission had been appointed in 1924, chaired by Ormsby-Gore. It completely ignored the issue of Indians in Kenya $^{29}$ apart from relations between Indian employers and native labour. ${ }^{30}$

For the first time, the DEHL was to play a major role, with Ewbank preparing briefs on the role and interests of Indians in East Africa. ${ }^{31}$ Those briefs, however, were completely ignored. Instead, the report of the commission gave a glowing account of the impact of white settlers. Bajpai analysed that its key idea was to develop the rich resources of Africa with the settlers' support, while 'the non-European and the non-native have no place in this scheme of progress'. Nevertheless, as there was no open discrimination of Indians, he saw no chance for representations, even more because of the Colonial Office's 'past attitude and the studied avoidance of all reference to Indian matters in the commission's report'. ${ }^{32}$

As early as April 1923, the DEHL had suggested to send a deputation or an agent to Africa. ${ }^{33}$ A year later, Viceroy Reading insisted again, ${ }^{34}$ but SSI Olivier did not consider the time appropriate. ${ }^{35}$ As no other community in Kenya had asked for assistance, Ormsby-Gore even warned that an agency was prone to create the impression that Indians were keen to reopen the debate on political equality. ${ }^{36}$ The GoI decided to wait whether a new governor appeared more forthcoming. ${ }^{37}$

In 1926, a commission investigated a closer union of British east and central African territories, chaired by liberal politician Edward Hilton Young. Bajpai and Jagdish Prasad considered the commission an insidious manoeuvre by SSC Leo Amery, who

sprang a surprise on us ... although only a year or so beforehand one of his own committees had pronounced definitely against closer 
union. One cannot, therefore, altogether banish from one's mind suspicion of this particular branch of His Majesty's Government. ${ }^{38}$

The so-called Hilton Young Report from 1929 recommended an administrative union of the East African territories under a strong high commissioner. Self-government and a common electoral roll were considered long-term prospects at best, but there should be more seats reserved for Indians in the legislative councils. The DEHL found the report 'an eminently fair document'. The high commissioner and his staff would coordinate native policy and Indians were to be represented adequately in a General Advisory Council. Native paramountcy was fine if not applied to discriminate Indians. The suggestions for the Kenya Legislative Council were unacceptable per se but might open the door for a common roll. ${ }^{39}$

The report, however, was repudiated by both Europeans ${ }^{40}$ and local Indians. The East African Indian National Congress launched a noncooperation campaign against communal franchise, including municipal boards. ${ }^{41}$ Bajpai found it 'impossible even to pretend any sympathy. ... This kind of irrational non-cooperation is not likely to help our fellow countrymen in Kenya' and made it 'increasingly difficult for the GoI to help them'. There were but two municipal councils. Delhi had pressed successfully for equal numbers of Europeans and Indians in the one for Mombasa; Nairobi provided at least seven nominated Indians versus nine elected Europeans.

All this is now brushed aside . . because it is thought that by accepting the principle of nomination to the Nairobi Cooperation the success of the battle which Indians are now waging for a common electoral roll will be greatly jeopardised.

Kenyan Indians seemed 'determined to destroy themselves'. ${ }^{42}$ Habibullah commented that nothing could be done 'except to leave them to dig their own grave with their own hands!'43

In advance of the publication of the Hilton Young Report, the GoI did its best to limit its negative impact. In late November 1928, Viceroy Irwin urged SSI William Peel to permit a delegation to Africa to prepare the ground. ${ }^{44}$ It turned out, however, that Amery insisted on publishing the report on 18 January $1929,{ }^{45}$ making it impossible for the GoI to send a representative to East Africa to prepare local Indians. ${ }^{46}$ The SSC also repudiated any consultation before publication, though Peel hoped for full local discussion before the implementation of changes. ${ }^{47}$ This revived the debate around whether to establish an agency in East Africa. Irwin hoped that Governor Edward Grigg might find a mediator useful, ${ }^{48}$ but Grigg felt that the 'suggestions rather reflect on his own ability as governor to deal fairly with Indian community'. Furthermore, his position vis-à-vis the settlers 'would be seriously damaged and agent's position rendered hopeless from the outset' ${ }^{49}$ In this 
context, Peel made an even more problematic suggestion: An agent should make local Indians accept the outcome of the discussion. ${ }^{50}$ Irwin strongly objected: Any agent would receive instructions 'with due regard to the views of HMG, in so far as we find ourselves able to support these views consistently with our duty to advocate legitimate Indian aspirations, and with demands of moderate public opinion in India'. ${ }^{51}$

When Amery sent USSC Samuel Wilson to East Africa to discuss the report, Bajpai won Sastri, formerly agent in South Africa, to support Wilson and help local Indians to state their views. While explaining the position of the GoI, he was not to commit it. It was of cardinal importance that the report declared self-government out of discussion and that the common electoral roll was supported on principle. Its later implementation needed the settlers' consent, wherefore the creation of a friendly spirit was essential. ${ }^{52}$

Having arrived in Mombasa on 10 May 1929, Sastri drew a gloomy picture: In Uganda, the Indian claim for representation was resisted with vigour, though 'if race and colour were not sovereign considerations, we should have something more than parity of representation'. The settlers in Tanganyika were as racist as elsewhere, but kept at bay by the governor and the League of Nations' rules for the mandate. Nowhere, however, were conditions as bad as in Kenya, Europeans considering themselves arbiters of the destiny of that territory and Indians being but a 'very subordinated voice in the administration of the affairs of the colony'. Whereas Wilson saw no prospects for a consensus, Sastri recommended to demand equal franchise and a central body where Indians from each province could participate in adequate numbers. The official majority in the Kenya Legislative Council should continue and the representation of natives there 'should be by natives or by Europeans and Indians in equal proportions'. ${ }^{53}$

The new SSC Passfield took objection to the publication of Sastri's report, which was allegedly not the purpose of the mission. He found 'reference to the unsympathetic policy of Sir E. Grigg . . provocative' and 'unfair'. ${ }^{54}$ For once, Delhi did not give in. Sastri's report was published in the UK, East Africa and India without 'alterations and omissions which would have robbed the report of all its value'. ${ }^{55}$ In the meantime, a delegation of Indian representatives from East Africa, led by Pandit Hriday Nath Kunzru, had visited London in the autumn of 1929, where Bajpai introduced them to the India and the Colonial Offices and helped them with a preliminary presentation case. ${ }^{56}$

In the first half of 1930, the British cabinet discussed the reports of Hilton Young and Wilson. The new SSI William Wedgwood Benn's plea for a common roll found support because he argued that this issue, next to constitutional reforms in India itself, was given utmost importance among Indians. ${ }^{57}$ Kenya could develop further only if the communities cooperated. ${ }^{58}$ On 20 June, two white papers were published, the first with conclusions regarding a closer union of Kenya, Uganda and Tanganyika and the second on native 
policy in those territories. Bajpai saw definite concessions to local Indians, with the cabinet insisting on an official majority in the Kenya Legislative Council and declaring a common electoral roll as the political aim. The new high commissioner was to take care that no policy was pursued against the intentions of the British government. In a future Central Council, there would be at least one Indian from each of the three territories. As soon as three members of that council demanded, the high commissioner had to refer any measure to the Colonial Office. ${ }^{59}$

Benn and the GoI consented that a spokesman should present the Indian case before the joint committee of parliament, which would further discuss the cabinet's proposals. The Viceroy's Executive Council emphasised that the recommendations for a closer union were agreeable if the related measures were not used against Indians. The safeguards provided by the mandatory system in Tanganyika should be extended to Kenya and Uganda, not Kenyan conditions to the other two territories. The introduction of a common electoral roll in Kenya was of vital importance; otherwise, the communities would be further antagonised. ${ }^{60}$

Once again, Fazl-i Husain, Bajpai and the viceroy considered Sastri the best spokesman, enjoying broad support in India and East Africa. ${ }^{61}$ Once again, Sastri asked Bajpai to assist him; ${ }^{62}$ Bajpai, however, was amid preparations for the second Round Table Conference with South Africa. ${ }^{63}$ But all Indian efforts failed: The joint committee admitted the force of Indian arguments but found the common roll impracticable under present conditions. ${ }^{64}$

\section{An uneasy balance}

For the years to come, an uneasy balance had been achieved. Kenyan Indians and the DEHL, however, had learned to distrust both the settlers and the Colonial Office. Therefore, even rumours and fair modification of legislation were prone to rouse emotions. In 1933, fruitless settlers' attempts to gain control over the financial affairs of Kenya triggered hefty representations. ${ }^{65}$ There was more reason for concern with the Carter Report on the Kenya Highlands from May 1934, taking care for their notable extension. SSC Cunliffe-Lister wanted to fix them via an Order in Council, arguing that the final decision to reserve the Highlands for Europeans had been taken in 1906 and could not be changed after 30 years. 'India and Indians had ... received the most ample economic recognition and satisfaction in the Colonial Empire' otherwise. ${ }^{66}$ In particular Jagdish Prasad objected that an Order in Council 'will make rigid past practice and will bring into prominence the racial character of the transaction' ${ }^{67}$ No Indian could

accept the position that under no circumstances and whatever may have been his services to the Empire or his social status, can he be 
allowed to own even an acre of land within a defined area in the Kenya highlands.

This would make 'reconciliation between Europeans and Indians almost impossible'. ${ }^{68}$

Viceroy Willingdon emphasised with SSI Samuel Hoare that the decision collided with the principle of equal rights of all British subjects in the colonies and helped Congress agitation. ${ }^{69}$ When Ormsby-Gore, nevertheless, insisted on an Order in Council, Jagdish Prasad demanded a strong-worded protest. As after the first free elections in 1937 Indian provinces were ruled by Indian politicians ${ }^{70}$ it was

unwise for us to create the impression here and in Kenya that we are not prepared to give strong support to our countrymen when the question of their status is involved. It is no argument to say that because Indians have been precluded by administrative practice from acquiring or occupying land in the highlands since 1906 they should acquiesce in this racial discrimination. Indians cannot accept the position that while a German or Italian can acquire land in the highlands. . . . India is advancing rapidly towards self-government and no longer views these problems with the same passive acquiescence as in the past. ${ }^{71}$

Typically, Bajpai took a more pragmatic stand, holding that there were more relevant issues to be settled with the Colonial Office. ${ }^{72}$

Short-lived uneasiness was caused by the introduction of the Native Produce Marketing Bill in 1934, aiming at better crops and fairer prices for producers via reducing the number of licences. In 1933, similar legislation had been introduced in Uganda and Tanganyika without causing any problems. Although the bill was not considered alarming, ${ }^{73}$ DS Muhammed Saleh Akbar Hydari, ICS, had 'come to be suspicious of legislation or acts in Kenya designed to help the native'. ${ }^{74}$ The India Office was not trusted either, Bajpai remarking 'that, even when Indian requests are eminently reasonable, they are apt to be viewed with lack of enthusiasm in that quarter' ${ }^{75}$ K.P.S. Menon, sent on deputation to East Africa, confirmed that there was not much reason to complain. The restriction of licenses, however, might result in less competition among traders, possibly to the detriment of natives and Indians. In the last paragraph of his report, Menon emphasised fears of local Indians that the bill 'is part of a policy to eliminate the Indian from East Africa'. Though this was a 'gross exaggeration', systematic agitation to reduce their numbers had not been forgotten, and the 'fear exists that some subtler methods may be devised'. Experiences from the years before 1923 had 'generated the apprehension that under less happy auspices a measure which purports to be economic may be converted into a political weapon' ${ }^{76}$ 
It took until the day before the bill was introduced in the Kenya Legislative Council on 27 June 1935 that the DEHL was permitted to publish Menon's report. The Colonial Office, nevertheless, wanted to rectify the impression the last paragraph created: Cunliffe-Lister provided 'the most categorical assurance that there is no ground whatsoever' for such apprehension. ${ }^{77}$ Bajpai noted this statement with great satisfaction. ${ }^{78}$ Furthermore, the GoI ensured certain safeguards: Both Europeans and Indians could apply for exclusive licences; reasons for refusal had to be given in written, and there was the possibility of an appeal. ${ }^{79} \mathrm{In}$ sum, the episode was a victory of Indian diplomacy that went beyond the bill in debate. The position of Kenya's Indians as legitimate part of society and East African economy was no more to be challenged.

This explains Bajpai's relaxed attitude when Kunzru informed that the natives had been reserved a second seat in the Legislative Council; both these seats were occupied by Europeans, who were meant to represent native interests. ${ }^{80}$ The secretary replied that the new member was a retired official, the arrangement 'certainly less objectionable than if ordinary settlers had been nominated'. ${ }^{81}$ Nevertheless, in internal communication, Bajpai wanted the Colonial Office to be reminded that native interests could be represented by Indians, too, as it 'is apt to have a short memory, especially when this is convenient' ${ }^{82}$ His distrust sat deep after a dozen years of continuous struggling. ${ }^{83}$

As in the case of South Africa, the DEHL did not hold representatives of local Indians in high esteem. The policy of the East Africa India National Congress was considered foolish and to the detriment of the community. Accordingly, the departmental brief on Kenya from 1934 held that their 'chequered history' of cooperation and non-cooperation 'affords proof of the sway of sentiment over the Indian mind' ${ }^{84}$ The only reliable contact in Kenya was businessman J. B. Pandya, president of the Federation of Indian Chambers of Commerce and Industry of Eastern Africa. He was the only Indian member of the Governor's Executive Council and did not support the non-cooperation campaign. Therefore, with all his suggestions being accepted, he could produce a minority report regarding the Marketing Bill. ${ }^{85}$ Bajpai got in touch with him personally, ${ }^{86}$ and so did K.P.S. Menon while in Kenya. ${ }^{87}$

\section{Zanzibar - clove trade}

For a long while, Zanzibar protectorate seemed untroubled by disputes around Indians overseas. If Indian traders had played a key role in developing East African economy, it was even truer for Zanzibar, where hardly any business transaction was being undertaken without Indian involvement. The islands of Zanzibar and Pemba nearly held a monopoly in cloves production. By 1926, next to 202,655 natives there lived 17,737 Indians and 
only 270 Europeans. The DEHL considered the Indian community adequately represented in the Legislative Council. ${ }^{88}$ From 1928, the clove price began to fall, a process dramatically sped up with the Great Depression. ${ }^{89}$ British Resident Richard Rankine and the Colonial Office decided that the crisis was caused mostly by unfair practices of Indian traders, abusing the naivety of producers, mostly Africans and Arabs. Such allegations were known from Kenya. In 1934, as a fait accompli, a set of six decrees was put into force: Alienation of Land Decree, Moneylenders' Decree, Clove Growers' Association Decree, Clove Exporters' Decree, Adulteration of Produce Decree and Agricultural Produce Decree. Both India Office and GoI were completely taken by surprise and protested against such procedure, providing no chance for voicing their views ahead of implementation. ${ }^{90}$ In his response, Philip Cunliffe-Lister emphasised that the measures were part of a consistent policy pursued throughout the Empire, accepted by Indians in Kenya and Uganda. In Zanzibar, Indian moneylenders had charged 'absolutely extortionate rates of interest'. ${ }^{91}$

The events, once again, proved the anti-Indian sentiment of the Colonial Office and colonial administrators. In the handling of the year-long dispute, however, the DEHL did not come off well, either. It faced great difficulties in properly assessing the decrees and formulating countermeasures. This was to no small extent caused by disunity among the ICS officers involved. Initially, Bajpai found most decrees reasonable or similar to rules in India. Only those on the clove trade appeared problematic. The hitherto irrelevant Clove Growers' Association (CGA) would gain an extremely privileged position in the cloves export owing to government funding and exemption from newly imposed export duties. Bajpai, therefore, suggested that the implementation of those decrees might be postponed. Pragmatic as usual, he felt that it 'can do no harm' to follow public demands for representations with the India Office..$^{92}$ Although he did not consider it to be Delhi's responsibility to find out about the extent of probably exaggerated grievances of Indians overseas, nevertheless, he contemplated sending a representative to Zanzibar. A report would provide the GoI with a strong defence against charges of subservience to the Colonial Office. ${ }^{93}$

It was decided to send K.P.S. Menon, who had made himself a name negotiating on behalf of Indians in Ceylon. His diaries and private letters show his great difficulties to maintain a professional approach. Upon reading the decrees for the first time, he found them 'monstrous' ${ }^{94}$ On arrival on Zanzibar in late August, he characterised the regulations on the clove trade as 'really iniquitous'. ${ }^{95}$ As driving force, he saw the 'self-confident, callous, independent' secretary-manager of the CGA Bartlett, whose policy had to be 'smashed'. ${ }^{96}$ Menon, together with the official report, sent a demi-official letter to Deputy Secretary K. R. Menon characterised by a similarly emotional approach. The author hoped that he had 'endeavoured not to succumb to 
the panicky atmosphere prevailing among Zanzibar Indians' but considered the anti-Indian Bartlett 'a kind of dictator in the clove world'. ${ }^{97}$

In his official report, Menon criticised but the decrees on the clove trade. He took objection to the introduction of licences, costing up to Rs 5,000 per annum. His main criticism was directed against the association, having no single clove grower in its ranks but being reshaped as a 'ruthless monopoly', with Bartlett playing a problematic role. Allegations that Indian exporters and their speculative tendencies had caused the fall of clove prices were wrong. The real causes were the Great Depression and overproduction. Zanzibar authorities, without having tried to regulate prices by other means and by massively exaggerating the profits of Indian middlemen, mostly petty shopkeepers, abused the crisis to eliminate Indian trade..$^{98}$

In his diaries, Menon held that he had 'a good grasp of the subject'99 and authored a 'brilliant' report. ${ }^{100}$ His superiors, however, neither took his assessments at face value nor agreed with all his suggestions. Hydari considered the Land Alienation Decree - a moratorium for sales of indebted land to others rather than Africans and Arabs, but no loss of interest - well affecting the interests of Indians, who owned little land but controlled much more. Furthermore, he wanted Indians born in Zanzibar to be exempted from the new rules. Hydari turned down Menon's suggestions regarding the clove legislation, as this was for Zanzibar authorities to judge. Interests of Indians would best be protected by including some of them on the board of the CGA. ${ }^{101}$ Bajpai agreed with Hydari regarding the Land Alienation Decree, adding that the clove decrees would allow the main Indian exporters to continue. Furthermore, he warned that the phrase 'ruthless monopoly' needed 'careful scrutiny'. ${ }^{102}$ For 'doubts and difficulties', he wanted to discuss the report with Menon. ${ }^{103}$

Once this had taken place, Menon wrongly held that Bajpai had taken over his views. ${ }^{104}$ Indeed, the secretary consented regarding the Land Alienation Decree but disagreed when discussing measures on the clove trade, considering state interference in trade 'almost a recognised principle of state policy'. The introduction of licences and their limited numbers, the control of storages and clove quality were all justified. The real problem he saw in the plan to leave most of this to the association, which was itself an exporting body. To ensure fair treatment of Indians, it needed to represent various races. ${ }^{105}$

The way in which Hydari and Bajpai assessed Menon's report indicates that they did not necessarily see him as the rising star of Indian diplomacy. Criticism in the department's internal communication was rather straightforward but varied with the official appraised. The members never ruffled Bajpai, who himself could be sharp with lower ranks but, even when dissenting, never once voiced open criticism of Hydari's or Bozman's work. Menon fell into another category. Bajpai did not attack his report as bluntly as Hydari, as he did not want to hurt Menon's feelings. Nevertheless, he 
criticised its content, and Menon took offence. ${ }^{106}$ Behind his return to the FPD in April 1936 notwithstanding worse career prospects stood hurt vanity and disappointment with his role in the DEHL. That Bajpai let him go indicates that he did not consider Menon as indispensable as the latter had hoped.

Referring to the report, Willingdon admonished with SSI Hoare that the restriction on sales of indebted land to certain races reduced the sales market, leading to a substantial loss for Indian creditors. Menon's comments on the clove decrees were 'vigorous' and 'justified' as they went beyond necessity to the detriment of Indians. The export monopoly of the CGA was 'unnecessary and unfair' and ran against recent analyses on Zanzibar's economy. Licensing, supervision and administration of the trade needed to be left to an impartial agency representing all interests on Zanzibar. ${ }^{107}$

While awaiting responses from London and the resident on Zanzibar, the DEHL tried to enlist public support. Bajpai, for example, asked for the views of Sarojini Naidu, part of the Indian delegation at the recent Round Table Conference in South Africa. She replied that the association 'must be dealt with in drastic fashion' and saw the legislation as part of an overall move to drive Indians out of East Africa. The colonial administrators were certainly not motivated by 'a sudden devotion to the welfare and interests of the Arabs or the Africans'. ${ }^{108}$ The decrees brought the business community into the picture too. Sir Purushottam Das Thakurdas from the Federation of Indian Chambers of Commerce and Industry suggested a conference of prominent non-officials, which finally materialised with Bajpai meeting the Council of the Imperial Indian Citizenship Association in Bombay. As a friend of the Mahatma, Thakurdas would have liked to include Gandhi as well, but Bajpai turned the suggestion down, not believing 'that His Excellency the Viceroy will be "glad to have some reason for a start being made in this connection" '. ${ }^{109}$ The secretary knew better than committing himself to a course guaranteed to raise questions about his loyalty to British rule in India.

To no surprise, Rankine repudiated Menon's views and challenged his economic data. ${ }^{110}$ As the Colonial Office backed the resident, ${ }^{111}$ Jagdish Prasad suggested an interview of Bhore with SSC Cunliffe-Lister. ${ }^{112}$ Bajpai instructed the former secretary to demand an expert inquiry into the real cause for the fall of prices and the best means to protect producers. ${ }^{113}$ Cunliffe-Lister, however, was 'extremely rigid'. ${ }^{114}$ Therefore, the DEHL came back to Hydari's suggestion that India as the main importer of Zanzibar cloves might retaliate with an embargo, ${ }^{115}$ an idea supported by Thakurdas. ${ }^{116}$ Allegations from the Congress that the GoI did nothing to help Zanzibar Indians and was unsympathetic regarding a boycott in general were unfounded. ${ }^{117}$ Indeed, the DEHL was guided by pragmatic considerations. In June 1935, the Commerce Department counselled against an embargo, as in this case the Ottawa Agreements from 1932 would have 
to be denounced as a whole. ${ }^{118}$ They had established low tariffs for trade within the Empire and high ones with the rest of the world, preferring home producers to Empire producers. An embargo would invite the rest of the Empire to hit back against India. 'With retaliation a broken sword', Bajpai maintained that the best that could be done was reminding the Colonial Office of its declared readiness to inquire into specific cases of hardship. ${ }^{119}$

Labour politician Malcolm Macdonald replaced the conservative Cunliffe-Lister on 7 June 1935 but declared to be committed to his predecessor's decisions. Though he promised closer cooperation with the India Office and to look after an Indian representation in the CGA, he emphasised the need of time. ${ }^{120}$ The Colonial Office's polite refusal came shortly after a harsh one by Rankine. The resident held that the decrees had positive effects for everyone: clove prices had risen and Indian firms of substance benefitted from the reduction of licences. Accordingly, agitation against the decrees had disappeared but would be revived with an enquiry. Bajpai was afraid that this familiar argument would prove decisive, as it had done in other cases. Nevertheless, Rankine's claims should be counterchecked; if true, they were to disarm public opinion. In any case, the GoI had to defend Menon, whom both Rankine and the association accused to have derived information mostly from highly prejudiced members of the Indian community on Zanzibar. Protests would not only be fair to Menon, but would also work as safeguards for future deputations. ${ }^{121}$

Menon foamed at being depicted partisan and that 'the resident pooh poohs my suggestion' that the decrees harmed Indian business interest. Rankine had been absent during his investigations, and the acting resident had recommended the ICS officer as helpful. ${ }^{122}$ Bajpai, however, advised against sending a controversial reply; it would suffice to hint at the change on the post of the resident. ${ }^{123}$ Jagdish Prasad, discussing the decrees with Thakurdas and the Council of the Imperial Indian Citizenship Association, too, argued that he 'could not make a case out of a mere suspicion or distrust', though he 'did not suggest for a moment that the Government of Zanzibar overflowed with love for the Indian'. ${ }^{124}$ In February 1936, Bajpai concluded that Delhi could but protest against the amount of licence fees and the character of the licensing authority. Until some experience had been gained with the effects of the decrees, there was no hope to get them modified. ${ }^{125}$

Help came from an unexpected side. A Commission for Agricultural Indebtedness disagreed with the decree on this matter and suggested that in case a debtor was unable to pay, his property should be sold and the mortgage creditor, of whatever race, should have the right to bid. Furthermore, the commission agreed with Menon that the decree must have no retrospective effect, as this would be tantamount to confiscation. Finally, it found the government's estimates on assets and debts wrong. Menon rejoiced about a 'complete vindication of the Indian case in Zanzibar' and the exposure of 
Bartlett's tactics. He suggested to give full support to the recommendations and to demand a reopening of the issue of the clove decrees. ${ }^{126}$ The shrewder Bajpai considered such steps premature and wanted the resident to show his hand first. He also warned against attacking Bartlett, whose influence could not be proven. ${ }^{127}$

Although the commission had been presided over by the chief justice, assisted by the chief secretary and the land settlement officer, Rankine criticised findings and suggestions as inadequate or controversial. The economic estimates used by the commission and the resident were indeed most different: Whereas the commission calculated the total indebtedness to Rs 60 lakh, the resident acted on the assumption of a minimum of Rs 130 lakh. ${ }^{128}$ Bajpai blamed Rankine for defending the decrees instead of examining the report. ${ }^{129}$

Indian acts on indebtedness were in line with the commission's suggestions. ${ }^{130}$ Indeed, Rankine's plan to reopen earlier transactions was without precedent in British law. Bajpai and Jagdish Prasad were willing to accept lower future interest rates - the resident suggested a maximum of 5 per cent - as they were even lower in India. The period of payment should depend on the amount due: 5, 10 or 20 years. ${ }^{131}$ Soon thereafter, Jagdish Prasad became even more specific: Whereas the debt legislation had to be accepted in general, it must not be of an expropriatory character. Therefore, the resident's suggestions that oral evidence could be used to vary terms of written agreements, that payment of past interests may be credited towards the principal, and that it should be possible to reopen decrees by law courts should be turned down. Before the bill was finally drafted, the GoI must be informed. If the Colonial Office played unfair, an embargo should be reconsidered. ${ }^{132}$ For the time being, however, apart from sending its comments, ${ }^{133}$ the GoI decided to play along to create a positive atmosphere. ${ }^{134}$

The focus was back on clove legislation with the report of chartered accountant B. H. Binder, whom the Colonial Office appointed to investigate the working of the trade and the CGA in April 1936. Binder approved the creation of a monopoly but recommended to loosen the grip of the CGA. It was to keep the only licence to buy cloves and fix the price, possible only via complete control of stocks. Only the government, however, could issue trade licences, and this on reduced fees to give small exporters a chance. Export duties on cloves needed to be abolished and the association had to finance itself. Bajpai wanted more, namely, a focus on Indian middlemen and shopkeepers, who should be given sub-licences as purchasing agents as the CGA itself was incapable to buy from growers. Furthermore, Indians needed to be given a fair representation on the board of the CGA and its advisory board. ${ }^{135}$

In Bajpai's absence in spring 1937, his cautious line was in danger of going overboard, emotions running high in the public and the DEHL, particularly with Hydari. The deputy secretary wondered whether an embargo 
would embitter relations with the Colonial Office to an extent further limiting chances to settle issues around Indians overseas elsewhere. ${ }^{136} \mathrm{He}$ believed that 'we shall lose all along the line if we do not occasionally hit back with decisive effect'. ${ }^{137}$

Hydari and the Council of the Imperial Indian Citizenship Association consented that the Colonial Office would give in only if an embargo was imposed. The association emphasised that the whole country would support it, while Hydari, wrongly, held that his department fully agreed. ${ }^{138}$ As a matter of fact, the DEHL's brief for the meeting of the SEC breathed a different attitude. It was felt that instead of criticising details of decrees and reports, the GoI should better raise general questions. Once the central aim of the reforms - relieving the growers from debt - was settled, legislation for the control of the clove trade would become unnecessary. If the allegedly ignorant Arabs needed protection, the population as a whole, including Indians, required it as well. The government should either take full responsibility for all measures for the control of the clove business or take care that the organisation to which it delegated this task was fully representative. Finally, it had to be emphasised that a century of thriving clove trade to the benefit of all had been built mostly upon the strength of Indian capital. Zanzibar owed something to its Indians. ${ }^{139}$

In the meeting of the SEC on 8 May 1937, Jagdish Prasad argued along the lines of the brief, warning against an embargo. Otherwise, the hitherto cordial relations of Zanzibar Indians with Africans and Arabs were prone to suffer, and the government might retaliate on debt legislation. Threats only made sense if the GoI was prepared to carry them out. Once again, he emphasised that the true contest was not between India and Zanzibar but with the Colonial Office. His statements fell on fertile ground; the committee decided that nothing should be done before Zanzibar Indians had been consulted, admitting that this would be most difficult to achieve. ${ }^{140}$

The position of the DEHL among public demands, loyalty to the Empire, and legal, financial and commercial considerations was delicate. This was highlighted by the full-fledged attack of acting Financial Member J.C. Nixon against an embargo. He agreed that the decrees were enacted to the detriment of the Indian community alone, but argued that the GoI had itself been misled by Indian non-official organisations and individuals. Under public pressure, the DEHL had carried the case too far without even asking for expert advice from the commerce and the finance departments, though 'economic problems cannot in all cases be solved by nationalist doctrines or in terms of popular opinion'. The DEHL attempted 'to dictate to another independent administration' and had 'gone much too far in conveying to the public in India and in pressing on the India Office its belief in the merits of the Indian cause in Zanzibar'. ${ }^{141}$ Nixon hit the nail on the head and at the same time revealed fundamental British fears caused by the DEHL's handling of the issue of Indians overseas and its effect on British colonial rule. 
To everyone's surprise, the Colonial Office and the Zanzibar authorities literally capitulated in early June 1937 . The CGA was henceforth forbidden to make profits for itself; all of them had to be passed to the growers. It was also denied any participation in export trade. Licences were to be provided by the government. Even better, Zanzibar Indians were offered adequate representation in the control machinery of the clove trade, a 'striking departure from normal practice' in most colonies. ${ }^{142}$ When the GoI was, nevertheless, again blamed for the failure of its efforts and suspected to have signed a secret bilateral agreement, the DEHL could easily defend itself: The British Agricultural Marketing Act from 1931 showed strong parallels; outside India, price stabilisation via licences and monopolies had become the rule rather than the exception. ${ }^{143}$ Otherwise, Nixon's line was followed. The GoI had expressed concerns that measures seemed to be too drastic, but had

no right to press that objection to the extent of inflicting conscious economic injury upon another country on that account alone. . . . There could be no possible justification for the GoI converting this difference in degree of control [over the clove trade] into a casus belli with another government.

Ongoing protests would but alienate the impartial ones among Zanzibar's administrators. ${ }^{144}$ On 23 August 1937, in the Legislative Assembly, a motion criticising the GoI was defeated. It had been supported by Congress but opposed by all non-Congress Muslims. Muslim League leader Muhammad Ali Jinnah and European members used the opportunity to emphasise the need for an Indian agent in East Africa. ${ }^{145}$

Even in retrospect, it is difficult to judge the relevance of the decrees, the appraisals by the DEHL and the adequacy of its responses. Apart from the mass of petty details, the lack of reliable information from Zanzibar and the not always transparent course pursued by Zanzibar authorities, the assessments differed with time and various officers. Nixon had a point that the department was groping in the dark but felt obliged to do something. Member and secretary pursued the only possible course in such circumstances. They expressed concerns about likely effects of the decrees, always emphasising that they had to be seen working. Until then, they warned against any premature steps and interference in domestic affairs. Bozman coolly analysed the situation but did not express personal views. On the contrary, first K.P.S. Menon and then Hydari let themselves be carried away by emotions, demanding retaliation. Without knowing internal decisionmaking in Zanzibar and the Colonial Office, there is some likelihood that those contrary approaches combined contributed to a change of mind. Given the massive protests by all segments of the Indian public and concerns of Zanzibar Indians, partly fuelled by Menon's report and Hydari's talks with politicians, it must have appeared the wiser course to admit those 
moderate modifications the realists asked for than to leave the field to more radical forces with unpredictable consequences. In August 1937, as a result, the GoI had to defend modified Zanzibar legislation against an aroused Indian public.

What might appear as superior application of the age-old strategy of good and bad cop, indeed, was not following any plan. Not knowing or misreading their superiors' intentions, subordinated officers became proactive in a situation characterised by uncertainty over more than three years. For many, the handling by the DEHL felt like indecisiveness. There was, however, no question of disobedience. Menon did not blacken his book with Bajpai, who soon requested his services once again, and there is no indication that Hydari had to face any consequences. Nevertheless, other than in the cases of South Africa or Kenya, diverging views surfaced not only in internal communication but also in public.

Notwithstanding obvious differences between the cases of South Africa, Kenya and Zanzibar, they had much more in common than being located on the same continent. When the DEHL came into being, the GoI got no permission to send agents to Africa. Delhi's involvement in the continent was not agreed in the context of an Imperial Conference but was the result of ad hoc efforts to settle problems. The main link between the three African political entities was racism: White minorities wanted to reduce the Indian population or get rid of economic competitors. Accordingly, the responses of the GoI were alike: Indian residents in those countries were owed equal rights or were on the same level of civilisation. In all three cases, Delhi commanded hardly any means to put pressure on the governments it dealt with. Whenever political or economic retaliation was considered, it turned out to be a blunt blade. Unable to enforce demands, the GoI had to convince its counterparts that they were just and fair. The parallels to Gandhian methods are striking.

Attempts to uplift Indians to the level of Europeans had a downside: Partly for tactical reasons, but even more for thinking in the very racist stereotypes used by Europeans against Indians, neither the GoI nor hardly any local Indians considered closing ranks with native populations. This again was in line with Gandhian thinking and tactics while in South Africa. ${ }^{146}$ The struggle for equality was nationalist, but not anti-colonialist. If Indians supported the native case, like they did in Kenya, it was because an official majority in legislative bodies and other safeguards for the indigenous population served Indian interests too. There was nothing of the claim of independent India to speak, let alone fight, for all suppressed people worldwide. This is a factor explaining why African governments after decolonisation were not too sympathetic with India and Indians, though many African leaders admired Gandhi and Jawaharlal Nehru for providing guidelines on how to achieve independence and maintain an independent position in world affairs thereafter. ${ }^{147}$ 
The differences between the three cases, nevertheless, are striking. The vast majority of Indians in South Africa were 'coolies', whereas most of those residing in Kenya and Zanzibar belonged to more privileged segments of society both on the subcontinent and abroad. In the first case, the GoI had to deal with a self-confident, de facto independent dominion. On the contrary, the British government remained the highest authority in East Africa, and the Colonial Office made it a point that British India had no right to interfere in a crown colony or a protectorate. This constellation resulted in diverging approaches. Interaction with South Africa took place in the form of bilateral relations between two sovereign governments. Unlike in East Africa, the DEHL willy-nilly focused on personal diplomacy. Gandhi had set the example with Smuts, and the GoI continued with Sastri, Habibullah, Fazl-i Husain and especially Bajpai. From 1927, agents took care for permanent personal contact. Although white racism continued, the discrimination of Indians was stopped because key actors won the respect of leading South African politicians.

On the contrary, issues in East Africa had to be settled with hardly any direct contact between the GoI and the Kenya or Zanzibar governments. Whenever Delhi wanted something to be done - or rather not to be done - it had to act via the India Office, hoping it would exercise sufficient influence on the Colonial Office, inducing the colonial administrators to change course. This was inter-Empire diplomacy, British India being but a colony, its claims not carrying much weight. To complicate things even more, Delhi dealt with two rivalling British ministries under frequently changing secretaries of state, all with views of their own. This needed skills in multilateral diplomacy.

In sum, Indian diplomacy in Africa was remarkably successful because it created some understanding that the claims of local Indians were just. Until the end of the Second World War, the downward spiral of anti-Indian legislation in South Africa was stopped. Even better, conditions of Kenya Indians distinctively improved: They were granted more seats in the Legislative Council and the principle of equal franchise was accepted. Furthermore, the SSC guaranteed that against clear evidence in the early 1920s, there was no discrimination intended. What appeared a major backlash for Indian traders in Zanzibar in 1934, turned out to be but an economic modernisation process, comparable with efforts in other parts of the Empire and British India. Like elsewhere, there were winners and losers among local Indians. While the GoI helped Indians in South Africa and Kenya, it is open to debate whether its partly contradictory efforts contributed toward a change of mind in Zanzibar.

\section{Notes}

1 Winston Churchill, My African Journey, London: Hodder and Stoughton, 1908, pp. 33-34.

2 NAI, DEHLO, 1925, B, April, 45. March 1925, Position of Indians in East Africa, Bajpai. 
3 I.R.G. Spencer, 'The First Assault on Indian Ascendancy: Indian Traders in the Kenya Reserves, 1895-1929', African Affairs, 1981, 80(320): 327-328.

4 Ronald Hyam, Britain's Declining Empire. The Road to Decolonisation, 1918 1968, Cambridge: Cambridge University Press, 2006, p. 46.

5 Levi I. Izuakor, 'Kenya: The Unparamount African Paramountcy, 1923-1939', Transafrican Journal of History, 1983, 12: 38.

6 NAI, DEHLO, 1924, A, July, B, 1-65. Memorandum on Indians in Kenya, presented to Parliament, July 1923.

7 Izuakor, 'Kenya', 33-34.

8 Christopher P. Youé, 'The Threat of Settler Rebellion and the Imperial Predicament: The Denial of Indian Rights in Kenya, 1923', Canadian Journal of History, 1978, 12(3): 355-359; Izuakor, 'Kenya', 35.

9 Youé, 'The Threat of Settler', 348-360.

10 Ibid., p. 348.

11 The Government and Administration of Africa, 1880-1939, vol. 2, Anderson, Casper, and Cohen, Andrews (eds.), London: Pickering \& Chatto, 2013, pp. 135-151. For a detailed pre-history see Robert M. Maxon, 'The Devonshire Declaration: The Myth of Missionary Intervention', History in Africa, 1991, 18 : 259-270.

12 Youé, 'The Threat of Settler', 351.

13 Izuakor, 'Kenya', 33.

14 NAI, DEHLO, 1924, July, B, 1-65. Letter, Andrews to Ewbank, 28 July 1923.

15 NAI, DEHLO, 1924, July, B, 1-65. Supplement to Servant of India, 'A Message to the Nation', 13 September 1923, Sastri.

16 NAI, DEHLO, 1924, July, B, 1-65. Note, Butler, 4 January 1924.

17 NAI, DEHLO, 1924, July, B, 1-65. Order in Council, Reading, 3 January 1924.

18 NAI, DEHLO, 1924, July, B, 1-65. Note, Ewbank, 14 November 1923.

19 NAI, DEHLO, 1924, July, B, 1-65. Note, Butler, 15 November 1923.

20 NAI, DEHLO, 1924, July, B, 1-65. Order in Council, Reading, 17 December 1923.

21 NAI, DEHLO, 1924, July, B, 1-65. Telegram 755, GoI to SSI, 28 August 1923.

22 NAI, DEHLO, 1924, July, B, 1-65. Note, Ewbank, 9 December 1923.

23 NAI, DEHLO, 1924, July, B, 1-65. Note, Corbett, 16 November 1923.

24 NAI, DEHLO, 1924, July, B, 1-65. Note, Secretary Commerce Dept D. T. Chadwick, 16 November 1923.

25 NAI, DEHLO, 1924, July, B, 1-65. Telegram, GoI to SSI, 25 December 1923.

26 NAI, DEHLO, 1924, July, B, 1-65. Telegram, PSV to SSI, 28 December 1923.

27 NAI, DEHLO, 1924, July, B, 1-65. Telegram, SSI to Reading, 31 December 1923.

28 NAI, DEHLO, 1924, May, B, 31. Letter, Colonial Office, J. E. Masterton-Smith, 8 February 1924.

29 NAI, DEHLO, 1925, September, B, 1-92. Telegram 2427, SSI, 2 August 1924.

30 NAI, DEHLO, 1925, September, B, 1-92. Telegram, Viceroy to SSI, 29 August 1924.

31 For the briefs on the part played by Indians in the past and present in the economic development of East Africa, on Tanganyika, Zanzibar and Nyasaland, see NAI, DEHLO, 1925, B, September, 1-92.

32 NAI, DEHLO, 1925, B, September, 1-92. Note, Bajpai, 9 June 1925.

33 NAI, DEHLO, 1924, B, April, 115. Note, Ewbank, 21 April 1923.

34 NAI, DEHLO, 1924, B, September, 1-92. Telegram 581, Viceroy to SSI, 5 July 1924.

35 NAI, DEHLO, 1924, B, September, 1-92. Telegram, SSI to Viceroy, 12 July 1924.

36 NAI, DEHLO, 1924, B, September, 1-92. Telegram 2427, SSI, 2 August 1924. 
37 NAI, DEHLO, 1926, B, October, 62-64. 'Appointment of Agents of the Government of India in South Africa, East Africa, British Guiana and Fiji', attached to Note, Ewbank, 17 May 1965.

38 NAI, DEHLO, 1933, B, 214. Note, Bajpai, 28 August 1933.

39 NAI, DEHLO, 1929, B, May, 42. Telegram 1124-S, DEHL to SSI, 19 March 1929.

40 Diana Wylie, 'Confrontation over Kenya: The Colonial Office and Its Critics 1918-1940', The Journal of African History, 1977, 18(3): 427-447.

41 NAI, DEHLO, 1929, B, August, 2. Note, G. R., 1 June 1929.

42 NAI, DEHLO, 1929, B, August, 2. Note, Bajpai, 2 June 1929.

43 NAI, DEHLO, 1929, B, August, 2. Note, Habibullah, 2 June 1929.

44 NAI, DEHLO, 1929, B, August, 96. Letter, Viceroy to SSI, 20 November 1928.

45 NAI, DEHLO, 1929, B, August, 96. Telegram 33, SSI to Viceroy, 18 December 1928.

46 NAI, DEHLO, 1929, B, August, 96. Note, Bajpai, 20 December 1928.

47 NAI, DEHLO, 1929, B, August, 96. Telegram, SSI to Viceroy, 9 January 1929.

48 NAI, DEHLO, 1929, B, August, 96. Letter, Viceroy to SSI, 20 November 1928.

49 NAI, DEHLO, 1929, B, August, 96. Telegram, SSI to Viceroy, 25 January 1929.

50 NAI, DEHLO, 1929, B, August, 96. Telegram, SSI to Viceroy, 9 January 1929.

51 NAI, DEHLO, 1929, B, August, 96. Telegram, Viceroy to SSI, 19 January 1929.

52 NAI, DEHLO, 1929, B, May, 42. Letter, Bajpai to Sastri, 27 April 1929.

53 NAI, DEHLO, 1930, B, May, 54-83. Report, Sastri, 31 August 1929.

54 NAI, DEHLO, 1930, B, May, 54-83. Letter, SSC to SSI Benn, 27 September 1929.

55 NAI, DEHLO, 1930, B, May, 54-83. Letter, Habibullah to Sastri, 19 January 1930.

56 NAI, DEHLO, 1929, B, October, 119-121. Telegram 797-OS, DEHL to Habibullah, 9 October 1929.

57 NAI, DEHLO, 1931, A, June, 6-59. Telegram 1215, SSI to Viceroy, 10 April 1930.

58 NAI, DEHLO, 1931, A, June, 6-59. Telegram 1216, SSI to Viceroy, 10 April 1930.

59 NAI, DEHLO, 1931, A, June, 6-59. Note, Bajpai, 19 June 1930.

60 NAI, DEHLO, 1931, A, June, 6-59. Letter, DEHL to SSI, 24 November 1930.

61 NAI, DEHLO, 1931, A, June, 6-59. Note, Ram Chandra, 16 November 1930.

62 NAI, DEHLO, 1931, A, June, 6-59. Telegram 203-S, Madras Government to DEHL, 30 March 1931.

63 NAI, DEHLO, 1931, A, June, 6-59. Telegram 303-S, Viceroy to Sastri, 4 April 1931.

64 NAI, DEHLO, 1934, B, 169-16. Memorandum on the Position of Indians in Kenya, February 1936.

65 NAI, DEHLO, 1933, A, 214-2. Note on Indians in Kenya, DEHL [1934].

66 NAI, DEHLO, 1933, A, 214-2. Letter, Cunliffe-Lister to Hoare, 18 April 1935.

67 NAI, DEHLO, 1933, A, 214-2. Note, Jagdish Prasad, 12 April 1935.

68 NAI, DEHLO, 1933, A, 214-2. Note, Jagdish Prasad, 16 June 1935.

69 NAI, DEHLO, 1933, A, 214-2. Letter, Willingdon to Hoare, 13 April 1935.

70 James Chiriyankandath, 'Democracy under the Raj: Elections and Separate Representation in British India', Journal of Commonwealth and Comparative Politics, 1992, 30(1): 53-56.

71 NAI, DEHLO, 1933, A, 214-2. Note, Jagdish Prasad, 15 February 1938.

72 NAI, DEHLO, 1933, A, 214-2. Note, Bajpai, 24 November 1937.

73 NAI, DEHLO, 1933, A, 362. Note, T.F.C., 24 January 1934.

74 NAI, DEHLO, 1933, A, 362. Note, Hydari, 4 February 1934. 
75 NAI, DEHLO, 1933, A, 362. Note, Bajpai, 29 June 1934.

76 NAI, DEHLO, 1933, A, 362. Report by Mr. K.P.S. Menon on Marketing Legislation in Tanganyika, Uganda and Kenya, 25 October 1934.

77 NAI, DEHLO, 1933, A, 362. Letter, Colonial Office, 24 May 1935.

78 NAI, DEHLO, 1933, A, 362. Note, Bajpai, 18 June 1935.

79 NAI, DEHLO, 1933, A, 362. Note, Bajpai, 18 May 1935.

80 NAI, DEHLO, 1934, B, 153. Letter, Kunzru to Bajpai, 30 April 1934.

81 NAI, DEHLO, 1934, B, 153. Letter, Bajpai to Kunzru, 11 May 1934.

82 NAI, DEHLO, 1934, B, 153. Note, Bajpai, 9 May 1934.

83 NAI, DEHLO, 1933, A, 362. Note, Bajpai, 27 August 1935.

84 NAI, DEHLO, 1934, A, 214-2. Note on Indians in Kenya, 1934.

85 NAI, DEHLO, 1933, A, 362. Note, C. S., 30 October 1935.

86 NAI, DEHLO, 1933, A, 362. Note, Bajpai, 31 October 1935

87 NMML, KPSMP, Diary 1934, 15 September.

88 NAI, DEHLO, 1926, B, April, 34-28. Note, G. R., 19 February 1926.

89 Mandar A. Thakur, 'Indian Agitation against Clove Decrees in Zanzibar', Proceedings of the Indian History Congress, 68th Session, New Delhi, 2007: 1232.

90 NAI, DEHLO, 1934, A, 206. Letter, Hoare to Cunliffe-Lister, 25 July 1934.

91 NAI, DEHLO, 1934, A, 206. Letter, Cunliffe-Lister to Hoare, 31 July 1934.

92 NAI, DEHLO, 1934, A, 206. Note, Bajpai, 5 July 1934.

93 NAI, DEHLO, 1934, A, 206. Note, Bajpai, 16 July 1934.

94 NMML, KPSMP, Diary 1934, 7 August.

95 NMML, KPSMP, Diary 1934, 23 August.

96 NMML, KPSMP, Diary 1934, 24 August.

97 NAI, DEHLO, 1934, A, 206. Letter, K.P.S. Menon to K.R. Menon, 10 September 1934.

98 NAI, DEHLO, 1934, A, 206. Report on the Effect on Indian Interests of Certain Decrees Passed by the Government of Zanzibar, Menon, 10 September 1934.

99 NMML, KPSMP, Diary 1934, 1 September.

100 NMML, KPSMP, Diary 1934, 27 August.

101 NAI, DEHLO, 1934, A, 206. Note, Hydari, 16 October 1934.

102 NAI, DEHLO, 1934, A, 206. Note, Bajpai, 19 October 1934.

103 NAI, DEHLO, 1934, A, 206. Note, Bajpai, 25 October 1934.

104 NMML, KPSMP, Diary 1934, 30 October.

105 NAI, DEHLO, 1934, A, 206. Note, Bajpai, 25 October 1934.

106 NMML, KPSMP, Diary 1935, 28 August.

107 NAI, DEHLO, 1934, A, 206. Telegram, Willingdon to Hoare, 4 December 1934.

108 NAI, DEHLO, 1934, A, 206. Letter, Naidu to Bajpai, 1 December 1934.

109 NAI, DEHLO, 1934, A, 206. Note, Bajpai, 3 November 1934.

110 NAI, DEHLO, 1934, A, 206. Statement Showing the Effect on Indians in Zanzibar of the Clove Legislation in that Protectorate, Rankine, 12 December 1934.

111 NAI, DEHLO, 1934, A, 206. Note, Hydari, 28 February 1935.

112 NAI, DEHLO, 1934, A, 206. Note, Jagdish Prasad, 2 April 1935.

113 NAI, DEHLO, 1934, A, 206. Letter, Bajpai to Bhore, 16 April 1935.

114 NAI, DEHLO, 1934, A, 206. Telegram 1630, Bhore to Jagdish Prasad, 27 May 1935.

115 NAI, DEHLO, 1934, A, 206. Note, Hydari, 28 February 1935.

116 NAI, DEHLO, 1934, A, 206. Note, Hydari, 8 March 1935.

117 Thakur, 'Indian Agitation against Clove Decrees in Zanzibar', 1238.

118 Hyam, Britain's Declining Empire, p. 73.

119 NAI, DEHLO, 1934, A, 206. Note, Bajpai, 17 June 1935.

120 NAI, DEHLO, 1934, A, 206. Letter, Zetland to Willingdon, 2 August 1935. 
121 NAI, DEHLO, 1934, A, 206. Note, Bajpai, 9 August 1935.

122 NAI, DEHLO, 1934, A, 206. Note, Menon, 14 August 1935.

123 NAI, DEHLO, 1934, A, 206. Note, Bajpai, 15 August 1935.

124 NAI, DEHLO, 1335, B, 165. Minute, Jagdish Prasad, 18 October 1936.

125 NAI, DEHLO, 1934, A, 206. Note, Bajpai, 10 February 1936.

126 NAI, DEHLO, 1935, B, 165. Note, Menon, 8 July 1935.

127 NAI, DEHLO, 1935, B, 165. Note, Bajpai, 9 July 1935.

128 NAI, DEHLO, 1935, B, 165. Despatch 236, Rankine to Macdonald, 15 August 1936.

129 NAI, DEHLO, 1935, B, 165. Note, C.S., 14 November 1935.

130 NAI, DEHLO, 1935, B, 165. Note, Menon, 7 February 1936.

131 NAI, DEHLO, 1935, B, 165. Note, Bajpai, 10 February 1936.

132 NAI, DEHLO, 1935, B, 165. Note, Jagdish Prasad, 18 February 1936.

133 NAI, DEHLO, 1935, B, 165. Letter, DEHL to India Office, 22 February 1936.

134 NAI, DEHLO, 1935, B, 165. Letter, Bajpai to Mieville, 24 February 1936.

135 NAI, DEHLO, 1937, B, 45. Note, Bajpai, 26 December 1936.

136 NAI, DEHLO, 1937, B, 45. Note, Hydari, 29 April 1937.

137 NAI, DEHLO, 1937, B, 45. Note, Hydari, 3 May 1937.

138 NAI, DEHLO, 1937, B, 45. Note, Hydari, 11 May 1937.

139 NAI, DEHLO, 1937, B, 45. Memorandum for the meeting of the SEC on 8 May 1937.

140 NAI, DEHLO, 1937, B, 70-3. Minutes, B. N. Nanda.

141 NAI, DEHLO, 1937, B, 45-3. The Clove Industry and the Indian Community in Zanzibar, Nixon, 20 May 1937.

142 NAI, DEHLO, 1937, B, 67-2. Zanzibar Brief [August 1937].

143 NAI, DEHLO, 1937, B, 67-2. Note, Agricultural Advisor of ICAR, 22 July 1937.

144 NAI, DEHLO, 1937, B, 67-2. Zanzibar Brief [August 1937].

145 NAI, DEHLO, 1937, B, 67-2. Telegram, GoI/DEHL to SSI, 24 August 1937.

146 Paul F. Power, 'Gandhi in South Africa', Journal of Modern African Studies, 1969, 7(3): 445-447.

147 See also Gerard McCann, 'From Diaspora to Third Worldism and the United Nations: India and the Politics of Decolonizing Africa', Past \& Present, 2013, 218(suppl. 8): 258-280. 


\section{6 \\ CEYLON}

Compared to East and South Africa, conditions for Indians in Ceylon appeared favourable by 1923 . Over the next 16 years, however, BritishIndian relations with the island grew more and more complicated and tense. The focus was on two interrelated issues: minimum wages for estate labourers, who were partly seasonal workers, and the political status of Indians domiciled in Ceylon. As in East Africa, compromises were rather easily found with the colonial authorities. This changed with major political reforms in 1923 and 1931, which denoted 'a blueprint for independence'. ${ }^{1}$ From an Indian point of view, these reforms had a problematic side effect. They enabled the predominant ethnic group, the Sinhalese, to pursue a Ceylonisation policy, seemingly comparable to Indianisation. Giving preference to the indigenous population, though, meant limiting European influence in India and limiting 'Indian' influence in Ceylon. Whereas Indians considered Europeans foreign to South Asia, people of Indian origin understood their own presence in neighbouring Ceylon the natural outcome of an age-old multiple cultural and economic exchange to mutual benefit. This was the Gol's point of view too. On the contrary, given the British concessions, radical Sinhalese politicians like future Prime Ministers D.S. Senanayake and S.W.R.D. Bandaranaike together with labour leader A.E. Gunasinha felt no need to pursue anti-colonial campaigns. Instead, they targeted those they considered foreign to the island (i.e., Indian). This had the desired consequence of mobilising the Sinhalese masses. In British India, a parallel process had taken place owing to Gandhi and in response to British unwillingness to permit self-governance. The mass movements in the two colonies, however, were of a fundamentally different character: The Congress propagated the European idea of a nation with multiple beliefs, languages and ethnic groups. On the contrary, Ceylon was defined as Sinhalese and Buddhist. ${ }^{2}$ Notwithstanding such fundamental differences, Delhi found it difficult to protest due to the many parallels between the Sinhalese and the Indian Independence Movement.

This is among the reasons why the economic question of fixing and adjusting minimum wages won a political dimension. With the Delhi Agreement 
from March 1926, both governments had fixed rates according to the location of plantations: low-, middle- and up-country. Any intention to change those rates had to be announced six months in advance, followed by consultations. ${ }^{3}$ When the Great Depression hit hard on Ceylon's rubber and tea industries, the GoI agreed on a reduction. Radical Sinhalese politicians, however, demanded to replace Indian labourers and Malayalis employed in Colombo households with jobless Sinhalese. Vehemently resisted by the GoI and the planters' community, who disqualified Sinhalese labour as substandard, they started an occasionally violent campaign to oust Indians: Indians should be denied franchise, free immigration or employment by the government. The GoI, being in a strong position because of Ceylon's dependence on Indian labour, prevented the worst. On the eve of the world war, wages even were restored to pre-depression levels, though the political status of Indians had become precarious and relations between the communities tense.

\section{Minimum wages}

S. Ranganathan, the first Indian agent, arrived in Colombo on 1 October 1923. Political reforms were implemented shortly thereafter, which Ewbank found 'very satisfactory':4 The Legislative Council now consisted of 12 official and 37 unofficial members, 23 of the latter to be elected by territorial constituencies. Indians, with the necessary language and property qualifications, could enter their names in the register of voters. Furthermore, two Indian members were elected by their own community. ${ }^{5}$

Regarding the treatment of Indian estate labour, the Ceylon government was forthcoming. When Indian immigration boomed due to droughts in South India in 1924 and 1925, Colombo did its best to provide housing. It demonstrated much less interest, however, when Delhi brought up the lack of educational provisions for children. The GoI demanded a ban on child labour under the age of 10 to give minors the chance for at least some schooling. The number of schools on estates increased, but slowly ${ }^{6}$ and with hardly any qualified teachers, wherefore Ranganathan's successor M.S.A. Hydari, in vain, suggested recruitment in South India. ${ }^{7}$ The planters were not sympathetic, fearing 'that the growth of a class of literate labourers will be bad for the discipline'; Colombo even reduced the age limit from 10 to 8 , as minimum wages could be calculated lower if even young children contributed to family income. ${ }^{8}$

In 1917, the Marjoribanks and Marrakayar Report had found the wages on estates adequate, leaving a margin for savings, ${ }^{9}$ and the Indian Emigration Act of 1922 permitted emigration to Ceylon without specifying standard wages. ${ }^{10}$ Nevertheless, a considerable number of members of the Legislative Assembly and the SEC considered the rates insufficient. In August 1923, therefore, Ceylon's Assistant Director of Statistics R. 
Jones-Bateman provided a report on the relation between wages and cost of living on estates. ${ }^{11}$ DEHL officials in unison criticised that the investigation covered but two months and calculated that an average family consisted of only three persons. Otherwise, British and Indians in the department were divided. Ewbank found the report an 'able and impartial document' with generous calculation of the cost of living; the calculated scale of diet was 'certainly very superior to that of an ordinary male worker in Bombay city'. ${ }^{12}$ Ranganathan, on the contrary, assessed an average deficit of Rs 4.63 per month per family, ${ }^{13}$ and Sarma emphasised that though Ceylon wages appeared favourable compared with South India, they were 'phenomenally low' against those paid in North India or Mauritius. Labourers could hardly survive on them, let alone support family members in India, as was the common practice. ${ }^{14}$ In April 1924, Bajpai, still a junior officer, fired another broadside at his superior, writing of 'jail diet'. A purely mathematical calculation made no sense for including kanganies, who earned much more than ordinary labourers. ${ }^{15}$ The suggested standard of living without any tolerable comfort would not be regarded satisfactory by politicians or the public, the SEC demanding to ensure savings for old age and sickness. There was need for more reliable data, best raised by a joint inquiry. ${ }^{16}$

Although Viceroy Reading ruffled the DEHL for criticising the 'very careful report', ${ }^{17}$ Jones-Bateman accepted Ranganathan's calculation. Colombo set up a committee with five planters, the controller of labour and the director of statistics, and asked the agent to join. Though the committee's findings were not binding, Bajpai supported the proposal as it was prone 'to make assurances in this delicate matter doubly sure'. ${ }^{18}$ Indeed, the planters accepted the principle of standard wages and the new rates. For the lowcountry, it foresaw males earning 50 cents per day, women 40 and children 30 . In the mid-country they would rise to $52 / 41 / 31$ and in the up-country to $54 / 43 / 32$ cents. ${ }^{19}$

Notwithstanding this negotiation success, Bajpai still considered the rates insufficient. ${ }^{20}$ Ranganathan recommended a raise by another 10 per cent, ${ }^{21}$ but faced with such demands Colombo resorted to disruptive action. In early July 1925, without prior informing Delhi, a high-ranking Ceylonese deputation conducted talks with the home member of Madras Presidency arguing against minimum wages. While Bajpai emphasised that Madras had consented to the talks, ${ }^{22}$ Secretary Bhore demanded a sharp response. Regarding the emigration issue, the central government was the only counterpart for any foreign government. ${ }^{23}$ Habibullah wondered about the ulterior motives, ${ }^{24}$ while Ranganathan believed that the planters would never accept any settlement. ${ }^{25}$ Such suspicions were confirmed by Colombo's 'cynical disingenuousness' reply: ${ }^{26}$ The interview allegedly had been totally informal, the officials neither having formed a deputation nor having been authorised by their government. ${ }^{27}$ 
This prelude was followed by Controller of Indian Immigrant Labour Tim Reid repudiating a further raise of wages. Not only legally correct, he emphasised that the committee had accepted Ranganathan's calculations but never suggested an excess. Giving in to Delhi's new wishes would bring the colonial government into a most difficult situation. Real wages had increased over the last 18 years as the rise in cost of living had not much affected labourers, who were partly paid in kind. The new standard rates would benefit 20 to 40 per cent of them. The GoI had not explained how it had calculated the necessity for another increase, but it needed Colombo's consent within six months after notification. Thereafter, each government was free to choose its course of action. ${ }^{28}$

Delhi had to accept that its tactics had been flawed. Without clear ideas of its own, a discordant DEHL had left negotiations to an inexperienced agent. A smarter negotiator under better guidance had either not put his cards on the table so early or started with rather exaggerated claims to reach a final compromise which Delhi considered adequate. In a manner of speaking, Ranganathan's efforts had even been futile; with effect from 1 January 1929, Ceylon raised rates to the level negotiated between India and Malaya. ${ }^{29}$

On 10 October 1927, M.S.A. Hydari succeeded Ranganathan. Bajpai wanted him to focus on the educational question, ${ }^{30}$ but Hydari's poorly documented term was dominated by other issues. Planters were trying to circumvent minimum wages and the rubber price fell. Most problematic, however, was the challenge to the political status of Indians. The Donoughmore Commission, working on a new constitution, proposed abolishing communal representation, which would have made the two Indian seats in the Legislative Council obsolete. ${ }^{31}$ Furthermore, there was a 'small but clamant party among the Sinhalese which is not friendly to Indians'. Hydari initially felt that this should 'cause ... no apprehension'..$^{32}$ By January 1929, however, he was mostly absorbed with an 'outburst of unreasoning hostility toward Indians': They should be denied suffrage and prevented from buying land. Governor Herbert Stanley too was after excluding most Indians from franchise. The latter and Europeans, however, 'of more importance to the economic existence of the colony than the Sinhalese', worked together against any such discrimination. ${ }^{33}$

Immediately after his return to the DEHL in December 1929, Hydari further elaborated that Stanley apparently felt that the GoI 'were more concerned with the political repercussions in India ... than in the actual effect which such a measure would have on the welfare of Indians on Ceylon'. ${ }^{34}$ Bajpai linked Stanley's course to his former postings as imperial secretary in South Africa and governor of North Rhodesia, 'making him unduly fearful of Indian encroachment in Ceylon'. Bajpai admitted that the majority of Indian plantation workers, travelling hence and forth, could hardly be 
treated on an equal footing regarding land development schemes. Permanent residents, however, must not be excluded..$^{35}$

With Stanley's support, ${ }^{36}$ Reid went even further, attempting to exclude 'from the definition of "Ceylonese" any Indian who comes under the category of Indian emigrant'. Thereby, he wanted 'to show that the presence of an agent ... is unnecessary and the interference of the GoI in matters under the controller's charge uncalled for' ${ }^{37}$ The planters, however, disliked Reid's 'autocracy', found the agents of considerable assistance, did not want them to be replaced by unofficial agitators and emphasised that foreign diplomats looked after their nationals too. ${ }^{38}$ Reid, nevertheless, tried to prevent the agency from providing legal aid to labourers. ${ }^{39}$ His successor N. J. Luddington was similarly disobliging when Hydari's successor K.P.S. Menon reported cases of irregular recruitment of labourers. ${ }^{40}$

Menon's arrival in October 1929 coincided with the Great Depression. Had the terms of Ranganathan and Hydari been eventful, their successor had to manage a severe double crisis around wages and status. The more immediate concern was the efforts to recalibrate the balance between economic needs of labourers and planters in years of slump in the prices of rubber and, soon, tea. When Menon learned that the rubber planters would massively reduce either the labour force by $50,000-60,000$ or standard wages, he preferred the former as more acceptable to the public. ${ }^{41}$ In his correspondence with the DEHL, he complained 'that at a time when rubber was yielding profits beyond the dreams of avarice the only person who did not share in them was the Indian labourer'. ${ }^{42}$ Ram Chandra, ICS, found Menon right only in theory; without any profits, wages could not be paid. ${ }^{43}$ Nevertheless, the joint secretary saw India in a strong position - replacing Indians by Sinhalese appeared impossible. He wondered whether tea estates, employing the vast majority of labourers $(525,000)$, could absorb those working at rubber plantations $(175,000) .{ }^{44}$ The type of work, however, was too different and the labourers unwilling to change. Furthermore, Menon admitted that due to the unforeseen rapidity of the crisis, 'we cannot afford to adopt the inflexible attitude recommended in my previous letters' ${ }^{45}$ A Minimum Wages Committee with Menon participating discussed a reduction of wages versus a reduction of work time, the agent favouring the latter as 'the less objectionable to two evils'. ${ }^{46}$ Offering less than 24 working days per months was a violation of the Minimum Wages Ordinance, but most labourers were agreeable. The rest, Menon wanted to be offered free repatriation. ${ }^{47}$ In October 1930, the committee reached the same conclusions. ${ }^{48}$

A few months later, the planters' associations asked for a further reduction of wages, now for the fall of the price of rice. Menon understood that labourers would not be worse off under the new scale. ${ }^{49}$ Nevertheless, he warned the planters that once recruitment would be restarted, Indian villagers would 'seize on the reduction of minimum wages in Ceylon as a firstclass grievance'. ${ }^{50}$ In April 1931, the price for rubber had fallen to an all-time 
low and tea prices were in decline, too, after which the agent believed wage reduction 'well-nigh irresistible'. ${ }^{51}$ Ram Chandra agreed as against a much lower cost of living, labourers were actually gainers. It was a sign of good will that Colombo consulted Delhi, overruling Luddington's advice. ${ }^{52}$ Bajpai agreed that 'a legal quibble cannot dispose of hard economic facts and quibbling is only likely to lose us the good-will both of the Ceylon government and the employers of Indian labour'. In return, the GoI needed to demand a return to six-day week and free repatriation. ${ }^{53}$ In May 1931, Delhi agreed to a reduction of daily wages by 5,4 and 3 cents for men, women and children, respectively, an outcome which Menon - against the halving of the price of rice - considered 'eminently fair'.

The reduction, however, did not afford the planters substantial relief. ${ }^{54}$ A new subcommittee was installed to investigate how to adjust the minimum wages against the fall in cost of living, the agent again being invited to take part. Bajpai felt it difficult to resist in times 'when our own Retrenchment Committees are talking of reduction in salaries because of a fall in the cost of living, ${ }^{55} \mathrm{He}$ advised Menon to associate with the committee, though in strictly personal capacity. ${ }^{56}$ Whereas the planters soon estimated the fall of cost of living by 21.3 to 30 per cent, Menon calculated a mere 16 per cent ${ }^{57}$ winning the approval of the Government of Ceylon.

The focus shifted to up-country rubber estates, Menon admitting that they could not afford minimum wages. Nevertheless, he spoke out against a suspension of the Minimum Wage Ordinance as demanded by Luddington and the planters. Instead, Delhi should give sympathetic consideration of a reduction. Without the protection of the ordinance, Indians might be pushed down to the much lower level of Sinhalese labourers. ${ }^{58}$ Ram Chandra agreed that 'the ground which has been gained by us during the last six years by persistent negotiations with the Government of Ceylon would be lost'. ${ }^{59}$

A further fall of prices for rubber and tea made an extension of the reductions in low- and mid-country estates inevitable. ${ }^{60}$ Governor Graeme Thomson insisted on the procedure stipulated in the Delhi Agreement, but in October 1932, certain estates announced their decision to pay less than minimum wages on the plea that the labourers themselves accepted reduced rates. Menon emphasised that this would be illegal but understood the acute anxiety, many tea estates having to sell distinctly below the cost of production. ${ }^{61}$ By early January 1933, Ceylonese planters and officials had calculated new rates, based on the condition that estates would provide rice for Rs 4 per bushel. Wages for men, women and children in the up-country would be reduced from the level of May 1931 over those of February 1932 from 54/43/32 over 49/39/26 to now 44/35/26 cents. Reductions in midcountry estates would mean a fall from $52 / 41 / 31$ over $39 / 27 / 31$ to now $39 / 32 / 23$ cents, and in low-country estates from $50 / 40 / 30$ over $45 / 36 / 27$ to now $37 / 30 / 22$ cents. 
Menon saw the new wages as but an adjustment of the first reduction. ${ }^{62}$ Most Indian labourers were employed in the least affected up-country estates and even now would not be worse off than in $1925 .{ }^{63}$ After only 13 days, Delhi confirmed per telegram, but insisted on the adherence of four principles: The standard of living from 1928 was not to be seriously reduced, and the classification of estates in low-, mid- and up-country was without alternative. Labourers who refused to accept the lower rates were to be offered free repatriation. Finally, 'reductions should be treated as strictly temporary and emergent, and revision on upward grade should be considered as soon as industry revives'. ${ }^{64}$ The new rates would be valid from May 1933. Instead of insisting on the six months' notice, the GoI had immediately accepted the proposals from January, therefore, counting on Ceylonese good will. ${ }^{65}$

The press in both countries appreciated Delhi's stand as reasonable and fair in times of crisis. ${ }^{66}$ Bajpai was relieved that 'we seem to have come rather well out of this business'. ${ }^{67}$ In the months from May to July 1933, the price of rubber nearly doubled, tea yielding about 50 per cent more than in 1932. A special scheme for the repatriation of labourers from tea estates was ended after 25,961 had made use of it. Menon, however, repudiated the planters' associations' demands for a reopening of recruitment as - though varying from district to district - there was an overall surplus of labour. The first step had to be a recovery of wages. Holding that Wages Boards would take months and the planters showed no inclination to act on their own, he advised Delhi to make a restoration at least to the level of mid-1932, making it the precondition for any new recruitment. ${ }^{68}$

Bajpai advised Menon to lead informal talks, ${ }^{69}$ which proved a remarkable success. Colombo immediately summoned the Wages Boards for a formal restoration of wages, and the tea planters agreed to return to the rates prior to the last reduction from May. The higher wages were to be paid from November onwards. ${ }^{70}$ Menon calculated that against the lower cost of living, up-country labourers were now better off than in the late 1920s; discontinuation of recruitment had led to a quick and satisfactory solution. He emphasised that the new rates should be paid on rubber plantations as well. ${ }^{71}$

T.L.R. Chandran, succeeding Menon in October 1933, nevertheless, took objection to the procedures initiated by his predecessor. He complained that the Wages Boards took much time and the temporary measures from May legally would be in force for a full year. He admitted, however, that most estates already paid the higher rates. Chandran further disagreed with plans to lower wages according to the falling price of rice, as there were other relevant commodities. ${ }^{72}$ Bajpai found Chandran's reports neither clear nor convincing as rice was indeed an important factor for the calculation of cost of living. If its price did not rise, the new real wages were better than those paid before May 1933. ${ }^{73}$ 


\section{Cooperative societies}

The effects of the depression went beyond the temporary reduction of wages. In 1932, the number of estate schools declined together with the number of children attending them. Other benevolent measures like improvements in housing, the provision of midwives or the establishment of cooperative societies suffered setbacks too. ${ }^{74}$ Cooperative thrift societies had first been propagated by Menon as the only cure for the 'chronic and seemingly ineradicable indebtedness of Indian labourers', who had to pay a part of their wages to kanganies and normally held no bank account. As there existed only two such societies in Ceylon, the GoI should depute and finance an inspector. Thanks to the appointment of an Indian officer by the Federal Malay States in 1925, 70 cooperative societies had been established; the situation in Ceylon with many more labourers stood in 'disgraceful contrast' ${ }^{75}$ Bajpai, however, objected as emigration fees could not be used for such purposes. Making an exception would set a precedent for Fiji, Kenya and Tanganyika. The promotion of such societies was the responsibility of the Ceylon government, ${ }^{76}$ who turned down Menon's ideas owing to financial stringency.

The issue was revived by Chandran, his proposals leading to noteworthy disunity in the DEHL, especially between the former agents Hydari and Menon. Bajpai disapproved a memorandum by Chandran, ${ }^{77}$ and Hydari warned that it might be of doubtful utility in practice. Nevertheless, there would be no harm forwarding the proposals to the Ceylon authorities in strictly personal capacity. ${ }^{78}$ When, however, the agent suggested an amendment to the Labour Ordinance permitting deductions of the wages of labourers as contributions to cooperative thrift societies, Hydari objected: The DEHL had always insisted on full wages without deductions. Contributions collected by estate staff could be abused for binding labourers to the respective estate and thus detract from their freedom of contract.

Bajpai, however, changed his mind: A modified scheme appeared suitable if membership in such societies was made optional, withdrawals would be discouraged only for the first year and the transfer of savings to other estates would be made easy. ${ }^{79}$ Agent in Malaya K. A. Mukundan confirmed that cooperative thrift societies worked well and without abuse or undue control by estate staff. They had not affected the freedom of movement; on the contrary, there were complaints that labourers quit as soon as they had saved a substantial amount in order to get hold of the money. Nevertheless, the societies were the only means to ensure savings with the 'proverbially unthrifty' South Indian labourer. They were currently confined to single estates. A transfer of savings from one estate to another might become possible only if there were more such societies. ${ }^{80}$ Menon fell in for Chandran too. He considered labourers incapable to form such societies. If administrative tasks were not left to estate managers, kanganies would fall 
in, maintaining their hold on labourers via their indebtedness. All societies would be inspected by the Ceylon Cooperative Department. With the economy recovering, Colombo should be able to supervise such operations. ${ }^{81}$ Notwithstanding Chandran's efforts, however, the number of cooperative societies and stores increased but slowly. ${ }^{82}$

The general economic situation in Ceylon improved between 1934 and 1935, but short work remained the rule. Chandran explained this with tea and rubber restriction schemes, the failure of two successive monsoons and the highest immigration rate over a decade. On the contrary, Menon blamed his successor for the continued issuing of recruitment licences. Instead, he demanded a complete stop including cancellation of all outstanding licences. At least the first suggestion was implemented; ${ }^{83}$ Chandran escaped a reprimand as he quit work prematurely for his wife's poor health. ${ }^{84}$ By the end of 1936, most plantations offered five days of work per week. With the rubber price rising, there was hope for a return to normality. ${ }^{85}$

Ammembal Vittal Pai, the succeeding agent, did not issue any new licences until August 1937 and intended to pursue this line as long as there was the slightest surplus of labourers with tea estates. Some of them had been absorbed by rubber estates, facing a shortage of labour. While the Ceylon government, now dominated by Sinhalese politicians, demanded to employ Sinhalese, the planters circumvented the restrictions imposed by both governments by abusing two exceptions. Indians 'old to Ceylon' (i.e., having worked their earlier) required no licence, and the same was true for those classified 'close family' of labourers already employed. Especially the latter was used extensively, including even paternal uncles with their families. During the peak months of June and July, 12,937 labourers arrived that way. ${ }^{86}$ ADS R.S. Mani warned that a complete ban on all emigration of unskilled workers would be considered 'an open war with Ceylon'. ${ }^{87}$ This left Delhi without any means to put Colombo under pressure regarding the political status of Indians. Economic conditions, nevertheless, in June 1939 allowed a restoration of wages to the level of May $1931 .{ }^{88}$

\section{Political status}

The Donoughmore Reforms gave Ceylon one of the most modern constitutions worldwide. This was particularly true for the franchise: communal voting was abolished and both sexes from the age of 21 could register as voters if they proved five years of domicile. The need to register brought many Indians into a dilemma: Would accepting the status of being domiciled not go hand in hand with the loss of privileges for overseas Indians for which Delhi had fought over years? The radical reform highlighted a general dilemma for Delhi. Worldwide, it fought for equal rights for people of Indian origin. The moment those were granted, Indians became a minority and the GoI had to switch to the protection of minority rights. 
This had the unwelcome effect that Indians overseas did not merge with the majority population; even the second or third generation born abroad kept a separate status and identity. ${ }^{89}$ The tricky question of Indian citizenship, most burning in the years immediately after independence, ${ }^{90}$ surfaced for the first time, though common British citizenship camouflaged the core of the problem. ${ }^{91}$ The Donoughmore Reforms truly formed a watershed for the DEHL's policy.

The debate around the reforms took care that 'even the Naatukkottai Chettiars', moneylenders by profession, 'ordinarily dead to politics, evinced an interest in the franchise question'. The government did not clarify what the term 'domiciled' meant precisely; ${ }^{92}$ initially, it denoted five years of residence and the intention to stay in Ceylon, the latter considered confirmed with registration. Registration was to be closed on 11 September 1930 and elections were planned for June the following year. Menon expected Sinhalese organisations to object to the registration of numerous Indian voters, many of whom were illiterate and too poor to defend themselves; hence he suggested to provide counsel..$^{93}$ Moreover, the agent

prophesized that in view of the scattered and often inaccessible nature of the localities in which Indian labourers predominate, the necessity on the part of each individual to apply for registration, the lack of public spirit among Indians in Ceylon and the paucity of candidates with political ambitions who are prepared to get the estate labourers to register themselves, the number of Indians who will eventually go to the polls will be extremely small. ${ }^{94}$

As there were also pamphlets and rumours spreading that registered Indians would lose their special protection, Bajpai got upset with Menon: Had the agent interfered, the Ceylon government would have counteracted 'the unscrupulous campaign'. ${ }^{95}$ He requested data on the numbers of voters and means to activate the Indians. ${ }^{96}$

Indeed, no Indian was turned down. Among the 110 candidates for the State Council, 86 were Sinhalese, 14 Ceylon and 4 Indian Tamils. Among the latter, Menon considered the energetic barrister-at-law Peri Sunderam by far the best choice. The prominent merchant I.X. Pereira, hitherto member of the Legislative Council, did not contest in the elections but hoped for nomination. The other three Indians competed in the same constituency, confirming that the 'Indian community here is a house divided against itself' ${ }^{97}$ Statistics showed that about 60 per cent of the adult population had registered, but only 21 per cent of the Indians, roughly estimating 100,000. Nevertheless, their numbers had increased sevenfold compared to earlier elections to the Legislative Council. ${ }^{98}$ As a result of the elections, held from 13 to 20 June, out of 46 elected members 38 were Sinhalese. Next to Sunderam, the propriety planter Vytilingam was the only other Indian to have 
won a seat; Pereira was nominated by the governor. Menon was glad that the labourers had at least exercised their vote, ${ }^{99}$ and Bajpai found that 'considering the ignorance, the timidity and the disorganized state of the great majority', overall, they had not done badly. ${ }^{100}$ Surprisingly, Sunderam was appointed minister for labour, industry and commerce, much to the benefit of Indian labourers. Whereas Colonial Secretary Bernard Bourdillon took this as proof that there was no communalism in Ceylon, indeed it was the outcome of intrigues of other candidates against each other. ${ }^{101}$

He was proven correct when in late 1934 a debate around a restriction of Indian immigration was opened with a motion by Bandaranaike, demanding to hire Sinhalese instead of recruiting more Indians. ${ }^{102}$ Gunasinha wanted contractors for public works to employ Ceylonese labour only. ${ }^{103}$ Governor Reginald Edwards Stubbs, however, showed no inclination for quick action and asked Chandran to join a commission in personal capacity, ${ }^{104}$ the latter unlike his predecessors feeling 'a little awkward' ${ }^{105}$ After some internal discussion, Jagdish Prasad ruled that the agent should merely advise Indians how to prepare their case. ${ }^{106}$ What came close to a demonstration of distrust against Chandran was settled once Stubbs appointed a commissioner instead of a commission, winning Sir Edward Jackson, who until recently had been attorney-general of Ceylon.

The GoI up to Linlithgow was content with the developments ${ }^{107}$ but remarkably indecisive in internal communication. When the State Council wanted Jackson to investigate about Indian immigration, Bozman boasted that 'if the ultra-nationalist Sinhalese want a straight fight with India, let them have it'. ${ }^{108}$ Bajpai coolly countered that the struggle would anyway be between Indian and Sinhalese interests. ${ }^{109}$ When Jackson's final terms of reference included immigration from other countries also, Bozman, instead of being pleased, warned 'that large Indian interests' might be 'adversely affected by the consideration of, say, a few Chinese'. ${ }^{110}$ Now Bajpai felt 'reluctant to say too pointedly that the problem of immigration into Ceylon is primarily an Indian problem' as this might serve politicians like Gunasinha. ${ }^{111}$

Both Sinhalese radicals and Jackson focused on Malayalis, mostly peons and shopkeepers in Colombo. A typical complaint against them was the absence of women. The cost of living for men, living in chummeries or in informal relationships with Sinhalese women, was much lower compared to Sinhalese competitors. Menon understood the 'deep-rooted antipathy' as 'fundamentally economic' for other reasons as well: 'The Malayalee is a better, more docile, more regular, and infinitely cheaper workman than the Sinhalese, so that the latter regards the Malayalee as taking the bread of his mouth'. ${ }^{112}$ In the forefront of the elections in late February 1936, Labour Union Leader Gunasinha, in vain, tried to get 2,370 Indian voters disqualified, mostly Malayalis. ${ }^{113}$ After the announcement of the election results, he led a provocative and partly violent procession through their quarters in Colombo. ${ }^{114}$ Jackson too appeared particularly prejudiced until 
Pai explained to him that Malayalis lived in a matriarchal society, wives not accompanying husbands. ${ }^{115}$ Furthermore, supported by Pai and the DEHL, local Malayalis impressed Jackson with a memorandum. ${ }^{116}$

Delhi finally gave Agent Pai permission to give evidence, preferably in public and avoiding diverging statements. ${ }^{117}$ As Pai was deadly afraid of the idea of his appearance, ${ }^{118}$ the DEHL struggled to draft a memorandum. The first version was massively corrected by Bajpai and thereafter, most unusually, heavily criticised by Jagdish Prasad for being 'too general and vague'. The member alone pointed at the most problematic aspect, namely that Indians 'will not tolerate that immigration should be restricted to employments which the Sinhalese find either derogatory or uncongenial'. The Indian case should appear in a more favourable light without alienating individual Sinhalese politicians. ${ }^{119}$ Linlithgow approved that immigration should not be dealt with as a whole and not piecemeal. ${ }^{120}$

On 4 February 1937, Pai gave public evidence. Jackson attempted to divide the Indian community on issues of domicile, but the agent convinced him that it would not be fair to ban certain classes as long as Ceylon depended on Indian labour. ${ }^{121}$ In his report, published in the spring of 1938, Jackson spoke out against any restriction of Indian immigration. ${ }^{122}$ Ceylonese ministers, however, still wanted to admit but plantation labourers. Bozman burst out that 'Hitler seems to have come to Colombo', ${ }^{123}$ whereas Jagdish Prasad more temperately predicted 'a big tussle . . . with the growth of political particularism in Ceylon'. ${ }^{124}$ The proposals were considered 'more drastic than what is obtaining at the present in some of the dominions' and clearly opposed to the Empire's open-door policy. The DEHL considered taking up the case with London, ${ }^{125}$ but after the outbreak of the world war Bajpai found it useless even to involve Linlithgow. ${ }^{126}$ Governor Andrew Caldecott, opposing Sinhalese nationalists, indicated a more promising solution, namely to link the immigration issue with trade talks. ${ }^{127}$

While immigration and wages dominated the discussion, there were minor questions prone to affect the status of Indians as well. The Land Development Ordinance granted land to Ceylonese peasants, excluding Indians, unless at the time of birth their parents had been domiciled. ${ }^{128}$ Though this affected only a very few people of Indian origin, Hydari warned that such definition of 'Ceylonese' might soon be used in other laws. The Sinhalese would 'lose no opportunity ... . in obtaining preferential treatment in trades and callings in which under open competition they do not now succeed in elbowing the Indian out'. ${ }^{129}$ SSC Cunliffe-Lister, however, accepted the new definition. ${ }^{130}$ Bajpai, who had wanted to ensure that those having opted for Ceylon permanently should enjoy the same facilities, ${ }^{131}$ turned down Hydari's suggestion to approach SSI Hoare or even the British cabinet, not considering it relevant enough. ${ }^{132}$

Heatedly debated was the de facto exclusion of Indians from the Ceylon public services. In early 1937, Chief Secretary Maxwell MacLagan 
Wedderburn promised that job advertisements would not explicitly exclude Indians, who, however, 'in practice . . . will come last, after all other communities in the Island, without reasons being assigned'. The government, nevertheless, would employ Indians if lacking other candidates. ${ }^{133}$ When Pai informed Wedderburn of two cases where even sons of officers of the Colonial and the Ceylon Medical Service had been turned down, the chief secretary refused a discussion of these 'rather hard cases'. He, however, mentioned, that Stubbs considered one of the candidates 'Ceylonese, he would not know who else might be'. Nevertheless, he was resented by the Sinhalese minister. ${ }^{134}$

Only the atmosphere of general distrust and uncertainty explains why the Village Communities (Amendment) Ordinance gained relevance. An older version had ruled that the right to exercise village franchise came along with a capitation tax. Europeans and Burghers, the latter of mixed European and Ceylonese descent, were excluded because it was held that they could not be submitted to village tribunals. Indian estate labourers had been exempted as well: In 1932, Agent Menon found it too heavy a burden for labourers, their needs being provided by their estates. ${ }^{135}$ However, when in 1937 the ordinance was modified, now including Europeans and Burghers, Jagdish Prasad warned that this 'may only be the beginning of further franchise restrictions'. ${ }^{136}$ In the long run, Indians would be better off notwithstanding taxation. In colonies where they had no franchise, they faced greater difficulties. ${ }^{137}$

The department sent a telegram stating objections, ${ }^{138}$ but Colombo argued that Indian labourers had not indicated much interest in village affairs. If granted village franchise, they might dominate councils in certain areas. Bozman hinted at the contradiction: If labourers had truly no interest, they would not influence village affairs. Without awarding certain privileges to them, Ceylon would be denied a crucial supply of labour. ${ }^{139}$ Hydari shared Bozman's 'irritation at the unsympathetic tone of the minister's memorandum as if everything was fair in the garden'. In this case, however, Delhi was 'not on a strong wicket'. Furthermore, the new legislation discriminated estate labourers but not Indians as such. ${ }^{140}$ Bozman, nevertheless, drafted a reply 'somewhat strong in tone' and (for the first time) linked the political status of Indians with upcoming trade negotiations. ${ }^{141} \mathrm{He}$ was backed by Jagdish Prasad, demanding village franchise for those 75 per cent of Indians permanently settled. ${ }^{142}$ The public in India would not accept their exclusion. ${ }^{143}$

Only a year after the start of the debate, Bajpai took the initiative: With the exclusion of all estate labourers, the issue of racial discrimination was off the stove. The task was to carry along Indians in both countries. ${ }^{144}$ This proved difficult, as the Ceylon India League, the Madras government and Kunzru all were heavily opposed to the proposals; ${ }^{145}$ it was argued that Sinhalese labourers would not be affected by the modification for living in 
villages, not on estates. ${ }^{146}$ ADS Subimal Dutt gave for consideration that representations would merely satisfy the public without any definite benefit. ${ }^{147}$ Bajpai and Jagdish Prasad consented that 'for the present the best thing is not to disclose our hand'. Perhaps Ceylon would offer political concessions in return for some in bilateral trade. ${ }^{48}$

Bajpai, however, soon changed his mind and wanted the GoI to clarify its position so that the public and Ceylon government would not misunderstand. ${ }^{149}$ Jagdish Prasad gave in, but unwillingly: Delhi would be 'attacked for not successfully coercing the Ceylon government but that seems to be the only reward that we get for whatever we do'. ${ }^{150}$ How problematic IndoCeylonese problems appeared in the forefront of the world war is indicated by the preparations for the Imperial Conference of 1937. Bajpai did not want to trouble Linlithgow with any briefs except the one outlining problems with Ceylon. ${ }^{151} \mathrm{He}$ wanted the point to be carried home 'that these manifestations of anti-Indian feeling are having a bad effect on public opinion in India and threaten the good relations that have existed so far between the two countries'. Against the experiences with South Africa, he suggested a Round Table Conference, though in vain. ${ }^{152}$

\section{Department and agents}

Contrary to Patrick Peebles' assessment, Indians in Ceylon profited at large from the presence of Indian agents. To a large part thanks to their presence, the labourers certainly were not helpless victims of schemes of two governments and planters. Peebles is wrong to write of an 'Indian Protectorate' too; Delhi merely tried to safeguard legitimate interests of Indians overseas. His bizarre allegation that only the first agent Ranganathan had sympathies with the labourers for being one of the few non-brahmins in the Madras ICS cadre is proven wrong by the Muslim Hydari and the Nair Menon. ${ }^{153}$ In fact, for no other agency officers were selected so carefully.

Though the DEHL had appointed Ranganathan without any interview, he was considered to be more efficient than his colleague in Malaya. ${ }^{154}$ The appointment of Hydari in 1927 indicated a fundamental change in the selection process. Born in Bombay in 1894, with his appointment to the ICS in 1919, he was allotted to Madras Presidency, where he became fluent in Tamil. ${ }^{155}$ Since 24 June 1924, he had held the post of under secretary in the DEHL. In all likelihood, his appointment was the outcome of experiences of 1926, when the department sought a successor for Pillai. Madras refused to release the requested candidates, instead offering officers who were too junior and had insufficient qualifications. In deep frustration, Bajpai ventured

to think that we shall have carefully to take stock of the constitutional position and see whether we cannot insist upon getting the man that we want. If we cannot, then . . I can see no alternative 
for the Government of India but to recruit their own men. For, we cannot, obviously, be satisfied with the dross of provinces. ${ }^{156}$

Accordingly, Hydari was chosen from the department's own personnel. For the first time, the idea of something like a diplomatic service had surfaced.

In 1929, Hydari was called back to organise the Haj Committee, which was considered more relevant than the agency. ${ }^{157}$ Given the small number of officers in the department and the need to replace them when transferred, Menon (a probationer from the Political Service) was selected, again an officer working with the central government. The exact reasons why the choice fell on him remain in the dark. He was certainly a promising officer: the FPD had appointed him Census Superintendent for the NWFP. ${ }^{158}$ Furthermore, as a South Indian from the Madras ICS cadre he fitted well into the pattern. When arriving in Ceylon on 10 October 1929, he looked back on eight years of service. The lack of alternatives is reflected in the decision to accept an interlude of nearly five months, when head clerk A.S. Narayanan acted as agent. Like his counterpart T. G. Natarajan Pillai in Malaya, Narayanan, born in 1893 and a graduate from Madras University, was an element of continuance. After seven years in government service in Madras Province, he had started working with the agency in $1923 .{ }^{159}$

Menon arrived just before Black Friday and amidst the debate about the recommendations of the Donoughmore Commission. As his expertise was in demand, his term was extended twice, finally until the end of November $1933 .{ }^{160}$ As he profiled himself as a successful crisis manager, a few major lapses were forgiven. On 23 January 1933, the GoI, following the agent's advice, had consented to a reduction of wages. Shortly thereafter, Menon first reconfirmed the acceptance of reduced minimum wages, notwithstanding the rising price for tea. ${ }^{161} \mathrm{~A}$ mere six days later, he claimed that given this development the reduction was not justified. ${ }^{162}$ Bajpai fumed that he 'had greater confidence in his judgement than his last proposal would seem to justify. ... Our reputation for stability if not honesty of views will suffer'. He had 'grave doubts about the propriety, both ethical and practical, of going back upon our word'. ${ }^{163}$ Bajpai also toned down a chapter on indebtedness in Menon's annual report for 1932: 'views being published in too emphatic a form' would create the impression that the GoI tolerated some grave evil. ${ }^{164}$

Altogether, however, the DEHL was full of praise for Menon's reports, 'most interesting and written in a delightful style'. ${ }^{165}$ They not only provided facts and figures 'but dealt with the causes behind them in a very lucid manner'. ${ }^{166}$ This mirrored Menon's self-image. He demonstrated self-confidence when demanding rather than suggesting the quick publication of his annual report for 1930 to put pressure on the Ceylon government. Besides, he was a man of pronounced vanity. ${ }^{167}$ In his diaries, in a mantra-like fashion he characterised his reports and speeches as 'splendid'. ${ }^{168}$ In his last official 
letter from Ceylon he (as was usual) forwarded articles written on the occasion of his departure, not hesitating to add that they were 'so flattering that I can hardly recognise myself in them' ${ }^{169}$ Bajpai, unheard with other agents, sent a cordial response, emphasising that he had read the press cuttings

with genuine pleasure. ... I can assure you that the department has every reason to be satisfied with the ability, industry and good judgment which characterised your handling of the many difficult problems with which you had to deal during your term of office as agent. And, on my own behalf, I would add an expression of personal thanks for the help that you have given me. ${ }^{170}$

Once again, the DEHL faced difficulties to find a successor. Typically, the selection was undertaken in an ad hoc manner. Bajpai would have preferred T.C.S. Jayaratnam from the ICS cadre of the Central Provinces, among the very few Ceylonese in the service. The officer had served as under and deputy secretary with the central government. Bajpai was willing to 'ignore the possible objection that he is a native of Ceylon, where Indians are not eligible for appointment to the Superior Civil Service'. Nevertheless, he could not overcome the main obstacle: As senior officer, Jayaratnam would have costed Rs 6,000 more per year than foreseen in the budget. The choice, therefore, was between C.S. Venkatachar, a rejected probationer of the Political Service, and the junior T.L.R. Chandran, both from the Madras ICS cadre. The latter was selected for not receiving overseas pay and owing to recommendations, among others, made by former Member Habibullah. ${ }^{171}$ In an interview with Bajpai, the candidate appeared 'sensible and pleasant'. According to a senior European ICS officer, Chandran was 'a good "mixer"' who got on well with Europeans and Indians. Though he commanded no secretariat experience, Bajpai believed 'his general intelligence ... adequate to the calls of his office in Ceylon'. ${ }^{172}$

Chandran, however, turned out to be the most disappointing of the agents in Ceylon. Initially, he was awarded a period of grace, ${ }^{173}$ though Hydari criticised him for making unnecessary heavy weather ${ }^{174}$ and Bajpai found his reports neither clear nor convincing. ${ }^{175}$ The tone became harsher in February 1935, when the DEHL learned of the disqualification of Indian voters but by the press and the issue was to be discussed in the Legislative Assembly. ${ }^{176}$ The telegram he finally sent, Bajpai found 'to say the least of it . . . obscure'. ${ }^{177}$ Soon thereafter, he blamed the agent for 'platitudes' instead of providing 'information as to coming events'. ${ }^{178}$ Issuing recruiting licences while there was a surplus of Indian labour further damaged Chandran's reputation. When in late 1935 he asked to be relieved, ${ }^{179}$ the DEHL accepted with tacit relief.

The only candidate for his succession recommended by provincial governments was A. Vittal Pai from the Madras ICS cadre. The officer had served 
nine years, including secretariat experience of three years. Menon found him a good choice and had heard nothing but good about him. ${ }^{180}$ The interview, which by now had become obligatory, was undertaken by Jagdish Prasad, who approved the appointment. ${ }^{181}$ Pai took over on 29 April 1936. He was more alert than his predecessor but lacked courage, trying everything to avoid giving evidence for Jackson's enquiry on the restriction of immigration. ${ }^{182}$ Only after Jagdish Prasad personally took Pai to task did the agent give in. The member found 'that Pai is really too young and inexperienced in handling a question of this kind, and he is naturally nervous of appearing as a witness where he will certainly be severely cross examined'. ${ }^{183}$ Still, in preparation of the event, Pai against instructions instead of the requested memorandum prepared an imaginary dialogue with Jackson. ${ }^{184}$ Though, finally, Pai did rather well when giving public evidence, his standing had suffered even with Linlithgow. ${ }^{185}$ Jagdish Prasad complained that Ceylon officials 'had a better idea of the probable workings of the Government of India's mind than our agent'. ${ }^{186}$ Nevertheless, Pai grew on the job, the member now complimenting him for not yielding to the bullying of acting Chief Secretary Wodeman. ${ }^{187}$ That Pai won some respect is indicated in the correspondence around the issue of village franchise and even more by the fact that after the end of his term he joined the DEHL as deputy secretary.

Apart from Subimal Dutt, Menon is the only agent who left diaries, permitting intimate insights. It must be kept in mind, however, that Menon was an unusual agent and officer in many ways. During his term, he made no secret of his ongoing sympathies with the independence movement. As representative of the GoI, he could not attend a speech of the deeply admired Jawaharlal Nehru, but met him afterwards. ${ }^{188}$ In a speech on poet Sarojini Naidu, honoured as 'the Nightingale of India', he humorously remarked that if the same title were offered to Rabindranath Tagore, 'he would decline it as emphatically as he rejected the knighthood under the Martial Law Regime in the Punjab'. This won him a mild reprimand from Bajpai: such remarks were 'likely to be misunderstood in official circles this side'. ${ }^{189}$ Menon 'felt disturbed all day' after this 'bit of a bamboozle' and wanted to be more careful. ${ }^{190}$ Accordingly, no more such incidents are documented, but in his diaries Menon remained a full-fledged nationalist. He believed Gandhi to be 'the greatest character born since Jesus Christ'191 and approved of his Salt March. After the Mahatma's arrest, he hoped for a continuation of the civil disobedience movement ${ }^{192}$ and blamed the GoI for 'a reign of terror'. ${ }^{193}$ When Gandhi was discussed by estate managers, Menon felt the need to correct some of their notions. ${ }^{194}$ Accordingly, Menon approved the Gandhi-Irwin Pact from March 1931 for the government having 'yielded on all main fronts'. ${ }^{195}$ After riots had broken out, he demanded a boycott of all British goods. ${ }^{196}$ Certainly most problematic were his comments after a female student had fired on Stanley Jackson, the governor of Bengal in February 1932. Earlier, four British ICS colleagues had been murdered in that 
province. ${ }^{197}$ For Menon, it merely showed 'that this govt., by their present repression policy, are becoming utterly odious'. ${ }^{198}$ Notwithstanding those views, Menon never boycotted British goods, let alone quit his job.

Menon's diaries show his multiple duties, including extensive touring of estates, formal and informal talks and a certain amount of paperwork. The most enjoyable part of his job was giving speeches on political, historical and cultural topics. As the collection of numerous manuscripts among his private papers proves, Menon was a gifted orator with a knack for choosing topics fascinating his auditory. As Dutt would experience in Malaya in 1941, an agent was well paid and had plenty of leisure time. Menon, for once, was mostly free from his periodical severe headaches, a stress syndrome; he was fully aware that it was most difficult to find a comparable job. ${ }^{199}$

The later careers of the five agents in Ceylon took most different turns. Ranganathan did not play a significant role after his return; Chandran died in December $1937 .{ }^{200}$ Hydari, on the contrary, rose to the rank of deputy secretary in the DEHL and later, among others, became secretary in the Labour Department. During the war, he represented India in the Eastern Group Supply Council, to be transferred to the Foreign Department as officer on special duty. In 1945, as member of the Information and Broadcasting Department, he joined the Viceroy's Executive Council. From January 1947, he served as Governor of Assam, where his premature death on 28 December 1948 ended a most distinguished career. Menon excelled too. Given the performance of both officers together with their popularity, their careers in times of rapid changes were extraordinary, though not as completely unexpected as was the one of Pai. In the early summer of 1947, for a short while, he held the post of secretary in the Commonwealth Relations Department, to be transferred as counsellor to the embassy in Moscow. ${ }^{201}$ In March 1948, he was appointed principal secretary of the prime minister.

Regarding the department itself, the most significant feature was the comparatively little involvement of Bajpai. Omnipresent, decisive and nearly all-knowing in African issues, he left Ceylon mostly to Ram Chandra, who did a good routine job. Especially in the 1930s, Bajpai was surprisingly little informed: He displayed lack of knowledge about cooperative societies ${ }^{202}$ or indecisiveness regarding attempts to disqualify Indian voters. ${ }^{203}$ In January 1939, he asked whether assisted emigration had not recently been stopped, ${ }^{204}$ only to learn that this had indeed been done and twice referred to in replies to the State Council. ${ }^{205}$

This was the outcome rather of lack of time and capacities than of interest. The higher Bajpai climbed, the more he was in demand from all sides, among others for various major conferences. It tells a story that in 1936, he left the interview with Pai to Jagdish Prasad, although he considered the selection of those proto-diplomats crucial. ${ }^{206}$ With Bajpai at the helm, British Indian policy vis-à-vis Zanzibar had sporadically been meandering. In 
Ceylon, his characteristic cool logic was missing more than once. His critical comments of February 1933 on the lack of a calculable, transparent and trustworthy policy on the part of Menon must be understood as a warning to the department as a whole, where emotions occasionally ran high from Bozman over Hydari up to Jagdish Prasad.

Nevertheless, Ceylon was left to competent officers and ex-agents, though Hydari more than once felt the need to demonstrate what he considered superior knowledge. ${ }^{207}$ This attitude annoyed Menon, among others. ${ }^{208}$ In the short period between July 1935 and April 1936, when both worked in the department, a certain rivalry surfaced. In general, Hydari showed a tendency for hot-headed comments and fundamental distrust against the intentions of the Sinhalese ${ }^{209}$ or the planters. ${ }^{210}$ Menon initially had blamed the latter for extracting 'the maximum amount of work from labourers' in times of crisis too. ${ }^{211}$ Soon, however, he had come to appreciate their approach: Instead of having treated minimum as maximum wages, they had levelled them up. ${ }^{212}$ Hydari's harsh judgements matched with Bozman, the only higher-ranking British ICS officer in the department, who compared radical Sinhalese demands with those raised by Hitler in Europe. In general, Bozman displayed a close emotional bond to India. As late as 1939, when British ICS officers since long expected colonial rule in South Asia to come to an end, he saw 'the whole of India's honour . . . at stake' against efforts to dismiss all Indian daily paid labour in Ceylon government service. ${ }^{213}$ Accordingly, Bozman was appreciated by his Indian superiors, Jagdish Prasad praising him, among others, for 'his understanding of, and sympathy with, the Indian point of view' ${ }^{214}$ Bajpai certified 'promptness, thoroughness and general efficiency' and recommended him for further secretariat work. ${ }^{215}$

With Bajpai not playing a too prominent role, from April 1935 Jagdish Prasad called the shots. Unlike his predecessors, the member played a part in the department's work that compared to that of secretary or deputy secretary. Again unlike his predecessors, he did not hesitate to overrule Bajpai or to turn down his drafts. This did not necessarily indicate lack of esteem. As retired senior ICS officer, former chief secretary of the United Provinces and member of the Home Department, it was only too natural that Jagdish Prasad took the lead. His predecessors as politicians had had no standing or expertise matching those of their ICS subordinates. Whether his deep involvement into Ceylon affairs was beneficial is difficult to judge. Given inconclusiveness and contradicting views of those below him, there was certainly need for a decisive superior. His combination of remarkable energy and sharp intelligence proved to be of great advantage around the issue of the immigration commission, when he alone understood the core of the problem and personally made the timid Pai give evidence. His more than once straightforward and demanding comments in internal communication, however, indicate that he lacked Bajpai's superior handling of delicate issues via diplomatic channels. 


\section{Conclusion}

Overall, the DEHL handled Indo-Ceylonese relations in a professional manner without achieving the desired results everywhere. The success story was the economic side. The GoI not only managed to fix minimum wages. Notwithstanding the Great Depression, with immense flexibility it helped the survival of the Minimum Wage Ordinance, with rates fully restored in 1939. Facing similar problems at home, the DEHL thought and acted in the framework of a market economy where wages depended on profits. In some measure, the DEHL took the role of a trade union offering fair deals.

Regarding the political status of Indians, the balance is mixed. On the one hand, Indians after the Donoughmore Reforms enjoyed equal rights without losing their special status as guaranteed in the Minimum Wages Ordinance. All attempts to deprive them of essential political rights could be warded off. On the other hand, however, all sides were aware that Sinhalese nationalism had just begun to discriminate Indians. By 1939, nobody doubted that campaigns aiming at the expatriation of large numbers of Indians would further intensify. Notwithstanding fundamental differences, Ceylonisation was as irresistible as Indianisation.

Sinhalese anti-Indian campaigns followed their own intrinsic logic; British Indian diplomacy did not cause or intensify them. On the contrary, the DEHL displayed flexibility, fairness and transparency, the perfect example of it being the acceptance of the reduction of minimum wages within 13 days in January 1933. After some clumsiness around negotiating rates in 1925 , during the years of deepest crisis it was represented by K.P.S. Menon, a superior negotiator. Luckily, lesser able agents as Chandran and Pai in less critical times did not cause any harm. The more than once emotional reactions to developments in Ceylon as documented in internal communication did not come in the way of bilateral relations. Bajpai and Menon, both as much in disagreement with some of Colombo's decisions as were the other officials of the department, set examples how to interact with adversaries, even if personally disliked, in a most rational manner for mutual benefit, a feature of superior diplomacy.

In contrast to the procedures for settling problems in Africa, no conferences took place and no delegations were exchanged. Neither Bajpai nor any member of the DEHL ever went to neighbouring Ceylon, though they regularly visited nearby Madras Presidency. Instead, all dealings were undertaken via the agents. Rather surprisingly, the GoI forwent any involvement of London although Ceylon was a crown colony. While the Colonial Office and the India Office were regularly asked to intervene in African matters, they played absolutely no role in British India's dealings with Ceylon. Unsurprisingly, at the one occasion when Delhi asked the SSC for support for a round table conference, the latter remained non-committal. ${ }^{216}$ Apparently, the GoI felt itself in a strong enough position to deal with the Ceylon 
government, and whatever went wrong on the island from an Indian perspective was never considered too problematic.

Diplomacy with East Africa can be classified as triangular, the relations with South Africa rather bilateral but with some involvement of London. Indo-Ceylonese relations, on the contrary, were clearly bilateral. Nevertheless, while in South Africa (and Kenya) an Indian minority was struggling against discrimination by a European minority, with the indigenous population hardly playing any role, the Ceylonese issue was distinctly different. In Africa, the GoI could challenge European claims as being those of another immigrant community with a much shorter history in those territories. In Ceylon, especially after the Donoughmore Reforms, it was a struggle between an indigenous majority community and a minority their leaders classified as foreign. The close neighbourhood and the cultural and economic exchange over the millennia made a difference only for the selfimage of Indians and people of Indian origin. Representatives of British India, amidst a transformation inevitably leading to independence, could hardly demand from the colonial power to keep Sinhalese nationalism at bay. Indo-Ceylonese relations had not much to do with the struggle against colonialism or white supremacy. The 1930s saw two nationalisms competing on the island. If Indian relations with foreign countries ever witnessed a zero hour, this was not the case with Ceylon. Issues, attitudes, actors, and problems of the 1930s were those of the 1940s and thereafter.

\section{Notes}

1 Percival Spear, A History of India, vol. 2, Harmondsworth: Penguin Books, 1965, p. 206.

2 Jane Russel, Communal Politics under the Donoughmore Commission 19311947, Dehiwala: Tisara Press, 1982, p. 105.

3 Lanka Sundaram, 'Indian Labour in Ceylon', International Labour Review, 1931, 23(3): 374-375.

4 NAI, DEHLO, February 1924, B, 61-63. Note, Ewbank, 11 February 1924.

5 NAI, DEHLO, February 1924, B, 61-63. Letter, H.J. Read, Colonial Office, to USSI, 14 January 1924.

6 NAI, DEHLO, April 1928, B, 10-13. Letter, Hydari to Bajpai, 31 March 1928.

7 NAI, DEHLO, January 1929, B, 112-115. Half-yearly Report, January to July 1928, Hydari, 8 August 1928.

8 NAI, DEHLO, April 1928, B, 10-13. Half-yearly Report, July to December 1927, Hydari, 7 January 1928.

9 BL, IOR, V/27/820/12. Report on Indian Labour Emigrating to Ceylon and Malaya, 1917, N. G. Marjoribanks and A.K.G. Ahmad Tambi Marrakayar.

10 NAI, DEHLO, August 1924, A, 1-68. Note, RAD, Emigration Branch, 17 February 1923.

11 NAI, DEHLO, August 1924, A, 1-68. Report on an Inquiry into the Relation between the Wages and the Cost of Living of Estate Labourers, April-May 1923, Jones-Bateman, 3 August 1923.

12 NAI, DEHLO, August 1924, A, 1-68. Note, Ewbank, 19 December 1923. 
13 NAI, DEHLO, August 1924, A, 1-68. Letter, Ranganathan to DEHL, 15 January 1924.

14 NAI, DEHLO, August 1924, A, 1-68. Note, Sarma, 28 January 1924.

15 For the Kangani system see S. Suresh Kumar, 'The Kangany System in the Plantations of South India: A Study in the Colonial Mode of Production', Proceedings of the Indian History Congress, 1988, 49: 516-519.

16 NAI, DEHLO, August 1924, A, 1-68. Note, Bajpai, 19 April 1924.

17 NAI, DEHLO, August 1924, A, 1-68. Note, Reading, 4 July 1924.

18 NAI, DEHLO, November 1925, A, 1-24. Note, Bajpai, 11 February 1925.

19 NAI, DEHLO, November 1925, A, 1-24. Letter, DEHL to Secretary Madras, Law (General) Department, 15 September 1925.

20 NAI, DEHLO, November 1925, A, 1-24. Note, Bajpai, 15 May 1925.

21 NAI, DEHLO, November 1925, A, 1-24. Note, Bajpai, 14 July 1925.

22 NAI, DEHLO, August 1925, B, 31-38. Note, Bajpai, 9 July 1925.

23 NAI, DEHLO, August 1925, B, 31-38. Note, Bhore, 10 July 1925.

24 NAI, DEHLO, August 1925, B, 31-38. Note, Habibullah, 11 July 1925.

25 NAI, DEHLO, August 1925, B, 31-38. Letter, Ranganathan to DEHL, 4 July 1925.

26 NAI, DEHLO, August 1925, B, 31-38. Note, Bhore, 21 July 1925.

27 NAI, DEHLO, August 1925, B, 31-38. Telegram, Colonial Secretary Ceylon to DEHL, 20 July 1925.

28 NAI, DEHLO, May 1926, B, 97-98. Memorandum, Standard Wages on Ceylon Estates, Reid, 15 March 1926.

29 NAI, DEHLO, June 1929, B, 67-69. Half-yearly Report, August to December 1928, Hydari, 6 January 1929.

30 NAI, DEHLO, April 1928, B, 10-13. Letter, Bajpai to Hydari, 9 June 1928.

31 T.J. Barron, 'The Donoughmore Commission and Ceylon's National Identity', Journal of Commonwealth and Comparative Politics, 1988, 26(2): 147-157.

32 NAI, DEHLO, January 1929, B, 112-115. Half-yearly Report, January to July 1928, Hydari, 8 August 1928.

33 NAI, DEHLO, June 1929, B, 67-69. Half-yearly Report, August to December 1928, Hydari, 6 January 1929.

34 NAI, DEHLO, January 1930, B, 24-25. Note, Hydari, 20 December 1929.

35 NAI, DEHLO, January 1930, B, 24-25. Note, Bajpai, 21 December 1929.

36 NAI, DEHLO, April 1930, B, 84. Report, Menon to Bajpai, 5 March 1930.

37 NAI, DEHLO, January 1930, B, 24-25. Note, Hydari, 20 December 1929.

38 NAI, DEHLO, April 1930, B, 84. Report, Menon to Bajpai, 25 February 1930.

39 NAI, DEHLO, March 1930, B, 19. Letter, Menon to Bajpai, 5 March 1930.

40 NAI, DEHLO, July 1930, B, 161. Letter, Menon to DEHL, 24 June 1930.

41 NAI, DEHLO, September 1931, A, 1-49. Letter, Menon to Ram Chandra, 7 August 1930.

42 NAI, DEHLO, September 1931, A, 1-49. Letter, Menon to Ram Chandra, 18 August 1930.

43 NAI, DEHLO, September 1931, A, 1-49. Note Ram Chandra, 30 August 1939.

44 NAI, DEHLO, September 1931, A, 1-49. Letter, Ram Chandra to Menon, 2.9.1930.

45 NAI, DEHLO, September 1931, A, 1-49. Letter, Menon to Ram Chandra, 15 September 1930.

46 NAI, DEHLO, September 1931, A, 1-49. Letter, Menon to Ram Chandra, 10 September 1930.

47 NAI, DEHLO, September 1931, A, 1-49. Letter, Menon to Ram Chandra, 15 September 1930. 
48 NAI, DEHLO, September 1931, A, 1-49. Note, V.S.S., 16 October 1930.

49 NAI, DEHLO, September 1931, A, 1-49. Letter, Menon to Ram Chandra, 23 March 1931.

50 NAI, DEHLO, September 1931, A, 1-49. Speech at Special Meeting of the General Committee of the Planters' Association of Ceylon, 18 February 1931.

51 NAI, DEHLO, September 1931, A, 1-49. Letter, Menon to Bajpai, 22 April 1931.

52 NAI, DEHLO, September 1931, A, 1-49. Note, Ram Chandra, 4 May 1931.

53 NAI, DEHLO, September 1931, A, 1-49. Note, Bajpai, 5 May 1931.

54 NAI, DEHLO, September 1931, A, 1-49. Letter, Menon to Bajpai, 1 July 1931.

55 NAI, DEHLO, September 1931, A, 1-49. Note, Bajpai, 15 July 1931.

56 NAI, DEHLO, September 1931, A, 1-49. Letter, Bajpai to Menon, 17 July 1931.

57 NAI, DEHLO, September 1931, B, 169-170. Half-yearly Report, January to July 1931, Menon, 5 August 1931.

58 NAI, DEHLO, 1932, A, 235-1. Letter, Menon to Bajpai, 14 April 1932.

59 NAI, DEHLO, 1932, A, 235-1. Note, Ram Chandra, 27 April 1932.

60 NAI, DEHLO, 1932, A, 235-1. Note, Bajpai, 19 September 1932.

61 NAI, DEHLO, 1932, A, 235-1. Letter, Menon to Christie, 31 October 1932.

62 NAI, DEHLO, 1932, A, 235-1. Letter, Menon to Christie, 11 January 1933.

63 NAI, DEHLO, 1932, A, 235-1. Note, C.S., 14 January 1933.

64 NAI, DEHLO, 1932, A, 235-1. Telegram, GoI/DEHL to CS Ceylon, 23 January 1933.

65 NAI, DEHLO, 1932, A, 235-1. Letter, Menon to Christie, 7 February 1933.

66 NAI, DEHLO, 1933, B, 144. Letter, Menon to Christie, 31 March 1933.

67 NAI, DEHLO, 1933, B, 144. Note, Bajpai, 22 April 1933.

68 NAI, DEHLO, 1933, B, 144. Letter, Menon to S. R. Zaman, 16 July 1933.

69 NAI, DEHLO, 1933, B, 144. Note, Bajpai, 28 July 1933.

70 NAI, DEHLO, 1933, B, 144. Telegram, Menon, 26 August 1933.

71 NAI, DEHLO, 1933, B, 144. Letter, Menon to Zaman, 14 September 1933.

72 NAI, DEHLO, 1933, B, 144. Letter, Chandran to Bajpai, 10 February 1934.

73 NAI, DEHLO, 1933, B, 144. Note, Bajpai, 2 March 1934.

74 NAI, DEHLO, 1933, B, 178. Annual Report for 1932, Menon, 8 April 1933.

75 NAI, DEHLO, 1931, B, December, 46. Letter, Menon to Ram Chandra, 13 October 1931.

76 NAI, DEHLO, 1931, B, December, 46. Note, Bajpai, 20 November 1931.

77 NAI, DEHLO, 1934, B, 218 k.w. Note, Bajpai, 7 July 1934.

78 NAI, DEHLO, 1934, B, 218 k.w. Note, Hydari, 9 July 1934.

79 NAI, DEHLO, 1934, B, 218 k.w. Note, DEHL, 4 March 1935.

80 NAI, DEHLO, 1934, B, 218 k.w. Letter, Mukundan to Hydari, 5 June 1935.

81 NAI, DEHLO, 1934, B, 218 k.w. Note, Menon, 2 July 1935.

82 NAI, DEHLO, 1935, B, 21-1. Half-yearly Report, January to July 1935, Chandran, 9 August 1935.

83 NAI, DEHLO, 1935, B, 317. Note, Menon, 9 March 1936.

84 NAI, DEHLO, 1935, B, 312. Letter, Chandran to Menon, 5 December 1935.

85 NAI, DEHLO, 1935, B, 317. Note, C.S., 3 December 1936.

86 NAI, DEHLO, 1937, B, 24-2. Half-yearly Report, January to July 1937, Pai, 10 August 1937.

87 NAI, DEHLO, 1937, B, 26-19. Note, Mani, 3 March 1938.

88 NAI, DEHLO, 1937, B, 26-19. Unofficial Note to the Press, Public Information Office, 24 June 1939.

89 Srikant Dutt, 'India and the Overseas Indians', India Quarterly. A Journal of International Affairs, 1980, 36(3-4): 312-314. 
90 For the case of Ceylon see B.K. Jain, 'The Problem of Citizenship Rights of Persons of Indian Origin in Ceylon', The Indian Journal of Political Science, 1963, 24(1): 65-78.

91 Marie Lall, 'Mother India's Forgotten Children', in Eva Østergaard Nielsen (ed.), International Migration and Sending Countries: Perceptions, Policies and Transnational Relations, Houndmills: Palgrave Macmillan, 2003, p. 125; Aparajta Gangopadhyay, 'India's Policy towards its Diaspora: Continuity and Change', India Quarterly, 2005, 61(4): 97-102.

92 NAI, DEHLO, July 1931, B, 29-49. Letter, Menon to DEHL, 9 September 1930.

93 Ibid.

94 NAI, DEHLO, October 1930, B, 3-5 k.w. Half-yearly Report, Menon, 31 July 1930.

95 NAI, DEHLO, July 1931, B, 29-49. Note, Bajpai, 28 March 1931.

96 NAI, DEHLO, July 1931, B, 29-49. Letter, Bajpai to Menon, 30 March 1931.

97 NAI, DEHLO, July 1931, B, 29-49. Letter, Menon to Bajpai, 11 May 1931.

98 NAI, DEHLO, July 1931, B, 29-49. Despatch, Governor to SSC, 10 June 1931.

99 NAI, DEHLO, July 1931, B, 29-49. Letter, Menon to Bajpai, 29 June 1931.

100 NAI, DEHLO, July 1931, B, 29-49. Letter, Bajpai to Menon, 2 July 1931.

101 NAI, DEHLO, September 1931, B, 38. Letter, Menon to Bajpai, 13 July 1931.

102 NAI, DEHLO, 1935, B, 69. Letter, Chandran to Hydari, 16 December 1934.

103 NAI, DEHLO, 1935, B, 69. Letter, Chandran to Hydari, 14 February 1935.

104 NAI, DEHLO, 1935, B, 69. Letter, Chandran to Menon, 5 February 1936.

105 NAI, DEHLO, 1935, B, 69. Note, Menon, 15 February 1936.

106 NAI, DEHLO, 1935, B, 69. Note, Jagdish Prasad, 17 February 1936.

107 NAI, DEHLO, 1935, B, 69. Note, Bajpai, 4 September 1936.

108 NAI, DEHLO, 1935, B, 69. Note, Bozman, 8 September 1936.

109 NAI, DEHLO, 1935, B, 69. Note, Bajpai, 8 September 1936.

110 NAI, DEHLO, 1935, B, 69. Note, Bozman, 14 October 1936.

111 NAI, DEHLO, 1935, B, 69. Note, Bajpai, 17 October 1936.

112 NAI, DEHLO, 1930, B, 49-52. Report, 2nd half of 1930, Menon, 7 January 1931.

113 NAI, DEHLO, 1935, B, 306. Letter, Chandran, 25 November 1935.

114 NAI, DEHLO, 1935, B, 306. Telegram, Chandran, 25 February 1936.

115 NAI, DEHLO, 1935, B, 306. Letter, Pai to Bozman, 9 November 1936.

116 NAI, DEHLO, 1935, B, 69. Letter, Pai to R. K. Nehru, 19 December 1936.

117 NAI, DEHLO, 1935, B, 69. Note, Bajpai, 12 November 1936.

118 NAI, DEHLO, 1935, B, 69. Letter, Pai to Bozman, 19 November 1936.

119 NAI, DEHLO, 1935, B, 69. Note, Jagdish Prasad, 19 November 1936.

120 NAI, DEHLO, 1935, B, 69. Note, Bajpai, 21 November 1936.

121 NAI, DEHLO, 1935, B, 69. Letter, Pai to R. K. Nehru, 5 February 1937.

122 NAI, DEHLO, 1937, B, 26-7. Jackson Report, April 1938.

123 NAI, DEHLO, 1937, B, 26-7. Note, Bozman, 21 November 1938.

124 NAI, DEHLO, 1937, B, 26-7. Note, Jagdish Prasad, 21 November 1938.

125 NAI, DEHLO, 1937, B, 26-7. Note, V.S.S., 14 June 1939.

126 NAI, DEHLO, 1937, B, 26-7. Note, Bajpai, 27 October 1939.

127 NAI, DEHLO, 1937, B, 26-7. Note, Bozman, 19 June 1939.

128 NAI, DEHLO, 1933, B, 112. Letter, CS Ceylon to Chandran, 23 August 1934.

129 NAI, DEHLO, 1933, B, 112. Note, Hydari, 9 May 1934.

130 NAI, DEHLO, 1933, B, 112. Note, C.S., 22 September 1934.

131 NAI, DEHLO, 1933, B, 112. Note, Bajpai, 10 May 1934.

132 NAI, DEHLO, 1933, B, 112. Note, Bajpai, 10 May 1935.

133 NAI, DEHLO, 1937, B, 75-11. Letter, Pai to Bozman, 23 February 1937. 
134 NAI, DEHLO, 1937, B, 75-11. Letter, Pai to Bozman, 28 October 1937.

135 NAI, DEHLO, 1937, B, 26-8. Note, C. S., 22 May 1937.

136 NAI, DEHLO, 1937, B, 26-8. Note, Jagdish Prasad, 13 May 1937.

137 NAI, DEHLO, 1937, B, 26-8. Note, Jagdish Prasad, 28 May 1937.

138 NAI, DEHLO, 1937, B, 26-8. Note, Bozman, 15 July 1937.

139 NAI, DEHLO, 1937, B, 26-8. Note, Bozman, 11 August 1937.

140 NAI, DEHLO, 1937, B, 26-8. Note, Hydari, 11 August 1937.

141 NAI, DEHLO, 1937, B, 26-8. Note, Bozman, 2 September 1937.

142 NAI, DEHLO, 1937, B, 26-8. Note, Jagdish Prasad, 11 September 1937.

143 NAI, DEHLO, 1937, B, 26-8. Note, Jagdish Prasad, 23 November 1937.

144 NAI, DEHLO, 1937, B, 26-8. Note, Bajpai, 16 June 1938.

145 NAI, DEHLO, 1937, B, 26-8. Note, Mani, 24 August 1938.

146 NAI, DEHLO, 1937, B, 26-8. Note, Dutt, 23 August 1938.

147 NAI, DEHLO, 1937, B, 26-8. Note, Dutt, 14 September 1938.

148 NAI, DEHLO, 1937, B, 26-8. Note, Jagdish Prasad, 27 August 1938.

149 NAI, DEHLO, 1937, B, 26-8. Note, Bajpai, 15 September 1938.

150 NAI, DEHLO, 1937, B, 26-8. Note, Jagdish Prasad, 20 September 1938.

151 NAI, DEHLO, 1937, B, 26-12. Letter, Bajpai to PSV J.G. Laithwaite, 9 April 1937.

152 NAI, DEHLO, 1937, B, 26-12. Note, Bajpai, 1 April 1937.

153 Patrick Peebles, The Plantation Tamils of Ceylon, London: Leicester University Press, 2001, p. 149.

154 NAI, DEHLO, December 1926, B, 66-116. Note, Ewbank, 22 May 1926.

155 BL, IOR, L/PJ/6/1623, file 5811. Minute, G. C. Shepherd [September 1919].

156 NAI, DEHLO, December 1926, B, 66-116. Note, Bajpai, 12 August 1926.

157 NAI, FPD, Establishment, 60(2)-E. Letter, Bajpai to Foreign Secretary Denys Bray, 4 March 1929.

158 NAI, FPD, Establishment, 60(2)-E. Letter, NWFP to Foreign Delhi, 8 March 1929.

159 NAI, DEHLO, 1931, 50-52. Letter, Narayanan to DEHL, 29 October 1931.

160 BL, IOR, L/E/7/1516. Letter, Bajpai to USSI, 6 November 1933.

161 NAI, DEHLO, 1932, A, 235-1. Letter, Menon to Christie, 6 February 1933.

162 NAI, DEHLO, 1932, A, 235-1. Letter, Menon to Christie, 13 February 1933.

163 NAI, DEHLO, 1932, A, 235-1. Note, Bajpai, 20 February 1933.

164 NAI, DEHLO, 1933, B, 178. Note, Bajpai, 15 May 1933.

165 NAI, DEHLO, 1932, B, 85-96. Note, Ram Chandra, 8 May 1931.

166 NAI, DEHLO, 1933, B, 178. Note, Zaman, 13 May 1933.

167 NAI, DEHLO, 1932, B, 85-96. Letter, Menon to Bajpai, 7 April 1931.

168 For example, NMML, KPSMP, Diary 1931, 24 March and 24 November.

169 NAI, DEHLO, 1933, B, 187-2. Letter, Menon to Bajpai, 2 November 1933.

170 NAI, DEHLO, 1933, B, 187-2. Letter, Bajpai to Menon, 15 November 1933.

171 NAI, DEHLO, 1933, B, 187-2. Note, Bajpai, 16 September 1933.

172 NAI, DEHLO, 1933, B, 187-2. Note, Bajpai, 5 October 1933.

173 NAI, DEHLO, 1933, B, 144. Note, Hydari, 21 March 1934.

174 NAI, DEHLO, 1933, B, 144. Note, Hydari, 27 February 1934.

175 NAI, DEHLO, 1933, B, 144. Note, Bajpai, 2 March 1934.

176 NAI, DEHLO, 1935, B, 7-10. Note, C.S. 18 February 1935.

177 NAI, DEHLO, 1935, B, 7-10. Note, Bajpai, 3 March 1935.

178 NAI, DEHLO, 1935, B, 69. Note, Bajpai, 27 February 1935.

179 NAI, DEHLO, 1935, B, 312. Letter, Chandran to Menon, 5 December 1935.

180 NAI, DEHLO, 1935, B, 312. Note, Menon, 4 February 1936.

181 NAI, DEHLO, 1935, B, 312. Note, Bajpai, 9 March 1936. 
182 NAI, DEHLO, 1935, B, 69. Letter, Pai to R. K. Nehru, 8 January 1937.

183 NAI, DEHLO, 1935, B, 69. Letter, Jagdish Prasad to Bajpai, 11 January 1937.

184 NAI, DEHLO, 1935, B, 69. Note, Bajpai, 23 January 1937.

185 NAI, DEHLO, 1937, B, 26-12. Note, Bajpai, 12 April 1937.

186 NAI, DEHLO, 1937, B, 26-17. Note, Jagdish Prasad, 8 December 1937.

187 NAI, DEHLO, 1937, B, 26-17. Note, Jagdish Prasad, 26 October 1937.

188 K.P.S. Menon, Many Worlds, an Autobiography, Bombay: IBH, 1971, pp. 112-113.

189 NAI, DEHLO, 1932, B, 192. Letter, Bajpai to Menon, 12 November 1932.

190 NMML, KPSMP, Diary 1932, 22 November.

191 NMML, KPSMP, Diary 1930, 6 June.

192 NMML, KPSMP, Diary 1930, 6 May.

193 NMML, KPSMP, Diary 1930, 8 May.

194 NMML, KPSMP, Diary 1930, 10 May.

195 NMML, KPSMP, Diary 1931, 6 March.

196 NMML, KPSMP, Diary 1930, 25 May.

197 Michael Silvestri, 'The Bomb, Bhadralok, Bhagavad Gita, and Dan Breen: Terrorism in Bengal and Its Relation to the European Experience', Terrorism and Political Violence, 2009, 21(1): 5.

198 NMML, KPSMP, Diary 1932, 7 February.

199 NMML, KPSMP, Diary 1932, 24 December.

200 Peebles, The Plantation Tamils of Ceylon, p. 149.

201 NAI, MEA, 5(6)-FSP/47. Note, B. K. Kapur, 27 June 1947.

202 NAI, DEHLO, 1934, B, 218 k.w. Note, Bajpai, 2 May 1935.

203 NAI, DEHLO, 1935, B, 7-10. Note, Bajpai, 24 June 1935.

204 NAI, DEHLO, 1935, B, 26-8. Note, Bajpai, 7 January 1939.

205 NAI, DEHLO, 1935, B, 26-8. Note, V.S.S., 9 January 1939.

206 NAI, DEHLO, 1935, B, 312. Note, Bajpai, 13 March 1935.

207 NAI, DEHLO, 1933, B, 112. Note, Hydari, 12 April 1934.

208 NMML, KPSMP, Diary 1932, 6 October.

209 NAI, DEHLO, 1933, B, 112. Note, Hydari, 9 May 1934.

210 NAI, DEHLO, 1934, B, 218 k.w. Note, Hydari, 5 January 1935.

211 NAI, DEHLO, January 1931, B, 35-39. Letter, Menon to DEHL, 26.9.1930.

212 NAI, DEHLO, January 1932, B, 85-96. Annual Report 1930, Menon, 7 April 1931.

213 NAI, DEHLO, 1937, B, 26-19. Note, Bozman, 17 June 1939.

214 BL, IOR, L/SG/11/7/9. Note, Jagdish Prasad, 28 March 1940.

215 BL, IOR, L/SG/11/7/9. Note, Bajpai, 18 February 1939.

216 NAI, DEHLO, 1937, B, 26-12. Note, A.B.M., 21 July 1937. 


\section{MALAYA}

Since the late 19th century, Malaya had attracted Indian labourers for the 'rubber connection'. ${ }^{1}$ According to the census of April 1931, Indians counted 627,770 out of a total population of $4,381,342$. About 70 per cent of them were labourers; the rest were engaged in trade, business or learned professions. ${ }^{2}$ Though there were obvious parallels with Ceylon and a tendency to treat it on the same footing, Malaya formed a specific case. There was, first, a political order making it difficult to find solutions for the country as a whole. Nominally, it was split into the Strait Settlements (SS), with the most important ports (Dinding, Penang, Malacca, Singapore) under immediate British rule, the Federated Malay States (FMS: Perak, Selangor, Negri Sembilan, Pahang) and the Unfederated Malay States (UMS: Johor, Kedah, Kelantan, Perlis, Terengganu). The FMS and the UMS consisted of nominally independent sultanates, each with a British advisor. Though the UMS enjoyed more autonomy, the actual power lay with the British high commissioner, who was always the governor of Singapore. The second difference was closely related. As Malaya legally was no state, there was no political franchise for any community. Therefore, unlike in Ceylon, political status and citizenship together with related questions like domicile and representation in public bodies played but a subordinate role. Malaya was characterised by oldstyle colonialism throughout the interwar period. The third difference initially lay in the nature of employment. Unlike in Ceylon or South Africa, the vast majority of Indian labourers initially had no intention to stay on permanently. Given the geographical distance from South Asia, most of the predominantly male labourers left wives and children behind. This changed with the Great Depression. What for decades had been a circular migration came to an end. As only 'few if any provisions were made for their welfare' when returning to India, ${ }^{3}$ despite unemployment a growing number stayed on, started cultivating land and were joined by their families. ${ }^{4}$ Of lesser importance was, finally, the existence of another foreign group of competitors, Chinese labourers, who were considered more efficient as well as less docile and more expensive. 


\section{Minimum wages and immigration}

Among the three agencies, the one in Malaya was considered the least problematic and relevant. Due to the ongoing demand for labour, Malaya as early as 1907 had implemented reforms improving the lot of Tamil workers, among others taking care that they did not arrive already indebted. The reforms stood for a 'paradigm shift, a move away from labour circulation to a permanently settled Indian labour force on plantations and elsewhere'. ${ }^{5}$ Accordingly, in the first two decades of the 20th century, the Indian population quadrupled. ${ }^{6}$ Government relations were friendly throughout and Delhi did not doubt the willingness of colonial administrators to do their best to implement minimum wages and improve the conditions of labourers. When Agent Arulanandam Pillai was appointed, the GoI already was in the midst of negotiations with the FMS and the SS over standard wages. His first task was to collect data allowing the calculation of reasonable rates. ${ }^{7}$

In the spring of 1925, the authorities in Kuala Selangor District calculated minimum wages of 35 cents per day for men and 27 cents for women. These rates needed approval by the Indian Immigration Committee. ${ }^{8}$ As the body consisted mostly of employers together with a few officials, it was considered planter-friendly. Among its 16 members were only two Indians, who exercised little influence. ${ }^{9}$ After Pillai had provided data ${ }^{10}$ and calculated the actual needs, ${ }^{11}$ Bajpai produced an elaborate scheme, adding expenses of a passage to India every other year, for dependents, sickness and living. This resulted in daily wages of 51 cents for men, 41 for women and 21 for children, matching the rates in Ceylon and slightly higher than what Malaya's planters had recommended in $1920 .{ }^{12}$

The Indian Immigration Committee, however, decided on lower rates for the coastal districts of Selangor State (FMS), where the lowest wages were paid countrywide. ${ }^{13}$ With effect from January 1926, men received 40 and women 30 cents per day. Pillai found the rates inadequate, especially due to the rise of cost of living against an abnormally high price of rubber. Still, about 70 per cent of the estate labourers would earn more ${ }^{14}$ Efforts to induce the Malayan government to take care for an extension to more districts and an increase of rates did not bear fruit. The demand for estate labour seemed to provide a perfect position to negotiate unlimited emigration against concessions, but Bajpai found it unwise to appear brusque with a particularly friendly government. ${ }^{15}$ Instead, the Indian key bargaining chip became Rule 23 of the Indian Emigration Act, demanding a certain sex ratio among emigrants. ${ }^{16}$ Until 1917, this had been five men to two women. Thereafter, 'two married couples [were] to be sent in every batch of five [adult] emigrants'. ${ }^{17}$ The reasoning behind the rule was to allow labourers a healthy moral life. ${ }^{18}$ What due to geographical proximity was easily achieved in Ceylon was a different story in Malaya. ${ }^{19}$ At the end of 1925 , there were 2.5 men to one woman; the statistical relation was slightly better on the estates. ${ }^{20}$ 
This should have led to a ban on emigration, but in early 1925 the country was exempted from Rule 23 until December 1926. Bajpai informed the chief secretary of the SS that statistics covered too short a period to justify a permanent decision. ${ }^{21}$ The actual reason was that the rule could not be brought in operation. Selecting and refusing emigrants was genuinely a task of the GoI and its enforcement would have caused trouble at the emigration depots or led to 'depot marriages'. Preselection in the villages would have strengthened the kangani system, which Delhi wanted to abolish. This dilemma illustrated 'the chief use to which the sex ratio can be put - as a means of bargaining'. 22

In 1926, Bhore urged to use this linkage to achieve a countrywide fixation of minimum wages; massive emigration from South India, caused by severe economic problems, might weaken Delhi's future stand. ${ }^{23}$ When Malaya officials asked for a permanent exemption from Rule $23^{24}$ while Governor Laurence Guillemard refused to nominate an Indian to the Federal Council, the GoI informed Malaya that the rule would be enforced from May 1927.25 Internally, however, it was agreed to show flexibility if Malaya did so regarding minimum wages. ${ }^{26}$

Therefore, when Malaya sent Controller of Labour E.W.F. Gilman, Bajpai suggested another postponement. Gilman was known for bargaining hard, but an earlier visit had helped mutual understanding, resulting in the fixation of standard wages in Pahang. Moreover, Bajpai emphasised that 'the game is really ours at any stage, even in regard to the enforcement of the sex-ratio'. ${ }^{27}$ The informal talks in late August 1927 led to a sort of understanding. While the GoI prolonged the exemption until April 1928, explicitly considering a further extension until October, it clarified that it expected the FMS to extend the principle of standard wages to other areas and revise the current rates. ${ }^{28}$

Progress turned out to be slow, however. By March 1930, rates had been fixed except for the coastal districts of Selangor and the inland districts of Pahang, both FMS, together with Wellesley Province in the SS. Standard wages in those areas differed from each other. Klang District in Selangor with effect from 1 February 1929 followed the prescribed rate of 50 cents for men, 40 for women and 20 for children. There were, however, no standard wages for the whole of Malaya, no fixation of rates for children or higher ones for women. For Indians in government employment, wages had been fixed in the FMS, Johore and Kedah with effect from 1 January 1928, but there were numerous exceptions. The railways paid similar rates, Brunei much more. ${ }^{29}$

In the spring of 1929, the DEHL and Gilman agreed to send a deputation to Malaya to investigate the situation on the ground. ${ }^{30}$ Bajpai was to be accompanied by three non-officials. Though due to the Great Depression the plan never manifested, preparations illuminate considerations in the DEHL and the problems it faced. The non-officials should have been members of 
the SEC, but it was difficult to select proper candidates. Habibullah initially asked for a Hindu and a Muslim. ${ }^{31}$ The third non-official should represent the working classes. Bajpai tried to put together a list: G. A. Natesan should represent the State Council of Madras Province, from which most labourers originated. From the Legislative Assembly, Abdul Qaiyum was to represent Muslims and M.C. Rajah the depressed classes. Both Rajah and Natesan, however, were nominated members. Sending two such politicians would have left a bad impression in both India and Malaya. Instead, Kunzru, though at that time no member of the SEC, was to join as an independent and influential person. ${ }^{32}$

After Habibullah somewhat grudgingly had accepted the candidates, ${ }^{33}$ Bajpai raised the issue of timing, the DEHL with its small staff in demand at too many frontiers. In April 1930, it had to focus on East Africa. In October, the second Round Table Conference with South Africa would absorb most capacities. Furthermore, general elections might take place in India. Finally, Agent R. Subbayyu Naidu would leave Malaya not later than October. Given the relevance of African issues, Bajpai could not accompany the delegation, and replacing him with an official from outside the DEHL would cause extra expenses not justifiable in times of financial stringency. ${ }^{34}$ Ram Chandra would have been the logical candidate then, but Bajpai thought little about his immediate subordinate. ${ }^{35}$ Finally, Viceroy Irwin decided to defer the deputation until after the next general elections. ${ }^{36}$ For the time being, the exemption from Rule 23 was extended for another year. ${ }^{37}$

In August 1930, the Malayan government again asked for a permanent exemption. In the meantime, however, the Great Depression had hit hard. Notwithstanding the suspension of all recruitment licences from the first of that month and a notable increase of the number of Indians leaving the country, a general cut of wages by 20 per cent valid from October was decided..$^{38}$ With the stop of recruitment, any exemption made no difference in practice, ${ }^{39}$ but Malaya insisted. Naidu objected as the prevailing sex ratio allegedly had led to an 'immoral life of Indian labourers', which was 'a disgrace to India' ${ }^{40}$ Bajpai believed Naidu's statement to be exaggerated: 'The evil was frightful in the old days of indentured emigration in colonies like Fiji', but 'conditions never appear to have been as bad in Malaya and Ceylon'. After around 70,000 Indians had left the country over the last few months, things could not get worse. The core question was whether reforms would be more easily achieved by enforcing Rule 23 now or later. Overall, Indians had been treated reasonably. Without the good will of authorities and planters, the depression might lead to a disastrous reduction of wages. Free repatriation 'may only help to add to unemployment in Madras'. If the GoI granted but another temporary exemption, this would help improvements for the labourers. ${ }^{41}$ Against a hesitant Fazl-i Husain, Bajpai's views prevailed..$^{42}$

Bajpai was right about the comparatively reasonable treatment of Indians. The government provided not only proper housing. As a rule, the 
controller of labour asked for the establishment of a school whenever there were ten or more children aged 7 to 14 in an estate. In 1925, 7,010 children attended estate schools in the FMS. Educated and well-to-do families sent their offspring to English-medium schools, where they were taught together with children of other nationalities. Those counted 2,578 Indian boys and 559 girls, taught by 132 Indian teachers. ${ }^{43}$ The number of estate schools grew from 227 in $1923^{44}$ to 367 in 1925. As in Ceylon, they faced major difficulties in finding qualified teachers, and like Hydari, Pillai recommended recruitment in South India. ${ }^{45}$ Accordingly, Malaya in 1930 appointed an officer to reorganise Tamil education along the lines of the education of other communities. ${ }^{46}$

The most relevant improvement was the flourishing of cooperative societies, intensely propagated by Pillai, emphasising that labourers must be provided with an opportunity to deposit savings instead of wasting them on alcohol. In early 1924, the agent authored a tentative scheme and forwarded it to the registrar of cooperative societies, Taiping, and the director of posts and telegraphs, Kuala Lumpur. ${ }^{47} \mathrm{He}$ visited estates, explaining that managers were to control the accounts but that labourers should be able to withdraw their savings any time and leave estates after one month's notice. ${ }^{48}$ The DEHL was not happy with him taking the initiative. Bajpai criticised 'Sunday-school methods' and warned that if a withdrawal was possible only with the manager's consent, this would fetter the freedom of movement of labourers. Furthermore, clerks would charge the latter for their services. Bajpai preferred savings banks instead. ${ }^{49}$ Bhore pointed out that if Pillai managed to draw the attention of the authorities to the issue, this was welcome, but the details were 'matters for the Cooperative Department of the Malayan Govt. and not for the Govt. of India'. ${ }^{50}$ Shafi finally ruled that the agent should offer but advice and assistance. ${ }^{51}$

Pillai modified his scheme accordingly. As he believed that the GoI refused to play a role for financial considerations, he clarified that the Malayan government had decided to finance the staff of cooperative inspectors and higher rates of interest. ${ }^{52}$ In his reply, Bajpai elucidated that the main problem was the 'constitutional impropriety of interfering in a matter which is primarily the concern of the colonial authorities'. If the FMS, however, found Pillai's scheme feasible, the GoI would not raise any objection..$^{33}$ The agent's efforts paid off; the registrar of cooperative societies for the FMS and SS, at Pillai's instance, appointed an Indian officer and promised that more would follow if the scheme was successful. ${ }^{54}$ In 1935 , according to Agent K. A. Mukundan, cooperative societies flourished without any abuse by estate staff or restriction of the freedom of movement of labourers. ${ }^{55}$

The depression led to the temporary close-down of numerous rubber estates. Furthermore, hundreds of Indians lost their jobs with the railways. ${ }^{56}$ By 1932, about 150,000 Indians had left Malaya, ${ }^{57}$ wherefore hours of work and wages remained mostly stable. ${ }^{58}$ That year, the rubber price seemed to 
recover, wherefore Controller of Labour Christopher Dominic Ahearne asked for permission to restart recruitment of labourers who had earlier worked in Malaya. He argued that wages had been reduced by 20 per cent against cost of living by 30 per cent. Moreover, rates were much higher than in Ceylon. ${ }^{59}$ Agent M. Kunhiraman Nair suggested that Delhi in return should insist on statutory minimum wages, which could not be reduced. ${ }^{60}$ Bajpai, however, did not find the time ripe for such proposals:

India is not exactly a paradise at present for the unemployed of other lands. ... . Even working for a less than subsistence wage in Malaya may, within limits, be preferable to starvation or semistarved dependence on others in India. We must be watchful, but not imprudent. ${ }^{61}$

Before taking a final decision, it had to be clarified whether there still was any surplus labour in Malaya. ${ }^{62}$

Ahearne helped to overcome reservations in Delhi. Though there were no Indian labourers employed in Brunei, he made it a standing practice that the agent was heard before any rates in the sultanate were fixed. ${ }^{63}$ Ahearne also took it up with planters not treating Indians well, coming 'in bad odour' with some of them. ${ }^{64}$ When after a certain recovery of the rubber price some estates offered less than the new standard rates of 40 cents for men and 32 for women, Ahearne refused them recruitment licences. ${ }^{65}$ Bajpai praised him for his 'fearless championship of the cause of Indian labour'. ${ }^{66}$

Accordingly, Bajpai overruled the SEC in 1933, asking for a full restoration of wages and free repatriation. The Malayan government emphasised that there had been cuts in wages everywhere and they could not privilege one group against all others. Actual earnings had increased in the first half of 1933 and the cost of living was lower than in 1928. Bajpai gave for consideration that

only dire distress in India could induce people to emigrate to Malaya under such conditions and it does not seem right that, if, as this would indicate, they would probably be improving their lot by going to Malaya, we should put obstacles in their way because of political sentiment. ${ }^{67}$

As a consequence, the SEC in early 1934 modified conditions for a reopening of recruitment. Fresh emigration should be limited to a maximum of 20,000 labourers for the first year and Malaya was asked to provide monthly reports on Indian employment. ${ }^{68}$ In return, Malaya assured Delhi that only estates guaranteeing standard wages would be granted recruiting licences. ${ }^{69}$ Due to general economic improvement in the second half of 1934, many labourers indeed were paid higher wages. ${ }^{70}$ 
Notwithstanding a renewed fall of the rubber prices towards the end of 1934, the economic situation in Madras Presidency was so depressing that its government opposed any restrictions on emigration. ${ }^{71}$ Therefore, the number of assisted emigrants exceeded the agreed 20,000 after only nine months. ${ }^{72}$ Once again, Bajpai took a pragmatic stand: As long as there was famine, emigration could not be stopped. The GoI should better carry along Indian legislation. ${ }^{73}$ The SEC gave the go-ahead for a six-month exten$\operatorname{sion}^{74}$ for a maximum of 35,000 up to the end of September $1935 .{ }^{75}$ Indeed, between January and July 1935, nearly 13,000 labourers circumvented the quota by paying for their own passage, arriving in Malaya indebted. ${ }^{76}$

Finally, the GoI sent a deputation in December 1936. Bajpai's all-purpose weapon, Sastri, was meant to focus on wages and conditions for labourers and the political and social status of Indians. Further, he was asked for advice on assisted emigration. ${ }^{77}$ While the Malayan government promised to restore wages to pre-depression levels, with effect from April 1937, efforts to reach a further increase led nowhere. Sastri's counterparts hinted at the possible fall of cost of living. Moreover, Ahearne wanted to open a debate on a differentiation between standard and minimum wages. Sastri avoided any further discussion as he was neither feeling sufficiently informed nor did he want to cause a delay with the restoration of wages. A discussion of the sex ratio was avoided by both parties, Sastri warning the DEHL that an enforcement 'might cause as much difficulty in India as in Malaya, if not more'. Regarding education, his suggestion to send an expert from Madras was welcomed..$^{78}$ After his return to India, Sastri publicly emphasised that there was no justification to limit emigration if wages were restored. ${ }^{79}$

The official report, drawing a rather positive picture of conditions in Malaya, ${ }^{80}$ was harshly criticised in the Indian press. ${ }^{81}$ The focus, among others, was on the lack of Indians in the political and public bodies in Malaya. There was an Indian member in the Federal Council, and there had been a few more in various state councils. By early 1936, however, they had been succeeded by Ceylon Tamils, ${ }^{82}$ treated as Indians by Malayan authorities but not by the GoI. They indeed originated from South India, but migration dated back centuries. Furthermore, they formed but a small group, mostly clerks in government employment, therefore not representing Indian labourers. ${ }^{83}$ Against Sastri's protests, Governor Shenton Thomas maintained that he did not know any Indians of sufficient standing. ${ }^{84}$

The situation was even worse in advisory bodies and public services. The Malayan Civil Service consisted mostly of Europeans and a few nominated Malays, and the same was true for the Malay Administrative Service. For the clerical and other subordinated services, the government declaredly preferred Malay candidates; otherwise, those born in Malaya came under consideration. The selection of all others needed special sanction by the chief secretary. Mukundan found nothing objectionable in preferring Malays but insisted that the interests of other communities 
must be taken into consideration too. ${ }^{85}$ As Malaya was not responsive to Indian representations, the matter was brought to the notice of SSC Ormsby-Gore, who merely promised consideration. ${ }^{86}$ Bozman did not find the issue relevant enough to become a casus belli, but Bajpai was unwilling to accept the exclusion of locally born Indians from Malaya's higher services. ${ }^{87} \mathrm{He}$ also felt uneasy about the land settlement of Indians, supported by Malayan authorities. If greater numbers of Indians became permanent residents, this might make the planters less dependent on the supply from India, Delhi's only trump card in case Indians did not receive fair treatment. ${ }^{88}$

\section{Department and agents}

Overall, from the opening of the agency to the late 1930s, nothing much happened in Indo-Malayan relations that was not dictated by market rules. This explains why the agency was run by officers selected from the Provincial Civil Service, critically viewed in their mother department. The first agent, Pillai, was praised by C.F. Andrews as a 'brave and energetic man' who had 'won the respect of the European community'; ${ }^{89}$ Governor George Maxwell commended him on 'excellent service', tact and winning the planters' confidence..$^{90}$ On the contrary, in the DEHL, he was criticised for delayed, verbose and obscure reports, as were his successors Naidu and Nair. Already in 1924, Bajpai criticised 'unnecessary length and ... superfluity of detail'. ${ }^{11}$ Given that Pillai had 'been less successful in his post than Mr. Ranganathan, and the question of standard wages in Malaya is still far from settlement', Ewbank wanted a junior Indian ICS officer to succeed him. ${ }^{92}$ Habibullah bluntly added that the next agent should be more intelligent. ${ }^{93}$ Madras, however, turned down all requests. ${ }^{94}$ Finally, Naidu from the Provincial Service was appointed, arriving in Malaya on 15 November 1926.

The department found itself out of the frying pan into the fire. With unmistakable embarrassment, Bajpai criticised Naidu's annual report for 1927 as

characteristically long, indiscreet in many parts, and full of controversial or impractical suggestions. ... We must . . . call the agent's attention to the impropriety of cramming into the report his pet theories and favourite schemes, regardless of their effect on public opinion in India.

Naidu was free to pursue them, but only in confidential memoranda or letters. ${ }^{95}$ Naidu, however, went on reporting 'on such pet subjects of his as the sex-ratio, sex-crimes and drink. His suggestion that profits derived from the sale of toddy should be expended on temples is likely to cause the 
irreverent much amusement'. Nevertheless, unlike in the case of Pillai's successful efforts to establish cooperative societies, Bajpai gave credit to other aspects of Naidu's work:

We have suffered from his prolixity as a writer, and also, to some extent, from his lack of judgement, but on the whole, he has served government well. ... His defects indeed derive from his sincere enthusiasm which has indeed been his main strength. ${ }^{96}$

By March 1930, Naidu did not want to stay on much longer. He recommended appointing an ICS officer as successor, carrying more weight with the colonial government. The Standing Finance Committee, however, objected. ${ }^{97}$ Bajpai was not willing to give in, arguing that the GoI needed 'to send out a man who can appraise economic factors competently and dispassionately', who was impossible to find in the Provincial Service. The committee should not be overruled under normal circumstances, but the depression had created most difficult conditions. An ICS officer should be appointed for but one year, to be succeeded by an agent from the PCS. ${ }^{98}$ Madras, however, unwilling to release an ICS officer, recommended M. Kunhiraman Nair, PCS, special officer for South African repatriates in Madras. ${ }^{99}$ Bajpai was pleased with his paperwork and the recommendations; ${ }^{100}$ Nair took over on 4 September 1930.

Once again, the DEHL received verbose ${ }^{101}$ and delayed reports. A letter from the chief secretary from late December 1932 was assessed by Nair only in April 1933. ${ }^{102}$ Even worse, his comments were considered mostly 'unhelpful criticism of the facts of the situation'. ${ }^{103}$ When weighing the agent's arguments against those of the chief secretary, ADS S. R. Zaman found the latter legitimate and bona fide. ${ }^{104}$ Other recommendations were formulated 'not always in a clear-cut way'. ${ }^{105}$ The useful reports were summarised by headquarters, but the wording had to be modified. ${ }^{106}$ Nair's annual report for 1931, most unusual, even caused Malayan representations: The agent wrote, falsely, about criminal prosecution of Indian labourers. ${ }^{107}$ This triggered an official protest by the chief secretary. Moreover, Ahearne in a private letter to Bajpai emphasised that the agent was free to take views differing from the government's in matters of opinion, but not when it was about facts. ${ }^{108}$ The secretary believed that Nair had 'been the victim of his zeal for his compatriots in Malaya'. It would be 'sufficient to warn him demi-officially'; with Malaya, though, 'we need not be too abject on our expression of regret'. ${ }^{109}$ Nair in his correspondence with Bajpai meekly indicated that he was aware of his poor standing. ${ }^{110}$ Due to the sudden death of his wife, his term ended prematurely in July $1933 .{ }^{111}$

Nair's successor Mukundan, PCS, started with an even worse standing, as he was selected merely for the fact that he was the candidate involving the lowest cost. ${ }^{112}$ When in July 1933 he came to see Bajpai and Fazl-i Husain, 
both were thoroughly disappointed. ${ }^{113}$ In a letter to the Madras government, Bajpai elaborated that he doubted whether Mukundan had

the personality needed for the job of agent in Malaya, in which one has sometimes to take a strong and independent line against the highly organised planters and even the controller of labour who is a senior officer of the Malayan Civil Service. He also does not give one the impression of having the social qualities required of a good 'mixer' in the cosmopolitan society of Malaya.

Requested for alternatives, Madras suggested E.D. Philip, PCS, an Indian Christian, who in his personal file was criticised for his work as magistrate. ${ }^{114}$ Deeply frustrated, Bajpai found it 'immaterial whether we choose Mr. Mukundan or Mr. Philip', ${ }^{115}$ and Fazl-i Husain asked sarcastically whether the department 'should determine who is the least unsuitable'. ${ }^{116}$

Nevertheless, Mukundan, taking over on 21 October 1933, was the first agent not drawing any criticism from headquarters. Accordingly, his term was extended for six months until 21 April 1937, and he was even offered to stay longer. ${ }^{117}$ Once again, the DEHL requested an ICS officer, ${ }^{118}$ the demand supported by local Indians. ${ }^{119}$ With C. S. Venkatachar from the 1922 batch of the UP cadre, the wish finally was satisfied. Born in 1899, he originated from the neighbourhood of Bangalore and was fluent in Tamil, Telugu and Kannada. Whereas lack of files makes it difficult to assess his performance as agent, due to a changeful but distinguished career and the evidence he left at the British Library there is sufficient material to throw light on other stages of his professional life. His father being a lawyer, he graduated in chemistry and succeeded in the ICS entrance examination in 1921. His probation at Trinity College, Cambridge, like most of his compatriots he considered a useless anti-climax, the understanding of English life remaining 'on the surface, quite superficial'. As young district officer, one of his superiors warned him not to imitate the English. An Indian officer

should have courage to hold on to values which he feels are good for him. Indianisation of the service does not mean Anglicisation of the individual. The Indian officer may be a member of the English club but he should not keep away from fellow Indians. ${ }^{120}$

In the spring of 1924, Venkatachar was the first Indian ever to apply for the Political Service. ${ }^{121}$ Two years later, while still serving in the UP cadre, he attracted Bajpai's attention, hunting for South Indian ICS officers serving outside Madras Presidency. Bajpai found him promising but still too junior for the agency in Ceylon. ${ }^{122}$ For 11 years, Venkatachar remained an interesting candidate, but for various reasons he never made it. In November 1927, he was appointed to the Political Service, ${ }^{123}$ the second Indian probationer 
after K.P.S. Menon, and transferred to Rajkot and Baroda. From April 1930, he was employed for census work in Central India. In 1929, Bajpai asked for Venkatachar's services in Ceylon, though only as a reserve candidate; ${ }^{124}$ the following year, he was mentioned for the post in Malaya. ${ }^{125}$ In September 1932, to his disappointment, Venkatachar was sorted out from the Political Service for belonging to the wrong race. Though there was 'no suggestion of any kind of "misconduct"', his superiors held that he and Menon were 'temperamentally and in every other way - more suited for employment in regular ICS appointments'. ${ }^{126}$ Whereas Foreign Secretary Aubrey Metcalfe intervened on behalf of Menon, ${ }^{127}$ Political Secretary B. J. Glancey found Venkatachar lacking 'the form of character required to make an Indian officer a success in this department'. ${ }^{128}$ After his reversion to UP, Venkatachar was considered as successor for Ceylon once again ${ }^{129}$ but remained in UP, being praised for his performance as OSD in charge of rural reconstruction between April 1935 and July 1937..$^{130}$

Venkatachar's hour finally came on 17 September 1937. He arrived during a short-lived period of prosperity, based on stable rubber prices. While the legal rates for male and female estate labourers were fixed at 40 and 32 cents, respectively, the nominal rates rose to 50 and 40 cents. The Indian community increased rapidly, and the sex ratio improved to 1,000 men to 643 women against 1,000 to 531 the year before. Prospects were that promising that Indians began to acquire ownership of medium-sized rubber estates. ${ }^{131}$ There was a return of problems in 1938, with nominal rates falling to 45 and 35 cents respectively since May. The Indian population shrank, the sex ratio worsened dramatically and so did medical attention at estates. Accordingly, the GoI from 15 June imposed a ban on assisted emigration. The planters, keen to keep labourers for the high cost of repatriation, could offer nothing better than short work. ${ }^{132}$ The crisis continued in 1939. In February, Indians were involved in a minor strike at the FMS Railways Central Workshop at Kuala Lumpur.

Venkatachar considered his term uneventful; his account of his career mentions but the fact that he held the post. ${ }^{133}$ His successor Dutt passed down some more problems which Venkatachar had faced. There was, first, old-style Malayan colonialism. With much hesitation and uneasiness, Indian ICS officers had been admitted to European clubs in India, the heart of colonial social life, where officials and their families met. ${ }^{134}$ In Malaya, on the contrary, 'Venkatachar was blackballed when his name was put up for the Golf Club by the then British resident'. ${ }^{135}$ Furthermore, the agent was distrusted by Governor Thomas, who believed him secretly in league with the Central Indian Association in Malaya, ${ }^{136}$ allegedly closely connected with the Indian National Congress. ${ }^{137}$

For the period up to the appointment of Venkatachar, Malaya was the country with an agency where headquarters played the most dominant role. In South Africa or Ceylon, Sastri or Menon left a strong imprint. On the 
contrary, in Malaya, nothing of relevance was entrusted to the agents' discretion. Bilateral relations were friendly, and once the GoI had missed the opportunity for an early fixation of wages, the depression led to a lasting impasse. The agency was not needed for anything more than routine work.

Unlike in Ceylon, Bajpai was very much the man in charge. Although he never visited Malaya, he established close contact with the controllers of labour. Whatever had to be settled between the two governments was done at this level. Bajpai found not much to complain about the conditions for labourers in Malaya. While in Ceylon planters, colonial officials and Sinhalese were suspected of scheming against Indian interests, the secretary saw the mechanisms of market economy prevailing in Malaya. His refusal to ban emigration during the rubber slump, because conditions in South India were even worse, was no cynicism. In a world of limited opportunities, those struggling to survive could not be prevented from deciding on their own what might serve them best as long as their own government was incapable to provide them with a better life.

It is noteworthy that no other ICS officer of the DEHL left any imprint. Hydari occasionally authored lengthy notes without actually saying much. Otherwise, the analyses of conditions and developments in Malaya were in the hands of underlings, who signed but with their initials. The notes of C.S. or A.M. were impeccable, and the ranks immediately under Bajpai mostly forwarded them. In a manner of speaking, this mirrored conditions in Malaya, where the head clerk provided the actual element of continuity. Until 1923, T.G. Natarajan Pillai had been revenue inspector in Tanjore Collectorate, where he had come to work under Arulanandam Pillai, who had taken him along to Malaya. ${ }^{138}$ Highly praised for intelligence, reliability and honesty by all superiors, ${ }^{139}$ the head clerk was regularly appointed acting agent for month-long interludes between successive agents. Since 1932, Pillai drew the maximum grade pay of a mere $\$ 160$ or Rs 244 per month, a return passage second class to India costing $\$ 81 .{ }^{140}$ In comparison, even junior agents drew Rs 700 plus an overseas allowance of another Rs 300 per month. Although Pillai had already planned for retirement, he was the office holder once again when the Japanese invaded in 1942 and had to endure hardships until the end of the world war. ${ }^{141}$

Probably again for bilateral relations considered unproblematic, apart from Sastri's deputation, non-officials hardly played any role. Two visits of C.F. Andrews in 1924 appear to prove the point. The missionary drew a mostly favourable picture: Labourers compared to those in Assam received higher wages, enjoyed better health care and more freedom to change estates. The main disadvantage, considered by Andrews as well, was the sex ratio. In Assam, passages for family members were well organised and huts provided enough space. Older family members were free to join and offered light work. Finally, there was plenty of waste land for those willing to settle permanently. ${ }^{142}$ Andrew's report was read with interest in the DEHL ${ }^{143}$ 
but had no consequences. The same was true for his demand to abolish the kangani system. ${ }^{144}$ Bajpai agreed that it had problematic aspects but saw no practical alternative. ${ }^{145}$

\section{The crisis from 1941}

Subimal Dutt's term of eight months was by far the shortest of all agents but also the most eventful and controversial. ${ }^{146}$ As it triggered controversies even in London and as Dutt kept a diary much more detailed than those of Menon, it permits special insights in the work and life of an agent during the last months of interwar colonialism. The last agent in Malaya was the first one who did not belong to Madras Province. In 1937 new rules had been introduced, forcing officers on deputation to the central government to return to their provinces after a maximum of three years. ${ }^{147}$ The ambitious Dutt would have considered it an anti-climax in his career to revert to Bengal. Instead, he agreed to his transfer to Malaya; Bajpai promised that he would call him back to Delhi after completing the three-year term.

Beyond doubt, Dutt was aware that he was the wrong man for the job. He was the first and only agent who did not speak Tamil, thus needing an interpreter for all interactions with those he was meant to look after. Having avoided European clubs in Bengal, ${ }^{148}$ he certainly did not qualify as good 'mixer'. Furthermore, Dutt considered himself a poor speaker. ${ }^{149}$ Public appearances, however, decided much about the influence agents exercised. Finally, fearing a Japanese attack on Malaya, the agent had left his wife and children in Calcutta, terribly suffering from temporary separation. Nevertheless, unlike all his predecessors, after three years at headquarters he commanded expertise regarding Indians overseas, especially Malaya. Finally, Dutt wanted to prove himself, was very much his own man and stood the ground when coming under pressure.

Dutt's diary draws a very different picture compared to Menon's when posted in Ceylon. The latter loved to be a public figure and otherwise enjoyed much leisure time with his family; the former hated giving speeches ${ }^{150}$ and being the honorary guest at all sorts of events. Without his family, Dutt's leisure time was characterised by loneliness, boredom, frustration, and tentative efforts to make the best of what colonial life offered. He tried playing tennis and took a fancy to golf, but he refused to join European clubs. ${ }^{151}$ Dutt considered social life in Malaya much behind British India, which had rapidly changed with the independence movement and Indianisation.

While such difficulties to some extent can be explained by Dutt's peculiar personality, the political problems he faced were not of his making. The war had taken care for a rubber boom, Malaya providing more than one-third of the worldwide production. ${ }^{152}$ As this went along with a but moderate increase of wages, Chinese and Indian labourers repeatedly went on strike. ${ }^{153}$ The colonial government gave top priority to the war effort and 
reacted harshly, setting a precedent by sending the army, shooting three Chinese dead in late December $1940 .{ }^{154}$ A first strike of Indians in Klang District in February 1941 was settled with a small increase of wages, but in early May a renewed large-scale strike led to a clash with the police, leaving five Indians wounded and one dead. Things came to a head when, with the permission of Thomas, the resident in Selangor called in a battalion of Indian infantry. On 15 May, after an aggressive mob had surrounded the bungalow of an estate manager, firing 'in self-defence' left four Indians dead. ${ }^{155}$

Indian military shooting civilians was nothing uncommon in South Asia, but it was a different story abroad, even more as Indians in Malaya had donated to war funds and cordially welcomed Indian troops. Facing a storm of protest, Thomas consulted Dutt, the former maintaining that the strike was exclusively politically motivated. According to his account of the conversation, the agent agreed to this point of view. ${ }^{156}$ On the contrary, Dutt held to have 'said that the grievances of the labourers were not such that strikes should have been necessary. In his report to the Colonial Office he [Thomas] had apparently stated that according to me the labourers had no economic grievances'. ${ }^{157}$ In October, Dutt went ever further, elaborating that the

basic cause was failure of planters or Malayan Labour Department to give adequate attention to minor though genuine grievances of entirely non-political character followed by tactless and unsympathetic action on part of planters to remove persons who in their view were responsible for pressing such claims. ${ }^{158}$

In sum, the governor saw the shootings justified as a last resort to keep Malaya stable in times of war, whereas the agent drew the picture of a government taking sides in a purely economic conflict, resorting to lethal force against labourers. ${ }^{159}$

This difference of opinion went a long way. Not only was the relationship between governor and agent damaged beyond repair, but convinced of the correctness of Dutt's reports, Linlithgow vehemently supported the agent. ${ }^{160}$ In a letter to SSI Amery, he pointed out that Malaya,

possibly having been immune from the sort of political agitation with which we have become familiar in India during the past fifty years ... are apt to regard even manifestations of political labour alliance as dangerous to the state. ${ }^{161}$

Even the Colonial and the India Office in London entered into a vehement discussion about the merits of the case, the former prevailing once again. Apart from the fact that SSC Moyne could hardly dismiss a governor of 
a colony under the immediate threat of a Japanese attack, he considered Indian claims for an independent investigation of the events exaggerated. ${ }^{162}$ Any impression that the governor had to give in to Indian pressure had to be avoided. ${ }^{163}$ For Thomas, yielding to demands from Delhi, on principle, was tantamount to damaging his authority massively. ${ }^{164}$ Dutt got permission to attend some of the trials, which he found unfair and not up to the standards of the day. A number of so-called ringleaders were sentenced to deportation or detention. ${ }^{165}$

The Colonial Office and the governor refused an independent investigation, but the former asked its labour expert, Major Granville St. John OrdeBrowne, to report on his impressions when visiting Malaya. According to Dutt, he mostly consulted planters. ${ }^{166}$ Orde-Brown found nothing objectionable in Thomas' performance. Dutt he described as

genuinely honest and well-intentioned, though naturally with a decided bias in favour of anything Indian. He is however handicapped by a complete lack of any practical knowledge of labour matters, and he seems disinclined to repair this by visits to employment centres; furthermore, he can speak no Tamil.

Allegedly, Dutt had confessed to feel 'ill-qualified to form an opinion on labour conditions and that he relied largely upon information supplied to him by local compatriots'. Therefore, he provided the GoI with much the same material as the Indian Association, 'most active in their efforts to influence both government and press in India'. Here lay the roots of 'discrepancies occasionally arising between the statements of the GoI and the actual facts'. ${ }^{167}$

Orde-Brown's report made Dutt's position untenable; Linlithgow indicated willingness to drop him, ${ }^{168}$ which would have been a first time in the history of agencies. Dutt forestalled his dismissal. The combination of a difficult climate, unfamiliar food, loneliness and the massive pressure he had come under resulted in a breakdown of his health. After he had asked to be relieved from his post as early as August 1941, he left on 15 November. His health problems were no pretext, as Dutt took full two years to recover, but they also came in handy as his standing was shaken. He was so desperate to leave that he accepted his reversion to Bengal, seemingly ending his career with the central government.

Apart from 1941, Malaya remained but a sideshow for Indian protodiplomacy. Unlike South and East Africa or Ceylon, it never really transformed much into a settlement colony. Instead, the predominantly male labourers went hence and forth according to economic conditions in Malaya and South India. Given the comparatively satisfying wages, the lack of any political participation for all communities and the general willingness of the Malayan authorities to cooperate, there was little to be settled at government 
level. By 1941, Malaya formed a unique case again if only for its geographical position (i.e., proximity to the East Asian war theatre). The government dropped its former genuinely sympathetic attitude towards Indian labourers and resorted to force, triggering a fundamental conflict between agent, GoI and India Office on the one hand and governor and Colonial Office on the other. It would have been interesting to observe how the DEHL responded to such unprecedented constellation. With Dutt's departure and the Japanese occupation of Malaya, nevertheless, the story came to an abrupt end.

\section{Notes}

1 Sugata Bose, A Hundred Horizons. The Indian Ocean in the Age of Global Empire, Cambridge, MA: Harvard University Press, 2009, p. 108. For the history of Indian labour migration see P. Ramasamy, 'Labour Control and Labour Resistance in the Plantations of Colonial Malaya', The Journal of Peasant Studies, 1992, 19(3-4): 87-105.

2 NAI, DEHLO, November 1931, B, 58-70. Annual Report Malaya 1930, [July 1931].

3 Sunil S. Amrith, Crossing the Bay of Bengal. The Furies of Nature and the Fortunes of Migrants, Cambridge, MA: Harvard University Press, 2013, p. 184.

4 Ibid., pp. 162-163.

5 Amarajit Kaur, 'Plantation Systems, Labour Regimes and the State in Malaysia, 1900-2012', Journal of Agrarian Change, 2014, 14(2): 197.

6 For statistics on Indian immigration to Malaya between 1888 and 1935 see Adapa Satyanarayana, " "Birds of Passage": Migration of South Indian Laborers to Southeast Asia', Critical Asian Studies, 2010, 34(1): 98.

7 NAI, DEHLO, January 1924, B, 36-82. Note, Ewbank, 20 August 1923.

8 NAI, DEHLO, November 1925, A, 32-46. Note, Bajpai, 20 June 1925.

9 NAI, DEHLO, August 1931, A, 27-38. Note, DEHL, [March 1930].

10 NAI, DEHLO, November 1925, A, 32-46. Letter, Pillai to DEHL, 4 May 1925.

11 NAI, DEHLO, November 1925, A, 32-46. Letter, Pillai to DEHL, 17 July 1925.

12 NAI, DEHLO, November 1925, A. 32-46, Note, Bajpai, 30 July 1925.

13 NAI, DEHLO, October 1926, B, 95-102 k.w. Annual Report Malaya 1925, Pillai.

14 NAI, DEHLO, March 1926, B, 150-155. Half-yearly Report until December 1925, Pillai, 12 January 1926.

15 NAI, DEHLO, November 1927, A, 9-34. Note, Bajpai, 8 April 1927.

16 Kaur, 'Plantation Systems', 199.

17 NAI, DEHLO, August 1931, A, 27-38. Note, Naidu, 7 February 1930.

18 NAI, DEHLO, November 1927, A, 9-34. Letter, DEHL to Colonial Secretary SS, 13 October 1927.

19 NAI, DEHLO, November 1927, A, 9-34. Note, Ewbank, 17 January 1927.

20 NAI, DEHLO, October 1926, B, 95-102 k.w. Annual Report Malaya 1925, Pillai, undated.

21 BL, IOR, L/E/7/1328, 293. Letter, Bajpai to Colonial Secretary SS, 18 February 1925.

22 NAI, DEHLO, 1937, B, 117, part I. Memorandum, Sastri, 6 February 1937.

23 NAI, DEHLO, December 1926, B, 117-123. Note, Bhore, 16 June 1926.

24 NAI, DEHLO, October 1926, B, 29-33. Half-yearly Report, January to July 1926, Pillai, 10 August 1926. 
25 NAI, DEHLO, November 1927, A, 9-34. Letter, DEHL to Colonial Secretary SS, 28 October 1926.

26 NAI, DEHLO, November 1927, A, 9-34. Note, Bhore, 18 January 1927.

27 NAI, DEHLO, November 1927, A, 9-34. Note, Bajpai, 8 April 1927.

28 NAI, DEHLO, November 1927, A, 9-34. Letter, DEHL to Colonial Secretary SS, 13 October 1927.

29 NAI, DEHLO, August 1931, A, 27-38. Standard Rates of Wages for Indian Labourers, Acting Controller of Labour Malaya H. C. Bathurst, 18 March 1930.

30 NAI, DEHLO, June 1930, A, 1-25. Letter, Gilman to Bajpai, 20 April 1929.

31 NAI, DEHLO, June 1930, A, 1-25. Note, Bajpai, 28 June 1929.

32 NAI, DEHLO, June 1930, A, 1-25. Note, Bajpai, 1 March 1930.

33 NAI, DEHLO, June 1930, A, 1-25. Note, Habibullah, 2 March 1930.

34 NAI, DEHLO, June 1930, A, 1-25. Note, Bajpai, 21 March 1930.

35 NAI, DEHLO, June 1930, A, 1-25. Note, Joyce, 22 March 1930.

36 NAI, DEHLO, June 1930, A, 1-25. Note, Habibullah, 24 March 1930.

37 NAI, DEHLO, June 1930, A, 1-25. Note, Bajpai, 27 March 1930.

38 NAI, DEHLO, October 1930, B, 3-5 k.w. Half-yearly Report, Naidu, 9 August 1939.

39 NAI, DEHLO, August 1931, A, 27-38. Note, Bajpai, 14 August 1930.

40 NAI, DEHLO, August 1931, A, 27-38. Telegram, Naidu, 11 April 1931.

41 NAI, DEHLO, August 1931, A, 27-38. Note, Bajpai, 15 June 1931.

42 NAI, DEHLO, August 1931, A, 27-38. Note, Fazl-i Husain, 15 June 1931.

43 NAI, DEHLO, October 1926, B, 95-102 k.w. Annual Report 1925, Pillai, undated.

44 NAI, DEHLO, October 1925, B, 55-69. Report on the Working of the Labour Department for the Year 1924, Gilman, 3 April 1925.

45 NAI, DEHLO, October 1926, B, 29-33. Half-yearly Report, Pillai, 10 August 1926.

46 NAI, DEHLO, May 1930, B, 12-15. Note, Ram Chandra, 8 May 1930.

47 NAI, DEHLO, June 1924, B, 141-146. Letter, Pillai to EHL Dept., 18 March 1924.

48 NAI, DEHLO, June 1924, B, 141-146. Letter, Pillai to EHL Dept., 31 March 1924.

49 NAI, DEHLO, June 1924, B, 141-146. Note, Bajpai, 2 June 1924.

50 NAI, DEHLO, June 1924, B, 141-146. Note, Bhore, 3 June 1924.

51 NAI, DEHLO, June 1924, B, 141-146. Note, Bhore, 13 June 1924.

52 NAI, DEHLO, August 1924, B, 11-13. Letter, Pillai to EHL Dept., 18 July 1924.

53 NAI, DEHLO, August 1924, B, 11-13. Letter, Bajpai to Pillai, 4 August 1924.

54 NAI, DEHLO, October 1926, B, 29-33. Half-yearly Report, Pillai, 10 August 1926.

55 NAI, DEHLO, 1934, B, 218 k.w. Letter, Mukundan to Hydari, 5 June 1935.

56 NAI, DEHLO, September 1931, B, 169-170. Half-yearly Report, January to July, Nair, 7 August 1931.

57 NAI, DEHLO, 1932, B, 206-2. Memorandum, Ahearne, [1932].

58 NAI, DEHLO, December 1931, B, 104. Letter, Ahearne to Bajpai, 29 June 1931.

59 NAI, DEHLO, 1932, B, 206-2. Memorandum, Ahearne, [1932].

60 NAI, DEHLO, 1932, B, 206-2. Note, Christie, 18 November 1932.

61 NAI, DEHLO, 1932, B, 206-2. Note, Bajpai, 19 November 1932.

62 NAI, DEHLO, 1932, B, 206-2. Note, Bajpai, 15 May 1933.

63 NAI, DEHLO, October 1931, B, 87-88. Letter, Nair to DEHL, 5 September 1931.

64 NAI, DEHLO, 1932, B, 206-2. Letter, Ahearne to Bajpai, 23 June 1933. 
65 NAI, DEHLO, 1934, B, 22-1. Half-yearly Report, January to July 1934, Mukundan, 13 August 1934.

66 NAI, DEHLO, 1932, B, 206-2. Letter, Bajpai to Ahearne, 24 July 1933.

67 NAI, DEHLO, 1932, B, 206-2. Note, Bajpai, 15 November 1933.

68 NAI, DEHLO, 1932, B, 206-2. Note, C.S., 8 March 1934.

69 NAI, DEHLO, 1934, B, 195. Letter, Wilson, 10 May 1934.

70 NAI, DEHLO, 1935, B, 16. Half-yearly Report, August to December 1934, Mukundan, 11 January 1935.

71 NAI, DEHLO, 1934, B, 195. Note, Hydari, 21 January 1935.

72 NAI, DEHLO, 1934, B, 195. Note, C. S., 23 January 1935.

73 NAI, DEHLO, 1934, B, 195. Note, Bajpai, 25 January 1935.

74 NAI, DEHLO, 1934, B, 195. Note, C.S., 13 March 1935.

75 NAI, DEHLO, 1934, B, 195. Letter, Bajpai to Ahearne, 17 April 1935.

76 NAI, DEHLO, 1935, B, 16-1. Note, Menon, 5 September 1935.

77 NAI, DEHLO, 1937, B, 117, part I. Note, Bajpai, 17 October 1936.

78 NAI, DEHLO, 1937, B, 117, part I. Memorandum, Sastri, 6 February 1937.

79 NAI, DEHLO, 1937, B, 117, part I. Press Note, Director of Public Information, 2 March 1937.

80 NAI, DEHLO, 1937, B, 117, part I. Report on the Conditions of Indian Labour in Malaya, Sastri, 6 February 1937.

81 NAI, DEHLO, 1937, B, 117, part I. Letter, Bozman to Sastri, 2 April 1937.

82 NAI, DEHLO, 1936, B, 75. Letter, Mukundan to Menon, 8 February 1936.

83 NAI, DEHLO, 1936, B, 75. Note, Mukundan, 3 March 1936.

84 NAI, DEHLO, 1937, B, 117, part I. Memorandum, Sastri, 6 February 1937.

85 NAI, DEHLO, 1937, B, 117-3. Note Regarding the Representation of Indians on Public Bodies in Malaya and Their Appointment in Public Services, spring 1937.

86 NAI, DEHLO, 1937, B, 117-3. Note, Interview Zafrullah Khan with OrmsbyGore, 19 April 1937.

87 NAI, DEHLO, 1937, B, 117, part I. Note, Bajpai, 19 February 1938.

88 Ibid.

89 NAI, DEHLO, September 1925, B, 4-6. Letter, Andrews to Narasimha Sarma, 11 July 1924.

90 NAI, DEHLO, May 1926, B, 89. Letter, Maxwell to Pillai, 6 May 1926.

91 NAI, DEHLO, October 1924, B, 92-98. Note, Bajpai, 12 September 1924.

92 NAI, DEHLO, December 1926, B, 66-116. Note, Ewbank, 22 May 1926.

93 NAI, DEHLO, December 1926, B, 66-116. Note, Habibullah, 24 May 1926.

94 NAI, DEHLO, December 1926, B, 66-116. Note, Bajpai, 12 August 1926.

95 NAI, DEHLO, January 1929, B, 122-127. Note, Bajpai, 11 September 1928.

96 NAI, DEHLO, November 1930, B, 67-141. Note, Bajpai, 14 July 1929.

97 NAI, DEHLO, November 1930, B, 67-141. Note, DEHL, 31 March 1930.

98 NAI, DEHLO, November 1930, B, 67-141. Note, Bajpai, 23 July 1930.

99 NAI, DEHLO, November 1930, B, 67-141. Note, DEHL, 25 July 1930.

100 NAI, DEHLO, November 1930, B, 67-141. Note, Bajpai, 4 August 1930.

101 NAI, DEHLO, 1932, B, 206-2. Note, Christie, 18 November 1932.

102 NAI, DEHLO, 1932, B, 206-2. Note, Bajpai, 20 May 1933.

103 NAI, DEHLO, 1932, B, 206-2. Note, C. S., 8 May 1933.

104 NAI, DEHLO, 1932, B, 206-2. Note, Zaman, 13 May 1933.

105 NAI, DEHLO, 1932, B, 206-2. Note, Zaman, 7 August 1933.

106 NAI, DEHLO, 1932, B, 206-2. Note, C. S., 21 August 1933.

107 NAI, DEHLO, 1932, B, 257-2. Annual Report, 1931, Nair, 31 May 1932.

108 NAI, DEHLO, 1932, B, 257-2. Letter, Ahearne to Bajpai, 30 December 1932. 
109 NAI, DEHLO, 1932, B, 257-2. Note, Bajpai, 20 November 1932.

110 NAI, DEHLO, 1932, B, 257-2. Letter, Nair to Bajpai, 12 December 1932.

111 NAI, DEHLO, 1933, B, 104. Letter, Nair to Bajpai, 24 March 1933.

112 NAI, DEHLO, 1933, B, 104. Note, Bajpai, 23 June 1933.

113 NAI, DEHLO, 1933, B, 104. Note, Fazl-i Husain, 14 July 1933.

114 NAI, DEHLO, 1933, B, 104. Note, A. M., 8 August 1933.

115 NAI, DEHLO, 1933, B, 104. Note, Bajpai, 11 August 1933.

116 NAI, DEHLO, 1933, B, 104. Note, Fazl-i Husain, 11 August 1933.

117 NAI, DEHLO, 1936, B, 9. Note, Bajpai, 6 May 1936.

118 NAI, DEHLO, 1936, B, 9. Note, Jagdish Prasad, 3 March 1936.

119 NAI, DEHLO, 1937, B, 117, part I. Additional Report on the Conditions of Indian Labour in Malaya, Sastri, 6 February 1937.

120 BL, MSS.Eur, F180/85. Evidence Cadambi Sheshachar Venkatachar, 25 April 1977.

121 BL, IOR, R/1/4/1312. Note, Ogilvie, 8 May 1924.

122 NAI, DEHLO, December 1926, B, 66-116. Note, Bajpai, 12 August 1926.

123 BL, IOR, R/1/4/1312. Notification No. 2-E/D, Political Secretary C. C. Watson, 2 November 1927.

124 NAI, F\&P, Establishment, 60(2)-E. Letter, Bajpai to Denys Bray, 4 March 1929.

125 NAI, DEHLO, November 1930, B, 67-141. Telegram, Naidu, 19 July 1930.

126 NAI, F\&P, Establishment, 60(2)-E. Note, FPD, 4 June 1932.

127 NAI, F\&P, Establishment, 60(2)-E. Letter, Metcalfe to Political Secretary, 6 June 1932.

128 NAI, F\&P, Establishment, 60(2)-E. Note, Glancey, 7 June 1932.

129 NAI, DEHLO, 1933, B, 187-2. Letter, CS UP J.M. Clay to Bajpai, 30 August 1933.

130 UPSA, Appointment, 389/1937. List of Officers Suitable for Service with the Central Government, December 1940.

131 BL, IOR, V/24/1185. Annual Report 1937, Venkatachar, 13 July 1938.

132 BL, IOR, V/24/1185. Annual Report 1938, Venkatachar, 2 June 1939.

133 BL, MSS.Eur, F180/85. Evidence Cadambi Sheshachar Venkatachar, 25 April 1977.

134 Yezdezard Dinshaw Gundevia, In the Districts of the Raj, Hyderabad: Sangam Books, 1992, pp. 55-56.

135 BL, IOR, L/PJ/8/264. Letter, Dutt, 20 August 1941.

136 Kaur, 'Plantation Systems', 200.

137 BL, IOR, L/PJ/8/264. Telegram 70, Thomas to SSC Moyne, 26 June 1941.

138 NAI, DEHLO, January 1924, B, 19-22. Letter, Pillai to DEHL, 4 December 1923.

139 For example, NAI, DEHLO, September 1930, B, 108-111. Letter, Naidu to Ram Chandra, 2 September 1930.

140 NAI, DEHLO, 1934, B, 213. Letter, Mukundan, 22. June 1934.

141 Subimal Dutt, Autobiography, unpublished, 1984, pp. 71-72.

142 NAI, DEHLO, June 1925, B, 45. Letter, Andrews to Bajpai, 29 April 1925.

143 NAI, DEHLO, June 1925, B, 45. Letter, Bajpai to Andrews, 22 May 1925.

144 NAI, DEHLO, September 1925, B, 4-6. Letter, Andrews to Bajpai, 14 January 1925.

145 NAI, DEHLO, September 1925, B, 4-6. Note, Bajpai, 17 April 1925.

146 For a more detailed account see Amit Das Gupta, Serving India. A Political Biography of Subimal Dutt (1903-1992), India's Longest Serving Foreign Secretary, New Delhi: Manohar, 2017, pp. 67-84.

147 UPSA, Appointment, 389/1937. Note for CS C. W. Gwynne, 24 August 1937.

148 Das Gupta, Serving India, p. 38. 
149 Ibid., p. 26.

150 Dutt Diary 4, 20 July 1941.

151 BL, IOR, L/PJ/8/264. Letter, Dutt to GoI, 20 August 1941.

152 Kaur, 'Plantation Systems', 193.

153 Ramasamy, 'Labour Control and Labour Resistance in the Plantations of Colonial Malaya', 103-104.

154 BL, IOR, V/24/1185. Annual Report 1940, Dutt, 24 July 1941.

155 BL, IOR, L/PJ/8/264. Letter, General Officer Commanding, Fort Canning, Singapore, Lieutenant-General A.E. Percival to Commander-in-Chief, Army Headquarters, India, 2 July 1941.

156 BL, IOR, L/PJ/8/264. Letter, Thomas to Moyne, 12 May 1941.

157 BL, IOR, L/PJ/8/264. Letter, Dutt to GoI, 20 August 1941.

158 BL, IOR, L/PJ/8/264. Letter, DEHL to Political Dept., 10 October 1941.

159 For a different reading of the strikes see Harold Edmund Wilson, The Klang Strikes of 1941. Labour and Capital in Colonial Malaya, Singapore: Institute of Southeast Asian Studies, 1981.

$160 \mathrm{BL}, \mathrm{IOR}, \mathrm{L} / \mathrm{PJ} / 8 / 264$. Telegram 27556, Linlithgow to SSI Amery, 2 November 1941.

161 BL, IOR, L/PJ/8/264. Telegram 1775-S, Linlithgow to Amery, 26 July 1941.

162 BL, IOR, L/PJ/8/264. Telegram 3545, DEHL to Amery, 14 July 1941.

$163 \mathrm{BL}, \mathrm{IOR}, \mathrm{L} / \mathrm{PJ} / 8 / 264$. Note on a Conversation between Moyne and Amery, India Office, undated.

164 BL, IOR, L/PJ/8/264. Letter, Thomas to Moyne, 28 August 1941.

165 BL, IOR, L/PJ/8/264. Letter, DEHL to Political Dept., 10 October 1941.

166 BL, IOR, L/PJ/8/264. Telegram 2608, Linlithgow to Amery, 12 October 1941.

167 BL, IOR, L/PJ/8/264. Letter, Orde-Brown to Moyne, 30 October 1941.

168 BL, IOR, L/PJ/8/264. Telegram 27556, Linlithgow to Amery, 2 November 1941. 


\section{FIJI, BRITISH GUIANA, AUSTRALIA AND NORTH AMERICA}

Fiji

As relevant as the cases where British India established agencies were those where it did not, notwithstanding large Indian communities. The colonial power was never more aware of the value of taxes paid by Indian subjects than when those might have been spent to the benefit of those taxpayers, though not necessarily to the benefit of the Empire as a whole. Before the Great War, the conditions of Indians in Fiji had come into the focus, ${ }^{1}$ wherefore several deputations were sent there before the DEHL was created. It appeared only logical to establish another agency, but the interest rapidly decreased.

Fiji had become a British colony in 1874, and the immigration of mostly indentured labourers from India began five years later. In the early 1920s, among a total population of around 157,000, Indians formed more than 38 per cent against but 3,900 Europeans. By 1932, the Indian share had increased beyond 42 per cent. Unlike in other parts of the Empire, more than half of them originated from the United Provinces, South Indians providing but a little more than a quarter. By 1932, 27,000 of the Indians were born on the islands. Around 10,000 of them were employed with the key player in Fiji, the Colonial Sugar Refining Company, which fixed wages for the colony as a whole. In 1923, Bajpai found the standard of living among the lower middle classes better than in India, but among the great mass of labourers and small cultivators it was 'surprisingly low'.

Due to multiple complaints, in 1913 the GoI had sent a deputation to investigate conditions. Its report was not unfavourable ${ }^{3}$ but highlighted suicide rate, sex ratio, unsatisfactory methods of recruitment and the high percentage of prosecution and conviction. ${ }^{4}$ Together with a report by C.F. Andrews on indentured labour, ${ }^{5}$ it aroused feelings in India and led to the total abolition of indentured labour and a stop of emigration to Fiji. As the colony needed still more labourers, in 1919 it submitted a scheme for colonisation. As it guaranteed Indian immigrants a position equal to all other British subjects, Delhi promised to send a committee. 
Events took a distinctive turn in 1920 and 1921. A first strike of Indians was the outcome of rise of cost of living vis-à-vis stagnant wages. Given the changed political atmosphere in British India, Fiji Indians also hoped for an enhancement of their status. Governor Cecil Hunter-Rodwell, however, found it beneath him to discuss with the strikers, seeing a racial outbreak. He called in troops, shooting one protestor dead and wounding several others. Their alleged ringleader was deported. In response, more than 11,000 Indians registered for repatriation. ${ }^{6}$ The second strike in 1921 went much longer and 'shut down Fiji's sugar industries for most of a growing season' ${ }^{7}$ It was again on the issues of wages and prices, and its leader was deported as well. A supporter of Gandhi, Bashishth Muni had promoted an Indian identity and claimed equal wages for equal work. The government's response 'remained consistent with the principle of indenture days, denial of legitimacy to all Indian political spokesmen'. ${ }^{8}$

This was the atmosphere when the Indian deputation arrived in late January 1922. While in Fiji, due to a fall of the price of sugar the Colonial Sugar Refining Company even reduced wages. As Sastri or Kunzru were not available, B. Venkatapati Raju, a South Indian member of the Legislative Assembly, Govind Sahai Sharma from the UP Legislative Council together with G. L. Corbett, ICS, investigated conditions until 3 April 1922. ${ }^{9}$ The publication of their report was delayed sine die: The members of the deputation, the GoI, Fiji authorities, and the Colonial Office never found a compromise. The report recommended free repatriation, minimum wages, provisions for work for unemployed Indians, and land settlement. As the major grievances it named inadequate wages, indebtedness, heavy taxation, unequal treatment, insufficient arrangements for repatriation and land settlement, a judicial system partial to employers, insufficient education and medical relief. ${ }^{10}$ Corbett, 'the leading spirit of the deputation' and main author of the report, ${ }^{11}$ informed Ewbank that Raju and Sharma had focused on recent problems rather than on prospects for further emigration, what 'probably reflected Indian opinion' and was among the terms of reference 'to ascertain the causes of discontent'. The officer had played along to win his colleagues' consent to his recommendations on the future of Indians in Fiji. It had been necessary to produce a joint report to fight 'the wild stories of second "Amritsars", , a reference to the massacre at Jallianwala Bagh from 13 April 1919, when the military had shot hundreds of unarmed civilians. Apart from a few indiscrete utterances, the politicians had advised local Indians well.

It was impossible to spare the Fiji government from criticism for its attitude, though Corbett understood that this was mostly of SSC Churchill's making, who had 'at no time played straight with us, either in Fiji or in other matters'. Fiji made a revision of wages and a reform of the plantation system dependent on the resumption of immigration, but it could not tell how long it would take to establish a new system or whether the gap 
might be covered by Fiji Indians. Corbett wanted to ignore the complaints of the Colonial Sugar Refinery Company as its disappearance would suit Indian interests best. Notwithstanding the Colonial Office vetoing the publication of the report, the deputation had been a success. At its arrival, the Fiji government 'were expecting that the cut in wages threatened by the Colonial Sugar Refining Company would lead to widespread disorders, and that there would be a renewed demand for wholesale repatriation. Neither happened'. ${ }^{12}$

Secretary J. Hullah insisted on the publication of the report, warning that otherwise 'Fiji may become another Kenya'. ${ }^{13}$ The imposition of a heavy poll tax seemed to prove him right. Butler too gave for consideration that if the report was not published, 'it will be known that the Secretary of State has overruled us again'. ${ }^{14}$ Once it was decided to submit the report to a Crown Colonies Committee, appointed in 1923, the matter was settled for the time being. ${ }^{15}$

The committee recommended the establishment of an agency. Furthermore, by nomination or election on a communal basis, Indians were to be given three seats in the Legislative Council instead of two. ${ }^{16}$ The Colonial Office, however, opposed the recommendations: The third seat was not justified as there were 52,000 among the 60,000 Indians with the right for free repatriation. Instead of permitting an agency, Fiji should appoint an OSD. Again, the publication of the report of the Indian deputation was vetoed. ${ }^{17}$ Bajpai was not convinced by those arguments but gave for consideration that the decision of the Fiji government to stop recruitment from India had fundamentally changed the situation. Furthermore, he urged to drop the claim for a common electoral roll; instead, Indians should be allowed as many representatives in the Legislative Council as Europeans. Finally, the controversial report could not further be suppressed unless the Colonial Office gave a more satisfactory response. ${ }^{18}$

With the end of migration, the GoI had lost its leverage, ${ }^{19}$ but there was no more need to exercise pressure anyway. The labourers' economic situation improved and many Indians were exempted from the poll tax. Unlike Europeans and Fijians, they were also exempted from the education cess, which resulted in but 23 per cent of Indian children attending schools compared to 80 per cent Fijians. ${ }^{20}$ The Colonial Office went on vetoing the establishment of an agency, but J. R. Pearson, ICS, an officer with extensive experience in India and UP, was appointed secretary for Indian affairs. He emphasised on the need for the recognition of Indian rights, holding that Indians constituted a relevant part of Fiji's population. Though his efforts went in vain, he questioned 'whether the view that the Indians should be kept as menial labour "can be reconciled with the basic standards of our civilisation" '. ${ }^{21}$

In 1929, the number of Indians in the Legislative Council was raised to three. Only together with the three Fijian members, they matched the six Europeans, the Legislative Council completed with another 13 nominated 
members. In November, one of the Indians moved a resolution, though in vain, that his community was not represented properly. Thereafter, all Indians resigned, their seats remaining vacant. Official Fiji and Europeans from then on saw the Indian demand for equal rights as part of a worldwide assault on the Empire, closely connected with Gandhian campaigns in India. Pearson's call for moderation, holding that Indian nationalism could not be stigmatised as extremism, went unheard. Though all suspicions against a conspiracy to overthrow European rule proved groundless, Indian clerks were forced to resign from all political associations. In September 1930, an Intelligence Committee was established to spy on Indian activities. ${ }^{22}$

When Andrews visited Fiji once again in 1936, he found conditions much improved, many Indians having become peasant proprietors and tenant farmers. Agitation for a common roll had failed, but in the same year, the Colonial Office decided to reshape the Legislative Council, giving Europeans, Fijians and Indians five seats each. Linlithgow found the new setting satisfactory too. ${ }^{23}$ Thereafter, with no major economic or political grievances, Fiji went out of the focus of the DEHL.

\section{British Guiana}

British Guiana was another part of the Empire where the economy had been based on slave labour. Its main crop was sugar. With the abolition of slavery, indentured labour was meant to take over. Between 1838 and 1917, around 240,000 North Indians were shipped to north-east South America. About two-thirds of them made British Guiana their permanent home. As elsewhere, they were treated not much better than slaves and were termed 'coolies'; they frequently rioted against suppression. Most of them remained illiterate villagers, but the more enterprising started rice plantations and soon formed a small property-owning class. By 1945, the Indian community comprising 163,343 members was the largest in a total population of 375,701 . As in Fiji, there was one big company which held a de facto monopoly: the Booker Brothers, McConnell and Company Limited. ${ }^{24}$

As this was a particularly isolated part of the Empire, local Indians were literally cut off from South Asia. With the Great War and the ban on the emigration of indentured labour, the colony suffered from severe labour shortage. In 1919, the planters and the government provided a colonisation scheme to induce renewed immigration. Over a period of three years, 15,000 families were meant to be provided free passage and offered lease and later purchase of land for the lowest local rate. If they cultivated half of it within seven years, it became their absolute ownership. They would then be free to stay or to sell with the right for free passage back to India. Per holding, the colonial government was supposed to invest about Rs 450 . Alternatively, new arrivals could accept employment on sugar estates for a daily minimum rate of around Rs 3 for men and half of that for women. 
Cost of living was calculated to be below 40 per cent of the wages, and housing was provided for free. ${ }^{25}$ In February 1920, this proposal was accepted by the Select Committee of the Imperial Indian Legislative Council, though under certain conditions. A representative of the GoI should supervise the settlers and, following Gandhi's advice, an independent report was to be prepared by an officer appointed by the GoI, a member of the Indian legislative and C.F. Andrews. Free repatriation was to be granted whenever the officer requested. Furthermore, the colonial government was to guarantee ongoing equality of all rights as was prevalent in British Guiana. Finally, a deputation should investigate conditions on the ground. ${ }^{26}$

Due to debates around Indians in Kenya, nothing happened for two years. In February and March 1922, Kesava Pillai, deputy president of the Madras Legislative Council, V.N. Tewary from the Servants of India Society and Gerald F. Keating, a retired ICS officer, visited British Guiana. They complained that the scheme was misleading as the government supported sugar planters rather than colonisation. Wages were low, sanitary conditions bad and the general situation of local Indians unsatisfactory. Though the deputation approved the original scheme, it insisted on reforms in British Guiana. The report was not published for the time being, but the deputation let their views known to the press. From 1923, the sugar price was rising. On 21 January 1924, Joseph Nunan and J. A. Luckhoo arrived in South Asia to confirm that the scheme from 1919 was still valid. They held that Pillai and Tewary had been in South America at a moment when post-war depression and a bad season had hit hard. Furthermore, 'everybody with a grievance in the colony evidently had a field-day and there was no serious attempt to refute unfounded charges'. While Nunan and Luckhoo faced massive public protests, the GoI and the Special Committee considered their proposals favourably. They were asked, however, for guarantees for the establishment of voters' lists, free return passages for former indentured labourers and a preservation of the currently free status of Indians. These provisions in the eyes of Nunan were no obstacles at all. Their case was fully supported by a deputation from the British Guiana East Indian Association, Gandhi assuring its delegates that he would not further oppose the scheme. ${ }^{27}$

With the deputation still in India, things took a fundamental turn. On 1 April, dock labourers in Georgetown went on strike. As they allegedly were accompanied by 'loafers and disorderly elements', blocking traffic and terrorising private employees, ${ }^{28}$ the police opened fire, killing 12 and wounding 21. Among the 11 Indians killed were two women. Governor Wilfred Collet, wondering whether the colonisation scheme would invite interference from political agitators and become a continual source of unrest and anger, acknowledged that the riots complicated matters even further. ${ }^{29}$ Bajpai did not find convincing a report claiming that the police had acted in self-defence. He agreed 'as to the conduct of certain so-called Indian leaders' but also knew 'something of the psychology of an Indian crowd. More 
formidable mobs than the one made up of temperamentally timid labourers have been pacified by the exercise of firmness and courage tempered by a display of sympathy'. A request for further investigation, however, would lead nowhere and be understood as interference in domestic affairs. ${ }^{30}$ Bhore, nevertheless, found a delegation as necessary as ever to safeguard Indian interests, ${ }^{31}$ a point of view shared by the SEC. ${ }^{32}$ As no ICS officer from the UP cadre was available, Maharaj Singh was selected, commanding experience from a deputation to Mauritius the year before.

His observations from late 1925 provided hardly any new insights, though he approved of new sanitary measures and efforts to provide better housing. The equality of all British citizens had already been guaranteed by a declaratory ordinance in 1923. Singh urged to establish an agency and wage boards. The part of the scheme aiming at the immigration of plantation labour, he turned down, instead focusing on settlement. ${ }^{33}$ Singh's suggestions were adopted by the GoI and the modified scheme passed both chambers of the Indian legislation. In a notification, the DEHL listed some preconditions like the establishment of a settlement commission, periodical reports and free repatriation for all destitute Indians. Otherwise, it accepted the Nunan-Lukhoo scheme. ${ }^{34}$

When everything appeared settled for a resumption of emigration, Governor Cecil Hunter-Rodwell changed his mind, toying with the idea of getting Indians from South Africa instead from India. Ewbank found it 'inconceivable that we should agree to allow the colonization scheme which we have arranged with so much difficulty to be prejudiced by Indian emigration from Natal on less favourable terms' ${ }^{35}$ A further delay was caused by a findings committee, asked to report on the cost of bringing 500 Indian families to British Guiana. ${ }^{36}$ In April 1927, the colonisation scheme was finally buried by the British Guiana Commission. ${ }^{37}$ Bajpai had expected nothing better 'by anyone familiar with the outlook and administrative past of the present governor': Hunter-Rodwell had started his career in South Africa and openly displayed his anti-Indian attitude as governor in Fiji. He felt no need to "shed any tears over the closure of this somewhat dubious El Dorado to our "surplus population". The relief to our "redundant" millions would have been insignificant', controversies about possible financial share by the GoI numerous. The commission was right to characterise the scheme as a 'speculative and one-sided bargain'. ${ }^{38}$

Governor Edward Brandis Denham tried to revive the issue in $1931,{ }^{39}$ but the GoI refused to play a role, as any schemes fully depended on willingness and financial support of the colony. ${ }^{40}$ Bajpai shrewdly linked Denham's soundings with the upcoming second Round Table Conference with South Africa, which considered new destinations for parts of its Indian population. For the time being, any discussion had to be avoided. ${ }^{41}$ On Christmas Day 1934, Viceroy Willingdon finally ruled out any such scheme due to financial stringency. ${ }^{42}$ 


\section{Australia, Canada and the US}

According to the census from 1921, there lived but 2,881 Indians in Australia, mostly Punjabi Muslims engaged in retail trade and agriculture. Their disabilities after the Great War were few: They were not entitled to the same old-age pensions and did not enjoy franchise. At the Imperial Conference from 1921, Australian delegates had promised to remove those disabilities, and when Sastri and Bajpai visited the country in 1922, they were received with sympathy. In 1925, an amendment gave Indians full franchise at the federal level, but the states of Queensland and West Australia denied state franchise. It took until December 1930 for Queensland to change course. West Australia indicated willingness to follow suit only by late $1934 .^{43}$

Apart from Sastri's dominion tour, those issues were discussed in informal talks at Imperial Conferences. Typically, when at one of those conferences in 1925 T.B. Sapru suggested a joint commission to investigate disabilities, Prime Minister Stanley Bruce assured him that this was not necessary. Bajpai, who had met Bruce in 1922, had full confidence in him and therefore advised to allow him time to implement changes. ${ }^{44}$ Such confidence paid off later that year, and Bruce's successor James Scullin proved to be equally trustworthy, convincing the premier of Queensland to give Indians full state franchise. ${ }^{45}$

The situation in Canada was not much different. About 1,100 Indians, mostly Sikhs, had arrived before the Canadian Immigration Act of 1910 banned further migration from South Asia. Temporary entry for business, study and travel was, nevertheless, permitted. ${ }^{46}$ Among the nine provinces, however, British Columbia denied provincial and federal franchise to Asiatics. This was aimed at Chinese and especially Japanese, who were considered economic rivals, though the Indians were also placed in this group. Prime Minister William Lyon Mackenzie King in August 1922, on the one hand, promised Sastri to set the matter straight at the earliest favourable moment. On the other hand, he gave for consideration that such a step was prone to unite all conservative forces in the country against the government, and it was against the tradition of his Liberal Party to act against provincial governments in matters of franchise. Sastri, given his talks with former conservative Prime Minister Arthur Meighen in 1921, contradicted those arguments as hollow. Though the franchise issue was discussed at various occasions throughout the 1920s, nothing changed ${ }^{47}$ At the Imperial Conference affecting Indians in South Africa, Canada and Australia in late 1930, Bajpai took up the question with Prime Minister Richard Bedfort Bennett, who struck him 'as being more direct and forceful' than Mackenzie King. Bennett promised to investigate the matter immediately; he was also willing to accept an Indian delegation. ${ }^{48}$ It took until 1947, however, for Indians to be given full franchise in the province. From 1923, the GoI mused whether to exchange agents with Canada but never entered bilateral talks, other issues more pressing at imperial conferences. ${ }^{49}$ 
There were about 2,000 Indians living in the US, mostly in California. The country belonged to the field of responsibility of the FPD, but the DEHL was kept informed and occasionally asked for suggestions. The situation of local Indians dramatically worsened with Supreme Court rulings in 1923 declaring them ineligible for US citizenship, which meant that they could not own land or property. In a letter to SSI Peel, Viceroy Reading emphasised his impression 'that not only the British Commonwealth but the white races generally are combined against India'. ${ }^{50}$ The second blow was the Immigration Act of 1924, alternatively termed the Johnson-Reed or even more aptly the Asian Exclusion Act. In a first assessment, Bajpai feared that 'Indians might find themselves precluded even from working as wage earners'. Anti-Asiatic feelings ran high at the Pacific Coast, and Washington, ignoring even the privileges of a country as powerful as Japan, would not care about Indians. Perhaps later, resident Indians might get a better deal for their small numbers. ${ }^{51}$ British Indian Foreign Secretary Denys Bray pointed out that Indian professionals including merchants would no more be admitted. India had no treaty rights, and even if the UK took up its case, nothing better than a scathing rebuff was to be expected. Unlike Bajpai, he harboured vague hopes that Japan, with many more nationals in the US and treaty rights, might care for an amendment of the act, enabling India 'to slip along'. Since Bray was at a loss about what to do, he consulted the DEHL ${ }^{52}$ but without much result. Bajpai hoped to find a solution for temporary visits of businessmen via reciprocity. ${ }^{53}$ Nevertheless, it turned out that Americans without enjoying any special treaty rights in India were treated like European British subjects. ${ }^{54}$

Japan acquiesced to the abrogation of its rights; Bajpai commented that India could not hope to achieve a better deal. Furthermore, he warned against threats, referring to his experiences in the US from 1922:

I know something about American psychology and venture to submit that any threat of withdrawal of privileges enjoyed by American citizens in this country will only harden the Congress and Senate in their resolve to enforce the restrictions prescribed under the Johnson Act with even greater vigour than might otherwise be the case. ${ }^{55}$

British representations with the US led nowhere. It was not before the 1940s that Bajpai as India's agent-general in Washington returned to the issue.

\section{Notes}

1 K.L. Gillion, The Fiji Indians. Challenge to European Dominance, Canberra: Australian National University Press, 1977, pp. 8-9.

2 NAI, DEHLO, November 1923, B, 168. Summary of the Indian Position in Fiji, Bajpai [autumn 1923]. 
3 Gillion, The Fiji Indians, p. 9.

4 Report of the Government on the Conditions of Indian Immigrants in Four British Colonies and Surinam, Command Paper 7744-5, Simla: Government Printer, 1914.

5 Charles F. Andrews and W. W. Pearson, Indentured Labour in Fiji. An Independent Enquiry, 16 February 1916, Calcutta: Star Printing Works, 1916.

6 Gillion, The Fiji Indians, p. 35.

7 John Dunham Kelly, A Politics of Virtue: Hinduism, Sexuality, and Countercolonial Discourse in Fiji, Chicago: University of Chicago Press, 1991, p. 91.

8 Ibid., p. 92.

9 Gillion, The Fiji Indians, pp. 78-83.

10 NAI, DEHLO, November 1923, B, 168. Summary of the Indian position in Fiji, Bajpai [autumn 1923].

11 NAI, DEHLO, May 1924, A, 1-16. Note, A.K. Sarkar, 9 November 1922.

12 NAI, DEHLO, May 1924, A, 1-16. Letter, Corbett to Ewbank, 12 February 1923.

13 NAI, DEHLO, May 1924, A, 1-16. Note, Hullah, 28 March 1923.

14 NAI, DEHLO, May 1924, A, 1-16. Note, Butler, 2 September 1923.

15 NAI, DEHLO, May 1924, A, 1-16. Order in Council, Reading, 17 December 1923.

16 NAI, DEHLO, August 1925, B, 1-4. Note, S.B.H., 15 December 1924.

17 NAI, DEHLO, August 1925, B, 1-4. Letter, Colonial Office, 20 March 1925.

18 NAI, DEHLO, August 1925, B, 1-4. Note, Bajpai, 23 April 1925.

19 Kelly, A Politics of Virtue, p. 142.

20 NAI, DEHLO, 1934, 169. Memorandum on Certain Important Questions Relating to Indians in Fiji, June 1934.

21 Kelly, A Politics of Virtue, p. 151.

22 Ibid., pp. 153-165.

23 Gillion, The Fiji Indians, pp. 153-356.

24 Stephen G. Rabe, U.S. Intervention in British Guiana. A Cold War Story, Chapel Hill: University of North Carolina Press, 2005, pp. 16-21.

25 NAI, DEHLO, September 1925, A, 156-185. Memorandum British Guiana and the Empire, 14 April 1919.

26 NAI, DEHLO, September 1925, A, 156-185. Proposals of 10th February 1920 conditionally accepted by the Select Committee of the Imperial Indian Legislative Council.

27 NAI, DEHLO, September 1925, A, 156-185. Preliminary Report, Nunan, 20 November 1924.

28 NAI, DEHLO, August 1924, 1. Telegram, Collet to SSC, 3 April 1924.

29 NAI, DEHLO, August 1924, 1. Telegram, Collet to SSC, 7 April 1924.

30 NAI, DEHLO, September 1925, A, 156-185. Note, Bajpai, 8 October 1924.

31 NAI, DEHLO, September 1925, A, 156-185. Note, Bhore, 9 October 1924.

32 NAI, DEHLO, September 1925, A, 156-185. Minutes of a Meeting on 21 February 1925.

33 NAI, DEHLO, May 1926, A, 13-47. Report, Singh, 18 December 1925.

34 NAI, DEHLO, May 1926, A, 13-47. Notification no. 240, DEHL, 23 March 1926.

35 NAI, DEHLO, March 1927, 46-48. Note, Ewbank, 20 December 1926.

36 NAI, DEHLO, March 1927, 46-48. Letter, G. Grindle, Colonial Office, to USSC Economic and Overseas Dept., India House, 8 February 1927.

37 NAI, DEHLO, July 1927, B, 18-22. Report, April 1927.

38 NAI, DEHLO, July 1927, B, 18-22. Note, Bajpai, 15 June 1927.

39 NAI, DEHLO, December 1931, B, 26. Letter, Denham to Andrews, 9 June 1931. 
40 NAI, DEHLO, December 1931, B, 26. Note, Ram Chandra, 16 November 1931.

41 NAI, DEHLO, December 1931, B, 26. Note, Bajpai, 29 November 1931.

42 NAI, DEHLO, 1932, B, 228(2). Letter, Willingdon to Duncan, 25 December 1934.

43 NAI, DEHLO, 1934, B, 169-112. Brief on Australia, 5 October 1934.

44 NAI, DEHLO, 1934, B, 139-141. Note, Bajpai, 21 January 1925.

45 NAI, DEHLO, 1925, September, B, 28-29. Minutes on a Meeting of the SEC, 19 August 1925.

46 NAI, DEHLO, 1937, B, 75-66. Letter, Hydari to N. N. Sircar, 12 August 1937.

47 NAI, DEHLO, 1931, June, B, 121-134. Memorandum on Certain Questions Relating to Indians Overseas, [1930].

48 NAI, DEHLO, 1931, June, B, 121-134. Letter, Bajpai to HM, 5 December 1930.

49 NAI, DEHLO, 1931, June, B, 121-134. Memorandum on Certain Questions Relating to Indians Overseas, Appendix II, [1930].

50 NAI, DEHLO, 1923, B, 1-9. Letter, Reading to Peel, 6 September 1923.

51 NAI, DEHLO, 1925, May, B, 24-27. Note, Bajpai, 1 May 1924.

52 NAI, DEHLO, 1924, B, 185. Note, Bray, 1 May 1924.

53 NAI, DEHLO, 1924, B, 185. Note, Bajpai, 8 May 1924.

54 NAI, DEHLO, 1925, May, B, 24-27. Note, Sen, 12 May 1924.

55 NAI, DEHLO, 1924, B, 185. Note, Bajpai, 12 June 1924. 


\section{9 \\ SECOND WORLD WAR}

The Second World War formed a watershed in South Asian history. Among others, the Lahore Resolution from 23 March 1940 turned out to be a major step towards the partition of British India in 1947. Furthermore, the Quit India Movement made it apparent to the colonial power that unlike during the Great War, it would not be able to count on the unconditional cooperation of the colonised any more when threatened by an external enemy. ${ }^{1} \mathrm{On}$ the contrary, S.C. Bose with his Indian National Army sided with the foe's foe. Whatever the immediate effects, both combined sped up the British departure from the subcontinent.

The war also went along with great changes in the careers of the protagonists. Subimal Dutt's story is the shortest among the three. After his term in Malaya had been overshadowed by British war hysteria and the threat of a Japanese invasion, he returned to his home province. While suffering from severe health problems for two years, he was given less relevant tasks. From 1944 , however, as secretary for agriculture, in the immediate aftermath of the Bengal Famine, he held an important post in that part of the subcontinent. This promotion meant an enormous gain in prestige, but also cut Dutt loose from the issue of Indians overseas and the capital. Once his mentor Bajpai had left Delhi and the demand for ICS officers in the provinces had grown to hitherto unknown dimensions, Dutt seemed to look forward to a distinguished career in Bengal but hardly to any relevant role in foreign affairs. ${ }^{2}$

\section{G.S. Bajpai}

\section{Fall from grace}

Girja Shankar Bajpai had risen higher than any other Indian ICS officer, but the war brought a humiliating downfall. Given a subordinate role as agent-general in Washington, he even witnessed how K.P.S. Menon, seven years junior in the service, was awarded the rank of ambassador, which was denied to his mentor. Beyond doubt, Bajpai's rise had created enviers and rivals, but it was rather changes in domestic affairs that led to his transfer. 
Right from the start, Bajpai must have considered his new posting a disaster. Over two decades, he had established extensive networks, from which he was now cut off. As he fell from grace with the British and, unlike K.P.S. Menon, had never cared to make friends with the powers to come, he had hardly any future prospects. The Indian politicians he had worked with were those moderates who increasingly lost influence as things came to a head. This dilemma had become apparent when Bajpai conducted talks with various politicians in April 1940, attempting to sound out their plans for India's future. Jinnah he found bursting with self-confidence and a 'sense of exaltation', propagating the two-nation theory and blaming most Congress leaders 'as [a] collection of "crooks"'. The intense dislike for the Muslim League leader, whom Bajpai had never known to 'suffer from diffidence', was mutual. ${ }^{3}$ He further interviewed Congress politician Bhulabhai Desai, ${ }^{4}$ Chimanlal Harilal Setalvad ${ }^{5}$ and Tej Bahadur Sapru, ${ }^{6}$ none commanding much influence or indicating any closeness to Bajpai.

The power to come, Nehru, had an ambivalent attitude regarding civil servants and the ICS in particular. In 1915, a year after Bajpai, he had been ready to sit for the entrance examination until his father for the prospect of being separated from his only son abandoned the plan. ${ }^{7}$ As chairman of the municipal board in Allahabad, he worked smoothly with efficient civil servants, at the same time criticising their general mindset. ${ }^{8}$ After the Congress formed numerous provincial governments from 1937, he tried to develop a friendly atmosphere with the officials in the ministries while making it 'clear to them privately how much he disapproved of the conformism'. In his autobiography from 1938, he criticised ICS officers as 'self-satisfied and self-sufficient, narrow, with fixed minds, static in a changing world and wholly unsuited to a progressive environment'. No new order could be built 'so long as the spirit of the ICS pervades our administration', wherefore 'the ICS and similar services must disappear completely as such' ${ }^{10}$ Bajpai as the very representative of the 'brown Englishmen' could not count on a continuation of his career under Congress rule. Apparently, he never tried to get in touch with Sardar Vallabhbhai Patel, who would become known as the man of the apparatus. ${ }^{11}$

In September 1940, Linlithgow mentioned that Bajpai had suggested an agency in the US to tackle Congress propaganda. If true, the viceroy shrewdly used the proposal to get rid of the member of the DEHL, sanctimoniously adding that he hoped 'not doing him [Bajpai] an injustice in thinking that he may have himself in view as the first incumbent of any such post!' 12 Bajpai could not be spared at the moment, but Linlithgow would keep 'my mind open as regards names, not even excluding that of Bajpai himself' ${ }^{13}$ For a while, the discussion among Delhi, London and the British Ambassador in Washington Philip Lothian focused on status and competences of an agent. Linlithgow wanted all political questions to be dealt through the embassy. The agent would occupy a separate office and be 
proof of a 'further stage in India's coming of age internationally', though the post should have a mostly symbolic value. ${ }^{14}$ This sounded like squaring the circle and described Bajpai's dilemmas for the next five years. Hardly any more realistic was Amery's idea of a good speaker and negotiator needed if Washington pressed hard 'to concede something quite impracticable in India'. ${ }^{15}$ Indeed, nobody could plausibly represent India and at the same time plead for a continuation of colonial rule at that stage any more. Amery and Lothian suggested Bajpai too. ${ }^{16}$ The latter won himself extra time as the viceroy wanted him to complete negotiations with Burma and Ceylon. ${ }^{17}$ In early June 1941, 'with considerable hesitation for family reasons', however, he had to give in, asking for a king's appointment. ${ }^{18}$

There were two more reasons for Bajpai's transfer. By declaring war against the Axis Powers without prior consultation of political parties, Linlithgow had created tensions. The Congress, notwithstanding outspoken sympathies for the struggle against Nazism, refused to fight for the freedom of western democracies as long as the latter denied the same freedom to India. ${ }^{19}$ In order to prevent another non-cooperation campaign, Linlithgow in August 1940 offered an expansion of the Viceroy's Executive Council and the establishment of an Advisory War Council. After the war, Indians would be offered the right to frame a constitution. The political parties, however, responded unfavourably, and in October, Congress launched another civil disobedience campaign. Linlithgow soon dropped the idea of including party representatives and instead invited three non-officials 'of good-will and ability as individuals' to the Executive Council. In order to create the impression that Indian public opinion would be given more weight, officials had to make room. Bajpai was one of them. ${ }^{20}$

In addition, the appointment of Bajpai's successor Madhav Shrihari Aney, a Congress politician of little influence indicated that the issue of Indians overseas was put on the back burner as long as the war went. As the British in South Asia argued that the war did not permit to give in to Congress demands, they had even less interest in fighting for equal rights and fair payment of Indians abroad. This is amply showcased by Dutt's term in Malaya. Therefore, the hitherto indispensable Bajpai became dispensable. Actually, the GoI urgently needed officials of Bajpai's qualities. By transferring him to an irrelevant, faraway post, it lost an extraordinarily able and loyal official.

\section{Struggle for an appropriate status}

In October 1941, Bajpai took up work in Washington with the personal rank of minister, but only the precedence of a counsellor, attached to the British embassy. Therefore, he ranked below all Empire representatives functioning as heads of mission. Caroe ordered Bajpai to follow certain tentative directives: The agent-general was to represent India in public and coordinate its 'part in all matters affecting the common interests of both 
countries', but 'normally not deal with the United States Government in regard to political matters'. His correspondence with the GoI was to go through the External Affairs Department (EAD), the successor of the FPD. ${ }^{21}$ Bajpai had been degraded to a subaltern of the department which he implicitly had rivalled for two decades. To make things even worse, his colleague in China, Muhammad Zafrullah Khan, received his instructions from the viceroy personally and was told to address the Chinese Foreign Office directly, ${ }^{22}$ a privilege explicitly denied to Bajpai.

According to his instructions, the agent-general was to exercise 'general political and diplomatic control over all GoI officials and official missions accredited to the USA' without interfering in the details of their work. The two other representatives of British India in the US, however, refused to accept him as their superior. The problems with the Indian Supply Commission, headed by Hardit Singh Malik, ICS, and the Indian Trade Commissioner in New York, K. C. Mahindra, began to surface in 1943, the latter 'actively exerting himself to avoid reasonable coordination'. ${ }^{23}$ In February 1944, Bajpai gave for consideration that the State Department had formally approached him to discuss aid issues and silver supplies for India. ${ }^{24}$ He could not conduct such talks without any background information. ${ }^{25}$

Even the Foreign Office was alarmed. Under Secretary for India and Burma David Taylor Monteath noted that it seemed

to be a point of honour on the part of Mr Mahindra to avoid keeping Sir G. Bajpai informed even of the outline of his activities. . . . Mr Mahindra attended a meeting at the State Department with Sir G. Bajpai, carrying in his pocket a telegram from the Government of India which he intentionally refrained from showing to Sir G. Bajpai until after the meeting, with the result that Sir G. Bajpai took at the meeting a line inconsistent with that in the Government of India's instructions and subsequently made to appear rather foolish. ${ }^{26}$

The Foreign Office feared an open confrontation in committees with American participation and even to be addressed by the State Department. ${ }^{27}$ With the decision to let Bajpai represent India in a new informal tripartite committee on Indian supply questions, the matter became urgent. Amery urged the viceroy to give Bajpai general supervision ${ }^{28}$ and Linlithgow's successor Wavell finally convinced the departments concerned to give in. ${ }^{29}$

Throughout Bajpai's terms, his status remained his core problem. This was more than the personal struggle of a distinguished and ambitious official pars pro toto, it stood for the struggle around the status of India and the future of the Empire. An early example of the many contradictions coming along with his role as Indian representative of British India was his signing of the Atlantic Charter. After some confusion, 'he was directed to sign 
merely for, "India", and . . . to erase the words "Government of" '. ${ }^{30}$ Truly problematic was the charter's claim for the right of self-determination. Notwithstanding Churchill's clarification that it was not valid for India, ${ }^{31}$ Amery lamented that after an Indian had signed, it could hardly be maintained that it was not binding for India. ${ }^{32}$

At first glance, it seems absurd to portray Bajpai as champion of the independence movement. Apart from numerous derogatory comments on Congress leaders during the interwar period and his anti-Congress propaganda while posted abroad, Bajpai himself would have vehemently declaimed to be a sort of spokesman of those demanding independence. Nevertheless, the many parallels in his and his supporters' claims with those of the Congress are no mere coincidence. Ironically, this was completely overlooked by both the Indian public then and historiography until today.

In his first, though late report from Washington of August 1943, Bajpai threw down the gauntlet to his opponents (i.e., the British conservatives). In the preamble, he claimed a global role for India, which

according to sober opinion both in Great Britain and elsewhere, stands on the eve of equal partnership with the free members of the British Commonwealth of Nations. She must, therefore, survey a wider horizon in international relations than the one represented by her present contact with purely limitrophe countries.

In other words, British India looked forward to at least dominion status and an independent foreign policy. This was a frontal attack on British conservatives plus the traditional line of the FPD/EAD, now Bajpai's mother department. From this assessment, Bajpai deduced the claim to report about much more than the much-limited American interest in India. ${ }^{33}$

With this preamble, Bajpai crossed the Rubicon, and the smart tactician definitely knew that he did. Over 20 years, he had meticulously avoided anything that might have been understood as taking sides in the ongoing British debates around the future of India and the Commonwealth as a whole. Both issues were intertwined as the conservatives with regard to British India's size, population, revenue and army considered it to be the keystone of the Empire. As one of their leading protagonists and at the same time the most prominent India hater, ${ }^{34}$ Churchill warned that self-government 'will bring a fatal disaster upon the British Empire'. ${ }^{35}$ Accordingly, he considered the Government of India Act from 1935 'a monstrous monument of sham' and its architects 'pygmies'. ${ }^{36}$ These 'pygmies' were liberals who understood that, for financial reasons among others, South Asia lost its value and could not be kept under control forever. Independence could but be delayed by cautious concessions; they might permit a smooth transfer of power. ${ }^{37}$ Their ideas on India corresponded with those on the Commonwealth as a whole, 
which was meant to be transformed into a brotherhood of independent countries, sharing values and cooperating for mutual benefit. ${ }^{38}$

Although observing strict silence on those issues, Bajpai since long must have sympathised with the liberals. The policy of the DEHL right from the start had aimed at an increasingly Indian in contrast to British Indian foreign policy. Wherever Indian and British interests clashed - Kenya, Zanzibar or wartime Malaya - Bajpai and his department had taken up the fight. This was directed primarily against the Colonial Office, maintaining the idea of a strongly centralised Empire with all major decisions taken in the metropolis. Without ever saying so, the DEHL had pursued a subversive strategy, emphasising the contradictions within the Empire and claiming the Indian right to have a say as much as Australia, Canada or South Africa.

Bajpai virtually declared war on Churchill, Caroe and their followers, and the reasons were obvious. First, 20 years of efficient and absolutely loyal work for the colonial power had finally earned him what he considered exile. Second, claiming a greater role for India in global politics was in line with the policy pursued with his former department. Third, Bajpai was a patriot at heart, having dedicated his career to Indians overseas. Fourth, if there is a term explaining both Bajpai's inner motivation and his approach to international affairs, it is fairness. Though he fought only for Indians, he genuinely believed in the equality of men and wanted to achieve his goals by fair means. There is not one example when he ever considered gulling a counterpart in order to achieve an advantage. The idea of fairness is very British, but everyone as deeply involved in British colonial policy saw to what extent London violated any idea of fairness throughout large parts of the Empire. For any Indian of Bajpai's generation, the ideal of achieving fair aims by fair means might have originated in Great Britain but had been adopted by Gandhi with much more credibility.

The timing of Bajpai's bombshell was obvious. In September 1943, Wavell took over as viceroy. He was no friend of Churchill and much more sympathetic with far-reaching reforms than the conservative and inflexible Linlithgow. ${ }^{39}$ Bajpai's first 22 months in the US had brought home the lesson that attempts to raise his status were as vehemently supported by some British liberals as they were staunchly opposed by the conservatives. Shortly after his arrival in Washington, the agent-general had complained that the British embassy impaired his usefulness by emphasising that he was but attached. ${ }^{40}$ The Foreign Office wanted to have the cake and eat it: Bajpai should give the impression of mostly working on his own without actually doing so. ${ }^{41}$ Once the State Department treated the agent-general like any other head of mission, the Foreign Office warned that the US government (USG) 'get so much into the habit of dealing directly with the Government of India and its representative that they will ignore the interests of HMG'. A recent interview between President Franklin Delano Roosevelt and Bajpai seemed illustrative 
'of the opportunities which might be given to a less discreet agent-general to stray outside his proper sphere'. ${ }^{42}$

Bajpai's staunchest supporter was British Ambassador Lord Halifax, a leading figure of the liberals. Formerly Viceroy Lord Irwin, in the Irwin Declaration of 1929 he had propagated dominion status for British India and concluded the Gandhi-Irwin Pact, ending civil disobedience in exchange for a round table conference. The same year, he had insisted that Indian agents must represent Indian aspirations and views, not necessarily identical with London's. ${ }^{43}$ Halifax was also among the architects of the Government of India Act of $1935 .{ }^{44} \mathrm{He}$ argued, first, that the agent-general would be more efficient with a higher status. After the launch of the Quit India Movement on 8 August 1942, he intensified his efforts, arguing that journalists had begun to avoid Bajpai, and the circle around Nobel Prize Laureate and novelist Pearl Buck had started a 'whispering campaign that he is merely a tame gramophone record of His Majesty's Government'. Whenever the agent-general met Secretary of State Cordell Hull or Roosevelt, 'they could hardly banish from back of their minds ... that he is a mere mouthpiece of His Majesty's Government' ${ }^{45}$

Halifax, second, emphasised that the Indian public was concerned with Bajpai's 'position on paper rather than in practice'. Third, he opened Pandora's box, hinting at the position of the Indian delegation to the League of Nations, enjoying the same authority as, for example, France 'by reason of being constitutionally responsible to the Secretary of State of India'. ${ }^{46}$ This last point was supported by Zafrullah Khan, judge of the Federal Court of India, appointed the first Indian agent-general in China in 1942. With sympathetic former Foreign Secretary Anthony Eden, he held that constitutional issues could be overcome if Delhi and London really wanted. ${ }^{47}$

The India Office commented with good cause that the public neither in the US nor in India showed any interest in the question of status. ${ }^{48}$ As much more problematic, however, conservative forces considered constitutional and practical problems. Monteath burst out that the fact that India in the League of Nations had been given 'an international status and functions not justified by its constitutional position, has involved 25 years of skating over very thin ice and occasionally putting one's foot through it'. If Bajpai was given a higher rank, he would become 'the envoy extraordinary and minister plenipotentiary of - what? Of His Majesty's Government in India? But there is not one. Of His Majesty's Government in the United Kingdom? But that is the function of the ambassador' ${ }^{49}$ Already earlier, the India Office had considered it a 'convenient obscurity whether in respect of a certain field of Sir G. Bajpai's activities he speaks to the Americans on behalf of the Government of India or, as a member of Lord Halifax's staff, on behalf of HMG'. ${ }^{50}$

It also warned that Washington would demand reciprocity. The personal representative of Roosevelt in British India, Colonel William Phillips, held 
the rank of commissioner, but would certainly claim that of minister, too, as the USG had demanded reciprocity right from the start. ${ }^{51}$ Equipped with more competences, he might exercise direct pressure on the viceroy regarding some policy vis-à-vis Afghanistan or China, which again might lead to an inconsistency between the policies of Delhi and London 'or a naked exposure of the fact that neither the Government of India or its minister had full diplomatic competence and that the Indian representative in Washington, though so described, was not in fact a Minister Plenipotentiary'. ${ }^{52}$ Linlithgow too opposed raising any constitutional issues. He saw no need for a 'neat mould of logic' or anticipation of future developments. Hardly anything could be more embarrassing 'than a formal recognition of India's independence in exchanges of diplomacy', which would lead to demands for legations by China, Persia and Afghanistan. ${ }^{53}$ According to the India Office, this would put Delhi under pressure to open missions in these countries though it lacked suitable officials. Among the now 13 Indians in the Political Service, K.P.S. Menon was posted to China and Major A.S.B. Shah to Canada. The rest were military officers by origin, unlikely to prove suitable diplomats. ${ }^{54}$

Linlithgow generally was unwilling to deal with any influential American representative in Delhi. Rather absurdly, he also warned that an upgrade of Bajpai's posting would trigger demands to appoint a non-official, an appropriate candidate near impossible to find. ${ }^{55}$ This was a response to Halifax's suggestion that a higher-ranking US representative would be preferable, who would be in closer touch with the GoI instead of being exposed to unofficial influences. Moreover, the missions of the dominions were working closely with the UK, and their governments accepted concerted views more readily if reported by their own representatives. In vain, Amery and Eden supported the ambassador. ${ }^{56}$

In the first half of 1942, Bajpai even faced a downgrade. Between 28 February and 1 April, Frederick Puckle, secretary in the British Indian Department of Information and Broadcasting, and A.H. Joyce, advisor on publicity to the SSI, visited the US to find out how to improve publicity on India with a particular focus on the division of responsibilities between British agencies and the agent-general. They found the mixture of American 'interest and ignorance' striking. Both considered the UK to 'have a good case, a clear conscience about our intentions for the future and, speaking broadly, remarkably little to apologise for in our actions in the past'. Americans would have to be educated 'to the facts of India as it is today and so to convey, objectively and not by propaganda, the story of British achievement in India'. The main responsibility for publicity on India should rest with the British agencies. A British expert on India was recommended as advisor to the embassy, ${ }^{57}$ who would have made the agent-general superfluous.

Bajpai seemed ready to capitulate, commenting the report as 'sound'..$^{58}$ For his opponents in the India Office, it provided ample ammunition. 
Among others, Private Secretary to the SSI Francis Fearon Turnbull warned that Wavell, 'with little background in regard to our policy with America', would have to deal with an American minister. Bajpai, further, should not get in touch with matters related to US forces in India. ${ }^{59}$ Wavell's accession, however, had turned the tide. Amery overruled his subordinates, remarking that he already had dealt with such arguments in the 1920s. ${ }^{60}$ Moreover, he vehemently pushed for an upgrade: He 'should sooner have definite foreign diplomats [in India] than roving representatives of presidents with no clearly defined functions and with an inclination to put their fingers into every pie'. It would be preferable to invite them now than after constitutional changes. ${ }^{61}$ Wavell agreed and 'in spite of constitutional anomaly' was keen to make Bajpai minister. ${ }^{62}$ Monteath 'intensely' disliked the proposal:

I do not believe that in sponsoring the proposal H.M. ambassador [Halifax] is moved by other considerations than (i) to yield to the personal importunity of an ambitious agent-general and (ii) to be quit of a troublesome inconvenient volume of rather undefined responsibility. ${ }^{63}$

Bajpai's alleged vanity had already been emphasised by Linlithgow. ${ }^{64}$ Even less surprising, his old opponent Caroe joined in as well. As minister, Bajpai would have to report to both Delhi and London, which gave him the responsibilities of an ambassador, thereby bypassing Halifax. The upgrade would satisfy Bajpai only, whereas Indian political parties would regard it as unreal. Caroe also wondered which special Indian interests in the US might justify such a major change. ${ }^{65}$

This convinced neither Wavell nor Caroe's deputy Hugh Weightman. The viceroy commented that all 'objections have never seemed to me to be very real'. ${ }^{66}$ Weightman gave for consideration that an upgrade would satisfy Indian moderates and - against the background of upcoming US presidential elections - 'indicate integrity of British intentions'. He also found nothing wrong in exchanging missions with more countries, as it was desirable for Indians to establish standards for service appointments to diplomatic posts. ${ }^{67}$ Once more against Caroe,${ }^{68}$ he also supported Bajpai's claim to report on more than the much-limited American interest in India: ${ }^{69}$

U.S.-India relations or problems cannot be properly viewed in a water-tight compartment of their own but must be set against a wider background descriptive of trends of American thought and developments of American foreign policy in general. . . . Surely it is of value to us to see how developments in America appear to an able Indian who is our representative in that country. 
Weightman finally managed to convince Caroe because both were embarrassed that the British Foreign Office was 'excessively bad about passing information to us on American affairs' ${ }^{70}$ Clearly, Weightman shared Bajpai's and Halifax's expectations of dominion status and independence in the near future.

Wavell was even more explicit and ordered Caroe to inform Amery of the importance of taking steps now to place India on world stage at least, as dominion with independent voice. It is far better to take present opportunity to train Indian diplomatists' under British guidance, increase Indian self-respect,

and to direct Indian thought from present introvert tendencies towards foreign affairs than to be rushed at later stage. . . . Genius of British Empire institutions has often been bound up with illogicality and fact that diplomatic position of India was in advance of her internal constitution should not . . . be conclusive argument against change proposed. We think too that step will do something to encourage those who visualise India's future as lying within the Empire. $^{71}$

Caroe's objection that there were no special Indian interests with the US was overruled as well. Amery suggested immigration; ${ }^{72}$ Assistant Secretary in the External Department of the India Office Roland Tennyson Peel added trade and recommended to authorise Bajpai to negotiate war supplies, aid and land-lease issues. ${ }^{73}$ Halifax, finally, mentioned international food arrangements and the newly founded UN Relief and Rehabilitation Administration. ${ }^{74}$ On 24 April, the secretaries of state for India and for foreign affairs authored a joint memorandum for the cabinet supporting the upgrade. ${ }^{75}$ Nevertheless, on 9 June the British War Cabinet turned down the proposal, bringing forward nothing but the well-known and well-refuted counterarguments. ${ }^{76}$ Bajpai personally was not considered a risk, but it was doubted whether it would be possible to find an equally suited successor. ${ }^{77}$ According to Amery, it had been Churchill putting down his foot. ${ }^{78}$ Wavell commented with bitterness that the decision did not make sense and supposed it 'just part of Winston's general hate against India'. ${ }^{79}$ Amery agreed and hoped for a change of government in London. ${ }^{80}$

As so often in his career, Bajpai considered to resign but let himself be convinced by Halifax that this would be embarrassing for the viceroy. Nevertheless, he let know that he felt 'strongly that cabinet decision is out of harmony with independent status of India before the world on all these inter-governmental conferences and organisations' ${ }^{81}$ As consolation, Bajpai received the title of Knight Commander of the Most Exalted Order of the Star of India. ${ }^{82}$ Otherwise, nothing changed until October 1945, when the British cabinet approved the upgrade..$^{83}$ Bajpai, though, never made it, as 
the US government did not play along, arguing that 'India was not a country in control of her foreign affairs' ${ }^{84}$

This stood in contrast to Washington's attitude immediately after the agent-general's arrival. In February 1942, the State Department had told Bajpai that 'the clarification of his status was a matter between him and the British government'. ${ }^{85}$ In practice, the US dealt with him 'on the same basis as that maintained between our own diplomatic agent and the authorities in India'. When British Minister Noel Hall, against the line of his superior Halifax, emphasised the agent-general's subordinated status and even doubted his trustworthiness, US Assistant Secretary of State Adolf A. Berle Jr replied that India was obviously undergoing rapid constitutional changes. Bajpai had arrived with a letter of credence from the king and signed the Declaration of the United Nations on behalf of India. 'This appeared to be a line of authority extending, of course, from the British Empire, but distinct from the line of authority of the British Embassy'. ${ }^{86}$

Roosevelt showed no reserve regarding Bajpai at all, extending to him the 'privilege of direct access to him whenever I want'. ${ }^{87} \mathrm{He}$ even took a liking to him, nicknaming him 'Bagpipe' and overruling the head of protocol fussing whether to invite the agent-general to a reception with the queen of the Netherlands. ${ }^{88}$ During the first half of 1942, when Roosevelt put intense pressure on Churchill for compromising on India, ${ }^{89}$ they had three long exchanges. On 12 March, the president found that British policy towards India "needs the inspiration of a "new thought" and that Indians must be given the chance to find out the type of government suiting them best. Internal differences in the Philippines had come to an end when Washington named the date for independence; the same might happen in India..$^{90}$ In early April, the president criticised the proposals of the Cripps Mission for not going far enough. Sir Stafford Cripps, in vain, tried to negotiate Indian support for the war effort against promises of free elections and dominion status after the war. Instead, Roosevelt suggested to give the provinces full autonomy, 'including power to raise armies'. Like in the first interview, Bajpai replied along the British line that it was most unlikely that Indian political forces would reach a consensus among themselves, but he found the president 'not a good listener'. ${ }^{91}$

Already before the actual launch of the Quit India Movement, Roosevelt changed his mind. ${ }^{92} \mathrm{He}$ was disappointed about Gandhi's attitude towards the war but still seemed 'to retain fondness for Nehru and to regard him as Gandhi's victim rather than a political Hamlet'. Roosevelt considered to invite Sir Stafford Cripps, Bajpai hoping the latter would explain the complexity of the situation and 'choke off prospective embarrassing political pilgrims like Nehru'. ${ }^{33}$ With the Quit India Movement and the arrest of the Congress leadership, the USG lost interest in the independence movement and Bajpai. The agent-general was aware that he was considered a 'mere 
mouthpiece of the British'. ${ }^{94}$ It appears that his reputation had not recovered even by 1945 .

\section{Propaganda and politics}

Neither Bajpai's fall from grace with the USG top echelons nor his status affected what was meant to be his main task: propaganda. He was to influence American opinion on colonialism and on British policy in South Asia by providing 'correct' facts. For this purpose, in 1942, a publicity unity was set up with the agency-general..$^{95}$ Bajpai himself, apart from regularly conducting interviews, gave speeches, trying to convince the public and local Indians 'that Subhas Bose was a Quisling who did not represent the heart or mind of the real India'. ${ }^{96}$

In September 1944, Bajpai authored a brochure for the Indian Institute of International Affairs in New Delhi, providing a positive outlook: Before the Cripps Mission, Americans had made London responsible for the attitude of the Congress; hence those denied freedom could not be expected to fight for the freedom of others. The failure of the Cripps Mission, however, had brought about a fundamental change. Since then, Nehru was 'regarded as petulant', while Gandhi's demand for non-violent resistance against the Japanese appeared naïve. 'Faith in the statesmanship of the Congress Party has almost disappeared', wherefore the arrests of its leaders were 'accepted as a regrettable necessity'. American post-war attitudes were uncertain; Indian nationalism could not expect more than sympathy and moral support. ${ }^{97}$ The Indian press, of course, blamed Bajpai being a lackey of the British..$^{98}$ Those attacks intensified throughout 1942. Caroe made Bajpai's position even more difficult, emphasising in the Central Assembly that the agent-general 'could not undertake to forward to America the views of the opposition in this country'. ${ }^{9}$

Apart from propaganda, Bajpai became deeply involved in issues of war production and financing. Shortly after his arrival, he had initiated American support for an increase of Indian war production. ${ }^{100}$ The outcome was the US Technical Mission to India, advising the GoI on industrial expansion. Bajpai negotiated war supplies ${ }^{101}$ and, in early 1943, concluded a lend-lease agreement. ${ }^{102}$ While discussing with Assistant Secretary of State Dean Acheson, he warned that the agreement might create the impression that the GoI, 'having won its fiscal independence from the British, was now compromising it by the agreement with the United States'. His suggestion for an exchange of notes clarifying that it 'did not in any way limit the fiscal sovereignty of India', Acheson turned down for the possibility of 'some misconceptions' ${ }^{103}$

Bajpai's relevance further increased with his participation in the UN Conference on Food and Agriculture, held at Hot Springs, Virginia, from 18 May to 3 June 1943, where he helped drafting the constitution of the Food and Agriculture Organization of the UN (FAO). For being the man on the 
ground, he also was given the power to sign. ${ }^{104}$ Already in March, he had taken over as Indian member of the Supervisory Committee of the League of Nations. ${ }^{105}$ The UN Relief and Rehabilitation Administration (UNRRA) came into being shortly after the FAO; its founding document was signed on 9 November, and again it was the agent-general representing British India. ${ }^{106}$

In July 1944, Amery and Wavell consented that it should be Bajpai who was to keep in touch with discussions among the US, the Soviet Union and China on the subject of 'future world organisation'. This would enable him to advise any Indian delegation. ${ }^{107}$ The agent-general thereby transformed into an expert on post-war international affairs. When in the summer of 1945 a meeting of the UNRRA in London was announced, the India Office and the GoI took it as self-evident to nominate him as British India's representative. ${ }^{108} \mathrm{He}$ also got in close touch with East Asian affairs when a Far Eastern Commission was established after the Japanese defeat, the first meeting taking place in Washington on 23 October 1945. The EAD saw no alternative to Bajpai attending, ${ }^{109}$ who could not even be briefed, given the lack of time. ${ }^{110}$

In many cases, Bajpai merely functioned as the bearer of messages from Delhi. His essentially political talks with members of the USG and State Department officials, however, were delicate sometimes, especially as American perceptions of Congress politics underwent a fundamental change with the failure of the Cripps Mission. In late February 1942, Bajpai had warned against any involvement in domestic debates by the head of the US Technical Mission to India. ${ }^{111}$ Thereafter, he 'purposely refrained from visiting the [State] Department during the period of Sir Stafford Cripps' negotiations in India in order to avoid any possible impression that he was endeavoring to influence in any way the course of those negotiations'. Once the mission had failed, however, he provided strong opinions in a conversation with Adviser on Political Relations Wallace Murray: Among others, he blamed Indian industrialists for being 'extremely reactionary and self-seeking' and expecting US imperialism to replace British imperialism in India. Their views differed massively from those of the Congress, but they supported the party nevertheless, hoping to win some influence on its decisions.

The official statements of Indian parties should not be taken at face value: Rajagopalachari and Nehru 'had every desire to negotiate a successful settlement', realising 'that India must resist aggression by force and not by passive resistance'. They were, however, blocked by Gandhi and the Congress Working Committee, playing a tactical game:

With the Cripps proposals on record, they can never be withdrawn by the British Government. Therefore, why accept them now in the present grave situation of India and run the risk of failure which ought to rest on the shoulders of the British rulers. If Britain wins, the offer can always be taken up and tried out, with better chances 
of success. . . . Some members of the party reasoned that if Britain loses and the Japanese succeed in occupying India the Indians would be in a better position to negotiate a satisfactory settlement with the Japanese.

Bajpai admitted 'that he was not one of those who regarded India under British rule as the best of possible worlds'. This appears a surprising act of disloyalty not only against the British government but also against his mentor Halifax, from whom he confessed to differ sharply on this issue. Bajpai even forwarded insider information on confidential exchanges between the ambassador and Cripps. He expressed hopes that the US would exercise influence to reach a settlement in India, though this had to be done with utmost caution. Nehru and other Congress leaders 'undoubtedly welcomed the presence and assistance of Colonel Johnson during the negotiations', but they 'would be careful to avoid any charge by the opposition that the course of the negotiations was being dictated or even influenced by this government or its local representative. ${ }^{112}$

Bajpai also told Berle that he had told Halifax 'rather bluntly' that his plans for India would not work. 'The only way now of handling matters was to announce to India that she would be given independence on a date certain'. ${ }^{113}$ After the Quit India Movement had been launched, Berle informed him that his government would not get involved. While the US had always sympathised with independence, the war had to be won and the British contribution was crucial. Bajpai approved and then complained about obsolete British attitudes: 'it was difficult to see that much could be done until their views had developed further'. When Berle strongly criticised Gandhi for contemplating talks with Japan, Bajpai indicated that he was rather unhappy with the Mahatma's tactics than the idea itself. ${ }^{114}$ Regarding possible US involvement in Indian controversies, after the arrest of Congress leaders Bajpai suggested to send a more assertive American representative to Delhi, who 'would be able to bring his influence to bear upon the viceroy'. Linlithgow 'had been in India for seven years and was probably more or less out of touch with outside opinion'. ${ }^{115}$

At first glance, Bajpai's exchanges with US counterparts appear as acts of disloyalty. ${ }^{116}$ It would, however, be naïve to believe that the agent-general risked confiding delicate personal views to American officials, of whom he thought little. Furthermore, Bajpai had profiled himself as an opponent of the Congress. Conspiring against all and everyone at the same time without any backing in India would have been a suicidal act not to be expected from such a shrewd tactician. Bajpai was known for weighing each word. He must have been aware that what appeared as acts of disloyalty might be forwarded to Halifax or Linlithgow immediately. As he was meant to appear as an independent Indian voice of weight, Bajpai played the role he was meant to play, even more as it corresponded with his self-assessment as 
foreign policy expert. Indeed, he was an efficient part of the British propaganda machinery in the US. ${ }^{117} \mathrm{He}$ not only obeyed orders but also advised his superiors how to further discredit Gandhi with an anthology of hostile comments on America. ${ }^{118}$

Bajpai's critical assessments of US policy, much in harmony with Halifax ${ }^{119}$ and those in charge in London and South Asia, were unlikely to be leaked. They are worth to be analysed in some detail not only for breathing Bajpai's typical sense of realism. They were also fully in line with his impressions of the US of the 1920s and the predominant British perception of American politics. Most important, they indicate a relevant stage in the development of Bajpai's view of the post-war world with a dominant US, carrying weight when he de facto functioned as India's first foreign minister from 1947. Finally, quotations from the reports give evidence of the elaborate and somewhat flowery but, nevertheless, precise and strong language of Bajpai during the last but two stages of his career.

Throughout, he portrayed Americans and their leadership as politically immature and unpredictable. The instability of US foreign policy was entrenched 'in the lack of experience and, principally, in a deep-rooted tendency to subordinate foreign relations to domestic politics'. ${ }^{120}$ There were a few decision-makers like Under Secretary of State Sumner Welles, who earned his respect for 'a wider knowledge of the outer world' and 'for constructive boldness rather than excessive caution'. ${ }^{121}$ Altogether, however, secretaries and top diplomats 'could not be more conspicuously free from the qualifications that one would normally expect it to possess even if its members had been deliberately chosen for complete lack of them'. US politicians were no better. ${ }^{122}$

He diagnosed 'self-righteous American idealism' as the core problem of US foreign policy. ${ }^{123}$ In late 1945, Bajpai strongly criticised American policy in the Middle East and Indonesia for

lack of moral firmness; a state of mind which seeks to clothe fear of the unpleasant in the garb of idealism.... The cause of true liberty will never be advanced amongst backward peoples by divorcing liberty from order, nor the grievous wrongs of one race in Europe righted by the infliction of new wrong on another people in the Middle East. Until Americans learn that . . . justice can neither please all nor be enforced without severity to some, their leadership in world affairs will be neither strong nor constructive. ${ }^{124}$

American ideas would not be adopted by the rest of the world

merely because Americans consider them to be superior to all others. ... It is surprising that Americans who are extremely sensitive to snobbery in manners should be completely unconscious of 
their own snobbery in morals. Europe, and Asia, will readily admit their claim to world leadership if, with the privileges of leadership, the United States will also assume its obligations. This involves not only the acceptance of military and economic commitments, but also a moderation of moral pretensions and a recognition that other nations may also have some contribution to make to a code of international relations based on justice. ${ }^{125}$

American views on India only shortly played a prominent role in the reports. The Bengal Famine was the first development to draw attention. Given heavy taxation and 'the large contribution already made by the American public for relief in Great Britain, Russia, China and most of the occupied countries', the agent-general did not expect any lasting effect on US public opinion in October 1943. ${ }^{126}$ Two months later, however, he warned that the famine had led to massive differences between Roosevelt and Churchill. The public believed that the release of Congress leaders would help fighting the famine and improve chances to liberate Burma and China. ${ }^{127}$ By March 1944, the focus on India remained, now due to the combined attack of Japanese forces and the Indian National Army. Some Americans expected a general revolt in India, an 'unjustifiable panic' and

a painful reminder of the mercurial temper of the American people and the extent to which this national weakness may be exploited by those whose hostility, to Great Britain in general and to British policy towards India in particular, is latent only under a sense of expediency. ${ }^{128}$

After the attack had been fended off, Bajpai criticised 'a lack of real generosity': British and French contributions to the war had been completely ignored, and now 'the contribution of Indian troops, either to the victories in Italy or the defeat of the Japanese in Assam and Northern Burma could scarcely expect to earn attention in this ecstasy of [American] self-admiration'. ${ }^{129}$

Bajpai criticised the US perception of China as naïve, especially the blind support of Chiang Kai-shek. 'China's "greatness"' might serve as 'a useful wartime fiction', but after the war, 'some more realistic policy must be thought out'. ${ }^{130}$ Only in the third quarter of 1944 did Bajpai see some Americans understand the true value of China as 'the only available buffer to absorb the shock of possible Russian imperialism in the Far East after Japan has been reduced by defeat to the position of a minor power'. ${ }^{131}$ After the war had ended, Bajpai once again warned against America's persisting faith in China's unity and effectiveness as a great power. ${ }^{132}$

Regarding the USSR, Bajpai indicated some respect for Stalin's realism. Already in August 1943, he commented Soviet designs on the Baltic states, Poland and the Balkans. Washington saw 'symbols of an old-fashioned 
imperialism, or cynical selfishness, dangerously out of accord with popular American sentiment'. The core of such suspicions were the deep-rooted fears of a Bolshevik revolution in Europe after the Great War. Notwithstanding 'some mystification' in the UK, too, British and Soviet points of view

are nearer accord than Russian and American. Conferences do not achieve harmony of opinion and purpose without common will in the participants to achieve it. The American attitude towards Russia's political requirements in Europe must become more realistic and less distrustful. A better understanding between the USSR and the USA cannot be secured without a sacrifice of self-righteous American idealism. ${ }^{133}$

This did not mean that Bajpai sympathised with Soviet expansionism. On the contrary, he warned that military successes were 'likely to stiffen M[arshall] Stalin's demands regarding frontiers and spheres of influence ... Russian appetite ... in the past, has been known to mount with repletion'. ${ }^{134}$

By early 1944, Bajpai believed the State Department

reconciled, albeit with many reservations, to the doctrine of Treitschke that world-history-constitutes-world-right. . . . History and morality have only a passing acquaintance and still seem to be a long way from permanent fusion. But to the high priests of a new world-order, based on absolute justice, these deviations from the path of true rectitude must come with all the shock of rank apostasy. ${ }^{135}$

He understood that Washington did not consider the price for Moscow's support in terms of control over Poland, Finland and the Baltic states too high. Roosevelt appeared to harbour the idea of American-Soviet cooperation against a block of European colonial powers, once again revealing the 'nebulous character of American thinking on foreign affairs'. ${ }^{136} \mathrm{At}$ the end of the year, Bajpai expressed understanding that Stalin, after the USSR's enormous sacrifices, aimed at controlling Eastern and Southeastern Europe. Such safeguards could not be neglected only because this would hurt American suspicions. Nevertheless, the agent-general warned against Soviet schemes: 'Russian nationalism, the most potent factor in Russia today has all the makings of a military dictatorship'. With its immense territory and economic potential, 'a peaceful Russia will be a pillar against aggression, but Russian pacifism is at least as uncertain a factor as the constancy of American support of a new world order'. Unlike Washington, London had understood that only solidarity with Moscow provided a solution. ${ }^{137}$ 
The unexpected succession of President Harry S. Truman did not change Bajpai's assessments. The US administration again showed

confused perspectives and vacillating judgment. ... For a long time to come peace will endure only if backed by sufficient power. The desire to see the bounds of freedom extended is divorced from all willingness to assume responsibility for the maintenance of order in countries where the struggle for freedom threatens to establish anarchy. ${ }^{138}$

Accordingly, Bajpai criticised American hasty demobilisation after the war; anti-Soviet sentiment alone provided no equivalent to military power. ${ }^{139}$ Notwithstanding all American shortcomings, however, there was no practical alternative for the Commonwealth to close cooperation, though Washington's immaturity was 'a reminder that the countries of the Commonwealth must conserve their unity and their strength' ${ }^{140}$

For American supporters of the Indian independence movement, ${ }^{141}$ Bajpai showed nothing but contempt. The India League of America organised a public event at the occasion of the first anniversary of Gandhi's arrest on 9 August 1943. According to Bajpai, the speakers, among them Louis Fischer and Roger Baldwin, 'were a few champions of Indian liberties whose names have by now become painfully familiar through the repeated iteration of unchanging views', winning little public interest. ${ }^{142}$ Even more vitriolic were the agent-general's comments when a National Committee for the Freedom of India was founded in October 1943: Any account of the speeches was 'superfluous; they said nothing new and nothing good ... The oddity of an Indian "national" committee operating from Washington should be apparent to anyone endowed with a sense of logic or a sense of humour'. Only 'neurotic women and almost equally neurotic legislators will prove easy victims'. ${ }^{143}$

Bajpai criticised those

large-hearted though not very wise liberals. . . [who] continue to repeat that there is no communal or any other obstacle to Indian unity and that Indian freedom is being delayed, to the advantage of the Japanese and the detriment of the United Nations, by a blind and stubborn imperialism.

But he did not want to blame the 'humble and innately honesty' of average Indians living in the US, who were victims of propaganda and neglect. As the GoI had ignored them for too long, Bajpai suggested regular visits to California, where most of the altogether but 2,000 Indians lived: 'A discontented colony of Indians in a foreign country is a political liability. If the active malcontents can be deprived of their following, this ... may greatly 
reduce ... their influence for evil'. ${ }^{144}$ In April 1943, he produced an aidememoire against new legislation to the detriment of local Indians. US law prohibited aliens ineligible for citizenship from holding and working land, but some Indians had circumvented this rule, having property registered in the names of their Mexican wives, who were eligible for citizenship. A new act prohibited spouses from benefitting from such land. ${ }^{145}$

In April 1944, Nehru's sister Vijaya Lakshmi Pandit applied for a visa to the US. She wanted to see her two daughters, but nobody doubted her using the opportunity for political activities. Bajpai initially advised against letting her travel but soon changed his mind. Halifax followed suit, arguing that 'a refusal might create a worse impression in the view of the fact that she is a widow purporting to visit her two young daughters in college'. ${ }^{146}$ Bajpai portrayed her visit as a failure: Press articles soon after her arrival in December reflected interest in her person rather than her political statements. People might listen to her speeches but would quickly forget her unless AmericanBritish tensions deepened. ${ }^{147}$ In the first quarter of 1945, the agent-general admitted that Mrs Pandit's 'charm and oratory have had their effect; though her professions of indifference to the outcome of the war have hardly been calculated to win American audiences'. ${ }^{148}$ Caroe found Bajpai's assessments 'far too optimistic', ${ }^{149}$ a view shared by Amery: Though Mrs Pandit 'seems to have talked egregious nonsense', Americans were naïve.

She has ... so attractive a personality that from her they might even swallow the statement that India is one vast concentration camp and that there are no religious differences, but only unanimity of passionate desire to escape from British oppression. ${ }^{150}$

Among the members of the Indian delegation to the UN Conference on International Organization in San Francisco, it was Ramaswami Mudaliar who, according to Bajpai, won recognition 'for the distinction and value of his contribution to the work of the conference'. ${ }^{151}$ Supporters of independence around Mrs Pandit were around as well, taking care for publicity but otherwise not achieving much. ${ }^{152}$ Soviet Foreign Minister Vyacheslav Mikhailovich Molotov all the same called the group India's true voice, and Truman invited Nehru's sister to the White House. ${ }^{153}$ Bajpai commented with biting sarcasm that the American press 'showed no sign of abating fervour for chaos through freedom'. The champions of independence 'have good lungs. Their weakness is higher up ... India is not an American "interest" in the same sense as China or the Philippines; it is a theme for moral reprobation of colonial powers and empires'. ${ }^{154}$

The longer the war lasted, the more Bajpai won competences and expertise. In India, however, where the focus was on the Congress and the Muslim League, nobody showed any interest in his fate. He was both 'persona non grata to the Congress ${ }^{155}$ and intensely disliked by Jinnah. ${ }^{156}$ Even the British 
appeared to have forgotten him: In discussions around more responsible positions for Indians in foreign affairs, Bajpai was never even mentioned. When in April 1945 Wavell contemplated to appoint an Indian minister for the EAD, 'as a first step' he suggested an Indian foreign secretary, ${ }^{157}$ finding K.P.S. Menon

best fitted by ability and experience. ... But Menon, though attractive and good with his pen, is rather a light weight and I doubt if he could cope with an Indian Member for External Affairs if one is appointed next year. ${ }^{158}$

Amery, when leaving the India Office after the general elections in the UK on 5 July 1945, in his farewell letter to Wavell recommended Mudaliar as minister for external affairs. ${ }^{159}$

The lack of esteem for Bajpai's qualities once again was indicated with the nomination of the secretary for the Indian delegation to the UN in 1945. The agent-general was available nearby and had been part of various international conferences. On orders from Delhi, he also followed multilateral discussions on a new world order. Instead, Caroe asked for the services of K.P.S. Menon, who had to travel around the world to attend his first international conference ever. ${ }^{160}$ When Menon met Bajpai, he found him concerned about his future. After the former subordinate had first poisonously commented that 'this is the worst of getting to the top too quickly', ${ }^{161}$ he later pitied his former boss for being 'so mellowed, subdued'. ${ }^{162}$ When Menon returned in the following year, he wrote of 'a once great official in ruin'. ${ }^{163}$ Bajpai also suffered from health problems.

\section{K.P.S. Menon}

After his departure from the DEHL, K.P.S. Menon's career had been rather unspectacular. As deputy secretary in the FPD between April 1936 and April 1937, he came in touch with British India's relations with its immediate neighbours and occasionally also with those with the US and Japan. Thereafter, he served in Fort Sandeman in Baluchistan and was appointed dewan in the princely state of Bharatpur near Delhi in 1940. His tasks were not much different from those of a district officer. Working in the northwestern outskirts of British India won him Caroe's respect: Menon had held 'a pretty stern post for a Madrasi Hindu' ${ }^{164}$ relating to the contempt of North Indians for their darker and allegedly less masculine countrymen in the south. While in Bharatpur, Menon tactfully handled various conflicts in the ruling family, proving his skills as a diplomat.

Most important for Menon's later career were his contacts with influential British members of the Political Service, among them Political Secretary Glancey, who kept the Indian official in high esteem. ${ }^{165}$ The Indian deputy 
secretary was close with Aubrey Metcalfe and Menon's role-model Caroe, the current and the future foreign secretary, dealing with them on a firstname basis. ${ }^{166}$ This was common among the Europeans in the service but not self-evident among the Indians, and even less between Europeans and lower-ranking Indians. To Menon's disappointment, however, Metcalfe was 'too much of a gentleman to be effective' 167 and could not extend his term in the department. ${ }^{168}$

Menon did not neglect Indian colleagues and politicians either. His diaries read like a who's who of independent India and Pakistan, mentioning private meetings with promising officers like N.B. Bonarjee, V.P. Menon, R. K. Nehru and N.R. Pillai, future ministers like Amrit Kaur and Liaquat Ali Khan or prominent freedom fighters as Sarojini Naidu. Menon always had two strings in his bow: For his never manifesting dreams of taking over another agency, he kept in touch with Bajpai, applauding him for passing Indian rivals in the race to top positions. ${ }^{169}$ At the same time, he pursued his career in the Political Service, towards the end of his term in Bharatpur counting on being 'the first Indian to be a P[olitical] A[gent] or Resident in Indian States'. ${ }^{170}$

Some of Menon's diary entries indicate inner distance from the colonial world. He disliked Indians copying Englishmen ${ }^{171}$ and felt humiliated 'to see Indian princelings carrying the Viceroy's train' at the latter's investiture. ${ }^{172}$ Accordingly, he approved Congress accepting office in the provinces ${ }^{173}$ and celebrated the day when it manifested. ${ }^{174}$ Nevertheless, when in early 1938, following S. C. Bose's advice, Hari Vishnu Kamath resigned from the ICS, Menon found it doing 'credit to his heart rather than to his head'. ${ }^{175}$ A moral dilemma he felt only when the Quit India Movement was launched and Congress leaders were arrested: 'It is all too sad for words. And yet I have myself to take steps here to preserve law and order!'176 The dewan was fortunate that Bharatpur remained comparatively calm. ${ }^{177}$ He prayed for 'Gandhi's sake (than whom no truer servant Thou hast ever had)' and independence. ${ }^{178}$ For Churchill, he felt nothing but contempt. ${ }^{179}$

His esteem for Nehru was absolute. He admired his 'stern logic. .., chaste English, lofty idealism' and 'practical common sense'; ${ }^{180}$ if anyone could make India, it was Nehru. ${ }^{181}$ There was 'a good deal of false rhetoric about Churchill's writing' but nothing like this with Nehru. ${ }^{182}$ After the latter's first autobiography had come under sharp criticism for spreading communist ideas, Menon believed he would be arrested soon. ${ }^{183}$ On the contrary, he did not like S. C. Bose, 'the reason why I cannot tell. One feels we can't trust him as one can Gandhi and Jawaharlal Nehru'. ${ }^{184}$ The Mahatma, he admired for his 'triumph of the soul over matter' when breaking his fast in early 1939 . He believed that only he was capable to solve the communal problem. ${ }^{185}$ In October 1940, when Congress offered individual satyagraha, however, Menon admitted that 'Gandhiji's tactics sometimes pass comprehension'. ${ }^{186}$ Like Bajpai, he harboured no sympathies for Jinnah. ${ }^{187}$ When 
the leader of the Muslim League turned down the Cripps proposals, he commented with a short 'Damn him!'188

Menon closely followed international events, but hardly commented on them; if so, his views were commonplace. Appalled by German aggression, he did not make much of the complicity of the Soviet Union in the partition of Poland. His comments on the 'insatiable Stalin'189 and the Russian colossus 'bestriding his narrow Baltic world' ${ }^{190}$ were stereotypes on Russian expansionism without explicit anti-communism. This was rather unusual. The British considered communism and the USSR the very threat to the existing world order. Moscow for many years refused to play along the established rules of international diplomacy and, even worse, allegedly believed that world revolution might spread from Calcutta. ${ }^{191}$ Had Tsarist Russia rivalled Great Britain in Asia, the USSR formed a much more fundamental threat to colonial rule over South Asia from both without and within. The independence movement was in driving the British out, though with demands derived from British law and the intention to establish an indigenous form of a Westminster democracy. The small Communist Party of India (CPI), on the contrary, aimed at a total system change. ${ }^{192}$ Therefore, British rulers, British and Indian civil servants and the majority of the Congress Party were deeply anti-communist.

Regarding Indian domestic affairs, Menon was disappointed that India did not support the war effort, but blamed the colonial power, which had not made 'a great and generous gesture promising freedom' ${ }^{193}$ Menon was especially disappointed about Churchill's unwillingness to compromise on India. ${ }^{194} \mathrm{He}$ welcomed the Cripps proposals, ${ }^{195}$ wherefore he found Gandhi's famous comment that they were nothing but a " "post-dated cheque on a bank on liquidation" ... amusing but unfair'. ${ }^{196}$ When the talks failed, Menon suspected Linlithgow 'and his sun-burnt advisors' to be 'an insuperable obstacle' against 'an "irresistible force" ' ${ }^{197}$ Nevertheless, Menon found the appointment of Wavell 'thoroughly bad', expecting Congress leaders to be kept in detention as long as the war lasted. ${ }^{198}$ The Indian princes in Menon's eyes had 'no right to exist in a rapidly moving world'. ${ }^{199}$

Apparently, Menon did not hesitate to disclose such views with friendly Indian ICS officers, mentioning that N.R. Pillai was 'so nationalistic at heart. So is V. P. [Menon] - but more openly'. ${ }^{200}$ Otherwise, however, he must have hidden his private thoughts very well, as in mid-January 1943 he was offered the agency-general in Chungking. ${ }^{201}$ The designated agentgeneral was well aware that

one must steer one's course very carefully through conflicting interests in China. Tibet is going to be a thorough problem. Another thorny problem is going to be China's intense and sympathetic interest in India which is not very sympathetic to the British imperialists. ${ }^{202}$ 
Briefed by both Caroe and Linlithgow, ${ }^{203}$ Menon learned that China claimed large parts of northern India and their friendship with Congress was by no means altruistic. ${ }^{204}$ To his embarrassment, the British, however, showed no willingness to clarify relations with Tibet. ${ }^{205} \mathrm{He}$ did not like the general British attitude regarding China as well, considering the latter's government 'fascist and totalitarian' and 'not doing anything. All their "successes" are a myth'. 206

Unscheduled, Menon was appointed political agent in Jodhpur, proud for having 'broken the tradition of the impossibility of an Indian holding this job'. He hoped to make things easier 'for the brown bearers of the white man's burden'. ${ }^{207}$ The journey to China was further delayed when in July 1943 he was appointed OSD in the EAD. Finally, on 17 September, Menon flew over 'the Hump' (an airlift connecting Ledo in Assam with Kunming), accompanied by his wife and their eldest daughter.

Whereas Bajpai was the first agent-general in Washington, Menon succeeded Zafrullah Khan, member of the Viceroy's Executive Council and later Pakistan's first foreign minister, who had taken up work on 11 April 1942. Zafrullah Khan had been Linlithgow's choice, the viceroy expecting that 'the post would be in the nature of a heroic one ... Diplomatic gifts of a high order' would enable Zafrullah Khan 'starting us off on the right foot with the Chinese'. ${ }^{208}$ Linlithgow was so pleased with his performance that he wanted him to accompany a delegation to the US. ${ }^{209}$

The first agent-general reported on severe problems: The Chinese harboured an 'exaggerated idea of the power and influence of China in world affairs', which had intensified xenophobia, mostly directed against the British. Furthermore, officials and the press looked upon the Congress and its leaders

as representing and voicing the sentiments and views of the whole of India. Gandhi's proposals and arguments were treated as being the last word on the subject and attempts to show the underlying ambiguity and sophistry in them, although received with interest, did not appear to have any effect on the preconceived Chinese view.

Only later, Chiang seemed to have considered a solution between Hindus and Muslims as the precondition for any political settlement. ${ }^{210}$ Given this assessment, Caroe suggested that Zafrullah Khan should use his farewell reception with Chiang to explain India's 'constitutional and political problem' (i.e., ask him not to interfere). ${ }^{211}$

The post remained vacant for a full year, with Hugh Edward Richardson, ICS, a renowned expert on Tibet, running the agency. Menon was not even the second choice, and his final appointment went along with serious doubts whether he was fit for the job. Linlithgow's favourite was Gyan Nath, ICS, an officer of the Political Service and until recently prime minister of Jaipur 
State. ${ }^{212}$ Amery, however, doubted him to be the skilled diplomat required in China, hinting at reports about frictions with the maharaja. As Chungking was perfectly suited to train urgently needed Indian diplomats shouldering greater responsibility, he suggested Menon, 'who has varied experiences of the right sort'. ${ }^{213}$ Probably, Caroe had thrown in Menon's name first. ${ }^{214}$ Amery saw no need for 'a forceful personality', ${ }^{215}$ an implicit criticism taken up by Linlithgow: 'Menon's quality' was 'very good, but we do not think he has enough firmness of purpose'. ${ }^{216}$ Ironically, this deficit together with the candidate's oratory skills would have fulfilled the criteria of the India Office, preferring 'some quiet man who will do little more than keep the post in existence. Any serious business regarding India must necessarily be conducted by H.M. Ambassador'. What was left was talking to the press. ${ }^{217}$ After other candidates were unavailable, Gyan Nath settled the matter when refusing the post, considering the conditions of service unacceptable. Wearily, the viceroy agreed 'to fall back on Menon despite disadvantages already discussed'. ${ }^{218}$

In sum, Menon was chosen for Amery's initiative because the post was considered rather irrelevant and the new agent-general seemed unlikely to create trouble. Once selected, Menon was painted in much brighter colours. Linlithgow for one pointed out his years of service outside India, ${ }^{219}$ and Peel calmed down concerns in the Foreign Office by emphasising that Menon had worked under diehards like Caroe. ${ }^{220}$ The India Office, nevertheless, found Linlithgow's views 'rather doubtful' and refused any responsibility for the selection. ${ }^{221}$

Immediately after his arrival, like Bajpai two years earlier, Menon learnt that he was meant to play but a subordinated role: Richardson tried to impose his views on him and regarded the agency a mere subordinate branch of the embassy. ${ }^{222}$ As usual, Menon criticised his predecessor and wanted to outdo him. That Weightman praised Richardson's annual report as 'so wellbalanced' and instructed the new agent-general accordingly, ${ }^{223}$ Menon must have considered embarrassing. The agent-general found Richardson and other British colleagues 'a little imperialist'. ${ }^{224} \mathrm{He}$ was impressed, though, by Ambassador Lord Horace Seymour, who was 'not a diehard like Richardson' but confessed having doubts about British policy in India. ${ }^{225}$

Menon's first impressions of Chungking were extreme poverty and a liberal People's Political Council. ${ }^{226}$ To his deep satisfaction, he was treated like a minister, preceding a chargé d'affaires (CDA). ${ }^{227}$ His first encounter with Chiang and his wife was rather emotional; Mrs Chiang had her 'eyes almost full of tears when she made inquiries about Nehru'. ${ }^{228}$ Known as friend of the latter and his party, Menon was most welcome in Nationalist China, even more as in 1938, the Congress had helped to organise an Indian medical mission to help Chinese victims of the war with Japan. ${ }^{229}$ Immediately, the new agent-general delivered speeches. Already the first of them about 'India and the three Principles', emphasising on the 'underlying unity of 
India', annoyed Muslim politicians in India. ${ }^{230}$ Menon did not care, seeing Jinnah develop all the airs of an 'imitation Führer'. ${ }^{231}$ In a press conference, he presented himself 'out and over nationalist'. ${ }^{232}$

Unlike Zafrullah Khan, who was blamed for financial irregularities and stirring up Chinese Muslims, ${ }^{233}$ Menon quickly made himself popular. His observations on China, nevertheless, were far from positive. Already in his first report of January 1944, he drew a gloomy picture: At least for another 25 years, China would depend on others, especially the US. No solution was in sight for the massive financial problems. Nationalists and communists were 'facing rather each other than the enemy', the central government's authority varying from province to province. ${ }^{234}$ Initially, Caroe was pleased, recommending this 'excellent' report to his arch-rival Bajpai. ${ }^{235}$ By June 1944, the foreign secretary commented Menon's analyses still worth reading, but nothing demanding a response; ${ }^{236}$ the British embassy reported in much shorter intervals. ${ }^{237}$

Menon's knowledge of Chinese domestic affairs might have proven useful in his later career, had not the Guomindang lost the civil war. He was hardly in touch with the Communist Party of China, although in March 1943 he enthusiastically described Mao Zedong as a 'superb leader'. ${ }^{238}$ Their only encounter took place in May 1945 at the San Francisco Conference, where Menon found the conversation interesting enough to hope for a continuation. ${ }^{239}$ More useful should have been the expertise regarding Tibet, which had come into the focus in 1904 when the Younghusband expedition established a diplomatic and military presence. ${ }^{240}$ At the tripartite Simla Conference from 1914, the British had attempted to clarify Tibet's status vis-à-vis imperial China. The Chinese delegation, however, left without signing the Simla Convention. Thereafter, in bilateral talks, the boundary between Tibet and British India was fixed along the so-called McMahon Line, reflecting 'concerns for a militarily defensible boundary alignment' rather than giving an accurate account of the watershed, at that point hardly known. Tibet was considered under Chinese suzerainty. ${ }^{241}$ While, thereafter, Chinese governments kept up their claims to sovereignty over Tibet and the Eastern Himalayas, Delhi and London were after maintaining a northern buffer. Soon after the signing of the Simla Convention, China went through political turmoil; the October Revolution and its aftermath took care to limit Moscow's capacities. The British lost interest in the area for about two decades. ${ }^{242}$

In the mid-1930s, however, the Guomindang government seemed to seek control over Tibet. As a countermove, the McMahon Line, hitherto kept secret, made it into maps of British India. The Second World War changed things once again. Nationalist China was mostly cut off from the coast and relocated its centre of gravity westwards. With the Japanese occupation of Burma, critical supplies became available only via British India. The Tibetans as well as the British, however, eyed with scepticism any attempts to 
open a road connection over the Himalayas, expecting it mostly a means to extend Chinese influence in Tibet. ${ }^{243}$ Finally, supplies and personnel were flown in via 'the Hump'. Only in January 1945 did the completion of the Ledo or Stilwell Road make the airlift mostly superfluous.

Richardson's report on China for 1942 and 1943 gives a good impression of the arm-wrestling around Tibet before Menon's arrival: Lhasa had stopped private merchandise with the neighbour to the east, demanding a satisfactory agreement, while there were rumours of Chinese troops moving toward the border. Richardson saw indications of China stirring unrest in the border areas. British protestations had led nowhere, as 'the only result of pushing matters further would have been to elicit a reiteration of the old Chinese claims'. Richardson also reported dissent between the British embassy in Chungking and London, the former holding, in vain, 'that our policy towards Tibet was mistaken, and that we should seek to slide out of our present relationship with Tibet'. As another factor, Washington refused to commit itself 'in any way that might offend the Chinese'. ${ }^{244}$ Whereas the status of Tibet remained unchanged, Delhi decided to establish a permanent presence in the areas south of the McMahon Line. ${ }^{245}$

Menon was in line with London and his superiors in Delhi. In June 1944, he reported a conversation between a British representative and Vice-Minister of Foreign Affairs K.C. Wu, the latter emphasising on the close cultural links between China and Tibet. He further underlined that if India ever went to war with China, it could not be invaded 'via a country with the physical and geographical characteristics of Tibet'. ${ }^{246}$ In his comment, Menon advised against giving up the Tibetan buffer. London had informed Chiang 'that they can recognise Chinese suzerainty only if China recognises Tibetan autonomy'. Menon added that 'India has an essential frontier interest in this region. If we abandon our interests in Tibet, our interests in Sikkim and Bhutan will also suffer'. If Chungking acknowledged this, 'it should not be difficult to arrive at an amicable settlement of this problem on some such lines as the Tripartite Convention of 1914 which was all but ratified'. Furthermore, a buffer was needed even more 'against a more aggressive power who may appear in this part of China as it has done in other parts' (i.e., the USSR). ${ }^{247}$ Seeing Lhasa 'playing a double game', Menon did not approve Tibetan politics. ${ }^{248}$

The USSR controlled Sinkiang since the Xiang War from 1937 but in 1944 left it to the Guomindang. The India Office lauded Menon's reports on that area, ${ }^{249}$ which were to a large part derived from his spectacular three-month trip through the Himalayas, starting in mid-August 1944 in Srinagar, leading through Chinese Turkestan and Sinkiang and ending in Chungking. The British Consul-General in Kashgar M. C. Gillett had suggested to investigate 'this side of an undelimited frontier (Caroe's hobby I understand)'. Soviet influence had collapsed for 'preoccupation elsewhere, clumsy interpreters of Soviet policy, and Chinese resilience' together with inability to handle the 
peoples of Sinkiang. He advised British India to make itself indispensable. It would not be able to replace the USSR in terms of trade but might send experts for irrigation and communication and offer scholarships. ${ }^{250}$

With some mockery, Menon wrote about his arrival in Gilgit, where he was taken in a procession with a village band:

I do not know whom I felt like - whether like Julius Caesar entering Rome in triumph or a village bridegroom being paraded through the streets. However this I suppose is one of the ways in which we keep our end up in that farthest outpost of the Empire.

He observed that high-ranking Chinese officials came all from outside the region, an indication of massive 'Sinovisation'. The locals had come to hate the Russians.

Over a full decade, Indians had been treated badly, suffering from trade restrictions, refinement and cruelties. ${ }^{251}$ Menon, therefore, advised against 'showing any undue anxiety to help Sinkiang until the present administration shows, not merely in words but in deeds, its will to redress the more crying grievances from which Indians are suffering in Southern Sinkiang. ... "Face" might stand in the way of the Chinese' accepting it. Menon did not believe that China could keep Sinkiang under control for long; the standards of living were extremely low and officials were corrupt and inefficient, expecting the locals to speak Mandarin. 'This is a reflection of their lack of interest in, and contempt for, the peoples of Sinkiang whom, in theory, they claim as belonging to the same race as themselves, and, in practice, they regard as altogether barbarian'. ${ }^{252}$ After the EAD asked Menon to publish a short book on his journey, ${ }^{253}$ the agent-general completed the manuscript as early as February 1945. ${ }^{254}$ Caroe found it even better than Peter Fleming's well received News from Tartary. ${ }^{255}$ When the book, originally titled A Passage to India, finally came out in 1947, named as DelhiChungking: A Travel Diary, ${ }^{256}$ the British part of the Great Game in the Himalayas already had come to an end.

Regarding Chinese interest in India, Menon confirmed Zafrullah Khan's assessment that there was much sympathy for the independence movement. The new agent, nevertheless, saw a better understanding of the situation in South Asia and applause for Wavell's handling of the Bengal Famine..$^{257}$ In 1944, he reported that an Indian Famine Relief Fund had collected Rs 11 lakh and there was constant demand for books and photographs from India. The Chinese press, obviously on orders from the top, remained 'frigidly correct' or fully quiet. ${ }^{258}$ During Menon's Himalayan journey, CDA Major A. Napier gave a much bolder assessment. He held the Chinese 'abysmally ignorant about India and Indians' though keen to learn more. 'The Chinese are not interested in a European representative from India', 
Therefore, it was 'advisable that the whole staff of the agent-general's office should be Indians. The office work is negligible, but the personal contacts made by the staff are important and the Chinese like meeting them socially'.259

It took until 1946 that Menon in one of his reports articulated a statement on Indian domestic affairs, and this a rather unexpected one. He held that all major parties in China and India had

a totalitarian touch. . . . The Indian National Congress claims to represent the totality of Indian peoples and to be in fact the only political, as distinct from communal, party. The Muslim League claims to represent 90 million Muslims despite the existence of the Unionist Muslims of the Punjab and the Congress Muslims of the North West Frontier Province.

Equally, the Guomindang claimed to be the only party representing China.

The Communists in China have obvious affiliations with the Soviet [sic] which with all its economic democracy is politically totalitarian. A true democrat would find it hard to choose between these parties. There is, however, no doubt that the policy of the Communists in China and the Pakistanis in India is a menace to national unity and therefore to national independence. ${ }^{260}$

Regarding Pakistan, Menon back in 1943 had had a heated discussion with Tajuddin, a Muslim member of his staff in Chunking. ${ }^{261}$ This had been a private debate, however. With independence becoming a realistic prospect, Menon in an official report positioned himself as a supporter of national unity and Congress. ${ }^{262}$ Furthermore, for the first time, Menon confessed to be anti-communist or, better, anti-totalitarian, a distinction to be kept in mind to assess his later term as ambassador in Moscow. Following a common cliché, he characterised the USSR as a steamroller continuing 'its relentless march through Manchuria'. ${ }^{263}$

For a short moment, in 1945, he was considered to succeed Caroe as foreign secretary. ${ }^{264}$ Amery saw no risk involved in appointing an Indian as 'India's external interests are essentially dominated by geography and would naturally be dealt with in consultation with His Majesty's Government very much as at present' ${ }^{265}$ Like Linlithgow, however, Wavell turned down Menon as 'rather a light weight'. ${ }^{266}$ Menon had proven a capable diplomat plus an extraordinary writer and speaker, but numerous taunting comments on his reports from China indicate that they were considered well written rather than relevant. Furthermore, Menon had never overseen a department, not even in officiating capacity, and openly displayed his dislike for deskwork. 
Menon used his years abroad for socialising and extending networks. Wartime China, however, was nearly cut off from the rest of the world. In a manner of speaking, both Bajpai and Menon had disappeared into the periphery. Whereas the former, however, was deeply frustrated, the latter enjoyed his term abroad. Nevertheless, Menon's career prospects were not much more promising. Bajpai, for sure, had no idea when his term might end, let alone what he would be offered thereafter. He was far from popular with Indian party leaders and had many influential antagonists among the British. On the contrary, Menon was in the good books of the British both in Delhi and London and could count on good relations in particular with Jawaharlal Nehru. Whether this would lead him anywhere, nevertheless, was uncertain. As the British did not consider him having backbone enough to head a department, he was likely to continue as a diplomat with few prospects of rising higher than the post he held.

Regarding the experience acquired, Bajpai held the much more relevant posting. China was not the backwaters of international politics, but developments there had much less immediate impact on both international affairs and the future of South Asia compared to those in North America. Future events would prove this true: Notwithstanding his unique knowledge of conditions on the ground including remote Sinkiang, Menon was appointed ambassador of independent India in Beijing but in the 1960s. During his term as foreign secretary from 1948 to 1952, he apparently did not exercise much influence on India's China policy. Though Bajpai could make much more use of his experiences in the US from 1947 onwards, it appears idle to discuss who among the two had more reason to complain about years wasted.

\section{Notes}

1 Indivar Kamtekar, 'The Shiver of 1942', Studies in History, 2002, 18(1): 81-102.

2 Amit Das Gupta, Serving India. A Political Biography of Subimal Dutt (19031992), India's Longest Serving Foreign Secretary, New Delhi: Manohar, 2017, pp. 84-106.

3 BL, IOR, L/PJ/7/3738. Note 1, Bajpai, 18 April 1940.

4 BL, IOR, L/PJ/7/3738. Note 2, Bajpai, 21 April 1940.

5 BL, IOR, L/PJ/7/3738. Note 4, Bajpai, 22 April 1940.

6 BL, IOR, L/PJ/7/3738. Note 5, Bajpai, 24 April 1940.

7 Sarvepalli Gopal, Nehru: A Biography, vol. I, New Delhi: Oxford University Press, 1975, p. 23.

8 Ibid., p. 91.

9 Ibid., p. 231.

10 Jawaharlal Nehru, Autobiography, London: Bodley Head, 1938, pp. 442-445.

11 Sunil Khilnani, The Idea of India, Gurgaon: Penguin Books, 1998, p. 81.

12 BL, IOR, L/PS/12/2636. Letter, Linlithgow to Amery, 5 September 1940.

13 BL, IOR, L/PS/12/2636. Letter, Linlithgow to Amery, 27 November 1940.

14 BL, IOR, L/PS/12/2636. Letter, Linlithgow to Amery, 9 September 1940. 
15 BL, IOR, L/PS/12/2636. Letter, Amery to Prime Minister Churchill, 25 October 1940.

16 BL, IOR, L/PS/12/2636. Letter, Amery to Linlithgow, 4 November 1940.

17 BL, IOR, L/PS/12/2636. Telegram, Linlithgow to Amery, 27 May 1941.

18 BL, IOR, L/PS/12/2636. Telegram, Linlithgow to Amery, 5 June 1941.

19 Bipan Chandra, Mridula Mukherjee, Aditya Mukherjee, K. N. Panikkar, and Sucheta Mahajan, India's Struggle for Independence 1857-1947, New Delhi: Penguin Books, 1988, pp. 448-454.

20 BL, IOR, L/PO/196. Note, Amery, 11 July 1941.

21 BL, IOR, L/PS/12/2636. Letter, Caroe to Bajpai, 7 October 1941.

22 BL, IOR, L/PS/12/2646. Letter, Linlithgow to Zafrullah Khan, 16 April 1942.

23 BL, IOR, L/E/8/2670. Note, FO, 18 July 1944.

24 Srinath Raghavan, Fierce Enigmas. A History of the United States in South Asia, New York: Basic Books, 2019, p. 128.

25 BL, IOR, L/PS/12/4627. Monthly Report, February 1944, Bajpai.

26 BL, IOR, L/E/8/2670. Note, Monteath, 5 July 1944.

27 BL, IOR, L/E/8/2670. Note, Monteath, 8 July 1944.

28 BL, IOR, L/E/8/2670. Letter, Amery to Wavell, 8 August 1944.

29 BL, IOR, L/E/8/2670. Letter, Wavell to Amery, 28 August 1944.

30 Foreign Relations of the United States (FRUS), Washington, DC: Government Printing Office, 1942, I, doc. 19. MEMCON, Berle, 2 January 1942.

31 Raghavan, Fierce Enigmas, p. 107.

32 The Transfer of Power, vol. I, Nicholas Mansergh and E.W.R. Lumby (eds.), London: Her Majesty's Stationery Office, 1970, doc. 5. Letter, Amery to Linlithgow, 5 January 1942.

33 NAI, EAD, 205-X/44. Monthly Report, July 1943, Bajpai, 6 August 1943.

34 Madhusree Mukerjee, Churchill's Secret War. The British Empire and the Ravaging of India during World War II, Chennai: Tranquebar Press, 2010, especially p. 10 .

35 Winston Churchill, India. Speeches and an Introduction, London: T. Butterworth, 1931, p. 11.

36 Ronald Hyam, Britain's Declining Empire. The Road to Decolonisation, 19181968, Cambridge: Cambridge University Press, 2006, pp. 64-65.

37 Ibid., p. 67.

38 Ibid., pp. 69-73.

39 Ibid., p. 66.

40 BL, IOR, L/PS/12/2636. Note, A.C.B. Symon for D.T. Monteath, 24 November 1941.

41 BL, IOR, L/PS/12/2636. Note, E. W. Light, 11 December 1941.

$42 \mathrm{BL}, \mathrm{IOR}, \mathrm{L} / \mathrm{PS} / 12 / 2636$. Note, Light to Secretary Political Department, 17 March 1942.

43 NAI, EHL, Overseas, 1929, B, August, 96. Telegram, Viceroy to SSI, 19 January 1929.

44 Hyam, Britain's Declining Empire, pp. 64-65.

45 BL, IOR, L/PS/12/2636. Telegram, Halifax to Foreign Office, 2 September 1942.

46 BL, IOR, L/PS/12/2636. Telegram 2486, Halifax to Foreign Office, 29 April 1942.

47 BL, IOR, L/E/PS/2636. Letter, Eden to Amery, 29 January 1943.

48 BL, IOR, L/PS/12/2636. Note, India Office, 22 July 1942.

49 BL, IOR, L/E/PS/2636. Note, Monteath, 1 February 1942.

50 BL, IOR, L/PS/12/2636. Note, India Office, 22 July 1942.

51 Raghavan, Fierce Enigmas, p. 105.

52 BL, IOR, L/PS/12/2636. Note, India Office, 2 July 1942. 
53 BL, IOR, L/PS/12/2636. Telegram 2113.8, Linlithgow to Amery, 17 July 1942.

54 BL, IOR, L/E/PS/2636. Note, India Office, 4 February 1942.

55 BL, IOR, L/PS/12/2636. Telegram 400-SC, Linlithgow to Amery, 3 October 1942.

56 BL, IOR, L/PS/12/2636. Telegram, Amery to Linlithgow, 25 September 1942.

57 CSAS, Frederick Puckle Papers, box 1, Mission to the US. Report, Puckle, Joyce, 8 May 1943.

58 BL, MSS Eur, D.714/61. Letter, Bajpai to Monteath, 5 April 1943.

59 BL, IOR, L/E/PS/2636. Note, Turnbull, 13 November 1943.

60 BL, IOR, L/E/PS/2636. Note, Amery, 15 November 1943.

61 The Transfer of Power, vol. IV, 1973, doc. 183. Letter, Amery to Wavell, 21 October 1943.

62 BL, IOR, L/E/PS/2636. Telegram, Wavell to Amery, 1 November 1943.

63 BL, IOR, L/E/PS/2636. Note, Monteath, 8 November 1943.

64 The Transfer of Power, vol. III, 1971, doc. 62. Letter, Linlithgow to Amery, 3 October 1942.

65 BL, IOR, L/E/PS/2636. Telegram, Caroe to Weightman, 17 November 1943.

66 The Transfer of Power, vol. IV, 1973, doc. 278. Letter, Wavell to Amery, 22 December 1943.

67 BL, IOR, L/E/PS/2636. Telegram 10168, Weightman to Caroe, 22 November 1943.

68 NAI, EAD, 205-X/44. Note, Caroe, 3 January 1944.

69 NAI, EAD, 205-X/44. Monthly Report, July 1943, Bajpai, 6 August 1943.

70 NAI, EAD, 205-X/44. Note, Weightman, 13 January 1944.

71 BL, IOR, L/E/PS/2636. Express Letter 875/S., Caroe to Amery, 24 December 1943.

72 BL, IOR, L/E/PS/2636. Note, Amery, 15 November 1943.

73 BL, IOR, L/E/PS/2636. Note, Peel, 17 November 1943.

74 BL, IOR, L/E/PS/2636. Letter, Halifax to Amery, 29 January 1944.

75 BL, IOR, L/E/PS/2636. Joint Memorandum, 24 April 1944.

76 The Transfer of Power, vol. IV, 1973, doc. 532, minute 2. Extract, War Cabinet Conclusions 100(44), 3 August 1944.

77 BL, IOR, L/E/PS/2636. Draft Letter, Amery to Wavell, undated.

78 The Transfer of Power, vol. IV, 1973, doc. 635. Letter, Amery to Wavell, 9 August 1944.

79 Ibid., doc. 670. Letter, Wavell to Amery, 23 August 1944.

80 Ibid., doc. 676. Letter, Amery to Wavell, 31 August 1944.

81 BL, IOR, L/E/PS/2636. Telegram 4461, Halifax to Wavell and Amery, 20 August 1944.

82 BL, IOR, L/E/PS/2636. Letter, Halifax to Eden, 27 June 1944.

83 The Transfer of Power, vol. IV, 1973, doc. 131. Letter, Pethick-Lawrence to Wavell, 5 October 1945.

84 Ibid., doc. 375. Memorandum, Pethick-Lawrence, 22 January 1946.

85 FRUS, 1942, vol. I, doc. 504. MEMCON, Berle, 28 February 1942.

86 Ibid., doc. 505. MEMCON, Berle, 4 March 1942.

87 The Transfer of Power, vol. I, 1970, doc. 621. Telegram, Bajpai to Linlithgow, 14 April 1942.

88 BL, IOR, L/PS/12/2636. Letter, Campbell to Robert Dunbar, Foreign Office, 5 August 1942.

89 Raghavan, Fierce Enigmas, pp. 110-112.

90 The Transfer of Power, vol. I, 1970, doc. 318. Telegram, Bajpai to Linlithgow, 12 March 1942.

91 Ibid., doc. 508. Telegram, Bajpai to Linlithgow, 2 April 1942.

92 Raghavan, Fierce Enigmas, p. 115. 
93 The Transfer of Power, vol. II, 1971, doc. 100. Telegram, Bajpai to Linlithgow, 26 May 1942.

94 BL, IOR, L/PS/12/2636. Telegram, Halifax to Foreign Office, 2 September 1942.

95 Auriol Weigold, Churchill, Roosevelt and India. Propaganda during World War II, New York: Routledge, 2008, pp. 70 and 73.

96 BL, IOR, L/PS/12/4627. Monthly Report March 1944, Bajpai.

$97 \mathrm{BL}, \mathrm{IOR} / \mathrm{L} / \mathrm{PS} / 12 / 4624$. 'India and the United States', Indian Institute of International Affairs, Bajpai, September 1944.

98 The Transfer of Power, vol. I, 1970, doc. 30. Letter, Linlithgow to Amery, 23-27 January 1942.

99 BL, IOR/L/I/1/1250. Telegram 69, GoI to Bajpai, 24 September 1942.

100 FRUS, 1942, I, doc. 493. Memorandum, Berle to Hull, 20 December 1941.

101 Ibid., doc. 476. Letter, Bajpai to Alling, 10 July 1942.

102 Johannes Voigt, Indien im Zweiten Weltkrieg, Stuttgart: Deutsche-VerlagsAnstalt, 1978, pp. 113-114.

103 FRUS, 1943, IV, doc. 295. MEMCON, Acheson, 4 March 1943.

104 BL, IOR, L/PS/12/4378. Note, Audrey Dibdin, 6 July 1944.

105 NAI, EAD, 217-X. Telegram 2730, Caroe to Bajpai, 10 March 1944.

106 NAI, EAD, 271-X/44. Report of the Visit on 24 March 1944, undated.

107 The Transfer of Power, vol. IV, 1973, doc. 601. Telegram, Amery to Wavell, 26 July 1944.

108 BL, IOR, L/PS/12/4624. Telegram 11455, Amery to GoI, Commerce Department, 24 May 1945.

109 NAI, EAD, 127-P.W.R./1945. Note, R. R. Burnett, 16 October 1945.

110 NAI, EAD, 127-P.W.R./1945. Telegram 254.SC, Wavell to Bajpai, 17 October 1945.

111 FRUS, 1942, vol. I, doc. 504. MEMCON, Berle, 28 February 1942.

112 Ibid., doc. 539. MEMCON, Murray, 24 April 1942.

113 Ibid., doc. 576. MEMCON, Berle, 1 July 1942.

114 Ibid., doc. 605. MEMCON, Berle, 12 August 1942.

115 Ibid., doc. 616. MEMCON, Alling, 4 September 1942.

116 See the assessment by Weigold, Churchill, Roosevelt and India, pp. 138-139.

117 Weigold, Churchill, Roosevelt and India.

118 The Transfer of Power, vol. II, 1971, doc. 201. Telegram, Halifax to Eden, 29 June 1942.

119 Weigold, Churchill, Roosevelt and India, pp. 69-70.

120 BL, IOR, L/PS/12/4627. Quarterly Report, July to September 1945, Bajpai.

121 BL, IOR, L/PS/12/4627. Monthly Report, August 1943, Bajpai.

122 BL, IOR, L/PS/12/4627. Quarterly Report, October to December 1945, Bajpai.

123 BL, IOR, L/PS/12/4627. Monthly Report, August 1943, Bajpai.

124 BL, IOR, L/PS/12/4627. Quarterly Report, October to December 1945, Bajpai.

125 BL, IOR, L/PS/12/4627. Quarterly Report, October to December 1944, Bajpai.

126 BL, IOR, L/PS/12/4627. Monthly Report, October 1943, Bajpai.

127 BL, IOR, L/PS/12/4627. Monthly Report, December 1943, Bajpai.

128 BL, IOR, L/PS/12/4627. Monthly Report, March 1944, Bajpai.

129 BL, IOR, L/PS/12/4627. Quarterly Report, July to September 1944, Bajpai.

130 BL, IOR, L/PS/12/4627. Quarterly Report, April to June 1944, Bajpai.

131 BL, IOR, L/PS/12/4627. Quarterly Report, July to September 1944, Bajpai.

132 BL, IOR, L/PS/12/4627. Quarterly Report, July to September 1945, Bajpai.

133 BL, IOR, L/PS/12/4627. Monthly Report, August 1943, Bajpai.

134 BL, IOR, L/PS/12/4627. Monthly Report, September 1943, Bajpai.

135 BL, IOR, L/PS/12/4627. Monthly Report, January 1944, Bajpai. 
136 BL, IOR, L/PS/12/4627. Monthly Report, February 1944, Bajpai.

137 BL, IOR, L/PS/12/4627. Quarterly Report, October to December 1944, Bajpai.

138 BL, IOR, L/PS/12/4627. Quarterly Report, July to September 1945, Bajpai.

139 BL, IOR, L/PS/12/4627. Quarterly Report, October to December 1945, Bajpai.

140 BL, IOR, L/PS/12/4627. Quarterly Report, July to September 1945, Bajpai.

141 For organisations and activities see Marika Sherwood, 'India at the Founding of the United Nations', International Studies, 1996, 33(4): 409-412.

142 BL, IOR, L/PS/12/4627. Monthly Report, August 1943, Bajpai.

143 BL, IOR, L/PS/12/4627. Monthly Report, October 1943, Bajpai.

144 BL, IOR, L/PS/12/4627. Monthly Report, March 1944, Bajpai.

145 FRUS, 1942, I, doc. 351. Letter, Bajpai to Berle, 24.4.1943.

146 The Transfer of Power, vol. V, 1974, doc. 179. Memorandum, Amery, 3 January 1945.

147 BL, IOR, L/PS/12/4627. Quarterly Report, October to December 1944, Bajpai.

148 BL, IOR, L/PS/12/4627. Quarterly Report, January to March 1945, Bajpai.

149 BL, IOR, L/PS/12/4627. Handwritten Comment Caroe on Note, J. P. Jervis, 4 February 1945.

150 The Transfer of Power, vol. V, 1974, doc. 254. Letter, Amery to Wavell, 7 February 1945.

151 BL, IOR, L/PS/12/4627. Quarterly Report, April to June 1945, Bajpai.

152 Sherwood, 'India at the Founding of the United Nations', 428.

153 Dennis Kux, Estranged Democracies. India and the United States 1941-1991, New Delhi: Sage, 1993, pp. 47-48.

154 BL, IOR, L/PS/12/4627. Quarterly Report, October to December 1945, Bajpai.

155 NMML, KPSMP, Diary 1946, 4 September.

156 BL, MSS Eur, F.203/84. 'Springs of Enchantment. A Saga of East and West, written with Assistance of George Chowdhary-Best', unpublished book manuscript, 1980/81, Caroe, pp. 9-10.

157 The Transfer of Power, vol. V, doc. 396. War Cabinet, 20th meeting, 18 April 1945.

158 BL, IOR, L/PO/10/22. Letter, Wavell to Pethick-Lawrence, 5 November 1945.

159 The Transfer of Power, vol. V, doc. 640. Letter, Amery to Wavell, 28 July 1945.

160 NMML, KPSMP, Diary 1945, 1 March.

161 NMML, KPSMP, Diary 1945, 9 July.

162 NMML, KPSMP, Diary 1945, 11 July.

163 NMML, KPSMP, Diary 1946, 9 December.

164 NMML, KPSMP, Diary 1943, 9 February.

165 NMML, KPSMP, Diary 1934, 1 November.

166 NMML, KPSMP, Diary 1936, 1 September.

167 NMML, KPSMP, Diary 1936, 23 July.

168 NMML, KPSMP, Diary 1936, 12 June.

169 NMML, KPSMP, Diary 1936, 1 November.

170 NMML, KPSMP, Diary 1941, 23 November.

171 NMML, KPSMP, Diary 1937, 22 January.

172 NMML, KPSMP, Diary 1937, 27 February.

173 NMML, KPSMP, Diary 1937, 19 March.

174 NMML, KPSMP, Diary 1937, 21 July.

175 NMML, KPSMP, Diary 1938, 12 February.

176 NMML, KPSMP, Diary 1942, 7 August.

177 NMML, KPSMP, Diary 1942, 19 September.

178 NMML, KPSMP, Diary 1942, 17 August.

179 NMML, KPSMP, Diary 1942, 13 September. 
180 NMML, KPSMP, Diary 1936, 13 April.

181 NMML, KPSMP, Diary 1936, 20 May.

182 NMML, KPSMP, Diary 1942, 16 April.

183 NMML, KPSMP, Diary 1936, 11 June.

184 NMML, KPSMP, Diary 1939, 2 February.

185 NMML, KPSMP, Diary 1939, 7 March.

186 NMML, KPSMP, Diary 1940, 17 October.

187 NMML, KPSMP, Diary 1942, 25 February.

188 NMML, KPSMP, Diary 1942, 4 April.

189 NMML, KPSMP, Diary 1939, 1 October.

190 NMML, KPSMP, Diary 1939, 3 October.

191 Geoffrey Moorhouse, Calcutta, Harmondsworth: Penguin Books, 1973, p. 19.

192 Kris Manjapra, M. N. Roy. Marxism and Colonial Cosmopolitanism, London: Routledge, 2010, p. 123.

193 NMML, KPSMP, Diary 1942, 17 February.

194 NMML, KPSMP, Diary 1942, 11 March.

195 NMML, KPSMP, Diary 1942, 29 March.

196 NMML, KPSMP, Diary 1942, 2 April.

197 NMML, KPSMP, Diary 1942, 19 April.

198 NMML, KPSMP, Diary 1943, 19 June.

199 NMML, KPSMP, Diary 1942, 16 March.

200 NMML, KPSMP, Diary 1943, 18 July.

201 NMML, KPSMP, Diary 1943, 14 January.

202 NMML, KPSMP, Diary 1943, 10 February.

203 NMML, KPSMP, Diary 1943, 2 March.

204 NMML, KPSMP, Diary 1943, 7 March.

205 NMML, KPSMP, Diary 1943, 23 March.

206 NMML, KPSMP, Diary 1943, 7 March.

207 NMML, KPSMP, Diary 1943, 14 May.

208 BL, IOR, L/PS/12/2646. Letter, Linlithgow to Amery, 31 March 1942.

209 BL, IOR, L/PS/12/2646. Telegram 2791-S, Linlithgow to Amery, 15 September 1942.

210 BL, IOR, L/PS/12/2648. Report for 27 May to 2 October 1942, Zafrullah Khan, 2 October 1942.

211 BL, IOR, L/PS/12/2646. Telegram 7329, EAD to SSI, 16 September 1942.

212 BL, IOR, L/PS/12/2646. Telegram, Linlithgow to Amery, 31 October 1942.

213 BL, IOR, L/PS/12/2646. Telegram, Amery to Linlithgow, 9 November 1942.

214 NMML, KPSMP, Diary 1943, 9 February.

215 BL, IOR, L/PS/12/2646. Telegram, Amery to Linlithgow, [November 1942].

216 BL, IOR, L/PS/12/2646. Telegram 3287-S, Linlithgow to Amery, 19 November 1942.

217 BL, IOR, L/PS/12/2646. Note, Rumbold to Peel, 26 November 1942.

218 BL, IOR, L/PS/12/2646. Telegram 628-SC, Linlithgow to Amery, 28 December 1942.

219 BL, IOR, L/PS/12/2646. Telegram 636-SC, Linlithgow to Amery, 29 December 1942.

220 BL, IOR, L/PS/12/2646. Letter, Peel to Ashley Clarke, 2 January 1943.

221 BL, IOR, L/PS/12/2646. Note, Rumbold, 31 December 1942.

222 NMML, KPSMP, Diary 1943, 20 September.

223 NAI, EAD, 964-X/43. Note, Weightman, 5 September 1943.

224 NMML, KPSMP, Diary 1943, 18 October.

225 NMML, KPSMP, Diary 1943, 23 October. 
226 NMML, KPSMP, Diary 1943, 26 September.

227 NMML, KPSMP, Diary 1943, 27 September.

228 NMML, KPSMP, Diary 1943, 2 November.

229 Maria Framke, "We Must Send a Gift Worthy of India and the Congress!" War and Political Humanitarianism in Late Colonial South Asia', Modern Asian Studies, 2017, 51(6): 1969-1998.

230 NMML, KPSMP, Diary 1943, 6 December.

231 NMML, KPSMP, Diary 1943, 31 December.

232 NMML, KPSMP, Diary 1943, 14 December.

233 NMML, KPSMP, Diary 1943, 25 February and 8 March.

234 BL, L/PS/12/2648. Quarterly Report October to December 1943, Menon, 12 January 1944.

235 NAI, 977-X/43. Letter, Caroe to Bajpai, 14 February 1944.

236 NAI, 1014-X/44. Note, Caroe, 20 June 1944.

237 NAI, 1014-X/44. Note, Richardson, 3 November 1944.

238 NMML, KPSMP, Diary 1943, 18 March.

239 NMML, KPSMP, Diary 1945, 28 May.

240 Parshotam Mehra, The Younghusband Expedition (to Lhasa): An Interpretation, New Delhi: Gyan Publishing House, 2005, 2nd edition.

241 Bérénice Guyot-Réchard, Shadow States. India, China and the Himalayas, 1910-1962, Cambridge: Cambridge University Press, 2017, pp. 51-52.

242 Ibid., pp. 56-57.

243 Ibid., pp. 60-63.

244 NAI, EAD, 964-X/43. Report for 1942-43, Richardson, 25 August 1943.

245 Guyot-Réchard, Shadow States, pp. 67-76.

246 NAI, EAD, 103-C.A./44. Letter, Menon to Caroe, 14 June 1944.

247 NAI, EAD, 103-C.A./44. Note, Menon, 13 June 1944.

248 NMML, KPSMP, Diary 1946, 11 March.

249 BL, IOR, L/PS/12/2648. Minute, External Dept. India Office, 13 March 1944.

250 NAI, EAD, 406-C.A./55. D.O. 1118-H/6/S-42, Gillett to J.S. Weightman, 29 December 1943.

251 NAI, EAD, 448-C.A. Letter, Menon to Caroe, 25 October 1944.

252 NAI, EAD, 448-C.A. Letter, Menon to Caroe, 19 December 1944.

253 NAI, EAD, 448-C.A. Note, Weightman, 12 February 1945.

254 NMML, KPSMP, Diary 1945, 1 February.

255 Peter Fleming, News from Tartary. A Journey from Peking to Kashmir, London: Cape, 1936.

256 K.P.S. Menon, Delhi-Chungking: A Travel Diary, Bombay: Oxford University Press, 1947.

257 BL, IOR, L/PS/12/2648. Quarterly Report October to December 1943, Menon, 12 January 1944.

258 BL, IOR, L/PS/12/2648. Quarterly Report January to March 1944, Menon, 9 April 1944.

259 BL, IOR, L/PS/12/2648. Quarterly Report 11 June to 30 September 1944, Napier, 25 October 1944.

260 BL, IOR, L/PS/12/2648. Annual Report 1945, Menon, 23 January 1946.

261 NMML, KPSMP, Diary 1943, 21 October.

262 BL, IOR, L/PS/12/2648. Report April to 15 June 1946, Menon, June 1946.

263 BL, IOR, L/PS/12/2648. Annual Report for 1945, Menon, 23 January 1946.

264 NMML, KPSMP, Diary 1945, 21 April.

265 BL, IOR, L/PO/10/22. Letter 51, Amery to Wavell, 19 July 1945.

266 BL, IOR, L/PO/10/22. Letter 75, Wavell to Pethick-Lawrence. 


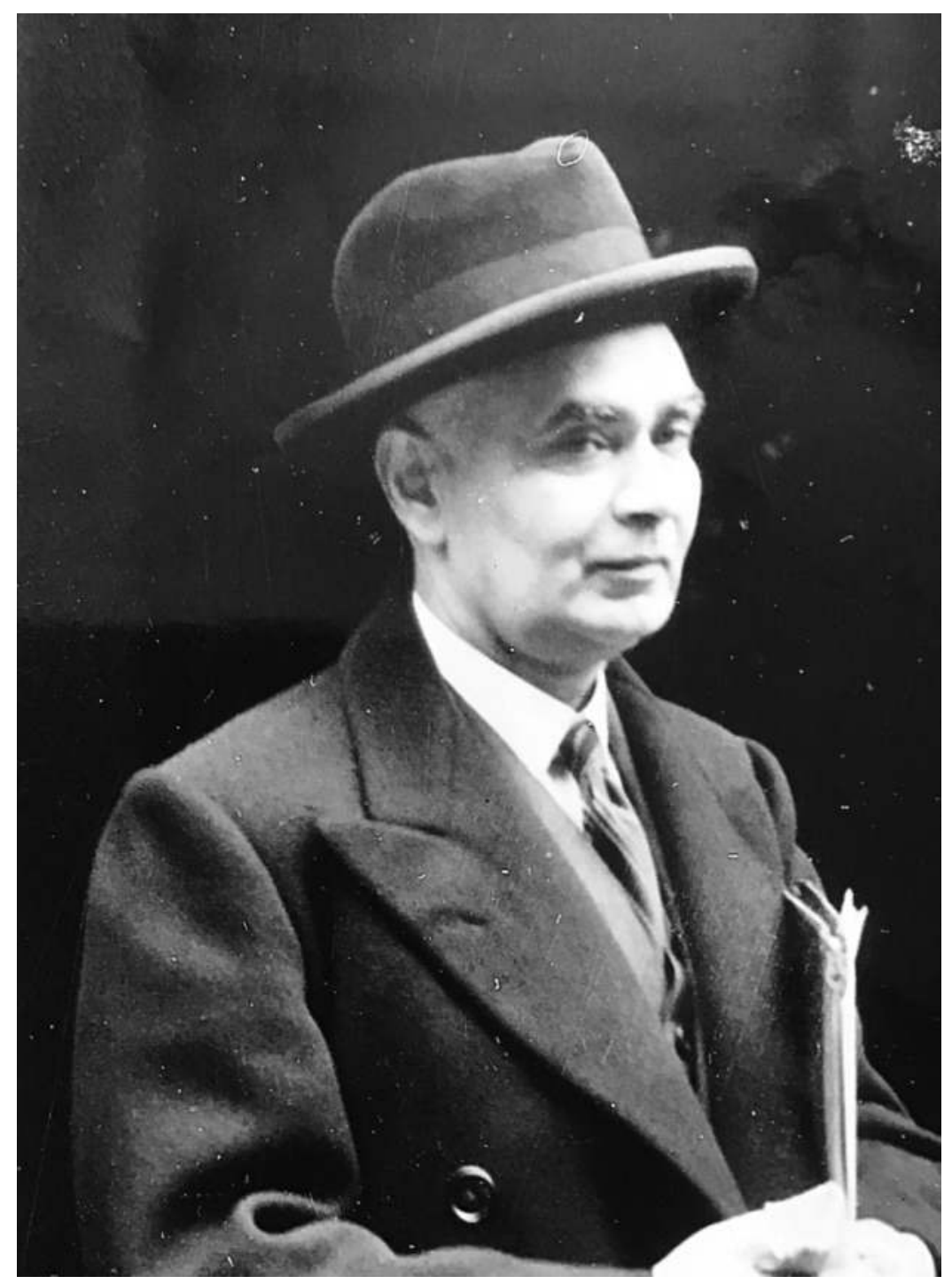

Figure 1 Girja Shankar Bajpai as Secretary-General of the Ministry of External Affairs

Source: K.S. Bajpai 


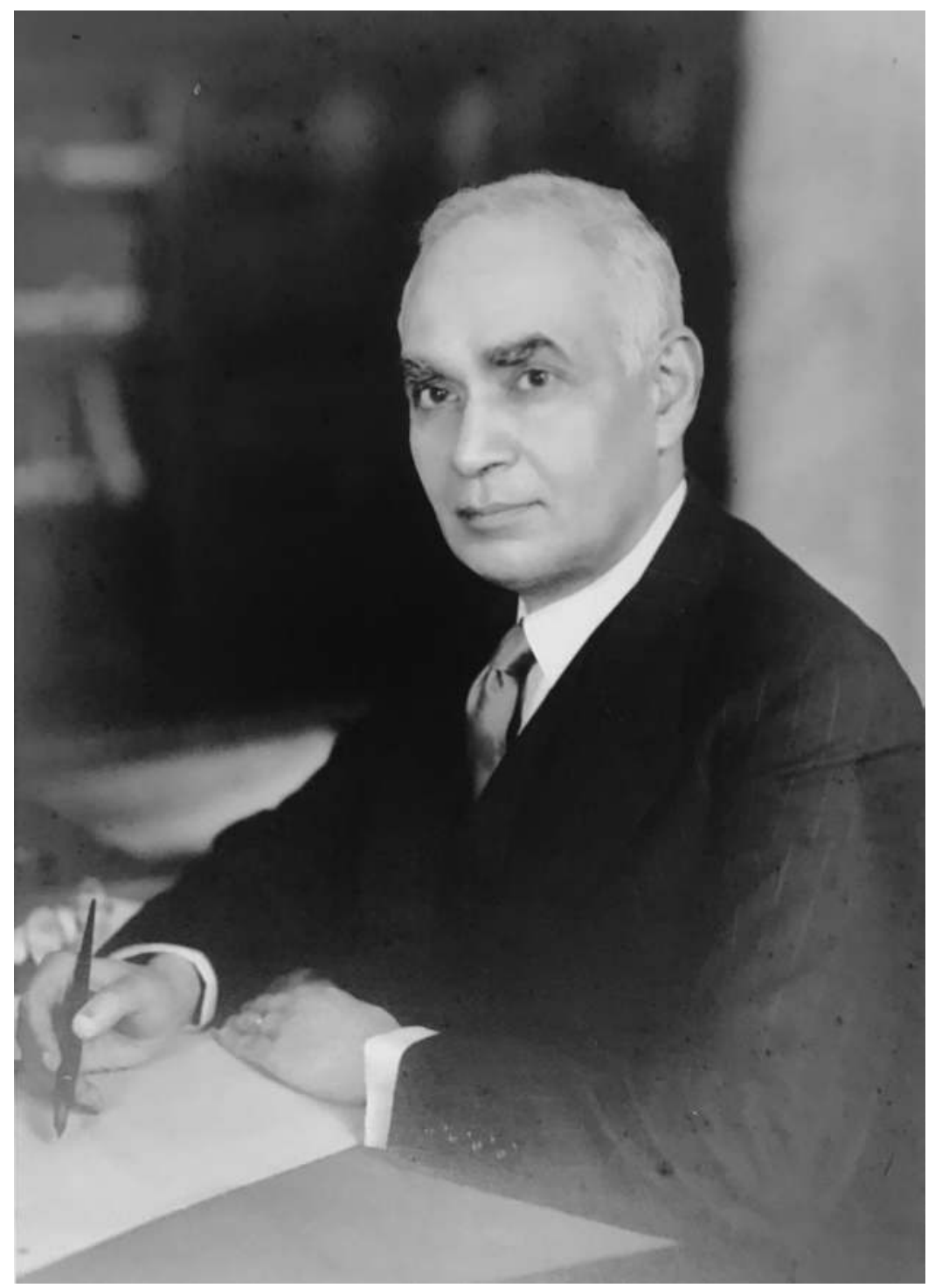

Figure 2 Girja Shankar Bajpai in his study

Source: K.S. Bajpai 


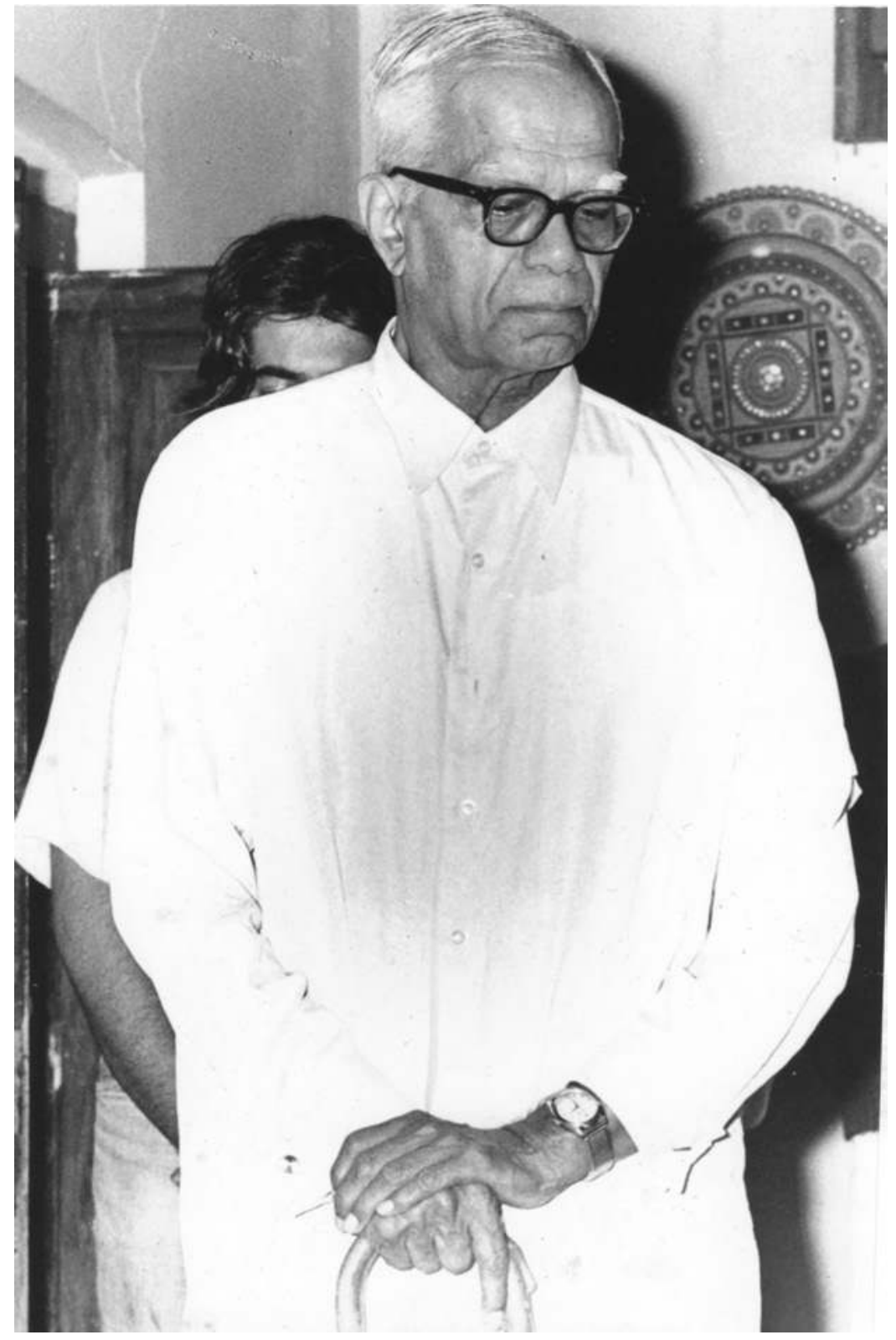

Figure 3 K.P.S. Menon at a family ceremony Source: Shivshankar Menon 


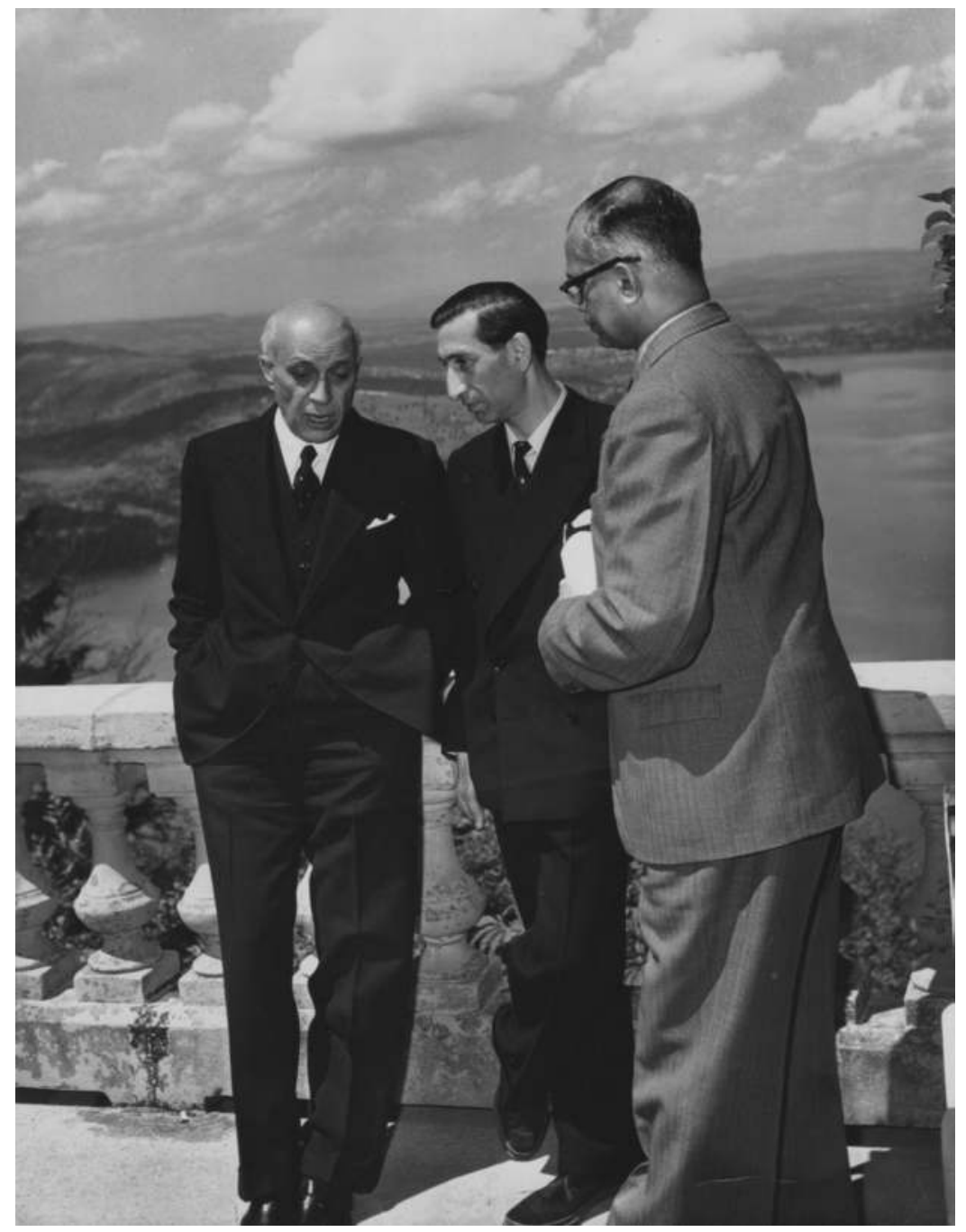

Figure 4 K.P.S. Menon with Jawaharlal Nehru and Y.D. Gundevia Source: Shivshankar Menon 


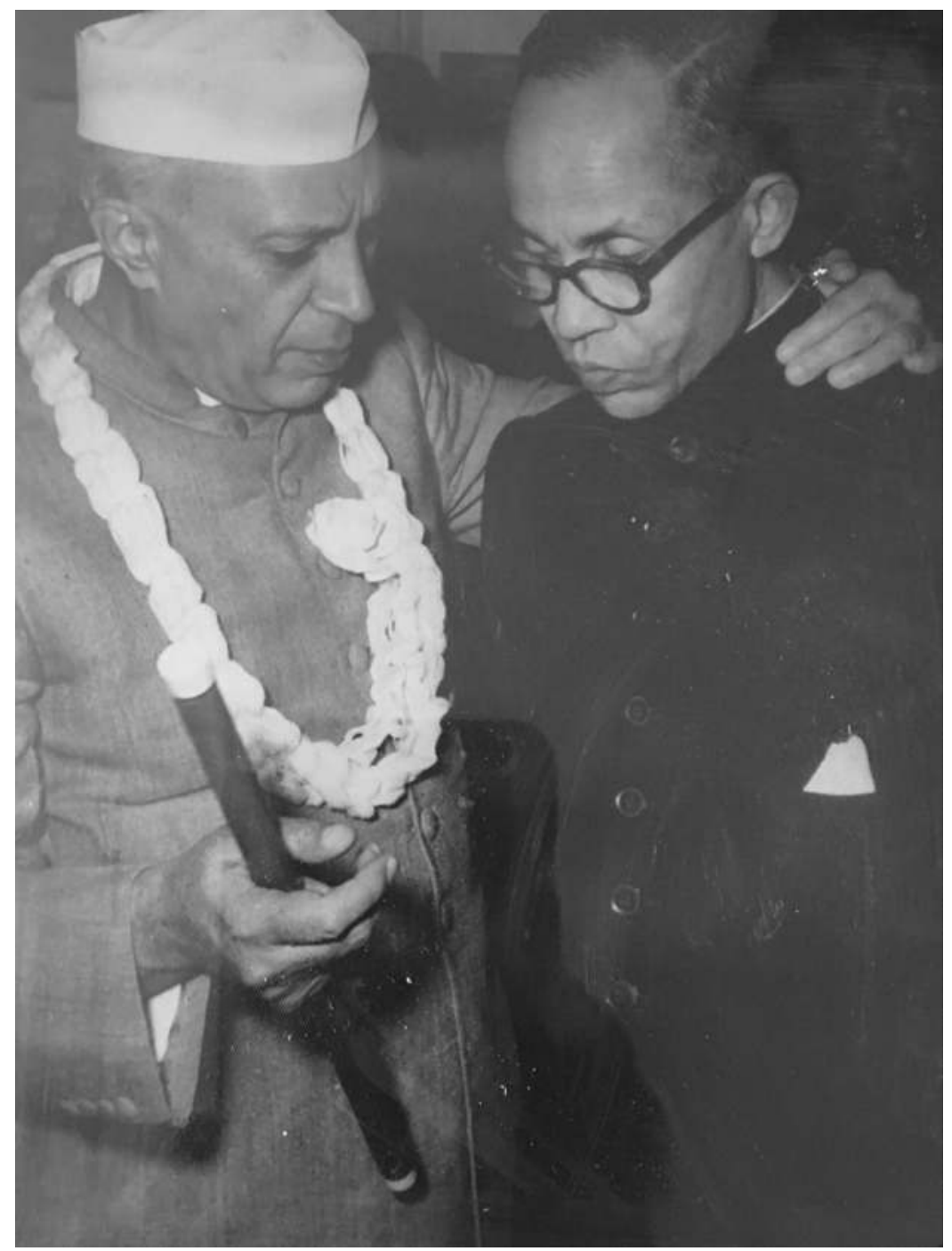

Figure 5 Subimal Dutt with Jawaharlal Nehru Source: Supriya Guha 


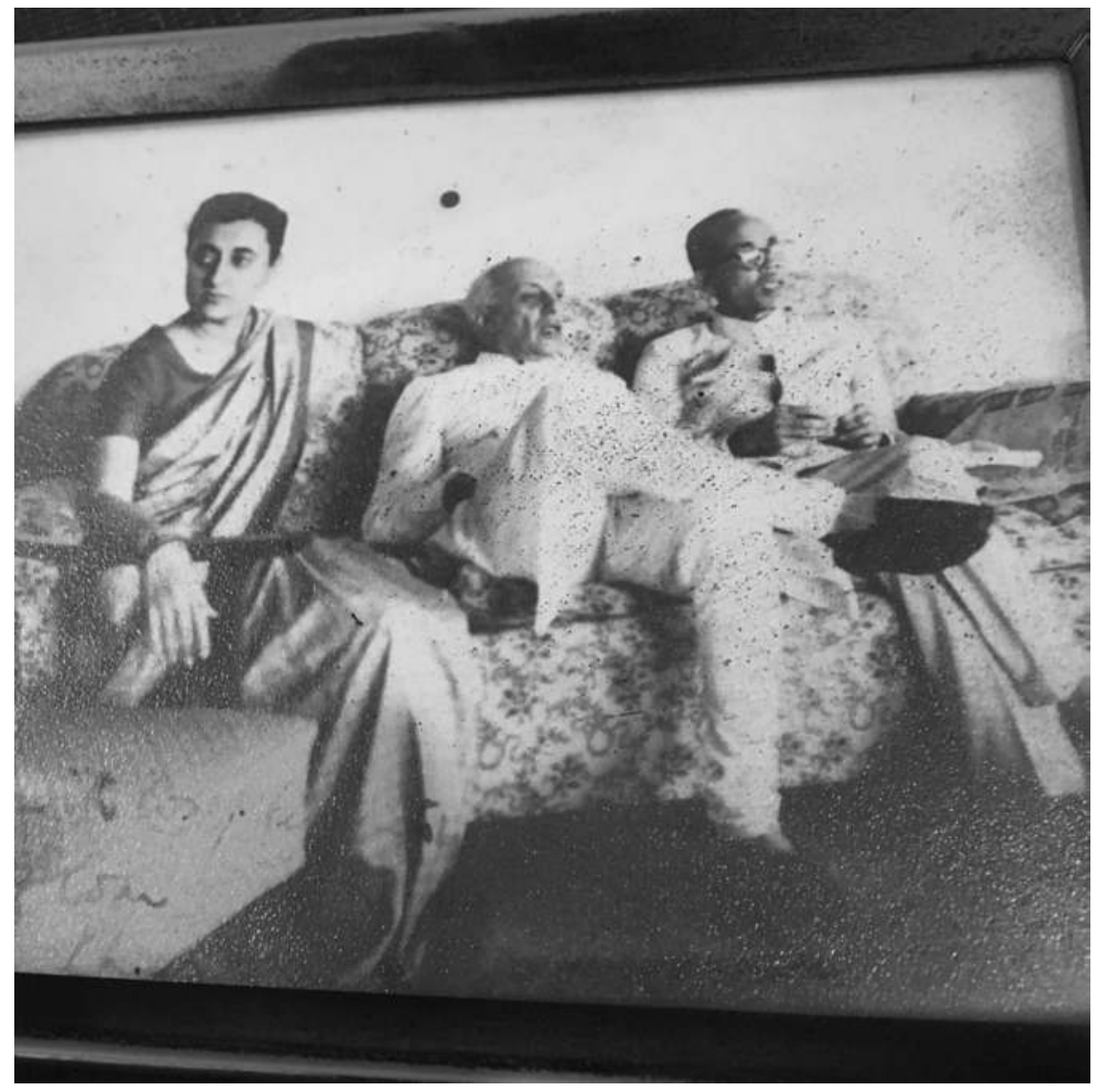

Figure 6 Subimal Dutt with Jawaharlal Nehru and Indira Gandhi Source: Supriya Guha 


\section{Part III}

NEHRUVIAN FOREIGN POLICY 
$\Longrightarrow$ Taylor \& Francis

Taylor \& Francis Group

http://taylorandfrancis.com 


\section{0 \\ RETURN TO POWER}

\section{K.P.S. Menon as Nehru's foreign policy advisor}

Until December 1946, Bajpai had nothing to hope for. On the contrary, Caroe offered Menon an interesting and relevant role as secretary of the Indian delegation to the UN Conference on International Organization. ${ }^{1}$ At what is commonly known as the San Francisco Conference, held between 25 April and 26 June 1945, the delegates finalised the UN Charter. Menon was briefed in Delhi, expecting criticism of the provisions for voting. ${ }^{2}$ Regarding the delegation, he welcomed the participation of Mudaliar, said to create 'a very good impression in committees', and scoffed at Malik Feroze Khan Noon's attempts to have his wife included. ${ }^{3}$ This corresponded with Menon's political preferences: Feroze Khan led the Unionist Party, opposing independence. After a four-year term as high commissioner in London, in 1941 he had been appointed Churchill's military advisor on the Indian Army. Later, in his capacity as labour minister, he joined the Viceroy's Executive Council. Since 1944, together with Mudaliar, he represented British India in the Pacific War Council, and he soon would be appointed British India's permanent representative to the UN. There was nothing that could have endeared him to Menon.

There were four more officials with the delegation. Robert Francis Mudie and Mohammed Ikramullah favoured the Pakistan Movement, P. A. and especially V.P. Menon were considered supporting the Congress. K.P.S. Menon considered the delegation the best the GoI could recruit from its own ranks, but he lamented the absence of Nehru. ${ }^{4}$ A meeting of the Viceroy's Executive Council he found 'a depressing affair', as none of its members understood the relevance of the upcoming conference. ${ }^{5}$ While socialising with British officials and Wavell, Menon was also anxious to keep in touch with the powers to come: A few days before his departure, he enjoyed a party with Nehru and N.R. Pillai. ${ }^{6}$

On 1 April he arrived in London, taking part at a conference where representatives of various parts of the Empire prepared for San Francisco. At the same time, the Indian delegation together with Wavell discussed the future 
of India. Menon praised the viceroy for 'doing his best to end the political deadlock' and having a vision for India. Wavell, however, faced stiff opposition 'from diehards like [Chancellor to the Exchequer and former Governor of Bengal John] Anderson and stick-in-the-winds [Clemence] Attlee'. ${ }^{7}$ Furthermore, Mudie and Feroze Khan were 'trying their hardest to wreck the viceroy's efforts at a settlement. . . . The India Office, I am told, is thoroughly obscurantist and obstructionist'. ${ }^{8}$

Attending a meeting at 10 Downing Street, Menon found Churchill 'his usual self; and his remark that China can have Hongkong over his dead body was characteristic'. ${ }^{9}$ On the contrary, he was impressed by Smuts ${ }^{10}$ and other representatives of the dominions. Compared to them, Menon considered the Indian delegates 'pretty poor ... though Ramaswami Mudaliar occasionally makes a good speech. May Nehru come here!'11 Himself, Menon criticised for being capable to 'face an auditory in a big hall, but not a committee'. ${ }^{12}$

Having arrived in San Francisco on 22 April, Menon attended his first major international conference, a quarter century after Bajpai. There were 50 countries participating, but colonies were excluded. British India and the Philippines formed the exception; ${ }^{13}$ their representatives, however, were selected by the colonial governments. Mrs Pandit was around but was not an official part of the conference. In his usual informal manner, Menon saw no problem in meeting her at a dinner party and was charmed. ${ }^{14}$

The official delegation was far from unanimous: While Mudaliar kept 'aloof from Indian internal politics altogether', ${ }^{15}$ Feroze Khan launched 'a most vicious attack on Gandhiji and the Congress'. ${ }^{16}$ During the conference, reforms were announced in India. Menon privately jubilated when he learned that Congress leaders were released from jail and all portfolios but defence would be transformed into Indian ministries. Indian representatives were meant to be appointed to foreign countries soon. ${ }^{17}$

Menon's comments on the conference sometimes show him as a newcomer to power politics. Back-door deals, for example, took him by surprise. ${ }^{18}$ One of his tasks was to author a report on the trusteeship debate. Not a bureaucrat at heart, he found nothing in 'interminable discussions on procedure' in committees headed by 'incompetent and inexperienced chairmen'. ${ }^{19}$ In vain, he hoped that London would set an example, ${ }^{20}$ but was not surprised about the unchanged British and French attitude vis-à-vis colonialism. ${ }^{21}$ Regarding the conflict around the veto right, Menon was disappointed that it remained an exclusive right of the Permanent Five. ${ }^{22}$

What truly intrigued him was the power struggle between the USSR and its antagonists. Major debates concerned the extent of the veto right of the great powers ${ }^{23}$ and admission to the UN. The latter was part of a wider struggle around which parts of Europe would come under Soviet control. Menon saw former allies blaming each other 'of tactics similar to those of Hitler and Franco', feared another world war and was upset that 'we are 
fiddling while Europe is burning! ${ }^{24}$ Accordingly, he was relieved when the 'the biggest stumbling block' was overcome and the USSR finally gave up its claim that the veto right applied even to the discussion and consideration of any dispute..$^{25}$

Menon was fascinated by the Soviets and especially Molotov, whom he found a powerful speaker ${ }^{26}$ and clever tactician. ${ }^{27}$ In his official report, he elaborated that the foreign minister knew how to play public opinion. Stalin had originally demonstrated indifference by sending only the ambassador in Washington, Andrei Andreyevich Gromyko. He had changed his mind after Roosevelt's death on 12 April had made the course of the conference uncertain. Molotov's 'somewhat brazen attempt' to get communist Poland admitted against the Polish government-in-exile failed, but he scored a moral victory regarding the admission of Argentine, which London and Washington supported 'with indecent haste', although it was

so notoriously fascist. ... Equally cunning was his incidental, and seemingly innocent, reference to the presence of the Indian delegation at the Conference and the hope which he expressed amidst loud cheers that 'we all hope that before long the voice of an independent India will be heard at the conference'.

Fascination did not necessarily mean sympathy: Menon considered Soviet tactics as unscrupulous. Molotov, before his departure, had casually announced the arrest of 15 Poles. Thereafter, friction over the occupation zones in Germany or the treatment of Soviet POWs by the UK grew even worse. Menon found Soviet gestures mostly cosmetic:

Unashamedly Russia set her face against all proposals for liberalizing the Charter - with one significant exception. On the question of international trusteeship she was on the side of the angels. She was keen that independence, and not self-government alone, should be the objective of colonial policy.

This was a move clearly 'playing for the gallery'.

In the conclusion of his report, Menon found the USSR showing

in her true colours - strong, determined, pugnacious, certain of the end and unmindful of the means, insusceptible to 'appeasement', defiant of public opinion and yet only too ready to court public opinion so as to cause embarrassment to others.

Mudaliar in a speech had wisely commented that 'some nations . . . are still young in international cooperation'. Menon, nevertheless, showed an understanding of the causes of Soviet politics partly similar to Bajpai but 
otherwise rather unusual in those years. He wondered whether Moscow's expansionism did not

merely signify an exaggerated and - in the light of the events of the last 25 years - not altogether unjustified search for security on her borders ... There is little doubt that Russia's uncouth tactics in San Francisco as well as her unprincipled conduct in Europe are largely traceable to the fact of her prolonged isolation and the fear of being isolated in the future.

Menon believed that ending the isolation of the USSR might be 'the greatest achievement of the San Francisco Conference', though eternal vigilance would be needed to keep her there. ${ }^{28}$ Mudaliar added two distinct impressions: No Soviet delegate could take any decision without reference to Moscow. Furthermore, bluffing was a typical feature of Soviet diplomacy, best to be tackled by 'counter-bluff or rather by straight talk'. ${ }^{29}$

Menon's fascination with the USSR cannot come as a surprise. Since his term in the FPD it had played a role in his work, but only San Francisco provided first-hand experience. His responses were characteristic; no resentment or sympathy coloured his rational analysis of Soviet moves and motives. There were neither traces of the instinctive disgust felt by so many British and Indian officials and politicians nor the whitewashing so characteristic for leftists all over the world, including Nehru or V.K. Krishna Menon.

Menon was back in Chungking in late 1945, keen to play a more permanent role in global politics. More than once, in early 1946, he played host for Soviet diplomats, finding them sympathetic. ${ }^{30}$ Reading 'Russia without Illusions', ${ }^{31}$ Menon appreciated that the authors had 'disposed of many illusions - or distortions' around the country he urgently wished to visit. ${ }^{32}$ Furthermore, his diaries show close interest in the UN combined with dislike against the predominance of western interests. The Netherlands, for example, 'playing an unenviable part in Indonesia', was elected as a nonpermanent member of the UNSC, while India's candidature failed..$^{33}$ The same body refused to discuss Iran, where both British and Soviet forces had occupied parts of the territory. ${ }^{34}$ In Menon's eyes, notwithstanding 'highsounding platitudes' in the Charter, 'the underdogs still have no place in this world'. ${ }^{35}$

Unlike Bajpai, Menon was not much troubled by his status; he understood that nothing would change in Chungking unless the post in Washington was upgraded. ${ }^{36}$ Instead, from mid-February 1946, his focus switched towards India, where the second round of trials against members of the INA caused demonstrations and riots. Menon's diary entries indicate sympathy for the culprits, typically excluding Abdul Rashid for being 'the only one who set up a communal instead of a nationalistic defence for his case'. ${ }^{37}$ 
With keen interest, the agent-general followed the Cabinet Mission, arriving in Karachi on 23 March. It was meant to discuss the transfer of power while preserving the unity of India. Menon welcomed Attlee's statement 'that "the minority will not be allowed to veto the majority"', referring to Muslims and Hindus. ${ }^{38} \mathrm{He}$ was deeply concerned about Muslim politicians, Jinnah 'more and more obstreperous' and uncompromising ${ }^{39}$ and Feroze Khan, having been 'a lackey of Whitehall', threatening with civil war or even calling for Soviet help. ${ }^{40}$ When the Cabinet Mission's proposals from 16 May turned down partition, he jubilated that 'at long last the Jinnah bubble has been pricked' ${ }^{41}$ Nevertheless, he still harboured hopes for a compromise between the Congress and the Muslim League and their cooperation in an interim government. When Wavell clarified that he was anxious for Nehru to join, Menon found Jinnah's response 'not so dictatorial as usual nor does it breathe blood and thunder as before'. ${ }^{42}$

It was a lucky coincidence that Menon spent some time in India for the marriage of one of his daughters. From close distance, he watched the attempts to form an interim government under Nehru. Initially, the Mus$\lim$ League refused, but the agent-general wished that 'the caravan will go on' notwithstanding Jinnah and the Direct Action Day. ${ }^{43}$ Furthermore, he observed Foreign Secretary Weightman 'in a flat spin over Nehru becoming member of the External Affairs Department'. The same was true for plans to make Ikramullah Joint Secretary, whom Menon still considered communal, his wife 'a rioting Muslim League propagandist'. ${ }^{44}$

Menon himself came to ride the wave. For the time being, Nehru wanted him to stay and prepare a memorandum on UN matters. On request of Mrs Pandit, leader of India's next delegation to the UN, Menon was to join once again, ${ }^{45}$ though he had doubts about her capability of presenting the South African case. ${ }^{46}$ Once the interim government had been sworn in, he thoroughly enjoyed getting a bit of the attention: 'Nehru was charming to me. Coming out of his room, he put his arm round mine; and we walked arm in arm, to the astonishment of clerks and chaprassies and so on!' Menon's new role, however, meant mostly hard work and political manoeuvres. He 'foiled Weightman's attempt to foist a Muslim Leaguer ... in our delegation', instead trying to win Fazl-i Husain's son Azim Husain, 'a non-communal Muslim'. ${ }^{47}$ Moderate politicians who had earlier worked with the DEHL like Kunzru declined; Raza Ali was 'awaiting Jinnah's pleasure'. The obvious choice, Bajpai, was 'persona non grata to the Congress'. ${ }^{48}$

In a manner of speaking, Menon started playing a double game. On the one hand, he was Nehru's informant, warning him of the EAD's negative attitude towards a forthcoming mission of Maulana Abul Kalam Azad to the Middle East. On the other hand, he was keen to please Weightman. ${ }^{49}$ Nehru was grateful, asking him not to return to China. ${ }^{50}$ According to Menon's diaries, he functioned as the vice-president's right-hand man, among others, advising him on postings. ${ }^{51}$ 
Almost immediately, however, there turned out to be a major point of dissent. Like so many others, K.P.S. Menon disapproved of Krishna Menon, both for his role and his personality. On the surface, the two Menons had more in common than their surnames. Krishna was but three years senior and had also grown up in what today is Kerala. Both fathers had studied law and both sons underwent a part of their education in Madras. Both left for England, but here the parallels end. Whereas K.P.S. applied for the ICS, Krishna took time for an extended academic education and joined the British Labour Party, being elected borough councillor of St. Pancras in London. He was leftist and wrongly suspected to have joined the Communist Party. From 1929, his work for the India League became his main occupation, Menon transforming the campaign for independence 'from an uncoordinated and ineffectual movement into a cohesive and dynamic political force'..$^{52}$ In his capacity as secretary, he came in touch with many protagonists of the independence movement, the most prominent and relevant of which was Nehru. Their first encounter in November 1935 was the beginning of a friendship lasting until India's humiliating defeat against China in 1962. The future prime minister of India was impressed by Menon's brainpower but also noted that he had 'the virtues and the failings of the intellectual'. ${ }^{53}$ By 1946, Krishna Menon was a prominent overseas Indian with much experience in campaigning. Having left India in 1924, however, he had hardly maintained any links with South Asia. Furthermore, he could not provide any experience qualifying him for any diplomatic mission. This did not mean that Nehru or Krishna Menon did not consider him perfectly qualified for every task.

In the last week of September 1946, the vice-president insisted on establishing direct contacts with other countries. Though India was still a colony, it would otherwise be impossible to play any effective role in international politics. 'The foundation for this must be laid by semi-official and rather informal approaches which do not commit any party and yet will help to understand each other'. Those who had worked for the British should not be employed, as 'that would in effect be a British approach with the background of British foreign policy'. India would be looked upon as a satellite. ${ }^{54}$ In December, Nehru elaborated that he was 'anxious to have public men as our ambassadors as far as possible, more especially in regard to our first appointments'. ${ }^{55}$

Regarding foreign affairs, Nehru specified that new India would keep away from antagonistic groups of powers. It would work 'with other peace-loving nations for international cooperation and goodwill without exploitation of one nation by another' - a meaningless standard confession in international politics. The interim government would send a goodwill mission to the Middle East, whereas Krishna Menon was to establish diplomatic relations all over Europe. India needed a foreign service and about 300 diplomats for a start. There were, however, only 50 available commanding some experience from work with the existing agencies plus Australia. Apart from Bajpai 
and K.P.S. Menon, S.K. Chettur in Malaya was the only ICS officer among them. ${ }^{56}$

On 19 September, the two Menons came to know each other, K.P.S. finding Krishna 'a bit of a poser', ${ }^{57}$ 'essentially an egoist' ${ }^{58}$ Almost immediately, they took opposite sides. When Wavell spoke out against sending Krishna on a roving mission to Europe, K.P.S. produced a note emphasising 'that "personal representatives" are not very popular'. ${ }^{59}$ This challenged the wisdom of Nehru's claim that they had become a common feature and 'can work unofficially and informally' ${ }^{60}$ The vice-president was not pleased, ${ }^{61}$ and he was even less so when facing opposition in cabinet too. Krishna Menon proved his opponents right when meeting Molotov in Paris on 28 September 1946.

\section{Krishna Menon and the USSR}

The idea to approach Moscow for food dated back to spring when Mudaliar, in vain, had made a 'very strong and direct appeal' to the Soviet delegation in San Francisco. ${ }^{62}$ Nehru had taken up the issue once again, while Weightman counselled against it: The USSR hitherto had kept out of international organisations for pooling and distributing food grains.

The Russians are determined and aggressive bargainers, and I fear that the very urgency of our need would determine them to raise their bid. This is not the time, I suggest, to invite the impact of an aggressive ideology in this country, whatever form that impact takes. ${ }^{63}$

In general, Nehru shared the concerns regarding communist influences in India. In his reply, though, he argued with pragmatism: 'Another party's lack of courtesy should [not] prevent us from taking a step which might yield possible results'. An approach should be made 'confined to matters of food. . . . In the natural course of events India should deal directly with a great country like the Soviet Union which lies on its borders whether we approve of its policy or not'. ${ }^{64}$

From a different angle, Bajpai supported this line, arguing that India needed Soviet support for its candidature for a non-permanent seat in the UNSC. Moscow had recently blocked admission to the UN for countries with which it had no diplomatic relations. ${ }^{65}$ 'Horse-trading . . . may be unseemly but I fear it is inevitable in the present atmosphere of international bargaining'. The Soviets were 'extremely reticent and non-committal. . . . If we wish them to open out, not only on this but other matters, I think that we must expedite exchange of diplomatic representatives'. ${ }^{66}$

Nehru thought along Bajpai's lines too. In a letter to Molotov, he expressed an earnest desire to open diplomatic relations. ${ }^{67}$ The Soviet foreign minister 
when meeting Krishna Menon, however, doubted that London would give permission. Unless there was an independent government, there was little prospect for cooperation. Regarding food, he did not commit himself in any way. Menon in a most naïve manner admitted being the novice he was in international affairs, and this with a foreign minister who was up to every trick, having negotiated the infamous Molotov-Ribbentrop Pact from 1939. Known for his vanity, Nehru's emissary in his own account translated every courteous but clearly non-committal comment of his counterpart as a eulogy for India and the vice-president. He not only invited himself to Moscow but 'casually even mentioned military experts for our military schools in the future'. ${ }^{68}$

As to be expected, the USSR did not provide any food grains. ${ }^{69}$ While Krishna Menon went to the UN, the other issues he had touched caused uneasiness in Delhi. Privately, K.P.S. Menon found his namesake 'getting a little beyond himself ${ }^{70}$ and scoffed at his 'foolish telegrams' ${ }^{71} \mathrm{He}$ managed to convince Nehru to deny him a free hand in European affairs. In his official comment, however, he recommended a visit to Moscow to get an impression of the city and leading personalities. ${ }^{72}$ JS G.C.L. Crichton from the EAD vehemently disagreed: Krishna Menon might commit Delhi

unwittingly and with the best intentions in the world, to courses of actions which might be prejudicial to the conduct of India's future relations with the Soviet government. The trained and hard-headed diplomatists of the Soviet government could be relied on, I thought, to exploit his visit to the utmost for their own future diplomatic advantage and unless Mr. Menon showed extreme discretion and diplomatic acumen the task of a future Indian ambassador in Moscow might well be made more difficult.

He drew Nehru's attention to parts of the interview 'which were much better left unsaid at this stage', in particular 'the matter of Russian military experts for Indian military schools in the future. This might well have laid in M. Molotov's brain the germs of a future approach for a Soviet military mission to India!'

[Nehru] agreed that Mr. Krishna Menon had been somewhat indiscreet on this point but did not feel that his proposed visit to Moscow in November would lead to any real difficulties. He felt it would be ungracious and difficult to refuse the invitation.

Krishna Menon, however, needed to be thoroughly briefed this time. ${ }^{73}$

Foreign Secretary Weightman opposed Krishna Menon's plans, too, and suggested sending K.P.S. Menon instead. Nehru responded favourably 'but at the same time thought that it would be embarrassing to exclude 
Mr. Krishna Menon ... in view of what he has done so far'. He, therefore, wanted a joint mission of the two Menons. Weightman countered that

we cannot send one official and one unofficial or semi-official representative or negotiator and if both of them were to be officials there would be difficulty in deciding which was the representative and which the assistant since they could scarcely both be invested with parallel authority. . . . It is clearly essential now to come off the unofficial level on to the official plane' as 'what now remains is purely official and largely technical discussion. ${ }^{74}$

Wavell got involved as well, questioning the wisdom of sending a noted Congress propagandist without first discussing the matter with the Muslim League. ${ }^{75}$ Nehru finally asked his sister to continue the talks with Molotov in New York. ${ }^{76}$

In the meantime, Krishna Menon had tried to rush matters, suggesting there was no need to visit Moscow in the company of a senior official. ${ }^{77}$ The opposition of British officials might have been ineffective had Krishna Menon not made another influential enemy for life in New York. Nehru's sister and his closest advisor came to loathe each other. Much later, she even would insinuate him with plans for a military coup in India. ${ }^{78}$ After a conversation with Molotov, Mrs Pandit informed her brother that the foreign minister 'evidently' did not see any need for a preliminary mission before exchanging diplomatic representatives. Krishna Menon might like to continue his talks in Moscow, 'but this is unnecessary and clearly undesirable in view of proposed appointment of our accredited representative in Moscow' ${ }^{79}$ This was a vote of distrust and dislike. K.P.S. Menon seized the opportunity, suggesting that the usual exchange of notes would be enough. This could best be done in Nanking, where he was on cordial terms with the Soviet ambassador. ${ }^{80}$ Bajpai, finally, came in as well, reporting that diplomatic relations between Canada and the USSR had been established by simple agreements, not requiring ratification. ${ }^{81}$ Equipped with such support, Weightman convinced Nehru that an exchange of notes in Nanking would suffice. ${ }^{82}$ This took place on 2 April 1947.

The episode about the establishment of Indo-Soviet diplomatic relations deserves to be portrayed in such detail as it highlights characteristic features, conflicts and failures of the upcoming Nehru era. Given the old Anglo-Russian rivalry around Central and South Asia, intensified with the ideological conflict since the October Revolution, the British wanted to keep the USSR out of the subcontinent. Given that the Soviet Union had become a key player in international politics, the interim government naturally was keen to have normal relations with a great power separated from British India but by Afghanistan's Wakhan Corridor ${ }^{83}$ Furthermore, a government of independent India, beyond the horizon, was free and keen to open a new 
chapter in foreign affairs. While in the case of Bajpai this was pragmatism, Nehru and Krishna Menon were also driven by leftist romanticism so characteristic of their generation. ${ }^{84}$ Typically, the vice-president held that at the UN, the USSR but 'prima facie' was 'more noncooperative and often rather aggressively rude' ${ }^{85}$ In the instructions for his sister leaving for Lake Success, he emphasised 'that in this world tug-of-war there is on the whole more reason on the side of Russia'. ${ }^{86}$ As the British were about to depart, this antagonism would have had no relevance for the future had not so many British-trained officials played important roles in post-colonial Indian foreign affairs.

A divide emerged. On the one hand were the civil servants, and on the other were men and women from the public sphere. Though this is a worldwide phenomenon, there was a special Indian aspect: The second group, notwithstanding their mostly poor performance, was granted an unusual amount of influence by a new head of government similarly lacking expertise in foreign affairs. Neither in 1946 nor in later years would any official openly challenge Nehru or his blind support for Krishna Menon, though privately nearly all of them considered the latter a fundamental mistake. And Krishna Menon would be only the most prominent of the nonprofessionals in charge of India's most important missions abroad despised by the professionals of the IFS, the core of the new service comprising elitist ICS officers.

Nehru's performance in late 1946 would be characteristic for the years to come too: He did not hold his hand over his protégé for his merits but for their friendship. Though Krishna Menon, by overstepping his instructions, had overruled the vice-president and betrayed a friend, Nehru could not bear refusing him the role his confidant had designed for himself. Though this was clearly a government issue, Nehru acted as friend, not as head of government. Confusing political needs with private obligations to friends, who so often were poorly chosen, ${ }^{87}$ would become a feature of the Nehruvian years.

Both ICS officers involved performed in a characteristic manner. Bajpai, who was not a friend of Krishna Menon or the USSR at all, thought along pragmatic lines. If national interest demanded diplomatic relations with the USSR, so be it. Whatever he thought privately - and there can be no doubt how he noticed Nehru's and Krishna Menon's amateurish performance - it never surfaced in any official communication. Whereas the only marginally involved agent-general in Washington pursued a continuous realist line, his colleague from Nanking floated with the tide. As long as he believed Nehru to back Krishna Menon, he supported the latter's blue-eyed plans. As soon as the wind changed, he promoted a prominent role for himself. As seasoned foreign affairs expert, K.P.S. Menon looked through his namesake's manoeuvres and their detrimental effects, but his focus was on his own career rather than on national interest. The power-hungry Bajpai was no stranger to vanity either, but he did not know that sort of narcissism 
overruling political considerations. Dutt, being no part of this episode, would hold similar views.

\section{Bajpai's return to Delhi}

While the last parts of this episode played, seemingly out of the blue, Nehru asked Bajpai to return to Delhi. The agent-general had grown restless with the war ending and him being excluded from the delegation to the San Francisco Conference. His request of June 1945, when his term in Washington was meant to end, found but a vague response. Caroe, keen to keep Bajpai in the US, ${ }^{88}$ informed him that his appointment would end in October 1946 at the latest. ${ }^{89}$

When the Indian delegation to the UNGA for late 1946 was put together, this time by the interim government, once again Bajpai was not included although he had put much effort in work at the UN, strongly advocating India's candidature for a non-permanent seat in the UNSC. ${ }^{90}$ Furthermore, in late October, Bajpai learned that K.P.S. Menon would be appointed ambassador in Nanking. Bajpai himself, senior both in service and at his current post, for a transitory period would continue as CDA to make place for Ambassador Asaf Ali, a Congress politician who in the interim government held the portfolio for Railways and Communications, Post and Air.

Bajpai must have grown desperate, approaching Mrs Pandit in late November in New York. He offered 'to "serve" in any capacity or retire' according to Nehru's wishes. Should he be considered useful, he would have preferred a posting in Paris, France being his favourite country in Europe. Mrs Pandit wrote to her brother that Bajpai, compared to other officials she had met, 'seems much superior and has some dignity and self-respect'. ${ }^{91}$ She also mentioned that the agent-general felt hurt that unlike other heads of mission in Washington, he was no part of the delegation of his country. Bajpai had further indicated 'the capacity to adapt himself to changing circumstances'. ${ }^{92}$ Nehru almost immediately responded in a positive fashion, in a letter of 5 December offering Bajpai a role in new India without giving any details. This was the sweet core of what was otherwise a bitter pill: The vice-president firmly stated that he disagreed with much of Bajpai's work in the past and 'the ICS outlook on anything'. Even worse, for the time being, he asked him to stay on in Washington as 'Asaf Ali's second in command'. ${ }^{93}$

Notwithstanding Nehru's claims to rid India of the ICS, it was exactly those days in early December when a complete turnover regarding his standing vis-à-vis that service took place. The very same day, he also wrote to his sister. Whereas he expressed hopes 'to put an end to the Indian Civil Service as it exists at present fairly soon', all British officers and 'a number of others' to be released, he also admitted that some might continue. ${ }^{94}$ Rather milder, with Bajpai he acknowledged that he 'as well as many others, though not all, have not only ability but are quite capable of adapting yourself to the 
new India that is taking shape'. ${ }^{95}$ Nehru obviously had started realising that diplomats appointed according to political correctness were not necessarily good diplomats. His motive for asking Bajpai to stay on in Washington was that he considered the ambassador-designate a poor candidate and 'somewhat inefficient'. ${ }^{96}$

Nehru formulated his frustration both with the personnel he had selected and the general line of foreign policy most explicitly in a third letter of 5 December, addressed to K.P.S. Menon in New York: The delegation to the UN had 'shown up our numerous deficiencies', not working 'as a first-rate team with a definite policy of our own'. But the frustration went even deeper and beyond the performance in New York:

Our policies too seem to be rather confused, and there is a tendency to adapt ourselves to this or that varying policy initiated by others. To some extent this is inevitable, but this should not be allowed to go far and we shall certainly have a very definite policy of our own in the future.

Nehru thus admitted not having an idea which line to pursue in foreign affairs, a point confirmed by his biographer Gopal. ${ }^{97} \mathrm{He}$ merely wanted India not being party 'to British foreign policy or the old methods of the British Foreign Office'. A non-policy, however, was not yet a policy. The vice-president was aware of that and concluded that 'our policy will be determined by us later'. ${ }^{98}$ Notwithstanding becoming a mantra, non-alignment would be but another non-policy and disunity of Indian delegations at summits and conferences an ongoing feature.

Putting up a façade but leaving the actual business to those who had been in charge earlier could not be a solution. After three months in charge of the interim government, Nehru had had his tryst with reality. This was true for domestic affairs, the Muslim League having joined the interim government on 26 October but continuing its disruptive politics. ${ }^{99}$ And this was equally true for foreign affairs. Notwithstanding all enthusiasm to open a new chapter in Indian and global foreign affairs, Nehru by December 1946 realised how little room he had to manoeuvre. The UN would have been the very forum to establish a new mode of interaction. When Indian independence came in sight, however, the new world order had already been shaped without India having a say or given a role adequate to its size and ambitions. At the Dumbarton Oaks Conference of 1944, the UK, the US and the USSR had produced proposals for a new world organisation, reflecting their interests. As a result, the UN, as constituted in 1945, was dominated by them, partly with absurd side effects. The Soviet Republics Belarus and Ukraine, despite complete lack of autonomy, were given seats in the UNGA, wherefore the USSR had three votes in that body. Instead of making the $\mathrm{UN}$ a democratic institution, the veto right of the great powers guaranteed 
the opposite. While France and China, both having proved helpless against military onslaughts (the latter even amid a civil war), were given permanent seats in the UNSC, India - considering itself of relevance equalling that of China - had been left out. When the UN was in the making, the Churchill government had not considered granting independence; Attlee's turnover had come too late. India was but one of around 50 members of the UN with no more weight as, for example, Luxembourg.

Nehru, emphasising India's pivotal role in Asia, found it 'absurd for India to be treated like any small power'. He wanted to take up the attitude 'that India is the centre of security in Asia and ... must a have a central place in any council considering these matters'. Since he also wanted 'an independent attitude with no marked alignment with any group', India lacked a lobby in the UN to make its dreams come true, for example, a non-permanent seat in the UNSC. ${ }^{100}$ The latter was given great relevance by the cabinet as well as Bajpai, but in vain. ${ }^{101}$ Furthermore, as Nehru considered the establishment of a functioning world organisation more relevant than Indian national interest, he was willing to accept the veto right of the Permanent Five instead of insisting on reforms which might lead to one of them leaving the UN. ${ }^{102}$

Other Indian hopes on the international floor had not come true either. Krishna Menon's meeting with Molotov had not brought about a spectacular breakthrough in Indo-Soviet relations. Moreover, the latter's amateurish performance must have told the vice-president a lesson about entrusting absolute freshmen with delicate initiatives. All consequential steps were undertaken by professionals, following the established customs of international politics. Furthermore, it seems that Nehru had understood that his enthusiasm for getting rid of the old ways had led him into a trap. If the interim government could not provide any better candidate than Asaf Ali for the ambassadorship in Washington, the most important capital in 1946, this was a bad omen. Appointing second-raters to the capitals of the great powers became a feature and a weakness of Nehruvian diplomacy. If Nehru, however, did not want to admit that new India to a large extent was but old wine in new skins, there had to be some new faces where India would be most visible abroad. In the circles which Nehru thought fit to provide such personalities, nevertheless, he did not find anyone coming close to the qualities of Srinivasa Sastri.

Even routine steps around the accreditation of new representatives led to unpleasant hiccups. Bajpai was upset, first, that the 'normal procedure of seeking President's agreement to appointment of your ambassador through your own representative in Washington' had not been followed. He wanted to leave the US as soon as possible. ${ }^{103}$ After Nehru ordered him to stay, ${ }^{104}$ he tried to explain to the vice-president 'the extreme embarrassment of my remaining a member of the embassy staff after Asaf Ali's arrival'. He suggested to continue as India's representative either in the Far Eastern 
Commission or in the Economic and Social Council of the UN in a personal capacity, supporting the new ambassador. ${ }^{105}$ Even K.P.S. Menon came to his aid, emphasising that Nehru's plan would be embarrassing for both Bajpai and Asaf Ali. ${ }^{106}$ In mid-December, the ambassador designate's name was leaked to the press, causing an even more embarrassing situation for Bajpai. ${ }^{107} \mathrm{He}$ was lastly ordered to brief Asaf Ali in London. ${ }^{108}$ On 5 February 1947, when Bajpai finally left Washington, more than five mostly dark years came to an end.

While Bajpai seemed to hit the rock bottom of his career, K.P.S. Menon for the second time was part of an Indian delegation to the UN. Among the officials of the Indian team, he considered Kapur 'slow and ponderous' and his own candidate of choice Azim Husain stubborn. ${ }^{109}$ The presence of Krishna Menon, 'able but so egoistic' and 'working . . . up' Mrs Pandit, did not improve his mood. ${ }^{110}$ The two Menons 'had a first-class row' on 8 November about a speech K.P.S. had drafted for Mrs Pandit: K.P.S. found Krishna 'most insufferable. Thinks himself all-knowing and superior to everybody else'. K.P.S. 'snubbed him hard', the speech going off excellently afterwards. ${ }^{111}$ Thereafter, the Menons used to take opposite views on principle, independent on the subject; Krishna, however, was 'far more polite to us all now'. ${ }^{112}$ When the session neared its end, K.P.S. confided into Mrs Pandit, handing her 'a couple of letters, one an outspoken on my bête noire. She said she agreed with every word I had written. I hope Jawaharlal takes it in the right spirit'. ${ }^{113}$

Altogether, K.P.S. Menon was not impressed by the session of the UNGA. A speech of President Truman he considered 'all commonplace like the man himself'. ${ }^{114}$ The only positive points he noted in his diary were a well-received speech of his own in a debate on the veto right ${ }^{115}$ and one of Molotov against the presence of foreign troops in non-enemy countries. ${ }^{116}$ Visiting Washington thereafter, he pitied Bajpai, not knowing that Nehru had already asked his former superior to continue his career in a distinguished position. The embassy, still under a caretaker, he found 'a badly run office! Everybody is against everybody else'. ${ }^{117}$ At least he was positive about Asaf Ali, whom he met in Delhi in late December 1946. ${ }^{118}$

Back in India, K.P.S. Menon surprisingly was not given any relevant role. He attended interviews of candidates for the Foreign Service, ${ }^{119}$ but nobody seemed keen to keep him as advisor for foreign affairs. Weightman wanted Menon's quick return to China, feeling that the now ambassador was too close to Nehru. ${ }^{120}$ The latter showed all signs of personal affection, visiting Menon when ill in bed ${ }^{121}$ and writing a foreword to Passage to India, ${ }^{122}$ but no interest to keep him in Delhi. Liaquat Ali Khan, the proponent of the Pakistan Movement Menon appreciated most, assured him that he would 'keep up India's prestige in China all right'. ${ }^{123}$ This was both a compliment and a farewell. Menon, in vain, tried to bring his influence to bear with Nehru on behalf of his friend N.R. Pillai, who felt maligned by senior 
officials like H.M. Patel or V.P. Menon. ${ }^{124}$ The vice-president replied that 'he didn't doubt N.R.'s ability and loyalty, but he is "so neutral" '. ${ }^{125}$ All this indicates that K.P.S. Menon's standing in Delhi was weaker than one would have expected after his meteoric rise since early 1945. The embassy in China was not irrelevant, but being sent back there in the crucial months when new India was set on rails meant keeping K.P.S. Menon out of the game.

Nehru was known for forgetting even close aides once they were not in regular contact any more, but this did not apply in this case. It appears that it was rather Menon's lack of interest or even ambition which played a key role. ICS colleagues like H. M. Patel and soon Bajpai lost no time to secure themselves a maximum of influence in new India. On the contrary, K.P.S. Menon, when the press falsely reported in early May that he would be appointed principal secretary of the combined External Affairs and Commonwealth Relations Department, felt pleased but showed no inclination 'to leave China until the end of this year'. ${ }^{126}$ Instead, he approached Nehru for the ambassadorship in Moscow. ${ }^{127}$ Thereafter, Menon felt satisfied advising Nehru on matters like Baluchistan. ${ }^{128}$ Obviously, it did not even embarrass him that he was not sent to the UNGA again. ${ }^{129}$

On the contrary, Bajpai did not miss the opportunity to establish his position. After Mrs Pandit, he received even more unexpected support. While Bajpai was still on board the ship carrying him from Europe to Karachi, Krishna Menon, who must have met him in the US, wrote to the vicepresident, praising the returnee's grasp of international affairs and suggesting to employ him for the organisation of the Foreign Service and the EAD. Nehru approved ${ }^{130}$ and appointed Bajpai OSC for these tasks. ${ }^{131}$ Among others, the latter travelled the provinces, interviewing applicants for the IFS. The interim government had approved the creation of the service on 9 October 1946, ${ }^{132}$ but there was an acute manpower shortage. Already in 1944, the Home Department had lamented about 'considerable difficulties . . . in finding suitable officers for employment as under secretaries in the GoI'. The usual sources, ICS and Provincial Civil Services, had 'more or less been exhausted'. ${ }^{133}$

\section{Return of the ICS}

After Krishna Menon had visited European capitals in the spring of 1947, he had written to Nehru that he found interest in establishing diplomatic relations everywhere. ${ }^{134}$ Manpower shortage, however, made it impossible to establish missions. The transfer of power and partition deepened the problem. Most British officials were meant to quit or joined the Pakistani civil service. When Michael Hadow, under secretary in the EAD, applied for the IFS, Nehru told him 'that much as he liked me my face was the wrong colour'. ${ }^{135}$ Furthermore, many Muslim officers opted for Pakistan. According to a tentative calculation from early April 1947, there were 152 officers 
needed for the missions abroad and another 54 for headquarters. So far, 36 vacancies had been filled by candidates who were not meant to join the new service: Earlier recruitments and men over 45 were usually not eligible for the IFS. ${ }^{136}$ By early May, of 288 applicants, 152 had been selected for interviews. Bengal with 38 candidates, followed by UP with but 19 , provided by far the most. ${ }^{137}$

In September, Krishna Menon once again reported on the general desire of European countries to establish diplomatic relations, ${ }^{138}$ Bajpai replying that due to manpower shortage the "possibility of opening new missions abroad is scant in the extreme'. ${ }^{139}$ Opening up the IFS for women did not cover the gap either. Nehru had overruled officials, emphasising that postings in remote parts and with unhealthy conditions were not suitable for women. Whereas appointments of rather senior female ambassadors and personal assistants for adequate missions were desirable, young recruits of both sexes would have to be treated on an equal footing. The British Foreign Service had recently admitted women, though none had joined that far. Those who did had to resign upon marriage. ${ }^{140}$ Nehru, however, insisted that women had to be eligible even if there would be only few applications, considering the high qualifications demanded. The GoI 'should function in tune with this general sentiment of the age', giving 'a desirable impetus to the women's movement and to women's education in India'. In the long run, the IFS 'would gain greatly by the inclusion of some women'. If problems arose, they should be considered on their own merits. ${ }^{141}$ Indeed, over the next decade but three women were selected for the IFS. ${ }^{142}$

Given his experiences from the interwar period, nobody was better suited for selecting candidates than Bajpai. Furthermore, when the British had warmed up to the idea of training more Indian diplomats, he had noted his views on the selection process in a letter to Caroe. He advised against choosing diplomats on a purely party basis, as this would 'mean that the spoils go to the victors, whenever there is a change of party'. Instead, he suggested to keep to the British tradition 'to put foreign policy about party politics and to make diplomatic appointments solely on the basis of the fitness of an individual for a post'. ${ }^{143}$

Bajpai's preference for career diplomats would not be the only issue on which he differed with the vice-president. In early 1946, as part of a quarterly report, Bajpai had formulated a concept for the foreign policy of independent India. His analysis of India's standing and options in global affairs was unique: Neither authored Bajpai a comparable assessment throughout his career, nor did anyone else at this crucial juncture when new India was taking shape. The only point where the then agent-general met Nehru's views was the scepticism regarding the US. They were 'immensely powerful but cannot be relied upon to use that power except when her own security is directly assailed'. But 'a combination of the weak' (i.e., close cooperation 
with China or Middle East countries) could not provide 'the complimentary strength that India will need'.

Until the United Nations become really united, close association for defence with one of the world's three major powers . . . alone will furnish India the needed element of security. . . . From a military standpoint the Soviet Union will prove a more dependable ally but the price of her support will be a measure of conformity to Soviet policies which would greatly circumscribe India's freedom of action. . . . Unless India is prepared to see her social and economic system assimilated to that of a communist state, close association with Russia, except within the framework of a world organisation such as the United Nations, is to be avoided. The British Commonwealth still offers the best opportunity for partnership with security and honour, a partnership of mutual advantage in which, in return for her manpower, her growing industrial capacity and the immense value of her strategic position, Indian will have at her disposal the resources in science, in technical equipment, in modern armament and, last but not least, in political experience of the UK.

In his conclusion, Bajpai warned that

no nation can shape a safe and progressive future by the lone light of memories of a wronged past; had memories alone governed national policies, France and England should never have formed the Entente Cordiale nor the ghosts of George III and Lord North permitted the United States to become England's ally against Germany. ... Sentiment must serve, not master the national interest. ${ }^{144}$

The last sentence was the credo of a realist, who had drawn conclusions mostly differing from those of the future prime minister. The latter saw India, first, not in categorical need of great power support, let alone an ally. Unlike Nehru or Krishna Menon, Bajpai, second, did not give the USSR the benefit of the doubt, and third, he thought little of Nehruvian attempts to augment the close cooperation of African and Asian countries as manifested at the Asian Relations Conference in March and April 1947. Supporting a partnership with the UK might appear as paying lip service to his British superiors. If one takes Bajpai's calculation seriously that India needed great power support and followed his reasoning why Moscow and Washington could not be taken into account, it left London as the only option through the process of elimination. Perhaps even more relevant than differences of opinion were those in terms of method. Whereas Bajpai's approach was strictly rational, Nehru's was driven to no small extent by emotions. 
Whether the vice-president ever read Bajpai's analysis is unknown, but their diverging views prevented neither of the two to cooperate to mutual benefit. Immediately after his return to India, Bajpai asked confidants to join the foreign service, and Dutt was among them. ${ }^{145}$ In no time, Bajpai made himself indispensable once again. Already in mid-March, when Nehru urged a discussion on India's stand on the future of Germany, he relied on the advice of Weightman and Bajpai. ${ }^{146}$ On 1 March, he had already suggested to the new Viceroy Louis Mountbatten to appoint Bajpai secretary-general of the recently amalgamated External Affairs and Commonwealth Relations departments. Nehru wanted to keep the two secretaries - Weightman and Rabindra Nath Banerjee - and have someone to supervise and coordinate the whole department: 'The only suitable person that I can think of is Sir Girija [sic] Shankar Bajpai who is both very senior and has considerable experience of diplomatic relations and foreign work'. ${ }^{147}$

As head of government and charismatic leader of both the ruling party and a nation in the making, furthermore holding the external portfolio, even the near-inexhaustible disciplinarian Nehru needed reliable aides. Whereas he 'had little patience with the details of administration', ${ }^{148}$ the secretary-general (and Dutt) were born administrators. The extent of time Nehru could spend on foreign affairs is difficult to calculate, but Bajpai de facto filled the role of foreign minister, shouldering much more than routine business. What had started with explicit reservations at least as far as Nehru was concerned, transformed into pragmatic cooperation dictated by circumstances to become a partnership based on respect. In a letter to K.P.S. Menon from mid-October 1947, Nehru whole-heartedly praised Bajpai as omnipresent: His performance had been such that the vice-president had overcome his initial hesitation. Bajpai was the senior-most official in Delhi, and 'whatever he may have been in the past ... he has changed considerably'. Given his propaganda activities in the US, the appointment had not been popular, but Nehru found the criticism

somewhat exaggerated and his other qualities certainly outweighed them. I am so tired of second-rate work that sheer efficiency appeals to me. Personally I do not know how I could have carried on during the last difficult few months without the help of Bajpai in the Foreign Ministry. ${ }^{149}$

Like in the DEHL, Bajpai was the unchallenged boss. The British officers focused on the smooth transfer of power, and Weightman since long appreciated the secretary-general. Furthermore, Bajpai was soon supported by a staff he knew only too well, though the selection in parts was coincidence. ${ }^{150}$ The case of Dutt, appointed commonwealth secretary, proves the point: He had been meant to go to Moscow, but the Government of 
Bengal ordered that no officer of the Bengal cadre must be transferred, as the upcoming division of the province between the Indian Union and Pakistan needed everyone on board. Mountbatten intervened on behalf of Dutt, but until the latter became available, the arrangements for Moscow had been modified.

On 20 February 1947, Attlee had appointed Mountbatten viceroy and announced the transfer of power not later than June 1948. The Mountbatten Plan of 3 June advanced the day of what was now independence and partition to 14 and 15 August 1947. The hasty departure of the British caused many difficulties, among them the need to establish diplomatic missions within a little more than two months. As the interim government considered good relations with the USSR of great relevance, Nehru appointed his sister ambassador, apart from Krishna Menon the only prominent nonofficial with experience on the diplomatic floor. Because Dutt was not available until July, A. V. Pai accompanied her, most unhappy about the decision after he only recently had succeeded R. N. Banerjee as secretary of the Commonwealth Relations Wing of the MEA. He tried his best to ensure a quick return to headquarters, while Dutt only officiated on his post. After a short interlude after Pai's return in the spring of 1948, Dutt finally remained commonwealth secretary until 1952. ${ }^{151}$

Bajpai had worked with both officers from 1936 and 1938, respectively, but he undoubtedly preferred Dutt. The contact with Pai, posted in Ceylon, had mostly been via mail, whereas Dutt had worked immediately under Bajpai, who fostered him for his efficiency, work discipline and loyalty. While in Malaya, he had shown stamina; as secretary for agriculture in Bengal, he had excelled as head of department. This made him the perfect choice to keep the back of the secretary-general free without ever thinking of challenging him. One of those who much later came to envy Dutt for his extraordinary and allegedly undeserved career accordingly termed him 'a blue-eyed boy of Bajpai'. ${ }^{152}$

While the allocation of individual officers to postings was often decided ad hoc, the general predominance of ICS officers in the IFS was consolidated with the Report of the Secretariat Reorganisation Committee, fittingly also called the Bajpai Committee, of 10 August 1947. In his autobiography of 1938, Nehru had attacked the ICS as 'wholly unsuited to a progressive environment' (i.e., new India). ${ }^{153}$ Those views initially were shared by many in the Congress. When the party, however, had formed provincial governments in the late 1930s, many had come to appreciate 'the onerous responsibility of governance that the civil servants undertook'. Moreover, when British India after the war was heavily affected by communalism, the mostly unbiased, secular and efficient ICS officers became near irreplaceable. ${ }^{154}$ Nehru took longer to change his mind, articulating his scepticism once again when contacting Bajpai in December 1946. Nevertheless, by the summer of 1947 he, like so many prophets of a new era, had had to learn that while 
governments change they need to rely on the administrative apparatus of their predecessors, hoping officials to be as loyal to their new masters as they had been to their old. The difficulties to find recruits for the IFS and suitable personalities from the public sphere indicated but the tip of the iceberg. New India, even more in the chaotic days of partition, had 'no alternative to reliance on the Indian Civil Service if the administration was not to break down completely'. ${ }^{155}$

The report stated that 'the Indian Civil Service officer, both because of his education and the training in administration he receives in the formative stages of his career', had to remain the very source of recruitment for the higher administrative and secretariat posts. ICS officers should occupy all top postings of the ministries. Given the chaotic conditions in the summer of 1947, the committee certainly had a point. Its composition, nevertheless, had guaranteed the outcome. Bajpai as chair was supported by five senior colleagues from the ICS (R. N. Banerjee, R. L. Gupta, V.K.R. Menon, H. M. Patel, S. A. Venkataraman) and two officers of the Audits and Account Service (P.C. Bhattacharyya, N. Sundaresan). The committee also calculated the demand: Against the need of 207 posts of the grade of deputy secretary and above, plus 125 more for posts outside the secretariat, merely 48 officers would be available for service with the central government after partition. The MEA alone needed 33 officers as joint, deputy and under secretaries, excluding headships of missions, for which mostly persons of public life would have to be appointed. ${ }^{156}$

As a consequence, the MEA became a stronghold of ICS officers. Every rank of relevance was held by them, and there was hardly a mission without a representative of the 'brotherhood'. Bajpai as secretary-general outranked any other official in Delhi, giving the ministry the status of primus inter pares in the capital, mirroring Nehru's predilection for foreign affairs. From 16 April 1948, when K.P.S. Menon joined as foreign secretary, the MEA could rightfully claim to have assembled all expertise civil servants had gained in foreign affairs since the early 1920s.

After his return to Nanking in the spring of 1947, Menon had continued as ambassador. Among the Big Five, nevertheless, China was the least relevant, wherefore in a manner of speaking he was a wasted asset. Given the acute manpower shortage in the IFS, it was only logical to make better use of India's second-most experienced diplomat. On 21 September, Bajpai offered Menon the post of foreign secretary. The ambassador at first was pleased but then 'decided to decline it politely', hoping that Nehru would not misunderstand: 'It will be terrible to work under Bajpai'. ${ }^{157}$

A telegram and a letter to Bajpai, mentioned in Menon's diary, ${ }^{158}$ could not be traced, but a letter to Nehru was. Menon wanted to be sure that Bajpai would never see it, adding 'to be destroyed after perusal'. M. O. Mathai, Nehru's private secretary, however, did not do him the favour, wherefore the 
scathing critique of the secretary-general survived. The 'overriding reason' for Menon's denial were massive difficulties

to work with, or under, Bajpai. ... I have the greatest admiration for his ability. He is wonderful to the people above him and condescending to the people directly below him; but to those who are more or less his equals and whom he rightly or wrongly suspects as his rivals, he is simply insufferable. I do not think he has forgotten that I was ambassador when he was chargé d'affairs; and now the tables are being turned on me. I can put up with the personal unpleasantness of the situation; but I feel that, however much I may try, this will not come to good team work and efficiency. ... I feel strongly that so long as Bajpai is there, I can be of far greater use to you outside the secretariat. ${ }^{159}$

Nehru, however, convinced Menon to change his mind. He praised the secretary-general's work and indicated that the appointment had been Bajpai's idea. Given the latter's poor health, Menon, after a sort of apprenticeship, was meant to succeed him. Appealing to the ambassador's duty to the nation, Nehru did 'not like personal considerations to come in the way of any work'. His father Motilal, after having been president of the Congress, had functioned as its secretary because he felt he was needed in this capacity. 'At the present moment, the really important diplomatic posts ... are at Washington, Moscow and London', the headquarters for guiding them even more relevant. 'The foreign secretary's work is at least as important, if not more, as that of the average ambassador'. ${ }^{160}$ The 'touching letter' made Menon reconsider his decision. ${ }^{161} \mathrm{He}$ thoroughly enjoyed the last speeches he would give for a long while, ${ }^{162}$ 'feeling like a Hollywood star' after a broadcast to the Korean people. ${ }^{163}$ When leaving Nanking, he was sure that 'we have only left splendid impression behind and endeared India to China'. ${ }^{164}$

Whether Bajpai ever saw the exchange between Menon and Nehru is unknown, but it is unimaginable that such intense dislike escaped his attention. If so, the professional he was did not let such feelings influence their work. Menon, however, continued in the same tone and immediately complained about his immense workload with all sorts of visitors, making it impossible to concentrate on anything else. ${ }^{165} \mathrm{He}$ was so absorbed with his many tasks that he stopped his diary entries by late April. The diaries for 1949 and 1950 are lacking. The rather fragmentary one for 1951, however, proves that his intense resentment against Bajpai had not disappeared. In March, he was gloating when K.S. Bajpai, the secretary-general's second son to join the IFS, did not do too well in the entrance examination. He suspected the father to have helped with the essay and, in vain, trying to replace 
Dutt and Menon on the board for oral interviews viva board. 'His paternal anxiety is touching; but intrigue is in his blood ... Mrs Bajpai refused Dutt's sweets because Bajpai's son didn't get more marks in the viva!'166 Menon believed to be more popular in the MEA. When leaving Delhi for a trip abroad,

Dutt, Chakravartys and almost all officers of the Foreign Ministry saw me off. I could not help thinking that they would not have seen off Bajpai! Not a soul saw Mrs Pandit off when she went as ambassador to Washington. After all confidence begets confidence, kindness begets loyalty. ${ }^{167}$

Dutt did not share this last point of Menon's self-assessment. His working relationship with the foreign secretary was correct and there was no difficulty in openly discussing policy matters. ${ }^{168}$ Menon, however, kept a certain distance and did not take him into confidence when deciding on personnel. Furthermore, in private, Dutt blamed him for 'nepotism', ${ }^{169}$ 'weakness and favouritism' ${ }^{170}$ Later in their careers, they were to respect each other without love being lost. The causes might have been their very contrary characters and their respective standing in Delhi. Dutt was a strict disciplinarian with the self-diagnosed inferiority complex of a poor Bengal village boy who had risen to the highest heights. His diaries of those years display nightmares of a sudden downfall. Partly due to his lack of self-confidence and partly due to vows to remain strictly non-partisan, he deliberately avoided to make friends in his professional environment. To those who did not know him in private, he appeared brash, lacking charm.

K.P.S. Menon, four years his senior, was the exact opposite. By upbringing, he belonged to the educated and rather privileged. Whereas the pious and conservative Dutt in his diaries poured out self-doubts, the optimistic and jolly Menon embraced life. While on probation in the UK, Dutt had strictly kept to Indians and Indian food; his only touristic journeys had led him to the Isle of Wight and the Lake District. ${ }^{171}$ On the contrary, Menon drank alcohol and enjoyed sinful Paris including its nightclubs and brothels. ${ }^{172}$ Dutt had the typical features of a Bangal, a person from the Eastern part of Bengal Province - slender, short, high cheekbones - earning him the nickname General Tojo. ${ }^{173}$ For his physical appearance, he feared to be looked down at as 'that little man', ${ }^{174}$ whereas Menon was considered handsome and was aware of it. Dutt lived a frugal life; Menon spent lavishly. Those opposite characters translated into two officers representing opposite extremes from the spectrum of diplomats: a desk-man versus a field-man, each loving what the other hated. Dutt never liked the limelight, let alone giving speeches, whereas Menon could not get enough of both. Instead of standing 'on one's flat feet talking inconsequential things' at receptions, ${ }^{175}$ Dutt preferred paperwork and debates in small circles of the competent. 
What Menon hated most was being but a near invisible cog in the wheel, buried in piles of papers. For most of his life Dutt was happy in a serving capacity, whereas Menon was horrified by doing preliminary work for superiors. Menon had many friends in the civil service, but among the often enthusiastic comments in his diaries on colleagues, not one indicated any warm feelings for Dutt.

Both worked hard, overwork causing chronic and partly psychosomatic health problems: lifelong digestion problems with Dutt, lifelong headaches with Menon. Apart from dedication to their families, they shared mostly one thing: they both admired Nehru. Ironically, this was another source of an unsaid rivalry. Menon was friends with India's first prime minister since the early 1930s. The charming, outgoing, eloquent, open-minded, and handsome officer with his intellectual leanings belonged to the rare category of men whom Nehru considered in his own league and a worthy friend. In particular, when posted in Moscow from 1952, Menon would impress his friend with verbose reports styled as intellectual essays, almost inevitably starting with references to historians and philosophers. Nehru loved them and distributed them in the cabinet. Not only for his style, Dutt envied Menon and the attention he got from the prime minister. He had not met the latter before being appointed commonwealth secretary. Appearing the archetypical apparatchik, it took him a while to win Nehru's respect. ${ }^{176}$ Even then, he would never have dared to consider themselves friends. $\mathrm{He}$ preserved the rare tokens of expressions of sympathy by Nehru like relics. ${ }^{177}$ Where Menon impressed Nehru as an elegant orator and writer, Dutt perfected his laconic style, perfectly suited for notes for an overburdened head of government. ${ }^{178}$ Nehru appreciated working with both, Dutt preferably at headquarters, Menon at important missions abroad. With Dutt, though, it was no more than a most efficient working relationship based on mutual respect. Dutt's deep personal affection was not mirrored by the prime minister. Between 1948 and 1952, among the secretaries in the MEA, Menon was Nehru's man, while Dutt was Bajpai's.

\section{Notes}

1 NMML, KPSMP, Diary 1945, 1 March.

2 NMML, KPSMP, Diary 1945, 9 March.

3 NMML, KPSMP, Diary 1945, 8 March.

4 NMML, KPSMP, Diary 1945, 12 March.

5 NMML, KPSMP, Diary 194514 March.

6 NMML, KPSMP, Diary 1945, 24 March.

7 NMML, KPSMP, Diary 1945, 6 April.

8 NMML, KPSMP, Diary 1945, 17 April.

9 NMML, KPSMP, Diary 1945, 6 April.

10 NMML, KPSMP, Diary 1945, 4 April.

11 NMML, KPSMP, Diary 1945, 9 April.

12 NMML, KPSMP, Diary 1945, 11 April. 
13 Ruth B. Russell, A History of the United Nations Charter. The Role of the United States 1940-1945, Washington, DC: Brookings Institution Press, 1958, p. 355.

14 NMML, KPSMP, Diary 1945, 11 May.

15 NMML, KPSMP, Diary 1945, 2 May.

16 NMML, KPSMP, Diary 1945, 28 April.

17 NMML, KPSMP, Diary 1945, 14 June.

18 NMML, KPSMP, Diary 1945, 12 May.

19 NMML, KPSMP, Diary 1945, 4 May.

20 NMML, KPSMP, Diary 1945, 3 May.

21 William C. Johnstone, 'The San Francisco Conference', Pacific Affairs, September 1945, 18(3): 220-226.

22 NAI, MEA, 143(20)-P.W.R. Letter, K.P.S. Menon to Caroe, 31 August 1945.

23 Johnstone, 'The San Francisco Conference', 214-216.

24 NMML, KPSMP, Diary 1945, 19 May.

25 NMML, KPSMP, Diary 1945, 7 June.

26 NMML, KPSMP, Diary 1945, 26 April.

27 NMML, KPSMP, Diary 1945, 27 April and 1 May.

28 NAI, MEA, 143(20)-P.W.R. Letter, K.P.S. Menon to Caroe, 31 August 1945.

29 NAI, MEA, 143(20)-P.W.R. Note, Mudaliar, 8 August 1945.

30 NMML, KPSMP, Diary 1946, 2 and 30 January.

31 Pat Sloan and Beatrice Webb, Russia without Illusions, London: Muller, 1938.

32 NMML, KPSMP, Diary 1946, 4 July.

33 NMML, KPSMP, Diary 1946, 10 January.

34 NMML, KPSMP, Diary 1946, 1 February.

35 NMML, KPSMP, Diary 1946, 15 February.

36 NMML, KPSMP, Diary 1946, 2 February.

37 NMML, KPSMP, Diary 1946, 14 February.

38 NMML, KPSMP, Diary 1946, 16 March.

39 NMML, KPSMP, Diary 1946, 20 April.

40 NMML, KPSMP, Diary 1946, 26 April.

41 NMML, KPSMP, Diary 1946, 18 May.

42 NMML, KPSMP, Diary 1946, 24 May.

43 NMML, KPSMP, Diary 1946, 16 August.

44 NMML, KPSMP, Diary 1946, 11 September.

45 NMML, KPSMP, Diary 1946, 1 September.

46 NMML, KPSMP, Diary 1946, 5 September.

47 NMML, KPSMP, Diary 1946, 3 September.

48 NMML, KPSMP, Diary 1946, 4 September.

49 NMML, KPSMP, Diary 1946, 12 September.

50 NMML, KPSMP, Diary 1946, 14 September.

51 NMML, KPSMP, Diary 1946, 17 September.

52 Paul McGarr, “A Serious Menace to Security”: British Intelligence, V.K. Krishna Menon and the Indian High Commission in London, 1947-52', Journal of Imperial and Commonwealth History, 2010, 38(3): 442.

53 NAI, Home Dept., 1/2/36. Letter, Nehru to Rajendra Prasad, 22 November 1935. Quoted after Sarvepalli Gopal, Nehru: A Biography, vol. I, New Delhi: Oxford University Press, 1975, p. 202, fn 2.

54 Selected Works of Jawaharlal Nehru, vol. 1, Second Series (SWJN2), New Delhi: Jawaharlal Nehru Memorial Fund, 1984-, pp. 489-491. Note, Nehru, 24 September 1946.

55 Ibid., pp. 549-550. Letter, Nehru to Bajpai, 5 December 1946.

56 Ibid., pp. 492-505. 
57 NMML, KPSMP, Diary 1946, 19 September.

58 NMML, KPSMP, Diary 1946, 25 September.

59 NMML, KPSMP, Diary 1946, 14 September.

60 SWJN2, vol. 1, pp. 489-491. Note, Nehru, 24. September 1946.

61 NMML, KPSMP, Diary 1946, 14 September.

62 NAI, MEA, 20(4)-EUR/47. Note, R.H. Hutchins, Food Dept., 3 September 1946.

63 NAI, MEA, 20(4)-EUR/47. Note, Weightman, 5 September 1946.

64 SWJN2, vol. 1, pp. 481-482. Note, Nehru, 6 September 1946.

65 NAI, MEA, 20(4)-EUR/47. Telegram 698, Bajpai to GoI, 18 September 1946.

66 NAI, MEA, 20(4)-EUR/47. Telegram 699, Bajpai to GoI, 18 September 1946.

67 SWJN2, vol. 1, pp. 486-487. Letter, Nehru to Molotov, 21 September.

68 NAI, MEA, 20(4)-EUR/47. Letter, Krishna Menon to Nehru, 28 September.

69 NAI, MEA, 20(4)-EUR/47. Telegram 9898, Krishna Menon to Nehru, 5 October 1946.

70 NMML, KPSMP, Diary 1946, 10 October.

71 NMML, KPSMP, Diary 1946, 2 October.

72 NAI, MEA, 20(4)-EUR/47. Note, K.P.S. Menon, 10 October 1946.

73 NAI, MEA, 20(4)-EUR/47. Note, Crichton, 12 October.

74 NAI, MEA, 20(4)-EUR/47. Note, Weightman, 30 October.

75 SWJN2, vol. 1, p. 544, fn. 2. Letter, Nehru to Wavell, 20 November 1946.

76 Ibid., pp. 550-552. Letter, Nehru to K.P.S. Menon, 5 December 1946.

77 NAI, MEA, 20(4)-EUR/47. Letter, Krishna Menon to Nehru, 19 October 1946.

78 Paul McGarr, The Cold War in South Asia. Britain, the United States and the Indian Subcontinent, 1945-1965, Cambridge: Cambridge University Press, 2013, p. 143.

79 NAI, MEA, 59(4)-W/44. Telegram GA-57, Pandit to Nehru, 8 December 1946.

80 NAI, MEA, 59(4)-W/44. Telegram GA-58, K.P.S. Menon to Nehru, 8 December 1946.

81 NAI, MEA, 59(4)-W/44. Telegram 130, Bajpai to GoI, 23 December 1946.

82 NAI, MEA, 59(4)-W/44. Notes, Weightman, 30 January 1947, and Nehru, 31 January 1947.

83 Andreas Hilger, Sowjetisch-indische Beziehungen 1941-1966. Imperiale Agenda und nationale Identität in der Ära von Dekolonisierung und Kaltem Krieg, Vienna: Böhlau, 2018, p. 58.

84 François Furet, The Passing of an Illusion. The Idea of Communism in the Twentieth Century, Chicago: University of Chicago Press, 1999. For Nehru, see Harish Kapur, Foreign Policies of India's Prime Ministers, New Delhi: Lancer, 2009, p. 26.

85 SWJN2, vol. 1, pp. 441-444. Note, Nehru, 7 September 1946.

86 Ibid., p. 539. Letter, Nehru to Pandit, 14 November 1946.

87 Subimal Dutt, With Nehru in the Foreign Office, Calcutta: Minerva Associates, 1977, p. 288.

88 NAI, MEA, 351-FE/45. Note, Caroe, 19 June 1945.

89 NAI, MEA, 351-FE/45. Note, Caroe, 29 June 1945.

90 SWJN2, vol. 1, pp. 464-466, Note, EAD, 30 October 1946.

91 Letter, Pandit to Nehru, 20 November 1946, quoted after Vineet Thakur, Postscripts on Independence. Foreign Policy Ideas, Identity and Institutions in India and South Africa, New Delhi: Oxford University Press, 2018, p. 171.

92 Letter, Pandit to Nehru, 29 November 1946, quoted after Thakur, Postscripts on Independence, p. 171.

93 SWJN2, vol. 1, pp. 549-550. Letter, Nehru to Bajpai, 5 December 1946.

94 Ibid., pp. 132-135. Letter, Nehru to Pandit, 5 December 1946. 
95 Ibid., pp. 549-550. Letter, Nehru to Bajpai, 5 December 1946.

96 Ibid., pp. 132-135. Letter, Nehru to Pandit, 5 December 1946

97 Sarvepalli Gopal, Nehru: A Biography, vol. II, New Delhi: Oxford University Press, 1979, p. 43.

98 NMML, M.O. Mathai Papers, Correspondence with K.P.S. Menon. Letter, Nehru to K.P.S. Menon, 5 December 1946.

99 Bipan Chandra, Mridula Mukherjee, Aditya Mukherjee, K. N. Panikkar, and Sucheta Mahajan, India's Struggle for Independence 1857-1947, New Delhi: Penguin Books, 1988, pp. 494-495.

100 SWJN2, vol. 1, pp. 438-441. Note, Nehru, 5 September 1946.

101 Ibid., pp. 464-466. Note, Nehru, 30 October 1946.

102 Ibid., pp. 441-444. Note, Nehru, 7 September 1946.

103 NAI, EAD, 456-FEA/47. Telegram 54, Bajpai to EAD, 3 December 1946.

104 NAI, EAD, 456-FEA/47. Telegram, Nehru to Bajpai, 10 December 1946.

105 NAI, EAD, 456-FEA/47. Telegram, Bajpai to Nehru, 12 December 1946.

106 NAI, EAD, 456-FEA/47. Note, Trevelyan, 28 December 1946.

107 NAI, EAD, 456-FEA/47. Telegram 96, Bajpai to EAD, 13 December 1946.

108 NAI, EAD, 456-FEA/47. Letter, EAD to Bajpai, 11 January 1947.

109 NMML, KPSMP, Diary 1946, 27 October.

110 NMML, KPSMP, Diary 1946, 25 October.

111 NMML, KPSMP, Diary 1946, 8 November.

112 NMML, KPSMP, Diary 1946, 22 November. See also 9 December.

113 NMML, KPSMP, Diary 1946, 10 December.

114 NMML, KPSMP, Diary 1946, 23 October.

115 NMML, KPSMP, Diary 1946, 16 November.

116 NMML, KPSMP, Diary 1946, 20 November.

117 NMML, KPSMP, Diary 1946, 17 December.

118 NMML, KPSMP, Diary 1946, 26 December.

119 NMML, KPSMP, Diary 1947, 23 January and 11 February.

120 NMML, KPSMP, Diary 1947, 27 January.

121 NMML, KPSMP, Diary 1947, 5 February.

122 NMML, KPSMP, Diary 1947, 9 February.

123 NMML, KPSMP, Diary 1947, 15 February.

124 NMML, KPSMP, Diary 1947, 12 February.

125 NMML, KPSMP, Diary 1947, 19 February.

126 NMML, KPSMP, Diary 1947, 4 May.

127 NMML, KPSMP, Diary 1947, 14 May.

128 NMML, KPSMP, Diary 1947, 13 June.

129 NMML, KPSMP, Diary 1947, 22 July.

130 SWJN2, vol. 2, 1984, pp. 415-416. Letter, Nehru to Krishna Menon, 23 February 1947.

131 NAI, MEA, 2(6)-FSP/47. Note, Weightman, 22 February 1947.,

132 SWJN2, vol. 2, 1984, pp. 411-413. Cabinet Meeting, 19 February 1947.

133 NAI, MEA, 9(9)-FSP/47. Office Memorandum, H. K. Chainani, 21 March 1944.

134 NAI, MEA, 19-EUR/47. Telegram 8294, Krishna Menon to Nehru, 8 March 1947.

135 BL, Mss.EUR, F.226/10, Reginald Michael Hadow Papers, 7-8.

136 NAI, MEA, 2(6)-FSP/47. Proceedings of the Deputies Meeting held on the 11th and 12th April 1947.

137 NAI, MEA, 2(6)-FSP/47. Note, B. K. Kapur, 5 May 1947.

138 NAI, MEA, 19-EUR/47. Telegram 2256, Krishna Menon to Bajpai, 2 September 1947. 
139 NAI, MEA, 19-EUR/47. Telegram 7331, Bajpai to Krishna Menon, 3 September 1947.

140 NAI, MEA, 4(4)-FSP/47. Note, B. K. Kapur, 22 February 1947.

141 NAI, MEA, 4(4)-FSP/47. Note, Nehru, 22 February 1947.

142 Thakur, Postscripts on Independence, p. 167.

143 NAI, MEA, 351-FE/45. Letter, Bajpai to Caroe, 28 June 1945.

144 BL, IOR, L/PS/12/4627. Quarterly Report October to December 1945, Bajpai, undated.

145 Subimal Dutt, Autobiography, unpublished, 1984, pp. 86-87.

146 SWJN2, vol. 2, p. 432. Note, Nehru, 11 March 1947.

147 Ibid., p. 464-465. Letter, Nehru to Mountbatten, 1 May 1947.

148 Durga Das, India from Curzon to Nehru and after, New Delhi: Rupa, 2012, 5 th edition, p. 48.

149 SWJN2, vol. 4, 1986, pp. 583-585. Letter, Nehru to K.P.S. Menon, 12 October 1947.

150 Thakur, Postscripts on Independence, pp. 162-166.

151 Amit Das Gupta, Serving India. A Political Biography of Subimal Dutt (19031992), India's Longest Serving Foreign Secretary, New Delhi: Manohar, 2017, pp. 111-112.

152 M. O. Mathai, My Days with Nehru, New Delhi: Vikas, 1979, p. 121.

153 Jawaharlal Nehru, Autobiography, London: Bodley Head, 1938, pp. 442-445.

154 Thakur, Postscripts on Independence, p. 158.

155 Gopal, Nehru, vol. II, p. 35.

156 NAI, MEA, 319-AD/47. Report of the Secretariat Reorganization Committee, 10 August 1947.

157 NMML, KPSMP, Diary 1947, 21 September.

158 NMML, KPSMP, Diary 1947, 22 September.

159 NMML, M.O. Mathai Papers, Correspondence with K.P.S. Menon. Letter, Menon to Nehru, 23 September 1947.

160 SWJN2, vol. 4, 1986, pp. 583-585. Letter, Nehru to K.P.S. Menon, 12 October 1947.

161 NMML, KPSMP, Diary 1947, 4 November.

162 NMML, KPSMP, Diary 1948, 14 and 16 January.

163 NMML, KPSMP, Diary 1948, 21 January.

164 NMML, KPSMP, Diary 1948, 28 March.

165 NMML, KPSMP, Diary 1948, 26 April.

166 NMML, KPSMP, Diary 1951, 6 March.

167 NMML, KPSMP, Diary 1951, 26 April.

168 Das Gupta, Serving India, p. 149.

169 Dutt Diary 8, 5 November 1954.

170 Dutt Diary 6, 10 November 1952.

171 Das Gupta, Serving India, p. 41.

172 NMML, KPSMP, Diary 1922, 19 July, 25, 26 and 27 October.

173 M. O. Mathai, My Days with Nehru, New Delhi: Vikas, 1979, p. 121; Yezdezard Dinshaw Gundevia, Outside the Archives, Hyderabad: Sangam Books, 1984, p. 56.

174 Dutt Diary 6, 16 November 1952.

175 NMML, SDP, Bangladesh Diary II, 20 February 1973.

176 Das Gupta, Serving India, pp. 138-139.

177 Ibid., p. 384.

178 Ibid., p. 198. 


\section{THE BAJPAI YEARS IN THE MEA}

In his long career, Bajpai never exercised more influence than between 1947 and 1952. In the colonial period, he had had to assure the support of the viceroy, the secretary of state for India and finally the British government. With independence, he was responsible only to the foreign minister (who happened to be the prime minister), who shouldered multiple tasks. That Bajpai was not part of the cabinet and formally ranked below the irrelevant temporary Deputy Minister B. V. Keskar ${ }^{1}$ could hardly bother him: Bajpai never attempted a political career. As the only official holding the rank of secretary-general, he outdid all others in independent India.

Trust and even better sympathy of the prime minister were essential to exercise maximum influence. Like his earlier superiors, he managed to win Nehru too. As during the interwar period, he accompanied his boss to major conferences and led high-level talks of great relevance. Typically, it was Bajpai and not Krishna Menon or Mrs Pandit representing India's case on Kashmir at the UN in 1948. Nehru considered the issue too relevant and, between the lines, told his sister that she was not up to the task; Krishna Menon would not fit in the delegation ${ }^{2}$ - meaning he might disturb Bajpai - and was ordered to stay in London. ${ }^{3}$ A year after independence, the secretary-general had outperformed Nehru's closest confidants from 1946 and 1947.

Nehru appreciated Bajpai's experience, networks and knowledge of various foreign languages. ${ }^{4} \mathrm{He}$ even defended his unwillingness to give up the British title 'sir'. Bajpai somewhat sanctimoniously argued that he would immediately drop it but felt that it would have been courageous and meaningful only earlier while suffering consequences for his career. Now it was for the government to give general guidelines on this issue. ${ }^{5}$ Apart from their professional cooperation, a personal bond grew. Not later than in July 1949, they were on a first-name basis. ${ }^{6}$ Apparently, the prime minister had come to consider the secretary-general as among the very few in his league. When discussing promotions in the IFS with Krishna Menon, Nehru complained about

the service mentality [that] does not think very much in terms of work to be done, but in terms of service, promotions etc.... Bajpai, 
in spite of his long service experience, is able enough to think of other considerations. ${ }^{7}$

The prime minister also valued the work discipline of the secretary-general, who had not been expected to last long on his post. ${ }^{8}$ In a letter to Bajpai from March 1950, he remembered that around his appointment in 1947, he had hinted at his poor health and

to the necessity of your resting in the afternoon under doctor's orders. As a matter of fact, you have worked harder and put in more hours in the office than anyone else in External Affairs. I have deeply appreciated the work you have done and the manner of doing it, and it has been a pleasure to work with you.

Therefore, Nehru, himself considering resignation, ${ }^{9}$ did not accept Bajpai's numerous tactical offers to resign. If the pilot went off board, the secretarygeneral had to keep the ship on course..$^{10}$ Apparently, Bajpai's health was further deteriorating towards the end of his term. In August 1951, he fainted in office and was confined to bed thereafter. ${ }^{11}$ On top of it, his wife went through a prolonged period of ill health. ${ }^{12}$

Keeping Bajpai for five years, nevertheless, was not exploiting him against his will. Dutt, among his confidants, had forebodings that Bajpai with his 'vanity ... to be in the thick of things' would sooner or later 'kill himself'. ${ }^{13}$ Nehru was painfully aware that there was no adequate successor, regularly consulting Bajpai after he had been appointed governor of Bombay. ${ }^{14}$ It was Bajpai again who in February 1953 presented the Indian case at the Kashmir talks in Geneva. Nehru even toyed with the idea to nominate him as candidate for the post of secretary-general of the UN; Bajpai, aware that he stood no chance, declined. ${ }^{15}$

Bajpai had an extraordinary standing not only vis-à-vis his boss. As a matter of course, none of his subordinates ever challenged his position. Everyone of relevance had an ICS background: With C.S. Jha and Parakuta Achutha Menon, K.P.S. Menon had two ICS officers working under him as joint secretaries; their colleague Y.D. Gundevia, holding the same rank, supported Dutt. Temporary Joint Secretary Badr-ud-din Tyabji from the 1932 ICS batch remembered how Bajpai dominated meetings in the MEA 'with great aplomb' and his 'barbed wit'. He had a point, considering it unfortunate that both Menon and Dutt had served under Bajpai earlier and

could never get over the inhibitions of those days in regard to him. They served more as clay pigeons to be shot down at will than as sparring partners with whom the champion could not only exercise his own skill but also teach them how to develop their own. ${ }^{16}$ 
Gundevia drew a similar picture: For the daily morning meetings in Bajpai's office, 'we always trooped in strict order of precedence and sat down in strict order of precedence and marched out in the same order when the session was over'. When Gundevia burst out laughing about an ill-humoured sarcastic remark of Bajpai, he was rebuked by Dutt 'that one did not laugh, not like this, before the secretary general'. ${ }^{17}$ Both memoirs tell, first, that Bajpai was as power-conscious and dominating as ever, insisting on hierarchies and office rules, full-heartedly assisted by his deputies. Unsurprising, second, this was not always to the liking of ambitious junior officers who wanted to find an attentive ear on the highest level. Some bypassed their superiors at occasions and approached Nehru directly: while Gundevia won the prime minister's support, ${ }^{18}$ Tyabji would soon be considered as an overconfident troublemaker. ${ }^{19}$

\section{Foreign service}

Bajpai hardly had time to train junior officers. In 1951, Tyabji initiated monthly departmental meetings to discuss recent events. They displayed a tremendous lack of knowledge at headquarters, mirrored in the extravagant assessments made by Tyabji, who had not spent much time abroad. He was contradicted by heads of missions mostly from Europe, insisting on their superior knowledge of conditions on the ground. There was always one of the secretaries present, but neither Menon nor Dutt ever took part in the partly controversial debates. ${ }^{20}$ Bajpai occasionally attended, remarking but good-humouredly that they were meant to give junior officers a chance to discuss with more experienced ones and get an all-round picture of world affairs. $^{21}$

Like in the interwar period, Bajpai was straightforward and occasionally harsh regarding substandard work. Ambassador P. Subbarayan Gounder, Djakarta, he criticised for 'stale quotations from British weeklies';22 High Commissioner Kesava Menon, Colombo, he did not see up to his tasks. Bajpai might have been especially blunt with career changers who did not enjoy Nehru's special protection. On occasion, prime minister and secretary-general differed on promotions, about both principles and actual candidates. ${ }^{23}$ Regarding the former, Nehru generally agreed with bureaucratic principles laid down by Bajpai but insisted on their proper application. Seniority was relevant, 'but mere experience is not enough'. The IFS required a certain aptitude not possessed by many. These were not only those civil servants Bajpai suggested; some of those chosen from the public 'were equally entitled to special consideration'. ${ }^{24}$

What at first sight appears not even worth a footnote leads to a major conflict determining foreign policy under Nehru. If anyone challenged Bajpai's position, it was those women and men chosen from the public sphere. On the surface, it was the usual rivalry between career diplomats and career 
changers, and, closely linked with it, differences about observation of office rules and procedures - self-evident for the former, cumbersome for the latter. Particularly when considering the role of Krishna Menon, there was more to it: a conflict about the means of Indian diplomacy. ${ }^{25}$ The policy around Indians overseas in the interwar period had been pursued along the lines of established diplomacy, and often so with elegance. Bajpai or Sastri had observed the difference between cladding controversial views in decent words, presented with courtesy, and the verbal sabre rattling that became Krishna Menon's trademark. Even if classical diplomacy had but delayed the implementation of apartheid in South Africa, its protagonists had won the respect even of a racist like Malan. On the contrary, Krishna Menon regularly made enemies for life. Finally, and most important, there was armwrestling about the general direction of Indian foreign policy.

It was easy for Bajpai to bypass the inefficient Asaf Ali, who had no clout with Nehru or the cabinet. ${ }^{26}$ Nevertheless, the most prominent ambassadors chosen from the public sphere - Krishna Menon, Vijaya Lakshmi Pandit and, to a lesser extent, Kavalam Madhava Panikkar - all had the ear of the prime minister and figured as foreign policy advisors. To the embarrassment of the MEA, the former two regularly bypassed the ministry and sent letters to their friend and brother, respectively. This practice continued throughout the Nehru years and resulted in parallel foreign policies. With an emotional, influenceable and often wavering head of government, officials and influential non-officials more than once were not pulling together. At least during the years when Bajpai was secretary-general, the non-officials were at a disadvantage for mainly three reasons. Notwithstanding a flood of private letters and telegrams, they were, first, out of Delhi. Second, they never cooperated against the officials, instead intensely rivalling each other. Finally, their performance as heads of missions hardly earned them any merits.

Mrs Pandit's appointment as first ambassador in Moscow had been a gesture toward the USSR. After having led the Indian delegation to the UN in 1946 and for being the prime minister's sister, she was the best-known Indian face on the international floor after Gandhi and Nehru. In New York, she had met Molotov and Deputy Foreign Minister Andrey Yanuaryevich Vyshinsky. The Soviets had responded accordingly, allowing her to arrive by her own aircraft - a privilege granted to no other foreign diplomat. Within a fortnight she was given a house, whereas other diplomats for years had to reside in hotels. These efforts fell on fertile ground. Mrs Pandit had the best intentions to further Indo-Soviet cooperation and was eager to study country and language. She was anxious 'to see the Soviet Union in proportion and, unlike some diplomats, not have her view entirely obscured by the frustrations of daily life and the stupidities of the press'. ${ }^{27}$

Her initial enthusiasm cooled down quickly as the friendly overture ended nowhere. Instead, the USSR soon attacked India as being only seemingly independent, a lackey of the imperialists oppressing the CPI. Nevertheless, 
an interview with Stalin would have been mandatory for every diplomat. Mrs Pandit, however, never was given the chance, and the Soviet ambassador in Delhi, Kirill Vasilyevich Novikov, blamed her for never having even tried. ${ }^{28}$ Mrs Pandit clarified that she 'had not ever applied for an interview with Stalin', but told Molotov or Vyshinsky that she was keen to pay her respects to him. Her counterpart had replied 'that Stalin did not give interviews ordinarily'. She received the same response when asking once again a few months later. ${ }^{29}$ Bajpai took this as 'equivalent to a polite request'. ${ }^{30}$

Whereas she could not be blamed for Stalin's lack of interest and courtesy, she did little to win sympathies. She was shocked by the 'relative squalor' of the embassy, the lack of all comforts and the difficulties to arrange even small commodities. ${ }^{31}$ Soon she began to hate the general atmosphere, where one was 'considered guilty until proved innocent'..$^{32}$ Never good in hiding her feelings, British diplomats characterised her as 'a voluble talker'. ${ }^{33}$ They warned that 'perhaps because she is so ready to talk, she sometimes contradicts herself', ${ }^{34}$ a feature certainly not winning her much respect with Soviet officials. Deeply disappointed, she kept close contact with western missions in Moscow, deepening the impression that India was but part of the western bloc. Personally, she even did not profit from the conclusion of an Indo-Soviet barter agreement on 12 July 1948: Krishna Menon created the impression that it had been negotiated in London. ${ }^{35}$ With regard to establishing good relations with the USSR, her term was a complete failure.

Putting the blame on others, especially her staff, was an unpleasant feature of Mrs Pandit. She was flabbergasted that junior members 'such as the messengers and guards' were 'most impressed by Moscow, which they contrasted very favourably with the living conditions of the poorer classes in India'. Everyone appeared well housed and there was enough food and no 'racial or caste feeling'. ${ }^{36}$ The higher ranks, as with every ambassador from the public sphere, were ICS officers. Among the troika of Minister A. V. Pai, First Secretary Prem Krishen and Private Secretary T.N. Kaul, only the first commanded considerable experience in foreign affairs. Prem Krishen from the 1935 batch had been deputy secretary in the Health Department, and Kaul from the 1937 batch had been secretary of the Imperial Council of Agricultural Research.

Whereas British and Canadian diplomats appreciated Pai and Prem Krishen, ${ }^{37}$ Mrs Pandit complained that they stood in her way. While the Soviets considered her 'the heroine defying, with the aid of Russia, the might of imperialism . . . there was dislike of our officials' and remarks about 'reactionary servants'. ${ }^{38}$ She fully agreed with such assessments, complaining about 'a conservativeness of approach to all problems by my staff which has been very harmful to the cause of India'. Mrs Pandit wished that Delhi might send someone 'in whose judgment they have confidence to report on Moscow'. ${ }^{39}$ Kaul she appreciated, ${ }^{40}$ but Pai, who had been faint-hearted during his posting in Ceylon in the 1930s, she characterised as 'diffident and 
of a very nervous temperament', unable to take decisions on his own. 'Prem Krishen is extremely arrogant and has the worst kind of ICS complex. . . . His behaviour with the Russians is casual, sometimes even rude'. She asked Bajpai to remove both. ${ }^{41}$ Pai and Prem Krishen, themselves keen to leave, were transferred in the spring of 1948, though without suffering any setback in their respective careers. Whereas Pai soon became principal secretary of the prime minister, Prem Krishen was appointed head of mission in Kabul and later Berlin.

It was no sign of wisdom to blacken nearly all subordinates, and it was even less so to include colleagues like Asaf $\mathrm{Ali}^{42}$ and Krishna Menon. ${ }^{43}$ Mrs Pandit possibly did not even realise that her blunt criticism on the general course of Indian foreign policy, the selection of officers and the manner the MEA was run implicitly targeted prime minister and secretary-general. In letters to Bajpai, she lamented that she had been sent to Moscow without any instructions and, therefore, ran the danger to be brought to task for mistakes. ${ }^{44}$ Furthermore, she complained that

one of our great handicaps today is the lack of any clearly defined foreign policy - we have said that we shall not ally ourselves to any groups and will consider each question on merit. This sounds well enough but means nothing. Inevitably one finds oneself aligned on one side or the other. ${ }^{45}$

Both complaints were well justified, but it was unwise to criticise Bajpai and at the same time fire such a broadside against Nehru. With the secretarygeneral of all people she regularly criticised the influence of ICS officers in the foreign service. In her eyes, most missions were set up wrongly because of hierarchies. When she allegedly ran the Moscow embassy as a family, it was 'this very thing that the ICS officials could not appreciate'. ${ }^{46}$

Scheming against others went hand in hand with exaggerated self-praise. Already in February 1948, she asked her brother to be transferred to Washington. There was little to do in Moscow 'and those who attempt to preserve an independent attitude are made to feel outcastes by both sides'. Neither she nor India would gain anything from her being in Moscow, the ambassador holding but 'a watching brief'. On the contrary, she claimed that 'owing to my personal success in the States I have a large number of American friends and admirers' including John Foster Dulles.

This is quite soothing coming from a bunch of reactionaries. Neither ability nor sincerity nor anything else can help us in America today any more than in the USSR, but there is no doubt that I could . . . sway public opinion considerably in favour of India. I do appeal successfully to the common man and have a wide audience in the States. ${ }^{47}$ 
Mrs Pandit fulfilled none of her promises; her performance in the US was as unremarkable as her term in the USSR. ${ }^{48}$ By May 1951, she asked to leave, again finding reasons for her failure elsewhere, this time permanent press criticism from India. Moreover, she blamed the MEA for lack of support, its officials not feeling bound to Nehru's principles and policies. ${ }^{49}$ As high commissioner in London, she found herself bypassed and ridiculed by Krishna Menon, one of her predecessors who had not yet left the British capital. ${ }^{50}$ Due to her poor performance, her star quickly sank, and her permanent complaints about nearly all and everyone earned her a special reputation. In 1954, Nehru's influential private secretary M. O. Mathai advised Dutt to keep distance. ${ }^{51}$

Her successor in Moscow qualified as the most unusual among the nonofficials appointed ambassador. Sarvepalli Radhakrishnan counted among India's leading intellectuals, since 1936 named Spalding Professor of Eastern Religions and Ethics at Oxford University. Before sent to Moscow, he had represented India at UNESCO. To a large extent, he shared Nehru's worldview. For this and his personality, the prime minister believed him especially suited for the posting, though he admitted that it would be an 'interesting experiment'. ${ }^{52}$ The upper echelons of the MEA commented with more scepticism. K.P.S. Menon wondered how the philosopher would be playing the diplomat, ${ }^{53}$ and Bajpai remarked with unmistakable fatalism that it would take time until 'the philosopher . . . has been "broken in"'. ${ }^{54}$ The unorthodox new ambassador, spending most of his time in bed reading, aroused the curiosity of Stalin, who gave him a first audience in January 1950. Though the exchange was friendly, it was mostly a succès d'estime, Stalin expressing doubts about the factual independence of India. ${ }^{55}$ Otherwise, Bajpai was unhappy with Radhakrishnan's performance, ${ }^{56}$ complaining with the American embassy that he "frequently displayed certain amount of "wooliness" and "naiveté" in his dealing with Russians'. When discussing the North Korean attack on South Korea, he had not countered Soviet allegations that Americans were killing Asians by pointing out 'that North Koreans began killing of Asians and ... it could be no comfort to Asians who were being killed and wounded that their attackers were Asians' ${ }^{57}$ Furthermore, he had to intervene when Radhakrishnan launched initiatives on sensitive issues without consulting headquarters. Among them were a proposal for a treaty of friendship, a scheme for ending the Korean War and suggestions that Moscow should get involved in the Kashmir dispute. ${ }^{58}$

Until the generalissimo's death in 1953, Moscow showed no inclination to open up towards India. In the meantime, the GoI had changed course in terms of personnel. Radhakrishnan, who could not stand the Russian winter and was keen to continue in Oxford, for around half of the year left business to his deputy Gundevia, who after years in Burma and headquarters commanded sufficient experience for a difficult place like Moscow. In 1952, 
this turn towards a professional head of mission was completed with the appointment of K.P.S. Menon, India's star diplomat.

Bajpai was wise enough never to criticise the prime minister's sister; her performance and that of her successor spoke for itself. Occasionally, he suggested to US diplomats to bypass her as she was likely to forward information in such a manner that the effect would be opposite to the intention. ${ }^{59}$ His replies to her permanent complaints, however, were polite and full of understanding. It was a different story with Krishna Menon, whom Nehru gave a much more prominent permanent role and who openly challenged Bajpai and the MEA. With independence, Menon was appointed high commissioner in London. On the one hand, he was the obvious choice for having been the voice of the independence movement in Great Britain. After 20 years in British politics, he knew all and sundry, and as delegate to the $\mathrm{UN}$ and for travelling Europe, he was up to international politics better than any other Indian public figure. On the other hand, the British, since long, considered Menon as 'one of the most important Indian extremists in the country'. ${ }^{60}$ The India Office had been shocked when it learned that Menon had expressed his ambition to represent independent India in London while he had shown a 'strongly anti-British attitude' in New York and held that the UK was of little or no relevance in world politics. His allegiance to Moscow 'seemed to be so complete as to render him incapable of any balanced judgment of the merits of any matter under discussion' ${ }^{61}$ Viceroy Mountbatten, however, was a friend of Menon and supported the appointment. ${ }^{62}$

The MI5, nevertheless, continued to consider the high commissioner a security threat, wherefore India was excluded from the dominion intelligence loop. Furthermore, British missions were instructed to be cautious about sharing material with Indian colleagues. ${ }^{63}$ The Indian Intelligence Bureau shared these suspicions but did not dare to approach Nehru, known for his dislike for secret services. ${ }^{64}$ The allegations of Menon secretly being a member of the CPGB proved wrong, ${ }^{65}$ but the British would have preferred to communicate with the GoI rather through the trusted Bajpai. ${ }^{66}$ Menon truly kept to his reputation to make enemies wherever he went; he was considered Nehru's bête noire and India's unpleasant face all over the western world. ${ }^{67}$ Against the availability of so many others with a deep knowledge of British politics, Nehru with the appointment did India a disservice.

The blunder from September 1946 had caused but a minor setback in Menon's career planning. While he was denied a visit to Moscow, he was sent to Bern, Prague and Rome for preliminary talks to establish diplomatic relations. Menon proposed

that a temporary Indian diplomatic establishment should be set up in London headed by a person with the rank of an ambassador who will be accredited as ambassador or minister plenipotentiary to a 
number of smaller countries in Europe, probably Belgium, Holland, Denmark, Norway, Sweden, Finland and Switzerland. ${ }^{68}$

This would have created a sort of parallel foreign ministry in Europe which, given Menon's regular presence at the UN, would have got involved in relations with North America as well. The MEA, however, refused to hand over European affairs to Menon. For a short while, manpower shortage in the IFS seemed to keep the door open for a super-embassy in London. In the case of France, it was not until late 1947 that the GoI announced the selection of Narayanan Raghavan Pillai, ICS, as CDA. ${ }^{69}$ With Italy, an exchange of ambassadors was agreed in November 1947, but it took more than a year until R.S. Mani from the 1932 ICS batch was appointed CDA. Around the same time, the military mission in Berlin was taken over by Khub Chand from the 1935 ICS batch, whereas Tyabji led the mission in Brussels. Notwithstanding frequent changes of personnel in the early years, most of those missions remained under members of the 'ICS brotherhood'. They were used to observe office rules and unlikely to dance to Krishna Menon's tune, even more as the latter did not hide his contempt for civil servants. Soon, non-professionals became a rare occurrence among the heads of missions. ${ }^{70}$

Thenceforth, Bajpai, who had earlier welcomed Menon's initiative in Europe, was ready to rap his knuckles. When Menon insisted that it should be him to confirm the request of his Italian counterpart to send Renzo Carrobio as ambassador to Delhi, ${ }^{71}$ the secretary-general replied harshly that he did not recall any conversation with the high commissioner on this issue. Moreover, the appointment could not be announced yet as Menon, against the rules, had not attached Carrobio's CV. ${ }^{72}$ Bajpai treated Menon as any other head of mission, and as one lacking professional experience. This did not stop the high commissioner from creating the wrong impression that negotiations around an Indo-Soviet barter agreement 'cannot take place without some help from London'. ${ }^{73}$ Feeling sacrosanct, he treated Mrs Pandit rudely when passing through London on her way to the US. ${ }^{74}$

The hour of Menon's antagonists came when an Economic Committee under Chairman Kasturbhai Lalbhai looked into the expenses of ministries. $^{75}$ To Nehru's embarrassment, it demanded an evaluation of the high commission in London, by far the largest and most costly mission abroad. ${ }^{76}$ Bajpai suggested to send a senior MEA official. Only seemingly, this met both ends without hurting anyone. The secretary-general chose Dutt, sufficiently senior and with a reputation for being thorough, impartial and not involved in ministry intrigues or party politics. Nevertheless, the commonwealth secretary was, of course, aware of his mentor's 'quarrel with Krishna Menon' and what outcome Bajpai had in mind. ${ }^{77}$ As agent in Malaya, he had shown a stiff upper lip. His new task, however, he considered a suicide mission unless the results were fully in line with Menon's views. 
It was a close escape. In May and June 1949, while in London, Dutt believed his letters intercepted and the dustbins searched. Both Menon and Nehru, in vain, put him under pressure to prepare a joint report with the high commissioner, which would have been running counter to an impartial evaluation. ${ }^{78}$ As the prime minister had feared, Dutt's report was a disaster for Krishna Menon. It mostly confirmed what had been well known before in general, ${ }^{79}$ but it did so in such accurate detail and manner that it was impossible to ignore it or to blame its author as biased. Having a knack for writing short and precise reports, Dutt reviewed strengths and weaknesses of the mission in the style of an executive consultant.

He analysed the high commission as chaotically grown, inefficient, poorly run, and wasting money on a large scale. Its authoritarian head deliberately ignored all rules established by the GoI, especially those regarding recruitment and promotion. Staff was employed in a 'more or less chaotic' manner. As a result, senior posts were held by former temporary clerks 'with average intelligence and qualification' instead of IFS officers - what translated into Menon promoting favourites and refusing candidates selected by the MEA. Dutt's demand that the cipher section had to be run by IFS officers implicitly referred to the suspected leaks in the high commission. His distrust against Menon manifested in the request that the deputy high commissioner must see all files of the heads of departments before the high commissioner - perfectly camouflaged as a means to spare Menon from routine work. Moreover, the report criticised Menon's reports for commenting issues outside the UK though India maintained missions there as well. Dutt, finally, drew attention to the luxurious car park, the high commissioner moving around in a Rolls-Royce. ${ }^{80}$

While Menon, refusing a salary and living a frugal life, ${ }^{81}$ could not be blamed for abusing taxpayers' money for private purposes, Dutt portrayed him as high-handed and incapable to run an office. The high commissioner was expected to focus on his core business, the UK, and the mission should come under close scrutiny of the MEA. Though London would remain India's largest mission, its head would be but one among many of heads of missions. Menon slandered against Dutt to anybody and threatened with resignation. Nehru asked the commonwealth secretary to change his report, who retorted

that I had expressed my views honestly and would not change them in any circumstances. If the prime minister disapproved of my views he should reject them. Further, if he thought that my presence in his ministry would be embarrassing to him, I was ready to go out.

Since Dutt had provided Bajpai with exactly the report he must have hoped for, the secretary-general stepped in, threatening resignation if Nehru took action against the commonwealth secretary without letting Bajpai comment 
on the report. ${ }^{82}$ None of the three had to resign. Dutt for his steadfastness and balanced judgement won Nehru's respect, the report paving his way to the foreign secretaryship. Menon could count on his friend, who would appoint him minister first without portfolio and then for defence with an even worse track record. Even after the disastrous evaluation, the high commissioner refused to send reports to the territorial division of the MEA, allegedly believing it to be beneath his dignity. ${ }^{83}$ Finally, Bajpai, for the time being, had won one over the high commissioner.

The one career changer who outdid Bajpai was the historian K. M. Panikkar. Steven A. Hoffmann's assessment that Nehru found his 'intellectual style of geopolitical argument to be closer to his own than were the styles of more narrowly focused officials such as Bajpai ${ }^{84}$ perfectly fits into the broader pattern of Nehruvian foreign policy. The cases of Krishna and later K.P.S. Menon give ample evidence. Panikkar's beginnings show many parallels to K.P.S. Menon's. Born in 1895 in Travancore State, he too attended Madras Christian College and studied history at Oxford. Unlike Menon, he turned first to teaching at Aligarh Muslim and Calcutta University. From 1925, he served India's princely states, collecting broad experience in administrative matters. Though foreign minister of Patiala and later Bikaner, he had not much knowledge of international affairs as those states were only formally independent. In the spring of 1948, he was appointed K.P.S. Menon's successor in Nanking. After the victory of the communists was beyond doubt, Panikkar on his own initiative stayed on, waiting for an indication what attitude the new government was going to take. In those months, he endured a complete breakdown of law and order, water and the electricity supply in Nanking. ${ }^{85}$ After the $\mathrm{CPCH}$ had taken over the city, the embassy was completely cut off, ${ }^{86}$ the communists refusing to have anything to do with the foreign missions. ${ }^{87}$ For a while, the diplomats were kept rather as hostages. ${ }^{88}$ The MEA, nevertheless, ordered that if Panikkar left, he should rather be among the last diplomats to do so. ${ }^{89}$

It was not until August 1949 that the new rulers indicated a desire for friendly relations with India. ${ }^{90}$ By mid-September, Panikkar was the only ambassador who had stayed in Nanking. He suggested to move to Beijing and to close the embassy of National China in Delhi. ${ }^{91}$ This did not mean sympathising with Communist China at all. The ambassador saw 'an aggressive communist government ... in complete accord with international communism'. A further expanding People's Liberation Army (PLA) would form the steel frame for industrialisation and enforce suzerainty over Outer Tibet by May 1950. Though they were unlikely to attack foreign forces, 'that would bring the communists to the border of India and it was politically and militarily difficult to counter such a move. Effective control of Outer Tibet may raise the question of defence of Nepal for us'. ${ }^{92}$

Panikkar gave up this sense of realism once the Chinese launched the attack on Tibet. Bajpai told British High Commissioner Frank Roberts that 
'he had some difficulty in understanding Panikkar's views who . . . was becoming lost in a maze of self-deception'.$^{93}$ In notes to Nehru, he wondered

what interest the ambassador thinks he may be serving by showing so much solicitude for the Chinese government's policy of false excuses and wanton high-handedness towards Tibet. ... Our ambassador has allowed himself to be influenced more by the Chinese point of view, by Chinese claims, by Chinese maps and by regard for Chinese susceptibilities than by his instructions or by India's interests. ${ }^{94}$

That the foreseeable clash of Chinese and US forces in East Asia might be limited to Korea as assessed by the ambassador further intensified Bajpai's doubts about 'Panikkar's reasoning ability'. ${ }^{95}$ Nehru, however, shared the ambassador's views and, based on them, formulated a double strategy: Tibet could not be helped militarily but might enjoy maximum autonomy if no outside power got involved. India did not need to fear an open attack but gradual infiltration, wherefore it needed to secure its northern border. The best and cheapest defence policy vis-à-vis China, however, would be friendly relations. ${ }^{96}$

Though Nehru did not abandon this strategy, Bajpai managed to pull him along regarding Panikkar's assessments on China. In November 1951, the prime minister told US Ambassador Chester Bowles that 'Panikkar usually succumbed to whatever situation he was in', having earlier represented some of the most reactionary princes. Today, he 'tended dangerously [to] idealize Chi[nese] scene', wherefore he would soon be transferred. Nehru even 'emphasized he did not accept Panikkar's present views about Chi[na] nor was he in any way blind to potential dangers which might be developing in China'. ${ }^{97}$

Panikkar prevailed once again in a much more delicate issue: the boundary. In late 1947, Bajpai had turned down protests of the Chinese ambassador against maps showing Tibet as an independent country. ${ }^{98}$ With the communist takeover, negotiations about Tibet, where India held extraterritorial rights from the colonial period, became a necessity. Bajpai and K.P.S. Menon wanted Delhi to give up those rights in return for the acceptance of the boundary as India defined it. Panikkar was to investigate the Chinese position but did not touch the issue with Prime Minister Zhou Enlai, arguing that silence should be taken as acquiescence. Bajpai disagreed right from the start but to no effect, though Nehru soon started wondering whether the GoI was not going to overreach itself, trying to be clever. ${ }^{99}$ Panikkar tried to convince the secretary-general that if the matter was raised, the Chinese were unlikely to accept the Simla Agreement from 1914. Instead, they would offer negotiations, knowing that India was in a weak position. Delhi should simply state that there was nothing to discuss after the boundary had 
been declared fixed by Nehru in a statement from 1950;100 this position was adopted by Nehru. Even after his transfer to Bombay, Bajpai countered such views in letters to his successor N.R. Pillai but to no avail. ${ }^{101}$

The pros and cons of Panikkar's approach have been discussed widely. Srinath Raghavan holds that critiques have overlooked that the ambassador was starting from the assumption that India needed time to establish its position in the border areas, lacking any civilian or military infrastructure. He admits, nevertheless, that an opportunity was missed to settle the boundary at a moment when China, facing a multitude of other difficulties, might have been more willing to compromise. ${ }^{102}$ Undoubtedly, Panikkar's forbearance had long-term consequences, culminating in the border war from 1962. Finally, however, this was a political decision taken by the prime minister. It is another story that an ambassador came away with insubordination in such a crucial case; it throws a bad light on decision-making in the Nehruvian years. Not only at this occasion had the tail wagged the dog.

In later years, Panikkar would face stiffer resistance. After his departure from China, his career took a steady decline, though Cairo by name was a relevant posting again. When foreign secretary, Dutt advised Nehru against entrusting Panikkar with another mission. Formally, he held that there was no obligation to keep someone being no part of the IFS; in truth, he considered Panikkar lacking a moral compass. ${ }^{103}$ Although the latter was appointed ambassador to France, producing some doubtful reports on European politics, ${ }^{104}$ he disappeared into oblivion.

Bajpai tried hard to limit the influence of all those who worked outside or against the hierarchies of the MEA. An intriguing question is how Bajpai felt working under Nehru. Though he was one and a half years junior to the prime minister, he commanded much more expertise in foreign affairs and in running a department. Nehru's much celebrated baptism in international politics had been the Brussels Conference in 1927, where the League against Imperialism had been founded. It was a gathering of representatives of the communist world and delegates from 37 countries under colonial rule. ${ }^{105}$ Though mostly inconsequential, Nehru from then on was praised for his networks with leaders of the anti-colonial movements worldwide. For good reasons, the value of this so-called anti-colonial cosmopolitanism has been questioned for its mostly strategic nature. ${ }^{106}$ Thereafter, rather for his wife's health, Nehru had been travelling abroad occasionally, advertising the case of India. Kapur's assessment that 'no one in the country could really match him' in terms of experience in foreign affairs ${ }^{107}$ is only true if the Congress is wrongly taken for 'the country'. The world and world politics, furthermore, necessarily looked different from the view of a representative of an independence movement compared to someone who was part of government politics in a leading capacity. Whereas Nehru had given speeches and conducted mostly informal talks, Bajpai had excelled at international conferences, led talks with heads of governments and learned international diplomacy from 
scratch. And while Nehru had spent most of the world war in prison, Bajpai had been in Washington, the perfect place to understand post-war developments. From September 1946, India needed skills in traditional interstate diplomacy rather than those of a campaigner for independence. If the country had such a foreign policy expert, it was Bajpai, not Nehru.

The secretary-general's ideas about Indian foreign policy differed from those of the prime minister. Bajpai, however, would not have had such an extraordinary career had he not internalised the fundamental rule of civil servants: orders from superiors were to be obeyed. Gundevia's recollections give evidence of this: Nehru, preparing for visiting the US in 1949, was embarrassed that he was meant to show up 'with a begging bowl' (i.e., to ask for food aid, needed after a poor monsoon). Bajpai explained that 'there was no begging bowl about this. It just happens to be one of the pending matters between two independent countries'. The prime minister, nevertheless, crossed the paragraph in the note prepared by the MEA, and so did Bajpai, demonstrating absolute loyalty notwithstanding disagreeing on the matter. ${ }^{108}$ The episode also tells of the different approaches to foreign affairs and of different dispositions. Whereas Bajpai appears as the always calculating, rational advocate of national interest, Nehru could not overcome his personal pride for the sake of the nation.

This was confirmed by US diplomats, who on numerous occasions were warned by the secretary-general not to approach the prime minister when he was in one of his proverbial moods. ${ }^{109}$ Furthermore, particularly in the Kashmir dispute, Bajpai more than once complained about the mostly emotional approach of Nehru and the cabinet. For the first time in his long career, however, Bajpai too was noted for moods and emotional outbursts. US Ambassador Loy W. Henderson observed that 'he at times indulges in fits of pique from which he rapidly recovers. He has had these fits for many years, and I do not take them too seriously'. ${ }^{110}$

On rare occasions, Bajpai also indicated more fundamental differences with Nehru, for example, when the prime minister at a Commonwealth conference held 'that the key to security in South Asia lay in weakness, that is, in disarmament rather than rearmament'. Bajpai in private informed British officials that " "many of us" do not share these views and that he had reminded the prime minister there was such a thing as tempting providence'. ${ }^{111}$ Otherwise, even at moments of despair, like the day his term ended, Bajpai never ever came close to disloyalty. He well warned US CDA Clifford C. Taylor that from this day Nehru would completely dominate the GoI and Indian foreign policy. Bilateral relations would 'depend completely on our personal relations with Nehru'. Those ministers the latter consulted on an intimate basis had either no backbone or no say in foreign affairs. What initially appeared like a warning transformed into a profession of faith: Bajpai praised Nehru's 'complete personal integrity, brilliant mind, unlimited courage and profound dislike for totalitarian methods'. Notwithstanding 
considering himself 'quite far to the left and somewhat of a revolutionary', his conservative background and education 'would strongly influence him towards middle road policies'. Nehru was 'vain and extremely sensitive' but had learned his lessons about China and especially the USSR. He was talking soft with Beijing only because of the long common border and fear of Chinese aggression. The cabinet was anti-communist throughout, and the only point where Nehru and Bajpai disagreed was that the latter believed that Moscow was ready to start a major war 'if they felt odds over-whelmingly with them'. ${ }^{112}$

\section{Impact on decision-making}

While there is no doubt about Bajpai's standing in general, the scarcity of source material for his term does not permit any systematic analysis of his impact on central issues. As with many newly created foreign ministries, record-keeping in the MEA initially was a poor affair. ${ }^{113}$ Neither the National Archives of India nor the ministry's internal archives provide insights into internal decision-making processes comparable to the files of the DEHL. Only at random do they give an idea of how Bajpai advised Nehru, moderated discussions, and took and implemented decisions. For other periods investigated in this book, diaries and collections of K.P.S. Menon and especially Subimal Dutt allow conclusions on discussions in the MEA. Unfortunately, for the 'Bajpai years', both have left but fragments of little significance. The Selected Works of Jawaharlal Nehru, finally, give an idea of Bajpai's crucial role, the prime minister regularly referring to papers authored by the secretary-general. Naturally, those have only been summarised, if at all. Today US and British archives offer better insights. Observations by others, let alone foreign diplomats, however, cannot substitute internal comments by Bajpai himself, even more as the secretary-general was much too smart to lay his private thoughts open even when he claimed to do so. Henderson, for example, observed that whenever Bajpai confided something in him, this was mostly but half the truth. There were, first, leaks in the State Department, making Bajpai most cautious in order to protect his personal integrity. Second, while he shared parts of confidential telegrams from Indian missions or internal decisions of the GoI, he kept other parts secret, being aware that those would annoy Washington. ${ }^{114}$

Naturally, the secretary-general played a decisive role when it was about Indians overseas. Regarding South Africa, India had driven home its first diplomatic victory ever in the UNGA. In June 1946, the Asiatic Tenure and Indian Representation Act - which local Indians termed the Ghetto Act - entered into force, deepening segregation. India saw a violation of the Round Table Agreement of 1927, called back its high commissioner, cancelled a trade agreement and brought the case to the UN. The question was whether the 1927 agreement should be considered an international treaty 
or a domestic issue on which two members of the Empire had agreed. On 8 December 1946, an Indian-sponsored resolution won a two-thirds majority: South Africa should observe the regulations from 1927 and both countries report on the measures adopted. South Africa refused to adopt the resolution, but it won India a reputation as a spokesman of the underprivileged. ${ }^{115}$

Independent India wanted more at the 1947 session of the UNGA. Nothing had changed in South Africa, and Delhi was aware that a round table conference would lead to nothing; sanctions were unlikely to find a majority. The delegation, therefore, demanded immediate bilateral talks based on the resolution of 1946; if not, the UNSC were to act. Finally, the UN secretary-general should submit a report to the UNGA in $1948 .{ }^{116}$ Mostly owing to US influence, India failed to win sufficient support. ${ }^{117}$ In 1950, lastly, a preliminary trilateral conference, including Pakistan, took place; the Indian delegation was led by Kunzru. Bajpai had been in close touch with the Indian delegation to the UN and was now deeply involved in the preparations for the conference, demonstrating his outstanding memory. Gundevia was to support the delegation and grew desperate with the mass of files. When approaching Bajpai, the secretary-general

started neatly and masterfully tearing open each of the files at exactly the correct page, saying 'Read this ... not this . . . If you end up by half of what I am trying to forget ... you will know more than any two podgy Dr Malans', the prime minister of South Africa. ${ }^{118}$

As earlier, Bajpai tried to establish a practicable agenda, but this time the attempt failed. South Africa refused to refer to the UN resolutions and, instead, insisted on a maximum reduction of its South Asian population. The latter was not to be given political rights as this would lead to similar demands from the natives. Bajpai instructed Kunzru not to accept any formula indicating that local Indians did not belong to the country. Instead, he wanted him to insist that the conference was to discuss the 'future of South African nationals of Indo-Pakistani origin in South Africa'. The aim had to be the 'firm removal of the political, social and economic disabilities' and 'provision of opportunities for their fullest development'. Local Indians had to be taken into confidence and any compromise had to be acceptable for them. ${ }^{119}$ This line had been successful in the 1930, but now South Africa was no more willing to compromise. The preliminary conference failed and apartheid was introduced firmly. ${ }^{120}$

\section{Kashmir}

A feeling of déjà vu was characteristic for relations with the US too. This was particularly true for the Kashmir conflict, though it extended to the 
general handling of foreign affairs. Given the rapidly declining influence of the UK in world affairs together with lack of Soviet and Chinese interest in India, the US turned out to be the great power that Bajpai had to deal with most intensely. On the one hand, he was anxious to establish a good relationship; the numerous occasions when he shared classified papers were gestures of goodwill. He also indicated that he did not approve Nehruvian policy asking for American aid and at the same time demonstrating deep embarrassment owing to conditions enforced on him. ${ }^{121}$ In June 1951, with Henderson, he even made Nehru's stubbornness partly responsible for the growing rift between the two countries. The prime minister's mind 'had been fixed and he was not to be deterred by any persuasion or obstacles. Nehru convinced he was right and his character was such he would go straight ahead regardless consequences'. He was unhappy about the failure to obtain wheat from the US and Washington's stand regarding the recognition of communist China.

US hurry to make decisions re[garding] North Korean invasion and to make its own policies re Formosa had nettled; turn down his peace proposals in July had made matters worse; and crossing 38th Parallel had made differences really serious. ${ }^{122}$

There can be no doubt that Bajpai found the prime minister's way of handling such differences harmful.

The 'confirmed cold warrior' Henderson disdained nonalignment but came to respect Bajpai, ${ }^{123}$ being fully aware of the latter's limited room to manoeuvre. His successor Chester Bowles, a leading figure of the India lobby in the US, praised him as an 'emphatically anti-Soviet' official without illusions on China. Bajpai was the 'hardest-headed of all GOI officials and most realistic so far as Cold War conflict is concerned'. ${ }^{124}$ It was a different story with those in charge in Washington. More than once, Bajpai complained that some misread Indian intentions. ${ }^{125}$ The USG also ignored the advantage of the secretary-general, instead of Krishna Menon, formulating the initial response to the outbreak of the Korean War. Bajpai took the negative 'reply as personal affront and ... made number of sarcastically critical remarks to other chiefs of mission' ${ }^{126}$ Much worse, someone in the State Department undermined Bajpai's position by regularly leaking information to the press, which the secretary-general had shared under the pledge of secrecy. ${ }^{127}$ With increasing force, but in vain, Henderson demanded a stop to this, warning against alienating the most reliable official in the MEA.

Bajpai was fully aware of his special role vis-à-vis the western powers in general. In a conversation with Bowles, he expressed deep disappointment about the opportunistic attitude of the US regarding colonialism and questioned the preference of short-term advantages versus 'long-range forces which in end would determine course of the world'. With bitterness, he 
also warned that Washington should not take pro-western attitudes in Asia for granted. Nehru and others had been educated in Europe and 'probably we were right in counting on them because whether or not they liked it, these individuals emotionally tied to West and too late in life to change'. US cooperation with colonialist forces, however, undermined the ability of such leaders to work with the West. ${ }^{128}$ His many hints that things would become more difficult once he had left proved true. After his departure, foreign missions in Delhi experienced 'extremely critical lack of contacts with Nehru or competent GOI spokesman'. ${ }^{129}$

The main issue of the first half of Bajpai's term was the Kashmir conflict. The partition of British India had left numerous open questions, among them the future of the princely states. With the Indian Independence Act, in force from 15 August 1947, the British Crown terminated treaty relations with them. Though formally they were given the option for independence, London, Delhi and Karachi wanted them to join one of the successor states. Kashmir held a unique position for size, strategic location and providing the water supply for the north-west of the subcontinent. It was the one big state bordering both India and Pakistan. Maharaja Hari Singh played on time, but in October 1947 Muslim tribesmen, secretly guided by Pakistani officials, invaded Kashmir. In response, the maharaja signed the instrument of accession with India, which sent troops driving the raiders out of most of the state. In 1948, the Pakistani army formally joined the raiders.

India approached the UNSC, where it wanted that Pakistan be blamed as aggressor. The western powers, however, set both antagonists on the same footing. In various resolutions it was ruled that a plebiscite should decide the future of Kashmir, but Delhi and Karachi never came to terms about the conditions. The initially intense negotiations began petering out in 1950 with little prospect for a compromise. Bajpai was deeply involved, but the lack of sources makes it difficult to differentiate between many opportunities when he acted as spokesman of the GoI and the rare ones when he set a course of his own. For the 1948 session of the UNGA, Nehru sent him to represent the Indian case. ${ }^{130}$ Bajpai also gave two speeches at the UNSC ${ }^{131}$ and took the Indian seat there in early 1950, mostly for Kashmir again. ${ }^{132}$ For the many foreign initiatives for a solution of the conflict, he was the preferred contact person in Delhi instead of the more impulsive prime minister.

He set a first marker in early November 1947 when (with Nehru's support, but more creditworthy) he tried, in vain, to alert US Ambassador Henry Francis Grady to the danger that the USSR might get involved unless the conflict was resolved. ${ }^{133}$ By 1949 Bajpai changed track, holding that he did not believe that anyone might threaten South Asia via the Kashmiri part of the Himalayas. ${ }^{134}$ On occasion, Bajpai appeared to be readier to compromise on minor points than Nehru. The USG believed that the secretary-general was committed to a plebiscite; if Delhi failed to live up to its commitments, it might damage India's general standing in world affairs, 
an aspect that troubled Bajpai much more than Nehru. ${ }^{135}$ In a discussion with Charles P. Noyce of the US mission to the UN, Bajpai was willing to admit the plebiscite administrator an additional staff as long as they were mere observers, but not regular staff to run the plebiscite. ${ }^{136}$ In September 1949, he approached Henderson suggesting, 'only personally and without authority from his government', that the UNSC should 'explore further arbitration or preferably mediation' not limited to truces, but covering a wider range, 'including even final solution Kashmir problem'. ${ }^{137}$

Bajpai supported plans for partition cum plebiscite, V.P. Menon being its chief advocate since 1948. There was, however, no consensus within the GoI about which parts of the state should be given the right to vote, and the Pakistani government was not favourable at all. ${ }^{138}$ Bajpai brought up the idea once again in late 1949. ${ }^{139}$ The model he preferred was Azad Kashmir going to Pakistan, Jammu to India and a plebiscite to be held in the Vale of Kashmir. India neither 'want[ed] rule over bitter relentless minority in Azad Kashmir' nor did it want to 'face new shifts population', he told Bowles. ${ }^{140}$ Bajpai's plan was never discussed with Pakistan, but Owen Nixon and Frank Graham, appointed by the UN for solving the dispute, pursued similar ideas. They failed because India insisted on a complete withdrawal of Pakistani forces, whereas Pakistan did not want to give up the claim for a plebiscite over the whole state and did not trust India to allow a free vote. ${ }^{141}$ In 1952, Bajpai at least twice supported Graham, hoping he would extend his mission. ${ }^{142}$ Against his advice, the Cabinet Committee on Foreign Affairs turned down Graham's proposal to associate his mission with a plebiscite administrator. ${ }^{143}$ According to Bowles, Bajpai, in vain, hoped for nothing more than a solution of the conflict before his departure in late May 1952, and was growing increasingly disillusioned about his own government. In the last month of his term, he told Bowles that

again GOI had definitely not thought through its position as sharply and specifically as it sh[ou]ld, and that he had sent long detailed memo to Pri[me]Min[ister] . . . stating it essential GOI clarify own mind as to just what it w[ou]ld agree do on Kashmir and what it c[ou]ld not do. ${ }^{144}$

When Bajpai prepared for the Geneva talks in 1953, once more he felt disappointed about both the USG ${ }^{145}$ and his own government. In private, he informed Bowles that his suggestion to be more flexible with regard to the number of Azad Kashmir troops had been overruled: 'Discussions in Government India inevitably return to what Nehru and other Government India officials believe to be fundamental point, i.e., India's prior rights in Kashmir on basis of accession by Maharaja and acceptance by Viceroy'. Bajpai disagreed with this approach and, to no avail, warned that the ongoing stalemate stood in the way of economic development, political stability 
and military defence. Sheikh Mohammed Abdullah, the prime minister of Jammu and Kashmir, was under great pressure and would be happy with almost any solution. ${ }^{146}$

Like earlier, when facing a seemingly insolvable conflict, Bajpai did not stick to dogmatic positions. He did not consider emotions to be helpful in any way. The lesson learned until 1952 was that even if India was right in Kashmir, it would not get right. Since long, Bajpai had understood that insisting on legal positions did not necessarily win a case or help a compromise. He was after a sustainable solution. Azad Kashmir was lost, Jammu safe and the Vale worth the risk of a plebiscite. A compromise might have freed India from a conflict binding resources urgently needed elsewhere.

\section{Communism}

Differences of opinion went much deeper regarding the communist powers. While Nehru and Krishna Menon gave the USSR more than the benefit of the doubt, the cabinet and most IFS officers were staunchly anti-communist. As the professional he was, Bajpai did business with the Soviet ambassador, but his heart was not into it. With Australian High Commissioner Warwick Fielding Chipman, he confessed being

not worried so much by the economics of communism but my whole soul revolts against its totalitarianism. I find it difficult to be more than polite to the Russian and Chinese ambassadors. I am not a hypocrite. How can I converse with [Soviet Ambassador Kirill Vasilyevich] Novikov? ${ }^{147}$

Accordingly, Bajpai could be unusually straightforward with Novikov. In June 1948, he complained about the recent cooling of the Kremlin towards India and the treatment of Mrs Pandit. Foreign and domestic affairs not being related, it was the Gol's business to fight the CPI where it did not accept Indian laws. When Novikov criticised India's stand regarding Korea, the secretary-general emphasised that Delhi chose its position independently. ${ }^{148}$

He had used the same argument two months earlier. When requesting US arms, he had tried to convince acting Secretary of State Lovett against allegations of India being 'somehow "in the Russian camp"'. The country had not won independence to be dominated by foreign powers again. He and Nehru agreed that

two fundamental considerations prevented Indian adherence to the Soviet bloc. First, through its association with the British, unhappy as it had been in some aspects, India had acquired the ideals of democracy and individual liberty which were held by the US and other nations of the west. Second, India can expect no effective 
assistance from the USSR in its primary objective of developing and strengthening itself economically and militarily. In fact, the US is the only country which is in a position to aid India. ${ }^{149}$

Though both points were true, the statement might qualify as paying lip service to the West when deemed useful. They were, however, in line with numerous internal comments. For Bajpai, the USSR was a totalitarian state. A report about a revival of religions in the Soviet Union was rated by him 'as a concession to human nature which even the most autocratic state cannot afford to flout indefinitely'. ${ }^{150}$ In the summer of 1949, he agreed with a report by Rajeshwar Dayal on Sino-Soviet relations. Dayal held that the Kremlin typically did not put all eggs in one basket, playing friendly to the future rulers of China and at the same time taking care of a good amount of control. He expected Stalin to urge Mao Zedong into some action leading to an irrevocable break from the West, resulting in complete dependence on the USSR. ${ }^{151}$ K.P.S. Menon forwarded the analysis to Bajpai with the remark 'tallies with your own', the secretary-general approving Dayal's text as 'substantially sound'. ${ }^{152}$

The North Korean assault on the south (falsely) ${ }^{153}$ seemed to prove the assessments of Stalin's tactics. Bajpai believed to understand the latter's policy even without any detailed reports. 'From his knowledge of way Russians operate', he was sure that the USSR did its best to persuade Beijing to attack Taiwan. ${ }^{154}$ 'War between US and China which Russia now seemed to desire would strengthen Russia vis-à-vis US in Europe and elsewhere'. ${ }^{155}$ This clearly referred to Soviet strategy on the eve of the Second World War, when Stalin had hoped for a military escalation between fascism and capitalism, the USSR finally overwhelming the weakened winner. This time, China should probe western resistance. In Bowles' paraphrase, Bajpai believed that Moscow was 'well aware of US industrial power and the fact that USSR cannot win Third World War'. It might, however, 'allow or even encourage the Chi-Commies to embark on an aggressive program in which they themselves w[ou]ld not take a direct part unless later developments indicated the West's inability to cope with the conflagration which the Chi[nese] had started'. ${ }^{156}$ When the USSR returned to the UNSC after an absence of more than a year, Bajpai considered it a destructive force, ${ }^{157}$ and he was embarrassed when an Indian draft resolution created the wrong impression that Delhi supported Moscow's views. ${ }^{158}$

Bajpai was on the alert regarding the USSR, but the differences of opinion with Nehru and Krishna Menon did not surface, for Stalin was never interested in closer cooperation with India. Moreover, Moscow did not yet exercise much influence where Indian vital interests were concerned. It was a different story with the other communist great power, China, both for the intervention in the Korean War and even more for the occupation of Tibet. That the two Asian giants would to a certain extent rival each other was a 
natural assumption for Bajpai, sharing Nehru's vision of Indian leadership in Asia. ${ }^{159}$ When the communist victory in the civil war was beyond doubt, Bajpai with Henderson expressed moderate concern regarding the consequences. A communist China would strengthen communist forces all over Southeast Asia, but the GoI was confident to be able to keep the CPI under control as long as there was no considerable deterioration in economic conditions. Henderson found Nehru and Mountbatten even less alarmed. ${ }^{160}$

The note from Dayal of June 1949 had also summarised Indian expectations regarding future Sino-Soviet cooperation: Moscow had neither played any role in the communist victory nor trained the $\mathrm{CPCH}$ leaders. The Chinese were strongly nationalist and had always opposed the Russian drive eastwards. For being isolated and sharing Marxist ideology, communist China would seek close cooperation with the USSR; it would not, however, put all eggs in one basket. ${ }^{161}$ Delhi's pragmatic general position vis-à-vis the new government was quickly formulated. On 1 September 1949, Under Secretary S. Sinha found India not 'in the fortunate position of the USA to throw down the gauntlet'. ${ }^{162}$ Bajpai explained to the American embassy that the 'GOI could not look askance at regime merely because it was Communist'. Only acceptance of the regime would give 'more leeway to patriotic elements among Chinese communists, thus increasing chances of "an oriental Titoism"' ${ }^{163}$ In the eyes of Henderson, Bajpai accounted among what the ambassador considered a minority in the GoI understanding communists as 'irreconcilable enemies of non-communist world'. On the contrary, the ambassador suspected that Panikkar was hoping to 'obtain special position for self in China, and would like for India assume leadership in matter recognition'. ${ }^{164}$ Therefore, and correctly, he did not trust Bajpai's assurance that all decisions regarding China were taken in Delhi. ${ }^{165}$

After Delhi had announced its intention to recognise new China, Bajpai explained to Henderson that India could not remain behind other Asian countries. Waiting for the UK to take the lead would feed criticism that Delhi had no foreign policy of its own. Though nonaligned, India 'was in practice making more and more decisions "based on merit" in harmony with Western policy, particularly US policy, rather than with Soviet policy'. Delhi had no intention to appease China. ${ }^{166}$ After the Chinese intervention in Korea, Bajpai maintained with Henderson that notwithstanding Soviet pressure, Beijing was unlikely to attack Taiwan soon. ${ }^{167}$ In September 1950, he expressed confidence that China was both less dependent on the USSR and aggressive as commonly believed. ${ }^{168}$ Altogether, he pleaded for a rational assessment of communist China and a pragmatic approach.

Nobody in Delhi harboured any illusions about Beijing's will and capacity to re-establish control over Tibet. Since 1914, Lhasa by all practical means had been acting independently, but the British had always recognised Chinese suzerainty. By December 1949, the Tibetan government panicked about an invasion of the PLA and hoped for India to take over the defence 
of the country. ${ }^{169}$ In a meeting with K.P.S. Menon, Political Officer in Sikkim Harishwar Dayal and Panikkar, Nehru warned that

whether Tibet remains independent in the future will depend ultimately on the Tibetans themselves and on no one else. . . Nothing should be done which might appear to justify the untrue suggestions emanating from communist sources that in its dealings with Tibet India is merely acting as an instrument of the UK and the USA.

Regarding arms and ammunition, Lhasa should receive 'a little more than has been customary', but neither nature nor quantity should 'attract undue attention and so give the impression that the Govt. of India are actively encouraging the Tibetans to fight the Chinese'. ${ }^{170}$

After Nehru in November 1949 had talked vaguely of Chinese suzerainty 'how far it goes one does not know' - Donovan asked Bajpai whether India would prefer a continuation of the status quo; the latter consented. ${ }^{171}$ The very same day, he clarified his stand in an internal note:

We cannot and therefore should not attempt to help the Tibetan Government militarily in order to pick a quarrel and wage war against the communists. We cannot, however, give up the special relationship that we have had with Tibet. My provisional view is that this is one of the matters to be taken into account when we take up, with the Communist regime, the question of recognition. ${ }^{172}$

The last suggestion was never implemented; India recognised the People's Republic of China on 30 December 1949 without clarifying the status of Tibet or India's northern boundary.

Initially, the Korean War hardly altered the Indian perception of new China. In the UN, India refused military assistance for South Korea but supported the condemnation of North Korean aggression. ${ }^{173}$ In general, though, Delhi treated China cautiously. Bajpai refused to forward an American warning to Beijing to keep out of the war but ordered Panikkar to advise restraint; otherwise it would become difficult for India to support the admission of communist China to the UN. ${ }^{174}$ Once again, Panikkar disobeyed, arguing that such advice might be misunderstood: Unless the conflict transformed into a world war, the PRC would not intervene anyway. Once again, he came away enjoying subsequent support from Nehru. ${ }^{175}$

The picture changed with the invasion of Tibet on 6 October, followed by the Chinese military intervention in Korea on 25 October. In early August, Delhi had taken a strong stand, warning Beijing that an invasion of Tibet might be answered with a cessation of relations. ${ }^{176}$ Bajpai had believed that 
China would not resort to force but install a communist regime in Lhasa and integrate Tibet step by step. ${ }^{177}$ The invasion caused shockwaves in India. The GoI made strong representations to no avail, also because Panikkar deemed it best to tone them down. ${ }^{178}$ Bajpai prepared a memorandum for Nehru

in which he suggested with considerable heat that if it were true that China should now invade Tibet it should be regarded as sign of indifference of Indian sensibilities and lack of appreciation of India's efforts on China's behalf. After India had aroused irritation in US and other countries by supporting China with regard to Formosa, Korea and entrance into UN, and after it had conveyed to world China's insistence that China would intervene in Korea in case US forces should enter North Korea it would be ironical if China instead of intervening in Korea should now invade Tibet. ${ }^{179}$

The British high commission noted gloatingly that Delhi had a 'salutary experience'. ${ }^{180}$

On 21 October, Bajpai expressed deep indignation that Beijing had kept Delhi completely in the dark about its intentions in both Tibet and Korea. ${ }^{181}$ Ten days later, he confided into Henderson that 'he personally had almost arrived at opinion that Peiping was mere puppet of Moscow and represented grave danger Asian peace'. ${ }^{182}$ With Roberts, he blamed India's new neighbour as 'militaristic and aggressive nation whose friendliness would be open to considerable doubt'. ${ }^{183}$ Bajpai grew 'openly suspicious and cynical re[garding] Peiping. ${ }^{184}$

Behind closed doors, there was much more than disappointment. On 2 November, Rajagopalachari attacked Nehru's Tibet policy in the cabinet. The real challenge, nevertheless, came from Home Minister Sardar Vallabhbhai Patel, supported by the Director of the Intelligence Bureau B. N. Mullik and Bajpai. Patel's letter to Nehru, dated 7 November, spoke of Chinese delusion and claims to parts of northern India. Panikkar had been at great pains to justify Chinese policy and actions with 'lack of firmness and unnecessary apology in one or two representations'. The Chinese 'will disown all the stipulations which Tibet has entered into with us in the past' and had 'racial, national or historical claims' on the southern slopes of the Himalayas. India would need to defend two borders from now, one against a threat 'both communist and imperialist', inspired by the USSR. The new threat was external as well as internal, with the latter relating to the CPI. There was need for a proper threat assessment and an evaluation of defence needs, a redisposition of Indian forces to guard access routes and areas which might come under dispute. Patel urged for a whole set of political, military and administrative measures to strengthen the frontier areas. In a wider context, India's China policy should be reviewed, especially the support of admission 
to the UN. A reconsideration of Indian relations with Beijing, London, Moscow and Washington might be necessary. ${ }^{185}$

To a large extent, the letter was based on a note from Bajpai, dated 3 November. The secretary-general was disappointed about Nehru's response to the invasion. He told Roberts that the prime minister was 'less detached' and began 'to have considerable doubts about the honesty and friendliness of the Chinese Government'. ${ }^{186}$ This, however, was not enough in Bajpai's eyes. The note suggested a withdrawal of the missions in Tibet under protest. Keeping them might mean war, 'for which we are not prepared'. The GoI should clarify that India's frontier ran along the McMahon Line and prepare for the defence of it; furthermore, it would be well advised to join forces with Nepal and Burma, more vulnerable to a Chinese attack. While the GoI should no more advocate UN membership for Beijing, a cessation of diplomatic relations appeared unwise for the time being. ${ }^{187}$ With this note, Bajpai returned to an earlier discussion with Nehru and K.P.S. Menon in the summer of 1949. Both officials had emphasised the need to strengthen the frontier, while the prime minister saw no necessity at present, believing a Chinese occupation of Tibet 'remote' if a possibility at all. 'Any present thought being given to it will affect the balance we are trying to create in India. It may also not remain a secret and that would be unfortunate'. ${ }^{188}$

The renewed and more intense debate around India's China policy came to a sudden end with Patel's death on 15 December $1950 .{ }^{189}$ Shortly before, Bajpai in a conversation with Henderson had toyed with the idea of 'a neutral zone around areas in which China has particularly strong strategic and economic interests' ${ }^{190}$ Half a year later, with little credibility, he held that the old British policy of keeping Tibet as a buffer had never been adopted by independent India. Bajpai was, however, unhappy with the terms of the 17-Point Agreement for the Peaceful Liberation of Tibet of 23 May 1951, India being a helpless observer. Asked about the repercussions for India's position vis-à-vis Nepal, Bhutan, Burma, and Korea, he evasively replied that there had not been time yet to consider these matters. ${ }^{191}$

Internally, he held that

whether Chinese thinking is or is not independent, Chinese foreign policy is influenced by the USSR; it is not necessary that such an influence should be the result of the subservience of China to the USSR. The two countries regard the USA as a common enemy. Both are fundamentally communist, and politically, communism is expansionist.

Had the western powers recognised the PRC,

China could not have the excuse that their isolation from the West forced her into Soviet arms. Moreover, diplomatic contact with 
the West would ... undoubtedly have given a greater measure of real independence to Chinese thinking and, therefore, to Chinese policy. In our appraisal of international trends, it would be wise to assume that the USSR and China are more likely to cooperate than otherwise. ${ }^{192}$

Regarding the frontier with China, the Himmatsinghji Committee advised to develop the border areas and establish a large number of military posts. Patrols supported by radar installations should control the main passes. Administrative control was to be established in unpopulated areas of Ladakh. ${ }^{193}$ Bajpai hoped that the report would lead to a 'marked change in whole aspect Ind[ian] policy border areas' within two years. ${ }^{194}$ Nevertheless, he held it 'quite possible that Chi[na] might embark on irresponsible campaign of aggression', though lacking immediate Soviet support. ${ }^{195}$ It fits that in October 1950 - without Nehru's knowledge - Bajpai approached Burmese Foreign Minister U Sao Hkun Hkio suggesting 'that in view of the developments in Tibet, the question of some mutual defence agreement between India and Burma may be considered'. ${ }^{196}$ On the contrary, the prime minister believed that there was

no urge for the Chinese to go to war with a neighbouring country unless that country deliberately joined a power which is hostile to China. It is doubtful whether, if war is extended to Burma, even America would be able to do much to help Burma.

Rangoon should accept the Chinese occupation of Tibet. ${ }^{197}$

What Bajpai thought about trying to prevent an attack by a power just having given proof of aggressive expansionism by disarming oneself is documented in efforts to formulate an Indian policy vis-à-vis Japan and the San Francisco Peace Treaty of 8 September 1951. Two years earlier, P. A. Menon had analysed Indian interests in East Asia with Moscow building up North Korea as a communist stronghold, Washington trying to transform Japan into an ally: India welcomed a strong Japanese economy and saw its

aims in general ... at present more in line with that of the USA than of the USSR. We wish to see a strong and united China, an independent Korea and a Japan restored to an honourable place among sovereign nations. ${ }^{198}$

Bajpai, likewise, favoured a stronger role of Japan as a stabilising factor in Asia and, therefore, implicitly welcomed the US military presence. ${ }^{199}$ With the Permanent Under Secretary in the British Foreign Office William Strang, Bajpai specified that India could not accept defence provisions to be made part of a peace treaty. It would be a different story, however, if after the 
conclusion of a non-restrictive treaty, Japan at his own request entered a defence agreement with the US. Bajpai mentioned differences with Nehru, who 'felt that Japan's security could best be ensured by disarming'. Once again, the secretary-general 'had pointed out to Pandit Nehru that there was such a thing as tempting providence'. ${ }^{200}$ When the negotiations around the peace treaty were completed, the GoI found fault in not including the PRC and the USSR among the signatories. Whereas Bajpai advised to sign under protest, Nehru and the cabinet refused to be part of the treaty at all. ${ }^{201}$ The secretary-general believed that Nehru's actual reason for this decision was that he wanted to avoid any impression that India might support US bases in Japan or nearby. ${ }^{202}$

\section{K.P.S. Menon}

While Bajpai was a highly relevant factor in shaping foreign policy since 1947, the foreign secretary, as far as the sources permit an assessment, remained almost invisible. The UN Commission on Korea for a long while was the last occasion when K.P.S. Menon, still ambassador in Nanking, appeared in the limelight. From 12 January to 14 February 1948, he functioned as chairman. To his deep frustration, he experienced how the Cold War blocs neutralised each other, the commission being refused entry into North Korea. In response, he chose a position favouring the US. Part of it was tactics, namely, the hope that they 'will now see our point of view about Kashmir even as we have gone out of our way to see theirs over Korea'. Typically for an ICS officer, he also stood against totalitarianism:

The Soviet government seem determined to set up a communist state in North Korea as they have done in Czechoslovakia; and it seemed hard to deny South Korea, which contains two-thirds of the population of Korea, the right to have a national government. The important thing now is to see that the elections are really free. ${ }^{203}$

The GoI, however, held

that a government based on elections in South Korea only cannot be recognised as the government of the whole of Korea. To do so, or even to recognise it as the government of South Korea, would be to perpetuate and harden the division of Korea. ${ }^{204}$

As foreign secretary, Menon advised against a continuation of the UN commission, instead suggesting mere observers. He was overruled by Bajpai, giving in to US representations though 'we still felt that a single commissioner would operate more effectively'. ${ }^{205}$ After the outbreak of the war, Menon saw himself confirmed regarding the uselessness of the commission. 
He felt, however, unable to give guidance how to handle the matter at the 1950 session of the UNGA. ${ }^{206}$ Both the secretary-general and the foreign secretary opposed a western proposal for an embargo against the PRC. Bajpai warned against another world war, ${ }^{207}$ while Menon emphasised India's need of exporting jute and food grains to China. Like Nehru, he counted on establishing amicable relations with Beijing. ${ }^{208}$

Only too naturally, Nehru regularly consulted Menon on matters related to China and Tibet, the latter's guidance mostly unknown. ${ }^{209}$ Like his superiors, he considered the recognition of the PRC as inevitable; ${ }^{210}$ he also advised the US against admitting Tibet to the UN as this 'might provoke earlier action by Chinese Communists' ${ }^{211}$ Moreover, he harboured no illusions that the new government in Beijing would prosecute the claims regarding the southern slopes of the Himalayas 'with vigour, whenever they get an opportunity'. ${ }^{212}$ Obviously, he thought in longer terms. Even after the PLA had launched its attack, he "discounted as mainly "for record" recent public statements from Peking about "liberation" of Tibet'. ${ }^{213}$ Henderson even blamed the foreign secretary for sharing Panikkar's views on China. ${ }^{214}$ If true, this changed when reports of the Chinese invasion were confirmed. Menon 'expressed himself in strong terms'215 and complained with Roberts that Panikkar had played a poor part, his representations 'a good deal weaker than the Indian Government had intended'. Therefore, Menon himself took the matter up with the Chinese ambassador, urging for a peaceful solution. Like Bajpai had suggested earlier, he threw in a possible withdrawal of Delhi's support for UN membership. ${ }^{216}$ Like Bajpai again, Menon from that point lost confidence in Panikkar, one week looking 'at the brighter side of things' and the next writing about repression, executions and crisis. ${ }^{217}$

In the ministry, Menon was mostly responsible for personnel and administration, ${ }^{218}$ his colleague Dutt blaming him for favouritism. ${ }^{219}$ There were jokes about an epidemic of 'Menongitis' in the MEA, referring to the large number of officers with that surname. The latter was coincidence, as most of the Menons had joined the civil service in the colonial period. Tyabji, however, maintained that the foreign secretary preferred to recruit new officers from his home state Kerala and conversed with them in Malayalam, thus excluding others. ${ }^{220}$ Menon in return disliked Tyabji's 'pontifical tone'. ${ }^{221}$

The foreign secretary's subordinate role once again became marked in 1949, when the MEA discussed whether to recognise the two newly established German states. ${ }^{222}$ Although the issue stood rather high on the list of burning questions of the early Cold War, neither Nehru nor Krishna Menon gave any guidelines. Independent India had taken over a military mission in Berlin, established for reasons of prestige, ensuring India's share of reparations, recruiting experts, and locating Indian nationals. From 1948, Delhi had concluded trade agreements with western occupation zones, whereas the Soviet zone showed no interest. The enactment of the West German 
constitution in May 1949 did not bother anyone in Delhi. Soon, however, the Allied High Commission as the highest authority in West Germany asked the military mission to open an office in Bonn, the new seat of government, where a parliament would be constituted in September. Head of Mission Khub Chand advised to follow suit, what de facto meant recognising the Federal Republic of Germany. His arguments were commercial interests with West Germany and American goodwill. The mission in Berlin was to continue for contacts with the USSR and as a proof that India was no American stooge..$^{223}$ This was in line with Bajpai's views. ${ }^{224}$

Only after the Soviets in October established the German Democratic Republic, there took place a short-lived debate in the MEA around the quality of sovereignty of both Germanies and which stand India should take. Once again, Khub Chand won the day, arguing that

all the logic and all the loyalty to principles in the world will defeat their own ends if the country goes under. We are deeply interested in financial and technical assistance from the United States; otherwise we run the risk in ten or fifteen years of an internal revolution fed on hunger and distress. We must not, therefore, turn Congress and private American businessmen from the task of Indian reconstruction by premature and ill-considered political moves in Europe. ${ }^{225}$

K.P.S. Menon disagreed, holding that India had

not been exactly logical in recognizing the West German Government, set up under the Allied High Commission, while refusing to recognize the South Korean Government, which has been set up under the aegis of the United Nations. We do not want to commit a further illogicality by recognising the West German Government and refusing to recognise the Government of East Germany. ${ }^{226}$

'If recognition is asked for', India should accept. ${ }^{227}$ Until 1951, neither did Moscow or East Berlin ask for nor did anyone care for Menon's objections. In 1952, Bajpai let West German diplomats know that India's one-sided stand might end with his term. ${ }^{228}$ This did not relate to Menon, who was transferred to Moscow.

\section{Subimal Dutt}

Though holding the same rank as K.P.S. Menon, Subimal Dutt understood himself as number three in the MEA hierarchy. According to his memoirs, the Commonwealth Wing was 'generally regarded as a poor relation in a big family', ${ }^{229}$ its secretary busy mostly with 'humdrum' work. ${ }^{230}$ To some extent, this part of the ministry continued interwar policy regarding Indians 
overseas, which quickly lost relevance in Indian foreign affairs as a whole..$^{231}$ Bajpai had called Dutt back to Delhi rather as an able administrator to keep his back free: the secretary-general shouldered the tasks of a foreign minister, and the foreign secretary was known for his dislike for deskwork.

Accordingly, Dutt established office routines. ${ }^{232} \mathrm{He}$ proved a rather strict headmaster, going into petty details like the language to be used in internal communication. The tone of his circulars was brusquer than that of K.P.S. Menon. ${ }^{233}$ Strictly following office orders gave Dutt a feeling of security vis-à-vis Nehru, whom he considered belonging to a sphere to which he had no access. He felt so insecure that as late as 1951, he cancelled a vacation at the seashore because he mistook a humorous remark by Nehru. Instead, he visited Kashmir, believing that the prime minister wanted him to gather some first-hand impression. ${ }^{234}$ Nevertheless, he stood his ground when he was fiercely criticised for his evaluation of the London high commission. In Dutt's eyes, Nehru had 'unjustly judged an innocent worker of his' for saving 'his devotee' Krishna Menon. The civil service would be ruined if the country was guided like this: 'Maybe he [Nehru] will be triumphant in the field of world politics, but what about the administrative machine?' Dutt was ready to resign, but not to 'fold my hands to tell him that I have made a mistake and want forgiveness. I will tell him that I have written what I thought to be true and justified'. ${ }^{235}$

Dutt erroneously believed that neither his stubbornness nor his role as headmaster, his tone or his reserved manner earned him any friends in the MEA. Indeed, for his East Bengal features, he was nicknamed General Tojo after the Japanese prime minister during the world war. This referred to his reserve, but it also indicated respect and sympathy. ${ }^{236}$ Furthermore, Bajpai was not alone in understanding Dutt's usefulness. In those years, M.O. Mathai was the second-most powerful man in Delhi. Though a stenographer, he had risen to be head of Nehru's office, and only half-jokingly styled himself the deputy prime minister: everything Nehru came to see passed over Mathai's desk. ${ }^{237} \mathrm{He}$ became Dutt's second mentor, pushing for his appointment as foreign secretary in $1955 .{ }^{238}$ Nehru himself, finally, came to appreciate the commonwealth secretary's straightforwardness, work discipline and impartiality.

Dutt soon became more than a mere administrator. Among his tasks was the recovery of women and children abducted around partition. In the context of the mass migration in the summer of 1947 , family members had lost each other: male relatives had been murdered; women had been forced to marry men of the majority communities, were kept as hostages, or were raped. Already in the autumn of 1947, Delhi and Karachi agreed to cooperate to help the victims and chose Mridula Sarubhai as chief social worker. Dutt was the MEA official to support her. Mrs Sarubhai worked tirelessly and with tremendous success, but her unorthodox manner was prone to drive Nehru mad. For a bureaucrat like Dutt, she should have been a sheer 
nightmare, but the commonwealth secretary developed a soft spot for Mrs Sarubhai and managed the unmanageable so well that she asked Nehru for Dutt's renewed support when the latter returned from his first posting abroad in 1954. ${ }^{239}$

Together with Bajpai, the commonwealth secretary was also the one to conduct Indo-Pakistani talks. ${ }^{240}$ It was useful that, owing to his term as secretary for agriculture in Bengal, he was well acquainted with numerous Muslim League politicians and on good terms with then Premier Huseyn Shaheed Suhrawardy. ${ }^{241}$ Dutt was part of delegations to interdominion conferences, discussing financial issues, among others. When in August 1949 Nehru suggested a no-war declaration, there was agreement on first solving disputes on water, evacuee property and Pakistani assets with the Reserve Bank of India. Bajpai, however, turned down Pakistani demands to include the territorial debates around Junagadh and Kashmir; he considered the first a closed chapter, the second in the hands of the UNSC. For once, Dutt's skills as analyst surfaced, much in line with Bajpai:

It is likely that the Pakistan Government will not subscribe to the proposed declaration. If they reject the approach, the blame will be theirs and ground will then be cut from under their feet in so far as their constant propaganda in other countries about the bellicose intentions of the Government of India is concerned. To that extent some advantage may be gained from this approach to Pakistan even if it is to end in failure..$^{242}$

That Dutt, always keeping in the background, had a sense for public diplomacy can be seen when he, together with K.P.S. Menon, pushed for the creation of a post of a public relations officer to counter Pakistani propaganda. ${ }^{243}$ The commonwealth secretary also played an important role in resolving the Bengal crisis from early 1950. Rumours of police action against Hindus in Khulna District in East Pakistan had led to a mass exodus into Indian West Bengal, where anti-Muslim sentiments resulted in the murder of 72 Muslims in Calcutta. This triggered a vicious cycle of retaliation in both parts of Bengal. ${ }^{244}$ The Nehru-Liaquat or Bengal Pact of 8 April 1950 calmed down hostility in the east of the subcontinent. The pact ruled property issues and the safe return of refugees and abducted women. It also confirmed minority rights in both parts of Bengal. Representatives of the minorities were to be included in provincial governments, and commissions were meant to look into the effects. Shortly thereafter, Nehru mentioned that Dutt 'has been specially in charge of this Bengal problem and the agreement and what flows from it'. ${ }^{245}$ He went on relying on the commonwealth secretary's expertise on Bengal thereafter. ${ }^{246}$

In this context, Dutt also came in touch with Patel, whom he accompanied to Calcutta in mid-April. ${ }^{247}$ The home minister made use of Dutt's 
acquaintance with Shyama Prasad Mukherjee, to whom after the Direct Action Day of 16 August 1946 the then secretary for agriculture had leaked classified papers. Dutt had felt that while the Muslim League government in Bengal encouraged Muslim communalists, it was his duty to his own community to provide 'the acknowledged champion of Hindu interests in Bengal' with material helping to protect what he considered legitimate rights and demands of Hindus. ${ }^{248}$ Mukherjee criticised the Bengal Pact for not blaming Pakistan to have caused the unrest. Furthermore, he wanted an exchange of minorities. When Nehru refused, Mukherjee and the second Bengali minister in the cabinet, K.C. Neogy, resigned. Patel, sympathising with their claims, asked the commonwealth secretary to convince Mukherjee that if he wanted to help the case of Hindus, he would better remain in the cabinet. Dutt's mission failed, but he kept busy with Indo-Pakistani problems. In February 1951 he visited the Punjab, among others reporting on the tensions between Sikhs and Harijans on language issues. ${ }^{249}$ In 1952, he was involved in the dispute around the sharing of the canal waters in the north-west of the subcontinent. ${ }^{250}$

Regarding issues within the Commonwealth, Bajpai usually gave directions on important issues. ${ }^{251}$ Dutt's views surfaced only in the absence of the secretary-general. In 1949, when trilateral talks between India, Pakistan and South Africa were prepared, the question of lifting the trade embargo was discussed, which had been imposed by both Delhi and Karachi. Nehru decided against such a step. While he and Bajpai visited the US, for once it was Dutt giving directions:

My own personal view is that having fought S[outh] A[frica] for the last three years and reached a crucial stage in the negotiations with them, we should not do anything which will create the impression that their unbending attitude is making us yield and this I say despite our quarrel with Pakistan. ${ }^{252}$

This comment reads like Bajpai's school, and the same was true for a remark on Vietnam. Consul General F. M. de Mello Kamath, based in Hanoi, held that Ho Chi Minh could not be interested in 'mixing up his people in communist adventures'. Dutt commented that 'having regard to Ho Chi Minh's past and present relations with Russia, this seems a facile assumption'.253

\section{Conclusion}

Indian foreign policy over its first five years near exclusively kept busy with its immediate neighbourhood. Otherwise, it was rather uneventful. India was mostly an observer of the Cold War and, with nonalignment but a non-policy, found it difficult to position itself on the global stage. The issues of Indians overseas and the British Commonwealth soon lost relevance. 
Nevertheless, the stage was set for an essential change. British India had been safe behind the Himalayas and buffer states toward the north. The failed joint attack of Japanese and INA forces in 1944 had shown that the subcontinent could hardly be threatened from the east as well. Partition and the Kashmir War made established colonial security policy obsolete. Unlike British India, the Indian Union faced a determined enemy within the confines of the subcontinent. The Kashmir dispute also took care that India became an object of great power politics. To Delhi's embarrassment, London and Washington did not support what Nehru considered a just case but pursued their own global interests not in line with India's. This resulted in mutual disappointment.

With the communist victory in China and the Chinese occupation of Tibet, a potential powerful threat to the northern boundary came into the equation as well. Nehru's assumption that disarmament and demonstrations of friendship was the best defence policy vis-à-vis new China was not shared by many in the cabinet and the MEA. As a matter of fact, by 1952 India stood alone against two neighbours whose intentions were considered hostile. The Indian Army was strong enough to keep Pakistan at bay but not the PLA. Asian solidarity, celebrated at the Asian Relations Conference in Delhi in March and April 1947, was mostly a hollow phrase, not bolstering up India's political, let alone military strength. In years when both superpowers knew but friends and foes, nonalignment had left India without any influential partners.

Nehru's and Krishna Menon's pride made them confident that new India could stand on its own feet. Even asking for urgently needed food aid appeared beneath them. On the contrary, Bajpai did not consider pride too helpful in external affairs. In late 1945, he had concluded his assessment of a foreign policy of independent India with the remark that 'sentiment must serve, not master the national interest'. ${ }^{254}$ The seasoned expert he was, the secretary-general's approach to foreign affairs remained realistic and pragmatic. He based his assessments on reliable facts and preferred Otto von Bismarck's credo that politics are the art of the possible over Nehru's tendency to base visions on a world how he would like it to be. Therefore, more and more, he considered the prime minister's Kashmir policy too dogmatic and emotional. Bajpai was after a sustainable solution freeing resources needed elsewhere, not after being right. Furthermore, like many others in the IFS, he was fully aware that notwithstanding differences regarding Kashmir and numerous other issues, India was in dire need of western and especially US support. No admirer of American policy at all, therefore, he tried to balance Nehru's and Krishna Menon's anti-American reflexes with gestures of confidence. Unfortunately, Washington paid Bajpai back rather poorly.

Though there was nothing of this in Nehru's Kashmir policy, the prime minister advised other countries that disarmament was the best means to prevent an attack. Bajpai considered this quixotic, especially when it was 
about China and the USSR. Like everyone else in the GoI, the secretarygeneral despised communism for being totalitarian. Unlike the prime minister, however, he also believed it inevitably expansionist. This aspect of Bajpai's anti-communism was not based on his reading of communist theory but on historical experience. His assessment of Soviet foreign policy clearly related to the Hitler-Stalin Pact, the de facto annexation of Eastern Europe, the attempt to conquer the Korean peninsula and, finally, Tibet. Accordingly, Bajpai urged a change of India's China policy toward utmost caution, preparedness to defend the border militarily and a quid quo pro diplomacy: In return for the recognition of communist China or the closure of Indian missions in Tibet, India should demand a guarantee for its northern border. In his eyes, it did not matter much whether Beijing's foreign policy was rather communist or nationalist - it was threatening India. Nehru did not want to hear of this, and after Patel's death, Bajpai lacked allies to do more than alert those who were willing to listen.

The 'Bajpai years' established patterns in Indian foreign affairs valid until 1962. First, there was a latent but intense clash of realism versus idealism or naivety. The mostly British trained apparatus stood for the former, Nehru, Krishna Menon and some of the career changers in the IFS for the latter. To some extent, this clash was one between British-trained professional diplomats and politicians rooted in a civil rights movement. The former stood for practical solutions and compromises, the latter for rightfulness and idealism with a tendency to be unrelenting. Second, India became a country to speak with contradicting voices. Those heads of missions abroad who exercised most influence on Nehru tended to ignore the MEA. The fact that Panikkar came away with ignoring instructions at critical junctures not only was to the detriment of India but also indicated that Indian foreign affairs could be prone to anarchy. Too often Nehru felt bound by personal friendship rather than by the obligation to steer the country.

Bajpai let his views be known but altogether failed to have them implemented. He played an important role in Kashmir affairs, but his advice for a change of course went unheard. The same is true for India's China policy. His attempts to improve Indo-US relations did not bear fruit either. Unlike in the colonial period, the dissent between him and his bosses on crucial issues went too deep. On the one hand, Bajpai, though doing his best, suffered the fate of an experienced official working under a much less experienced political leader with a mind of his own. On the other hand, he failed to win allies for a change of course. Admittedly, this was hardly his fault. With emotions running high around the Kashmir conflict, nothing could be done. The China policy might have turned out a different story had not Patel died. Nevertheless, it appears that Bajpai was too much a civil servant to search allies among India's politicians. The liberals he had been working with in the interwar period had disappeared into oblivion, and he never won or cared to win a lobby among Congress politicians. Playing the game of 
exercising pressure on the prime minister via members of parliament or the cabinet Bajpai apparently tried but once.

The secretary-general left the MEA at a moment when he was convinced that India needed to prepare for a problematic future. Given his dissent with Nehru on crucial issues, it must come as a surprise how little he cared about his succession. N. R. Pillai neither commanded much experience in foreign affairs nor did he have any particular standing in the 'ICS brotherhood'. K.P.S. Menon had no will to rule the MEA and soon gladly left for Moscow. The new Foreign Secretary Ratan Kumar Nehru had as little backbone as Pillai when it was about standing up to Jawaharlal Nehru. Dutt, finally, who had done well and much better than most had expected, was transferred to Bonn, a posting of little relevance. Possibly, Bajpai hoped that the resulting vacuum of expertise and power in the MEA would quickly smooth his way back to Delhi. In the meantime, he would remain a sort of informal secretary-general. If this was his plan, his health put a spoke in his wheel.

\section{Notes}

1 Selected Works of Jawaharlal Nehru, vol. 9, Second Series, New Delhi: Jawaharlal Nehru Memorial Fund, p. 398. Letter, Nehru to Keskar, 14 February 1949.

2 SWJN2, vol. 7, pp. 684-686. Letter, Nehru to Pandit, 3 August 1948.

3 Ibid., pp. 686-688. Letter, Nehru to Krishna Menon, 4 August 1948.

4 SWJN2, vol. 8, p. 300. Note to Cabinet Members, Nehru, 6 November 1948.

5 Ibid., pp. 214-215. Letter, Nehru to Devadas Gandhi, 6 December 1948.

6 SWJN2, vol. 12, p. 331. Letter, Nehru to Bajpai, 3 July 1949.

7 Ibid., p. 465. Letter, Nehru to Krishna Menon, 12 August 1949.

8 SWJN2, vol. 4, p. 584. Letter, Nehru to K.P.S. Menon, 12 October 1947.

9 Sarvepalli Gopal, Nehru: A Biography, vol. 2, New Delhi: Oxford University Press, 1980, pp. 85-86.

10 SWJN2, vol. 14/I, pp. 138-139. Letter, Nehru to Bajpai, 21 March 1950.

11 SWJN2, vol. 16/II, p. 245. Letter, Nehru to Sheikh Abdullah, 18 August 1951.

12 Dutt Diary 8, 5 December 1955.

13 Dutt Diary 6, 22 February 1953.

14 Dutt Diary 6, 22 February 1953.

15 Foreign Relations of the United States, Washington, DC: Government Printing Office, 1953-1954, vol. III, doc. 189. Telegram, Bowles to DoS, 17 November 1952.

16 Badr-ud-din Tyabji, Memoirs of an Egoist, vol. 1, 1907 to 1956, New Delhi: Roli Books, 1988, p. 257.

17 Yezdezard Dinshaw Gundevia, Outside the Archives, Hyderabad: Sangam Books, 1984, p. 24.

18 Amit Das Gupta, Serving India. A Political Biography of Subimal Dutt (19031992), India's Longest Serving Foreign Secretary, New Delhi: Manohar, 2017, pp. $118-119$.

19 Ibid., p. 196.

20 Ibid., pp. 139-143.

21 MEAA, 14(21)-IA/51. Minutes 2nd Meeting, Tyabji, 28 February 1951.

22 MEAA, 565-IANZ/51. Note, Bajpai, 27 March 1951. 
23 Vineet Thakur, Postscripts on Independence. Foreign Policy Ideas, Identity and Institutions in India and South Africa, New Delhi: Oxford University Press, 2018, pp. 159-160.

24 SWJN2, vol. 15/II, pp. 577-578. Note, Nehru, 26 October 1950.

25 Andreas Hilger, Sowjetisch-indische Beziehungen 1941-1966. Imperiale Agenda und nationale Identität in der Ära von Dekolonisierung und Kaltem Krieg, Vienna: Böhlau, 2018, p. 123.

26 FRUS, 1947, vol. VI, doc. 788. Telegram, Grady to DoS, 23 July 1947.

27 NAUK, DO, 35/2912. Report, Canadian Embassy Moscow, 37, J. W. Holmes, 21 January 1948.

28 NAI, MEA, 20(11)-EUR/48. Note, Bajpai, 25 June 1948.

29 NMML, VLPP, 1st instalment, SF 55. Letter, Pandit to Bajpai, 10 July 1948.

30 NMML, VLPP, 1st instalment, SF 55. Letter, Bajpai to Pandit, 22 July 1948.

31 NAUK, FO, 371/66320. Report, British Embassy Moscow, Roberts, 12 September 1947.

32 NMML, VLPP, 1st instalment, SF 57. Letter, Pandit to Nehru, 11 February 1948.

33 NAUK, DO, 35/2912. Note, Dominions Office, 18 February 1948.

34 NAUK, DO, 35/2912. Report, British Embassy Moscow, 5 February 1948.

35 Rakesh Ankit, 'India-USSR, 1946-1949. A False Start?', in Madhavan Palat (ed.), India and the World in the First Half of the Twentieth Century, New Delhi: Routledge, 2018, pp. 172-173.

36 NAUK, FO, 371/66320. Report, British Embassy Moscow, Roberts, 12 September 1947.

37 NAUK, FO, 371/66320. Report, British Embassy Moscow, Roberts, 12 September 1947; Report, Canadian Embassy Moscow, Holmes, 21 January 1948.

38 NMML, VLPP, 1st instalment, SF 57. Letter, Pandit to Nehru, 11 February 1948.

39 NMML, VLPP, 1st instalment, SF 55. Letter, Pandit to Bajpai, 5 February 1948.

40 NMML, VLPP, 1st instalment, SF 55. Letter, Pandit to Bajpai, 14 August 1950.

41 NMML, VLPP, 1st instalment, SF 55. Letter, Pandit to Bajpai, 9 October 1947.

42 NMML, VLPP, 1st instalment, SF 55. Letter, Pandit to Bajpai, 9 October 1947.

43 NMML, VLPP, 1st instalment, SF 55. Letter, Pandit to Bajpai, 6 May 1949.

44 NMML, VLPP, 1st instalment, SF 55. Letter, Pandit to Bajpai, 5 February 1948.

45 NMML, VLPP, 1st instalment, SF 55. Letter, Pandit to Bajpai, 9 October 1947.

46 NMML, VLPP, 1st instalment, SF 55. Letter, Pandit to Bajpai, 9 January 1950.

47 NMML, VLPP, 1st instalment, SF 57. Letter, Pandit to Nehru, 11 February 1948.

48 Hilger, Sowjetisch-indische Beziehungen, p. 122.

49 NMML, VLPP, 1st instalment, SF 55. Letter, Pandit to Nehru, 1 May 1951.

50 Das Gupta, Serving India, p. 130.

51 Dutt Diary 8, 12 November 1954.

52 Hilger, Sowjetisch-indische Beziehungen, p. 123.

53 NAI, MEA, 1(68)-EUR/II. Letter, K.P.S. Menon to R. Dayal, 21 June 1949.

54 NMML, VLPP, 1st instalment, SF 55. Letter, Bajpai to Pandit, 9 September 1949.

55 https://digitalarchive.wilsoncenter.org/document/119261 [accessed 4 October 2018]. Telegram, Radhakrishnan to K.P.S. Menon, 14 January 1950.

56 Gopal, Nehru, vol. 2, 1980, p. 64.

57 FRUS, 1950, vol. VII, doc. 203. Telegram, Henderson, 3 July 1950.

58 Hilger, Sowjetisch-indische Beziehungen, p. 124.

59 FRUS, 1949, VI, doc. 1202. Telegram, Henderson, 29 July 1949.

60 Quoted after Paul McGarr, “A Serious Menace to Security”: British Intelligence, V.K. Krishna Menon and the Indian High Commission in London, 1947-52', Journal of Imperial and Commonwealth History, 2010, 38(3): 442.

61 NAUK, FO, 371/63320. Letter, India House to R.M.A. Hankey, Foreign Office, 31 December 1946. 
62 McGarr, “"A Serious Menace to Security”, 447-448.

63 Ibid., pp. 448-449.

64 Ibid., pp. 456-457.

65 Ibid., p. 461.

66 NAUK, FO, 371/63562. Letter, High Commissioner Terence Shone to R.H.S. Allen, Foreign Office, 13 August 1947.

67 For the US, see Dennis Kux, Estranged Democracies. India and the United States 1941-1991, New Delhi: Sage, 1993, p. 128; the West German press called him 'Nehru's Mephisto', Handelsblatt, 20 December 1961.

68 NAI, MEA, 15-58/48-O.S. IV. Telegramme 3798, EAD to SSI, 17 May 1947.

69 NAI, MEA, 8(8)-EUR/47. Press Communiqué, 24 December 1948.

70 Thakur, Postscripts on Independence, p. 160.

71 NAI, MEA, 13-EUR/47. Letter, Krishna Menon to Bajpai, 4 February 1948.

72 NAI, MEA, 13-EUR/47. Telegram, Bajpai to Krishna Menon, 10 February 1948.

73 NMML, VLPP, 1st instalment, SF 55. Letter, Pandit to Bajpai, 10 July 1948.

74 NMML, VLPP, 1st instalment, SF 55. Letter, Pandit to Bajpai, 6 May 1959.

75 Das Gupta, Serving India, pp. 124-131.

76 SWJN2, vol. 10, p. 25. Letter, Nehru to Krishna Menon, 21 March 1949.

77 Dutt Diary 8, 5 December 1954.

78 Dutt Diary 4a, 4 July 1949.

79 Gopal, Nehru, vol. 2, pp. 140-141.

80 NAI, MEA, 7-27-1/49-UK. Report, Dutt, undated.

81 Thayil Jacob Sony George, Krishna Menon, London: Cape, 1964, pp. 156-157.

82 Subimal Dutt, Autobiography, unpublished, 1984, p. 92.

83 Tyabji, Memoirs of an Egoist, pp. 255-256.

84 Steven A. Hoffmann, India and the China Crisis, Berkeley: University of California Press, 1990 , p. 33.

85 NAI, MEA, 611-C.A./49. Telegram 65, Panikkar, 8 February 1949.

86 NAI, MEA, 611-C.A./49. Telegram 154, Panikkar, 11 May 1949.

87 NAI, MEA, 611-C.A./49. Telegram 177, Panikkar, 2 June 1949.

88 NAI, MEA, 611-C.A./49. Telegram 185, Panikkar, 10 June 1949.

89 NAI, MEA, 611-C.A./49. Telegram 24727, MEA to Panikkar, 3 June 1949.

90 NAI, MEA, 611-C.A./49. Telegram 263, Panikkar to Nehru, 10 August 1949.

91 NAI, MEA, 611-C.A./49. Telegram 294, Panikkar, 13 September 1949.

92 NAI, MEA, 611-C.A./49. Minutes, Chief of Staff Committee, 9 November 1949.

93 NAUK, FO, 371/84456. Telegram 2995, Roberts to CRO, 26 October 1950.

94 Notes, Bajpai, 27 and 31 October 1950. Quoted after Gopal, Nehru, vol. 2, p. 107.

95 FRUS, 1950, VII, doc. 613. Telegram, Henderson to DoS, 5 October 1950.

96 SWJN2, 15/II, 342-346. Note, Nehru, 18 November 1950.

97 FRUS, 1951, VI/II, 2186-91. Telegram, Bowles to McGhee, 7 November 1951.

98 NAU, DO, 142/468. Letter, Fry to Donaldson, 22 December 1947.

99 Srinath Raghavan, War and Peace in Modern India. A Strategic History of the Nehru Years, Ranikhet: Permanent Black, 2010, pp. 235-237.

100 Hoffmann, India and the China Crisis, p. 33.

101 Gopal, Nehru, vol. 2, pp. 178-179.

102 Raghavan, War and Peace in Modern India, pp. 238-239.

103 Das Gupta, Serving India, p. 234.

104 For example, Report on Poland, 9 August 1956. MEAA, 21(12)-EUR/56.

105 Gopal, Nehru, vol. 1, pp. 100-106.

106 Harald Fischer-Tiné, Shyamii Krishnavarma. Sanskrit, Sociology and AntiImperialism, New Delhi: Routledge, 2014, pp. 91-93. 
107 Harish Kapur, Foreign Policies of India's Prime Ministers, New Delhi: Lancer, 2009, p. 27.

108 Gundevia, Outside the Archives, pp. 89-90.

109 For example, FRUS, 1952-1954, vol. XI/2, doc. 751. Telegram, Bowles to DoS, 17 November 1952.

110 FRUS, 1950, vol. VI, doc. 377. Report, Henderson, 30 December 1950.

111 FRUS, 1951, vol. VI/2, doc. 104. Memorandum, John Frick Root, 14 February 1951.

112 FRUS, 1952-1954, vol. XI/2, doc. 1009. Telegram, Taylor, 26 May 1952.

113 NAI, MEA, 722-C.J.K./49. Note, S. Sinha, 5 September 1949.

114 FRUS, 1950, vol. VI, doc. 377. Report, Henderson, 30 December 1950.

115 Lorna Lloyd, “"A Most Auspicious Beginning”: The 1946 United Nations General Assembly and the Question of Treatment of Indians in South Africa', Review of International Studies, April 1990, 16(2): 152.

116 Ibid., p. 149.

117 NAI, MEA, 2(19)-UNOI/47.

118 Gundevia, Outside the Archives, p. 66.

119 MEAA, 21-9/50-AFRI/I. Telegram, Bajpai to Kunzru, 9 February 1950.

120 Das Gupta, Serving India, pp. 115-118.

121 FRUS, 1951, vol. VI/2, doc. 468. Telegram, Henderson to DoS, 4 May 1951.

122 FRUS, 1951, vol. VII/1, doc. 108. Telegram, Henderson to DoS, 27 January 1951.

123 Howard B. Schaffer, The Limits of Influence. America's Role in Kashmir, Washington, DC: Brookings Institution Press, 2009, p. 25.

124 FRUS, 1952-1954, vol. III, doc. 189. Telegram, Bowles to DoS, 17 November 1952.

125 FRUS, 1950, vol. VII, doc. 286. Telegram, Henderson to DoS, 14 July 1950.

126 Ibid., doc. 345. Telegram, Henderson to DoS, 23 July 1950.

127 FRUS, 1950, vol. VI, doc. 377. Letter, Henderson to Weil, 30 December 1050.

128 FRUS, 1952-1954, vol. XI/1, doc. 412. Telegram, Bowles to DoS, 25 April 1952.

129 Ibid., doc. 1021. Telegram, Bowles to DoS, 19 August 1952.

130 SWJN2, vol. 7, pp. 686-688. Letter, Nehru to Krishna Menon, 4 August 1948.

131 Documents on Kashmir Problem, vol. III, pp. 100-104, 108-109.

132 SWJN2, vol. 14/1, p. 521. Proceedings meeting Standing Committee of the Central Legislature for the MEA, 17 December 1949.

133 FRUS, 1947, vol. III, doc. 120. Telegram, Grady to DoS, 3 November 1947.

134 Rakesh Ankit, The Kashmir Conflict. From Empire to the Cold War, 1945-66, London: Routledge, 2016, p. 86.

135 FRUS, 1949, vol. VI, doc. 1194. Telegram, Henderson to DoS, 11 June 1949.

136 FRUS, 1948, vol. V/1, doc. 247. Memorandum, 22 March 1948.

137 FRUS, 1949, vol. VI, doc. 1209. Telegram, Henderson to DoS, 8 September 1949.

138 Raghavan, War and Peace, pp. 139-140.

139 FRUS, 1949, vol. VI, doc. 1220. Telegram, Austin to DoS, 16 December 1949.

140 FRUS, 1952-1954, vol. XI/2, doc. 697. Telegram, Bowles to DoS, 5 May 1952.

141 Alastair Lamb, Kashmir. A Disputed Legacy 1846-1990, Hertingfordbury: Roxford, 1991, pp. 171-176.

142 FRUS, 1952-1954, vol. XI/2, doc. 632. Telegram, Bowles to DoS, 2 January 1952.

143 Ibid., doc. 685. Telegram, Bowles to DoS, 11 April 1952.

144 Ibid., doc. 697. Telegram, Bowles to DoS, 5 May 1952.

145 Ibid., doc. 751. Telegram, Bowles to DoS, 17 November 1952. 
146 Ibid., doc. 758. Telegram, Bowles to DoS, 29 January 1953.

147 Library and Archives Canada, RG25, 3262. Despatch 1198, Chipman, 30 November 1951.

148 NAI, MEA, 20(11)-EUR/48. Note, Bajpai, 25 June 1948.

149 FRUS, 1948, vol. V/1, doc. 404. Memorandum, 2 April 1948.

150 NAI, MEA, 1(62)-EURII/49. Note, Bajpai, 2 June 1949.

151 NAI, MEA, 733-C.J.K./49. Note on Soviet Reactions to Developments in China, R. Dayal, 30 June 1949.

152 NAI, MEA, 733-C.J.K./49. Notes, K.P.S. Menon and Bajpai, 13 July 1949.

153 Bruce E. Bechtol Jr, 'Paradigmenwandel des Kalten Krieges. Der Koreakrieg 1950-1953', in Bernd Greiner et al. (eds.), Heiße Kriege im Kalten Krieg, Hamburg: Hamburger Edition, 2006, pp. 146-147.

154 FRUS, 1950, vol. VI, doc. 263. Telegram, Henderson to DoS, 24 August 1950.

155 Ibid., doc. 201. Telegram, Henderson to DoS, 9 July 1950.

156 FRUS, 1952-1954, vol. XIV/1, doc. 19. Telegram, Bowles to DoS, 11 April 1952.

157 FRUS, 1950, vol. VIII, doc. 364. Telegram, Henderson to DoS, 28 July 1950.

158 Ibid., doc. 621. Telegram, Henderson o DoS, 6 October 1950.

159 FRUS, 1947, vol. VI, doc. 792. Telegram, Grady to DoS, 26 July 1947.

160 FRUS, 1947, vol. V, doc. 412. Telegram, Henderson to DoS, 22 December 1948.

161 NAI, MEA, 733-C.J.K./49. Note on Soviet Reactions to Developments in China, R. Dayal, 30 June 1949.

162 NAI, MEA, 615-C.J.K./49. Note, Sinha, 1 September 1949.

163 FRUS, 1949, vol. II, doc. 107. Telegram, Donovan to DoS, 20 September 1949.

164 FRUS, 1949, vol. IX, doc. 83. Telegram, Henderson to DoS, 6 September 1949.

165 Ibid., doc. 55. Telegram, Henderson to DoS, 21 June 1949.

166 Ibid., doc. 234. Telegram, Henderson to DoS, 6 December 1949.

167 FRUS, 1950, vol. VI, doc. 263. Telegram, Henderson to DoS, 24 August 1950.

168 FRUS, 1950, vol. VIII, doc. 524. Telegram, Henderson to DoS, 29 September 1950.

169 MEAA, 7(16)-P/50.I. Letter, V. V. Ghokale to Political Officer Sikkim H. Dayal, 12 December 1950.

170 MEAA, 7(16)-P/50.I. Note, undated [December 1949].

171 FRUS, 1949, vol. IX, doc. 1038. Telegram, Donovan to DoS, 21 November 1949.

172 MEAA, 612-C.A./49. Note, Bajpai, 21 November 1949.

173 ChanWahn Kim, 'The Role of India in the Korean War', International Area Review, 2010, 13(2): 26.

174 MEAA, 12/1/NGO. Telegram 242989, Bajpai to Panikkar, 17 September 1950.

175 MEAA, 12/1/NGO. Telegram 21175, Nehru to Krishna Menon, 28 September 1950.

176 NAUK, FO, 371/84456. Note, 9 August 1949, Scott.

177 FRUS, 1950, vol. VI, doc. 264. Telegram, Henderson to DoS, 25 August 1950.

178 NAUK, FO, 371/84456. Telegram 3006, Roberts to CRO, 27 October 1950.

179 FRUS, 1950, vol. VI, doc. 324. Telegram, Henderson to DoS, 13 October 1950.

180 FRUS, 1950, vol. VII, doc. 697. Telegram, Henderson to DoS, 21 October 1950.

181 Ibid.

182 FRUS, 1950, vol. VI, doc. 336. Telegram, Henderson to DoS, 31 October 1950.

183 NAUK, FO, 371/84456. Telegram 2995, Roberts to CRO, 26 October 1950.

184 FRUS, 1950, vol. VI, doc. 356. Telegram, Henderson to DoS, 30 November 1950.

185 Sardar Patel's Correspondence, vol. 10, doc. 245, pp. 335-342. Letter, Patel to Nehru, 7 November 1950.

186 NAUK, FO, 371/84456. Telegram 2995, Roberts to CRO, 26 October 1950. 
187 Quoted after Chandrashekhar Dasgupta, 'Nehru, Patel and China', Strategic Analysis, 2014, 38(5): 718.

188 SWJN2, vol. 12, pp. 410-411. Note, Nehru, 9 July 1949. For Menon's and Bajpai's statements, see fns. 4-5.

189 Dasgupta, 'Nehru, Patel and China', 723-724.

190 FRUS, 1950, vol. VII, doc. 944. Telegram, Henderson to DoS, 2 December 1951.

191 FRUS, 1951, vol. VII/2, doc. 98. Telegram, Henderson to DoS, 31 May 1951.

192 MEAA, 12/2/NGO/50. Note, Bajpai, 22 April 1951.

193 Bhola Nath Mullik, My Years with Nehru. The Chinese Betrayal, New Delhi: Allied, 1971, pp. 115-116.

194 FRUS, 1951, vol. VII/2, doc. 205. Telegram, Steere to DoS, 6 October 1951.

195 FRUS, 1952-1954, vol. XIV/1, doc. 19. Telegram, Bowles to DoS, 11 April 1952.

196 MEAA, 48-SB/50. Letter, K.M. Kannampilly, Embassy Rangoon, to Dutt, 7 December 1950.

197 MEAA, 48-SB/50. Letter, K. M. Kannampilly to Dutt, 6 November 1950.

198 NAI, MEA, 885-FEA/48. The Japanese Problem and the Future of the Pacific, P.A. Menon, 25 September 1948.

199 FRUS, 1950, vol. VI, doc. 500. Telegram, Henderson to DoS, 12 April 1950.

200 NAUK, FO, 371/92889. Record of Interview, 15 January 1951.

201 SWJN2, vol. 16/2, 613. Letter, Nehru to Pandit, 6 August 1951.

202 FRUS, 1951, vol. VI/1, doc. 712. Memorandum, William S. Williams, 29 August 1951, fn 7.

203 MEAA, 1272/NGO/49. Letter, K.P.S. Menon to Nehru, 1 March 1948.

204 NAI, MEA, 885-FEA/48. Note on Korea, undated [September 1948].

205 NAI, MEA, 2(62)-UNII/49. Note, Bahadur Singh, 19 October 1949.

206 NAI, MEA, 52(3)-CJK/50. Note, K.P.S. Menon, 7 September 1950.

207 MEAA, 23-CJK/51. Note, Bajpai, 23 May 1951.

208 MEAA, 23-CJK/51. Note, K.P.S. Menon, 3 August 1951.

209 For example, Letter, Nehru to Rajagopalachari, 1 November 1950. SWJN2, vol. 15/II, pp. 336-338.

210 FRUS, 1949, vol. IX, doc. 129. Telegram, Donovan to DoS, 10 October 1949.

211 Ibid., doc. 1449. Telegram, Henderson to DoS, 14 December 1949.

212 NAI, MEA, 612-C.A./49. Note, K.P.S. Menon, 19 November 1949.

213 NAUK, FO, 371/84456. Telegram 2861, Roberts to CRO, 10 October 1950.

214 FRUS, 1950, vol. 7, doc. 697. Telegram, Henderson to DoS, 21 October 1950.

215 Ibid.

216 NAUK, FO, 371/84456. Telegram 3006, Roberts to CRO, 27 October 1950.

217 MEAA, 12/2/NGO/50. Note, K.P.S. Menon, 21 April 1951.

218 Subimal Dutt, With Nehru in the Foreign Office, Calcutta: Minerva Associates, 1977, pp. 24-25.

219 Dutt Diary 6, 10 November 1952.

220 Tyabji, Memoirs of an Egoist, p. 258.

221 NAI, MEA, 615-C.J.K./49. Note, K.P.S. Menon, 2 September 1949.

222 Amit Das Gupta, 'The Fateful Indian Recognition of West Germany, 1949', Cold War History, 2019, 19(1): 101-117.

223 NAI, MEA, 5(42)-EURII/49. Telegram, Khub Chand to MEA, 3 August 1949.

224 NAI, MEA, 5(42)-EURII/49. Note, Bajpai, 6 August 1949.

225 NAI, MEA, 5(115)-EUR.II/49. Letter, Khub Chand to K.P.S. Menon, 19 October 1949.

226 NAI, MEA, 5(115)-EUR.II/49. Note, K.P.S. Menon, 12 November 1949.

227 NAI, MEA, 5(115)-EUR.II/49. Note, K.P.S. Menon, 18 November 1949. 
228 Amit Das Gupta, Handel, Hilfe, Hallstein-Doktrin. Die bundesdeutsche Südasienpolitik unter Adenauer und Erhard 1949-1966, Husum: Matthiesen, 2004, pp. 69-70.

229 Dutt, With Nehru in the Foreign Office, p. 24.

230 Dutt, Autobiography, p. 89.

231 Charles H. Heimsath and Surjit Mansingh, A Diplomatic History of Modern India, Bombay: Allied, 1971, pp. 302-303.

232 NAI, MEA, 120-48/48-O.S.III. Note, Dutt, 22 October 1947.

233 Das Gupta, Serving India, p. 139.

234 Ibid., pp. 138-139.

235 Dutt Diary 4a, undated entry, pp. 3-4.

236 Das Gupta, Serving India, p. 119.

237 Gopal, Nehru, vol. 2, p. 310.

238 Das Gupta, Serving India, pp. 137-138.

239 Ibid., pp. 134-137.

240 SWJN2, vol. 14/1, p. 177. Letter, Nehru to Neogy.

241 Dutt, With Nehru in the Foreign Office, p. 18.

242 NAI, 23(75)-PAKIII/50. Memorandum, Dutt, 19 December 1949.

243 NAI, MEA, 7-26/48-G. Note, S. Ratnam, 11 August 1948.

244 Raghavan, War and Peace, p. 152.

245 SWJN2, vol. 14/2, p. 34. Letter, Nehru to R. R. Diwakar, 13 April 1950.

246 Ibid., p. 41. Letter, Nehru to Prasad, 14 April 1950.

247 Ibid., p. 48. Letter, Nehru to B. C. Roy, 15 April 1950.

248 Dutt, Autobiography, pp. 85-86.

249 SWJN2, vol. 16/1, pp. 291-292. Letter, Nehru to Gopichand Bhargava, 2 March 1951.

250 SWJN2, vol. 17, pp. 483, fn 2. Note, Nehru, 22 February 1952.

251 Das Gupta, Serving India, p. 117.

252 NAI, MEA, 2-1/49-AFR (I). Note, Dutt, 13 October 1949.

253 MEAA, 403-IANZ/51. Report G/12, Kamath, 20 December 1950, and handwritten Comment Dutt.

254 BL, IOR, L/PS/12/4627. Quarterly Report, October to December 1945, Bajpai, undated. 


\section{2 \\ BAJPAI'S HEIRS}

\section{A new tandem leading the MEA}

In the summer of 1952, Bajpai left a power vacuum behind. His successor, Sir N. R. Pillai, was appointed in autumn, and during the interregnum Foreign Secretary K.P.S. Menon was 'loath [to] accept responsibility and act on own initiative in manner comparable Bajpai'. ${ }^{1}$ To make things worse, R.K. Nehru was appointed as Menon's successor mostly for seniority and being a cousin of the prime minister. He performed poorly both as foreign secretary and as secretary-general (since 1960). Only with Dutt's appointment as foreign secretary on 12 October 1955 did the MEA become truly functional again; Pillai and Dutt formed an efficient tandem with pronounced views on international affairs.

Like K.P.S. and Krishna Menon, Pillai originated from the very southwest of the subcontinent. Born in Trivandrum in Travancore State on 24 July 1898 , he was three months senior to K.P.S. Menon. Apparently, they were friends from boyhood. With a B.A. from Madras University, in 1918 Pillai joined Trinity Hall in Cambridge, studying natural sciences and law. K.P.S. Menon and Pillai, meeting regularly while in England, both joined the ICS in 1922. The latter started in the Central Provinces and thereafter pursued a distinguished though unusual career. After holding various secretariat posts in the United Provinces, he was appointed assistant collector of customs in Madras and deputy director of commercial intelligence in Calcutta. In 1932 he joined the Commerce Department in Delhi, rising to the rank of secretary in 1942. At the time of independence, he was a leading all-India economic expert, but he neither commanded experience in foreign affairs nor had a strong standing among senior ICS colleagues. ${ }^{2}$ A short term in Paris from December $1947^{3}$ and his task as Indian representative for economic and commercial affairs in Europe ${ }^{4}$ brought him in touch with the European Cold War theatre, mostly on the commercial side again. Among others, he negotiated a trade agreement with the western occupation zones of Germany in the summer of $1949 .{ }^{5}$ According to Dutt, Pillai's 'stars were very low in 1948-49'. ${ }^{6}$ Nevertheless, in 1950 he was appointed cabinet secretary and secretary of the Planning Commission. 
While the experienced Bajpai had been towering over the MEA and selfconsciously claiming a say in foreign policy, Pillai learned on the job rather and was most unlikely to play a similarly dominant role, both vis-à-vis the ministry and the prime minister. ${ }^{7}$ Not only did he lack the expertise of his predecessor, but the new secretary-general also preferred another style of management. Known as a true gentleman, he was less prone to impose his views. Instead, he displayed a knack for moderating discussions. Married to Edith Minnie Arthurs, like his predecessor he was highly anglicised. At a juncture when India willy-nilly mostly interacted with western countries, this was an asset. From the mid-1950s, British High Commissioner Malcolm MacDonald would invariably start his day with an informal conversation with Pillai, sorting out bilateral issues. ${ }^{8}$

Nehru had relied on Bajpai and might have preferred a successor with comparable qualities. In 1952, however, there were few senior officers available. Pillai at least commanded some experience abroad and had adapted to various postings. Although he never won a standing comparable to Bajpai, in the long run and, in a sort of tandem with Dutt, he proved a good choice. Accordingly, Nehru kept him for nearly eight years, longer than any other MEA secretary in the history of independent India. As there are neither private papers available nor a bulk of official files like in the cases of Bajpai and Dutt, a fair assessment of his long term is difficult. Dutt's papers, however, throw some light on the years between 1955 and 1960.

Whereas Pillai grew on the job, R. K. Nehru remained a lightweight. Born on 10 October 1902, he joined the ICS in 1924 and served in the Central Provinces. His pre-independence experience in foreign affairs was limited to three months as officiating additional deputy secretary in the DEHL in 1936/1937. In 1948 he was appointed CDA in Washington; from January 1949 he served as ambassador to Sweden. R.K. Nehru had not distinguished himself like other senior ICS officers, and Stockholm did not provide opportunities to leave a mark. In the spring of 1949, he pressed his cousin for a secretaryship, emphasising his seniority and that he had not been promoted earlier only 'as a result of my not being on the spot'. ${ }^{9} \mathrm{He}$ was given the runaround, though, as the prime minister kept the troika of secretaries in the MEA. In the summer of 1951, R. K. Nehru was transferred to Canada. Only with the great exchange of the MEA's top ranks was he appointed foreign secretary. The prime minister once again put private obligations and family above ability.

In the MEA, the new foreign secretary was considered opportunistic. ${ }^{10}$ Around the transfer of power, it had been agreed that the privileges of ICS officers as guaranteed in the Government of India Act from 1935 would remain valid. IFS officers with a different background felt discriminated, ${ }^{11}$ and by 1955 the prime minister too opposed constitutional guarantees. He held that he had been absent from India when they had been accepted by Sardar Vallabhbhai Patel. ${ }^{12}$ To the embarrassment of Pillai and Dutt, 
R.K. Nehru floated with the tide. He criticised that India kept to British tradition, "which failed time and again because reform was the exclusive responsibility of the higher services and was usually attempted from below'. ${ }^{13}$ The 'class approach' had to be eliminated to develop a 'sense of one public service'. ${ }^{14}$ The initiative went nowhere, but Dutt steamed that

all this big talk of social equality comes with ill grace from a man who ... compelled the P[ublic] W[orks] D[epartment] to make very expensive alterations and improvements in their house; threw huge and costly parties at government cost, treats junior officers so curtly etc. etc. ${ }^{15}$

Worse, R.K. Nehru more than once appeared incompetent. ${ }^{16}$ In 1949, the GoI for economic as well as political reasons had recognised the Federal Republic of Germany (FRG) but not the German Democratic Republic (GDR). Thereafter, both Bonn and Delhi were after intensifying economic ties for mutual benefit. In 1950, a West German delegation suggested a treaty of friendship and cooperation, ${ }^{17}$ initially receiving a lukewarm response. Two years later, however, Delhi pushed the matter, suggesting a mostly 'political document' to give evidence of amicable relations and meant to serve as foundation for more agreements. ${ }^{18}$ When the FRG had hesitantly entered negotiations, however, R.K. Nehru out of the blue turned down the treaty proposal. He felt that such an agreement might be interpreted as a preliminary peace treaty and acceptance of German partition. ${ }^{19}$ This was a gross misreading of a note from the prime minister that advised to keep out of discussions around the German question. ${ }^{20}$ To no avail, Dutt, ambassador in Bonn, emphasised that the treaty would not have altered the Indian position at all. The FRG had concluded similar treaties with other parties without any bearing on the issue of German reunification. After Delhi had pushed for the treaty, the turnaround was considered a rebuff. ${ }^{21}$ Truly, August Hilger van Scherpenberg, who led the German delegation, indicated irritation and 'felt that if Sir Raghavan Pillai were in Delhi, things might have gone smoother'. ${ }^{22}$

Even more problematic were R.K. Nehru's assessments of China. Initially, the GoI had adopted the British position of mere Chinese suzerainty over Tibet. ${ }^{23}$ With the Tibet Agreement from 29 April 1954, Delhi bartered 'lofty phrases in the preamble', the Panch Shila, against practical concessions. British High Commissioner Alexander Clutterbuck found it 'certainly illogical for the Government of India to put much weight on the reference to mutual respect for territorial integrity when they have throughout the negotiations been concerned to deny that border questions have formed any part of them'. According to Clutterbuck, an unnamed MEA official shared that view, criticising that though 'the Chinese had shown a mania for reciprocity ... the Indian negotiators had given way to some of the Chinese 
requests' without getting anything in return. The only gain was that India, having shed its 'quasi-imperialist privileges in Tibet, would in future feel morally qualified to stand up for their rights there', which had come close to none. There was 'no reason ... to derive special satisfaction from it as an example of how it is possible to negotiate with the Chinese'. He, however, hoped that it would reduce frictions along the frontier, though the value of the agreement could be assessed only when it was seen how Beijing would operate it. ${ }^{24}$ Concerns that the Chinese would soon come up with territorial claims were even voiced by T.N. Kaul, one of the chief negotiators of the agreement and known for pro-Chinese leanings. ${ }^{25}$

The top ranks of the MEA, however, showed no concern. Pillai held that there was little in the agreement in general, ${ }^{26}$ whereas R.K. Nehru found that the use of the phrase 'Tibet region of China' was but a concession to realism. ${ }^{27}$ After the latter's transfer to Beijing in 1955, he characterised the ruthless Sinovisation of Tibet as necessary means to modernise a backward society: 'We should not jump to the conclusion ... that all this is a prelude to aggression, or some form of penetration of our border area'. ${ }^{28}$ While the GoI rapidly lost trust in China, he warned against contacts with 'hostile elements in Tibet'. ${ }^{29}$

By 1953, Pillai decided to replace R.K. Nehru with the more experienced, competent and reliable Dutt. On numerous occasions, he assured the latter of his full-hearted support; on this matter Dutt also had M. O. Mathai as his ally. ${ }^{30}$ For both, their disregard for R. K. Nehru went hand in hand with concerns regarding the ever-growing influence of Krishna Menon. After nearly three decades abroad, Nehru's friend had finally returned to India, where on 26 May 1953 he became a member of the Rajya Sabha. He went on playing a key role in Indian foreign affairs, having his finest hour at the Geneva Conference on Indochina from April to July 1954: Though he had not even been invited to participate, owing to his mediation efforts a compromise was achieved. Non-alignment finally seemed to pay off, with India becoming the much-needed mediator in Cold War conflicts. Menon went on representing India at the UN; furthermore, he led talks with the British government, bypassing High Commissioner Vijaya Lakshmi Pandit. ${ }^{31}$

MEA officials had considered Krishna Menon's role highly problematic from early on: An amateurish, haughty outsider, showing open contempt for officials and ministry procedures while enjoying jester's licence. Menon in Delhi, with the same attitude but more experienced and freed from any formal affiliation with the MEA, was even worse. Pillai was not the man to fight him, and R. K. Nehru could be expected to float with the tide. On the contrary, Dutt had demonstrated how to clip Menon's wings.

Dutt also shared Pillai's views on foreign affairs. Notwithstanding fundamental criticism of US policy, especially the alliance with Pakistan, both believed good relations with the West in India's best interest. Nehru's and Menon's anti-western reflexes in Dutt's eyes unnecessarily hampered India's 
capacity to cooperate for mutual benefit. His attitude towards the West was based rather on pragmatic considerations than genuine sympathy, but he was known for his staunch anti-communism. ${ }^{32}$ This was neither the result of British training nor his deep religiosity:

I do believe that the primary loyalty of the communists in all noncommunist countries is to foreigners. They are fanatics. They would side with Russia in order to make their country communist. They are unpatriotic. I am against them. ${ }^{33}$

His feelings were reconfirmed during his term in West Germany, when he had to travel to Berlin through the GDR regularly, feeling appalled at what he saw. ${ }^{34}$ This included the Russians, whom he found 'devoid of the slightest spark of humour and kindness'. ${ }^{35}$

For five years, Pillai and Dutt formed a highly efficient tandem. The secretary-general treated the foreign secretary as colleague, and the usually reserved Dutt responded with warmth, praising Pillai as a 'good soul', helpful and never entertaining ill against anybody. ${ }^{36}$ Dutt took Pillai and his balanced judgement as ideal, and soon mutual respect transformed into friendship. ${ }^{37}$ They complemented each other professionally: Pillai was the charming face of the MEA, both for moderating internal discussions and with foreign diplomats; Dutt shunned the limelight and routine conversations with foreign representatives. He turned out to be a strict headmaster, a realist analyst and a tough negotiator. His extremely laconic notes and his bluntness found the approval of the chronically overburdened prime minister.

Other than Pillai's, Dutt's term is densely documented in the vast collection of official files he left with the Nehru Museum and in his detailed diaries. Therefore, inevitably, the story of the tandem must be told with a strong bias on Dutt, which by no means indicates lack of leadership, capacity or initiative with Pillai. The two faced three main antagonists. Commonwealth Secretary M.J. Desai, ICS, and Dutt loathed each other from the time of probation back in 1927/1928. ${ }^{38}$ Desai had served in the Bombay cadre, and in 1948 he had been appointed advisor to the Indian delegation to the UN. From 1948, for three years he had served in London, both tasks making him a favourite of Krishna Menon. After an ambassadorship in Scandinavia, he had been appointed chairman of the International Commission for Supervision and Control in Vietnam. Having collected much more experience abroad than Dutt and equalling him in terms of seniority, for five long years Desai fought hard for equal competences. If only for his close relationship with Krishna Menon, Pillai and Dutt successfully kept him at bay. Krishna Menon, who had his office in South Block but remained outside of any ministry control, ruled into the MEA, including questions of personnel..$^{39}$ When he was appointed minister without portfolio and principal advisor on foreign affairs on 4 February 1956, Nehru ordered that everything of relevance 
had to go over Menon's desk. The latter's influence grew further after he was appointed minister for defence in April 1957. The third antagonist was the one most difficult to fight: K.P.S. Menon, India's ambassador in Moscow for nearly nine years. He did not interfere in the business of the MEA at all, and nominally he was under the control of headquarters like any other head of mission. Nevertheless, he exercised immense influence on Indian foreign policy through his elegantly written reports, which the prime minister read and spread with enthusiasm. K.P.S. Menon's accounts of Soviet policy and international affairs were coloured with unshakable optimism: Whatever went wrong in the USSR and its satellites was but the exception from the rule. To no small extent, the ambassador put in motion what would become known as 'Hindi-Russi bhai bhai': Indo-Soviet friendship, lasting throughout the Cold War. India's beginning tilt towards the USSR was intensely fought by Pillai and Dutt, who grew increasingly frustrated in their attempts to contradict a former foreign secretary vis-à-vis Nehru.

Dutt was promoted when Nehru had already modified the general course of foreign policy. In June and July 1955, the prime minister had visited the USSR, which again was the result of a change of course by its new leaders, Nikolai Alexandrovich Bulganin and Nikita Sergeyevich Khrushchev. Unlike Stalin, they sought cooperation with nonaligned countries as potential allies in the Cold War. India, for its size, its charismatic prime minister and its claim to leadership in the Afro-Asian world, was given top priority. The new policy of the Kremlin, however, did not necessarily appear plausible right from the start, among others because its protagonists had been close aides of Stalin. With K.P.S. Menon, they could count on an interpreter reading only the best intentions in their initiative. ${ }^{40}$

Menon had asked for a transfer to Moscow as early as May $1947,{ }^{41}$ but his wish came true only on 19 October 1952. Radhakrishnan had been seen off with 'unusual courtesy' and CDA Gundevia characterised bilateral relations as 'cordial', though Moscow went on viewing events in India under 'purely ideological considerations' ${ }^{42}$ Once again, K.P.S. Menon was but the second choice, this time after Krishna Menon, who had turned down Nehru's offer for 'sheer unsuitability'. ${ }^{43}$ K.P.S. Menon's first impressions are not documented, but when he attempted to explain away differences in both countries' policies regarding the Korean War, he met staunch resistance in the Soviet foreign ministry (MID)..$^{44}$ In the monthly report for January 1953, he listed well-known facts like the campaign against Jewish doctors, but he did not comment at all. ${ }^{45}$ The first noteworthy event of this term was his one and only interview with Stalin on 17 February, though, to Menon's disappointment, nothing of relevance was discussed. ${ }^{46}$ The ambassador, nevertheless, was impressed by Stalin's

almost rustic simplicity, his spontaneous humour, his singlemindedness, his perspicacity, his vision of the world as divided into 
white and black - with a lonely grey, India, standing in between his utter ruthlessness, and his cynical and thoroughly Marxist disregard of morals which he made no attempt to hide. ${ }^{47}$

After Stalin's death on 5 March, Menon composed an obituary full of commonplaces, praising the dictator for industrialisation 'at terrible cost'. Furthermore, he counted the USSR as the second industrial and 'most formidable political power on earth'. No successor could give up the ultimate objective of universal communism, but Menon believed that Moscow, for the time being, was willing to accept coexistence. If the West showed enough courage, a five-power peace might become possible. ${ }^{48}$

Like any other foreign diplomat in Moscow, Menon mostly speculated about motives and decision-making in the Kremlin. His reports followed a certain pattern: First, they listed events, but hardly ever provided personal views on them. Second, if Soviet brutality made some comment inevitable, the ambassador whitewashed Moscow, finding reports exaggerated or action justified on principle. The annual report of 1953 provides a good example: The uprising in East Berlin on 17 June 1953 he turned down as 'riots', in contrast to terms with rather positive associations like 'rising' or 'revolution' as used in western papers. There was no way to deny that those 'riots' had been crushed by the Red Army, though according to Menon, who relied on nothing but Soviet press reports, 'with the minimum use of force'. Indeed, 55 people had been shot dead or had died in detention. When explaining the background, he contrasted Soviet allegations of West German provocations with views 'elsewhere . . a the release of pent-up anger and resentment at Russian control', scrupulously avoiding any assessment of his own. Third, as a pattern, even in the darkest hours, Menon saw indications of liberalisation. In the same report, in a particularly blatant case he held that of all people Stalin had allowed liberal influences to flourish via literature: 'Shakespeare, Shelley, Byron, and Bernard Shaw brought with them a whiff of freedom. Moreover, the grand revolutionary tradition of the great Russian writers themselves was bound to undermine the cruder aspects of Stalinist absolutism'.

A fourth feature was massive criticism of western politics, especially targeting US Secretary of State John Foster Dulles and FRG Chancellor Konrad Adenauer as crusaders. Typically, Dulles in the report was blamed for suspecting the but recent Soviet friendly gestures as deception. ${ }^{49}$ That an ambassador in Moscow, glaringly open to Soviet propaganda, scrupulously avoided any critical assessment of the politics of his host country but regularly condemned Washington and Bonn relying on nothing but press reports without ever being reprimanded tells that Menon was nearly sacrosanct. Apart from his general status in the IFS and his friendship with Nehru, Menon's reports supported the prime minister's view of the world, giving the USSR the benefit of the doubt and suspecting the US and its allies of the 
worst. That they were garnished with references to literature or history was according to Nehru's taste as well. Accordingly, the prime minister ordered to forward this and many other reports to all ministries, chief ministers and heads of mission. ${ }^{50}$

Nehru clearly preferred Menon's assessments even of countries outside the Soviet sphere to those of ambassadors posted there. This surfaced at a conference of heads of missions in Europe, taking place at Swiss Bürgenstock between 16 and 19 June 1953, exactly the days of unrest in the GDR. Nehru described the USSR, together with the US and China, as one of three expansionist forces in world politics, characterising expansionism as not necessarily territorial. Only three months after Stalin's death, he found it 'clear that Russia felt that she could probably attain her ultimate objectives better through peace than through war', hoping to detach some European countries from US influence, allegedly a tendency in Europe. Dutt, ambassador in Bonn, held against that western politics had to be treated with fairness as well. Adenauer, for example, was equally interested in peace and harboured no illusions of getting back those former German territories incorporated into Poland and the USSR. Unmoved, Nehru expressed deep distrust against Adenauer and his territorial ambitions. ${ }^{51}$

Dutt shared Menon's dislike for Dulles and complained that the Germans had 'sold themselves to the Americans'. ${ }^{52}$ The events of 17 June in the GDR, however, he read as 'mass upsurge'; 'communist indoctrination' had failed to replace the 'German yearning for freedom and re-unification'. ${ }^{53}$ An exchange between the two ambassadors revealed fundamental differences of opinion. It took place in the context of the downfall of Lavrentiy Pavlovich Beria on 26 June 1953, often related to a conciliatory Germany policy. ${ }^{54}$ Beria had been Stalin's long-time head of the secret service NKVD and after the generalissimo's death formed part of the ruling troika with Georgy Maximilianovich Malenkov and Molotov. Menon held that despite his downfall and the 'riots', the USSR persisted on decollectivisation and decommunisation in the GDR to defer German unification: ${ }^{55}$ 'Individuals rise and fall but Soviet Leviathan goes on, remorseless, unperturbable, indestructible', pursuing a policy of détente. ${ }^{56}$ This was a paradoxical assessment, Menon himself emphasising that Stalin's heirs had undertaken a fundamental change of course. Dutt consented regarding recent measures in the GDR and continuity in Soviet foreign policy, but in a negative sense: Conciliatory gestures and ongoing heavy repression were but two sides of the same coin. Continuity for Dutt meant that the Soviets would neither loosen their grip on East Germany nor permit a change of course in domestic affairs. Everything else was tactics. ${ }^{57}$ When Bulganin succeeded Malenkov as prime minister, Dutt privately saw a moderate replaced by a close follower of Stalin, who would pursue

a tough policy if nothing more happens. What an ironical sequel to KPS's last annual (1954) report on Soviet Russia. KPS has tried to 
prove on the basis of progressive reduction of the Russian defence budget that Soviet Russia is but on a period of peace! ${ }^{58}$

Perhaps an even stronger contrast to Menon's optimism provided reports from Prague, India's only mission in a satellite state apart from Budapest. The latter was associated with the Moscow embassy. Czechoslovakia in Indian eyes had played a special role in the interwar period, a sort of stronghold of democracy granting asylum among others to A.C.N. Nambiar, head of the Indian Students' Bureau in Berlin, driven out of Nazi Germany. ${ }^{59}$ The communist coup d'état of February 1948 had shocked Delhi, and Ambassador Nedyam Raghavan harshly condemned Soviet policy: 'The Czechs and the Slovaks, who today seem to put up with totalitarian tyranny of the Red variety, as they had endured that of the Nazi type, may rise in arms if occasion or opportunity is afforded'. Communist rule had led to 'intellectual stagnation, caused by withholding from the people of opportunities for foreign travel and by the effective banning of foreign literature penetrating into the country' - nothing of the liberalism Menon had ascribed to Stalin. There was no Soviet resident as 'the subordination of slaves who glorify in their chains is so complete that it is not necessary for the master to watch or direct them'. One had to see communism in action, its practice so different from precept:

The propelling force of communism in many countries today is Russian power, money or mendacious propaganda. Curiously enough Stalinist Russia has also been its biggest stumbling block. Had the adaption of communism not necessarily carried with a blind and slavish acceptance of Russian domination, communist ideology might have had stronger appeal to most workers and quite a few intellectuals.

Moscow might be aware of the dilemma but gave priority to its 'national and imperialist (it may be blasphemy in a Russian context to use the word, but it is none the less true) interests' ${ }^{60}$

As foreign secretary, Menon had been confronted with similar allegations from someone who had to know: Czechoslovak Ambassador Bohuslav Kratochvil 'spoke bitterly of communist tactics. Said his people were slaves of Russia'. Menon, who must have known of Raghavan's report, nevertheless, considered Kratochvil a 'Brutus'. ${ }^{61}$ The reports from Prague did not change after Stalin's death: In August 1953, CDA K. L. Dalal reported a vehement campaign against absenteeism and labour indiscipline, pursued again with means of a 'totalitarian system'. The tone had changed, but not much else. ${ }^{62}$ Dharma Vira, an ICS officer from the 1930 batch who took over as ambassador in 1954, reported in a similar manner that 'all Czechoslovak policies are really dictated by the USSR' and its ambassador was 'treated like a viceroy'. 
The regime was lacking popular support, 'resulting in hysterical reliance on Russia'. Socialists had no ideological qualms about starting a war but, for the time being, considered peaceful coexistence the better option. Prague was wooing Delhi to bring about peaceful coexistence; friendship, however, would only be genuine if India turned communist. ${ }^{63}$

Notwithstanding such reports from Prague and Dutt's similarly sceptical assessments of conditions in the GDR, Menon's rosy descriptions of a thaw prevailed. The picture drawn of Hungary was ambivalent, though, the ambassador in September 1953 admitting that hopes for at least a bit of freedom within a communist system had little chance to be fulfilled soon. Typically, however, he did not hold Moscow responsible, but international developments, in this case Adenauer's election victory, ruled out an early settlement in Germany. ${ }^{64}$ The USSR, on the contrary, stood for new liberalism, having acknowledged 'the error of rigorously foisting, on "satellite" states, economic methods which had proved successful in the Soviet Union' ${ }^{65}$ The term 'satellite', indicating that Budapest was as little independent as Prague or East Berlin, appeared unacceptable. The worst example for whitewashing Soviet and socialist politics that Menon provided was when commenting on elections in Hungary in May 1953: They were

basically different from elections in the accepted sense in which voters vote for rival candidates, the majority of votes deciding as to who will be the winning candidate. At the same time, it would be a mistake to treat these elections as a fake, because the candidates ... were those who had distinguished themselves in their work. ${ }^{66}$

Such assessment from a representative of a country priding itself the world's largest democracy did not raise eyebrows in Delhi. On the contrary, the prime minister ordered wide distribution. ${ }^{67}$

\section{Indo-Soviet overtures}

Nehru, nevertheless, must have taken notice of critical reports as well before visiting the USSR from 7 to 23 June 1955. Without first-hand knowledge of the satellite states, he believed that the Czechoslovaks were unhappy under Soviet control. ${ }^{68}$ Moreover, he did not doubt the existence of the Gulag and labour camps. Collectivisation had cost an enormous number of human lives and there was 'no civil liberty as we know it'. The Cold War, whoever responsible, had created apprehension and a continuing sense of danger, but 'if normality comes in, there is no reason to expect a continuance of communist aggressiveness and interference elsewhere'. He was impressed by extensive reconstruction and modernisation, the care for children and 'an extraordinarily warm-hearted people'. Like Menon, he found it 'quite absurd for anyone to say that the welcome we got was organised'. ${ }^{69}$ Beyond 
doubt, the Soviet leaders also knew of Nehru's vanity and, as usual, had taken care of an impressive reception. Nevertheless, state visitors from former colonies were received with genuine curiosity worldwide, and this was even truer for a country isolated for decades. Menon even held the absurd belief that Nehru, driven around in an open car with Bulganin - a first time for the latter - had brought Soviet leadership and people closer together. It was mere sycophancy to find 'the secret of the great welcome given to the prime minister ... in the fact that the Soviet people regard him as the architect of Indian independence'. ${ }^{70}$ There was no free forming of opinion in the USSR, and just as Stalin had blamed Nehru a lackey of the imperialists, the new leaders had imposed another image.

Pillai, being part of the delegation, commented with more reservation, welcoming the new course: Peaceful coexistence was genuine as it was based on pragmatic needs, and 'suspicions about our intentions and our ability to act in an independent manner' had vanished. Moscow had come to appreciate nonalignment and would not like India to join the Soviet bloc as it 'would, being still underdeveloped, prove a drag and a liability to the older and stronger communist countries'. Like for many other Indians, progress in the USSR's Asian republics played an important role, where Pillai found no colour prejudice. Otherwise, he was sceptical: Living standards everywhere were surprisingly low; youth education encouraged precocity and would lead to 'the mass production of a new type of extrovert'. The Soviet leaders were 'all very able men, and some perhaps strikingly so, but of dazzling brilliance I am afraid I did not see much evidence'.$^{71}$ The three assessments varied from Menon's enthusiasm over Nehru's benevolent but balanced judgement to Pillai's pragmatism mixed with scepticism.

Nehru's talks in Moscow were characterised by mutual sympathetic gestures. They were of little consequence but helped to build confidence. Bulganin promised to support India's initiative for the release of US pilots kept in Chinese detention; the Soviets even suggested that India should claim a sixth permanent seat in the UNSC. In return, Nehru criticised the western policy of strength and welcomed Soviet policy vis-à-vis Austria and Yugoslavia as well as regarding disarmament. ${ }^{72}$ The return visit brought to light divisions in the GoI regarding the general attitude toward the USSR and practical cooperation, among others for military purposes. During preparatory meetings, Nehru expressed willingness to buy Ilyushin bombers, the first weapon system to be procured from the socialist bloc. ${ }^{73}$ Pillai and Dutt in their staunch opposition were supported by Defence Secretary M.K. Vellodi, ICS, arguing that western supply and spare parts for existing systems would dry up. ${ }^{74}$ The secretary-general was 'worried about the way we are inclining towards communists by slow but sure steps while maintaining neutrality'. ${ }^{75}$

In an interdepartmental meeting of secretaries, all with an ICS background, it was agreed that all possible schemes of Indo-Soviet cooperation 
should be coordinated by a committee under the chairmanship of Pillai. Production Secretary Khera wanted to be understood that the 'Russian approach is motivated by political considerations'. Moreover, Nehru did his part, calming down the overenthusiastic Minister of Natural Resources K.D. Malaviya and Prasanta Chandra Mahalanobis, an influential member of the Planning Commission. ${ }^{76}$ Nevertheless, Dutt saw several officials and ministers falling 'head over heels to bring Russians in in a big way'. Regarding K.P.S. Menon, the foreign secretary wondered 'whether he has that love for communists; but he is going even farther', lacking objectivity. ${ }^{77}$

Once Bulganin and Khrushchev had arrived, Nehru bluntly clarified that he would not tolerate any Soviet support of the CPI. ${ }^{78}$ Otherwise, however, the visit took a rather unexpected turn..$^{79}$ Bulganin and Khrushchev, received with partly organised and partly genuine enthusiasm, ${ }^{80}$ abused Indian hospitality for fierce anti-western speeches, tolerated among other reasons because they supported Delhi regarding the disputes around Kashmir and Goa. There were but very few Indians of relevance objecting, among them Vice-President Radhakrishnan, finding the GoI going too far by displaying communist flags everywhere. Furthermore, he insisted to discuss the repression of writers in the USSR with the guests. ${ }^{81}$ With western diplomats, he spoke of 'these awful people' proclaiming 'gospels'.$^{82}$ Nehru's Private Secretary H.V.R. Iengar from the 1926 ICS batch, too, expressed concern that 'overenthusiasts' would inevitably draw India into the Soviet orbit. ${ }^{83}$ Otherwise, Dutt observed even Pillai doing his best to appear even-handed and Nehru weighing words about socialist countries with unusual caution..$^{84}$

The warnings about Moscow's political aims proved right; the visitors were far from being generous. Even small schemes of cooperation were meant to come with bilateral agreements containing a political message..$^{85}$ Otherwise, 'discussions about Russian supply were proceeding in a normal businesslike manner' ${ }^{86}$ Only after Pillai had pressed hard, Deputy Foreign Minister Gromyko offered credits to finance the Bhilai steel plant. ${ }^{87}$ The Soviet loans over a total of Rs 70 crore were comparatively small 'against total assistance of 240 crore from the US and under the Colombo Plan' ${ }^{88}$ As Nehru had prevailed regarding the CPI, the guests did on Cold War issues; Indian silence gave the impression of consent. Furthermore, against Dutt's protests, the prime minister agreed that in the final communiqué in the passage on the Far East, expressing hopes for a settlement, the word 'peaceful' was omitted. ${ }^{89}$ Finally, the Defence Committee of the cabinet decided to buy a squadron of Soviet bombers. ${ }^{90}$

Already in the first stages of the state visit, Dutt's trust in Nehru's judgement was shaken. He was sure that US President Dwight D. Eisenhower 'would not have received such warm welcome nor would PM be so enthusiastic either'. In the long run, this might strengthen communist forces in India. The foreign secretary had faith in Nehru, but 'no blind faith', and he hoped the prime minister knew what he was doing. ${ }^{91}$ Dutt felt confirmed in 
his scepticism, for most of the officials, 'still of the old British neutrality', found the Soviet remarks on Kashmir embarrassing. ${ }^{92}$ And the foreign secretary could not deny that western criticism was in large part justified. Canadian Prime Minister Lester Pearson, for example, complained that seven Soviet experts paid by India won more credit than scores from the West, financed by their own governments. ${ }^{93} \mathrm{He}$ also wondered about reactions if western politicians had abused the USSR while in India. ${ }^{94}$

The effect of the visit on Indian foreign policy could be seen immediately. CDA in Moscow P. Ratnam welcomed the reduction of western influence in Asia. He suggested to make use of the impression 'that India is gradually changing its neutral position'. Delhi should renew requests for western aid without any political strings attached. If successful, India would be the gainer, otherwise 'the western countries stand exposed'. Dutt disagreed, ${ }^{95}$ but Ratnam's approach would inevitably play in the background of India's aid diplomacy. Furthermore, Nehru, against all advice of officials and ministers, insisted on the procurement of Ilyushin bombers, changing his mind but for the intervention of his friend Mountbatten. ${ }^{96}$

\section{Hungarian crisis}

Had the visit of Bulganin and Khrushchev shown divides within the GoI, the crisis in Hungary a year later nearly led to an open clash between leftists and realists. The Indian focus in late 1956 had been on the Suez crisis, where France and the UK (in coalition with Israel) in a relapse of old-style colonialism tried to enforce what they considered their rights. This fitted into the Nehruvian worldview of a general struggle of progressive forces versus imperialism. On the contrary, news about developments in Hungary did not. There, a liberal-minded government under Imre Nagy tried to throw off the Soviet yoke, the allegedly progressive USSR responding with force. Exponents of rapprochement with Moscow - prominently Nehru and the two Menons - turned down reports from Budapest as a diversion from the Suez crisis, invented by western powers and spread via western media. The prime minister refused to take any stand before receiving reliable information from Hungary. Indeed, India maintained a mission in Budapest, K.P.S. Menon being accredited since late 1952. As the ambassador spent most of his time in Moscow, it was CDA Mohammed Ataur Rahman providing the MEA with reports so accurate that the ministry would later publish them as a book. ${ }^{97}$ On 28 October, he wrote of 'considerable casualties' in the context of mass demonstrations, though the Red Army probably had acted in self-defence. ${ }^{98}$ Three days later, he reported a national uprising against 'Soviet colonisation'. The 'revolution' had gone 'far further than Titoism.... If the Russians now in Hungary withdraw, prospects for democracy are bright'. ${ }^{99}$ Nagy on 30 October had declared the end of one-party rule; a day later, he proclaimed neutrality and Hungary leaving the Warsaw Pact. The Red Army had withdrawn for 
a few days only to return on 2 November to wreak carnage, killing at least 2,500 civilians.

The two Menons, however, followed Christian Morgenstern's dictum, 'that which must not, cannot be'. ${ }^{100}$ Dutt noted how Krishna Menon 'sought to find some explanation of Soviet action - misrepresented etc. - blamed Rahman who has sent an alarming report from Budapest'. ${ }^{101}$ Nehru was ambivalent: He did not doubt a national uprising 'against Soviet forces and interference' with 'large-scale killing on both sides'. K.P.S. Menon in Moscow informally should express Indian concern and sympathy with those 'who represent the national desire for freedom'. ${ }^{102}$ Moscow should provide 'the true position and facts', the information available coming from sources 'usually hostile to the Soviet Union' ${ }^{103}$ The prime minister, however, wondered whether the ruckus in Budapest allowed a correct appraisal; Rahman 'must avoid getting entangled in internal issues'. ${ }^{104}$ After bloodshed had started, Nehru ordered the delegation at the UN 'to avoid condemnation of Soviet [sic] as we lack full information'. ${ }^{105}$

K.P.S. Menon on 5 November spread Soviet propaganda that the US had stirred unrest by sending saboteurs and ammunition. The MEA felt helpless, issuing a circular but summarising the contradicting views of the ambassador in Moscow and his deputy in Budapest, respectively. The GoI did not know to what extent 'reactionary elements within and incitement from without' played a role and, therefore, could 'not subscribe to any resolution in the UN condemning Soviet government'. ${ }^{106}$ Nehru in letters to Bulganin either did not mention Hungary at all ${ }^{107}$ or formulated cautiously that 'developments there have caused us much concern' ${ }^{108}$ Accordingly, when on 4 November the UNGA voted on a resolution condemning the use of force and calling for a complete withdrawal of the Red Army from Hungary, ${ }^{109}$ India abstained. Five days later, another resolution added the demand for free elections under UN auspices, which India considered unacceptable in the case of Kashmir. ${ }^{110}$ Krishna Menon, representing India, first sent a telegram to headquarters that he would abstain. While Dutt and Nehru were still discussing an approving reply, Menon, unauthorised, joined the nine socialist countries opposing the resolution, thereby isolating India and spoiling the image of a moral power. Nehru responded with a mild expression of dissent, finding Menon's high-handedness even justifiable for lack of information. Nevertheless, he advised that against the fact of a national uprising and 'terrible killing and misery' caused by Soviet forces, it appeared better 'to abstain from voting on resolutions containing some objectionable features and moving amendments, rather than voting against it'. ${ }^{111}$

Pillai and Dutt had made desperate efforts to convince Nehru of the accuracy of Rahman's reports. On 2 November, the secretary-general urged the prime minister 'to raise our voice' and choose an attitude 'in the light of principles we have been advocating. ${ }^{112}$ He had Dutt's support, seeing 'Soviet policy unmasking itself' ${ }^{113}$ Furthermore, the foreign 
secretary was concerned that Indian silence was understood as consent. ${ }^{114}$ Privately, he blamed K.P.S. Menon for having 'swallowed Soviet propaganda wholesale' and Nehru for his overcautious remarks. ${ }^{115}$ The prime minister had given 'credence to the Soviet story of counterrevolutionaries committing murder, pillage, of Soviet troops intervening at the instance of' the Hungarian Communist Party. Nehru at a Congress meeting had said 'that this seemed to have the majority support. Where he got this information from I do not know. We have lost our moral prestige among many democratic countries. The Soviet govt. are utter rascals - as rascals as' the British attacking Egypt. 'We have condemned the latter in unmeasured language - not the former. How can we justify ourselves?' For the first time, Dutt considered to resign, but hoped that Nehru would prove right as he had done in the past. ${ }^{116}$

The foreign secretary was flabbergasted when on 9 November, Krishna Menon voted with the Soviet bloc without awaiting instructions and against existing guidelines. ${ }^{117}$ Menon obviously had acted 'in a huff. Pity is he will come away with it'. ${ }^{118}$ And Dutt was proven right, Nehru finding it 'clear enough' that the resolution had been voted paragraph by paragraph. Menon had abstained apart from the one on elections under UN auspices, with the result that he had voted down the resolution as a whole. ${ }^{119}$ The foreign secretary was not the only one to object to such technical argument. Ambassador G. L. Mehta from Washington pointed out that India's worldwide standing depended on 'dedication to certain moral values'. There was a growing feeling 'that we use different yard-sticks to measure the actions of the Russians and those of the West'. The USSR was 'prepared to use ruthless force in order to prevent any change in economic and political systems' of satellites 'which does not meet with its approval'. ${ }^{120}$ Furthermore, there was much opposition against Menon's vote in India. Typically, this made Nehru even more defiant. When the New York Times correctly reported that the MEA did not approve Menon's vote, Nehru accused ministry officials of having leaked information. Dutt, prepared against such 'familiar tactics', told the prime minister 'bluntly that I at least did not speak to any newspaper correspondent'. ${ }^{121}$

Nevertheless, he remained Nehru's loyal servant. He explained to Rahman why Delhi opposed elections and that it could not be party to efforts 'by some Western countries in the name of Hungary to push aside Egypt's case and to condone Anglo-French aggression on Egypt'. ${ }^{122}$ Privately, however, Dutt complained that Rahman's reports confirmed 'every word of the Western version of recent events', bringing out 'Russian barbarity in a worse manner', whereas Nehru kept silent in his correspondence with Bulganin. Krishna Menon had 'never been objective, intensely anti-American and anti-West'. Dutt did not want to be 'a silent spectator of what I think to be unfair assessment of facts' and, once again, he considered to resign. ${ }^{123}$ When he confided in Pillai, he found him 'passing through similar agony'. ${ }^{124}$ 
Nevertheless, on 17 November 1956, they made up their minds to stay on to prevent worse. ${ }^{125}$

The very same day, the tides seemed to turn. Dutt permitted forwarding one of Rahman's unsparing telegrams to all missions abroad, while he urged Rahman to

bear in mind that whether we like it or not, and for understandable reasons, the Soviet Government will not permit any anti-Soviet regime in Hungary. It would therefore be in the interest of Hungarians themselves to let the process of democratisation take the same course as in neighbouring Poland. ${ }^{126}$

Poland had witnessed demonstrations as well, but its leadership, while permitting certain reforms, had kept it in the Warsaw Pact and thus prevented a Soviet intervention. ${ }^{127}$ Three days later, Nehru in parliament described the situation in Hungary in proper perspective. Shortly thereafter, he urged János Kádár, general secretary of the Hungarian Communist Party, to receive UN Secretary-General Dag Hammarskjöld and admit UN observers. Furthermore, India's ambassador in Prague, J. N. Khosla, in the capacity of a personal representative, would visit Budapest together with K.P.S. Menon. ${ }^{128}$ Nehru's meandering, however, was not over yet: In parliament, once again, he defended Menon's vote, with Dutt wondering how the judgement of a country and its leadership could change from day to day. ${ }^{129}$

The foreign secretary remained extremely tense also because he was aware of the influence of friends of the USSR in the IFS. When T.N. Kaul, for example, justified the Soviet intervention 'by implication', Dutt retorted, saying how he would react if the US sent forces to India claiming they had been called by some Indian politician. ${ }^{130}$ When it was rumoured that the Soviets deported Hungarians, Nehru believed that merely students had been sent to the borders for vigilance. ${ }^{131}$ Nevertheless, he wanted K.P.S. Menon to clarify the matter, with Dutt steaming about one 'whitewashing telegram' from Moscow after the other. ${ }^{132}$ When Bulganin assured Menon that if deportations had occurred at all, nobody had been brought into the USSR, ${ }^{133}$ Dutt commented with sarcasm 'not to the USSR but to Romania. . . Pandit Nehru must know with what kinds of people he is dealing'. ${ }^{134}$

At this juncture, K.P.S. Menon must have understood that he had been too trusting and, therefore, misled; he starting portraying matters in a way reducing his responsibility for the mess to a minimum. In his account of the conversation, he claimed that Bulganin had turned down suggestions to admit UN observers, openly warning India: 'I do not wish to draw an analogy between Hungary and Kashmir, but it comes in one's mind'. ${ }^{135}$ This would have been a convincing reason to drop the matter. In the more creditworthy Soviet account, however, Bulganin had not commented on Menon's hint at the usefulness of UN observers monitoring the ceasefire line in 
Kashmir. The ambassador, usually most understanding, had been somewhat more persistent but did not press this particular point. ${ }^{136}$ The attempt of a cover-up did not end here. When Rahman in late December confirmed that large numbers of Hungarians had been deported to camps in the USSR, ${ }^{137}$ Menon meekly commented that 'Bulganin's assurance on this subject to me was too fervent to be doubted'. ${ }^{138}$

The prime minister was wise enough to send Khosla along with Menon. They immediately confirmed Rahman's reports as accurate. ${ }^{139}$ Dutt, most unusual, in a letter to the CDA expressed his personal esteem for Rahman's performance. ${ }^{140}$ After his return to Moscow, Menon met with Foreign Minister Dmitri Trofimovich Shepilov and for the very first time expressed deep embarrassment both about having been misled and the massive use of force in Hungary: Counterrevolutionary forces had hardly played any role. Nehru had trusted the USSR only to face unknown worldwide criticism. Personally, Menon advised to reinstall Nagy, ${ }^{141}$ indicating that he still lacked understanding for the situation after the bloodbath. The ambassador, of course, could not pursue a confrontational course for long, given India's need of Soviet support in other issues. By mid-January 1957, again with Shepilov, Menon - unasked - expressed sympathy for the view that the Hungarian question was but part of a greater conflict, which probably could be solved only by a system of collective security as promoted by the USSR and supported by India. Nevertheless, he hoped for a liberalisation in Hungary. Thereafter, Menon as usual abused US policy. ${ }^{142}$ This was both an expression of his views and meant to curry favour with his counterparts. There was no comprehensible reason, however, why Menon in May not only emphasised with the MID that he refused to take part in any joint account on the events in late 1956 but even apologised for inaccuracies in his reports on them, notwithstanding the best intentions. ${ }^{143}$ As late as 1959, Menon insisted that the USSR had had no intention to intervene in Hungary, but had seen no alternative for 'unfortunate events, internal and external, of which the most decisive one was the Anglo-French attack on Suez'. ${ }^{144}$

Nehru was impressed by Khosla's and K.P.S. Menon's reports from Budapest, but not so Krishna Menon. When a new resolution demanding Soviet withdrawal and Hungarian independence was put to a vote, Nehru agreed with Pillai and Dutt to support it. 'Then came a long telegram from KM to PM why we should not participate in voting', Dutt noted. 'It is obvious that KM does not take the Soviet action in Hungary seriously. Late in the evening PM sent another telegram asking him to participate in voting but to abstain'. ${ }^{145}$ Instead, India introduced a resolution itself, still critical of the USSR and demanding a withdrawal of the Red Army, though less condemnatory. ${ }^{146}$

At first sight, the Hungarian episode had not led to major changes in Indian foreign policy. Krishna Menon had spoilt India's reputation and, not aware of having done anything wrong, went on poisoning Delhi's relations 
with the West. K.P.S. Menon quickly returned to the old pattern, in his reports and in nearly every conversation in Moscow portraying Soviet policy in the brightest colours. While Krishna Menon's attitude was consistent, K.P.S. Menon's needs an explanation. Occasionally allowing his initial judgement to be coloured by emotions was a feature known since his first posting in Ceylon. Nevertheless, he had never taken long to arrive at realist assessments. Many shared his assumption that closer relations with the USSR would benefit India, and there were enough pragmatic arguments not to react too harshly to the Soviet intervention. What K.P.S. Menon displayed, however, was not pragmatism but blindness. Disbelieving the reports of his immediate subordinate as the only Indian representative with first-hand information threw a bad light on both his judgement and his performance as superior.

Among the reasons for such fundamental errors by India's by then most experienced diplomat certainly was his overlong term in Moscow. For good reasons, most governments transfer their representatives after no more than three years - with time, the influence of the host country inevitably grows stronger than that of the home country. When the Hungarian crisis started, Menon had already completed four years. A second factor was the ambassador's fascination for the USSR. For the rest of his life, he spent all summer vacations at the Black Sea. ${ }^{147}$ Third, notwithstanding all the restrictions of life in the Soviet Union, Menon enjoyed a comparatively great amount of freedom while travelling around. Reporting on a largely isolated country gave him a sort of monopoly. As he always preferred, he also enjoyed jester's licence: Nobody in the MEA dared to ruffle the former foreign secretary, and Nehru approved of his work.

Fourth, Menon had won much reputation with earlier postings abroad but had never been in the very focus of attention. Moscow was the posting of his life. His work and his reports were appreciated by both Nehru and his hosts, who were aware of his love for their country. Menon had arrived at a perfect moment, witnessing the last months of Stalin's rule and transformation processes thereafter, intriguing the whole world. India, always after reducing international tensions, pinned its hopes on liberalisation in both domestic and international affairs, and its ambassador often was the bearer of good news. During Menon's term, Moscow became one of India's most important missions abroad. Relations with Karachi and Washington were strained; those with Beijing were first uncertain and then increasingly hostile; France and the UK were great powers in decline. From early on, Menon portrayed the post-Stalin USSR as the country of a never-ending thaw and of Indian opportunities, and he was proved correct, at least in part.

This is not the place to discuss the pros and cons of India's ever-closer friendship with the USSR in later years. Beyond doubt, however, Moscow's friendly overtures provided Delhi with more options, and Menon did not belong to those who considered differences of political systems an insuperable 
obstacle. Bajpai and Dutt never overcame their disgust for communism and its representatives. On the contrary, Menon was the only influential Indian diplomat shaped by the colonial Political Service, where 'character' had had more relevance than anything else. Translated into Indo-Soviet relations, Menon cared more for the bearer of the message than the message itself. While he never showed any leanings towards communism, he was intrigued by the Soviet leadership. Even Dutt had acknowledged Khrushchev as a 'forceful speaker' and 'witty'. ${ }^{148}$ Menon, initially more impressed by the less rustic Bulganin, soon acknowledged that Khrushchev - who he admired for his intellect - called the shots. ${ }^{149}$

Moscow's policy in the Hungarian crisis made the trust Menon had believed to have built with the Kremlin appear an illusion. The Soviets neither felt committed to Nehru's moral standards nor did they hesitate to dupe his representative. By November 1956, Menon appeared the self-deceived naked ruler in Hans Christian Andersen's The Emperor's New Clothes, and Nehru indicated distrust by insisting on a joint mission with Khosla. In one of the key tasks for any diplomat, giving a realistic picture of the policy of the host country, Menon had failed dramatically. Nevertheless, the ambassador stayed on for another five years and did not fall from grace with Nehru.

It would be interesting to know about the Soviet assessment of Menon's work. Unfortunately, the MID's notes on conversations typically gave Menon's statements in detail but only summarised those of his counterparts and avoided any evaluation of the talks. One of two exceptions was an exchange in July 1959, when the ambassador tried to dismiss India's responsibility for granting asylum to the Dalai Lama. When he fabulated about the possibility of Japan inviting the latter, Deputy Foreign Minister Georgii Maksimovich Pushkin expressed utter disbelief, indicating he did not take Menon seriously. ${ }^{150}$ The second exception occurred at the time of the ambassador's final departure, when an assessment of the ministry praised him for his loyalty - to the USSR. ${ }^{151}$ For the Kremlin, the ambassador probably was both an appreciated understanding friend and easily manipulated if need be.

For Dutt, and to no small extent for Nehru, the Hungarian crisis was a turning point. That far, the former had been happy to be a relevant but near invisible $\operatorname{cog}$ in the wheel, doing preliminary work for his superiors. The exception had been Dutt's few months in Malaya, ending as an unhappy experience. His term in Bonn, on the one hand, had been uneventful for a lull in Indo-German relations. On the other hand, Dutt had finally emancipated himself from his mentor Bajpai. While the former secretary-general still held a disarmed and neutralised united Germany possible, pursuing a third way independent from the two Cold War blocs, the ambassador had understood that all political forecasts had to be based on the assumption that the global and the German divisions would last. ${ }^{152}$ Returning to Delhi 
in the summer of 1954, Dutt as designated foreign secretary had undergone a sort of apprenticeship, bringing him in touch with all major issues of Indian foreign affairs. ${ }^{153}$ After his promotion, for a full year he had rather remained in the background, as usual. His misgivings about the new course vis-à-vis the USSR he had kept to himself, typically rather doubting his own judgement instead of the prime minister's.

The Hungarian crisis woke him to realities: Bajpai had passed away on 5 December 1954, and Pillai had neither standing nor backbone to counterbalance the two Menons. Nehru let himself be misled by biased advisors and, due to his prepossessions, lacked a political and moral compass. Indian policy in the UN had caused an enormous loss of prestige, the strongest trump card for an underdeveloped country in serious financial trouble and lacking hard power. The internal conflict in the GoI was not primarily about ideological questions. In Dutt's eyes, the two Menons, and in consequence Nehru, acted against national interest. The foreign secretary understood that if not him, there was no one else to put his foot on the ground. As had been seen around the evaluation of the London high commission in 1949, he disliked open conflicts with his superiors, above all the deeply admired Nehru, but stood his ground when convinced of the rightfulness of his views. In late 1956, Dutt had reached a parting of ways: Either he denied his deepest beliefs - first of all, fair and realist judgement - together with his duty to the nation, or he stood up against a course he considered fundamentally wrong. Resigning would have been a symbolic gesture to no lasting effect. Now that the damage was done, Dutt, assertive of late, managed to pull the influenceable prime minister along. Which role the principally like-minded Pillai played in the process cannot be said due to lack of documentation.

Dutt was wise enough to understand that the Kremlin would not care for Indian dissent. Given the military alliance between Pakistan and the US, India's growing tensions with China and the urgent want for aid, nevertheless, Delhi needed Moscow's goodwill. When in June 1957 Bulganin declared the USSR an eternal friend of India, Dutt commented with his typical pragmatism: 'There is no everlasting friendship in this world; all the same we must not make light of this offer'. ${ }^{154}$ The foreign secretary also was aware that he was in no position to reduce K.P.S. Menon's influence on Nehru. Nevertheless, he took care for a change of course in relations with Hungary. Behind closed doors, he and the prime minister urged the repressive Kádár government to release political prisoners and refused an upgrade of Hungary's mission in Delhi. ${ }^{155}$

\section{China}

Of much more importance was the turn in the China policy, which was initiated by Dutt. It was the outcome of realism, not anti-communism: The GoI considered Beijing pursuing a nationalist policy rather than following 
orders from Moscow. Its diplomacy had features known from the Soviets, but its territorial aims were in line with those of earlier Chinese governments. Immediately after the conclusion of the Tibet Agreement, a dispute developed around a grazing ground in the middle sector of the joint border, named Bara Hoti in India, Wu Je in China. ${ }^{156}$ In October 1954, Prime Minister Zhou Enlai apologised that his government had not yet had time to survey the border and, therefore, had republished Guomindang maps, claiming large parts of the southern slopes of the Himalayas. Nehru did not pursue the matter further. ${ }^{157}$ When more Chinese patrols turned up south of the Indian claim line, he believed them to be the outcome of misunderstandings by local commanders. ${ }^{158}$ With R.K. Nehru as foreign secretary, this was the attitude of the MEA too. ${ }^{159}$ In May 1956, the atmosphere began to change: Both the prime minister and Dutt now distrusted Chinese explanations regarding the maps, but they still disagreed about the repercussions. Nehru felt but somewhat disquieted about Chinese road-building in border areas together with 'petty raids and the maps', whereas the foreign secretary saw a larger scheme: He blamed Beijing for a 'truculent attitude', the patrols acting on instruction. Though he counselled Nehru against discussing the frontier as a whole, he urged him to settle local disputes. ${ }^{160}$

It took some time until Dutt's realism had its impact on the prime minister, but in September, when another Chinese patrol had crossed the Indian claim line, Nehru ordered to use force if necessary. ${ }^{161}$ The foreign secretary took up the issue of border administration ${ }^{162}$ and convinced the prime minister to raise the boundary issue with Zhou. The latter at the turn of 1956/1957 accepted the McMahon Line but kept a back door open, emphasising the supposed need to consult the Tibetan government. ${ }^{163}$ Unlike Nehru, who thought that the eastern part of the boundary had been settled, Dutt correctly took Zhou's statement as ambiguous and felt his apprehensions confirmed when China rejected the McMahon Line in talks with Burma. He feared that the border as defined by the GoI might be challenged as a whole, ${ }^{164}$ India being both unwilling to enter a confrontation on principle and totally unprepared if such eventuality arose. Delhi also lacked financial resources for a belated military build-up, wherefore coexistence was the only feasible course. ${ }^{165}$ After all, the GoI declared that Bhutan and Sikkim enjoyed its special protection. ${ }^{166}$

The Chinese did not care for Indian sensibilities and constructed a road through Aksai Chin without informing Delhi. As India's claim to this barren and uninhabited high plateau was well known, the GoI considered it as an open provocation that it learned about the completion of the road from the Chinese press in September 1957. As neither the military nor the Intelligence Bureau had had any clue about the construction of the road, ${ }^{167}$ Dutt saw Delhi in a near impossible situation: Soviet and Chinese maps showed Aksai Chin as part of China, and India could hardly protest without knowing the exact location of the road. Its claim to a territory where no Indian had set 
his foot since independence did 'not seem to be based on very sure grounds' and might be given up. If Delhi, nevertheless, did 'not do anything at all at this stage we shall never again be able to assert our claim to this area'. ${ }^{168}$ It took nearly a year to confirm that the road indeed ran through territory claimed by India. 169

Already, Dutt had pushed for a general change of course. The Gol's previous non-policy, hoping for the issue of the boundary to settle by itself or Chinese goodwill, had failed glaringly. Instead, it was high time to find out whether Beijing was willing to negotiate at all. Finally introducing a realist approach, the GoI let China know of its position that the watershed principle determined the Indo-Tibetan border 'practically all along its length'. ${ }^{170}$ Dutt found it too risky to offer talks on the border as a whole but chose Bara Hoti as the litmus test, consciously risking defeat in a minor case. ${ }^{171} \mathrm{He}$ suggested to drop all preconditions to get 'an inkling into the Chinese mind in regard to frontier questions in general'. ${ }^{172}$

When talks started on 19 April 1958, India provided precise data while China remained vague and suggested an enquiry of locals. Dutt turned this down, as both sides could produce any number of supporters. He saw a much larger problem looming behind the local dispute: Beijing not only rejected any British map as colonialist but also refused to acknowledge the passes for pilgrims and traders as mentioned in the Tibet Agreement as border passes. Thereby, implicitly, it repudiated the watershed principle. The Chinese even turned down a standstill agreement. ${ }^{173}$

Nehru also had become suspicious of Chinese intentions; the experiences around the Hungarian crisis seemed to have brought a lesson home as well. When briefing the ambassador designate to Beijing, G. Parthasarathy, that China was 'arrogant, devious, hypocritical and thoroughly unreliable', the prime minister also ordered to bypass Krishna Menon, 'clouded on the matter of our relations with China merely because China is a communist country'. ${ }^{174}$ In 1959, Nehru, appreciating unbiased realism, asked Dutt to let his other tasks rest and concentrate on the border issue. ${ }^{175}$ Consequentially, the foreign secretary kept Krishna Menon's favourite M.J. Desai out of India-China relations and formed a team of experts, among whom were the director of the Historical Division, Sarvepalli Gopal, and the director of the newly created Northern Division, Jagat S. Mehta, ICS. The foreign secretary had limited Ambassador R. K. Nehru's influence as early as 1956, among others refusing a broader distribution of his reports for not being comprehensive enough. ${ }^{176}$

Dutt's team focused on the bone of contention, Aksai Chin. The foreign secretary doubted the validity of India's claims ${ }^{177}$ and was aware of its helplessness: 'The Chinese will continue to use the road and we shall merely be going on record as having asserted our claim to this area without being able to enforce our right or obstruct the use of the road by the Chinese'. If Delhi kept quiet, however, it would encourage intrusions into other areas. ${ }^{178}$ Dutt 
also urged Nehru to remind Zhou of his statement regarding the McMahon Line and to suggest talks on Aksai Chin. ${ }^{179}$ The prime minister's letter of 14 December 1958 closely followed the foreign secretary's counsel, but the response was most disappointing: Zhou held that Aksai Chin was a part of China; otherwise, the whole border was open to dispute. ${ }^{180}$

The Tibetan uprising from spring 1959 led to an escalation of tensions between Beijing and Delhi. China wrongly accused the GoI of supporting Tibetan resistance, and allegations sharpened after India granted asylum to the Dalai Lama. Ambassador Pan Zili openly threatened India with a second front, apart from the one with Pakistan. ${ }^{181}$ While Chinese officials harassed Indian trade missions and nationals in Tibet, Dutt prepared countermeasures against people of Chinese origin in India. ${ }^{182}$ The first military clash took place on 25 August 1959 at Longju, north of the McMahon Line, in which an Indian border guard died. On 25 October at the Kongka Pass in Ladakh, a number of Indian police officers were shot dead. India went public as a response. Had the exchanges and intrusions so far been kept secret, the GoI published the first in a series of white papers, hoping, in vain, to calm domestic criticism caused by press reports about the clashes. ${ }^{183}$ The move backfired: Emotions in parliament and public went high and severely reduced the government's room to manoeuvre.

The prime ministers continued their correspondence to no avail, apart from buying time for Dutt and his team. The foreign secretary earlier had criticised the lack of archival evidence for India's territorial claims, particularly papers of the Simla Conference from 1914. He now ordered Gopal to investigate British archives. ${ }^{184}$ Gopal's findings, internally presented in February 1960, made Nehru and Dutt consider the claim for Aksai Chin nearly foolproof. 185

Now that India's legal position seemed to be strong, Dutt counselled Nehru to accept Zhou's earlier offer for a summit. ${ }^{186}$ In border negotiations with Burma, China finally had accepted the McMahon Line as the customary boundary, but Dutt was uncertain if Beijing would choose the same attitude with India. ${ }^{187} \mathrm{He}$ also feared that 'our whole system is such that in a struggle with' the much more determined Chinese, 'we are doomed to lose'. ${ }^{188}$ Efforts to develop some infrastructure in the border areas had been rather ineffective, and the Indian Army was in no position to seal the border, let alone put up a fight against the PLA. The superpowers showed no inclination to get involved. Eisenhower merely expressed hopes for a peaceful solution, ${ }^{189}$ seeing India in no shape to form a counterweight to China. Washington feared that the need for economic support alone 'would be so great that America would probably bankrupt itself in the process' ${ }^{190}$ Delhi had taken it with relief when Moscow declared itself neutral in the conflict in September 1959. In February 1960, Khrushchev confirmed that the Kremlin would not take any stand between two friends. ${ }^{191}$ Whereas the prime minister gave another example of wishful thinking regarding the 
USSR, inexplicably reading the remark as Soviet support for India, ${ }^{192}$ Dutt soberly commented that nothing of relevance had been discussed. ${ }^{193}$ Indeed India, in a much weaker military position than China, would have needed active support, not merely neutrality.

Zhou correctly was expected to propose a deal, both sides keeping those areas they considered essential and where they exercised actual control: Aksai Chin in the west was to remain with China, Assam in the east with India. Delhi, however, did not accept. Pragmatism might have suggested otherwise, but especially Nehru would, first, not barter away a position which he considered rightful. The Indian Supreme Court, second, had ruled that territory could be ceded or accepted only with an amendment to the constitution. Chinese tactics in the years before the summit, third, had made Beijing untrustworthy in Indian eyes. And for all those reasons, finally, the public would never have accepted the ceding of large areas which were considered Indian territory. ${ }^{194}$ Accordingly, the summit failed.

Nearly as bad for India was the lack of unity displayed at the summit. For a long while Dutt had played a key role in devising Delhi's strategy. He had been the one who had managed to alert Nehru and to formulate and implement a strategy for the boundary conflict. At the summit itself, however, matters were taken out of Dutt's hands. Negotiations took place at four levels - another glaring example of Nehru's chronic inability to concentrate foreign policy in one hand. Had he excluded Krishna Menon, he now brought in Railway Minister Swaran Singh and Home Minister G. B. Pant, pursuing individual strategies while the Chinese at all four levels argued precisely along the same lines. Furthermore, once Zhou had understood that Nehru would discuss but minor modifications, he urged to see Krishna Menon, highlighting the impression of the GoI being deeply divided. Dutt was upset that he, as the mastermind, was given but a subordinate role. ${ }^{195}$ His strategy had not paid off anyway, however, as the Chinese did not care for documentary evidence but were after a 'political solution', ensuring Aksai Chin as part of China. ${ }^{196}$

The summit ended nowhere apart from the face-saving decision to conduct discussions between experts. The outcome by December 1960 was but a lengthy report including documentary on the boundary issue. ${ }^{197}$ Now that a bilateral peaceful solution had become impossible, Dutt's last contribution to the dispute was an effort to win world opinion by publishing the joint report together with a separate Indian one. ${ }^{198}$ In the spring of 1961, he left Delhi for Moscow, his successor as foreign secretary M. J. Desai, a favourite of Krishna Menon. The latter gleefully welcomed the departure of his staunchest opponent, who was transferred to the USSR of all countries. ${ }^{199}$

Though Desai and R.K. Nehru, having returned to Delhi as secretarygeneral in late 1960, were both ICS officers, an era characterised by Bajpai's realism and western leanings came to an end. Dutt in many ways was Bajpai's true heir. Admittedly, he lacked his mentor's power of persuasion 
with representatives of foreign countries and, therefore, apart from his final term in Bangladesh between 1972 and 1974, ${ }^{200}$ he never engaged in personal diplomacy. Furthermore, he had nothing of Bajpai's grandeur. Much more the inexhaustible desk worker, the foreign secretary, nevertheless, shared other qualities and values: Assessing cases on their merits and understanding politics as the art of the possible were among them. Like anyone else, Dutt was predisposed by his upbringing. Whereas Nehru or Krishna Menon, however, at more than one occasion let their judgement be blurred by their predispositions, Dutt (not only for his chronic self-doubt) always scrutinised whether his assessments and decisions were beneficial for India. Therefore, though staunchly anti-communist, he understood the relevance of good relations with the USSR and, though exercising caution, did his best to play his part both as foreign secretary and as ambassador in Moscow. ${ }^{201}$ Another feature Dutt shared with Bajpai was total loyalty to the prime minister combined with readiness to gainsay in internal discussions. Finally, both did not find much in visionary politics, even more if those visions were not based on much substance. None ever indicated to be guided by Nehru's dreams to reshape international affairs.

When Dutt left, Indian foreign policy underwent a tangible change. Until then, it had never been adventurous, let alone aggressive - if one shares the point of view that it had been Pakistan dragging India into a war in Kashmir in 1947. In December 1961, however, Indian forces invaded Goa, Portugal not willing to give up its colonial possessions. Militarily, this was a very minor affair; politically, it turned out to be a major blow for India's reputation: Gandhi's disciple, preaching non-violence, had resorted to force. In the Himalayas, Delhi, led by Krishna Menon, pursued a more adventurous course as well, termed 'forward policy': Though standing no chance against the PLA, Indian forces attempted to establish bases behind Chinese lines. Indian provocations were no major factor for Beijing's decision to go to war in autumn $1962,{ }^{202}$ but they were unwise nevertheless. The humiliating defeat resulted in the dismissal of Krishna Menon and a period of agony under an ailing prime minister. Caution and realism once again shaped Indian foreign policy after the war, but it would be Nehru's daughter Indira Gandhi profiling herself as a most pragmatic prime minister on the international floor. Key advisors and foreign secretaries (the post of secretarygeneral was abolished in 1964) continued to be ICS officers, the most influential being probably P. N. Haksar as Mrs Gandhi's chief advisor. ${ }^{203}$ Jagat S. Mehta, who retired in 1979, was the last foreign secretary with an ICS background, though he had been recruited but around the transfer of power. As they belonged to another generation, they had learned foreign policy in the Nehruvian era, not under the British.

In 1961, another era came to an end as well: K.P.S. Menon left Moscow after nearly nine years. His enthusiasm for his host country had much helped Indo-Soviet rapprochement, though it would take another decade 
until the USSR finally sided with India in the context of the Bangladesh crisis. More than any other individual Indian diplomat, he helped modify India's stand in world affairs: In many ways, the country had willy-nilly stood much closer to the West when he arrived in Moscow. By 1961, relations with the USSR and its satellites were at least as good as those with the West. That Menon enjoyed Nehru's full-hearted support and that the precondition for his success had been a fundamental turn of Soviet foreign policy, does not impair his importance. He functioned as a sort of interpreter, making Soviet policy and motives more comprehensible. Vice versa, he certainly contributed to a better understanding of Indian policy in Moscow. Though his tendency to paint the USSR in the brightest colours had contributed to the disastrous Indian performance around the crisis in Hungary, altogether he had helped closer relations, beneficial for India if only for the West feeling the need to counter them by intensifying its own efforts.

\section{Notes}

1 Foreign Relations of the United States, Washington, DC: Government Printing Office, 1952-1954, vol. XI/2, doc. 1007. Telegram, Bowles to DoS, 15 May 1952.

2 NMML, KPSMP, Diary 1947, 12 February.

3 NAI, MEA, 8(8)-47. Press Communiqué, 24 December 1947.

4 NAI, MEA, 11(11)-PT/48. Note, K.P.S. Menon, 25 August 1948.

5 NAI, MEA, 14(7)-EA/49. Telegram, Pillai to Commerce Secretary Desai, 8 June 1949.

6 Dutt Diary 8, 9 April 1954.

7 Harish Kapur, Foreign Policies of India's Prime Ministers, New Delhi: Lancer, 2009, p. 34.

8 Paul McGarr, The Cold War in South Asia. Britain, the United States and the Indian Subcontinent, 1945-1965, Cambridge: Cambridge University Press, 2013, p. 29.

9 NAI, MEA, 5(17)-FSP/49. Letter, R. K. Nehru to K.P.S. Menon, 31 May 1949.

10 Amit Das Gupta, Serving India. A Political Biography of Subimal Dutt (19031992), India's Longest Serving Foreign Secretary, New Delhi: Manohar, 2017, pp. 203-204.

11 Dutt Diary 8, 20 August 1955. See also Mohammad Yunus, Persons, Passions and Politics, Sahibabad: Vikas, 1980, p. 91.

12 NMML, SDP, SF 84. Note, J. Nehru, 8 September 1955.

13 NMML, SDP, SF 84. Note, R. K. Nehru, undated.

14 NMML, SDP, SF 84. Letter, R.K. Nehru to J. Nehru, 4 September 1955.

15 Dutt Diary 9, 9 September 1955.

16 For the following see Das Gupta, Serving India, pp. 171-173; Das Gupta, Handel, Hilfe, Hallstein-Doktrin. Die bundesdeutsche Südasienpolitik unter Adenauer und Erhard 1949-1966, Husum: Matthiesen, 2004, pp. 71-72.

17 AIEB, SEC-4/B. Letter, Dutt to R.K. Nehru, 14 November 1952.

18 BAK, B 102, 58102. Note, Sachs, 11 September 1952. Original in German.

19 AIEB, SEC-4/B. Letter, R. K. Nehru to Dutt, 28 October 1952.

20 MEAA, EII/52/1871/63. Note, J. Nehru, 3 September 1952. 
21 AIEB, SEC-4/B. Letter, Dutt to R. K. Nehru, 14 November 1952.

22 AIEB, SEC-4/B. Note, B. P. Adarkar, 20 January 1953.

23 NAUK, DO, 35/6709. Letter, A. A. Gold to F. Wilkinson, Eastern Dept. Foreign Office, 28 May 1954.

24 NAUK, DO, 35/6709. Letter, Clutterbuck to Swinton, 16 May 1954.

25 Srinath Raghavan, War and Peace in Modern India. A Strategic History of the Nehru Years, Ranikhet: Permanent Black, 2010, p. 241.

26 NAUK, DO, 35/6709. Telegram 304, High Commission to CRO, 27 March 1954.

27 NAUK, DO, 35/6709. Letter, Clutterbuck to Swinton, 16 May 1954.

28 MEAA, 7(3)NGO/56. Note, R.K. Nehru, 24 April 1956.

29 Dutt Diary 10, 29 March 1956.

30 Das Gupta, Serving India, pp. 137-138.

31 Dutt Diary 8, 29 July 1955.

32 Dutt Diary 9, 31 October 1955.

33 Dutt Diary 9, 20 February 1956.

34 Das Gupta, Serving India, pp. 173-174.

35 Dutt Diary 6, 3 January 1953.

36 Dutt Diary 8, 5 November 1954.

37 Das Gupta, Serving India, p. 202.

38 Ibid., p. 204.

39 Subimal Dutt, With Nehru in the Foreign Office, Calcutta: Minerva Associates, 1977, p. 281.

40 Andreas Hilger, Sowjetisch-indische Beziehungen 1941-1966. Imperiale Agenda und nationale Identität in der Ära von Dekolonisierung und Kaltem Krieg, Vienna: Böhlau, 2018, p. 343.

41 NMML, KPSMP, Diary 1947, 14 May.

42 NAI, MEA, EII/53/1321/67. Annual Report USSR for 1952, Gundevia, undated.

43 SWJN2, vol. 17, p. 647. Letter, Nehru to Krishna Menon, 25 March 1952, fn. 5.

44 AVP RF, fond 90, opis 14a, delo 5. Memorandum, Malik, 23 December 1952.

45 NAI, MEA, EII/53/1321/67. Monthly January, Menon, 4 February 1953.

46 FRUS, 1952-1954, vol. VIII, doc. 543. Telegram, Beam to DoS, 19 February 1953.

47 NAI, MEA, EII/53/1321/67. Monthly February, Menon, undated.

48 NAI, MEA, EII/53/1321/67. Monthly March, Menon, 9 April 1953.

49 NAI, MEA, EII/54/1311/67. Annual Report USSR 1953, Menon, 11 February 1954.

50 NAI, MEA, EII/54/1311/67. Note, J. Nehru, 13 March 1954.

51 PA AA, Files Embassy New Delhi, 17. Report, Pawelke, 30 June 1953.

52 Dutt Diary 6, 27 April 1953.

53 NAI, MEA, 29-R\&I/53. Monthly Report June, Dutt, 9 July 1953.

54 For the debate, see Christian Osterman (ed.), Uprising in East Germany. The Cold War, the German Question and the First Major Upheaval behind the Iron Curtain, Budapest: Central European University Press, 2001, pp. 13-15.

55 AIEB, Sec-48/53. Telegram 40, Menon to R. K. Nehru and Dutt, 22 July 1953.

56 AIEB, Sec-48/53. Telegram 117, Menon to Dutt, 21 July 1953.

57 NAI, MEA, 29-R\&I/53. Fortnightly Report, 1 to 15 July 1953, Dutt, undated.

58 Dutt Diary 8, 8 February 1955.

59 Das Gupta, Serving India, p. 244.

60 NAI, MEA, 3(60)-R\&I/50. Annual Report ČSSR 1949, Raghavan, 28 January 1950.

61 NMML, KPSMP, Diary 1951, 11 January.

62 NAI, MEA, EII/53/6411/65. Report, Dalal, 18 August 1953.

63 NAI, MEA, 21-R\&I/55. Note, Dharma Vira, 14 September 1955. 
64 NAI, MEA, EII/53/1321/62. The New Deal in Hungary, Menon, 11 September 1953.

65 NAI, MEA, EII/53/1321/62. Letter, Menon to R. K. Nehru, 27 July 1953.

66 NAI, MEA, EII/53/1321/62. Quarterly Report April to June 1953, Menon, undated.

67 NAI, MEA, EII/53/1321/62. Note, J. Nehru, 4 October 1953.

68 NMML, SDP, SF 16. Note, Nehru, 1 August 1955.

69 NMML, SDP, SF 16. Note, Nehru, 19 July 1955.

70 NMML, SDP, SF 16. Note, Menon, 6 July 1955.

71 NMML, SDP, SF 16. Note, Pillai, 29 July 1953.

72 NMML, SDP, SF 16. Note, Menon, 12 July 1955.

73 Amit Das Gupta, 'Indiens sicherheitspolitische Wende zwischen 1962 und 1974', in Sebastian Buciak and Rüdiger Dehn (eds.), Indien und Pakistan Atommächte im Spannungsfeld regionaler und globaler Veränderungen. Beiträge zur Außen- und Sicherheitspolitik Südasiens, Berlin: Kösters, 2010, pp. 99-102.

74 Dutt Diary 9, 15 October 1955.

75 Dutt Diary 9, 1 October 1955.

76 Dutt Diary 9, 16 November 1955.

77 Dutt Diary 9, 1 October 1955.

78 SWJN2, vol. 31, pp. 334-335. Records of Talks with N.A. Bulganin and N.S. Khrushchev, 12 December 1955.

79 Das Gupta, Serving India, pp. 234-240.

80 Dutt Diary 9, 18 November 1955.

81 Dutt Diary 9, 16 and 19 November 1955.

82 PA AA, Büro Staatssekretär, 338. Circular to all Missions, Foreign Secretary, 16 January 1956.

83 Dutt Diary 9, 20 November 1955.

84 Dutt Diary 9, 12 November 1955.

85 Ibid.

86 Dutt Diary 9, 25 November 1955.

87 AVP RF, fond 90, opis 17, delo 3. Memoranda, Gromyko, 26 November and 10 December 1955.

88 Dutt Diary 9, 28 November 1955.

89 Dutt Diary 9, 13 December 1955.

90 Dutt Diary 9, 11 December 1955.

91 Dutt Diary 9, 18 November 1955.

92 Dutt Diary 9, 15 December 1955.

93 Ryan Touhey, Conflicting Visions. Canada and India in the Cold War World, 1946-76, Vancouver: University of British Columbia Press, 2015, p. 105.

94 Dutt Diary 9, 5 December 1955.

95 NAI, MEA, 1(98)-EUR/55. Letter, Ratnam to Dutt, 22 December 1955. Handwritten comment, Dutt, 6 January 1956.

96 Das Gupta, Serving India, p. 240.

97 The Hungarian Revolution 1956. Documents, New Delhi: GoI, MEA.

98 The Hungarian Revolution, vol. I, Telegram, Rahman, 28 October 1956.

99 MEAA, 9/13/56. Telegram 13/56, Rahman to MEA, 2 November 1956.

100 Christian Morgenstern, Die unmögliche Tatsache, Max Knight (trans.), www. alb-neckar-schwarzwald.de/morgenstern/morgenstern_poems.html [accessed 28 November 2018].

101 Dutt Diary 10, 2 November 1956. 
102 SWJN2, vol. 35, pp. 452-453. Telegram, Nehru to K.P.S. Menon, 2 November 1956.

103 Ibid., p. 454. Telegram, Nehru to K.P.S. Menon, 3 November 1956.

104 MEAA, 9/13/56. Telegram 113/34, Dutt to Legation Vienna, 3 November 1956.

105 SWJN2, vol. 35, p. 455. Telegram, Nehru to K.P.S. Menon, 4 November 1956.

106 MEAA, 9/13/56. Circular 113/33, 5 November 1956.

107 SWJN2, vol. 35, pp. 430-431. Letter, Nehru to Bulganin, 2 November 1956.

108 Ibid., p. 437. Letter, Nehru to Bulganin, 6 November 1956.

109 UNGA, Resolution 1004 (ES-II), 4 November 1956.

110 MEAA, 9/13/56. Telegram 113/42, Dutt to Vijaya Raghavan, 16 November 1956.

111 SWJN2, vol. 35, p. 459-460. Telegram, Nehru to Krishna Menon, 11 November 1956.

112 Note, Pillai, 2 November 1956, quoted after Sarvepalli Gopal, Nehru: A Biography, vol. 2, New Delhi: Oxford University Press, 1980, p. 291.

113 Dutt Diary 10, 2 November 1956.

114 Dutt Diary 10, 4 November 1956.

115 Dutt Diary 10, 5 November 1956.

116 Dutt Diary 10, 9 November 1956.

117 Dutt Diary 10, 10 November 1956.

118 Dutt Diary 10, 11 November 1956

119 MEAA, 5(5)-EURE/56, II. Note, Nehru, 17 November 1956.

120 MEAA, 5(5)-EURE/56, II. Letter, Mehta to Nehru, 9 November 1956.

121 Dutt Diary 10, 13 November 1956.

122 MEAA, 9/13/56. Telegram 113/42, Dutt to Raghavan, 16 November 1956.

123 Dutt Diary 10, 16 November 1956.

124 Dutt Diary 10, 17 November 1956.

125 Ibid.

126 MEAA, 9/13/56. Telegram 113/47, Dutt to Rahman, 19 November 1956.

127 Mark Kramer, 'The Soviet Union and the 1956 Crises in Hungary and Poland: Reassessments and New Findings', Journal of Contemporary History, 1998, 33(2): 163-214.

128 SWJN2, vol. 35, pp. 476-477. Letter, Nehru to Kádár, 22 November 1956.

129 Dutt Diary 10, 21 November 1956.

130 Dutt Diary 10, 28 November 1956.

131 MEAA, 5(5)-EURE/56, II. Note, Nehru, 18 November 1956.

132 Dutt Diary 10, 22 November 1956.

133 AVP RF, fond 90, opis 18, delo 2. Memorandum, Bulganin, 29 November 1956.

134 Dutt Diary 10, 1 December 1956.

135 MEAA, 5(5)-EURE/56, II. Note, Menon, 29 November 1956.

136 AVP RF, fond 90, opis 18, delo 2. Memorandum, Bulganin, 29 November 1956.

137 MEAA, 9/13/56. Report, Rahman, 29 December 1956.

138 MEAA, 9/13/56. Telegram 21, Menon to Dutt, 3 January 1957.

139 MEAA, 9/13/56. Telegram, Rahman to M.A. Husain, 5 December 1956, and Telegram 20, Menon to Dutt, 1 January 1957.

140 MEAA, 9/13/56. Letter, Husain to Rahman, 24 December 1956.

141 AVP RF, fond 90, opis 18, delo 2. Memorandum, Shepilov, 12 December 1956.

142 AFP RF, fond 90, opis 19, delo 2. Memorandum, Shepilov, 14 January 1957.

143 AFP RF, fond 90, opis 19, delo 2. Memorandum, Kuznetsov, 9 May 1957.

144 MEAA, 5(55)-EUR(E)/59. Monthly for October 1959, Menon, 4 November 1959. 
145 Dutt Diary 10, 10 December 1956.

146 Dutt Diary 10, 11 December 1956.

147 Subimal Dutt, Autobiography, unpublished, 1984, p. 185.

148 Dutt Diary 9, 21 November 1955.

149 Dutt Diary 9, 19 November 1955.

150 AVP RF, fond 90, opis 21, delo 3. Memorandum, Pushkin, 16 July 1959.

151 Hilger, Sowjetisch-indische Beziehungen 1941-1966, p. 343.

152 Das Gupta, Serving India, p. 176.

153 Ibid., pp. 195-228.

154 Dutt Diary 11, 3 June 1957.

155 Das Gupta, Serving India, pp. 262-266.

156 Ibid., p. 274.

157 SWJN2, vol. 27, pp. 11-20. Minutes, 10 October 1954.

158 Dutt, With Nehru in the Foreign Office, p. 115.

159 Amit R. Das Gupta, 'Foreign Secretary Subimal Dutt and the Prehistory of the Sino-Indian Border War', in Amit R. Das Gupta and Lorenz M. Lüthi (eds.), The Sino-Indian War of 1962. New Perspectives, New Delhi: Routledge, 2017, p. 52.

160 Dutt Diary 10, 6 May 1956.

161 SWJN2, vol. 35, pp. 515-516. Note, Nehru, 21 September 1956.

162 Dutt Diary 10, 29 November 1956.

163 SWJN2, vol. 36, p. 614. Note, Nehru, 1 January 1957.

164 NMML, SDP, SF 27. Note, Dutt, 4 May 1957.

165 NMML, SDP, SF 27. Letter, Dutt to Vellodi, 4 June 1957.

166 NMML, SDP, SF 27, Telegram, Dutt to embassy Beijing, [late April 1957].

167 Das Gupta, Serving India, p. 323.

168 NMML, SDP, SF 31. Note, Dutt, 3 February 1958.

169 Das Gupta, Serving India, p. 328.

170 MEAA, 3/NGO/58. Letter, Acharya to Bahadur Singh, 26 November 1957.

171 NMML, SDP, SF 31. Note, Dutt, 24 February 1958, Dutt.

172 NMML, SDP, SF 31. Note, Dutt, 24 February 1958.

173 NMML, SDP, SF 32. Note, Dutt, 3 June 1958; see also Dutt, With Nehru in the Foreign Office, p. 117.

174 'Don't Believe in Hindi-Chini bhai-bhai Nehru told Envoy', Indian Express, 22 January 2010, http://archive.indianexpress.com/news/dont-believe-inhindichini-bhaibhai-nehru-told-envoy/570332 [accessed 26 January 2016].

175 NMML, SDP, SF 39. Note, Dutt, 29 December 1959.

176 MEAA, 1(13)-FEA/56. Note, Kaul, 6 March 1956. Handwritten comment, Dutt, 10 March 1956.

177 NMML, SDP, SF 33. Note, Dutt, 23 September 1958.

178 NMML, SDP, SF 33. Note, Dutt, 8 October 1958.

179 NMML, SDP, SF 34. Note, Dutt, 11 December 1958.

180 White Paper: Notes, Memoranda and Letters Exchanged between the Governments of India and China, 1954-1959, vol. I, New Delhi, 1959, pp. 52-55. Letter, Zhou to Nehru, 23 January 1959.

181 Ibid., pp. 73-77. Statement, Pan Tsu-li, 16 May 1959.

182 Das Gupta, Serving India, pp. 333-334.

183 Ministry of External Affairs, White Paper.

184 NMML, SDP, SF 39. Note, Dutt, 5 October 1959.

185 Steven A. Hoffmann, India and the China Crisis, Berkeley: University of California Press, 1990, pp. 82-83.

186 NMML, SDP, SF 41. Note, Dutt, 1 February 1960. 
187 Dutt Diary 11, 1 February 1960.

188 Dutt Diary 11, 7 March 1960.

189 Sarvepalli Gopal, Nehru: A Biography, vol. 3, New Delhi: Oxford University Press, 1984, p. 104.

190 Dennis Kux, Estranged Democracies. India and the United States 1941-1991, New Delhi: Sage, 1993, pp. 163-164.

191 NMML, SDP, SF 24. Memorandum, P. N. Kaul, 13 February 1960.

192 Raghavan, War and Peace in Modern India, p. 281.

193 NMML, SDP, SF 59. Letter, Dutt to Acharya, 23 March 1960.

194 Das Gupta, Serving India, pp. 342-343.

195 Ibid., pp. 344-345.

196 Hoffmann, India and the China Crisis, p. 86.

197 Das Gupta, Serving India, pp. 345-346.

198 Report of the Officials of the Governments of India and the People's Republic of China on the Boundary Question, New Delhi: MEA, 1961.

199 Dutt Diary 11, 21 May 1961.

200 Das Gupta, Serving India, pp. 466-544.

201 Ibid., pp. 405-439.

202 Dai Chaowu, "From "Hindi-Chini Bhai-Bhai" to "International Class Struggle" against Nehru: China's India Policy and the Frontier Dispute, 1950-1962', in Amit R. Das Gupta and Lorenz M. Lüthi (eds.), The Sino-Indian War of 1962. New Perspectives, New Delhi: Routledge, 2017, pp. 86-84.

203 Jairam Ramesh, Intertwined Lives. P. N. Haksar and Indira Gandhi, New Delhi: Simon \& Schuster, 2018. 


\section{3 \\ CONCLUSION}

Zero hours are a rare occurrence in history, and Indian foreign policy had none for sure. Independence and the first fully sovereign Indian government came on 15 August 1947. Foreign policy for Indians pursued by Indians, however, predated even Jawaharlal Nehru's first appearance on the international floor. The charismatic first prime minister stands for an era of a fascination never reached again in the history of modern India. Against the cliché that colonies cannot have a foreign policy of their own, however, independent India's built heavily on earlier fundamentals, both in terms of concepts and institutions as well as personnel.

The history of the foreign policy of colonial and post-colonial India is incomplete without acknowledging the impact of officers of the ICS, British India's elite cadre. This book is the first to analyse this aspect. Thereby, it provides a hitherto lacking history of the origins of the IFS and its early years. It further highlights the impact of the apparatus and some of its most outstanding representatives over four decades. No history of the formation of modern India can be written ignoring the role of officials like V. P. Menon or ICS officers like H.M. Patel, and the same is true for foreign policy and Girja Shankar Bajpai, K.P.S. Menon or Subimal Dutt, who by no means were just implementing decisions of their superiors. On the contrary, they were eminent foreign policy experts, shaping first British Indian policy around the issue of Indians overseas and then Nehruvian foreign affairs. Moreover, the MEA and the IFS to a large extent were their creations. With their professionalism, realism and pronounced political views, they partly assisted and partly formed a counterweight to an initially inexperienced, often overburdened prime minister, whose course more than once was guided by emotions and predispositions, and not always to the benefit of India.

The ICS is known as the 'steel frame of the Raj', but there are good reasons to credit the service with respect to its officers with a similar role around the transfer of power and the Nehruvian years. Already after a few months as head of the interim government, then Vice-President Nehru realised that, against earlier plans, neither India nor its foreign policy could be run without its most skilled administrators. Selection, training and work 
experience made them fit for many tasks: They had managed what was considered the most difficult examination worldwide. Thereafter, the never more than around 1,100 officers of the service shouldered great responsibility in districts or secretariats. The ideal ICS officer was unpolitical, unbiased, pragmatic, realist and loyal: exactly the sort of administrator needed from 1946. Intellectuals with political leanings like K.P.S. Menon formed the exception to the rule.

Until deep into the Second World War, the British never considered training Indians as diplomats. Ironically, they indeed had done so since 1923 in the context of the policy around Indians overseas. It turned out that ICS officers were well prepared for this task, associated with the DEHL which, notwithstanding its designation, conducted proper foreign policy. They continued to play an important role in the foreign affairs of independent India. Unlike most other former colonies, only with independence getting the chance to train diplomats and foreign policy experts, India and Pakistan had a pool of them available. Surprisingly, historiography has taken this enormous asset as a given, whereas indeed it was an exception that proves the rule. The rule were total newcomers, who had no idea of the basic practicalities of diplomacy, let alone international politics. The existence of an Indian cadre of trained diplomats contributed at large to a remarkably smooth transition from colonial to post-colonial foreign policy. In 1947, Bajpai as the most influential among these officers looked back to a quarter century of high-level involvement in international affairs. Compared to him, Nehru was rather a novice on the international floor.

The fate of Indians overseas has drawn much attention in the public and academia. Though the issue quickly lost relevance for post-independence foreign policy, interest was kept alive due to the ongoing discrimination of people of South Asian origin in South Africa and was temporarily intensified with their expulsion from Uganda in 1972. The focus, though, was hardly on the policy around the issue as pursued by the GoI. The key role of the DEHL, finally, has near completely been overlooked. This study for the first time tells the history of a department which must be considered the true predecessor of the MEA as institution, for its personnel and for the prevalent mindset.

Equipped with little manpower, its activities were far-reaching. Although British India did not enjoy dominion status, the list of political entities, all within the Empire, to which the DEHL sent agents and deputations is long. It stretched out much further than the FPD and its successor, the EAD, which kept busy but with South Asia's immediate neighbourhood. Furthermore, the DEHL was often successful. In South Africa, schemes to drive out people of Indian origin were buried, the latter's status enhanced and laws for segregation given up. In East Africa, the GoI managed to fend off European attempts to drive people of Indian origin out of business in Zanzibar or white settlers to take over control in Kenya. With the government 
of Ceylon the DEHL negotiated minimum wages, which were modified but not abolished in the years of the Great Depression. It also insisted on equal political rights, most importantly franchise. Though no countrywide minimum wages were implemented in Malaya, Delhi's efforts contributed to comparatively favourable conditions for Indian labourers. Already by the early 1920s, South Asians in Australia or Canada, apart from certain provinces, enjoyed equal rights, and difficulties in Fiji were quickly settled. The US were out of bounds, but the DEHL was kept informed and even was consulted, when in the mid-1920s Asiatics lost property rights and a ban on immigration was imposed.

The small department was always under Indian members, but the ranks immediately below were initially occupied by senior British ICS officers. The GoI as a whole and even more London, who had established the department rather to distract Indian frustration over the broken promises from the Great War, did not want Indian nationalism to become too strong a factor in relations with other parts of the Empire. Ironically, the department was rapidly Indianised both in terms of personnel and agenda. This had to do with the tangible impact of Gandhian campaigns on both the ICS and the policy around Indians overseas. Equality of officers of the service, whatever colour of skin, became increasingly self-evident as did Indian demands for equality at home and abroad. Conflicts like those Dutt faced in Malaya in 1941 give evidence of the enormous differences that had developed between conditions in South Asia and an old-style colony.

Growing Indian self-confidence could be seen with the DEHL as well. It did not play the intended side role but, unsaid, began rivalling the FPD, formally exclusively responsible for the foreign affairs of British India. More important, it pulled along most of the British ruling India. The case of Indians overseas was full-heartedly supported independently from the ethnic background of the officers involved, often against British officials in charge in other parts of the Empire. Viceroys from the liberal Irwin to the conservative Linlithgow insisted on Indian agents representing the interests of the GoI, not the British government. Due to the activities of the DEHL, and in full harmony with the policy pursued by the British representing the colonial power in South Asia, British India pushed toward more autonomy within the Empire, comparable to the proper dominions. Contrary to Australia, Canada, New Zealand, and South Africa, this was not undertaken by Europeans. That Indians pursued foreign affairs in the interest of Indians, sooner or later, had to pave the path to independence, although it appears that many among the British ruling India refused to think this out.

The DEHL was much more than a footnote in the general transition process. This is indicated by the fact that Bajpai was the first Indian ICS officer ever appointed secretary with the central government. In 1940, as the first active Indian ICS officer, he even became the member, in this capacity joining the Viceroy's Executive Council. The department's relevance for Indian 
history does not end here. Under the name of Commonwealth Relations Department, in 1947, it was merged with the EAD to form the Ministry of External Affairs and Commonwealth Relations of independent India. As the focus of Indian foreign policy had changed by then, commonwealth relations were considered as humdrum work compared to the big issues around the early Cold War and the conflict with Pakistan. Accordingly, the ministry was soon renamed Ministry of External Affairs. While the tasks of the DEHL lost relevance, those who had played relevant or even crucial roles in the department came to occupy the top ranks of the MEA. Independent India's foreign ministry was much more the successor institution of the DEHL than of the EAD. The personnel of the latter for most of its existence was near exclusively British, not permitted to continue after independence. Moreover, among the missions abroad which independent India inherited - another anomaly for a former colony - the three older ones in Ceylon, Malaya and South Africa had been under the DEHL. Those in Washington and Chunking/Nanking, under the EAD, had been established only during the Second World War and run by Bajpai and one of his favourites. The military mission in Berlin dated from 1946 only.

Indian politics for decades before and after independence were dominated by upper-class North Indians. Among the proto-diplomats of the interwar period, however, South Indians played a prominent role for their command of the languages spoken by most of their countrymen abroad. The 'Menongitis' in the early IFS (i.e., the large number of Menons and other South Indians) was the logical outcome, whereas Bengalis, the only other ethnic group equally successful at the ICS entrance examination, pursued their careers mostly in other functions and departments. In headquarters, though rather incidentally, with Bajpai or Jagdish Prasad, officers from the United Provinces called the shots. The Indians they cared for mostly belonged to the underprivileged in South Asia, who before Gandhi had been neglected by Indian politicians. The policy around Indians overseas was a rare and probably first occurrence when an Indian government campaigned for those otherwise considered but cheap labour.

In the eyes of the independence movement, the 'brown Englishmen' of the ICS stood for collaboration with the colonial power. Ironically, those working with the DEHL shared many aims and means of the independence movement. The demand for equal rights both at home and abroad was self-evident for both sides. Moreover, Indian diplomacy had much in common with the strategies of civil rights movements because Delhi was often in a poor bargaining position. The GoI could hardly strike deals or exercise pressure, let alone threat with force; it had to convince counterparts of the rightfulness of its demands. This was possible only after common ground had been found (i.e., after Europeans had accepted India's dark-skinned representatives as negotiating partners at eye level). South Africa initially welcomed only European officers from India, while Indians were considered 'coolies'. 
The change was brought about by individuals impressing with personality, style and education. Sastri was the first to break the ice. Bajpai too was soon held in high esteem even by diehards like Malan, and the performance of the wife of Agent Maharaj Singh in an era near completely dominated by men caused a fundamental change of the image of Indian women. Saraswati Menon, the witty and charming spouse of K.P.S. Menon, set another example of the potential of educated, sociable and modern Indian women on the diplomatic floor. The success story of Indian women in international affairs continued from 1946, though this time it was not based on the lessons from the interwar years but was brought about by a prime minister much more modern regarding gender issues than most of his contemporaries.

Indian representatives fought hard to achieve a higher status of their compatriots abroad, but not for the rights of other discriminated ethnicities. The most striking case was South Africa, where the DEHL refused to make common cause with the indigenous population. In part, this had tactical reasons: The natives had a much longer way to go, and to wait for the white rulers to acknowledge equality of all races would have delayed the Indian case for decades. Nevertheless, there was also Indian racial pride involved. South Africa's rural native population was considered extremely backward, and in South Asia itself darker-skinned people suffer disadvantages until today. Indians did not make common cause with Arabs, Malayans or Chinese overseas either. The Indian struggle for independence, for good reason, is usually considered the precursor for decolonisation in general, but many of its protagonists did not care for others who were equally discriminated. ${ }^{1}$

Certain parallels to Nehruvian foreign policy are striking. Independent India dominated its smaller neighbours and responded with military force to the Pakistani invasion into Kashmir. With the great powers, however, once again it found itself in a poor bargaining position. The preconditions for demands for an adequate role in international affairs were respect for and trust in its representatives - no easy task for an Asian newcomer to global politics. Bajpai and K.P.S. Menon in Washington, Chungking and New York had made it into the league of international top diplomats; Nehru and Krishna Menon impressed with their intellect. And once again, with Vijaya Lakshmi Pandit, a woman played an important role: Worldwide, it was a unique feature that a woman led a delegation to the UN and, thereafter, headed the most important missions in Moscow, Washington and London. All combined, for a former colony, India appeared surprisingly experienced and progressive on the international floor. On the other hand, India's claim to leadership among the newly decolonised countries in Africa and Asia remained hollow. In many African countries, Indians were considered rather collaborators of the colonial powers, and nationalism in Asian countries rivalled that of India. As the independence movement had not been the champion of all suppressed people, independent India rather claimed than played a leading role among decolonised countries. Accordingly, after the 
Asian Relations Conference from spring 1947, Nehru showed little enthusiasm for the Afro-Asian Conference in Bandung or the Non-Aligned Conference in Belgrade. ${ }^{2}$

Some schools of historiography consider a focus on individuals a near taboo. This study, nevertheless, would have been impossible without. The first reason is the sources. Several ICS officers who joined the IFS have left memoirs and collections of private and official papers. Often, the former are neither too reliable nor too detailed, the latter too sporadic to highlight more than individual events. On the contrary, the detailed diaries of K.P.S. Menon and Dutt provide a most authentic type of source. Whole parts of their careers, internal discussions, relations with superiors and colleagues, and their mindset in general could not be reconstructed without them. Furthermore, Dutt's unique collection of official papers from his term as foreign secretary permits insights in decision-making processes dearly lacking for other parts of the Nehruvian years. Finally, in official files, notes and letters of the top ranks predominate. Therefore, Bajpai's work is visible in much detail. It is a different story not only with underlings signing but with their initials: The career of the prematurely deceased M.S.A. Hydari, for example, was as extraordinary as that of K.P.S. Menon, but there is no documentary permitting anything near a deeper analysis.

The second reason for the focus on individuals is their tremendous impact. According to Max Weber, times of big upheavals produce charismatic leaders. ${ }^{3}$ The three decades preceding India's independence saw such leaders awakening their nations and pulling them along. Neither South Asian history of those years nor South Asia today can be understood without acknowledging the crucial role of, most prominently, Gandhi, Nehru or Jinnah. On a smaller stage, foreign policy, the same is true for distinguished officers: The DEHL was not intended the role it indeed played owing to Bajpai, Hydari, Menon or Dutt. Racist South African politicians opened first to Sastri and Bajpai, and only thereafter to India and Indians in general. The success of Indian agents depended on their individual performance to an extent unimaginable in contemporary foreign affairs. The picture was not much different after September 1946. Indian foreign policy was shaped much by the interaction of very few individuals, next to the three protagonists of this study mostly the prime minister and Krishna Menon. On the contrary, parliament hardly played any role,${ }^{4}$ and after the demise of Patel, only G. B. Pant exercised some influence on India-China relations.

Bajpai forms the strongest link between Indian foreign policy in the interwar and the post-independence period. He stands for a realist approach, including caution, moderation and readiness for pragmatic compromises, taking care for a stable, reliable, calculable course, inspiring confidence. Notwithstanding his intense dislike for communism and its representatives, his attitude as secretary-general was strictly professional. This was important for both the policy around Indians overseas as for the Nehruvian years, 
when foreign policy to no small extent was driven by emotions and predispositions. Bajpai embodied the professionalism associated with the 'ICS brotherhood'.

That an ICS upbringing did not necessarily qualify officers for the highest ranks could be seen thereafter. Pillai and R. K. Nehru did not manage to counterbalance the prime minister and Krishna Menon to the same extent as Bajpai had done. Only from late 1956, Dutt formed a congenial tandem with Pillai to similar effect. Before his promotion to the rank of foreign secretary, he had mostly been a highly efficient $\operatorname{cog}$ in the wheel. From late 1956, however, he left his mark. Though he finally failed to find a solution in the boundary conflict with China - hardly his fault - Indian foreign affairs once again had a strong element of realism and caution, modifying a course strongly influenced by wishful thinking and anti-western reflexes.

Bajpai and Dutt were extraordinary officers for all their capacities. In a manner of speaking, nevertheless, K.P.S. Menon was the most unusual in the troika, as observed in this study. With his intellectual leanings and his friendship with Nehru, he stood out in the 'ICS brotherhood' of the interwar period, which mostly kept out of the struggle for independence. A born diplomat supported by a modern wife, Menon never showed true interest in calling the shots in Delhi. Working within a hierarchy was not his cup of tea; he preferred the freedom coming along with heading missions abroad. When posted in Ceylon or on deputation to East Africa, he showed great capacity to analyse, negotiate and make friends. Twice he added the sort of professionalism to delegations to the UN that Bajpai and Dutt added to the MEA and the GoI. Menon was never more influential than during his nine years in Moscow. Like Nehru, he had the capacity to envision future developments and helped overcome deep-seated Indian anti-communism, focusing on the bright sides of the USSR. Whether close cooperation with Moscow benefitted India then and later is a matter of opinion. There can be no doubt, however, that (in large part due to Menon) Delhi did rather not choose that course for obvious pragmatic reasons but for partial blindness.

This monograph contributes to colonial and post-colonial studies and the debate around the Nehruvian years. Emphasising various aspects of continuity from 1921 to 1961 , it questions the argument that India through independence became a veritable post-colonial state. Truly, while the political leadership changed, the core of the 'new' foreign service were officers whose mindset had been shaped by the British. The highly anglicised Bajpai de facto functioned as foreign minister, and certain attitudes of him and his fellow-officers, especially anti-communism, can easily be traced back to colonial policy. He was succeeded by the equally anglicised Pillai, soon assisted by Bajpai's protégé Dutt. The author of this monograph, however, would rather emphasise that ICS officers, absolutely loyal to the new leadership, added an urgently needed dose of professionalism and realism to Nehruvian foreign policy. Nehru's own ideas distinctly differed both from 
colonial foreign policy and those of leading MEA officials. Bajpai, Pillai and Dutt deeply distrusted Soviet and even more Chinese intentions and would have preferred closer relations with the West. Whenever they could not convince Nehru, they loyally defended and implemented his decisions.

A study like this can never be complete, if only because archival collections are growing; private papers surface out of the blue. The papers of Jawaharlal Nehru and Krishna Menon became accessible too late to be included, wherefore future research will modify the picture drawn from hitherto available documentation. Several influential ICS officers mentioned, foremost Hydari, Pillai and R.K. Nehru, but also M.J. Desai, deserve a more prominent role in the history of Indian foreign policy once documentation permits. Furthermore, as long as archives remain closed in Pakistan, it is impossible to investigate the even greater influence of those ICS officers who opted for the second state that came into being in August 1947.

\section{Notes}

1 T.A. Keenleyside, 'Nationalist Indian Attitudes towards Asia. A Troublesome Legacy for Post-independence Indian Foreign Policy', Pacific Affairs, 1982, 55(2): 217-224.

2 G.H. Jansen, Nonalignment and the Afro-Asian States, New York: Frederick A. Praeger, 1966, p. 74.

3 Max Weber, Wirtschaft und Gesellschaft. Grundriss der verstehenden Soziologie, Tübingen: Mohr, 1989, pp. 140-141.

4 Jayantanuja Bandyopadhyaya, The Making of India's Foreign Policy. Determinants, Institutions, Processes and Personalities, Bombay: Allied, 1970, Revised edition, pp. 163-165. 


\section{BIBLIOGRAPHY}

\section{Archival sources}

Arhiv vneshnej politiki Rossijskoi Federacii, Moscow

British Library, London

Bundesarchiv, Koblenz

Indian Embassy Berlin

Ministry of External Affairs Archives, New Delhi

National Archives of India, New Delhi

National Archives of the United Kingdom, London

Nehru Memorial Museum and Library, New Delhi

Politisches Archiv des Auswärtigen Amts, Berlin

Tamil Nadu State Archives, Chennai

Uttar Pradesh State Archives, Lucknow

\section{Private collections}

\section{K.S. Bajpai}

Supriya Guha

- Subimal Dutt, Diaries

- Subimal Dutt, Autobiography

\section{Published records}

Documents on the Kashmir Problem, Deora, S., and Grover, R. (eds.), New Delhi: Discovery Publishing House, 1991.

Foreign Relations of the United States, Washington, DC: Government Printing Office.

Sardar Patel's Correspondence, Das, Durga (ed.), Ahmedabad: Navajivan Publishing House, 1971-1974.

Selected Works of Jawaharlal Nehru, Second Series, New Delhi: Jawaharlal Nehru Memorial Fund, 1984-.

Speeches and Documents on Indian Policy, 1750-1921, vol. I, Keith, Arthur Berriedale (ed.), London: Milford, 1922. 
The Government and Administration of Africa, 1880-1939, vol. 2, Anderson, Casper, and Cohen, Andrewas (eds.), London: Pickering \& Chatto, 2013.

The Hungarian Revolution 1956. Documents, New Delhi: Government of India, Ministry of External Affairs.

The Transfer of Power, Mansergh, Nicholas and Lumby, E.W.R. (eds.), London: Her Majesty's Stationery Office, 1970-1977.

White Papers. Notes, Memoranda and Letters Exchanged and Agreements Signed between the Governments of India and China, New Delhi: Government of India, Ministry of External Affairs, 1959-1968.

\section{Articles and book chapters}

Aiyar, Sana, 'Anticolonial Homelands across the Indian Ocean: The Politics of the Indian Diaspora in Kenya, ca. 1930-1950', American Historical Review, 116(4) (2011): 987-1013.

Ankit, Rakesh, 'India-USSR, 1946-1949. A False Start?', in Palat, Madhavan (ed.), India and the World in the First Half of the Twentieth Century, New Delhi: Routledge, 2018: 160-188.

Barron, T. J., 'The Donoughmore Commission and Ceylon's National Identity', Journal of Commonwealth and Comparative Politics, 26(2) (1988): 147-157.

Beaglehole, T.H., 'From Rulers to Servants. The I.C.S. and the British Demission of Power in India', Modern Asian Studies, 11(02) (April 1977): 237-255.

Bechtol, Bruce E., Jr, 'Paradigmenwandel des Kalten Krieges. Der Koreakrieg 19501953', in Greiner, Bernd et al. (eds.), Heiße Kriege im Kalten Krieg, Hamburg: Hamburger Edition, 2006: 141-166.

Bhagavan, Manu, 'A New Hope: India, the United Nations and the Making of the Universal Declaration of Human Rights', Modern Asian Studies, 44(2) (March 2010): 311-347.

Burra, Arudra, 'The Indian Civil Service and the Nationalist Movement: Neutrality, Politics and Continuity', Commonwealth \& Comparative Politics, 48(4) (November 2010): 404-432.

Chaowu, Dai, 'From "Hindi-Chini Bhai-Bhai" to "international class struggle" against Nehru: China's India Policy and the Frontier Dispute, 1950-1962', in Das Gupta, Amit R., and Lüthi, Lorenz M. (eds.), The Sino-Indian War of 1962. New Perspectives, New Delhi: Routledge, 2017: 86-84.

Chiriyankandath, James, 'Democracy under the Raj: Elections and Separate Representation in British India', Journal of Commonwealth and Comparative Politics, 30(1) (1992): 39-63.

Das Gupta, Amit R., 'Foreign Secretary Subimal Dutt and the Prehistory of the SinoIndian Border War', in Das Gupta, Amit R., and Lüthi, Lorenz M. (eds.), The Sino-Indian War of 1962. New Perspectives, New Delhi: Routledge, 2017: 48-67.

Das Gupta, Amit R., 'Indiens sicherheitspolitische Wende zwischen 1962 und 1974', in Buciak, Sebastian and Dehn, Rüdiger (eds.), Indien und Pakistan - Atommächte im Spannungsfeld regionaler und globaler Veränderungen. Beiträge zur Außenund Sicherheitspolitik Südasiens, Berlin: Kösters, 2010: 93-118.

Das Gupta, Amit R., 'The Fateful Indian Recognition of West Germany, 1949', Cold War History, 19(1) (2019): 101-117. 
Dasgupta, Chandrashekhar, 'Nehru, Patel and China', Strategic Analysis, 38(5) (2014): 717-724.

Du Toit, Brian M., 'The Mahatma Gandhi and South Africa', The Journal of Modern African Studies, 34(4) (1996): 643-660.

Dutt, Srikant, 'India and the Overseas Indians', India Quarterly. A Journal of International Affairs, 36(3-4) (1980): 307-335.

Ewing, Ann, 'The Indian Civil Service 1919-1924: Service Discontent and the Response in London and in Delhi', Modern Asian Studies, 18(1) (1984): 33-53.

Framke, Maria, “'We Must Send a Gift Worthy of India and the Congress!" War and Political Humanitarianism in Late Colonial South Asia', Modern Asian Studies, 51(6) (2017): 1969-1998.

Gangopadhyay, Aparajta, 'India's Policy towards its Diaspora: Continuity and Change', India Quarterly, 61(4) (2005): 93-122.

Hogben, W. Murray, 'An Imperial Dilemma: The Reluctant Indianization of the Indian Political Service', Modern Asian Studies, 15(04) (October 1981): 751-769.

Izuakor, Levi I., 'Kenya: The Unparamount African Paramountcy, 1923-1939', Transafrican Journal of History, 12 (1983): 33-50.

Jain, B.K., 'The Problem of Citizenship Rights of Persons of Indian Origin in Ceylon', The Indian Journal of Political Science, 24(1) (1963): 65-78.

Johnstone, William C., 'The San Francisco Conference', Pacific Affairs, 18(3) (September 1945): 213-228.

Kamtekar, Indivar, 'The Shiver of 1942', Studies in History, 18(1) (2002): 81-102.

Kaur, Amarajit, 'Plantation Systems, Labour Regimes and the State in Malaysia, 1900-2012', Journal of Agrarian Change, 14(2) (2014): 190-213.

Keenleyside, T. A., 'Diplomatic Apprenticeship: Pre-Independence Origins of Indian Diplomacy and its Relevance for the Post-independence Foreign Policy', India Quarterly. A Journal of International Affairs, 43(2) (1987): 97-120.

Keenleyside, T. A., 'Nationalist Indian Attitudes towards Asia. A Troublesome Legacy for Post-Independence Indian Foreign Policy', Pacific Affairs, 55(2) (1982): 210-230.

Kim, ChanWahn, 'The Role of India in the Korean War', International Area Review, 13(2) (2010): 21-37.

Kramer, Mark, 'The Soviet Union and the 1956 Crises in Hungary and Poland: Reassessments and New Findings', Journal of Contemporary History, 33(2) (1998): 163-214.

Kumar, S. Suresh, 'The Kangany System in the Plantations of South India: A Study in the Colonial Mode of Production', Proceedings of the Indian History Congress, 49 (1988): 516-519.

Lall, Marie, 'Mother India's Forgotten Children', in Nielsen, Eva Østergaard (ed.), International Migration and Sending Countries: Perceptions, Policies and Transnational Relations, Houndmills: Palgrave Macmillan, 2003: 121-139.

Lloyd, Lorna, “"A Most Auspicious Beginning”: The 1946 United Nations General Assembly and the Question of Treatment of Indians in South Africa', Review of International Studies, 16(2) (April 1990): 131-153.

Mahajani, Usha, 'India and the People of Indian Origin Abroad', in Rajan, M.S. (ed.), India's Foreign Relations during the Nehru Era, Bombay: Asia Publishing House, 1976: 199-254. 
Mathur, R.D., 'British Policy toward the Volunteer Movement in India during the Non-cooperation Campaign', Proceedings of the Indian History Congress, 32(2) (1970): 214-225.

Maxon, Robert M., 'The Devonshire Declaration: The Myth of Missionary Intervention', History in Africa, 18 (1991): 259-270.

McCann, Gerard, 'From Diaspora to Third Worldism and the United Nations: India and the Politics of Decolonizing Africa', Past \& Present, 218 (suppl. 8) (2013): 258-280.

McGarr, Paul, “"A Serious Menace to Security”: British Intelligence, V.K. Krishna Menon and the Indian High Commission in London, 1947-52', The Journal of Imperial and Commonwealth History, 38(3) (2010): 441-469.

Mehrotra, S. R., 'The Development of the Indian Outlook on World Affairs before 1947', Development Studies, 1(3) (1965): 269-294.

Mitra, Subrata, 'Symbiosis, Re-use and Evolution: Administrators, Politicians, Citizens, and Governance in Postcolonial India', Commonwealth and Comparative Politics, 48(4) (2010): 457-478.

Norbu, Dawa, 'Tibet in Sino-Indian Relations: The Centrality of Marginality', Asian Survey, 37(11) (November 1997): 1078-1095.

Phadnis, Urmila, 'Indo-Ceylonese Relations', in Rajan, M.S. (ed.), India's Foreign Relations during the Nehru Era, Bombay: Asia Publishing House, 1976: 21-49.

Polouse, T.T., 'India as an Anomalous International Person', British Yearbook for International Law, 44 (1970): 201-212.

Potter, David C., 'Manpower Shortage and the End of Colonialism. The Case of the Indian Civil Service', Modern Asian Studies, 7(01) (January 1973): 47-73.

Power, Paul F., 'Gandhi in South Africa', Journal of Modern African Studies, 7(3) (1969): 441-455.

Raghavan, Pallavi, 'Establishing the Ministry of External Affairs', in Malone, David M. et al. (eds.), The Oxford Handbook of Indian Foreign Policy, Oxford: Oxford University Press, 2015: 80-91.

Ramasamy, P., 'Labour Control and Labour Resistance in the Plantations of Colonial Malaya', The Journal of Peasant Studies, 19(3-4) (1992): 87-105.

Satyanarayana, Adapa, "Birds of Passage": Migration of South Indian Laborers to Southeast Asia', Critical Asian Studies, 34(1) (2010): 89-115.

Sherwood, Marika, 'India at the Founding of the United Nations', International Studies, 33(4) (1996): 407-428.

Silvestri, Michael, 'The Bomb, Bhadralok, Bhagavad Gita, and Dan Breen: Terrorism in Bengal and its Relation to the European Experience', Terrorism and Political Violence, 21(1) (2009): 1-27.

Spencer, I.R.G., 'The First Assault on Indian Ascendancy: Indian Traders in the Kenya Reserves, 1895-1929', African Affairs, 80(320) (1 July 1981): 327-343.

Sundaram, Lanka, 'Indian Labour in Ceylon', International Labour Review, 23(3) (1931): 369-387.

Thakur, Mandar A., 'Indian Agitation against Clove Decrees in Zanzibar', Proceedings of the Indian History Congress, 68th Session, New Delhi, 2007, 1229-1241.

Thakur, Vineet, 'Liberal, Liminal and Lost: India's First Diplomats and the Narrative of Foreign Policy', Journal of Imperial and Commonwealth History, 45(2) (2017): 232-258. 
Thakur, Vineet, 'The "Hardy Annual”: A History of India's First UN Resolution', India Review, 16(4) (2017): 401-429.

Vahed, Goolam, 'The Making of "Indianess": Indian Politics in South Africa during the 1930 and 1940s', Journal of Natal and Zulu History, 17 (1997): 1-36.

Weber, Thomas, 'Gandhian Philosophy, Conflict Resolution Theory and Practical Approaches to Negotiation', Journal of Peace Research, 38(4) (2001): 493-513.

Wylie, Diana, 'Confrontation over Kenya: The Colonial Office and Its Critics 19181940, The Journal of African History, 18(3) (July 1977): 427-447.

Youé, Christopher P., 'The Threat of Settler Rebellion and the Imperial Predicament: The Denial of Indian Rights in Kenya, 1923', Canadian Journal of History, 12(3) (1978): 348-360.

Zinkin, Maurice, 'ICS Revisited', Asian Affairs, 25(3) (1994): 293-302.

\section{Monographs}

Amrith, Sunil S., Crossing the Bay of Bengal. The Furies of Nature and the Fortunes of Migrants, Cambridge, MA: Harvard University Press, 2013.

Ankit, Rakesh, India in the Interregnum. Interim Government, September 1946August 1947, New Delhi: Oxford University Press, 2019.

Ankit, Rakesh, The Kashmir Conflict. From Empire to the Cold War, 1945-66, London: Routledge, 2016.

Appadorai, A., The Domestic Roots of India's Foreign Policy 1947-1972, New Delhi: Oxford University Press, 1981.

Bandyopadhyaya, Jayantanuja, The Making of India's Foreign Policy. Determinants, Institutions, Processes and Personalities, Bombay: Allied, 1970, Revised edition.

Belle, Carl Vadivella, Tragic Orphans. Indians in Malaysia, Singapore: Institute of Southeast Asian Studies, 2015.

Blyth, Robert J., The Empire of the Raj. India, Eastern Africa and the Middle East, 1858-1947, Basingstoke: Palgrave Macmillan, 2003.

Bose, Sugata, A Hundred Horizons. The Indian Ocean in the Age of Global Empire, Cambridge, MA: Harvard University Press, 2009.

Bose, Sugata, His Majesty's Opponent. Subhas Chandra Bose and India's Struggle against Empire, Cambridge, MA: Harvard University Press, 2011.

Brenner, Jeffrey, The Indian Foreign Policy Bureaucracy, Boulder: Westview Press, 1985.

Brown, Judith, Gandhi's Rise to Power. Indian Politics 1915-1922, Cambridge: Cambridge University Press, 1972.

Chandra, Bipan, Mukherjee, Mridula, Mukherjee, Aditya, Panikkar, K. N., and Mahajan, Sucheta, India's Struggle for Independence 1857-1947, New Delhi: Penguin Books, 1988.

Cheddie, Anand, The Colonial-Born and Settlers' Indian Association in Natal Indian Political 1933-1939, M.A. thesis, Durban, 1992, https://researchspace.ukzn.ac.za/bitstream/handle/10413/7623/Cheddie_Anand_1992. pdf? sequence=1\&isAllowed=y [accessed 12 December 2018].

Cumpston, I.M., Indians Overseas in British Territories 1834-1854, London: Oxford University Press, 1953.

Das, Suranjan, The Nehru Years in Indian Politics. From a Historical Hindsight, Edinburgh Papers in South Asian Studies, 16, 2001. 
Das Gupta, Amit, Handel, Hilfe, Hallstein-Doktrin. Die bundesdeutsche Südasienpolitik unter Adenauer und Erhard 1949-1966, Husum: Matthiesen, 2004.

Das Gupta, Amit, Serving India. A Political Biography of Subimal Dutt (19031992), India's Longest Serving Foreign Secretary, New Delhi: Manohar, 2017.

Dhupelia-Mesthrie, Uma, Gandhi's Prisoner? The Life of Gandhi's Son Manilal, Cape Town: Kwela, 2004.

Dixit, Jyotindra Nath, Indian Foreign Service: History and Challenge, New Delhi: Konark Publishers, 2005.

Eckert, Andreas, Herrschen und Verwalten. Afrikanische Bürokraten, staatliche Ordnung und Politik in Tanzania, 1920-70, Munich: Oldenbourg, 2007.

Ewing, Ann, Survey of Former Officers of the Indian Civil Service, Ewing Papers, Cambridge: Centre of South Asian Studies, 1978.

Fischer-Tiné, Harald, Shyamii Krishnavarma. Sanskrit, Sociology and AntiImperialism, New Delhi: Routledge, 2014.

Furet, François, The Passing of an Illusion. The Idea of Communism in the Twentieth Century, Chicago: University of Chicago Press, 1999.

George, Thayil Jacob Sony, Krishna Menon, London: Cape, 1964.

Gillion, K.L., Fiji's Indian Migrants. A History to the End of Indenture in 1920, Melbourne: Oxford University Press, 1962.

Gillion, K.L., The Fiji Indians. Challenge to European Dominance, Canberra: Australian National University Press, 1977.

Gopal, Sarvepalli, Nehru: A Biography, 3 vols., New Delhi: Oxford University Press, 1975-1984.

Gregory, Robert G., India and East Africa. A History of Race Relations within the British Empire 1890-1939, Oxford: Clarendon Press, 1971.

Gupta Deepak, The Steel Frame. A History of the IAS, New Delhi: Roli Books, 2019.

Guyot-Réchard, Bérénice, Shadow States. India, China and the Himalayas, 19101962, Cambridge: Cambridge University Press, 2017.

Hancock, William K., Smuts: The Sanguine Years, 1870-1919, Cambridge: Cambridge University Press, 1962.

Heimsath, Charles H., and Mansingh, Surjit, A Diplomatic History of Modern India, Bombay: Allied, 1971.

Hilger, Andreas, Sowjetisch-indische Beziehungen 1941-1966. Imperiale Agenda und nationale Identität in der Ära von Dekolonisierung und Kaltem Krieg, Vienna: Böhlau, 2018.

Hoffmann, Steven A., India and the China Crisis, Berkeley: University of California Press, 1990.

Hyam, Ronald, Britain's Declining Empire. The Road to Decolonisation, 19181968, Cambridge: Cambridge University Press, 2006.

Ishmael, Odeen, The Guyana Story from Earliest Times to Independence, Bloomington, IN: Xlibris, 2014.

James, Lawrence, The Rise and Fall of the British Empire, London: Little, Brown, 1994.

Jansen, G.H., Nonalignment and the Afro-Asian States, New York: Frederick A. Praeger, 1966,

Kapur, Harish, Foreign Policies of India’s Prime Ministers, New Delhi: Lancer, 2009. 
Kaur, Amarjit, Wage Labour in Southeast Asia since 1840. Globalisation, the International Division of Labour and Labour Transformations, Houndmills: Palgrave Macmillan, 2004.

Kelly, John Dunham, A Politics of Virtue: Hinduism, Sexuality, and Countercolonial Discourse in Fiji, Chicago: University of Chicago Press, 1991.

Khilnani, Sunil, The Idea of India, Gurgaon: Penguin Books, 1998.

Kux, Dennis, Estranged Democracies. India and the United States 1941-1991, New Delhi: Sage, 1993.

Lal, Brij V., Chalo Jahaji. On a Journey through Indenture in Fiji, Australian National University Press, 2012, http://press-files.anu.edu.au/downloads/press/ p212781/pdf/book.pdf? referer=123 [accessed 3 February 2018].

Lamb, Alastair, Kashmir. A Disputed Legacy 1846-1990, Hertingfordbury: Roxford, 1991.

Manjapra, Kris, M.N. Roy. Marxism and Colonial Cosmopolitanism, London: Routledge, 2010.

McGarr, Paul, The Cold War in South Asia. Britain, the United States and the Indian Subcontinent, 1945-1965, Cambridge: Cambridge University Press, 2013.

Mehra, Parshotam, The Younghusband Expedition (to Lhasa): An Interpretation, New Delhi: Gyan Publishing House, 2005, 2nd edition.

Moorhouse, Geoffrey, Calcutta, Harmondsworth: Penguin Books, 1973.

Mukerjee, Madhusree, Churchill's Secret War. The British Empire and the Ravaging of India during World War II, Chennai: Tranquebar Press, 2010.

Mukherjee, Meenakshi, An Indian for All Seasons. The Many Lives of R. C. Dutt, New Delhi: Penguin Books, 2009.

Nanda, B. R., Gokhale. The Indian Moderates and the British Raj, Oxford: Oxford University Press, 1977.

Osterman, Christian (ed.), Uprising in East Germany. The Cold War, the German Question and the First Major Upheaval behind the Iron Curtain, Budapest: Central European University Press, 2001.

Peebles, Patrick, The Plantation Tamils of Ceylon, London: Leicester University Press, 2001.

Potter, David C., India's Political Administrators 1919-1983, Oxford: Clarendon Press, 1986.

Prasad, Bimla, The Origins of Indian Foreign Policy. The Indian National Congress and World Affairs, 1885-1947, Calcutta: Bookland, 1960.

Rabe, Stephen G., U.S. Intervention in British Guiana. A Cold War Story, Chapel Hill: University of North Carolina Press, 2005.

Raghavan, Srinath, Fierce Enigmas. A History of the United States in South Asia, New York: Basic Books, 2019.

Raghavan, Srinath, War and Peace in Modern India. A Strategic History of the Nebru Years, Ranikhet: Permanent Black, 2010.

Rajan, M.S. (ed.), India's Foreign Relations during the Nehru Era, Bombay: Asia Publishing House, 1976.

Ramesh, Jairam, Intertwined Lives. P. N. Haksar and Indira Gandhi, New Delhi: Simon \& Schuster, 2018.

Ramusack, Barbara, The Indian Princes and Their States, Cambridge: Cambridge University Press, 2004. 
Rao, P. Kodanda, The Right Honourable V.S. Srinivasa Sastri. A Political Biography, London: Asia Publishing House, 1963.

Ray, Jayanta Kumar, India’s Foreign Relations, 1947-2007, New Delhi: Routledge, 2011.

Russel, Jane, Communal Politics under the Donoughmore Commission 1931-1947, Dehiwala: Tisara Press, 1982.

Russell, Ruth B., A History of the United Nations Charter. The Role of the United States 1940-1945, Washington, DC: Brookings Institution Press, 1958.

Schaffer, Howard B., The Limits of Influence. America's Role in Kashmir, Washington, DC: Brookings Institution Press, 2009.

Sen, Ashna, The Rusted Trunk, Kolkata: Writers' Workshop, 2011.

Sinha, Mrinalini, Colonial Masculinity: The 'Manly Englishman' and the 'Effeminate Bengali' in the Late Nineteenth Century, Manchester: Manchester University Press, 1995.

Spear, Percival, A History of India, vol. 2, Harmondsworth: Penguin Books, 1965.

Subramaniam, V., Social Background of India's Administrators. A Socio-economic Study of the Higher Civil Services of India, New Delhi: Publication Division Government of India, 1971.

Thakur, Vineet, Postscripts on Independence. Foreign Policy Ideas, Identity and Institutions in India and South Africa, New Delhi: Oxford University Press, 2018.

Tinker, Hugh, A New System of Slavery. The Export of Indian Labour Overseas 1830-1920, London: Oxford University Press, 1974.

Tinker, Hugh, Separate and Unequal. India and the Indians in the British Commonwealth 1920-1950, London: C. Hurst, 1976.

Tinker, Hugh, The Banyan Tree. Overseas Emigrants from India, Pakistan, and Bangladesh, Oxford: Oxford University Press, 1977.

Tinker, Hugh, The Ordeal of Love. C.F. Andrews and India, New Delhi: Oxford University Press, 1979.

Touhey, Ryan, Conflicting Visions. Canada and India in the Cold War World, 194676, Vancouver: University of British Columbia Press, 2015.

Voigt, Johannes, Die Indienpolitik der DDR. Von den Anfängen bis zur Anerkennung (1952-1972), Cologne: Böhlau, 2008.

Voigt, Johannes, Indien im Zweiten Weltkrieg, Stuttgart: Deutsche-Verlags-Anstalt, 1978.

Weigold, Auriol, Churchill, Roosevelt and India. Propaganda during World War II, New York: Routledge, 2008.

Wilson, Harold Edmund, The Klang Strikes of 1941. Labour and Capital in Colonial Malaya, Singapore: Institute of Southeast Asian Studies, 1981.

\section{Memoirs}

Bonarjee, Neil Bruniat, Under Two Masters, London: Oxford University Press, 1970. Churchill, Winston, India. Speeches and an Introduction, London: T. Butterworth, 1931.

Churchill, Winston, My African Journey, London: Hodder and Stoughton, 1908.

Das, Durga, India from Curzon to Nehru and After, New Delhi: Rupa, 2012, 5th edition. 
Dutt, Subimal, Autobiography, unpublished, 1984.

Dutt, Subimal, With Nehru in the Foreign Office, Calcutta: Minerva Associates, 1977.

Gundevia, Yezdezard Dinshaw, In the Districts of the Raj, Hyderabad: Sangam Books, 1992.

Gundevia, Yezdezard Dinshaw, Outside the Archives, Hyderabad: Sangam Books, 1984.

Mathai, M. O., My Days with Nehru, New Delhi: Vikas, 1979.

Mathai, M. O., Reminiscences of the Nehru Age, New Delhi: Vikas, 1978.

Menon, K.P.S., Many Worlds, An Autobiography, Bombay: IBH, 1971.

Mullik, Bhola Nath, My Years with Nehru. The Chinese Betrayal, New Delhi: Allied, 1971.

Nehru, Jawaharlal, Autobiography, London: Bodley Head, 1938.

Pandit, Vijaya Lakshmi, The Scope of Happiness. A Personal Memoir, London: Weidenfeld and Nicolson, 1979.

Patel, H.M., Rites of Passage: A Civil Servant Remembers, Mahajan, Sucheta (ed.), New Delhi: Rupa, 2005.

Shrinagesh, Jayavant Mallanah, Between Two Stools. My Life in the ICS before and after Independence, New Delhi: Rupa, 2007.

Tyabji, Badr-ud-din, Memoirs of an Egoist, Vol. 1, 1907 to 1956, New Delhi: Roli Books, 1988.

Yunus, Mohammad, Persons, Passions and Politics, Sahibabad: Vikas, 1980. 


\section{INDEX}

Adenauer, Konrad 267-268, 270

Ahearne, Christopher Dominic 124-126, 128, 136-137

Ali, Asaf 203-206, 223, 225

Ali, Raza 50, 59, 61-66, 69-71, 197

Amery, Leopold 42, 75-77, 133, 139, 152-154, 157-159, 162, 168-169, 173, 177-184

Andrews, Charles Freer 53, 55-57, 60-61, 66-69, 74, 90, 127, 131, 137-138, 140, 143-144, 148

Aney, Madhav Shrihari 152

Athlone, Alexander Cambridge 51, 53

Attlee, Clement 194, 197, 205, 211

Australia 4, 12, 23, 30, 140, 146, 155, 198, 239, 294

Bajpai, Girja Shankar 2, 4-14, 27-35, 37-44, 49-54, 56-59, 61-72, 75-85, 88-93, 96-97, 99-101, 103-119, 121-132, 135-138, 140, 142, 144-184, 193-199, 201-262, 279-280, 284-285, 292-299

Bandaranaike, S.W.R.D. 94, 104

Banerjee, Rabindra Nath 210-212

Baring, Evelyn 55, 60, 68

Bengal Presidency 25, 39, 55, 110-111, 132, 134, 150, 165, 176, 208, 210-211, 214, 249-251, 295

Berle, Adolf A. Jr 160, 163, 179-182

Bhore, Joseph William 50, 67-68, 83, 92, 96, 115, 122, 124, 135-136, 145,148

Bhutan 175, 244, 281

Bonarjee, Neil Bruniat 8, 28, 32, 170

Bose, Subhas Chandra 39, 150, 161,170
Bowles, Chester 231, 236, 238, 240, 254, 256-259, 286

Bozman, Geoffrey Stephen 63, 70, 82, 87, 104-106, 112, 117-119, 127,137

Bray, Denis 43, 118, 138, 147, 149

British Commonwealth 9, 22, 34, 63, 147, 154, 167, 209, 233, 251, 295

British Empire 3, 4, 9, 21-24, 34-35, 48-49, 51, 53, 78, 81, 84, 86, 89, $105,140,143,152-155,159-160$, 176, 193, 235, 293-294

British Guiana 4, 9, 12, 58-59, 61-62, 140, 143-145

Bulganin, Nikolai Alexandrovich 266, 268, 271-277, 279-280, 288-289

Burma 2, 21, 38-39, 152-153, 165, 174, 226, 244-245, 281, 283

Butler, Montagu Sherard Daws 24, 30, 49, 67, 74, 90, 142, 148

Canada 4, 12, 22-23, 146, 155, 157, 201, 262, 294

Caroe, Olaf 5, 38-39, 152, 155, 158-159, 161, 168-170, 172-177, 179-182, 184, 193, 203, 208, 216-217, 219

Central Provinces 35, 109, 261-262

Ceylon 3, 5, 6, 9, 12, 25-26, 37-38, 81, 94-126, 129-132, 134, 152, 211, 224, 278, 294-295, 298

Chandran, T.L.R. 100-102, 104, 109, 111, 113, 116-118

Chiang Kai-shek 165, 172-173, 175

China 5, 6, 10-11, 13, 153, 156-157, 162, 165, 168, 171-178, 194, 197-198, 205-207, 209, 212-213, 
230-232, 234, 236, 240-245, 247, 252-253, 263-264, 268, 280-284, 297-298

Churchill, Winston 22, 30, 72-73, 141, 154-155, 159-160, 165, 170-171, 179, 193-194, 205

Colonial Office 12, 72-75, 77-81, 83-87, 89, 113, 133-135, 141-143, 155

communism 2, 13, 170-171, 174, 177, 198-199, 209, 230, 232, 234, 239-246, 251, 253, 265, 267-272, 279-280, 282, 285, 297-298

Communist Party of India (CPI) 171, 223, 239, 241, 243, 272

Corbett, Geoffrey Latham 54, 57, 141-142

Cripps, Stafford 160-163, 171

Cunliffe-Lister, Philip 78, 80-81, 83-84, 91-92, 105

Czechoslovakia 39-40, 227, 246, 269-270, 276

Dalai Lama 279, 283

Das, Durga 2

Dayal, Rajeshwar 240-242, 255, 258

Department of Education, Health and Lands 3-7, 10-12, 23-24, 26, 28, 31-33, 37-40, 48, 50-52, 54, $56,60-61,63,73-76,78,80-81$, 83, 85-89, 96-98, 101, 103, 105, 107-111, 113, 122-124, 126-129, 131, 135, 140, 143, 145, 147, 151, 155, 169, 197, 210, 234, 262, 293-297

Department of State 153, 155, 160, 162, 166, 234, 236

Desai, M. J. 265, 282, 284, 299

Dulles, John Foster 225, 267-268

Dutt, Subimal 5-7, 9-11, 13, 32-33, 39-44, 107, 110-111, 116, 118, 130, 132-135, 138-139, 150, 152, 203, 210-211, 214-215, 217, 219, 221-222, 226, 228-230, 232, 234, 247-251, 254-256, 259-266, 268, 270-277, 279-292, 294, 297-299

East Africa 4-6, 9, 12, 37, 72-94, 114, 123, 134, 293, 298

Eden, Anthony 156-157, 179-181

Egypt 273, 275, 277

Eisenhower, Dwight D. 272, 283
Ewbank, Robert Benson 24-25, 27, 29-30, 41, 67, 74-75, 90-91, 95-96, 114, 118, 127, 135, 137, $141,145,148$

External Affairs Department (EAD) 153-154, 162, 169, 172, 176, 200, 207, 293, 295

Fiji 4, 9, 12, 21-22, 58, 101, 123, 140-143, 145, 294

Foreign and Political Department (FDP) 2-3, 7, 23-24, 36, 38, 40, 83, 108, 147, 153-154, 169, 196, 293-294

Foreign Office 2, 12, 24, 36, 153, 155, $159,173,204$

France 28, 38-39, 156, 165, 194, 203, 205, 209, 228, 232, 273, 275, 277-278

Gandhi, Indira 285

Gandhi, Manilal M. 9, 61

Gandhi, Mohandas Karamchand 3-4, 21, 29-30, 39, 41, 47-49, 52-55, 57, 59-61, 83, 88-89, 94, 110, 141, 143-144, 155-156, 160-164, 167, 170-172, 194, 223, 285, 294-295, 297

Germany 6, 10-11, 38-40, 195, 209-210, 248, 261, 263, 265, 268-270, 279

Glancey, Bertrand James 37, 43, 130, 169

Goa 272, 285

Great Game 3, 24, 40, 176

Gromyko, Andrei Andreyevich 195, 272, 288

Gopal, Sarvepalli 10, 204, 282-283

Gunasinha, Alexander Ekenayake 94, 104

Gundevia, Yezdezard Dinshaw 11, 33, 221-222, 226, 235, 266, 287

Guomindang 174-175, 177, 281

Habibullah, Mohammed 32, 54-55, $68,76,89,91,96,109,115,123$, 127, 136-137

Halifax, Edward Wood Earl of see Irwin, Edward Wood

Henderson, Loy W. 233-234, 236, 238, 241, 243-244, 247, 255-259

Hertzog, James Barry Munnick 49, $51-52,54,56-57,59$ 
Hoare, Samuel 42, 79, 83, 91-92, 105 Hofmeyr, Jan Hendrik 59, 60, 63-64 Home Department 7, 112, 207 Hungary 270, 273-277, 280, 286 Hunter-Rodwell, Cecil 141, 145 Husain, Azim 197, 206, 289 Husain, Mian Fazl-i 32, 38, 42, 56-58, 60, 62, 68-71, 78, 89, 123, 128-129, 136, 138, 197

Hydari, Muhammed Saleh Akbar 70, 79, 82-83, 85-88, 91-93, 95, 97-98, 101, 105-109, 111-112, 114-119, 124, 131, 136-137, 149, 297, 299

Ikramullah, Mohammed 193, 197 Indian Civil Service 1-3, 5-8, 10-11, 13, 24-25, 28-29, 31-37, 39-40, 47, 50, 54-55, 60, 63-64, 79, 81, 84, 98, 107-110, 112, 127-131, 141-142, 144-145, 150-151, 153, 170-172, 198-199, 202-203, 207, 211, 221, 224-225, 228, 246, 254, 261-262, 265, 269, 271-272, 282, 284-285, 292-295, 297-299

Indian Foreign Service (IFS) 1, 5-7, 10, 13, 32, 202, 206-208, 211-213, 220, 222-225, 228-229, 232, 239, 252-253, 262, 267, 276, 292, 295, 297

Indian National Army (INA) 196, 252 Indian National Congress 1, 2, 22, $35,39-41,61,79,83,87,94,130$, 151-152, 154, 160-163, 165, 168, 170-173, 177, 193-194, 197, 201, 203, 211, 213, 232, 253, 275

India Office 7, 35, 54, 73-74, 79, $81,84,86,89,96,113,133,135$, 156-157, 159, 162, 169, 173, 175, 194, 227

Intelligence Bureau 227, 243, 281

Irwin, Edward Wood 76-77, 110, 123, 156-160, 163-164, 168, 294

Italy 38, 63, 79, 165, 228

Jackson, Edward 104-105, 110, 117 Jagdish Prasad 32, 35, 62-63, 65, 70-71, 75, 78-79, 83-86, 91-93, 104-107, 110-112, 117-119, 138,295

Japan 12, 38, 40, 131-132, 134-135, 146-147, 150, 161-163, 165, 167,
169, 173-174, 245-246, 249, 252, 279

Jinnah, Mohammed Ali 87, 151, 168, 170, 174, 197, 297

Jones-Bateman, R. 95-96, 114

Kashgar 38, 175

Kashmir 11, 13, 220-221, 226, 233 , 235-239, 246, 249-250, 252-253, 272-274, 276-277, 285, 296

Kaul, Triloki Nath 224, 264, 276, 290

Kaur, Amrit 61, 170

Kenya 9, 12, 22, 30, 72-81, 88-89, 101, 114, 142, 144, 155, 293

Khan, Liaquat Ali 170, 206, 250

Khan, Muhammad Zafrullah 137, 153, $156,172,174,176,179,183$

Khosla, J.N. 276-277, 279

Khrushchev, Nikita Sergeyevich 266, 272-273, 279, 283, 288

Korea 213, 226, 231, 236, 239-246, 248, 253, 266

Kunzru, Hriday Nath 77, 80, 92, 106, 123, 141, 197, 235, 257

League of Nations 2, 29, 31, 38, 51, 77, 156, 162

Linlithgow, Victor Hope Marquess of $33,38,42,104-105,107,110$, 133-134, 139, 143, 151-153, 155, 157-158, 163, 171-173, 177-181, 183,294

Luddington, Norman John 98-99

Macdonald, Malcolm 84, 93, 262

Madras Presidency 7, 25, 34, 36, 50, 60, 63, 96, 106-109, 113, 123, 126-130, 132, 144, 169, 198, 261

Mahindra, K.C. 153

Malan, Daniel François 49-52, 55-59, 223, 235, 296

Malaya 3, 5-7, 9, 12, 25, 26, 38, 40, 95, 97, 101, 107-108, 111, 120-139, 150, 152, 155, 174-176, 199, 211, 228, 279, 294-296

Mani, R. S. 102, 116, 118, 228

Mao Zedong 174, 240

Mathai, M.O. 2, 212, 226, 249, 264

Mauritius 61, 96, 145

Mehta, Jagat S. 282, 285, 289

Menon, K.P.S. 3, 5-7, 11-13, 28, 31-40, 42-44, 79-84, 87-88, 
92-93, 98-104, 106-108, 110-113, 115-119, 130, 132, 137, 150-151, 157, 169-178, 182-184, 193-202, 204-206, 210, 215-219, 221-222, 226-227, 230-231, 234, 240, 242, 244, 246-250, 254-255, 258-259, 261, 266-280, 285-289, 292-293, 296-298

Menon, K. R. 81, 92

Menon, Parakuta Achutha 221, 245, 259

Menon, Saraswati Anujee 35-36, 296

Menon, V. K. Krishna 1, 198-202, 205-207, 209, 211-215, 217-220, 223-230, 236, 238-240, 247, 249, 252-258, 261, 264-266, 274-278, 280, 282, 284-285, 287, 289, 296, 298-299

Menon, V. P. 170-171, 193, 207, 238, 292

Metcalfe, Aubrey 37-38, 130, 138, 170

Ministerstvo Innostrannych Del (MID) 266, 277, 279

Ministry of External Affairs 1-2, 5-7, 10-11, 13, 32-33, 40, 211-212, 214-215, 220-221, 223, 225-230, 232-234, 236, 247-249, 252-254, 261-266, 273-275, 278, 281, 286, 292-293, 295, 298-299

Molotov, Vyacheslav Mikhailovich 168, 195, 199-201, 205-206, 217, 223-224, 268

Monteath, David Taylor 2, 13, 153, $156,158,179-180$

Mountbatten, Louis 210-211, 219, 227, 241, 273

Mudaliar, Ramaswami 168-169, 193-196, 199, 216

Mudie, Robert Francis 193-194

Mukundan, K.A. 101, 116, 124, 126, 128-129, 136-138

Muslim League 87, 151, 168, 171, 177, 197, 201, 204, 250-251

Nagy, Imre 273, 277

Naidu, R. Subbayyu 123, 127-128, 135-136, 138

Naidu, Sarojini 22, 34, 57, 59, 83, 92, 110, 170

Nair, M. Kunhiraman 125, 127-128, 136-138

Narayanan, A. S. 108
Nehru, Braj Kumar 35

Nehru, Jawaharlal 1-2, 5-8, 10-11, 13, 39, 88, 110, 151, 160-163, 168, $170,173,178,193-194,196-213$, 215-223, 225-234, 236-247, 249-268, 270-290, 292-293, 296-299

Nehru, Motilal 22, 213

Nehru, Ratan Kumar 35, 117, 119 , 170, 254, 261-264, 281-282, 284, 286-288, 298-299

Nehru, S. S. 35

Nepal 38, 230, 244

New Zealand 4, 23, 294

Noon, Malik Feroze Khan 193-194, 197

Novikov, Kirill Vasilyevich 224, 239

Ormsby-Gore, William 74-75, 79, 127,137

Paddison, George F. 50-52, 54-55, 57, 59, 61, 64, 66-67

Pai, Ammembal Vittal 102, 105-106, 109-113, 116-119, 211, 224-225

Pakistan 3, 5, 170, 172, 177, 193, 206-207, 211, 235, 237-238, 250-252, 264, 280, 283, 285, 293, 295-296, 299

Pandit, Vijaya Lakshmi 168, 194, 197, 201, 203, 206-207, 214, 217-218, 220, 223-226, 228, 239, 254-256, 259, 264, 296

Panikkar, Kavalam Madhavan 223, 230-232, 241-243, 247, 253, 256, 258

Pant, Govind Ballabh 1, 284, 297

Patel, H.M. 8, 207, 212, 292

Patel, Sardar Vallabhbhai 1, 11, 151, 243-244, 250-251, 253, 258, 262, 297

Peel, Ronald Tennyson 159, 173, 180, 183

Peel, William 76-77, 147, 149

Philippines 160, 168, 194

Pillai, Arulanandam 26, 107, 121, 124, 127-128, 131, 135-138

Pillai, Narayanan Raghavan 8,13 , 170-171, 193, 206-207, 228, 232, 254, 261-266, 271-272, 274-275, 277, 280, 286, 288-289, 298-299

Pillai, T.G. Natarajan 108, 131 
Poland 40, 165-166, 171, 195, 256, 268, 276

Political Service 5, 7-8, 24, 36-38, 40, 108-109, 129-130, 157, 169-170, 172, 279

Prem Krishen 224-225

Provincial Service 25-26, 36, 127-129

Puckle, Frederick 157, 180

Radhakrishnan, Sarvepalli 226, 255, 266, 272

Rahman, Mohammed Ataur 273-277, 288-289

Ram Chandra 68-70, 91, 98-99, 111, 115-116, 118, 123, 136, 138, 149

Ranganathan, Subramaniyam 26-27, 95-98, 107, 111, 115, 127

Reading, Rufus Daniel Isaacs Marquess of $67,75,90,96,115,147-149$

Reddi, Kurma Venkata 33, 55-58, 60-61, 69

Richardson, Hugh Edward 172-173, 175,184

Ricketts, C.S. 50, 55, 64

Roberts, Frank 230, 243-244, 247, 255-256, 258-259

Robertson, Benjamin 47-48

Roosevelt, Franklin Delano 156, 160, 165-166, 195

Sapru, Tej Bahadur 3, 30, 146, 151

Sarma, B.N. 24, 48, 67, 96, 115

Sarubhai, Mridula 249-250

Sastri, V.S. Srinivasa 3, 6, 9, 22-23, 29-30, 34, 41, 48, 54-55, 57-60, 64, 68, 74, 77-78, 89-91, 126, 130-131, 135, 137-138, 141, 146, 205, 223, 296-297

Shafi, Muhammad 23, 31, 48, 124

Shepilov, Dmitri Trofimovich 277, 289

Sikkim 175, 242, 281

Singh, Maharaj, and wife 58, 60, 61-63, 63, 69-71, 145, 148, 296

Sinkiang 175-176, 178

Smuts, Jan 4, 23, 31, 47-49, 52, 89, 194

South Africa 3-5, 9-10, 12, 21-24, 31-33, 37-38, 47-73, 77-78, 80, 83, 88-89, 94, 97, 107, 114, 120, $123,128,130,145-146,155,197$, 223, 234-235, 251, 293-297
Stalin, Josef 40, 165-166, 171, 195, 224, 226, 240, 253, 266-269, 271, 278

Standing Emigration Committee (SEC) 30, 86, 93, 95-96, 123, 125-126, 145,149

Tanganyika 3, 56, 72, 77-79, 101

Thomas, Shenton 126, 130, 133-134, 138-139

Tibet 3, 38, 171-172, 174-175, 230-231, 240-245, 247, 252-253, 263-264, 281-283

Truman, Harry S. 167-168, 206

Turnbull, Francis Fearon 158, 180

Tyabji, Badr-ud-din 11, 32-33, 221-222, 228, 247, 254

Tyson, John Dawson 55-56, 60, 64, 68-69

Uganda 37, 72, 74, 77-79, 81, 293

United Kingdom 3-5, 8, 22, 28, 38, 40, 52, 54, 72, 74, 77, 83, 105, 113-114, 132-133, 147, 151, 154-159, 161-162, 164-166, 169, 171, 174-175, 178, 194-195, 198, 200, 204, 206, 209, 213-214, 224, 226-229, 236-237, 241-242, 244, 252, 273, 278, 294, 296

United Nations 5, 10, 160-161, 167-169, 193-194, 196-197, 199-200, 202-206, 209, 220-221, 223, 227-228, 234-235, 238, 242-244, 246-248, 264-265, 274-276, 280, 296, 298

United Nations General Assembly 10, 203-204, 206-207, 234-235, 237, 247,274

United Nations Relief and Rehabilitation Administration (UNRRA) 159, 162

United Nations Security Council 196, 199, 203, 205, 235, 237-238, 240, 250, 271

United Provinces 28, 32, 61, 112, 129-130, 140-142, 145, 261, 295

United States of America 2, 4, 7-9, 11-12, 29-30, 38, 41, 146-147, 150-169, 172, 174-175, 178, 195-196, 203-210, 213-214, 225-228, 231, 233-242, 244-248, 251-253, 262, 264, 267-268, 271-272, 274-278, 280, 283, 294-296 
USSR 6, 10-11, 13, 40, 111, 162, 165-168, 171, 174-177, 194-197, 199-202, 204-205, 207, 209-211, 213, 215, 223-228, 234, 236-237, 239-241, 243-248, 253-254, 258, 266-281, 283-286, 296, 298-299

Vellodi, M. K. 271, 290

Venkatachar, Cadambi Sheshachar 37, 109, 129-130, 138

Viceroy's Executive Council 5, 23, 57-58, 78, 111, 152, 172, 193, 294

Vyshinsky, Andrey Yanuaryevich 223-224
Walton, John 29, 30, 41-42, 67

Wavell, Archibald 153, 155, 158-159, 162, 169, 171, 176-177, 179-182, 184, 193-194, 197, 199, 201, 217

Weightman, Hugh 5, 158-159, 173, 180, 183-184, 197, 199-201, 206, 210, 217-218

Willingdon, Freeman Thomas Marquess of $32,36,42-43,58,70-71,79,83$, 91-92, 145, 149

Zaman, S.R. 116, 118, 128, 137

Zanzibar 12, 37, 72, 80-89, 111, 155,293

Zhou Enlai 231, 281, 283-284 